\title{
Plant Relations
}

DOI: 10.1556/Novenyterm.59.2010.Suppl.4 


\section{ADAPTIVE CAPACITY OF WHEAT (TRITICUM AESTIVUM L.) AND MAIZE (ZEA MAYS L.) CROP MODELS TO ECOLOGICAL CONDITIONS}

Péter PEPÓ

University of Debrecen, Faculty of Agriculture, Institute of Crop Sciences, H-4032 Debrecen, 138.
Böszörményi str. e-mail: pepopeter@agr.unideb.hu

Abstract: The interactions of ecological conditions, genotypes and agrotechnical elements determine the yield quantity, quality and stability in cereal (wheat, maize) production. The applied input-level can modify the adaptive capacity of crop models to ecological conditions and resilience of agro-ecosystems. The effects of agrotechnical elements (crop rotation, fertilization, irrigation, crop protection, plant density) were studied in the long-term experiment on chernozem soil. Our scientific results proved that the high yields and good yieldstability were obtained in the input-intensive crop models, so these models had better adaptive capacity and resilience. Maize had lower ecological adaptive ability than winter wheat. The optimalization of agrotechnical elements reduces the harmful climatic effects so we can increase the resilience of cereals agro-ecosystems. The yields of wheat varied between 2 and $7 \mathrm{t} \mathrm{ha}^{-1}$ in extensive and 8 and $10 \mathrm{t} \mathrm{ha}^{-1}$ in intensive crop models and the yields of maize ranged between 2 and $11 \mathrm{t} \mathrm{ha}^{-1}$ and 10 and $15 \mathrm{t} \mathrm{ha}^{-1}$, respectively.

Keywords: wheat, maize, resilience, adaptive capacity, crop model

\section{Introduction}

In Hungary, winter wheat and maize production have determining importance, their combined growing area is $50 \%$ of the arable land. These crops are grown under variable ecological conditions with a diverse variety/hybrid portfolio by applying agrotechniques of different intensity.

The results of Olsen - Bindi (2002), Birkás et al., (2006), Várallyay, (2007), Balogh Pepó (2008), Pepó (2009), Vad - Dóka (2009) showed that as a result of global climate change the yields of crops have dropped and yield fluctuation has increased. The unfavourable abiotic stress effects can be reduced by appropriate variety/hybrid selection and the optimum use of different agrotechnical factors. Among agrotechnical elements, the optimum nutrient - and water - supply (Jolánkai, 1982; Ruzsányi, 1990; Berzsenyi, 1993; Pepó, 2004; Pepó, 2009; Vad - Dóka, 2009) have outstandingly high importance and the others can modify their main yield effects.

\section{Materials and methods}

Our long-term experiments were set up in 1983 on chernozem soil at the Látókép Research Station of the University of Debrecen in the Hajdúság region (eastern part of Hungary).

In our polyfactorial experiment we study different crop models. The treatments are as follows:

- crop rotation: monoculture (maize), biculture (wheat-maize), triculture (peaswheat-maize)

- fertilization: wheat $\rightarrow$ control, $\mathrm{N}=50 \mathrm{~kg} \mathrm{ha}^{-1}, \mathrm{P}_{2} \mathrm{O}_{5}=35 \mathrm{~kg} \mathrm{ha}^{-1}, \mathrm{~K}_{2} \mathrm{O}=40 \mathrm{~kg} \mathrm{ha}^{-1}$, and 2-, 3- and 4-folds maize $\rightarrow$ control, $\mathrm{N}=60 \mathrm{~kg} \mathrm{ha}^{-1}, \mathrm{P}_{2} \mathrm{O}_{5}=45 \mathrm{~kg} \mathrm{ha}^{-1}, \mathrm{~K}_{2} \mathrm{O}=45$ $\mathrm{kg} \mathrm{ha}^{-1}$, and 2-, 3- and 4-folds.

- irrigation: non-irrigated and irrigated 
- other factors: wheat $\rightarrow$ extensive, average and intensive crop protection maize $\rightarrow 40,60,80$ thousand plants ha $^{-1}$

The weather conditions of crop years were different from the aspect of yield formation in winter wheat and maize. In general, we can state that weather in crop years of 2004, 2005, 2008 was good for the crops, in 2006 and 2009 was average and the 2007 crop year was unfavourable.

\section{Results and discussion}

The applied agrotechnique, the level of agrotechnical inputs (extensive, low-input, midtech, intensive) and the interactions between the agrotechnical elements have determining importance. Namely, these interactions can be negative in certain cases and positive in others. Consequently, our objective is to maximally exploit the positive interactions and to minimize or eliminate the negative interactions as far as possible.

In a long-term experiment, we studied two plant species with different ecological sensitivity, winter wheat and maize, in crop models of different intensity on chernozem soil. From these models, we analyzed the yields of two crop models with very different

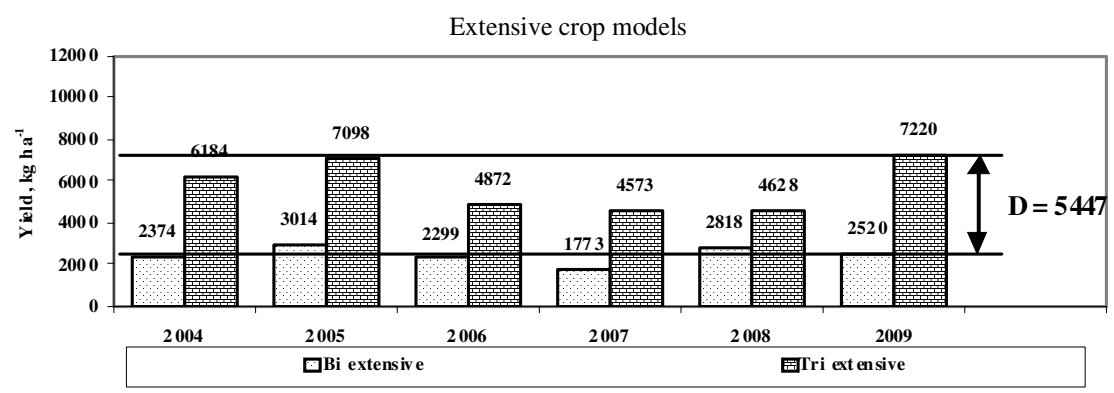

Intensive crop models

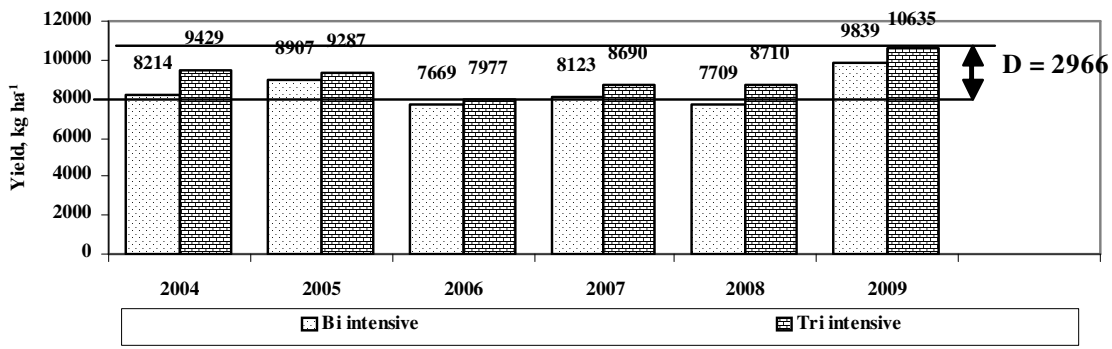

Figure 1. Yield and yield-stability of winter wheat crop models (Debrecen, chernozem soil, 2004-2009)

inputs, the extensive and intensive models. In the agro-ecosystems, we applied the same genotypes of winter wheat and maize in the studied years, the variable factors were the crop year so the weather factors. In the studied 6-year period, the years were significantly different from each other with respect to the vegetative and generative development and yield formation of the two plant species. Both for winter wheat and maize, the year 2007 was very unfavourable, the other years were average or 
favourable, almost optimal $(2004,2008)$. The resilience of the agro-ecosystem in its response to unfavourable weather conditions was essentially determined by the intensity level of the crop model both for winter wheat and maize. In the case of winter wheat in the extensive crop model, yields ranged from 1773 to $3014 \mathrm{~kg} \mathrm{ha}^{-1}$ in biculture and from 4573 to $7220 \mathrm{~kg} \mathrm{ha}^{-1}$ in triculture. On the one hand, it meant a moderate yield level (2-7 $\left.\mathrm{t} \mathrm{ha}^{-1}\right)$, on the other hand, it represented an extremely high yield fluctuation $(\mathrm{D}=5447$ $\mathrm{kg} \mathrm{ha}^{-1}$ ) in the extensive crop models in the two crop rotation systems. The intensive crop models differed from the extensive ones as in these the optimum fertilization $\left(\mathrm{N}_{\mathrm{opt}}+\mathrm{PK}\right.$ dosages), water supply (irrigation according to the demand) and crop protection (herbicide + fungicide application) were provided. As a result of this, the yields of winter wheat in intensive crop models ranged from 7669 to $9839 \mathrm{~kg} \mathrm{ha}^{-1}$ in biculture and from 7977 to $10635 \mathrm{~kg} \mathrm{ha}^{-1}$ in triculture. Accordingly, by applying a proper, intensive agrotechnique, a better resilience of the agro-ecosystem to the unfavourable environmental factors (weather effects) could be facilitated. Consequently, the yields of winter wheat in intensive crop models varied at a high level, in the interval between 7.5 and $10.5 \mathrm{t} \mathrm{ha}^{-1}$ in biculture and triculture. However, the yield fluctuation between years was considerably lower in intensive models $\left(D=2966 \mathrm{~kg} \mathrm{ha}^{-1}\right)$ than in the extensive wheat models $\left(\mathrm{D}=5447 \mathrm{~kg} \mathrm{ha}^{-1}\right)$ (Figure 1$)$.
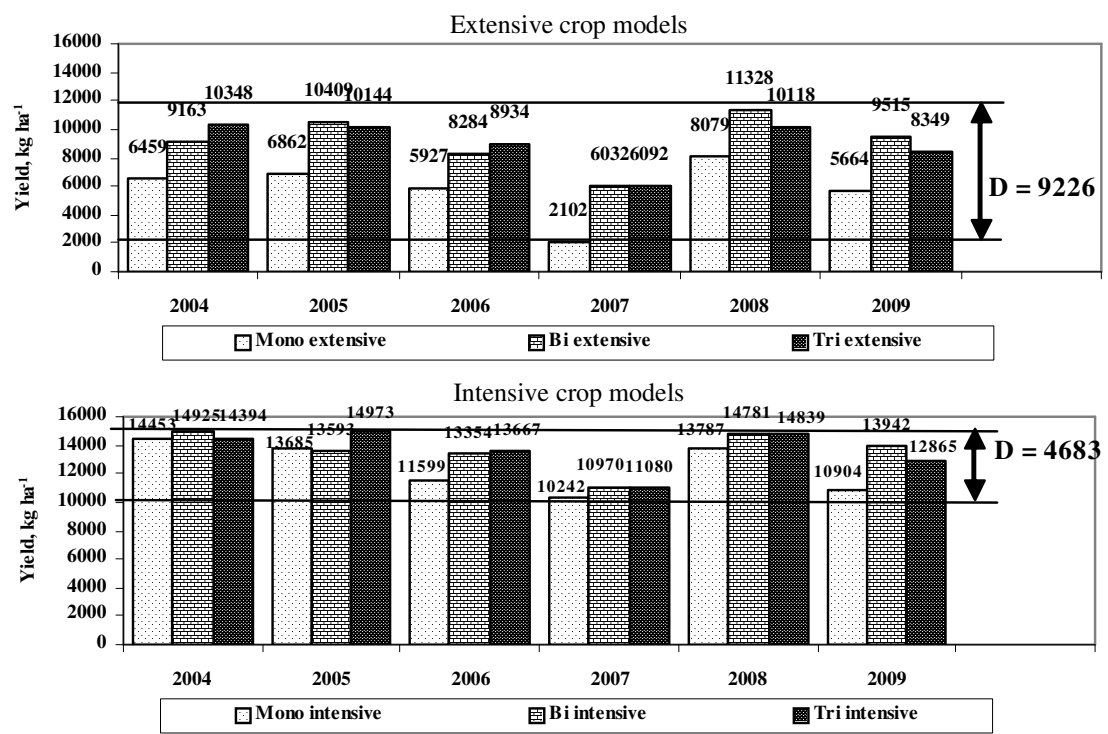

Figure 2. Yield and yield-stability of maize crop models (Debrecen, chernozem soil, 2004-2009)

For maize, we studied the interactions of weather factors and crop models with respect to the resilience of the agro-ecosystem in three crop rotation variations (mono-, bi- and triculture) on chernozem soil. Our research results proved that, in the case of extensive models (without fertilization and irrigation with moderate plant density), the yield of maize varied between 2102 and $8079 \mathrm{~kg} \mathrm{ha}^{-1}$ in monoculture, 6032 and $11328 \mathrm{~kg} \mathrm{ha}^{-1}$ in biculture and 6092 and $10348 \mathrm{~kg} \mathrm{ha}^{-1}$ in triculture. The much higher ecological 
sensitivity of maize as compared to wheat was proved by the greatly variable yields in the different years. In an unfavourable year (2007), the maize yield varied between 2 and $7 \mathrm{t} \mathrm{ha}^{-1}$ in the extensive model depending on the crop rotation. In a year with almost optimal water supply (2008), maize yield was $8-11 \mathrm{t} \mathrm{ha}^{-1}$ in the extensive model depending upon the crop rotation. In the case of intensive crop models (optimum fertilizer dosages, optimum plant density, irrigation), maize yields varied between 10242 and $14453 \mathrm{~kg} \mathrm{ha}^{-1}$ in monoculture, 10970 and $14925 \mathrm{~kg} \mathrm{ha}^{-1}$ in biculture, and between 10907 and $14973 \mathrm{~kg} \mathrm{ha}^{-1}$ in triculture, that is it was considerably higher than that of extensive models. In the case of intensive technologies, yields ranged from 10 to $15 \mathrm{t} \mathrm{ha}^{-1}$, while for extensive ones, yields were between 2 and $11 \mathrm{t} \mathrm{ha}^{-1}$ in the studied period (2004-2009). However, yield fluctuation caused by weather was significantly lower in intensive models $\left(D=4683 \mathrm{~kg} \mathrm{ha}^{-1}\right)$ than in the extensive ones $(D=9226 \mathrm{~kg}$ $\mathrm{ha}^{-1}$ ). Consequently, our research results proved that by applying the proper, intensive crop model the resilience of the given agro-ecosystem to the harmful effects induced by weather factors could be moderated even in the case of the ecologically very sensitive maize (Figure 2).

\section{Conclusions}

Results of our long-term experiments proved that the equilibrium of a given crop model and consequently, its productivity were greatly influenced by environmental, primarily weather factors. The application of input intensive technologies is also of favourable effect in winter wheat and maize production. According to our research results, the yield level of winter wheat was 8-10 $\mathrm{tha}^{-1}$ and the yield level of maize was $10-15 \mathrm{t} \mathrm{ha}^{-1}$ by applying an intensive technology on chernozem soil in the Hajdúság region. When applying an extensive technological model in the period of 2004-2009, the yields of winter wheat and maize ranged from 2 to $7 \mathrm{t} \mathrm{ha}^{-1}$ and from 2 to $11 \mathrm{t} \mathrm{ha}^{-1}$, respectively. By applying intensive technologies, yield stability could be significantly improved. Yield fluctuation of winter wheat was $2966 \mathrm{~kg} \mathrm{ha}^{-1}$ in the intensive model and $5477 \mathrm{~kg}$ $\mathrm{ha}^{-1}$ in the extensive model, while for maize the corresponding values were $4683 \mathrm{~kg} \mathrm{ha}^{-1}$ and $9226 \mathrm{~kg} \mathrm{ha}^{-1}$ depending upon the input level.

\section{References}

Balogh Á. - Pepó P.: 2008. Cropyear effects on the fertilizer responses of winter wheat (Triticum aestivum L.) genotypes. Cereal Research Communications. 36: 3. 732-734.

Birkás M. - Dexter A.R. - Kalmár T. - Bottlik L.: 2006. Soil quality - soil condition - production stability. Cereal Research Communications, 34: 1. 135-138.

Jolánkai M.: 1982. Öszi búzafajták tápanyag- és vízhasznosítása (Kandidátusi értekezés).

Olsen J. E. - Bindi M.: 2002. Consequences of climate change for European agricultural productivity, land use and policy. European Journal of Agronomy, 16: 4. 239-262.

Pepó P.: 2004. Öszi búza tápanyagellátása a Hajdúságban. (MTA doktori értekezés)

Pepó P.: 2009.: Effects of water supply as an abiotic stress on the yields and agronomic traits of winter wheat (Triticum aestivum L.) on chernozem soil. Cereal Research Communications. 37: 29-32.

Ruzsányi L.: 1990. A növények elővetemény-hatásának értékelése vízháztartási szempontból. Növénytermelés, 40: 1. 71-77.

Vad A. - Dóka L.: 2009. Cropyear as abiotic stress effect on the yields of maize (Zea mays L.) in different crop rotation. Cereal Research Communications. 37: 253-256.

Várallyay Gy.: 2007. A globális klímaváltozás: In: Láng I. - Csete L. - Jolánkai M.: A VAHAVA Jelentés,

Agrokémia és Talajtan, 56. 1. 199-202. 


\title{
ADVENTIVE WEED FLORA IN VINEYARDS OF BOSNIA AND HERZEGOVINA
}

\author{
Zlatan KOVAČEVIĆ ${ }^{1}$ - Danijela PETROVIĆ ${ }^{2}-$ Nevenko HERCEG $^{2}-$ Dijana VEGO $^{2}$ \\ - Katica ARAR ${ }^{2}$
}

Faculty of Agriculture, University of Banjaluka, Bulevar vojvode Petra Bojovića 1A, zlaja2005@blic.net ${ }^{2}$ Faculty of Agriculture, University of Mostar

Abstract: By floristic and phytocoenological research of weed flora in vineyards of Bosnia and Herzegovina 14 adventive species were determined: Amaranthus albus L., Amaranthus retroflexus L., Ambrosia artemisiifolia L., Asclepias syriaca L., Avena barbata Pott. ex Link., Bidens bipinnata L., Conyza canadensis (L.) Cronq., Erigeron annuus (L.) Pers., Foeniculum vulgare Mill., Galinsoga parviflora Cav., Oxalis stricta L., Portulaca oleracea L., Sorghum halepense (L.) Pers., and Xanthium italicum Moretti. Most of them (8 species or $57,14 \%$ ) have North American origin. The most important species from this origin in vineyard weed flora of Bosnia and Herzegovina are: Amaranthus retroflexus L. and Ambrosia aretemisiifolia L. The following species also had a higher frequency: Conyza canadensis (L.) Cronq., Erigeron annuus (L.) Pers. and Xanthium italicum Moretti. In the structure of adventive floristic elements, plants of Mediterranean origin were presented by 4 species or $28,57 \%$. Sorghum halepense (L.) Pers. and Portulaca oleracea L. were characterized by higher frequency in weed flora. However, Foeniculum vulgare Mill. Mediterranean spice species had been determined as a weed. Out of 2 species of South American origin, Galinsoga parviflora Cav. had high frequency in weed flora in vineyards of Bosnia and Herzegoivna.

Keywords: adventive species, vineyards, Bosnia and Herzegovina.

\section{Introduction}

The adventive flora is represented by allochthonous species that, as a result of human activity, were introduced into our region where they have, more or less, acclimatised themselves. In this connection, the term "adventive species" refers to all introduced species, regardless of the mode and time of their introduction, and of the level of their adaptation and successfulness of naturalisation. Invasive plant species are the introduced (alien or allochthonous) species that have become established in a certain area and overstepped the barrier dividing degraded habitats of ruderal communities from the habitats of secondary and primary plant communities. One of such barriers is the self-propagation in nature, i.e. independent maintenance and increase of population. This stage, when herbaceous plants are involved, most often occurs in ruderal plant communities, that is, on ruderal habitats since ruderal plant communities are distinguished by high dynamics and unstable coenocytic relations, and are very suitable for colonisation and propagation of adventive species (Richardson et al., 2000). The presence of these plants and their spreading represents a great danger to the autochthonous flora, which in this way can be directly jeopardised and ousted. Most often these are very resistant plants and strong competitors, which poses a special problem for agricultural production.

\section{Materials and methods}

In Bosnia and Herzegovina, floristic and phytocoenological research of weed flora in vineyards was carried out in the 2006-2008 period. The determination of plant species was done on the basis of the following publications: Flora Europaea I-V (Tutin, (ed.), 1964-1980), Flora of Bosnia and Herzegovina (Beck, 1906-1923), Flora of the SR of 
Serbia I-IX (Josifović, (ed.), 1970-1977), Flora of Croatia (Domac, 1994), Ikonographie der Flora des Südöstlichen Mitteleuropa (Javorka and Csapody, 1979), and Flora Italiana (Fiori and Paoletti, 1921). Taxonomy and nomenclature have been harmonised according to the publication Flora Europaea I-V (Tutin, (ed.), 1964-1980). Life forms have been determined according to the supplemented and updated classification based on the principles of Raunkiaer (Raunkiaer, 1934) given in the Flora of Serbia (Sarić, (ed.), 1992). This classification has allowed for an ecologically more specific nuancing of the biological spectrum. The affiliation of species to floristic elements was determined on the basis of land area maps of Meusel et al. and the Atlas of the Flora of Europe, which contain original land areas for adventive species (Oberdorfer, 2001).

\section{Results and discussion}

The weed flora of Bosnia and Herzegovina can be said to have been studied relatively well, except that adventive species have not been paid an adequate attention. Their spreading interested a certain number of researchers (Slavnić, 1960; Šarić et al., 1992; Šilić and Abadžić, 2000; Kovačević et al., 2008 and others). During 1999 a research was carried out with a special reference to the spreading of new weed species, such as Abutilon theophrasti, Xanthium strumarium and Datura stramonium, as well as to the expansion of former weeds, as is the case with Avena fatua, Sorghum halepense and Ambrosia artemisiifolia. During the research it was established that Ambrosia artemisiifolia intensively spreads from the north towards the Central Bosnia (Šarić et al., 2000). A very detailed study reports the changes in the communities that enter the system of segetal vegetation in the southern parts of Hungary caused by the invasion of allochthonous plant species (Erigeron annuus, Ambrosia artemisiifolia, Conyza canadensis, Xanthium italicum and Sorghum halepense) that appear with high frequency and dominate on the plough-fields and vineyards of the researched region. (Pál, 2004). The years-long research of the weed flora in the vineyards of Bosnia and Herzegovina resulted in the establishment of fourteen adventive species (Table 1).

The adventive flora in the vineyards of Bosnia and Herzegovina has been classified into 7 families, predominant among which being the representatives of the Asteraceae family with 6 species; by the way, this family is the most represented in the flora of Bosnia and Herzegovina (Beck, 1906-1923). In the biological spectrum of the adventive flora of the vineyards of Bosnia and Herzegovina, three life forms were established, terophytes with 10 species being absolutely predominant, while hemicryptophytes and geophytes are represented by 2 species each. Taking into consideration the quantitative and qualitative representation of the plants of individual life forms it may be said that the adventive weed flora in the vineyards of Bosnia and Herzegovina has a marked terraphytic character. The geophytic species Sorghum halepense (L.) Pers has somewhat higher numerousness and land cover. As for the life form structure of terraphytes, 8 of them are dendriform (T scap), among which Amaranthus retroflexus L., Ambrosia artemisiifolia L. and Galinsoga parviflora Cav. appear with high frequency; these, beside others, together with the species Portulaca oleracea L. - which is a dendriform succulent (T scap-succ) - account for $90,00 \%$ of the total number of terraphytes. The annual species of a tussock habit (T caesp) is Avena barbata Pott. ex Link. which is common on ruderal and agricultural habitats (olive woods and vineyards) of 
Herzegovina. As regards the category of growth, terraphytes are dominated by high plants of summer phenology (a).

Table 1. Taxonomic, ecological and phyto-geographical analysis of adventive weed flora in $\mathrm{B} \& \mathrm{H}$ vineyards.

\begin{tabular}{|c|c|c|}
\hline Weed species & Life form & Floristic element \\
\hline \multicolumn{3}{|c|}{ Family Amaranthaceae } \\
\hline Amaranthus albus $\mathrm{L}$. & a Meg T scap & $\operatorname{adv}$ (N. America) \\
\hline Amaranthus retroflexus $\mathrm{L}$. & a Mes-Alt T scap & $\operatorname{adv}$ (N. America) \\
\hline \multicolumn{3}{|c|}{ Family Apiaceae } \\
\hline Foeniculum vulgare Mill. & a Meg-Alt H scap & $\operatorname{adv}$ (W. Mediterranean) \\
\hline \multicolumn{3}{|c|}{ Family Asclepiadaceae } \\
\hline Asclepias syriaca $\mathrm{L}$. & a Meg-Alt G rhiz scap & $\operatorname{adv}$ ( N. America) \\
\hline \multicolumn{3}{|c|}{ Family Asteraceae } \\
\hline Ambrosia aretemisiifolia $\mathrm{L}$. & aut Meg T scap & $\operatorname{adv}($ N. America) \\
\hline Bidens bipinnata $\mathrm{L}$. & a Meg-Alt T scap & adv (S. America) \\
\hline Conyza canadensis (L.) Cronq. & a Meg-Alt T scap & $\operatorname{adv}$ (N. America) \\
\hline Erigeron annuиs (L.) Pers. & a Mes-Meg T scap/a H scap & $\operatorname{adv}$ (N. America) \\
\hline Galinsoga parviflora Cav. & a Mes-Meg T scap & adv (S. America) \\
\hline Xanthium italicum Moretti & a Meg-Alt T scap & $\operatorname{adv}(\mathrm{N}$. America) \\
\hline \multicolumn{3}{|c|}{ Family Oxalidaceae } \\
\hline Oxalis stricta $\mathrm{L}$. & a Mi-Mes H scap & adv. (N. America) \\
\hline \multicolumn{3}{|c|}{ Family Poaceae } \\
\hline Sorghum halepense (L.) Pers. & a-aut Meg-Alt G rhiz caesp & adv (E. Mediterranean) \\
\hline Avena barbata Pott. ex Link. & a Meg-Alt T caesp & adv (Mediterranean) \\
\hline \multicolumn{3}{|c|}{ Family Portulacaceae } \\
\hline Portulaca oleracea $\mathrm{L}$. & a Mes T scap-succ & adv (E.-C. Mediterranean) \\
\hline
\end{tabular}

The domination of terraphytes in terms of percentage confirms the anthropogenic conditions and changeability of the habitats of the researched area, and suggests the ruderal character. Hemicryptophytes are represented by 2 tree-shaped weed species $(\mathrm{H}$ scap) of summer phenology (a); as for the category of growth they are medium high and high plants. Geophytes are represented by rhizomatous ( $G$ rhiz) forms, out of which Sorghum halepense (L.) Pers. is of a tussock (G rhiz caesp), and Asclepias syriaca L. of a dendriform (G rhiz scap) habit. As regards the growth categories here we are dealing with high plants. The structure of the adventive group of floristic elements in the adventive weed flora of Bosnia and Herzegovina is such that the largest number of species (10) is of American origin, out of which 8 species $(57,14 \%$ of the total number of adventive species) have their land areas in North America, and 2 in South America. Out of the species of the North American origin in the weed flora of Bosnia and Herzegovina vineyards, the following especially stand out: Amaranthus retroflexus L. and Ambrosia aretemisiifolia L. With a major level of presence are also the species: Conyza canadensis (L.) Cronq., Erigeron annuus (L.) Pers. and Xanthium italicum Moretti. The species of the South American origin Galinsoga parviflora Cav. is highly frequent in the weed flora of the vineyards in Bosnia and Herzegovina. Four adventive

331 DOI: 10.1556/Novenyterm.59.2010.Suppl.4 
species have their original land areas in the Mediterranean region. Among the species of the Mediterranean origin in the structure of the adventive group of floristic elements, Sorghum halepense (L.) Pers. and Portulaca oleracea L. are represented in the weed flora of vineyards.

\section{Conclusions}

In the weed flora of the vineyards of Bosnia and Herzegovina 14 adventive species have been identified; they have been classified into 7 families, out of which the Asteraceae family has the largest number of species (6 species). The weed flora in the vineyards of Bosnia and Herzegovina has a pronounced terraphytic character with the domination of high denfriform ( $\mathrm{T}$ scap) plants of summer phenology (a). The phytogeographical analysis has established the domination of the species of American origin (10 species), among which prevail the species that have their original land areas in North America (8 species). On the basis of years-long researches it may be said that what is involved here is an increase in the number of adventive species and their intensive propagation, and that some species are assuming the character of invasive ones. In weed communities the participation of adventive species, especially in perennial plantations, poses a big problem because by entry into agrophytocenoses their propagation is accelerated.

\section{References}

Beck, G.: 1906-1923 Flora Bosne, Hercegovine i Novopazarskog Sandžaka. II dio, Zemaljska štamparija, Sarajevo.

Domac, R.: 1994. Flora Hrvatske. Školska knjiga, Zagreb.

Fiori, A. - Paoletti, G.: 1921. Flora Italiana, Illustrata. Sancasciano val di Pesa, Stab. Tipo-Lotografico Frtelli Stianti.

Javorka, S. - Csapody, V.: 1979. Iconographie der Flora des Südöstlichen Mitteleuropa. Gustav Fischer Verlag, Stuttgart.

Josifović, M. (ed.) : 1970-1977. Flora SR Srbije. I-IX, Srpska akademija nauka i umjetnosti, Beograd.

Kovačević, Z. - Šumatić, Nada - Kojić, M. - Petrović, Danijela. - Herceg N.: 2008. Adventivna korovska flora Bosne i Hercegovine. Acta herbologica, 17: 1, 89-93.

Oberdorfer, E.: 2001. Pflanzensoziologische Exkursionsflora für Deutschland und angrenzende Gebiete. Eugen Ulmer Verlag, Stuttgart.

Pál, R. : 2004. Invasive plants segetal weed vegetation of South Hungary. Weed Tehnology, 18: 5, 13141318.

Raunkieaer, C.: 1934. The life forms of plants and statistical plant geography. Clarendon, Oxford.

Richardson, D.M. - Pyŝek, P. - Rejmanek, M. - Barbour, M.G. - Panetta, F.D. - West, C.J.: 2000. Naturalization and Invasion of Alien Plants: Concepts and Definitions. Diversity and Distributions 6: $93-$ 107.

Sarić, M. (ed.): 1992. Flora Srbije 1. SANU, Odjeljenje prirodno-matematičkih nauka, Beograd.

Šarić, T. - Đikić, M. - Gadžo, D.: 2000. Promjena korovske flore pod utjecajem agrotehnike. Herbologija, 1: 1, 15-27, Sarajevo.

Šarić, T. - Elezović, Z. - Muminović, Š.: 1992. Ekspanzija divljeg sirka, ambrozije i smrdljive koprive u Bosni, Zbornik radova, Četvrti kongres o korovima, 327-337, Banja Koviljača.

Šilić, Č. - Abadžić, S.: 2000. Prilog poznavanju neofitske flore Bosne i Hercegovine, Herbologija,. 1:.1, 2940, Sarajevo.

Slavnić, Ž.: 1960. O useljavanju, širenju i odomaćivanju nekih adventivnih biljaka u Bosni i Hercegovini, Godišnjak Biološkog instituta Univerziteta u Sarajevu, XIII, 1-2, 117-146, Sarajevo.

Tutin, T. G. (ed.) : 1964-1980. Flora Europaea. 1-5, Cambridge University Press, London. 


\title{
APPLICATION OF THE GARDEN CRESS (LEPIDIUM SATIVUM) AS POSSIBLE BIOLOGICAL INDICATOR OF HEAVY METAL ACCUMULATION
}

\author{
Bernadett GYARMATI - Albert SZANISZLÓ - Balázs TÖRÖ-Ágnes BÁLINT
}

Department of Chemistry and Biochemistry, Institute of Environmental Science, Faculty of Agricultural and Environmental Sciences, Szent István University, Páter K. u. 1., Gödöllő, H-2103 Hungary e-mail: bernadett.gyarmati@gmail.com

Abstract: Condition of an eco-system greatly depends on different biotic and abiotic factors. The area along the Tisza River is highly imperiled by random appearance of heavy metal pollutants originated from mining accidents or other sources. Heavy metals are dangerous because of the bioaccumulation and they could be toxic or poisonous even at low concentration. The aim of our research was to test the reaction of a simplified soil- plant pot experiment, consists of garden cress (Lepidium sativum) for metal pollution close to the sanitary limiting value. Garden cress is considered to be one of the most important agricultural vegetables and its short reaction time for various treatments makes this plant ideal object of eco-toxicological test. Based on the results it is possible to deduct resilience processes. Furthermore soil samples were taken around the River Tisza in order to determine the degree of pollution.

Keywords: heavy metals, $\mathrm{Zn}$ and $\mathrm{Cu}$ accumulation, garden cress

\section{Introduction}

The heavy metal pollution in the human surrounding is one of the leading issues of nowadays. Heavy metal pollution can cause enormous changes in the flora and fauna community decreasing of resilience capacity of the soil (Bálint et al., 2007), although the estimation of its danger level alters according to loadabilty of the carrier medium.

Garden cress (Lepidium sativum) was chosen as a test plant to simulate the accessible pollutant uptake (R. van Herwijnen et al., 2008; P. Alvarenga et al., 2008; Gyarmati et al., 2008). Additionally L. sativum is a possible carrier of heavy metals in food chain, since it is a many-sided green vegetable consumed by human beings and animals (Terbe, 2000).

The present investigation was undertaken to examine the level of $\mathrm{Zn}$ and $\mathrm{Cu}$ pollution in Lake Rétközi and its surroundings, and its removal by phytoextraction.

\section{Materials and methods}

\section{1.) Monitoring of soil pollution}

Sampling: 50 soil and 4 control samples were collected from 0-30 $\mathrm{cm} \mathrm{(A)} \mathrm{and} \mathrm{70-100} \mathrm{cm} \mathrm{(B)} \mathrm{depth} \mathrm{along} \mathrm{Szabolcsveresmart}$ settlement, which frequently called Rétközi reservoir (located in Szabolcs - Szatmár - Bereg county, GPS coordinates: N: $48.29340^{\circ}$ E: $\left.22.03357^{\circ}\right)$. Samples were taken according to the sampling network based on standards no. MSz 21470-50 (See Figure 1.).

After transport to the laboratory, samples were left to dry by exposing to the air. In order to remove the bigger stones and

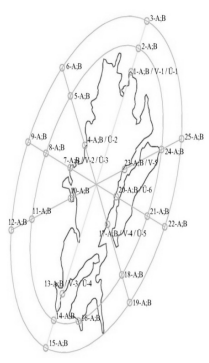
remnants of roots, the samples were sifted through a $2 \mathrm{~mm}$ sieve.

Figure 1. Sampling network 
Dry weight content and pH determination: Determination of dry weight content and pH were made according to standards no. MSz-08-0205-1978; MSz-08-0206/2-1987.

\section{2.) Phytoextraction experiment}

Phytoextraction processes with L. sativum in soil were conducted under laboratory condition.

\section{General treatment of the seeds:}

4 containers were filled the soil derived from Rétközi reservoir (see on Figure 1.: 17-A; 20-A; T-A; T-B). Three replicated were used in all variants. The soil type is Eutric Cambisol (WRB reference). 4 soil samples with outstanding value of concentration (compared to the average value) were used. The bio cress seeds, produced by BIOrganic Ltd, were scattered over the soil. Small amount of soil was sprinkled lightly over them, just to cover. A spray bottle was used to keep the seeds evenly moist. They sprouted after 2-3 days. $0.2 \mathrm{~g}$ (138 pieces) seeds were used for one experiment. The seedling occurred at room temperature (between $18-23{ }^{\circ} \mathrm{C}$ ). At the end of $14^{\text {th }}$ day, the fullgrown plants were removed and carefully washed off. The redundant water was done away and every plant was separated into roots, stems and leafs. The parts of the plants were digested as it is described below.

\section{Microwave digestion}

1.) Sample preparation Soil: at first samples were sifted through a $0.2 \mathrm{~mm}$ sieve. $0.5 \mathrm{~g}$ dry matter soil was taken into each teflon bomb. Then $5 \mathrm{~cm}^{3} 65 \% \mathrm{HNO}_{3}$ and $2 \mathrm{~cm}^{3} 30$ $\% \mathrm{H}_{2} \mathrm{O}_{2}$ were added before starting the digestion program.

Table 1. Digestion program

\begin{tabular}{|c|c|c|}
\hline Steps & $\begin{array}{c}\text { Time [min] } \\
\text { Soil / Plant }\end{array}$ & $\begin{array}{c}\text { Process [Watt] } \\
\text { Soil / Plant }\end{array}$ \\
\hline \hline 1. & $5 / 2$ & Digesting, 250/250 \\
\hline 2. & $2 / 2$ & Aeration \\
\hline 3. & $5 / 6$ & Digesting, $400 / 250$ \\
\hline 4. & $5 / 5$ & Digesting, $250 / 400$ \\
\hline 5. & $7 / 5$ & Digesting, 700 / 600 \\
\hline 6. & $5 / 5$ & Aeration \\
\hline
\end{tabular}

Plant: The preparation of plant samples happened the same way, but different quantity of acids were added: $6 \mathrm{~cm}^{3} 65 \% \mathrm{HNO}_{3}, 1 \mathrm{~cm}^{3} 30 \% \mathrm{H}_{2} \mathrm{O}_{2}$.

2.) Digestion:Samples were digested by a MILESTONE 1200 Mega Microwave Digester (see the digestion program in Table 1.).

3.) Determination of heavy metal content:

After the procedure described above the following elements were measured by ICPOES and FAAS: $\mathrm{Al}, \mathrm{Ca}, \mathrm{Cr}, \mathrm{Cu}, \mathrm{Fe}, \mathrm{Ni}, \mathrm{Mg}, \mathrm{Mn}, \mathrm{Pb}, \mathrm{Zn}$ in soil and $\mathrm{Zn}, \mathrm{Cu}$ in garden cress.

\section{Results and discussion}

1.) Monitoring of the soil pollution

It became clear after completing the variance analysis (ANOVA one-way test) that the heavy metal content of the soil samples significantly depends on the place of sampling. Only one soil sample's Cu concentration (sample id.: 22-A, see on Figure 1.) 84,8 mg 
$\mathrm{kg}^{-1}$ was higher than the limit value $\left(75 \mathrm{mg} \mathrm{kg}^{-1}\right.$ ) based on the Governmental Regulation 6/2009. (IV. 17.) KVVM-EÜM-FVM. In the case of other measured elements neither of them exceed the limit values after summarizing all the results. These results will be used as reference base of a long term monitoring system. The reason 22-A was not take into account is that the seed sprouting was inhibited at that degree of pollution causing the insufficient quantity of plant dry mater for the analysis.

Table 2. Pyisical and physico-chemical characteristic and composition (dry weight basis) of studied soils and plants

\begin{tabular}{|c|c|c|c|c|}
\hline \multirow[t]{2}{*}{ Parameter } & \multicolumn{4}{|l|}{ Soil } \\
\hline & $17-\mathrm{A}$ & $20-\mathrm{A}$ & T-A & T-B \\
\hline Soil Plasticity $\left(\mathrm{K}_{\mathrm{A}}\right)$ & 30 & 28 & $\overline{55}$ & 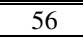 \\
\hline $\mathrm{CaCO}_{3}(\%)$ & 1 & 1 & 1 & $1-2$ \\
\hline Humus (\%) & 2.2 & 2.3 & 2.3 & 2.6 \\
\hline $\mathrm{C} / \mathrm{N}$ & 16.7 & 12.4 & 15.0 & 16.16 \\
\hline $\mathrm{pH}\left(\mathrm{H}_{2} \mathrm{O}\right)$ & 5.70 & 6.20 & 7.12 & 6.77 \\
\hline $\mathrm{pH}(\mathrm{KCl})$ & 5.69 & 6.19 & 7.13 & 6.78 \\
\hline Dry matter content (\%) & 98 & 99 & 99 & 1 \\
\hline $\mathrm{Zn}\left(\mathrm{mg} \mathrm{kg}^{-1}\right.$ d.w.) & 165.6 & 32.2 & 189.9 & 194.5 \\
\hline $\mathrm{Cu}\left(\mathrm{mg} \mathrm{kg}^{-1}\right.$ d.w. $)$ & 43.0 & 20.8 & 61.4 & 74.1 \\
\hline Cr[tot] (mg kg ${ }^{-1}$ d.w.) & 2.8 & 4.0 & 0.9 & 2.6 \\
\hline $\mathrm{Al}$ (mg kg-1 d.w.) & 1630.7 & 3519.3 & 1031.5 & 2421.2 \\
\hline $\mathrm{Pb}$ (mg kg ${ }^{-1}$ d.w.) & 3.4 & 2.0 & 1.4 & 1.2 \\
\hline $\mathrm{Ni}$ (mg kg${ }^{-1}$ d.w.) & 1.9 & 2.2 & 0.6 & 1.9 \\
\hline Dry matter content $(\%)$ & \multicolumn{4}{|l|}{ Plant } \\
\hline Root & 5.2 & 12.5 & 38.8 & 23.5 \\
\hline Stalk & 6.8 & 12.1 & 7.1 & 12.7 \\
\hline Leaf & 0.4 & 8.5 & 8.6 & 9.3 \\
\hline $\mathrm{T} \%(\mathrm{Zn})$ & 35.48 & 64.94 & 31.7 & 31.0 \\
\hline $\mathrm{T} \%(\mathrm{Cu})$ & 26.8 & 25.5 & 27.4 & 30.6 \\
\hline
\end{tabular}

\section{2.)Phytoextraction experiment}

It has to be taken into consideration, that soil parameters have notable effect on these experiments: metals, heavy metals, cations are not so mobile in carbonaceous soil (Kádár, 2007). The transfer coefficient (T \%) was calculated, too (F. Fornes et al., 2009). Although the organic matter content is determinant regarding the heavy metal concentration of the soil solution, straight correlation cannot be demonstrated by adsorptional experiments. The reason for this is $\mathrm{pH}$ affects the creation of metalorganic complexes and there is a strict correlation between $\mathrm{pH}$ and the degree of absorption. Another important factor beside this is that the structural diversity of the mouldmaterial, which is not mapped completely yet, cannot be regarded as a uniform material. Their absorption and cation-exchanging characteristics are different and depend on $\mathrm{pH}$ (FILEP 1988). It can be concluded that in almost every case the heavy metal concentration in the roots were significantly higher than in the other plant parts (see on Figures 2,3). It is favorable for the consumers because heavy metals accumulate only in a small proportion in leafs and stalks of the garden cress. 


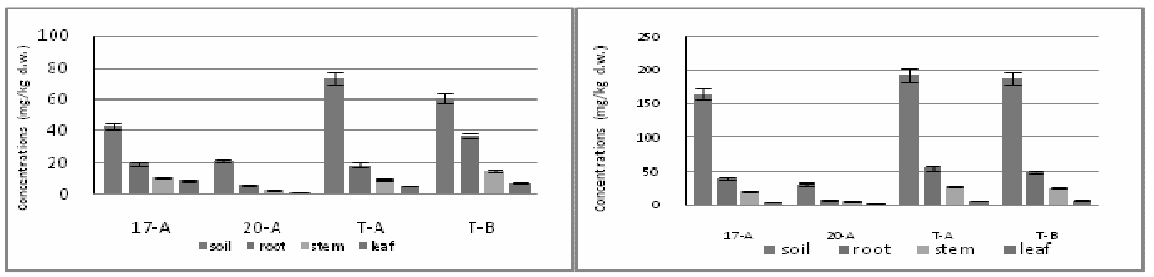

Firuge 2. $\mathrm{Cu}$ concentrations in different samples

Figure 3. Zn concentrations in different samples

\section{Conclusions}

After finishing this investigation it can be established, that the heavy metal content of the soil samples significantly depend on the place of sampling, although the examined area is in better condition than it was expected at the beginning. This investigation is in accordance with other authors's results of garden cress test, which show the highest accumulation were happened in the root (Smolinsk and Cedzynska, 2007). Since it is proved the garden cress was able to absorb and translocate heavy metals, it creates an opportunity to apply it in fitoremediation processes. The heavy metal removal from the ecosystem via melioration in all case increases its resilience.

\section{Acknowledgements}

Á. Bálint acknowledges support of DAAD Project P-MÖB/843. B. Gyarmati acknowledges support of PhD Scholarship for the Ministry of Education and Eötvös Scholarship for the Hungarian Scholarship Board. Special thanks to M. Horváth, Gy. Kampfl and A. Gyarmati for their help. We also would like to thank for the Hungarian Research Found OTKA (consortium K72926, K73326, K73768).

\section{References}

Alvarenga P. et al.: 2008. Evaluation of tests to assess the quality of mine-contaminated soils. Environ Geochem Health, 30: 95-99.

Balint A. - Gyarmati B. - Fodor I. - Kiss R.: 2007. Examination of several heavy metals in plants and soil of a shelter-belt. Cereal Research Communications, 35(2): 193-196.

Filep Gy. et al.: 2002. Szenyennyezett területek kármentesítése, Miskolci Egyetemi Kiadó, Miskolc

Fornes F.et al.: 2009. 'Alperujo' amendment of contaminated calcareous and acidic soils: Effects on growth and trace element uptake by five Brassica species, Bioresource Technology 100: 3982-3990

Gyarmati B. - Meszaros C. - Harshegyi Z. - Kampfl G. - Balint A: 2008. Effect of different nitrogen fertilizer on physiological parameters of garden cress (Lepidium sativum). Cereal Research Communications, 36: 1683-1686.

Győri D. - Palkovics M. - Matusné S. K.: 1998. Helyszíni és laboratóriumi talajvizsgálatok, Egyetemi jegyzet, Keszthely

Herwijnen R. van et al.: 2008. The effect of two different composts on the performance and metal uptake of popular growing on heavy metal contaminated soil. Seesoil, 17: 39-48.

Kadár I. - Morvai B.: 2007. Ipari- kommunális szennyvíziszap - terhelés hatásának vizsgálata tenyészedény kísérletben, Agrokémia és Talajtan, 56: 333-352.

Smolinsk B. - Cedzynska K.: 2007. EDTA and urease effects on $\mathrm{Hg}$ accumulation by Leopidium sativum. Chemosphere, 69: 1388-1395.

Terbe I.: 2000. Levélzöldségfélék (Type of leafvegetables). Dinasztia Kiadó, Budapest, 175-182 


\title{
BACTERIAL COMMUNITIES IN COMPOSTS FROM BIOMASS ENERGY PRODUCTION
}

\author{
Judit HÁHN ${ }^{1}$ - Péter HARKAI ${ }^{1}$ - Zsuzsa NAGY ${ }^{2}$ - Edit KASZAB ${ }^{2}$ - Sándor \\ SZOBOSZLAY ${ }^{2}$ \\ ${ }^{1}$ Regional Center of Excellence, Szent István University, 2100 Gödöllő, Páter K. U. 1. e-mail: \\ Hahn.Judit@kti.szie.hu \\ ${ }^{2}$ Department of Environmental Protection and Safety, Institute of Environmental and Landscape \\ Management, Faculty of Agricultural and Environmental Sciences, Szent István University, 2100 Gödöllő, \\ Páter K. U. 1
}

Abstract: Importance of composting technologies has grown in recent decades. Bacterial communities inhabiting in composting mixtures consisting of communal green waste and sewage sludge were investigated by microbiological cultivation and molecular taxonomic identification.

During the composting procession samples were taken and cultured with tryptone glucose yeast extract No.5 medium. The 73 isolates obtained from composted mixtures of different composition were identified comprehensively. Sequence of their $16 \mathrm{~S}$ ribosomal RNA gene was revealed by PCR method. Our strains proved to be representatives of 42 different species. After a detailed hygienic typifying we found a number of species (e.g. Serratia marcescens, Sphingobacterium mizutae, Pseudomonas aeruginosa) of health risk.

Opportunistic pathogens could be found in all kinds of composting mixtures but in mixture consisted of communal green waste and sewage sludge, and was treated with a combined inoculant preparate. According to the special literature 11 species can be considered as possible tools of biodegradation of polyvinyl alcohol (Microbacterium barkeri), atrazine (Bacillus megaterium), carbon tetrachloride (Pseudomonas stutzeri), phenyl chloride (Sphingopyxis chilensis). Concluding our results we suggest that incidence of opportunistic pathogens in composts should be emphasized more.

Keywords: compost, pathogenic bacteria, biodegradation

\section{Introduction}

During the compost experiment it is possible to permanently and efficiently dispose of organic refuses and also to use the composts as yield-enhancing substances. The composted material that we get is expected to be free of infectious micro- and macroorganisms that can be harmful to human, animal or plant health. According to the Hungarian legislations to authorise the utilisation examinations needed to determine the number of faecal coliform bacteria, faecal Streptococci and Salmonella sp. and also the number of human parasite helminth eggs. Many different kinds of pathogenic microorganisms could be found in the raw material of the compost (communal green waste and sewage sludge, manure) which should be eliminated within the aerob thermofilic phase (60-70 $\left.{ }^{\circ} \mathrm{C}\right)$. More and more studies deal with pathogenic microorganisms living though the thermophilic phase and they can reinfect and colonise again the composts in the mesophilic phase (M. L. Droffner et al., 1995). During the storage, transport and utilisation of the compost an exposure way could open for the pathogenic bacteria. In our studies we used inocula to accelerate composting communal green waste and sewage sludge. After the maturation of the compost we analysed the $16 \mathrm{~S}$ rDNA sequences of the cultured bacteria and followed the changes of the microbiota. 


\section{Materials and methods}

\section{Composted materials and additives}

In the course of composting we used $55 \mathrm{v} / \mathrm{v} \%$ sewage sludge and $45 \mathrm{v} / \mathrm{v} \%$ communal green waste. Right after mixing these components we got samples then we devided them into four equal parts (A, B, C, D). We use pile A - without inoculum treatment - as a control compost pile. Pile B was treated with Pseudomonas and Cellvibrio species (inoculum 1.), pile $\mathrm{C}$ was inoculated with Thermobidia fusca, Bacillus circulans, Scytalidium thermophilum and Paecilomyces variotii species (inoculum 2.). Pile D was treated with the mixture of both inocula. During the experiment sampling from the piles was made two times again, from the thermofilic phase, and the following mesophilic phase equally from the four piles.

\section{Isolation of typical bacteria}

In aseptic circumstances $10 \mathrm{~g}$ of the sample was put into an $300 \mathrm{ml}$ Erlenmeyer flask containing $90 \mathrm{ml}$ distilled water, Tween $80 \mathrm{mix}$ and then shaken for 30 minutes. Then we prepared dilution series from the suspension attenuated to $10^{8}$. 1-1 milliliters of each part of series were put into Petri dishes and poured up by hand warm tryptone glucose yeast extract No. 5 medium (trypton $5.0 \mathrm{~g}$, glucose $5.0 \mathrm{~g}$, yeast extract $2.5 \mathrm{~g}$, agar $15.0 \mathrm{~g}$ in $1000 \mathrm{ml}$ distilled water) and were incubated for 72 hours on $28{ }^{\circ} \mathrm{C}$. After outgrowing of the bacteria we defined the value of $\mathrm{CFU} \mathrm{ml}{ }^{-1}$ and isolated them in pure cultures by different morfological properties.

\section{Identificaton of isolated bacteria}

Species of the isolated strains were identified by $16 \mathrm{~S}$ rDNA amplifying (PCR) of the species specific and semi conservative DNA region by 27 forward and 1492 reverse primers. After that we made a partial sequence analysis with primer 519r and the sequencing of the nucleotide order of the amplified $16 \mathrm{~S}$ rDNA region was compared to the data of international reference DNA collections.

\section{Results and discussion}

As the results shown in the table 1., after 35 days of maturation procedure the incipient $10^{9} \mathrm{CFU} / \mathrm{ml}$ value decreased only 1-2 order of magnitude in the samples in the middle and at the end of compostation. Moreover there was no change in the samples from A and $\mathrm{C}$.

Table 1. CFU ml ${ }^{-1}$ bacteria in the composts treated in different way

\begin{tabular}{|c|c|c|c|c|}
\hline & \multicolumn{4}{|c|}{ Sign of sample } \\
\hline Age of sample & $\begin{array}{c}\mathrm{A} \\
\text { Control pile }\end{array}$ & $\begin{array}{c}\mathrm{B} \\
\text { With inoculum 1. }\end{array}$ & $\begin{array}{c}\mathrm{C} \\
\text { With inoculum 2. }\end{array}$ & $\begin{array}{c}\mathrm{D} \\
\text { With inoculum 1.+2. }\end{array}$ \\
\hline \hline 0. hour & \multicolumn{4}{|c|}{$1,42 * 10^{9}$} \\
\hline 20. days & $1,59 * 10^{7}$ & $7,28 * 10^{8}$ & $4,26 * 10^{8}$ & $2,4 * 10^{8}$ \\
\hline 35. day & $1,45 * 10^{9}$ & $8,26 * 10^{8}$ & $3,23 * 10^{9}$ & $8,85 * 10^{8}$ \\
\hline
\end{tabular}


We isolated 73 different strains of bacteria on tripton glucose yeast extract No. 5 medium, and as the $16 \mathrm{~S}$ rDNA sequence analysis showed they belong to 42 different species and 20 of them have significant health risk. Potentially pathogenic bacteria - we found in the first sample - at the begining of the composting are shown in table 2. Table 3. and 4. represent the isolated pathogenic bacteria from the four different piles in the thermophilic and mesophilic phase.

Table 2. Potentially pathogenic bacteria in the start-up sample ( 0 . hour)

\begin{tabular}{|l|l|}
\hline Alcaligenes faecalis subsp. phenolicus & Ochrobactrum anthropi \\
\hline Alcaligenes faecialis & Providencia rettgeri \\
\hline Enterobacter hormaechei subsp. steigerwaltii & Serratia rubidaea \\
\hline Klebsiella pneumoniae & Stenotrophomonas maltophilia \\
\hline Klebsiella pneumoniae subsp. pneumoniae & \\
\hline
\end{tabular}

Table 3. Isolated pathogenic bacteria occurence in the samples on the 20. day

\begin{tabular}{|l|c|c|c|c|c|}
\hline & A & B & C & D & CFUml $^{-1}$ \\
\hline \hline Acinetobacter baumannii & & & + & & $10^{6}$ \\
\hline Burkholderia multivorans & + & & & & $10^{6}$ \\
\hline Enterobacter cloacae & & & & + & $10^{7}$ \\
\hline Ochrobactrum anthropi & & + & & & $10^{6}$ \\
\hline Ochrobactrum intermedium & & + & & & $10^{6}$ \\
\hline Psedomonas alcaligenes & & & & + & $10^{5}$ \\
\hline Pseudomonas mendocina & & & & + & $10^{7}$ \\
\hline Sphingobacterium multivorum & & + & & & $10^{6}$ \\
\hline Sphingobacterium thalpophilum & & & + & & $10^{7}$ \\
\hline Serratia marcescens subsp. marcescens & & + & & & $10^{2}$ \\
\hline
\end{tabular}

Table 4. Isolated pathogenic bacteria occurence in the samples on the 35. day

\begin{tabular}{|l|c|c|c|c|c|}
\hline & A & B & C & D & CFUml $^{-1}$ \\
\hline \hline Ochrobactrum pseudintermedium & & + & & + & $10^{7}-10^{8}$ \\
\hline Pseudomonas aeruginosa & & & & + & $10^{6}$ \\
\hline Serratia marcescens & + & & & & $10^{6}$ \\
\hline Serratia marcescens subsp. marcescens & & & & + & $10^{5}$ \\
\hline Sphingobacterium mizutae & & + & & & $10^{7}$ \\
\hline Stenotrophomonas maltophilia & & & & + & $10^{7}$ \\
\hline
\end{tabular}

According to the results we can state that in the course of maturation the number of pathogenic bacteria was lower as well, although it was significant. Among the different piles $C$ (treated with inoculum 2.) proved to be the most successful, because it was the only sample, which had no pathogenic bacteria after composting process. Pile D, which was treated with mixed inoculum contained the most pathogenic bacteria. According to the special literatures 11 identified species are able to biodegrade certain materials, but three of them potentially pathogenic, and two species had never been described in Hungary. The list of the species and the materials they can biodegrade is found in Table 5. 
Table 5. Special species were isolated from the compost samples.

\begin{tabular}{|l|l|c|}
\hline \multicolumn{1}{|c|}{ Species } & $\begin{array}{c}\text { Biodegradable materials or the fact } \\
\text { of first isolation in Hungary }\end{array}$ & Risk Group \\
\hline \hline Alcaligenes faecalis subsp. phenolicus & Phenol & 2 \\
\hline Bacillus megaterium & Atrazine as nitrogen source & 1 \\
\hline Brevibacillus panacihumi & Firstly identified in Hungary & 1 \\
\hline Gordonia paraffinivorans & Hydrocarbons & 1 \\
\hline Microbacterium barkeri & PVA (polyvinyl-alcohol) & 1 \\
\hline Ochrobactrum anthropi & PAH, TPH & 2 \\
\hline Pseudomonas alcaligenes & PAH, 2,4-dichlorphenol & 2 \\
\hline Pseudomonas pseudoalcaligenes & Nitrobenzene, PCB oxidation & 1 \\
\hline Pseudomonas citronellosis & Atrazine as nitrogen source & 1 \\
\hline Pseudomonas pictorum & Phenol & 1 \\
\hline Pseudomonas tuomuerensis & Firstly identified in Hungary & 1 \\
\hline Pseudomonas stutzeri & Carbon tetrachlorid, phenanthrene & 1 \\
\hline Sphingopyxis chilensis & Chlorophenol, PHA accumulation & 1 \\
\hline $\begin{array}{l}\text { Risk Group (by German Collection of Microorganisms and Cell Cultures, http://www.dsmz.de/) } \\
1 \text { - not cause human disease }\end{array}$ & & \\
2 - may cause human disease &
\end{tabular}

\section{Conclusions}

During the compost experiment, after the thermophilic phase a huge number of pathogenic bacteria was isolated which may have survived the thermophilic phase and may have colonized the compost piles again during the mesophilic phase. It could be especially problematical that based on the current valid Hungarian legislations there are only a few microorganisms which have to be examined and the vast majority of pathogens isolated by us doesn't belong to these. Thus, the contact with the compost could have potential human and public health risk and an exposure way could open for the pathogenic bacteria. Some of the bacteria isolated by us can be used for biodegradation purposes, besides we have isolated two strains which have never been identified in Hungary. Among the species capable of biodegradation opportunistic pathogens can be found. The application of these species is not recommended because of the reasons mentioned previously. The inoculum used in pile $\mathrm{C}$ is proved to be the most effective and it is likely that it had an important role in decreasing the number of pathogenic miroorganisms. Summarizing all these we should consider more the presence of pathogenic microorganisms after the compost maturating process and should pay attention to analyze them, furthermore to regard the potential health risk of using matured composts.

\section{Acknowledgements}

This study was supported by the NKFP_Ányos Jedlik Programme (OM-00120/2007), BIOKOMP4 grant.

\section{References}

Kim, M. K. - Sathiyaraj, S. - Pulla, R. K. - Yang, D. C.: 2009. Brevibacillus panacihumi sp. nov., a betaglucosidase-producing bacterium. International Journal of Systematic and Evolutionary Microbiology 59: 1227-31

Mary L. Droffner - William F. Brinton, Jr. - Eric Evans: 1995. Evidence for the prominence of well characterized mesophilic bacteria in thermophil $\left(50-70{ }^{\circ} \mathrm{C}\right)$ composting environments. Biomass and Bioenergy 8(3): 191-195 


\title{
BAKING QUALITY PARAMETERS AS THE RESILIENCE INDICATORS IN WHEAT PRODUCTION
}

\author{
Éva SZABÓ
}

Institute of Crop Science, Agronomy Faculty, Centre of Agricultural Science and Engineering, University of Debrecen, H-4032 Debrecen Böszörményi str. 138., e-mail: szaboeva@agr.unideb.hu

\begin{abstract}
Baking quality parameters are good indicators of the flexibility of wheat production for those wheat varieties which showed good and stable baking quality parameters at different fertilization levels and in different years. In our experiment, we studied the baking quality parameters of two wheat varieties (GK Öthalom and Lupus) for five years $(2004,2005,2006,2007,2008)$ on chernozem soil. Fertilization and year had a significant influence. The valorigraph value, wet gluten and protein contents are the most strongly influenced by the year effect. The varieties respond differently to the year effect. The variety Lupus responded better to environmental effects and fertilization, it had stable and good baking quality values in all five years. For baking quality, the fertilizer dose of $\mathrm{N}_{90-120}+\mathrm{PK}$ proved to be the optimum treatment.
\end{abstract}

Keywords: winter wheat, fertilization, crop year, backing quality, resilience indicator

\section{Introduction}

The year and the technological procedures, treatments applied basically determine the milling and baking quality of wheat. Quality is a genetically determined trait of the variety, which can be asserted, deteriorated by agronomical methods, but cannot be improved anyhow. (Jolánkai et al., 2004).According to Győri and Györiné (1998), the year basically determines the uptake and accumulation of nutrients, therefore, it has an extremely large impact. According to Vida and Jolánkai (1995), baking quality is good when precipitation is good during April and May and weak in June and July. In poor varieties, baking quality was not good even under favourable agroecological conditions. The applied fertilization significantly influenced the baking quality. According to Peterson et al. (1998), the environmental factors have a significant effect on wheat quality. The winter wheat genotypes respond differently to the environmental factors. According to Pepó (2005), ecological factors account for one third of the effect determining wheat quality (weather $22 \%$, soil $10 \%$ ) under normal conditions. Variety selection is the starting point of quality wheat production (27\% influencing effect). Among agrotechnical factors, the elements of direct effect (primarily fertilization and crop protection) and the factors of indirect effect (forecrop, sowing, harvesting) determine the baking quality of wheat in $25 \%$ and $16 \%$, respectively. According to Tanács et al. (2006), variety and the year effect are of decisive importance in the formation of wet gluten content and baking parameters.

\section{Materials and methods}

The field experiments were carried out at the Látókép Experimental Station of the Institute of Crop Sciences, University of Debrecen. The soil of the experiment is calcareous chernozem. Our study contains the results of the period 2004-2008. The small-plot field experiment was set up in a split-split-plot design in four replications. Six fertilization levels were applied in the treatments. In addition to the control, the basic dosage of $\mathrm{N}=30 \mathrm{~kg} \mathrm{ha}^{-1}, \mathrm{P}_{2} \mathrm{O}_{5}=22.5 \mathrm{~kg} \mathrm{ha}^{-1}$ and $\mathrm{K}_{2} \mathrm{O}=26.5 \mathrm{~kg} \mathrm{ha}^{-1}$ and 2-, 3-, 4and 5-fold dosages were applied. The total $\mathrm{P}$ and $\mathrm{K}$ dosages were applied in the autumn, $50 \%$ and $50 \%$ of the $\mathrm{N}$ fertilizer dosages were applied in the autumn and in the spring. 
The forecrop was sweet maize. The precipitation values during the season and the temperature data during the period of 2004-2008 are presented in Table 1.

Table 1. Main meteorological data of vegetation period (Debrecen, 2004-2008)

\begin{tabular}{|c|c|c|c|c|c|c|c|c|c|c|}
\hline & $\mathrm{O}$ & & & Jan. & Feb.I & Mar. & Apr.May & Jun. & \begin{tabular}{|c|} 
Total/ \\
Average
\end{tabular} & Diff \\
\hline Precipitation (mm) 2004 & 90 & 21. & 8 & 37,2 & 446 & 6.5 & 40,017 & 61,7 & 376,5 & $-24,4$ \\
\hline Precipitation (mm) 2005 & 538,9 & 63,5 & 33,7 & 18,2 & 40,6 & 10,5 & $74,975,8$ & 54,3 & 410,4 & 9,5 \\
\hline Precipitation (mm) 2006 & 67,0 & 12,6 & 83,5 & 522,5 & 544,2 & 79,0 & $92,358,3$ & 77,1 & 476,5 & 75,6 \\
\hline Precipitation $(\mathrm{mm}) 2007$ & 722,9 & 9,2 & 5,0 & 23,9 & 53,2 & 14,0 & $3,654,0$ & 22,8 & 208,6 & $-192,3$ \\
\hline Precipitation (mm) 2008 & 871,4 & 40,9 & 29,8 & 26,4 & 4,6 & 41,7 & $74,947,6$ & 137,8 & 475,1 & 74,2 \\
\hline 30 year's average & 30,8 & 35,2 & 43,5 & 57 & 30,2 & 233,5 & $42,458,8$ & 79,5 & 400,9 & 0 \\
\hline \begin{tabular}{|l|} 
Temperature $\left({ }^{\circ} \mathrm{C}\right) 2004$ \\
\end{tabular} & 7,9 & 5,9 & $-0,5$ & $-3,3$ & $-0,7$ & 4,8 & $11,414,8$ & 19,3 & 6,6 & $-0,3$ \\
\hline \begin{tabular}{|l|l|} 
Temperature $\left({ }^{\circ} \mathrm{C}\right)$ & 2005 \\
\end{tabular} & 11,1 & 4,9 & 0,9 & $-0,9$ & $-3,7$ & 2,2 & $10,816,2$ & 18,4 & 6,7 & $-0,3$ \\
\hline Temperature $\left({ }^{\circ} \mathrm{C}\right) 2006$ & 10,8 & 3,5 & 0,2 & $-3,4$ & $-1,4$ & 3,2 & $12,1 \mid 15,4$ & 18,6 & 6,6 & $-0,4$ \\
\hline Temperature $\left({ }^{\circ} \mathrm{C}\right) 2007$ & 11,3 & 6,2 & 2,2 & 3,7 & 4,1 & 9,1 & $|12,6| 18,4$ & 22,2 & 10,0 & 3,0 \\
\hline Temperature $\left({ }^{\circ} \mathrm{C}\right) 2008$ & 9,7 & 3,5 & $-0,6$ & 1,0 & 3,0 & 6,2 & $11,4 \mid 16,8$ & 20,6 & 8,0 & 1,0 \\
\hline 30 year's average & 10,3 & 4,5 & $-0,2$ & $-2,6$ & 0,2 & 5,0 & $10,715,8$ & 18,8 & 6,94 & 0 \\
\hline
\end{tabular}

The years of 2004, 2005 and 2008 were favourable, 2006 was average as regards the vegetative and generative development of winter wheat. The season of 2007 was characterized by the lack of precipitation and by drought, which had an unfavourable effect on the development of winter wheat. The quality parameters were determined at the accredited Central Laboratory of the University of Debrecen, CASE. Wet gluten content, valorigraphic value and falling number were determined according to the standards ISO 5531:1993, MSZ ISO 5530/3:1995 and MSZ ISO 3093:1995, respectively.

\section{Results and discussion}

The results of the baking quality tests for GK Öthalom and Lupus are presented in Tables 2 and 3 respectively. Among the quality parameters, the year effect can be detected most strongly in the valorigraphic value, wet gluten content and the flour protein content. In the case of the falling number, no significant year effect could be observed as the weather at harvest was not rainy in either of the five years. Regarding the valorigraphic values, the variety Lupus gave better values in total in all years than GK Öthalom. The best valorigraphic values of GK Öthalom were 51.1, 64.2, 77.0 in the more favourable years of 2004, 2005 and 2008, respectively, while in the average and less favourable years of 2006 and 2007, the values were 61.5 and 54.7. Contrarily, the valorigraphic values of the variety Lupus, having better qualities due to its genotype, were higher in the favourable years $(72.4,76.5,74.3)$ and also in the average and unfavourable years (65.0 in 2006 and 69.9 in 2007). As the values reveal, the variety Lupus gave yields of excellent quality in the favourable years and it produced good baking quality even in the unfavourable year of 2007, while GK Öthalom could reach only good baking quality in the favourable years. The highest wet gluten contents of variety Lupus were $34.7 \%, 37.6 \%$ and $37.4 \%$ in the favourable years, $37.3 \%$ in the average year of 2006 and $30.2 \%$ in 2007 . The wet gluten content of the variety GK Öthalom in the favourable years of 2004, 2005 and 2008 was $31.3 \%, 31.0 \%$ and $33.2 \%$, respectively. The highest values were $32.3 \%$ in the average year of 2006 and only $25.3 \%$ in the unfavourable year of 2007 . The variety Lupus produced improver quality 
in the favourable years, while GK Öthalom reached only good baking quality in these years. The data revealed that both the year and the genotype have a significant effect on this quality parameter. For the third baking quality parameter, falling number, the effect of year and fertilization was moderate. Within this interval, an increasing trend can be observed in falling number values with increasing NPK fertilizer dosages.

Table 2. Effect of cropyear and fertilization on the baking quality of GK Öthalom (Debrecen, 2004-2008)

\begin{tabular}{|c|c|c|c|c|c|c|c|c|}
\hline Quality parameters & Cropyear & $\varnothing$ & N30+PK & N60+PK & N90+PK & N120+PK & N150+PK & LSD5\% \\
\hline \hline \multirow{4}{*}{ Valorigraphic value } & 2004 & 44,8 & 48,2 & 50,0 & 48,6 & 50,0 & 51,1 & 8,98 \\
\cline { 2 - 9 } & 2005 & 41,9 & 55,6 & 66,8 & 61,6 & 62,3 & 64,2 & 9,49 \\
\cline { 2 - 9 } & 2006 & 48,0 & 51,8 & 61,5 & 60,5 & 57,3 & 56,2 & 6,15 \\
\cline { 2 - 9 } & 2007 & 54,3 & 46,0 & 45,9 & 52,6 & 54,0 & 54,7 & 11,04 \\
\cline { 2 - 9 } & 2008 & 49,0 & 62,5 & 65,3 & 66,1 & 68,0 & 77,0 & 7,89 \\
\hline \multirow{4}{*}{\begin{tabular}{c} 
Wet gluten content $(\%)$ \\
\cline { 2 - 9 }
\end{tabular}} & 2004 & 25,4 & 27,2 & 30,8 & 30,2 & 31,3 & 31,3 & 3,18 \\
\cline { 2 - 9 } & 2005 & 17,7 & 25,3 & 29,8 & 30,4 & 29,8 & 31,0 & 2,19 \\
\cline { 2 - 9 } & 2006 & 28,3 & 28,4 & 30,4 & 32,3 & 31,3 & 31,9 & 1,91 \\
\cline { 2 - 9 } & 2007 & 22,8 & 20,2 & 21,2 & 23,8 & 24,8 & 25,3 & 3,79 \\
\hline \multirow{5}{*}{$\begin{array}{c}\text { Falling number } \\
\text { (sec) }\end{array}$} & 2004 & 20,1 & 26,0 & 29,1 & 29,2 & 32,5 & 33,2 & 1,96 \\
\cline { 2 - 9 } & 2005 & 312 & 329 & 356 & 349 & 334 & 340 & 22,89 \\
\cline { 2 - 9 } & 2006 & 317 & 399 & 359 & 389 & 395 & 397 & 66,04 \\
\cline { 2 - 9 } & 2008 & 318 & 295 & 336 & 327 & 322 & 357 & 41,84 \\
\hline \multirow{4}{*}{$\begin{array}{c}\text { Flour protein } \\
\text { content (\%) }\end{array}$} & 2004 & 10,07 & 10,59 & 12,06 & 12,08 & 12,40 & 12,21 & 0,96 \\
\cline { 2 - 9 } & 2005 & 8,39 & 10,35 & 11,47 & 10,90 & 12,16 & 12,75 & 1,72 \\
\cline { 2 - 8 } & 2006 & 11,89 & 11,42 & 12,72 & 12,84 & 12,97 & 13,83 & 0,86 \\
\cline { 2 - 8 } & 2007 & 10,75 & 10,48 & 11,01 & 10,67 & 10,94 & 11,28 & 0,34 \\
\hline
\end{tabular}

The moderate effect of year can be explained by the fact that weather at harvest, which has the strongest modifying effect on falling number, was dry in all five years, therefore, this quality was modified mostly by the genotype. The falling number values of both varieties were in the excellent quality class. The year also had a strong effect on the protein content of flour. The maximum values of variety Lupus were $13.47 \%$ in $2004,14.3 \%$ in $2005,15.14 \%$ in 2006 and $15.16 \%$ in 2008 . In the less favourable year of 2007 , the protein content was $13.59 \%$. The flour protein content values of the variety GK Öthalom were $12.40 \%, 12.75 \% 13.83 \%$, and $13.81 \%$ in the favourable and average years. In the unfavourable year of 2007 , the protein content was $11.28 \%$. In addition to the effects of year and genotype, the effect of fertilization could also be detected in the valorigraphic values, wet gluten content and the protein content of flour. The valorigraphic values, the wet gluten content and the protein content of the flour showed an increasing tendency as a result of the increasing NPK fertilizer dosages in both varieties. Our research data proved that the fertilizer dosages of $\mathrm{N}_{90-150}+\mathrm{PK}$ can be regarded optimum for achieving a good baking quality in both varieties. Fertilization had a weaker effect on falling number. Consequently, it can be concluded that the year had an effect on most baking quality parameters, but the effect varied with the variety. The variety Lupus was superior to variety GK Öthalom in all quality parameters. 
Table 3. Effect of cropyear and fertilization on the baking quality of Lupus (Debrecen, 2004-2008)

\begin{tabular}{|c|c|c|c|c|c|c|c|c|}
\hline Quality parameters & Cropyear & $\varnothing$ & N30+PK & $\mathrm{N} 60+\mathrm{PK}$ & $\mathrm{N} 90+\mathrm{PK}$ & $\mathrm{N} 120+\mathrm{PK}$ & $\mathrm{N} 150+\mathrm{PK}$ & LSD5\% \\
\hline \multirow{5}{*}{$\begin{array}{l}\text { Valorigraphic } \\
\text { value }\end{array}$} & 2004 & $\begin{array}{l}53,8 \\
\end{array}$ & 62,9 & 688,4 & 72,4 & 70,8 & 72,2 & 19,38 \\
\hline & 2005 & 47,0 & 64,1 & 70,9 & 75,2 & 76,5 & 75,0 & 13,61 \\
\hline & 2006 & 63,6 & 60,0 & 61,7 & 59,6 & 65,0 & 63,4 & 6,64 \\
\hline & 2007 & 47,4 & 56,7 & 62,9 & 60,5 & 66,8 & 69,9 & 6,70 \\
\hline & 2008 & 52,0 & 58,1 & 74,3 & 72,0 & 73,4 & 72,5 & 6,90 \\
\hline \multirow{5}{*}{$\begin{array}{c}\text { Wet gluten content } \\
(\%)\end{array}$} & 2004 & 27,7 & 32,1 & 34,0 & 33,9 & 34,1 & 34,7 & 14,43 \\
\hline & 2005 & 26,9 & 32,5 & 35,6 & 36,0 & 37,6 & 33,5 & 0,42 \\
\hline & 2006 & 32,1 & 34,9 & 35,8 & 37,2 & 37,3 & 37,2 & 2,35 \\
\hline & 2007 & 23,9 & 25,7 & 20,8 & 27,2 & 29,6 & 30,2 & 8,43 \\
\hline & 2008 & 20,2 & 25,3 & 33,3 & 34,1 & 37,4 & 37,0 & 1,81 \\
\hline \multirow{5}{*}{$\begin{array}{l}\text { Falling number } \\
\qquad(\mathrm{sec})\end{array}$} & 2004 & 296 & 312 & 340 & 336 & 319 & 326 & 43,79 \\
\hline & 2005 & 282 & 329 & 362 & 340 & 350 & 347 & 33,75 \\
\hline & 2006 & 354 & 363 & 371 & 369 & 402 & 390 & 34,41 \\
\hline & 2007 & 329 & 333 & 308 & 308 & 329 & 330 & 33,57 \\
\hline & 2008 & 313 & 340 & 343 & 369 & 366 & 365 & 27,75 \\
\hline \multirow{5}{*}{$\begin{array}{c}\text { Flour protein } \\
\text { content }(\%)\end{array}$} & 2004 & 10,88 & 12,24 & 13,42 & 13,37 & 13,47 & 13,40 & 0,81 \\
\hline & 2005 & 9,57 & 12,01 & 13,03 & 14,08 & 14,30 & 13,67 & 0,93 \\
\hline & 2006 & 13,98 & 13,82 & 14,18 & 14,61 & 15,14 & 14,75 & 0,66 \\
\hline & 2007 & 11,29 & 12,08 & 12,71 & 12,71 & 13,59 & 13,35 & 0,65 \\
\hline & 2008 & 11,07 & 11,66 & 13,35 & 13,56 & 15,16 & 14,90 & 0,56 \\
\hline
\end{tabular}

\section{Conclusions}

Based on the obtained results, it can be concluded that the valorigraphic value, the wet gluten content and the protein content are the most strongly influenced by the year effect. Therefore, these quality parameters are the best indicators of resilience of the wheat ecosystem. In the case of falling number, smaller changes or fluctuations could be observed between the favourable and unfavourable years. The varieties respond to the year effect at different extents. The deterioration in the baking quality of variety Lupus caused by the year effect and the negative effects of the environment was smaller due to its better quality potential as compared to that of the variety GK Öthalom. Although the harmful year effects can be prevented to a certain extent by optimal or high-dosage fertilization, the improving impact of fertilization is dependent upon the fertilizer response of the given genotype. In the case of the two tested varieties, the variety Lupus gave a better response both to the environmental effects and to the fertilization treatments, it had stable and good baking quality parameters in all the 5 years.

\section{References}

Győri, Z. - Győriné, Mile, I.: 1998. A búza minősége és minősítése. Mezőgazdasági Szakt. K., Bp. 46-47.

Jolánkai M. - Szőllősi G. - Szentpétery Zs.: 2004. Az őszi búza termesztésnek és minőségének változása különböző évjáratokban. Gyakorlati Agrofórum Extra 6. 6-9.

Pepó P.: 2005. A minőségi és a mennyiségi búzatermesztés kritikus elemei. Gyakorlati Agrof. 16: 9. 13-22.

Peterson, C.J. - Graybosch, R.A. - Shelton, D.R. - Baenziger, P.S.: 1998. Baking quality of hard winter wheat: response of cultivars to environment in the Great Plains. Euphytica. 100: 1/3. 157-162.

Tanács L. - Véha A. - Petróczi I. : 2006. Mủtrágyával és fungiciddel kezelt aestivum búzák nedvessikértartalom, valorigráfos és alveográfos vizsgálatai az évjáratok függvényében. Növénytermelés, 55: 5-6. 335-355.

Vida Gy. - Jolánkai M.: 1995. Eltérő sütőipari minőségű búzafajták vizsgálata különböző évjáratok és termesztési tényezők között. Növénytermelés. 44: 1. 43-54. 


\title{
BIOGAS PRODUCTION USING SILAGE MAIZE HYBRIDS BRED IN MARTONVÁSÁR
}

\author{
Ferenc RÁCZ ${ }^{1}$ - Géza HADI ${ }^{1}-$ Magda PÁL ${ }^{1}$ - Emil BODNÁR ${ }^{2}$ \\ ${ }^{1}$ Agricultural Research Institute of the Hungarian Academy of Sciences, Martonvásár, 2462 Hungary \\ ${ }^{2}$ Bázismag Ltd. Martonvásár, 2462 Hungary
}

Abstract: One important component of up-to-date environment protection and energy management aimed at achieving long-term sustainable development is the widespread use of renewable energy sources including bioenergy. It is particularly important for Hungary which has few fossil fuels but good agricultural potential to exploit this potential as much as possible.

Maize is a very favourable crop as a raw material for bioenergy as its production can be easily integrated into the farm structure.

There are certain differences however in the criteria which must be met by silage maize grown for biogas or feeding purposes. While a high level of methane production is the aim in biogas production the methane produced during the digestion process represents a source of pollution for the environment. In addition the raw material needs to be fermented for 60-90 days to achieve maximum methane production while only 24 hours are available for nutrient utilisation in the digestive system (Herrmann and Taube. 2006).

The cultivation of silage maize for biogas, due to which the energy dependency of farms may also be decreased, can easily be inserted in the existing technological background of farms.

Experiments were set up in Martonvásár in 2008 on eight silage maize hybrids grown in a random block design with two replications. The aim of the work was to determine the quantity of biogas that could be produced from unit dry matter for the most important Martonvásár silage maize hybrids.

Keywords: biogas, methane, silage maize, Lfy,

\section{Introduction}

At present silage maize is grown on an area of approx. 100.000 ha in Hungary Due to the reduction in the livestock numbers this area has declined over the last 15-20 years from around 250.000 ha in the late 1980 s.

Although the expansion of the growing area is currently restricted by the spread of the corn rootworm (Diabrotica virgifera virgifera) the present growing area could definitely be increased. In many countries of Europe the market for agricultural products intended for biogas production has expanded rapidly. In Germany the number of biogas factories has increased from 274 in 1995 to 3200 (Weiland, 2006; 2007; Schittenhelm, 2008). and the area sown to silage maize is likely to increase to 1.7 million ha by 2015 (Gömann et al., 2007). which is ten times the present area.

From the point of view of producing raw materials for bioenergy maize is a very favourable crop. as its production can be easily integrated into the farm structure. especially in dairy farms where all the necessary production technology is available. Under the climatic conditions of Hungary the nutrient requirements of dairy cattle cannot be satisfied by grazing so monodietary feeding based on silage maize is the norm. The conditions required for biogas plants operating with mixed raw materials are also available on these farms but foreign examples make it clear that biogas plants based purely on silage maize are also justified due to the ease with which the raw material production can be integrated into the crop structure.

There are certain differences, however in the criteria which must be met by silage maize grown for biogas or feeding purposes. While a high level of methane production is the aim in biogas production the methane produced during the digestion process represents 
a source of pollution for the environment. In addition the raw material needs to be fermented for 60-90 days to achieve maximum methane production while only 24 hours are available for nutrient utilisation in the digestive system (Herrmann and Taube, 2006).

The aim of the present work was to determine the quantity of biogas that could be produced from unit dry matter for the most important Martonvásár silage maize hybrids.

\section{Materials and methods}

Experiments were set up in Martonvásár in 2008 on eight silage maize hybrids grown in a random block design with two replications. Four of these were normal hybrids (Maros, Mv NK 333, Mv 437, Maxima) and four were leafy (Lfy) hybrids (Mv Siloking, Mv Massil, Mv Dunasil, Mv Limasil).

The data were analysed using multifactorial analysis of variance with the help of the AGROBASE statistical program.

The soil was loam with forest residues. The plots measured $3.8 \mathrm{~m}^{-2}$ and were fertilised with $300 \mathrm{~kg} / \mathrm{ha}$ NPK (1-1-1). Ten plants were cut from each plot on 28 August and. after chopping $0.5 \mathrm{~kg}$ mean samples were taken from each variety and stored at $-18^{\circ} \mathrm{C}$ until processing.

Prior to fermentation the samples were dried in a drying cabinet at $50^{\circ} \mathrm{C}$ for 48 hours to determine the dry matter content (Table 1).

Fermentation was carried out in 4-litre fermentation tanks fitted with a gas meter. Samples containing $12 \mathrm{~g}$ dry matter were mixed with 4 litres of degassed filtered inoculum so that the dry matter of the sample made up $0.3 \%$ of the total. In all cases the gas production of the inoculum was also tested.

Table 1. Dry matter content of the hybrids investigated

\begin{tabular}{|c|c|c|c|}
\hline \multirow{2}{*}{ Variety } & \multicolumn{3}{|c|}{ Dry matter \% } \\
\cline { 2 - 4 } & $1^{\text {st }}$ replication & $2^{\text {nd }}$ replication & Mean \\
\hline \hline Maros (FAO 330) & 37.6 & 43 & 40.3 \\
\hline Mv Limasil (FAI 380) & 40.6 & 35.7 & 38.15 \\
\hline Mv NK 333 (FAO 390) & 37.8 & 32.6 & 35.2 \\
\hline Mv Dunasil (FAO 390) & 39 & 43.6 & 41.3 \\
\hline Mv 437 (FAO 480) & 39.3 & 26.4 & 32.85 \\
\hline Maxima (FAO 580) & 39.9 & 35.4 & 37.65 \\
\hline Mv Massil (FAO 610) & 39.9 & 34.3 & 37.1 \\
\hline Mv Siloking (FAO 580) & 32.9 & 36.2 & 34.55 \\
\hline
\end{tabular}

The fermentor was operated at a temperature of $37-40^{\circ} \mathrm{C}$ and a $\mathrm{pH}$ of $7-8$. The contents were stirred once a day. Daily measurements were made on the quantity and composition of the biogas produced (methane. carbon dioxide. oxygen. hydrogen sulphide) and the temperature was checked. 
After gas production ceased the residual material was filtered and the dry matter content of the material retained on the filter was determined using the same method as for the raw material.

\section{Results and discussion}

The biogas yield of eight Martonvásár silage maize hybrids was examined in 2008. In terms of $1 \mathrm{~kg}$ dry matter the greatest quantity of gas $\left(\mathrm{LSD}_{5 \%}=15.7\right)$ was produced by the hybrids Mv Limasil (494.5 1/kg dry matter) and Mv Dunasil (490 1/kg dry matter) and the least by Mv NK 333 (409 1/kg dry matter) (Table 2). The grand mean of the experiment was $451.88 \mathrm{l} / \mathrm{kg}$ dry matter.

Table 2. Biogas production of silage maize hybrids

\begin{tabular}{|c|c|c|c|}
\hline \multirow{2}{*}{ Variety } & \multicolumn{2}{|c|}{ Specific biogas yield (1/kg raw material dry matter) } \\
\cline { 2 - 4 } & \multicolumn{2}{|c|}{ Bevitt szárazanyagra } \\
\cline { 2 - 4 } & $1^{\text {st }}$ replication & $2^{\text {nd }}$ replication & Mean \\
\hline \hline Maros (FAO 330) & 488.8 & 474.2 & 481.5 \\
\hline Mv Limasil (FAI 380) & 497.1 & 492.1 & 494.6 \\
\hline Mv NK 333 (FAO 390) & 400.0 & 417.5 & 408.8 \\
\hline Mv Dunasil (FAO 390) & 489.6 & 491.3 & 490.4 \\
\hline Mv 437 (FAO 480) & 461.3 & 464.2 & 462.7 \\
\hline Maxima (FAO 580) & 442.5 & 438.3 & 440.4 \\
\hline Mv Massil (FAO 610) & 409.6 & 412.9 & 425.0 \\
\hline Mv Siloking (FAO 580) & 425.0 & 425.0 & 41.3 \\
\hline
\end{tabular}

Table 3. Percentage gas production

\begin{tabular}{|c|c|c|c|}
\hline \multirow{2}{*}{ Variety } & \multicolumn{3}{|c|}{ Percentage gas production } \\
\cline { 2 - 4 } & $1^{1}$ st replication & $2^{\text {nd }}$ replication & Mean \\
\hline \hline Maros (FAO 330) & 88,50 & 88,75 & 88,6 \\
\hline Mv Limasil (FAI 380) & 89,92 & 88,17 & 89,0 \\
\hline Mv NK 333 (FAO 390) & 88,00 & 89,08 & 88,5 \\
\hline Mv Dunasil (FAO 390) & 88,75 & 88,42 & 85,2 \\
\hline Mv 437 (FAO 480) & 85,75 & 84,67 & 85,7 \\
\hline Maxima (FAO 580) & 87,33 & 86,08 & 86,8 \\
\hline Mv Massil (FAO 610) & 85,67 & 85,25 & 86,92 \\
\hline Mv Siloking (FAO 580) & 86,58 & \multicolumn{3}{|c|}{} \\
\hline
\end{tabular}


Averaged over the eight hybrids tested the mean percentage gas production was $87.37 \%$ (Fig. 3). The highest values were achieved for Mv Limasil (89.5\%) and Maros $(88.63 \%)$. Significant differences were observed between the hybrids $\left(\operatorname{LSD}_{5 \%}=1.57\right)$.

\section{Conclusions}

The hybrids with the highest biogas yields all belonged to the early maturity group. A correlation of -0.64 was found between the gas yield and the FAO number. However the greater yield potential of varieties with longer vegetation periods was able to compensate for this disadvantage. Environmental resilience, especially pollution load can be influenced by the use of appropriate biological bases in renewable energy production.

The results obtained suggest, that there was no correlation found in the present work between the Lfy gene and the biogas production.

\section{Acknowledgement}

The project was financed jointly by the European Union and the European Regional Development Fund
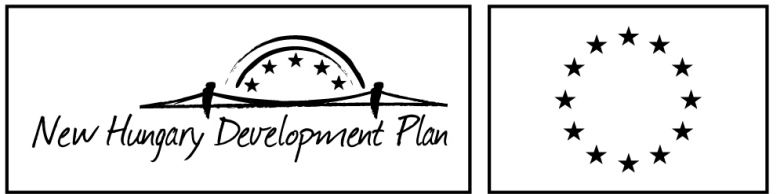

\section{References}

Gömann. H. - Kreins. P. - Osterburg. B. - Breuer. T.: 2007. Nutzungskonkurrenzen durch die Förderung von Biogas und anderen Energieträgern. Agrarspectrum 40. 135-150.

Herrmann. A. - Taube. F.: 2006. Die energetische Nutzung von Mais in Biogasanlagen - Hinkt die Forschung der Praxis hinterher? Berichte über Landwirtschaft 84. 165-197.

Schittenhelm. S.: 2008. Chemical composition and methane yield of maize hybrids with contrasting maturity. European Journal of Agronomy 29. 72-79.

Weiland. P.: 2006. Biomass digestion in agriculture: a successful pathway for the energy production and waste treatment in Germany. Eng. Life Sci. 6. 302-309.

Weiland. P.: 2007. Biogas - Stand und Perspektiven der Erzeugung und Nutzung in Deutschland. Agrarspectrum 40. 111-122. 


\title{
COMPARATIVE RESEARCHES ON RESILIENCE OF SPECIES COMPOSITION AND BIOMASS PRODUCTIVITY IN PASTURES AND HAYFIELD OF THE BALATON UPLANDS, HUNGARY
}

\author{
Szilárd SZENTES ${ }^{1}$ - Judit HÁZI ${ }^{2}$ - Sándor BARTHA ${ }^{3}$ - Zsuzsanna SUTYINSZKI ${ }^{2}$ - \\ Károly PENKSZA 2* \\ ${ }^{1}$ Szent István University, Faculty of Agricultural and Environmental Sciences, Institute of Plant Production, \\ Department of Grassland Management \\ ${ }^{2}$ Szent István University, Faculty of Agricultural and Environmental Sciences, Institute of Environmental and \\ Landscape Management, Department of Nature Conservation and Landscape Ecology \\ ${ }^{3}$ Hungarian Academy of Sciences, Institute of Ecology and Botany \\ "Corresponding author: K. Penksza, SZIE, 2103 Gödöllő, Páter K. 1. Hungary, penksza@ gmail.com
}

Abstract: Phytocenological releves were collected in two territories of the Balaton Uplands National Park (Hungary) dominated by grassland habitats. Studies were broadened to four areas of the Taploca Basin (undergrazed and overgrazed pastures, hayfield, control area) in 2007 and performed also in 2008. The areas were suitable for following up the changes of vegetation and production in every grazing season of a year. We evaluated the changes of species composition and ground cover, the measure of possible regeneration or degradation, and the changes of these factors in the point of view of feeding value.

In case of the Taploca Basin, low number of species (20 to 30) was detected in the undergrazed pasture and the control area. About one month per year grazing time in the undergrazed area was not enough to achieve a better state for species diversity, and the amount of forage remained high. The overgrazed pasture carries a low forage value and contains a high number of weed species, despite the spectacularly high total number of plant species (38 to 39), consequently, grazing pressure has to be decreased. Although the number of species is lower in the hayfield (26 to 27), species composition and ability for forage supply is much better, showing that the proper management of the area is taken here.

Keywords: grazing, pasture, hayfield, species composition, biomass productivity

\section{Introduction}

Separate animal breeds were bred to be best adapted to the climatic conditions of the Pannon region. The domestic Hungarian Grey Cattle had originally been grazing on wet grasslands, but it has almost been extinct. Similar to other EU countries, agricultural intensification was typical in Hungary between 1960 and 1980 and it ended in the same way as everywhere (Gregory et al., 2005). After changing the regime, productivity has significantly fallen (Báldi and Faragó, 2007). Excess use of herbicides and chemical fertilizers and the homogenization of the landscape were also characteristic phenomena on some grasslands (Benton et al., 2003; Robinson and Sutherland, 2002; Tscharntke et al., 2005). In the EU countries, agro-environmental programs were launched in order to stop or even reverse the decline of biodiversity (Kleijn and Sutherland, 2003). In Hungary, this effort was supported by the National Agro-environmental Program (NAKP) and the 2253/1999 (X.7.) government decree.

Hungarian Grey Cattle has come into the focus as a result of incentives for the sustainable use of grasslands, and has become the main preserver of grasslands under nature protection. Contrary to the traditional grazing methods, Hungarian Grey Cattle can be kept on the pasture for a longer period (from April till November, through 200 to 240 days). The labour demand is low and the rotational grazing system proved to be the most effective. The beef productivity per area unit depends not only on the performance of the animal, but on the head of cattle per area unit and the effectiveness of the use of pasture as well. There is negative correlation between the effectiveness of pasture use 
and the production per animal, but positive between the amount of ingestion and grass supply, if animals have the chance to select (Penning et al., 1986).

Natural grasslands were observed during the researches on botany and grassland management, and laying emphasize on the maintenance of nature conservation values as well. The current contribution presents a common view on extensively cultivated Transdanubian grasslands and detailed results in the Taploca Basin, where changes in vegetation, management type and nature conservation values are all important.

\section{Materials and methods}

Coenological studies were prepared on grazed grasslands and wet meadows in the Taploca Basin near Badacsonytördemic in 2007 and 2008, all belonging to the Balaton Uplands National Park (Hungary). The first phytocenological releves had been taken. Studies were broadened to the Taploca Basin in 2007 and performed also in 2008. Four areas were studied in the Taploca Basin (undergrazed and overgrazed pastures, hayfield and control area). The areas were suitable for following up the changes of vegetation and production in every grazing season of a year.

Standard phytocenological releves ( 5 each $2 \times 2 \mathrm{~m}$ ) were examined on each sample area, prepared according to the Braun-Blanquet method (Braun-Blanquet, 1964) in April, May, June, August and September 2008. For evaluation, plant cover (D) and species number (n) were chosen from the analytical parameters and distribution of nature conservation value categories (TVK) (Simon, 2000) from the synthetic parameters.

In parallel with coenological studies, production studies were also made 5 times per year. Vegetation was cut in certain designated points of the pasture and the hayfield, on a $1 \times 1 \mathrm{~m}$ plot, at a height of $7 \mathrm{~cm}$ above the surface. Cutting and measuring shoot biomass was also prepared on the control area in favour of determining potential accession. Cut shoot biomass was separated into the groups of Poaceae species important for grassland management; other Poaceae species, Fabaceae species important for grassland management; Carex and monocotyledonous species neutral for grassland management; dicotyledonous species neutral for grassland management; dead shoot biomass. The separated shoot biomass was dried in a dryer machine at $70{ }^{\circ} \mathrm{C}$ and weight was given in grams.

During grassland management studies, ratio and quantity of medicinal herbs, forage value and grassland management categories were analyzed. Forage values of significant species occurring in the grassland were determined according to the 10stage scale of Klapp et al., (1953), which gives value 8 for species with high forage value, 0 for those with the least value or not grazed by animals and -1 for poisonous species.

\section{Results and discussion}

Shoot biomass left by grazing animals was measured on the pastures, except for the data from April (Figure 1), when production before grazing is presented. These data from April are almost the same in the pastures and in the hayfield. The greatest amount was measured in the overgrazed area, as an effect of manure the fields in the previous year. Amounts are 5 to $10 \%$ less on the control area. 


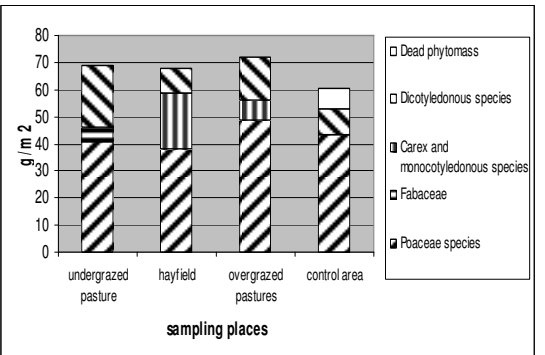

Figure 1. Green biomass production in April

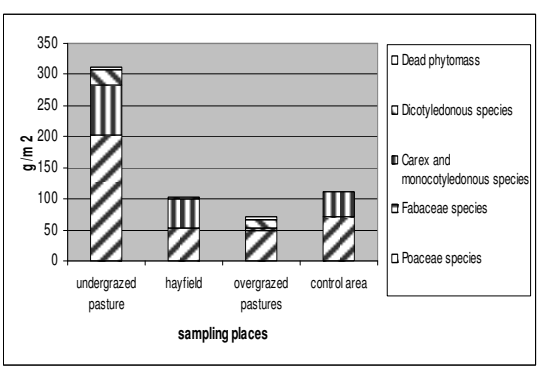

Figure 2. Green phytomass production in May

Phytomass production was greater in May than in April at every sample area. Almost 100 grams was produced on the hayfield and on the control area. About 300 grams was measured on the undergrazed area, resulting from the composition of the grassland, with a significant weight of Festuca arundinacea, giving the greatest part of the Poaceae mass (200 grams), growing intensively in this period. Only 65 grams of dry mass was measured on the overgrazed area (Figure 2).

Due to climatic conditions, greatest shoot biomass was measured in June (Figure 3). 155 grams dry matter was produced on the hayfield and 125 grams on the control area. Over 300 grams was measured on the undergrazed area, showing non-significant growth compared to May. The composition of the shoot biomass has shifted, as the amount of sedges (Carex spp.) has increased at the expense of grass species (Poaceae) at every sample area.

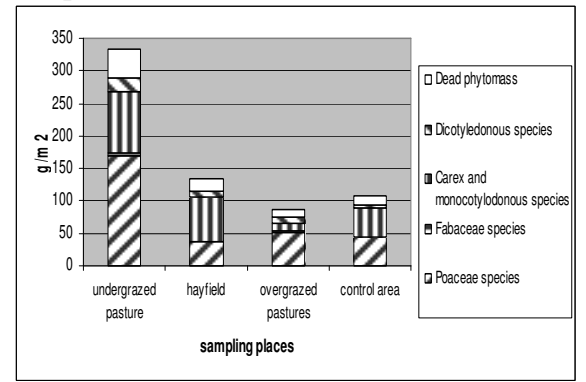

Figure 3. Green phytomass production in June

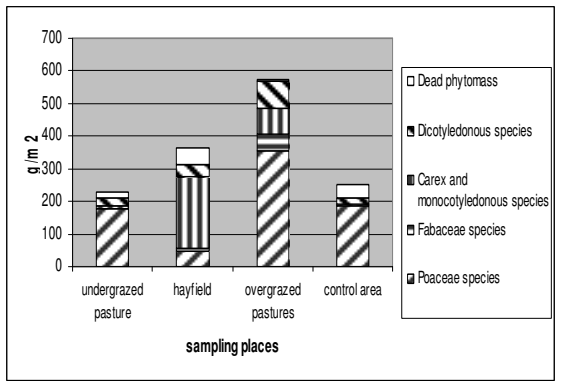

Figure 4. Green phytomass production in August

Shoot biomass weights have significantly changed by August (Figure 4). Cattles were shepherded onto the undergrazed area, thus, there was a mass decrease in the shoot biomass of that area. An outstanding weight was measured on the overgrazed area, being also a result of manure since April. The amount of dead shoot biomass has increased at every sample area due to summer dryness.

As a result of rainfalls, shoot biomass weights have significantly increased by September at every sample area (Figure 5). Cattles were shepherded back to the previous (overgrazed) pasture and have grazed almost all the feeding plants. Shoot biomass values increased in the other 3 areas. The amount of dead shoot biomass has increased at every sample area due to the autumn period, especially on the undergrazed area. 


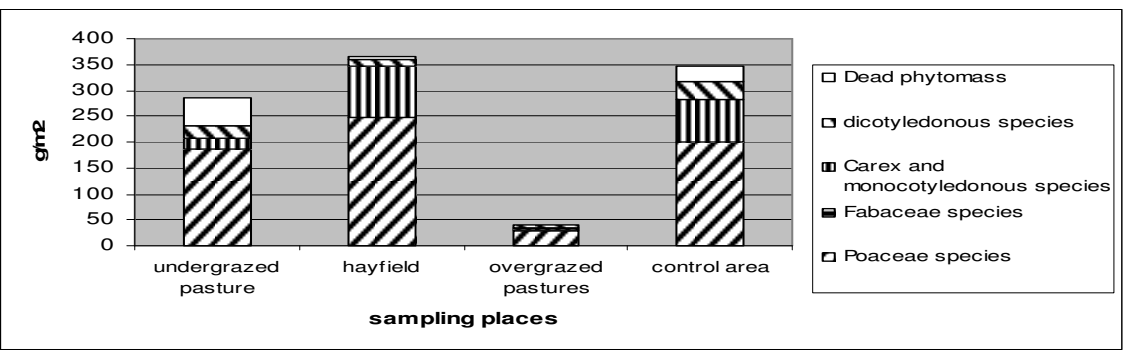

Figure 5. Green phytomass production in September

Based on nature conservation value categories, the undergrazed area is dominated by natural disturbance tolerant species and association composing species. Rate of natural disturbance tolerant species was above $50 \%$ in the overgrazed area every time, referring to overgrazing. Association composing species have disappeared from the grassland by the end of the year. Almost $50 \%$ of the surface of sample plots on the hayfield was covered by association composing species. High rate of weed is composed mainly by Carex hirta.

\section{Conclusions}

Total dry biomass weight of the year is $1228 \mathrm{~g}$ in the undergrazed area, $1035 \mathrm{~g}$ in the hayfield, $843 \mathrm{~g}$ in the overgrazed area and $879 \mathrm{~g}$ in the control (non-grazed) area. This means 12,28 t / 10,35 t / 8,43 t / 8,79 $\mathrm{t}$ of hay per hectare. The greatest amount was measured in the undergrazed area, one month per year grazing time in the undergrazed area was not enough to achieve a better state for species diversity, and the amount of forage remained high. The overgrazed area has a low forage value and contains a high number of weed species, despite the spectacularly high total number of plant species.

The hayfield species composition is showing that the proper management of the area is taken here.

\section{References}

Báldi A. - Faragó S.: 2007. Long-term changes of farmland game populations in a post-socialist country (Hungary). Agriculture, Ecosystems \& Environment, 118: 1-4. 307-311.

Benton T. G. - Vickery J. A. - Wilson J. D.: 2003. Farmland biodiversity: is habitat heterogeneity the key? Trends in Ecology and Evolution, 18: 4. 182-188.

Braun-Blanquet J.: 1964. Pflanzensoziologie 3. Aufl. Wien, Springer-Verlag.

Gregory R. D. - van Strien A. - Vorisek P. - Meyling A. W. G. - Noble D. G. - Foppen P. B. - Gibbons D. W.: 2005. Developing indicators for European birds. Philosophical Transactions of the Royal Society Biological Sciences, 360: 1454. 269-288.

Klapp E. - Boeker P. - König F. - Stählin A.: 1953. Wertzahlen der Grünlandpflanzen. Grünland, 2: 53. 3840.

Kleijn D. - Sutherland W.J.: 2003. How effective are European agri-environment schemes in conserving and promoting biodiversity? Journal of Applied Ecology, 40: 6. 947-969.

Penning P.D. - Hooper G.E. - Treacher T.T.: 1986. The effect of herbage allowances on intake and performance of ewes suckling twin lambs. Grass and Forage Science, 41: 3. 199-208.

Robinson R.A. - Sutherland W.J.: 2002. Post-war changes in arable farming and biodiversity in Great Britain. Journal of Applied Ecology, 39: 1. 157-176.

Szemán L.: 2003. Parlag gyepek javítása. Gyepgazdálkodási Közlemények, 1: 1. 42-45.

Tscharntke T. - Klein A.M. - Kruess A. - Steffan-Dewenter I. - Thies C.: 2005. Landscape perspectives on agricultural intensification and biodiversity - ecosystem service management. Ecology Letters, 8: 857874 


\title{
CORRELATIVE ANALYSIS OF MONTHLY VALUES OF APPLE AND CORN EVAPOTRANSPIRATION (ET) WITH EVAPORA- TION (E) AND POTENTIAL EVAPOTRANSPIRATION (PET)
}

\author{
Hamid CUSTOVIC
}

Faculty of Agriculture and Food Sciences, University of Sarajevo, St. Zmaja od Bosne 8, 71000 Sarajevo, BiH, e-mail: custovic.hamid@gmail.com

\begin{abstract}
This paper addresses a correlative analysis between the apple and corn ET on one, and evaporation measured by Piche and by Class A, as well as PET calculated by Thornthwaite, Turc and Penman, on the other hand. Based on the obtained results, the statistical analysis with regression equation and correlation coefficient shows a rather reliable relation between ET of apple and corn with E by Piche, while the subject relation between ET of apple and corn with Class A is even more reliable. Other methods in the correlative analysis are less reliable.
\end{abstract}

Keywords: lyzimeters, correlation, evapotranspiration, evaporation, apple, corn

\section{Introduction}

Water budgeting computer programs (SPAW, WIF) used to program irrigation, drainage outflow, water quality control and water stress in plants, being one of the key parameters, require real evapotranspiration (RET) data for specific crops. Given the fact that the measured RET data are rarely available, they can be obtained indirectly by finding a reliable correlation between crop RET on one, and measured E or calculated PET on the other side. In US and some other countries the Class A evaporation is used as a reference in making a reliable assessment of ET in various crops. The evaporation by Piche is believed to be less reliable, however it is widely spread in France, perhaps due to its simple application. Based on Class A evaporation, a special method for calculation of PET (FAO, No 24 and 33) has been developed.

With the development of agro-hydrology, this issue has been addressed in a more versatile way which includes meteorological, hydro-pedological and crop aspects. In this sense, a huge contribution was made by Thorntwate (1948), by introducing the terms of potential evapotranspiration (PET) and real evapotranspiration (RET).

Roblen (1958) was the first to evaluate the SET/PET ratio in programmed yield of agricultural crops, and develop a diagram, where SET/PET ratio. The same author made the following conclusion: the yield of agricultural crops presented by ratio of real and programmed maximum yield represents a linear function of the SET/PET quotient. This quotient has been accepted by many authors.

Clothier(1989) stated that divergent perceptions in agro-hydrology are a consequence of poor cooperation of scattered scientific disciplines lacking joint effort in studying the limiting role of water in development of agricultural crops.

\section{Materials and methods}

At the Lysimetric station in Popovo field, the following researches were conducted during a two-year period: a) measuring of evaporation (E) during the vegetation period (May - September) by Class A in the open, and by Pich in thermo-shield, b) calculation of potential evapotranspiration (PET) by Thorntwate, Turc and i Penman, c) measuring 
of maximal consumption of water on ET under the condition of unlimited water supply in apple and corn crops, using the lysimeter, in order to obtain data on real evapotranspiration (RET) for subject crops, c) performed correlation analysis of RET in apple and corn by Pich and Class A, as well as PET by Thorntwate, Turc and Penman.

\section{Results and discussion}

The results obtain during the two year research on major agri-hydrological parameters at the lysimeter station in Popovo field, show the following:

Mean evaporation (E) during the two years of trial, within the May - September periods), on evapometer of Class A amounted to $1138 \mathrm{~mm}$, while on evapometer by Pich, it amounted to $1476 \mathrm{~mm}$. On average, the evaporation by Pich was bigger by $29.70 \%$, which represents a considerable difference. The potential evapotranspiration (PET) was calculated by three methods, i.e Thorntwate, Turc and Penman. The mean values of PET during this two year trial, within the May - September periods, amounted to $586 \mathrm{~mm}$ by Thorntwate, $603 \mathrm{~mm}$ by Turc and $703 \mathrm{~mm}$ by Penman. The relative (index) ratios (Thorntwate $=100$ ) were the following: Thorntwate -100 , Turc -103 and Penman - 117. Evapotranspiration was measured in the situation of unlimited water supply in apple and corn crops, by using lysimeter, and data on real evapotranspiration (RET) in subject crops was thus obtained. The average water consumption over the twoyear period of trial, within the May-September period, amounted to $552 \mathrm{~mm}$ in apple, and $941 \mathrm{~mm}$ in corn. The energy available in atmosphere on one, and developmental stage of the crops on the other hand have a huge impact on the rhythm of water consumption in the majority of floral species, to include apple and corn, Table 1. Higher consumption of water in the second year most likely was a consequence of higher availability of energy in the atmosphere in that particular year (on average temperature for 5 months in the first year was $19.9^{\circ} \mathrm{C}$, and for 5 months in the second year was 21.5 $\left.{ }^{\circ} \mathrm{C}\right)$.

Table 1. Real evapotranspiration (RET) in $\mathrm{mm}$

\begin{tabular}{|l|l|l|l|l|}
\hline \multirow{2}{*}{ Month } & \multicolumn{2}{|l|}{ Apple (Granny Smith) } & \multicolumn{2}{l|}{ Corn ( Hybrid from FAO group 300) } \\
\cline { 2 - 5 } & First year* & Second year** & First year* & Second year** \\
\hline \hline May & 49 & 85 & 48 & 90 \\
\hline June & 106 & 106 & 118 & 159 \\
\hline July & 142 & 134 & 239 & 448 \\
\hline August & 128 & 129 & 261 & 275 \\
\hline September & 107 & 119 & 135 & 109 \\
\hline Total & 532 & 573 & 801 & 1.081 \\
\hline Average for 2 years & \multicolumn{2}{|c|}{941} \\
\hline
\end{tabular}

*average temperature for 5 months in the first year was $19.9^{\circ} \mathrm{C}$

** average temperature for 5 months in the second year was $21.5^{\circ} \mathrm{C}$

Correlative analysis of monthly SET, E and PET values: This paper provides a correlative analysis of apple and corn RET on one side, and evaporation measured by Pich and Class A, as well as calculated PET by Thorntwate, Turc and Penman, on the other side. 
Correlation between apple and corn RET and E by Pich and Class A: The statistical analysis with regression equations and correlation coefficients shows a considerably reliable relation between RET of apple $(\mathrm{r}=0.793)$ and corn $(\mathrm{r}=0.781)$ and E by Pich, during the vegetation period 199/90 g. (Fig. 1). This relation is similar for RET of apple $(r=0.819)$ and corn $(r=0.948)$ and E by Class A (Fig. 2). This relation is somewhat more reliable in case of apple and corn RET and E by Class A, than in case of $\mathrm{E}$ by Pich. This may be the reason why evaporation from Class $\mathrm{A}$ is used in a number of countries as a reference information for RET of various agricultural crops. However, it has to be stressed that verification over a longer period of time is required, although not too much time is being spent on finding practical solution to the problem in the world, considering the fact that the research network at local levels is much thicker.

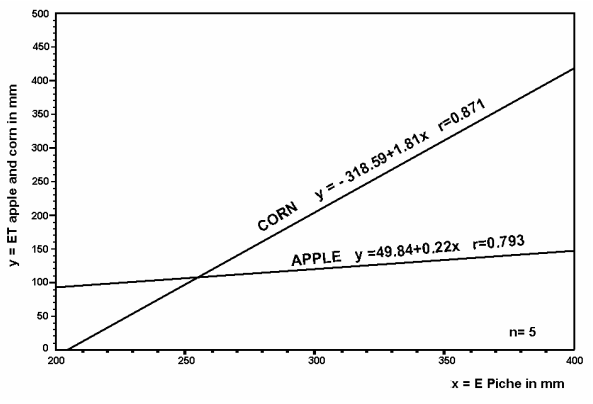

Figure 1. Correlation between monthly ET of Aple and Corn (Y) and E Piche (X)

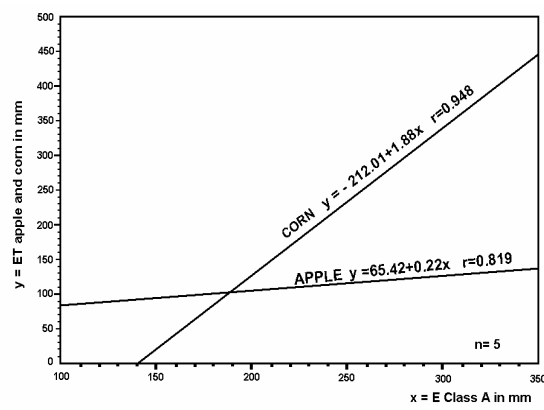

Figure 2. Correlation between monthly ET of Aple and Corn (Y) and E Class (X)

Correlation between apple and corn RET and PET by Thornthwaite, Turc and Penman: The statistical analysis with regression equations and correlation coefficients between apple and corn RET on one, and PET calculated by Thornthwaite, Turc and Penman on the other side, becomes evident from the diagram shown in Fig. 3, 4, 5. It encompasses two-year results for the period May-September $(n=10)$, and provides the following correlation coefficients (Table 2).

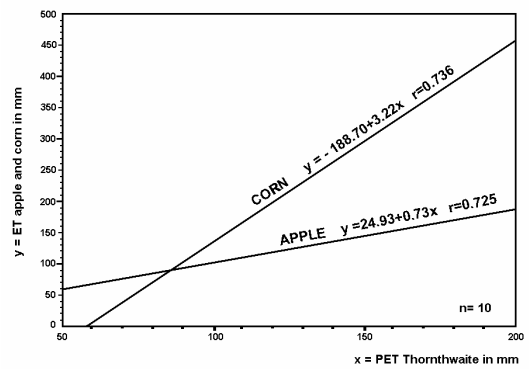

Figure 3. Correlation between monthly ET of Aple and Corn (Y) and PET Thornwaite (X)

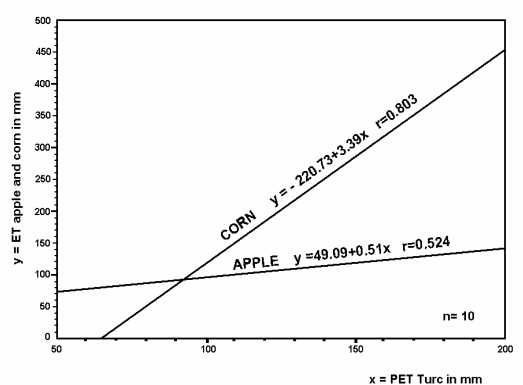

Figure 4. Correlation between monthly ET of Aple and Corn (Y) and PET Turc (X) 
Table 2. Correlation coefficients $\left(\mathrm{r}_{\mathrm{xy}}\right)$

\begin{tabular}{|c|c|c|c|c|}
\hline & $\mathrm{x}-\mathrm{PET}$ : & Thornthwaite & Turc & Penmanu \\
\hline y - RET apple & & 0,725 & 0,524 & 0,435 \\
\hline $\mathrm{y}-\mathrm{RET}$ corn & & 0,736 & 0,803 & 0,768 \\
\hline
\end{tabular}

It shows that the calculation method by Turc and Penman can not be used as reliable for apple $(r=0.524$ and $r=0.435)$, while the Thornthwaite's method is somewhat more reliable. However, when it comes to corn, the Turc's method is more reliable $(r=0.803)$ reletive to the Penman's $(r=0.786)$ and Thornwaite's $(r=736)$ ones. When using the measured data on E and calculated PET as references for RET, preference should be given to $\mathrm{E}$ by Class $\mathrm{A}$ data for getting RET, as the strongest correlative ties were identified on these specific relations.

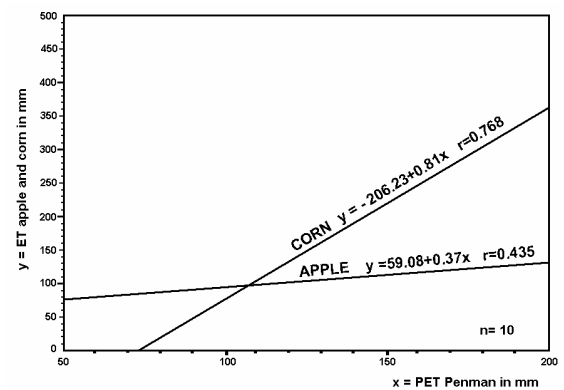

Figure 5. Correlation between monthly ET of Apple and Corn (Y) and PET by Penman (X)

\section{Conclusions}

With the irrigation at lyzimeteric station, consumption of water in two crops that are of great significance for Popovo field, in the Mediterranean part of $\mathrm{B} \& \mathrm{H}$, was researched: of apple and corn. Renewal of moisture reserves was conducted every five days, during the period from May to September. The average consumption of water for the subject two-year period reached $552 \mathrm{~mm}$ in apple, and $941 \mathrm{~mm}$ in corn. This paper addresses a correlative analysis between the apple and corn ET on one, and evaporation measured by Piche and by Class A, as well as PET calculated by Thornthwaite, Turc and Penman, on the other hand. Based on the obtained results, the statistical analysis with regression equation and correlation coefficient shows a rather reliable relation between ET of apple $(\mathrm{r}=0.793)$ and corn $(\mathrm{r}=0.871)$ with $\mathrm{E}$ by Piche, while the subject relation between ET of apple $(r=0.819)$ and corn $(r=0.948)$ with Class A is even more reliable. Other methods in the correlative analysis are less reliable.

\section{References}

FAO: 1998. Crop evapotranspiration, Guidelines for computing crop water requirement, Rome Jensen, M. E.: 1973. Consumptive use of water and Irrigation water requirement ASAE, 215.

Kabat, P., van den Broek,B.J., and Feddes, R.A., (1992): SWACROP: a water management and crop production simulation model, ICID Bull. 41 (2): 61-84.

Mather, J. R..: 1978. The Climatic Water Budget in Environmental Analysis,Lexington, MA, USA, 239.

Robelin, M. - Collier, D.: 1958. Evapotranspiration Rendement Cultureux, C.R.Acad.Sci. 247, Paris.

Thornthwaite, C. W. - Mather, J. R.: 1957. Instructions and Tables for Computing Potentia

Evapotranspiration and the Water Balance, Publications in Climatology, 10: 3:311.

Vlahinić, M. - Ćustović, H. - Alagić, E.: 2002. Situation of Drought in B\&H, ICID, Bled, Slovenia. 


\title{
DIFFERENT RESPONSES OF WEEDS TO REDUCED BENTAZONE DOSES
}

\author{
Michal VONDRA - Vojtech KOCUREK \\ Department of Agrosystems and Bioclimatology, Faculty of Agronomy, Mendel University in Brno, \\ Zemedelska 1, 61300 Brno, Czech Republic, e-mail: xvondra@mendelu.cz
}

Abstract: A small-plot field trial was carried out to evaluate the efficacy of reduced doses of bentazone on Fallopia convolvulus and Amaranthus retroflexus in the years 2005 - 2008. Three various doses of bentazone $(960-720-480 \mathrm{~g}$, included in herbicide Basagran Super) were applied at the third leaf stage of growth in Amaranthus retroflexus, and at the seventh leaf stage of growth in Fallopia convolvulus. Herbicide efficacy was assessed by PS1 meter 1, 2, 3, and 4 days after the treatment. This instrument measures the changes in absorbance induced by light and shows the degree of damage of photosynthetic apparatus of weeds. In case of Amaranthus retroflexus, the efficacy of $480 \mathrm{~g}$ dose of bentazone per hectare was $90-95 \%$. On the other hand, in the case of Fallopia convolvulus the efficacy of the same bentazone dose was under $85 \%$. Two days after the treatment, PS1 values declined as a consequence of regeneration and subsequent new growth of Fallopia convolvulus. This decline of PS1 values was also influenced by weather conditions after application. The results show that the sensitivity of Amaranthus retroflexus and Fallopia convolvulus to bentazone differs. This is the major cause of survival following reduced doses of bentazone.

Keywords: PS1 meter, weeds, regeneration

\section{Introduction}

Redroot pigweed (Amaranthus retroflexus) and black bindweed (Fallopia convolvulus) are weed species which often cause infestation of maize stands. Although these are weeds that can be relatively easily killed with registered herbicides, differences in the sensitivity to the currently used active substances may occur. Sensitivity level to the active substance can be influenced by a series of abiotic factors (air temperature, precipitations, sun radiation intensity, soil humidity etc.) - Lundkvist (1997), and biotic factors (plant species and structure, growth stage, plant ability to absorb, translocate and decompose toxic metabolites) - De Ruiter et al. (1999). In some cases depending on weed species, its growth stage and weather conditions, sufficient efficacy can also be obtained with reduced doses.

\section{Materials and methods}

Small-plot field trials have been established in a field experimental station of Mendel University in Žabčice in the period 2005-2008. In these trials, efficacy of differentiated bentazone doses $\left(480-720-960\right.$ g..$\left.^{-1}\right)$ on redroot pigweed (Amaranthus retroflexus) and black bindweed (Fallopia convolvulus) in maize stands was assessed using the PS 1 meter based on the measurement of light induced changes in the absorbance.

The field experimental station is located in the maize production region, sub-region $\mathrm{K}_{2}$. This region ranks among the hottest regions in the Czech Republic. The average annual temperature is $9.2{ }^{\circ} \mathrm{C}$, with July being the hottest month in the year with the average daily temperature $19.3^{\circ} \mathrm{C}$ and January being the coolest month with the average daily temperature $-2.0^{\circ} \mathrm{C}$. As regards precipitations, the location counts among dry regions with a thirty-year precipitation amount of $480 \mathrm{~mm}$. The locality with the experimental station is also hit by rain shadow. During the vegetativ period, precipitations are 
distributed very unequally. The highest precipitations are in June with $68.6 \mathrm{~mm}$ and the lowest precipitations are in March with $23.9 \mathrm{~mm}$. Sunshine duration varies within 1800 - 2000 h/year. According to the taxonomic classification system of soils in the Czech Republic, there is gley fluvisoil in the locality of the experimental station. Gley fluvisoil has been formed on alluvial sediments of the Svratka river. Groundwater varies during the year between 0.80 and $2.50 \mathrm{~m}$ under the surface. Soil particles composition determines the soil as heavy- to very heavy-textured soil.

Differentiated doses of the herbicide Basagran Super (Tab. 1) served as variants of the trial. The experiment consisted of four variants with four repetitions (plot size was 21 $\left.\mathrm{m}^{2}, 3 \times 7 \mathrm{~m}\right)$.

Table. 1. Experimental variants

\begin{tabular}{|c|c|c|c|}
\hline Variant & Herbicide used & Dose $\left(1 . \mathrm{ha}^{-1}\right)$ & Amount of the active substance $\left(\mathrm{g} \cdot \mathrm{ha}^{-1}\right.$ ) \\
\hline \hline 1. & Control & - & - \\
\hline 2. & Basagran Super & 2,0 & 960 \\
\hline 3. & Basagran Super & 1,5 & 720 \\
\hline 4. & Basagran Super & 1,0 & 480 \\
\hline
\end{tabular}

In all the experimental years, the same fore crop for maize was selected - winter wheat. After wheat harvesting, stubble breaking was carried out, a medium deep ploughing followed in autumn and surface levelling in spring with preparation of the seed bed. Prior to sowing, the plot was fertilized with urea in a dose of $120 \mathrm{~kg} \mathrm{~N}$. ha ${ }^{-1}$. Sowing of the hybrid was completed in the second half of April (Ribera - FAO 410) with inter-row space of $0.75 \mathrm{~m}$ and depth of $0.06 \mathrm{~m}$. Seeding rate was 80000 seeds $/$ ha.

Differentiated doses of the herbicide Basagran Super were applied under ideal conditions at the fourth leaf stage of maize (redroot pigweed - $\mathrm{BBCH} 13$; black bindweed - BBCH 17), using a power knapsack sprayer Solo 432 adjusted to application pressure $0.3 \mathrm{MPa}$ and water dose of 300 1.ha ${ }^{-1}$.

Damage rate of photosynthetic system of redroot pigweed and black bindweed was measured 1, 2, 3 and 4 days following herbicide application using the PS1 meter. Table 2 shows the assessment of the measured values. The scale of the PS1 meter ranges from 0 (no damage) to 100 (plant death). Final subjective evaluation of the herbicide efficacy using the class scale EWRC (European Weed Research Society) was carried out 14 days after the treatment. Results of this evaluation were then compared with efficacy predicted by the apparatus on day 4 after the treatment (DAT).

Table. 2. Categorization of photosynthetic system damage (MLHD PS1 Manual, 2006)

\begin{tabular}{|c|c|}
\hline Values measured by PS1 meter & Predicted effect on weed (efficacy) \\
\hline \hline$>80$ & $>99 \%$ efficacy \\
\hline $65-80$ & $>90 \%$ efficacy \\
\hline $50-65$ & medium effect (growth retardation) \\
\hline $30-50$ & small effect \\
\hline$<30$ & nearly no effect \\
\hline
\end{tabular}




\section{Results and discussion}

Statistical evaluation of the results using analysis of variance showed a highly significant effect of the variety, year, day of measurement and all interactions on the values measured by PS1. Percentage assessment of the effect of individual factors on the measured values, using the analysis of components of a relative variance, revealed in redroot pigweed $92.8 \%$ effect of the variant on the values measured by PS1. In black bindweed, the effect of variant was $76.2 \%$. The effect of other factors and their interactions was almost negligible.

In redroot pigweed, time development of the obtained values was very similar in variants treated with differentiated doses of Basagran Super. This was characterised by high PS1 values measured in the first date of measurement. This did not differ markedly in other dates of measurements in individual doses and ranged from 73 to 100 . The only exception was a $1 / 2$ dose compared with a dose registered in 2008 . In the case of this reduced dose, the increase of values in time was slower, but on 4 DAT the values reached those of other examined doses of the herbicide (Fig. 1A). The results predicted from the 4 DAT corresponded with those of visual assessment, when the efficacy was assessed as 90-97.5\% in dependence on the year and the dose applied. Such a high efficacy rate in redroot pigweed, even with a reduced herbicide dose, is reported e.g. by Vondra \& Smutny (2008).

In black bindweed, time development of the obtained values was different and great differences were found in individual doses and dates of measurement. The results suggest that black bindweed will show higher level of resistance to the active substance of bentazone. PS1 values obtained on 1 DAT were relatively high. However, after the second measurement date, decreases of PS1 values were recorded nearly in all herbicide doses, which could be associated in some cases with regeneration and subsequent growth recovery of black bindweed. The most considerable decrease was reported in all herbicide doses in 2005, 2006, and 2008 in $1 / 2$ a dose compared with the registered dose (Fig. 1B). In all these cases, an insufficient efficacy below $85 \%$ was predicted by the apparatus 4 DAT. These results were subsequently confirmed by visual assessment (14 DAT). In all the remaining doses in particular years, efficacy of $90 \%$ and more was predicted. This predicted efficacy responded to the results of visual assessment carried out on 14 DAT.

Different responses of black bindweed to bentazone doses can be explained by different weather conditions in individual years, but also by a higher level of tolerance of the bentazone active substance tolerance and a good regenerative power of this weed species. The effect of meteorological conditions was especially evident in 2005 when the regeneration ability was supported by precipitations following bentazone treatment (total rainfall of $6 \mathrm{~mm}$ was recorded between the second and fourth date of measurement). This rainfall helped to overcome the stress induced by herbicide treatment in black bindweed. Results of these experiments show that differences exist among individual weed species in the efficacy of low doses of herbicide applications as well as in regenerative power. These differences in the response of individual weed species to low doses of herbicides were also studied by Kempenaar et al. (2007). They found that a very good efficacy can be obtained at application of reduced bentazone 
doses to Amaranthus retroflexus and Chenopodium album. However in the case of Echinochloa crus-galli, bentazone efficacy at all dosed has been assessed as inefficient (the species is not sensitive to the active substance).

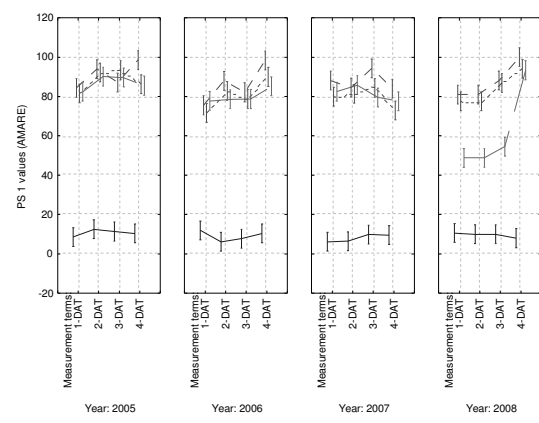

A
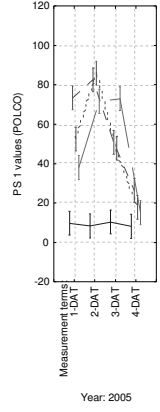

B

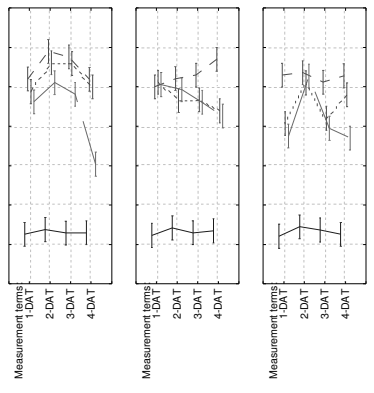

Year: 2008

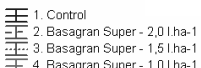

Figure 1. Development of growth, decrease of PS1 values in particular years and measurement dates in control variants and those treated with Basagran Super - A) redroot pigweed; B) black bindweed

\section{Conclusions}

The results showed that redroot pigweed (Amaranthus retroflexus) and black bindweed (Fallopia convolvulus) are weed species which show different sensitivity to the active substance of bentazone, and posses different ability to overcome stress conditions induced by herbicide application. The results further show that the PS1 meter can predict in time a possible regeneration of a weed, and can also be used for efficiency determination of differentiated bentazone doses on redroot pigweed and black bindweed.

\section{Acknowledgements}

This paper was written as a part of the research project MŠMT No. 2 B06124 and of the research project NAZV No. 1B53045.

\section{References}

Kempenaar, C. - Jiming, Y. - Xue, L. (eds.): 2007. Calibration experiments MLHD in CMHD project in China in 2005. Wageningen, Plant Research International B.V., 21.

Vondra, M. - Smutny, V.: 2008. Efficacy of reduced doses of herbicide Callisto 480 SC + Atplus 463 and Basagran Super on redroot pigweed (Amaranthus retroflexus). Acta univ. agric. et silvic. Mendel. Brun., LVI: 4. 207-214.

Lunkvist, A.: 1997. Predicting optimal application time for herbicides from estimated growth rate of weeds. Agricultural Systems, 54: 223-242.

De Ruiter, H. - Uffing, A. J. - Van Dijk, N.: 1999. The influence of growth stage of weeds on the glyphosate dose needed. In Proceedings 1999 british Crop Protection Council, Brighton, 615-620.

MLHD PS1 Manual: 2006. Manual Version 3.0 February 2006. Wageningen, Plant Research International B.V., 19. 


\title{
EFFECT OF ECOLOGICAL AND AGROTECHNICAL ELEMENTS IN RESILIENCE OF RAPE (BRASSICA NAPUS L.) PRODUCTION
}

\author{
Zoltán KÁTAI
}

Institute of Crop Sciences, Faculty of Agriculture, University of Debrecen; 4032, Böszörményi út 138., kataizoltan@agr.unideb.hu

\begin{abstract}
Our polifactorial experiment on rape was carried out at Látókép Research Centre of University of Debrecen, $15 \mathrm{~km}$ away from Debrecen in the crop year of 2007/2008 and 2008/2009. The ground of the research area was even, square and belonged to the type of chernozem in the aspect of soil genetics. In both crop years we analysed how sowing time influenced yield of rape in ploughing, loosening and disking cultivation systems. Different sowing time influenced significantly the yield of rape in both crop years. In crop year of 2007/2008 - due to mild winter - we got the best amount of yield in the first sowing time (at the end of August) in the case of loosening (3930 kg ha-1) and disking (3727 kg ha $\mathrm{kg}^{-1}$ while in the case of ploughing we experienced the best amount of yield $\left(3770 \mathrm{~kg} \mathrm{ha}^{-1}\right)$ in the second sowing time. There were no significant differences between the first and second sowing time, in the third sowing time $(-6,7 \%)$ crop failure was also moderate due to the favourable weather in winter and water supply of the crop year $2007 / 2008$. In the crop year of 2008/2009 all the three tillage systems showed the best results in the second sowing time (ploughing: $4886 \mathrm{~kg} \mathrm{ha}^{-1}$, loosening: $5186 \mathrm{~kg} \mathrm{ha}^{-1}$, disking: $\left.5090 \mathrm{~kg} \mathrm{ha}^{-1}\right)$, the first sowing time $(-4,1 \%)$ hardly differed from this, while we experienced significant crop failure in the case of late September sowing time ($11,1 \%)$.
\end{abstract}

Keywords: rape seed, polifactorial experiment, yield, crop year, sowing time, ploughing, loosening, disking, resilience of rape production

\section{Introduction}

The economic significance of oilseed rape has been greatly increasing for the last few years (Amar et al., 2008), as oilseed rape oil is being produced in ever increasing amount by the bioenergetics industry and food industry. Our polyfactorial oilseed rape experiment was set up at the Experimental Station of the University of Debrecen CASE FA at Látókép in 2007 and 2008. In both years, we studied the influence of sowing time on the yield of oilseed rape in different cultivation systems (ploughing, loosening, disking). The importance of alternative tillage operations in oilseed rape production had been verified by international research (Musnicki et al., 1993; Bury and Kopczynski, 1999; Loko et al., 2005).

Sowing performed at the optimum time and with good quality results in a yield of proper quantity and quality. Sowing time should be selected in such a way that oilseed rape could reach the 9-10 rosette leaves stage before the winter frosts (Izsáki and Lázár, 2004). Recently, the optimum sowing time of 20 August shifted to the end of August or the beginning of September with the spreading of more intensive varieties. At regions inclined to drought, sowing should be performed earlier, so that the plants could emerge by utilizing the general rainy period at the end of August. If the seedbed is prepared by around 20 August, then sowing can be performed as allowed by the weather. A too early sowing - especially if the autumn is warm - can result in lengthening. Such a stand becomes more sensitive to frost and will rot under the snow and will be winterkilled without snow. The consequence of a late sowing is that the stand will not reach the proper development stage before winter and due to their weak root system the plants 
will be winterkilled or their roots will be torn by the soil movements (EÖRI, 1996). Sowing as an agrotechnical element greatly determines the yield of oilseed rape. According to MÁTÉ and PEPÓ (2005), the autumn development, overwintering, stand development, plant density and homogeneity of the oilseed rape stand can be influenced via sowing. Stands sown after 15-20 September can overwinter without great losses only in exceptional cases and the yield loss due to late sowing cannot be counterbalanced by other factors during the vegetation period.

\section{Materials and methods}

Our polyfactorial oilseed rape experiment was performed on chernozem soil in the Hajdúság region in the crop years of 2007-2008 and 2008-2009. In the crop year of 2007-2008, the following three sowing dates were applied: Sowing date I = 24.08.2007; Sowing date II = 10.09.2007; Sowing date III = 22.09.2007. In 2008-2009, the three sowing dates were as follows: Sowing date $\mathrm{I}=25.08 .2008$; Sowing date II = 08.09.2008; Sowing date III = 26.09.2008.

Weather in the vegetation period of 2007/2008 was contradictory as regards the growth and development of oilseed rape. The rainy autumn of average temperature promoted the processes of emergence, early development, preparation for the winter and nutrient accumulation. The mild winter weather did not try the well-developed stands for winter hardiness. Weather in early autumn also provided favourable conditions for the development of the plants. The dry, warm weather in May had an unfavourable effect on early pod development and the emergence of seeds. The very rainy, windy weather of June with rainstorms caused a severe lodging which thoroughly moderated the previously favourable yield prospects. Due to the rainy weather, the harvest was delayed. As a result of the positive and negative weather effects, the yields obtained in the season of 2007-2008 were average and above the average. It can be stated that weather in the crop year of 2008-2009 was variable from the aspect of the generative and vegetative development of oilseed rape. The mild autumn and winter months, the rainy weather at the end of the winter, in the early spring and in June was of favourable effect, while the dry weather in early autumn and the dry, very warm period in AprilMay were of unfavourable effect in terms of stand development and yield formation. However, as a result of the combined effect of these factors, it is higher than average yields were achieved in the experiment.

\section{Results and discussion}

Our experimental results proved that there are significant differences between the yields of plots with different sowing time and soil cultivation (Tables 1-2). 
Table 1. The effect of sowing time for the yield of rape in different tillage systems (Dedrecen-Látókép, 2008)

\begin{tabular}{|l|c|c|c|}
\hline $2007-2008$ & ploughing $\left(\mathrm{kg} \mathrm{ha}^{-1}\right)$ & loosening $\left(\mathrm{kg} \mathrm{ha}^{-1}\right)$ & disking $\left(\mathrm{kg} \mathrm{ha}{ }^{-1}\right)$ \\
\hline \hline 1. sowing time & 3169 & 3930 & 3727 \\
2. sowing time & 3556 & 3770 & 3686 \\
3. sowing time & 3322 & 3667 & 3472 \\
\hline
\end{tabular}

The different sowing dates had a significant effect on oilseed rape yields in both years. In the crop year of 2007-2008, the largest yield was obtained at the first sowing date (end of August) in the case of loosening (3930 kg ha $\left.{ }^{-1}\right)$ and disking (3727 kg ha $\left.{ }^{-1}\right)$ due to the mild winter, while in the case of ploughing the second sowing date gave the best yield $\left(3770 \mathrm{~kg} \mathrm{ha}^{-1}\right)$. There was no significant difference in yield between the first and second sowing dates (beginning and end of September), the reduction in yield was also moderate for the third sowing date, which was related to the favourable winter weather and water supply of the crop year 2007-2008.

Table 2. The effect of sowing time for the yield of rape in different tillage systems (Dedrecen-Látókép, 2009)

\begin{tabular}{|l|c|c|c|}
\hline $2008-2009$ & ploughing $\left(\mathrm{kg} \mathrm{ha}^{-1}\right)$ & loosening $\left(\mathrm{kg} \mathrm{ha}^{-1}\right)$ & disking $\left(\mathrm{kg} \mathrm{ha}^{-1}\right)$ \\
\hline \hline 1. sowing time & 4622 & 5002 & 4916 \\
2. sowing time & 4886 & 5186 & 5090 \\
3. sowing time & 4479 & 4396 & 4586 \\
\hline
\end{tabular}

In the crop year of 2008-2009, the obtained yields were higher than in 2007-2008 for all sowing dates and soil cultivation types. In several cases, the yield exceeded 5 tons, which is excellent even under experimental conditions. We found that the second sowing date (08.09.2008) proved to be the best for all three cultivation types as regards the amount of yield. Yield of the ploughed, loosened and disked plots was $4886 \mathrm{~kg} \mathrm{ha}^{-1}$, $5186 \mathrm{~kg} \mathrm{ha}^{-1}, 5090 \mathrm{~kg} \mathrm{ha}^{-1}$, respectively. At all three sowing dates, the yield of the loosened plots was the highest.

In the crop year of 2007-2008, yield at the third sowing date was $6.7 \%$ lower on average than the highest yield. Thus, the yield loss due to the late sowing date was relatively low. The largest difference was found in the case of the ploughed plots, the difference between the second $(100 \%)$ and first $(89.1 \%)$ sowing dates was more than $10 \%$.

In the crop year of 2008-2009, the second sowing time proved to be the best in all treatments. Yields of the first sowing date treatment were only slightly lower with an average difference of $4.1 \%$. The difference in yield between the second and third sowing dates was larger; yield reduction due to the late sowing was $11.1 \%$ (Table 3).

Table 3. The difference between the average yield (\%) in 2008 and 2009 in different soil tillage systems (Debrecen-Látókép)

\begin{tabular}{|l|c|c|c|}
\hline & ploughing & loosening & disking \\
\hline \hline 2007-2008 & \multicolumn{3}{|c|}{} \\
\hline 1. sowing time & $89,1 \%$ & $100 \%$ & $100 \%$ \\
\hline 2. sowing time & $100 \%$ & $95,9 \%$ & $98,9 \%$ \\
\hline 3. sowing time & $93,4 \%$ & $93,3 \%$ & $93,2 \%$ \\
\hline 2008-2009 & $94,6 \%$ & $96,5 \%$ & $96,6 \%$ \\
\hline 1. sowing time & $100 \%$ & $100 \%$ & $100 \%$ \\
\hline 2. sowing time & $91,7 \%$ & $84,8 \%$ & $90,1 \%$ \\
\hline 3. sowing time & \multicolumn{3}{|l|}{} \\
\hline
\end{tabular}




\section{Conclusions}

In our experiment, we found that the different sowing dates had a significant influence on oilseed rape yields in both years. In the crop year of 2007-2008, the largest yield was obtained at the first sowing date (end of August) in the case of loosening (3930 kg ha-1) and disking ( $3727 \mathrm{~kg} \mathrm{ha}^{-1}$ ) due to the mild winter, while in the case of ploughing the second sowing date gave the best yield $\left(3770 \mathrm{~kg} \mathrm{ha}^{-1}\right)$. There was no significant difference in yield between the first and second sowing dates; the reduction in yield was also moderate for the third sowing date, $(6.7 \%)$, which was related to the favourable winter weather and water supply of the crop year 2007-2008. In the crop year of 20082009, the second sowing date (beginning of September) proved to be the best in all three soil cultivation types (ploughing: $4886 \mathrm{~kg} \mathrm{ha}^{-1}$, loosening: $5186 \mathrm{~kg} \mathrm{ha}^{-1}$, disking: $5090 \mathrm{~kg} \mathrm{ha}^{-1}$ ). Yields of the first sowing date (end of August) were hardly smaller, however, a considerable yield reduction $(11.1 \%)$ was observed in the case of the third sowing date (end of September). The volume of oilseed rape production is greatly dependent upon the different production factors, therefore, the quantitative and qualitative parameters of oilseed rape show great flexibility and resilience in the different years.

\section{References}

Amar, S. - Becker, H. C. - Möllers, C.: 2008. Genetic variation and Genotype $\times$ Environment Interactions of Phytosterol Content in Three Doubled Haploid Populations of Winter Rapeseed. Crop Science, 48: 10001006.

Bury, M. - Kopczynski, J.: 1999. Conventional and direct sowing cultivation technology of winter oilseed rape under Szczecin Voivodeship conditions. Inzynieria Rolnicza. 5: I, 89-94.

Eőri, T.: 1996. Amit a napraforgóról és a repcéről tudni kell. Agroinform Kiadó és Nyomda Kft. Budapest. $77-100$.

Izsáki, Z. - Lázár, L.: 2004. Szántóföldi növények vetőmagtermesztése és kereskedelme. Mezőgazda Kiadó, Budapest, 479.

Loko, V. - Koik, E. - Tamm, K.: 2005. Profitability of grain and rape seed production in Estonia: future prospects. Agronomy Research. Faculty of Agronomy, Estonian Agricultural University, Tartu, Estonia, 3: $1,81-90$.

Máté, A. - Pepó, P.: 2005. Repce. Növénytermesztéstan 2. Gyökér- és gumós növények. Hüvelyesek. Olaj- és ipari növények. Takarmánynövények. szerk.: Antal József, Mezőgazda Kiadó, Budapest, 249-266.

Musnicki, C. - Toboa, P. - Musnicka, B.: 1993. Effect of different methods of soil cultivation and crop tending on the size and quality of winter rape yield. Postepy Nauk Rolniczych. 40/45: 6, 7-14. 


\title{
EFFECT OF FERTILIZATION LEVEL ON POTATO YIELD FOR PROCESSING UNDER SUBSURFACE DRIP IRRIGATION
}

\author{
Nebojša MOMIROVIĆ ${ }^{1}$ - Zoran BROĆIĆ ${ }^{1}$ - Dobrivoj POŠTIĆ ${ }^{2}-$ Jasna SAVIĆ $^{1}$ \\ ${ }^{1}$ Faculty of Agriculture, University of Belgrade, Serbia, emomirov@agrif.bg.ac.rs \\ ${ }^{2}$ Institute for plant protection and environment, Belgrade, Serbia
}

Abstract: The main goal of this research was to establish rationale fertilization level with fully water soluble fertilizers for potatoes grown under drip irrigation. The field trials were established on low calcareous chernozemic soil type. To evaluate number of tubers per plant, average tubers weight, and yield of marketable and A class tubers, as well as dry matter content, moderately late variety Morene was chosen. Four different levels of mineral nutrition were achieved: $1.64,4 \mathrm{~kg} \mathrm{~N}^{-1} ; 66 \mathrm{~kg} \mathrm{P}_{2} \mathrm{O}_{5} \mathrm{ha}^{-1} ; 107 \mathrm{~kg} \mathrm{~K}_{2} \mathrm{O} \mathrm{ha}^{-1} ; 9,6 \mathrm{~kg} \mathrm{MgO} \mathrm{ha}^{-}$ ${ }^{1} ; 2.76,6 \mathrm{~kg} \mathrm{~N} \mathrm{ha}^{-1} ; 66 \mathrm{kgcP}_{2} \mathrm{O}_{5} \mathrm{ha}^{-1} ; 150 \mathrm{~kg} \mathrm{~K}_{2} \mathrm{O} \mathrm{ha}^{-1} ; 11,6 \mathrm{~kg} \mathrm{MgO} \mathrm{ha}^{-1} ; 3.88,6 \mathrm{~kg} \mathrm{~N} \mathrm{ha}^{-1} ; 66 \mathrm{~kg} \mathrm{P}_{2} \mathrm{O}_{5} \mathrm{ha}^{-1}$; $193 \mathrm{~kg} \mathrm{~K}_{2} \mathrm{O} \mathrm{ha}^{-1} ; 15,6 \mathrm{~kg} \mathrm{MgO} \mathrm{ha}^{-1} ; 4.114,6 \mathrm{~kg} \mathrm{~N}^{-1} ; 88 \mathrm{~kg} \mathrm{P}_{2} \mathrm{O}_{5} \mathrm{ha}^{-1} ; 233 \mathrm{~kg} \mathrm{~K}_{2} \mathrm{O} \mathrm{ha}^{-1} ; 17,6 \mathrm{~kg} \mathrm{MgO} \mathrm{ha}^{-1}$. Among examined levels significant statistical differences were found in total yield, and yield of marketable and A class tubers. As an optimal level in both years, the second level of fertilization was found, with respectively 83,25 tha $\mathrm{ha}^{-1}$ and 54,29 $\mathrm{t} \mathrm{ha}^{-1}$ of total yield, then 78,35 $\mathrm{t} \mathrm{ha}^{-1}$ and 43,00 $\mathrm{t} \mathrm{ha}^{-1}$ of marketable tubers and A class tubers yields of 75,20 $\mathrm{tha}^{-1}$ and 39,99 $\mathrm{t} \mathrm{ha}^{-1}$. Increase of nutrition among the third and fourth level, have influenced significant reduction in yields. The decrease of yield in second year, which was influenced by very high air temperatures and low humidity, indicate that for the maximum expression of genetic potential of variety Morene, except for balanced crop nutrition, it was very important to avoid stress conditions. Dry matter content was not influenced by fertilization level

Keywords: Fertilization level, drip irrigation, potato yield, quality for processing

\section{Introduction}

During the past several years, a main problem in the region was severe incidence of extremely drought periods that restricts yield of potatoes (Broćić et al., 2009). Phenomenon of stress caused by high soil temperatures, a lack of soil moisture, high bulk density, and lack of air permeability, have resulted in secondary growth of tubers (Beukema and van der Zaag, 1979), which could reduced market value and quality of yield. The soil content ratio between main nutrients is the key factor for the regular growth of potatoes, both above and underground biomass (Kaniuszak, 1996). Inadeqate $\mathrm{N}$ fertilization could limits tuber size and marketable yield (Long, 2004), while excessive application leads to delayed maturity and may adversly affect tuber quality and storability (Belanger et al., 2002), accumulation of nitrates and ocassionally reduction of tuber yield (Lauer, 1986; Harris, 1992; Poljak et al., 2007). Potato tubers are rich in starch and therefore its requirements for potassium is relatively high (Kumar et al., 2007), higher than any other mineral, except of nitrogen (Rhue et al., 1986). Quality indicators such as dry matter percentage, specific gravity, sugar concetration, flesh color and hollow heart disorder are affected by potassium fertilization (Panique et al., 1997). Under conditions of irrigation, the positive effect of potassium were found (Ilin et al., 1997), regarding reducing sugar contents, as well as prevented disscoloration during the processing in the snack industry. The aim of this research was to determine rationale use of high quality, fully soluble fertilizers, both soil applied and trough fertigation system. In such way we could reduce the negative impact on agroecosystem and environment, and on the same time to achive adequate quality and yield of potatoes. 


\section{Materials and methods}

Field experiments were conducted during the year 2002. and 2003. on low calcareous chernozemic soil type on field trial Zeleni hit in Zemun Polje, near Belgrade, according to fully randomised block design in four repetitions. Potato seeds tubers (Solanum tuberosum var. Morene) were planted in the beginning of April. At the initial germination of potatoes, irrigation drip tapes have been installed on each potato row fallowing operation of reshaping the ridge. Drip tape with emitters on $30 \mathrm{~cm}$ apart, with 3,41 hour ${ }^{-1}$ per running meter was buried on the depth of $5 \mathrm{~cm}$ under the top of the ridge. The standard measures were used to protect potato crop from fungal diseases, pests and weeds. Daily drip irrigation was performed to keep soil moisture inside the interval between $85 \%$ of FWC (Field Water Capacity) and CWC (Capillary Water Capacity), fallowing water deficit by tensionmeters from 0,4 bar to 0,1 bar.

Fully water soluble granular fertilizers have been used, supplied by Haifa Chemicals, Israel: a) Multi Comp Base 13:11:20+2MgO+microelements+humic acids, soil base applied, b) Multi KMg 12:0:43+2MgO (potassium nitrate enriched with magnesium), by top dressing in the finale operation of ridge reshaping. On all of examined levels of mineral nutrition, by the fertigation have been applied: $50 \mathrm{~kg} \mathrm{ha}^{-1}$ of $\mathrm{NPK}_{11: 44: 11}, 50 \mathrm{~kg}$ $\mathrm{ha}^{-1}$ of ammonium nitrate $(34,5 \% \mathrm{~N}), 50 \mathrm{~kg} \mathrm{ha}^{-1}$ of potassium nitrate $12: 0: 43+2 \mathrm{MgO}$, and $10 \mathrm{~kg} \mathrm{ha}^{-1}$ of magnesium nitrate $10: 0: 0+16 \mathrm{MgO}$. Four different fertilization levels were tested:

1. MCB $400 \mathrm{~kg} \mathrm{ha}^{-1}$

(N64,6: $\left.\mathrm{P}_{2} \mathrm{O}_{5} 66: \mathrm{K}_{2} \mathrm{O} 107: \mathrm{MgO} 9,6\right)$

3. MCB $400 \mathrm{~kg} \mathrm{ha}^{-1}+$ Multi KMg $200 \mathrm{~kg} \mathrm{ha}^{-1} \quad\left(\mathrm{~N} 88,6: \mathrm{P}_{2} \mathrm{O}_{5} 66: \mathrm{K}_{2} \mathrm{O} 193: \mathrm{MgO} 15,6\right)$

4. MCB $600 \mathrm{~kg} \mathrm{ha}^{-1}+$ Multi KMg $200 \mathrm{~kg} \mathrm{ha}^{-1} \quad\left(\mathrm{~N} 114,6: \mathrm{P}_{2} \mathrm{O}_{5} 88: \mathrm{K}_{2} \mathrm{O} 233: \mathrm{MgO} 17,6\right)$

Potato total yield was calculated as harvested tubers fresh weight per ha, marketable yields as weight of tubers $>70 \mathrm{~g}$, and A class for chips as weight of tubers $>55 \mathrm{~mm}$. The tubers quality was characterised by dry matter content (drying fresh tubers at $80^{\circ} \mathrm{C}$ ). Statistical significance was investigated by the method of analysis of variance, while the differences were tested by LSD test.

\section{Results and discussion}

The climate at the experimental field is mild continental, with hot and dry summers and cold winters. The average temperature of air for a vegetation period of potato crop was a bit higher in $2002\left(19,1^{\circ} \mathrm{C}\right)$, and especially in $2003\left(20,6{ }^{\circ} \mathrm{C}\right)$, comparing to the longtherm data $\left(18^{\circ} \mathrm{C}\right)$, which indicates very worm summers in both yers of examination Drougt was severe especially in 2003., besides precipitation amount was much lower than it is common $(345,6 \mathrm{~mm})$. Very limited precipitation $(243 \mathrm{~mm})$, fallowing very high temperatures in June $(24,6)$, and August $\left(24,7^{\circ} \mathrm{C}\right)$ have caused considerable water deficit and potato yield decrease (Fig. 1).

Chemical analysis of the particulare soil type have showed alcaline chemical reaction $(\mathrm{pH} 7,20$ in $\mathrm{nKCl})$, with low calcareous $\left(\mathrm{CaCO}_{3} 4,2 \%\right)$ and high humus content $(3,75 \%)$ rich in total nitrogen $(0.245 \%)$, and exchangable phosphorous and potassium. 

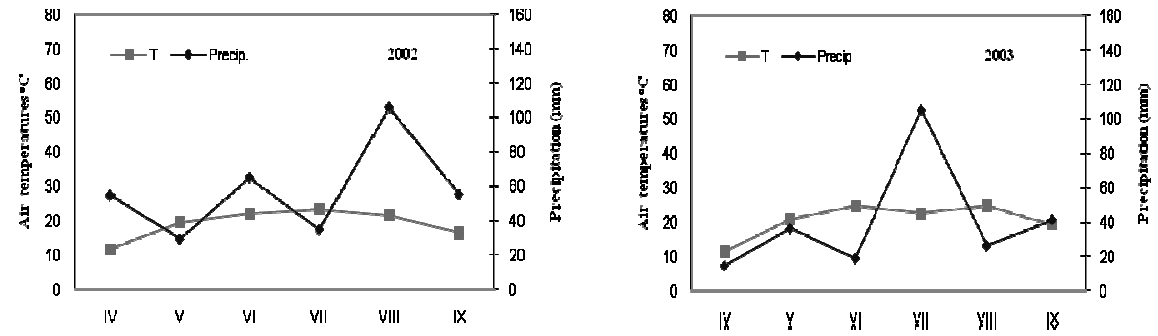

Figure 1. Climate diagram according to Walter for 2002. and 2003. in Zemun Polje, Belgrade

Comparison between investigated years (Tab. 1.) have showed that yield in the season 2002 was much higher than in the season 2003 because of severe drought, thus the increased number and intensity of irrigation which is corresponding to other research (Babett and Sarvary, 2006).

Table 1. The effects of fertilization level on total potato yield, yield of marketable tubers and yield of A class tubers, and its dry matter content in 2002 and 2003

\begin{tabular}{|c|c|c|c|c|c|c|c|c|c|}
\hline \multirow{2}{*}{$\begin{array}{c}\text { Fertilization } \\
\text { levels }\end{array}$} & $\begin{array}{c}\text { Total yield } \\
\mathrm{t} \mathrm{ha}^{-1}\end{array}$ & $\begin{array}{c}\text { Mark.yield } \\
\mathrm{t} \mathrm{ha}{ }^{-1}\end{array}$ & $\begin{array}{c}\text { A Class } \\
\mathrm{t} \mathrm{ha}^{-1}\end{array}$ & $\begin{array}{c}\text { Dry metter } \\
\%\end{array}$ & $\begin{array}{c}\text { Total yield } \\
\mathrm{t} \mathrm{ha}^{-1}\end{array}$ & $\begin{array}{c}\text { Mark.yield } \\
\mathrm{t} \mathrm{ha}^{-1}\end{array}$ & $\begin{array}{c}\text { A Class } \\
\mathrm{t} \mathrm{ha}^{-1}\end{array}$ & $\begin{array}{c}\text { Dry metter } \\
\%\end{array}$ \\
\cline { 2 - 10 } & \multicolumn{6}{|c|}{ Year 2002.} \\
\hline \hline 1. & 75,53 & 69,41 & 43,00 & 19,8 & 47,56 & 43,19 & 39,75 & 20,1 \\
\hline 2. & 83,25 & 78,35 & 75,20 & 19,6 & 54,29 & 43,40 & 39,99 & 19,9 \\
\hline 3. & 73,25 & 69,97 & 52,62 & 19,0 & 45,12 & 37,96 & 35,70 & 20,3 \\
\hline 4. & 71,28 & 67,08 & 33,33 & 19,6 & 45,62 & 41,20 & 36,77 & 20,3 \\
\hline Average & 75,83 & 71,20 & 51,04 & 19,5 & 48,15 & 41,44 & 38,05 & 20,2 \\
\hline LSD 0,05 & 5,8 & 7,3 & 18,1 & & 2,6 & 3,1 & 1,4 & \\
\hline 0,01 & 8,3 & 10,5 & 26,1 & & 3,8 & 4,4 & 2,0 & \\
\hline
\end{tabular}

In both years, the mineral nutrition have had a significant effects on total yield of tubers, which was higher on the plots following second fertilization level, ca. 15 to $20 \%$ than the other variants. Higher quantities of fully soluble fertilizers did not influenced yield increase since it's high availability nutrients. The same response on mineral fertilizers application, were proven on yields of marketable and A class tubers.

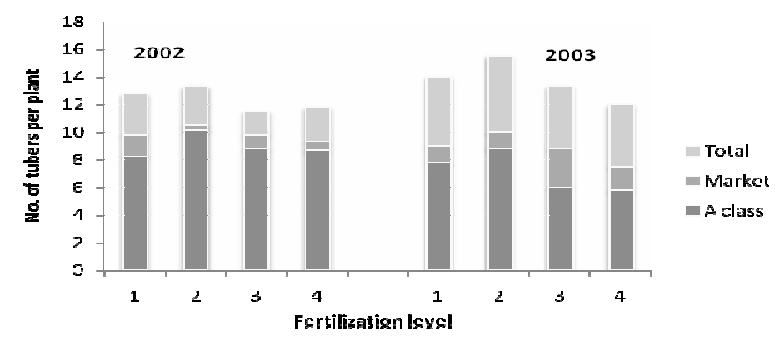

Figure 2. The total number of tubers and number of different processing grades per plant in the season 2002.and 2003. 
The total yield and yield of different processing grades of tubers were obviously affected with the number of harvested tubers (Fig. 2), while it is closely have been related to intensity of fertilization by nitrogen and phosphorous. After particular level of high availability (Cucci et al., 1999.) the number of harvested tubers decreased. Potato variety Morene has moderately sufficient dry matter content for processing into a French fries, but it seems reliable because of less susceptibility to secondary growth and chain tuberization, as well as processing quality. Fallowing the data of dry matter content, there was no any related respond on fertilization intensity, which is corresponding to research of Kumar et al., (2007) confirming on sandy soils that the quantities of nitrogen higher than $90 \mathrm{~kg} \mathrm{ha}^{-1}$ could not influence dry matter content.

\section{Conclusions}

By the intensive production of potatoes with optimal nutrition and irrigation, on low calcareous chernozem soil types high yield and an adequate quality of tubers for processing could be achieved. Fertilization level of $\mathrm{N}_{76} \mathrm{P}_{66}: \mathrm{K}_{150}: \mathrm{MgO}_{11,6}$ with the application of granular NPK and potassium nitrate enriched with magnesium and fertigation could provide optimal and rationale nutrition for potato crop of variety Morene, whereas extremely high yield of high quality potatoes for processing could be achieved especially in adequate climatic conditions. Dry matter content of tubers has not been related to applied fertilization levels.

\section{References}

Babett Eva Abraham - Sarvari M.: 2006. Effect of year and irrigation on the yield and quantity of different potato varieties. Cereal Research Communications, 32: 1, 369-372.

Belanger G. - Walsh J,R. - Richards J.E. - Milburn P.H. - Ziadi N.: 2002. Nitrogen fertilization and irrigation affects tuber ckaracteristics of two potato cultivars. Am. J. Potato Research, 79: 269-279.

Beukema H.P. - Van der Zaag D.E.: 1979. Potato improvement-some factors and facts. Int. Agr. Centre, Wageningen. 1-222.

Broćić Z. - Jovanović Z. - Stikić R. - Vucelić-Radović B. - Mojević M.: 2009. Partial root drying: new approach for potato irrigation. VIII Alps-Adria Sci. Workshop, Neum, Bosina-Hertzegovina, Cereal Research Communications, 37: Supplement.

Cucci G. - De Caro A. - Cordella S.: 1999. Effect of different dertilization formulae in potato crop (Solanum tuberosum). 14 ${ }^{\text {th }}$ Trienn. Conf. of the European Ass, for Potato Research.Abstracts of Conf. Pepers, Posters and Demonstrations: 470-471.

Harris P.: 1992. Mineral nutrition. In Harris P. (ed.) The potato crop, scientific basis for improvement. Chapman and Hall, London, 162-213

Ilin Ž. - Djurovka M. - Marković V.: 1997. Effects of fertility and irrigation on sugar content in potato tubers. Acta Horticulturae, 462: 2, 951-955.

Kaniuszak J.: 1996. Bilans ayotu, fosforu, potasu, magnezu, w glebie lessowey w warunkach nawozenia organiczno mineralnogo. Zeszitz Naukowe Akademii Rolniczej w Szczecinie, Rolnictwo, 62: 189-195.

Kumar P. - Pandey S.K. - Singh B.P. - Singh V.S. - Kumar D.: 2007. Influence of source and time of potassium application on potato growth, yield, economics and crisp quality. Potato research, 50: 1-13.

Lauer D.A.: 1986. Response of Nooksack potatoes to nitrogen fertilizer. Am. Potato J., 63: 251-262.

Panaque E. - Kelling K.A. - Schulte E.E. - Hero D.E. - Stevenson W.R. - Aames R.V.: 1997. Potassium rate and source effects on potato yield, quality and disease interaction. Am. Potato J., 74: 379-388.

Poljak M. - Mirjana Herak-Custic - Tea Horvat - Coga L.: 2007. Effects of nitrogen nutrition on potato tuber composition and yield. Cereal Research Communications, 35: 2, 937-940.

Rhue R.D. - Hensel D.R. - Kidder G.: 1986. Effect of K fertilization on yield and leaf nutrient concetrations of potato grown on a sandy soil. Am. Potato J., 63: 665-681. 


\title{
EFFECT OF FERTILIZATION ON YIELD OF SPRING BARLEY IN DIFFERENT PRECIPITATION CONDITIONS
}

\author{
Ildikó BÉLTEKI ${ }^{1}-$ József PETHES ${ }^{2}$ \\ ${ }^{1}$ Károly Róbert College, Mátrai u. 36., H-3200 Gyöngyös, Hungary, e-mail: ibelteki@ karolyrobert.hu \\ 2 Institute of Agrotechnology, Károly Róbert College
}

Abstract: The yield of field crops are influenced by many factors, among them nutrient and water availability play a determinative role. In the course of growing of spring barley, it is crucial that the above sources be available in time and in the necessary amount to produce the expected yield. To provide the required amount of supplementary nutrients, it is necessary to determine the suitable NPK nutrient rate for the plants. Our long term nutrient deficiency field experiment had been carried out at the "Fleischmann Rudolf" Agricultural Research Institute, Agrochemical Research Station. The experiment was set up in five replications with Latin block arrangement. The goal of the study was to determine how and in what extent the yield of spring barley is influenced by the quantity of supplementary nutrient, and the combinations of macronutrient doses (nitrogen, phosphorus, potassium). We also recorded how the effects of the above factors were modified under various precipitation regimes.

Keywords:, nitrogen efficiency, phosphorus, potassium, precipitation, spring barley

\section{Introduction}

Spring barley is a plant cultivated for the brewing industry and for animal feeding purposes (Jolánkai, 2005). Unlike other spring crops it shows unusual temperature needs and more moderate water requirements (ca. 225-250 $\mathrm{mm}$ in the growing season), but it is sensitive to the distribution of precipitation (Jolánkai, 2005).

The yield of arable crops is influenced by many factors, among them the nutrients play a determinative role in intensive field crop growing (Pepó, 2007; Petróczi, 2008). To provide the required amount of supplementary nutrients, it is necessary to determine the suitable NPK nutrient rate for the plants. Nitrogen can be absorbed only in the presence of the necessary phosphorus and potassium supplies, and large dose of nitrogen alone induces crop-depression (Sárvári, 2006). Based on spring barley experiments made at various fertilization rates Fodor et al. (2008) recommend a nutrient supply in harmony with the nutrient content of the soil and with the need of the plant.

In our field experiment we wanted to know how and in what extent the yield of spring barley is influenced by the quantity of additional nutrients and the combinations of macronutrient doses (nitrogen, phosphorus, potassium). We also recorded how the effects of the above factors were modified under various precipitation regimes.

\section{Materials and methods}

Our long term nutrient deficiency field experiment had been carried out at the "Fleischmann Rudolf" Agricultural Research Institute, Agrochemical Research Station, since 1963, for more than 40 years. The experiment was set up in five replications with Latin block arrangement on $56 \mathrm{~m}^{2}$ gross plots. The plant species in our experiment carried out in a crop rotation system, were maize, spring barley and winter wheat. The soil type was chernozem brown forest soil, characteristic of the region. Thickness of the humus layer was $0.5-0.8 \mathrm{~m}$. The humus content of the ploughed layer was $2.5-3 \%$. The $\mathrm{P}$ content was low, the $\mathrm{K}$ content was satisfactory, $\mathrm{pH}_{(\mathrm{KCl})}$ approximated 5-6. All across 
the experiment the usual farm production methods were applied. We used crop varieties, with good productive capacity and high adaptability to the ecological conditions of the region. In our study we have analyzed data obtained during three experimental years falling into three different categories of precipitation averages (dry, average, and rainy). Nutrient treatments applied in the studied years are presented in Table 1. Precipitation in the vegetation period was recorded (Table 2 ).

Table 1. The treatments of experiment, amount of spread nutrient (active ingredient $\mathrm{kg} \mathrm{ha}^{-1}$ )

\begin{tabular}{|l|c|c|c|c|}
\hline \multicolumn{2}{|c|}{ Treatment } & \multicolumn{3}{c|}{ Nutrients } \\
\hline Serial number & Sign & $\mathrm{N}$ & $\mathrm{P}_{2} \mathrm{O}_{5}$ & $\mathrm{~K}_{2} \mathrm{O}$ \\
\hline \hline $1 . \quad$ (Control) & 0 & 0 & 0 & 0 \\
\hline 2. & $\mathrm{~N}$ & 87 & 0 & 0 \\
\hline 3. & $\mathrm{P}$ & 0 & 63 & 0 \\
\hline 4. & $\mathrm{~K}$ & 0 & 0 & 140 \\
\hline 5. & $\mathrm{NP}$ & 87 & 63 & 0 \\
\hline 6. & $\mathrm{NK}$ & 87 & 0 & 140 \\
\hline 7. & $\mathrm{PK}$ & 0 & 63 & 140 \\
\hline 8. & $\mathrm{NPK}$ & 87 & 63 & 140 \\
\hline 9. & $\mathrm{~N} 2 \mathrm{PK}$ & 130 & 63 & 140 \\
\hline 10. & $\mathrm{NP} 2 \mathrm{~K}$ & 87 & 94 & 140 \\
\hline
\end{tabular}

Table 2. Precipitation in the studied crop years (mm) (Kompolt, 1992; 1995; 1998)

\begin{tabular}{|c|c|c|c|c|c|c|c|c|c|c|}
\hline & \multicolumn{10}{|c|}{ Month } \\
\hline \hline Year & X. & XI. & XII. & I. & II. & III. & IV. & V. & VI. & VII. \\
\hline 1992 & 115 & 75 & 33 & 4 & 3 & 23 & 1 & 26 & 41 & 28 \\
\hline 1995 & 42 & 19 & 12 & 17 & 53 & 36 & 33 & 61 & 117 & 18 \\
\hline 1998 & 6 & 57 & 29 & 24 & 1 & 16 & 52 & 121 & 42 & 82 \\
\hline
\end{tabular}

In term of quantity and distribution of precipitation in the vegetation period (from March to beginning of July) 1995 was an optimal year. It satisfied the water needs of the spring barley. The year 1992 was unfavorable, droughty. In the vegetation period the quantity of precipitation was only $91 \mathrm{~mm}$. In the vegetation period of 1998 the distribution of precipitation was unfavorable. Correlation of conditions with yield were tested with ANOVA.

\section{Results and discussion}

Results are presented in Table 3. For studying of effects of additional nutrients and their doses on the yield, the quantity of yield resulted under different regimes of treatment was compared to the yield of the control plots.

The influence of drought was reflected in the yield in 1992. The amount of grain yield was significantly lower than 1995. Nitrogen supplement in itself and together with the other two nutrients caused significant increase of yield compared to untreated control plots. In our experiment the NPK treatment did not increase significantly the amount of the yield compared to NP treatment. The NPK treatment increased yield considerably in droughty years compared to the NP treatment. 
Table 3. Yields recorded in the studied years $\left(\mathrm{t} \mathrm{ha}^{-1}\right)$

\begin{tabular}{|c|c|c|c|c|}
\hline \multicolumn{2}{|c|}{ Treatment } & \multicolumn{3}{|c|}{ Grain yield $\left(\mathrm{t} \mathrm{ha}^{-1}\right)$} \\
\hline Number & Sign & 1992 & 1995 & 1998 \\
\hline 1. & 0 (Control) & 1.97 & 3.76 & 1.17 \\
\hline 2. & $\mathrm{~N}$ & 3.82 & 6.24 & 4.45 \\
\hline 3. & $\mathrm{P}$ & 2.38 & 4.66 & 1.29 \\
\hline 4. & $\mathrm{~K}$ & 1.84 & 3.61 & 1.00 \\
\hline 5. & NP & 4.46 & 6.47 & 4.82 \\
\hline 6. & NK & 4.08 & 6.54 & 4.55 \\
\hline 7. & PK & 1.98 & 3.87 & 1.46 \\
\hline 8. & NPK & 4.67 & 6.67 & 5.22 \\
\hline 9. & N2PK & 4.67 & 5.82 & 5.55 \\
\hline 10. & NP2K & 4.81 & 6.58 & 5.20 \\
\hline \multicolumn{2}{|c|}{$\mathrm{LSD}_{5} \%$} & 0.3 & 0.66 & 0.72 \\
\hline
\end{tabular}

The yield did not increase significantly when increased doses of nitrogen and phosphorus was added, compared to the NPK treatment (Figure 1).

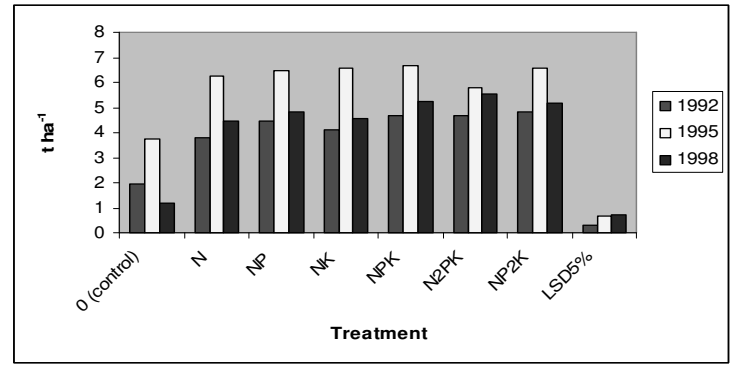

Figure 1. Effects of nutrient treatments on yield of spring barley

Phosphorus supplement caused higher yield in the studied years. Compared to control treatments it was significant except in 1998. The increase was the highest in 1995 compared to untreated plots. Potassium doses did not increase yield, compared to the control plots. Even more we found yield reduction in favorable and unfavorable years too (Figure 2). $\mathrm{K}$ added together with $\mathrm{N}$ and $\mathrm{P}$, increases the yield, because $\mathrm{K}$ increases the plants resistance to lodging (Jolánkai, 2005; Kádár, 2009).

Nitrogen and its combination treatments gave the highest increment of yield compared to the control in the studied three years (Figure 3). 


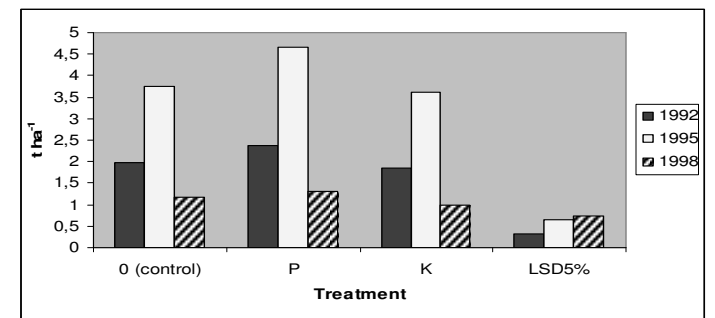

Figure 2. Effects of phosphorus and potassium doses on yield of spring barley

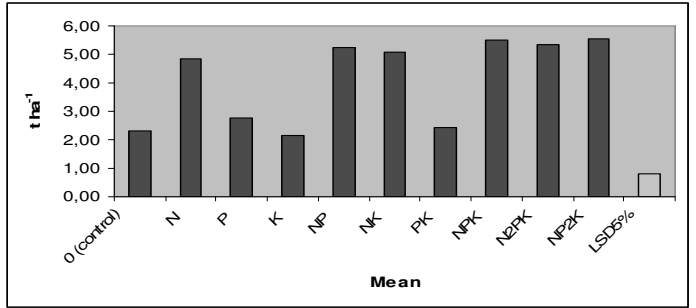

Figure 3. Effects of treatments on yield of spring barley in the average of three experimental years

\section{Conclusions}

Results of our experiment showed, that both the balanced nutrient supply and weather conditions play determinative roles in profitable spring barley production. The increased, additional doses of nutrients do not cause significant difference in yield, so use of high rate fertilization is not reasonable. The better water supply resulted better nutrient uptake for spring barley, so the same doses of additional nutrients resulted in increased yield in rainy years. Use of $\mathrm{K}$ can be ceased in crop rotation system with no yield loss.

\section{Acknowledgements}

We thank Prof. S. Holló, and L. Fodor (Károly Róbert College) for their helpful comments during this study.

\section{References}

Fodor, L. - Holló, S. - Fodorné Fehér, E.: 2008. Növény- és tájspecifikus tápanyagutánpótlás értékelése szabadföldi kísérletben. XI. Nemzetközi Tudományos Napok. 2008. március 27-28. Gyöngyös. 424-428.

Jolánkai, M.: 2005. Növénytermesztéstan 1. Gabonafélék. Mezőgazda Kiadó, Budapest. 244-276.

Kádár, I.: 2009. Mütrágyázás hatása a tavaszi árpára karbonátos homoktalajon. Növénytermelés, 58: 1. 51-63.

Petróczi, I. M.: 2008. Termeljünk több búzát! - Hogyan? Agrofórum. 19. évf. 7/M. sz. 2.

Pepó, P.: 2007. The role of fertilization and genotype in sustainable winter wheat (Triticum aestivum L.) production. Cereal Research Communications, 35: 2 917-920.

Sárvári, M.: 2006. A vetésforgó és a tápanyagellátás szerepe az őszi búza termesztésében. In: Búzavertikum aktuális kérdései. Szaktanácsadási füzetek 2. Debrecen. 64-72. 


\title{
EFFECT OF LOCATION AND YEAR ON THE GRAIN YIELD AND CHEMICAL QUALITY PARAMETERS OF MAIZE HYBRIDS
}

\section{Zsuzsanna HEGYI}

Agricultural Research Institute of the Hungarian Academy of Sciences, Martonvásár, H-2462, Brunszvik str. 2.e-mail: hegyiz@mail.mgki.hu

\begin{abstract}
A total of 96 hybrids from four maturity groups (FAO 200, 300, 400, 500) were tested in two years $(2006,2007)$ at two locations (Martonvásár, Szarvas). Considerable differences were found between the years for the grain yield per hectare and for the grain quality parameters. In 2006 record yields were achieved at both locations, averaging $11.61 \mathrm{t} \mathrm{ha}^{-1}$ in Martonvásár and $12.20 \mathrm{t} \mathrm{ha}^{-1}$ in Szarvas, due primarily to well-timed irrigation in Martonvásár and to good rainfall supplies in Szarvas. In 2007 both locations suffered from drought, with less rainfall than average during the critical months of the vegetation period, which was partially compensated for by irrigation in Martonvásár, giving a yield average of $5.96 \mathrm{t} \mathrm{ha}^{-1}$, while the hybrids grown in Szarvas had a yield average of $5.06 \mathrm{tha}^{-1}$. The grain quality parameters exhibited a close correlation with the yield in the individual FAO maturity groups. Hybrids of the flint type, which have a short vegetation period, had high protein and oil contents, but the yield averages were low due to the slower rate of starch incorporation. Hybrids of the dent type have a longer vegetation period and more intense carbohydrate accumulation, resulted in a greater grain yield but low protein and oil contents. In wet years and locations there was a higher rate of starch accumulation, while dry years were favourable for protein and oil accumulation.
\end{abstract}

Keywords: maize, protein, oil, starch, FAO maturity group

\section{Introduction}

Although maize is of tropical origin, the highest yields are not recorded in the tropics, but in the temperate zone, where both the rainfall and the temperature are adequate. Gyenesné-Hegyi et al. (2002) recorded a close positive correlation between ear yield and the rainfall quantity in July. Long-term water deficiency during flowering increased the frequency of aborted kernels in the ears (Zinselmeier et al., 1995). Quaranta et al. (2001) reported that water stress affected flowering, yield quantity and grain quality parameters. In wet locations more starch was incorporated in the grain, leading to higher yields (Hegyi et al., 2007). In field production, maize varieties with greater yields per hectare generally have a lower protein content, while varieties containing $12 \%$ or more protein usually have lower yields (Sprague, 1977). Similar findings were reported by Svecnjak (2007), who revealed negative correlations between the grain yield and the grain protein content $(\mathrm{r}=-0.48)$ and oil content $(\mathrm{r}=-0.19)$. In wet years maize hybrids had lower protein contents than in dry years (Gyenesné-Hegyi et al., 2001; 2002). Irrigation had a significant effect on the protein and oil concentrations (Josipovic et al., 2007).

\section{Materials and methods}

The experiment was set up at two locations in Hungary (Martonvásár, Szarvas) in 2006 and 2007 in a randomised block design with four replications. At each location 24 hybrids were tested from each of four maturity groups (FAO 200, 300, 400, 500). The experiments were sown and harvested mechanically. Prior to harvest, five sample ears 
were taken from each plot, and the yield average per hectare of each hybrid was corrected based on the ear mass of the sample ears. Evaluations were made of the yield average $\left(\mathrm{t} \mathrm{ha}^{-1}\right)$, followed by chemical analysis to determine the protein, oil and starch contents of the kernels. The measurements were made using a NIR spectrometer.

Rainfall conditions differed between both the locations and the years (Fig. 1). In Martonvásár there was less rainfall than average during the vegetation period in both years, with a critical rainfall deficiency during flowering in July. Irrigation water equivalent to $80 \mathrm{~mm}$ rainfall was applied during flowering in both years to reduce the atmospheric drought. In Szarvas rainfall exceeded the many years average during the vegetation period in both years, but in July 2007 the rainfall during flowering was 17 $\mathrm{mm}$ less than average, with 15 very hot days. The rainfall deficiency, combined with atmospheric drought, contributed to poor fertilisation.

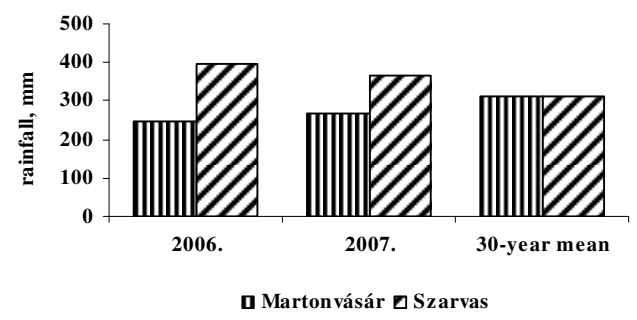

Figure 1. Rainfall conditions at the two locations during the vegetation period (Apr.-Sep.) in the experimental years

\section{Results and discussion}

In 2006 the grand mean for the yield of maize hybrids in Martonvásár was $11.61 \mathrm{t} \mathrm{ha}^{-1}$, compared with $12.20 \mathrm{t} \mathrm{ha}^{-1}$ in Szarvas. Although there was less rainfall than average during the vegetation period in Martonvásár, the distribution was favourable, and the plots were irrigated during flowering. In Szarvas there was above-average rainfall, so record yields were achieved without irrigation. There was a significant difference between the locations. At both locations the greatest yields were recorded for varieties in the FAO 400 maturity group (12.58 t ha $\mathrm{t}^{-1}$ in Szarvas; $12.52 \mathrm{t} \mathrm{ha}^{-1}$ in Martonvásár; Fig.2) . In the droughty year of 2007 there was less rainfall than average in Martonvásár throughout the vegetation period, with the exception of August and September. The irrigation water applied in July moderated the drought damage. In Szarvas there was more rain than usual during the vegetation period in 2007, but the distribution was unfavourable. The rainfall deficiency in July, coupled with very hot days, led to poor fertilisation and lower yields. The grand mean for the maize yield was $5.96 \mathrm{t} \mathrm{ha}^{-1}$ in Martonvásár and $5.06 \mathrm{t} \mathrm{ha}^{-1}$ in Szarvas. In Martonvásár the highest yields were obtained in maturity groups FAO $400\left(5.93 \mathrm{t} \mathrm{ha}^{-1}\right)$ and FAO $500\left(7.74 \mathrm{t} \mathrm{ha}^{-1}\right)$. Due to the longer vegetation period these hybrids were able to develop two ears in response to the 112.2 $\mathrm{mm}$ of rainfall during the first ten days of August. In Szarvas the highest yields were 
recorded for the FAO 300 hybrids $\left(5.40 \mathrm{t} \mathrm{ha}^{-1}\right)$, while the hybrids in FAO maturity groups 200 and 500 both had average yields of $4.81 \mathrm{t} \mathrm{ha}^{-1}$.

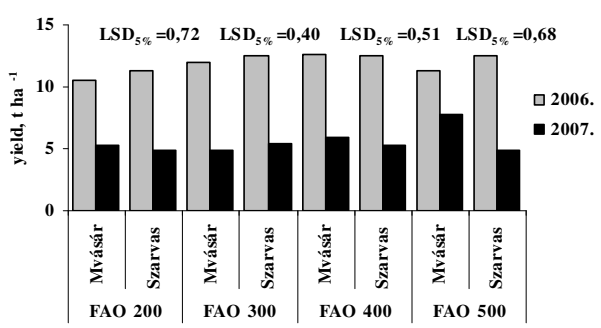

Figure 2. Yields of maize hybrids in different FAO maturity groups, locations and years, averaged over the varieties $\left(\mathrm{t} \mathrm{ha}^{-1}\right)$

The grain quality parameters (starch, protein and oil content) were evaluated for each FAO maturity group in both years. In 2006 higher yields were recorded at both locations than in 2007. Consequently the starch content was higher in 2006 (averaging $72.42 \%$ in Martonvásár and $72.98 \%$ in Szarvas). Starch incorporation was lowest at both locations in the FAO 200 maturity group, dominated by flint and semi-dent hybrids, which have smaller thousand kernel mass than the later maturing dent types. The greatest starch accumulation was recorded for the FAO 500 hybrids (Martonvásár: $73.74 \%$, Szarvas: 73.87\%). In 2007 the starch accumulation in the grains was significantly lower due to the drought (Martonvásár: $70.71 \%$, Szarvas: $72.04 \%$ ). In Martonvásár the starch content was lowest in the FAO 200 group (68.40\%), and averaged $71.18 \%$ in Szarvas. Due to the smaller yield averages, both the FAO 200 and FAO 300 hybrids had low starch contents. The greatest quantities of starch were measured in the dent hybrids in the FAO 500 group $(72.20 \%$ and $73.47 \%$ in Martonvásár and Szarvas, respectively).

The protein and oil contents exhibited an opposing tendency to the starch accumulation, the highest values being recorded in early maturing hybrids. Starch is accumulated in the endosperm, which also contains $80 \%$ of the total protein content, so one can only accumulate at the expense of the other. In 2006 the highest protein and oil contents were recorded in the drier Martonvásár location in the FAO 200 hybrids (8.46\%, compared with $8.07 \%$ in Szarvas). The grain oil content was closely correlated with the protein content, with maximum values of $3.78 \%$ and $3.87 \%$ in the FAO 200 hybrids at the two locations. As the vegetation period became longer, there was a decline in the protein and oil contents, with protein contents of $7.30 \%$ and $6.90 \%$ in the FAO 500 hybrids, and oil contents of $3.52 \%$ and $3.58 \%$ in Martonvásár and Szarvas, respectively. The oil is found chiefly in the embryo, and late-maturing hybrids with a large accumulation of starch in the endosperm generally have a smaller embryo. In the drier year of 2007 the protein and oil ratios were higher, with average protein contents of $9.89 \%$ and $9.03 \%$ and oil contents of $3.96 \%$ and $4.90 \%$ in the FAO 200 hybrids in Martonvásár and Szarvas, respectively. With an increase in the vegetation period there was a drop in protein and oil contents, with values of $7.58 \%$ and $7.35 \%$ for protein and $3.68 \%$ and $4.25 \%$ for oil in the FAO 500 hybrids in Martonvásár and Szarvas, respectively. 
The Bravais correlation coefficient was calculated between the yield and the grain quality parameters (averaged over years, locations and varieties). A positive, moderately strong correlation $(r=0.68)$ was found between the yield and the starch content, a negative, moderately strong correlation $(\mathrm{r}=-0.52)$ between the yield and the protein content, and a negative, weak correlation $(r=-0.19)$ between the yield and the oil content.

\section{Conclusions}

The grain quality parameters of 96 maize hybrids were analysed in two years, in close correlation with the grain yield. As previously reported by Sprague (1955) and Svecnjak (2007), starch accumulation in the kernels was found to increase with a rise in the yield average, while the protein and oil content declined. The two latter parameters are more strongly influenced by genetic factors than the starch content. It was concluded from the results that the flint and semi-dent types in the early maturing FAO 200 group had higher protein and oil contents, but lower starch contents, while the dent hybrids in the FAO 500 group, which have larger endosperms, have greater starch contents and a lower ratio of protein and oil. In agreement with Prokszáné et al. (1995), Hegyi et al. (2007) and Josipovic et al. (2007) it was observed than in wet years, or as the result of irrigation, more starch was accumulated in the kernels than in dry years. In contrast to the opinion of Pásztor (1998) it was thus found that the year played an important role in determining the grain quality parameters of maize.

\section{Acknowledgements}

This work was supported by the Nap_Bio_Project (OMFB-00519/2007).

\section{References}

Gyenesné-Hegyi Z. - Kizmus L. - Záborszky S. - Marton L. C.: 2001. Trends in the protein and oil contents and thousand kernel mass of maize under various ecological conditions. Növénytermelés. 50: 4. 385-394.

Gyenesné-Hegyi Z. - Pók, I. - Illés, O. - Szőke, C. - Kizmus, L. - Marton, L.C.: 2002. Effect of growing site, plant density and year on the yield components of maize hybrids. Növénytermelés. 51: 4. 425-435.

Hegyi Z. - Pók I. - Szőke C. - Pintér J.: 2007. Chemical quality parameters of maize hybrids in various FAO maturity groups as correlated with yield and yield components. Acta Agronomica Hungarica. 55: 2. 217225 .

Josipovic M. - Jambrovic A. - Plavsic H. - Liovic I. - Sostaric J.: 2007. Responses of grain composition traits to high plant density in irrigated maize hybrids. Cereal Research Communications. 35: 2. 549-552.

Pásztor K. - Győry Z. - Szilágyi S.: 1998. Changes in the protein, starch, ash, fibre and fat contents of maize parental lines and their hybrids. Növénytermelés. 47: 271-278.

Quaranta F. - Fornara M. - Mazzon V.: 2001. Maize with limited water supply: comparative tests between 68 hybrids of class 400 and 500. Informatore-Agrario. 57: 14. 55-58.

Sprague G. F.: 1977. Corn and Corn Improvement. American Society of Agronomy, Madison, Wisconsin.

Svecnjak Z. - Varga B. - Grbesa D. - Pospisil M. - Macesic D.: 2007. Environmental and management effects on grain quality of maize hybrids. Cereal Research Communications. 35: 2. 1117-1120.

Zinselmeier C. - Westgate M. E. - Schussler J. R. - Jones R. J.: 1995. Low water potential disrupts carbohydrate metabolism in maize (Zea mays L.) ovaries. Plant Physiology. 107: 2. 385-391. 


\title{
EFFECT OF SUBOPTIMAL NITROGEN FERTILIZATION RATE ON LEAF CHLOROPHYLL CONTENT, YIELD AND OTHER AGRONOMIC TRAITS OF MAIZE POPULATIONS
}

\author{
Miroslav BUKAN ${ }^{l}$ - Ivica BUHINIČEK ${ }^{2}$ - Branko PALAVER $\check{S} I C^{2}-A n a S A B L J O^{3}-$ \\ Vinko KOZUMPLIK ${ }^{1}$ \\ ${ }^{1}$ Department of Plant Breeding, Genetics and Biometrics, Faculty of Agriculture, University of Zagreb, \\ Svetošimunska 25, 10000 Zagreb, Croatia, e-mail: mbukan@agr.hr \\ 2 Bc Institute for Breeding and Production of Field Crops, Dugoselska 7, Rugvica, 10370 Dugo Selo, Croatia \\ ${ }^{3}$ Department of Plant Breeding, Genetics, Seed Production and Biometrics, Faculty of Agriculture and Food \\ Technology, University of Mostar, Biskupa Čule b.b., 88000 Mostar, Bosnia and Herzegovina
}

Abstract: Leaf chlorophyll content (LCC) determined by a portable chlorophyll meter such as CCM-200, or SPAD-502 was proposed earlier as an indicator of plant nitrogen status and for yield prediction. The purpose of this study was to investigate the effect of suboptimal nitrogen fertilization rate of $80 \mathrm{~kg} \mathrm{~N} \mathrm{ha}^{-1}$ on LCC, yield and some other agronomic traits of M3S maize population. LCC was determined by CCM-200 chlorophyll meter at silking in five $\mathrm{M} 3 \mathrm{~S}$ populations $(\mathrm{C} 0, \mathrm{C} 1, \mathrm{C} 2, \mathrm{C} 3$ and $\mathrm{C} 4)$ obtained by recurrent selection. Differences among populations were highly significant for LCC, grain yield ( $\left.\mathrm{kg} \mathrm{ha}^{-1}\right)$, ear width (mm), grain depth $(\mathrm{mm})$, and 1000 kernel weight $(\mathrm{g})$. Yield increased with later cycle-populations, but the leaf chlorophyll content did not follow the same pattern. Significant negative correlation was determined among LCC and ear width $(\mathrm{r}=-0.42 *)$, LCC and grain depth $(\mathrm{r}=-0.34 *)$ and LCC and 1000 kernels weight ( $\mathrm{r}=-0.49 * *)$ for the total data set (across all populations). When measured on separate populations, significant positive correlation was determined between LCC and ear length $\left(\mathrm{r}=0.91^{* *}\right)$ in $\mathrm{C} 3$ and between LCC and plant height $\left(\mathrm{r}=0.88^{* *}\right)$ in C4 population. Correlation between yield and LCC was not significant. The LCC did not appear to be a reliable indicator of grain yield in our study, and additional studies might be needed.

Keywords: maize, nitrogen, leaf chlorophyll content, yield, recurrent selection

\section{Introduction}

In maize, where nitrogen fertilization is often done in only one application early in the growth cycle, inadequate and excessive nitrogen fertilization may result in environmental and water pollution through leaching and denitrification. By applying efficient farming techniques and cultivars with better nitrogen use efficiency, farmers might optimize the use of nitrogen fertilizer in order to maintain sufficient profit and decrease the risk of nitrate pollution (Gallais and Coque, 2005). Determination of leaf chlorophyll content was proposed earlier as an indicator of plant nitrogen fertilization status and yield prediction, because of the strong significant relationship between leaf chlorophyll content and nitrogen fertilization, which is similar to relationship between grain yields and nitrogen status (Ványiné Széles, 2008; Zhang et al., 2008; Hawkins et al., 2007; Széles, 2007). Based on the chlorophyll content meter readings field diagnosis of the plant nitrogen status could be made quickly, providing information for nitrogen fertilization management (Ványiné Széles, 2008; Hawkins et al., 2007; Argenta et. al., 2004). Leaf chlorophyll content was also used as a secondary trait for improving maize for low-nitrogen target environments (Bänziger and Lafitte, 1997). Lafitte and Edmeades, (1994) found significant genetic correlations between grain yield under low nitrogen environment and leaf chlorophyll concentration, ear leaf area, plant height, anthesis-silking interval, and leaf senescence among full-sib progenies, indicating the potential value of these traits in a low nitrogen selection program. The purpose of this 
study was to investigate the relationship of LCC to grain yield and some other agronomic traits of the M3S maize populations under suboptimal nitrogen fertilization rate.

\section{Materials and methods}

M3S (Maksimir 3 Synthetic) maize population was developed at the Faculty of Agriculture University of Zagreb by intercrossing 12 inbred lines, whose origins trace back to several open-pollinated varieties and local populations from different regions of the former Yugoslavia. The population was subjected to several cycles of selfed (S1) and full-sib (FS) progeny recurrent selection for grain yield and disease resistance (Šarčević at al., 2004; Šarčević, 2006; Sabljo et al., 2008).

During the 2009 growing season, a field experiment with five M3S maize populations $(\mathrm{C} 0, \mathrm{C} 1, \mathrm{C} 2, \mathrm{C} 3$, and C4) was conducted at the Faculty of Agriculture's experimental station in Maksimir, Zagreb. Planting distance was $0.70 \mathrm{~m}$ between, and $0.20 \mathrm{~m}$ within rows. Suboptimal nitrogen fertilization rate of about $80 \mathrm{~kg} \mathrm{~N} \mathrm{ha}^{-1}$ was applied by fertilization with $400 \mathrm{~kg}$ of NPK 7-20-30 at winter ploughing in 2008, and sidedress fertilization with $200 \mathrm{~kg}$ of KAN $(27 \% \mathrm{~N})$ at the V3- third collar leaf stage. All other cultural practices were as recommended for optimal maize production. Experiment was set up as RCBD, with seven replications and four 20 plant rows per each experimental plot. Forty plants of the middle two rows were analyzed for eight traits. Ear leaf chlorophyll content (LCC), was measured using a CCM-200 Chlorophyll Content Meter at silking. Ear and plant height $(\mathrm{cm})$, were recorded after anthesis. Ear width and length $(\mathrm{cm})$ were recorded after drying all the harvested ears to $14 \%$ moisture. Grain depth $(\mathrm{mm}), 1000$ kernel weight $(\mathrm{g})$, and grain yield expressed as $\mathrm{kg} \mathrm{ha}^{-1}$ were recorded after grain shelling. All traits were modelled as GLM with populations as fixed explanatory variables. Pearson's correlation coefficients were calculated among all the traits for each population separately, and across all populations (across whole data set). All statistical analyses were performed using SAS Release 8.2 (SAS Institute 1999 - 2001) computer program.

\section{Results and discussion}

Significant differences among cycle-populations were found for LCC, ear width, grain depth, 1000 kernel weight and grain yield (Table 1). Differences found for ear and plant height, and for ear length were not significant. Efficiency of recurrent selection for yield improvement was confirmed by highest yielding C4 (8141.30 kg ha $\left.{ }^{-1}\right)$ and C3 (7997.80 $\mathrm{kg} \mathrm{ha}^{-1}$ ) population. The 1000 kernel weight was also highest in C4 (321.07 g) and C3 $(314.95 \mathrm{~g})$ population. The same pattern was not followed for grain depth and ear width. The $\mathrm{C} 4$ and $\mathrm{C} 1$ populations had the significantly highest values for grain depth (10.20 and $10.19 \mathrm{~mm}$, respectively), and for ear width (44.06 and $42.55 \mathrm{~mm}$, respectively). At the same time the $\mathrm{C} 4$ population had the lowest (38.85), and the $\mathrm{C} 0$ population the highest LCC values (50.26). 
Table 1. Mean values of ear height $(\mathrm{cm})$, plant height $(\mathrm{cm})$, leaf chlorophyll content (LCC), ear width $(\mathrm{cm})$, ear length (cm), grain depth (mm), 1000 kernel weight $(\mathrm{g})$, and grain yield $\left(\mathrm{kgha}^{-1}\right)$ among C0, C1, C2, C3, and C4 population, Maksimir, 2009.

\begin{tabular}{|l|c|c|c|c|c|}
\hline \multirow{2}{*}{\multicolumn{1}{|c|}{ Trait }} & \multicolumn{5}{c|}{ Population } \\
\cline { 2 - 6 } & C0 & C1 & C2 & C3 & C4 \\
\hline \hline Ear height, cm & $90.89 \mathrm{a}^{*}$ & $89.00 \mathrm{a}$ & $86.48 \mathrm{a}$ & $88.36 \mathrm{a}$ & $88.86 \mathrm{a}$ \\
\hline Plant height, cm & $208.60 \mathrm{a}$ & $207.77 \mathrm{a}$ & $202.61 \mathrm{a}$ & $215.63 \mathrm{a}$ & $206.66 \mathrm{a}$ \\
\hline LCC & $50.26 \mathrm{a}$ & $44.25 \mathrm{abc}$ & $46.94 \mathrm{ab}$ & $42.27 \mathrm{bc}$ & $38.95 \mathrm{c}$ \\
\hline Ear width, mm & $41.85 \mathrm{~b}$ & $42.55 \mathrm{ab}$ & $42.35 \mathrm{~b}$ & $42.18 \mathrm{~b}$ & $44.06 \mathrm{a}$ \\
\hline Ear length, cm & $16.60 \mathrm{a}$ & $17.24 \mathrm{a}$ & $17.15 \mathrm{a}$ & $17.75 \mathrm{a}$ & $17.25 \mathrm{a}$ \\
\hline Grain depth, mm & $9.59 \mathrm{~b}$ & $10.19 \mathrm{a}$ & $9.47 \mathrm{~b}$ & $9.67 \mathrm{ab}$ & $10.20 \mathrm{a}$ \\
\hline 1000 kernel weight, g & $276.45 \mathrm{~b}$ & $290.00 \mathrm{~b}$ & $287.55 \mathrm{~b}$ & $314.95 \mathrm{a}$ & $321.07 \mathrm{a}$ \\
\hline Grain yield, kgha $^{-1}$ & $6370.90 \mathrm{~b}$ & $5900.70 \mathrm{~b}$ & $7165.50 \mathrm{ab}$ & $7997.80 \mathrm{a}$ & $8141.30 \mathrm{a}$ \\
\hline
\end{tabular}

* Means followed by the same letter are not significantly different according to Bonferroni t test $(\mathrm{p}<0.05)$.

Correlation coefficients among all the traits measured across all the populations are shown in Table 2. Significant negative correlation was determined between LCC and ear width ( $\mathrm{r}=-0.42 *)$, LCC and grain depth $(\mathrm{r}=-0.34 *)$ and LCC and 1000 kernels weight $\left(\mathrm{r}=-0.49^{* *}\right)$. The results are in agreement with Bänziger et al. (1997), who found significant positive genetic correlation $\left(\mathrm{r}_{\mathrm{G}}=0.25\right)$ between leaf chlorophyll concentration and yield reduction due to nitrogen stress. Better yielding genotypes had lower leaf chlorophyll content under suboptimal nitrogen conditions.

Table 2. Pearson's correlation coefficients among ear height $(\mathrm{cm})$, plant height $(\mathrm{cm})$, leaf chlorophyll content $(\mathrm{LCC})$, ear width $(\mathrm{cm})$, ear length $(\mathrm{cm})$, grain depth $(\mathrm{mm}), 1000$ kernel weight $(\mathrm{g})$, and grain yield $\left(\mathrm{kgha}^{-1}\right)$ across all populations

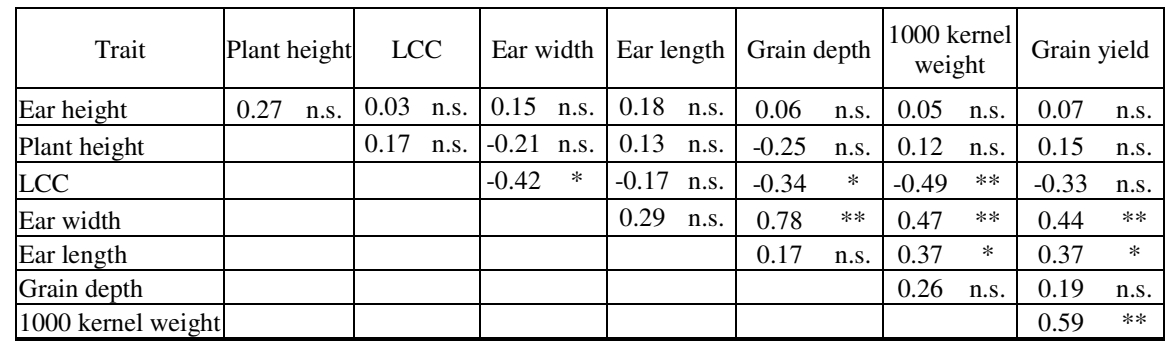

* - significant at $\mathrm{p}<0.05$

$* *$ - significant at $\mathrm{p}<0.01$

n.s. - not significant

For separate populations, significant positive correlation was determined between LCC and ear length $\left(\mathrm{r}=0.91^{* *}\right)$ in $\mathrm{C} 3$ and between LCC and plant height $\left(\mathrm{r}=0.88^{* *}\right)$ in $\mathrm{C} 4$ population. Correlation between yield and LCC was not significant. Ványiné Széles (2008) observed stochastic relation between SPAD chlorophyll content readings and grain yield of maize hybrids $(\mathrm{r}=0.449)$, and determined the yield quantity to the extent of $20.20 \%$. Széles (2007) stated that by SPAD value, the grain yield of maize can be estimated with an accuracy of $1 \mathrm{tha}^{-1}$. However, the parameters of the function largely depended on the hybrid. Zhang et al. (2008) stated that reduced chlorophyll

379 DOI: 10.1556/Novenyterm.59.2010.Suppl.4 
concentrations of corn leaves and loses of grain yields are both symptoms of nitrogen deficiency, and, the post season analyses should not assume that these two symptoms are cause and effect. In our study, later cycles of selection for yield improvement significantly outyielded the earlier ones, but yield increase was not followed by increase of leaf chlorophyll content.

\section{Conclusions}

The M3S maize populations from later cycles of recurrent selection had significantly higher yield, 1000 kernel weight, and grain depth than the earlier cycles-populations. Leaf chlorophyll content followed the opposite trend. The $\mathrm{C} 0$ population had significantly highest, and the C4 significantly lowest value of the leaf chlorophyll content. In this study, the leaf chlorophyll content did not appear to be a reliable indicator of grain yield, and additional studies might be needed.

\section{Acknowledgements}

Financial support for this study has been provided by the Croatian Ministry of Science, Education, and Sports research grant No. 178-1780691-0690.

\section{References}

Argenta, G. - Ferreira da Silva, P. R. - Sangoi, L.: 2004. Leaf relative chlorophyll content as an indicator parameter to predict nitrogen fertilization in maize. Ciência Rural, 34(5): 1379-1386.

Bänziger, M. - Lafitte, H. R.: 1997. Efficiency of Secondary Traits for Improving Maize for Low-Nitrogen Target Environments. Crop Science, 37: 1110-1117.

Gallais, A. - Coque, M.: 2005. Genetic variation and selection for nitrogen use efficiency in maize: a synthesis. Maydica, 50: 531-547.

Hawkins, J. A. - Sawer, J. E. - Barker, D. W - Lundvall, J. P.: 2007. Using Relative Chlorophyll Meter Values to Determine Nireogen Applicarion Rates for Corn. Agronomy Journal, 99: 1034-1040.

Lafitte, H. R - Edmeades, G. O.: 1994. Improvement for tolerance to low soil nitrogen in tropical maize. I. Selection criteria. Field crops researchs, 39: 1-14.

Sabljo, A. - Šarčević, H. - Palaveršić, B. - Buhiniček, I. - Kozumplik, V. - Bukan, M. - Gunjača, J. - Beljo, J. - Tomasović, S. - Ikić, I.: 2008. Improvement of grain yield and Fusarium stalk rot resistance in the M3S maize population by recurrent selection. Cereal Research Communications, 36: Suppl. C, 159-160.

SAS(c) System for Microsoft Windows(c) Release 8.2. SAS Institute Inc. Cary, N.C., USA

Széles, A.: 2007. The indication of nitrogen deficiency in maize growing using SPAD-502 Chlorophyll Meter. Cereal Research Communication, 35(2): 149-1153.

Šarčević, H. - Pejić, I. - Barić, M. - Kozumplik, V.: 2004. Performance and Inbreeding Depression of an Exotic Maize Population under Selfed Progeny Recurrent Selection. Die Bodenkultur, 55:1, 21-27.

Šarčević, H. - Pejić, I. - Barić, M. - Kozumplik, V.: 2006. Originality of MRS maize population and changes in allele frequencies revealed by SSR markers after two cycles of selfed progeny recurrent selection. Euphytica, 161(1-2): 97-105.

Ványiné Széles, A.: 2008. The effect of crop year and fertilization on the interaction between the SPAD value and yield of the maize (Zea mays L.) within non-irrigated conditions. Cereal Research Communication, 36:1367-1371.

Zhang, J. - Blackmer, A. M. - Ellsworth, J. W. - Koehler, K. J.: 2008. Sensitivity of Chlorophyll Meters for Diagnosing Nitrogen Deficiencies of Corn in Production Agriculture. Agronomy Journal, 100(3): 543550 . 


\title{
EFFECT OF SWEET SORGHUM (SORGHUM DOCHNA L.) RESTORER LINES ON STALK JUICE NUTRITIONAL PARAMETERS
}

\author{
Éva ERDEI ${ }^{1}$ - János CSAPÓ ${ }^{2,3}$ - Henriett OSKOLÁS KOVÁCSNÉ ${ }^{1}-$ \\ Erzsébet $S Z A B O^{1}-$ Béla SZABÓ ${ }^{l}$ \\ ${ }^{1}$ Department of Horticulture and Plant Biotechnology Centre for Agricultural Sciences and Engineering \\ ${ }^{2}$ Institute of Food Science, Assurance and Microbiology University of Debrecen Centre of Agricultural \\ Sciences and Engineering, H - 4032 Debrecen Böszörményi str. 138., evaerdei@agr.unideb.hu \\ ${ }^{3}$ Kaposvar University, Department of Chemistry and Biochemistry, Kaposvár
}

Abstract: Sweet sorghum can be utilized for bioethanol production because it has high sugar content (14$17 \%)$. We determined the most important nutritional values of 4 sweet sorghum restorer lines in waxy and full maturation phase. The examined restorer male lines were: $R L 4, R L 9, R L 15, R L 18$. The following nutritional parameters were examined: dry material content, refractometric total sugar content and reducing sugar content. We got concluded achieved strong relationship $\left(\mathrm{R}^{2}=0,8348\right)$ between dry matter and total sugar content in stalk juice of sweet sorghum. In waxy maturation $78,4-87.37 \%$ of dry matter in stalk juice makes the total sugar. Dry material content, total and reducing sugar content of stalk juice decreases from waxy to full maturation. The relationship between total soluble sugar content and dry matter in stalk juice of sweet sorghum was determined through one-dimensional linear regression. The relationship equation can be represented as follows: $\mathrm{y}=0,9751 \mathrm{x}-3,1398$ There are differences between lines in dry matter $\left(\mathrm{SD}_{5 \%}=0.76\right)$, total sugar $\left(\mathrm{SD}_{5}=0.79\right)$, reducing sugar content $\left(\mathrm{SD}_{5 \%}=0.30\right)$ and the non reducing sugar content $\left(\mathrm{SD}_{5 \%}=0,75\right)$. In waxy maturation ratio of reducing sugar content was higher than total sugar and there were differences in reducing sugar content between genotypes $\left(\mathrm{SD}_{5 \%}=6,16 \%\right)$. These lines upcoming for experiments are perspectives because of having excellent stalk juice nutritional parameters and they are great height, furthermore their stalks diameter are thick and stalk medullas are wet.

Keywords: sweet sorghum, dry matter, non-reducing sugar

\section{Introduction}

Changes in temperature, precipitation patterns and snowmelt can have impacts on water availability. Temperature is predicted to rise in most areas, but is generally expected to increase more in inland areas and at higher latitudes. Higher temperatures will increase loss of water through evaporation. Sweet sorghum has a great tolerance to a wide range of climatic and soil conditions. It is considered one of the most drought tolerant and water efficient crop species. It uses $\mathrm{C}_{4}$ type photosynthetic apparatus, which is widely accepted as an important mechanism in making sorghum more physiologically efficient under high temperature and low moisture conditions. One such feature is its ability to produce and deposit high amounts bloom or epicuticular wax. This and in this context the genotype $\mathrm{x}$ environment interaction are the important factors that could contribute to the greater water efficiency and drought tolerance of sorghum and in other wheat (Kokhmetova et al., 2003). They can perform well under sustainable agricultural system. The reducing sugar component and agronomical characters have important parts of drought tolerance (Farshadfar et al., 2002). It was found that above-ground dry biomass production from nonwater-stressed sweet sorghum plants suggests a high productivity potential among $\mathrm{C}_{4}$ crops. Under water shortage, radiation use efficiency may be significantly lower. Radiation use efficiency seems to be linearly related to water consumption. Stressed plants seem to use available water more efficiently than unstressed plants. High water use efficiency values tend to be related with low radiation 
use efficiency values. In addition to being highly productive in terms of biomass, sweet sorghum is also known to show high draught and water logging resistance and salinity tolerance. To evaluate the risk deriving from the introduction of a crop to a new environment, its agronomical behaviour should be analyzed. radiation use efficiency and water use efficiency are two agronomic criteria used for performing the risk evaluation. Accumulation of soluble materials will increase the osmotic potential an as a consequence will create seasonal osmoregulation capability (Erdei et al., 2008). Accumulation of sugars in different parts of plants is enhanced in response to a variety of environmental stresses (Stefanits et al. 2002.). In the case of salt and water stress adaptation to these stresses has been attributed to the stress induced increase in carbohydrate-levels. There is relationship between the dry material of stalk and the soluble sugar content $\left(\mathrm{R}^{2}=0,8234\right)$. There were linear correlation between these dates. The relationship equation can be represented as follows: $y=0,8111 \mathrm{x}-0,3728$. The sugar content of ZKR-295 and ZKR-162 was about $19-20 \%$ on $10^{\text {th }}$ August, just after blooming in Karcag (Antal et al., 2008). In Debrecen six restorer male lines of sugar contents of juices varied between 17 and $24 \%$ at the end of milk mature (Erdei and Pepó, 2008). Their stalk medullas were wet, stalk diameters were medium-thick (Erdei and Pepó, 2008). The sweet sorghum can be produced in low input cultivation system without significant decrease of sugar yield and with non significant decrease of bagasse yield (Blaskó et al., 2008). In sorghum sugar, the most component is sucrose (92\%) and glucose $(4.5 \%$ ) (Voca et al., 2007). Reducing sugar component has an important part of drought tolerance (Erdei et al., 2008). Sugar concentracions of samples were then calculated, along with percentages and determination of sugar yields on the basis of land area (Macesic et al., 2008). The content of non .reducing sugars differed significantly at all growth stages and it was highest at physiological maturity. (Non reducing sugars=Total sugars-Reducing sugars) (Channappagoudar et al., 2007).

\section{Materials and methods}

We selected the following lines: $R L 4, R L 9, R L 15, R L 18$ in the experimental field at Horticulture Institute. Reducing sugar contents were determined by applying LuffSchoorl methods, which is based on the following: aldehyde- and keto group of sugars under alkaline conditions, copper I oxide. We determineted quantitative of the remained copper with jodometric methods.

\section{Results and discussion}

The relationship between dry matter and total sugar content was determineted through one-dimensional linear regression $\mathrm{R}^{2}=0,8348$. The relationship equation can be represented as follows: $\mathrm{y}=0,9751 \mathrm{x}-3,1398$, where $\mathrm{y}$ is the total sugar content $(\%), \mathrm{x}$ stands for stalk juice. Changing of total sugar makes changing in refractometric dry matter (Figure 1.). These values were changed the following: total sugar of dry matter varied between $78,4 \%-87,37 \%$, while in full maturation total sugar of dry matter were between $71,57 \%-82,31 \%$. The highest differences in dry matter was at the $R L 4$ correlate to waxy maturation. This value was $12,36 \%$. The same value $5,79 \%$ was observed at $R L 9$ and $R L 15$. 


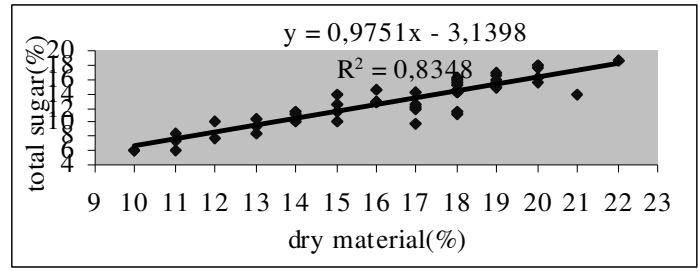

Figure 1.The relationship between refractometric dry matter content (\%) and total sugar of the examined restorer lines

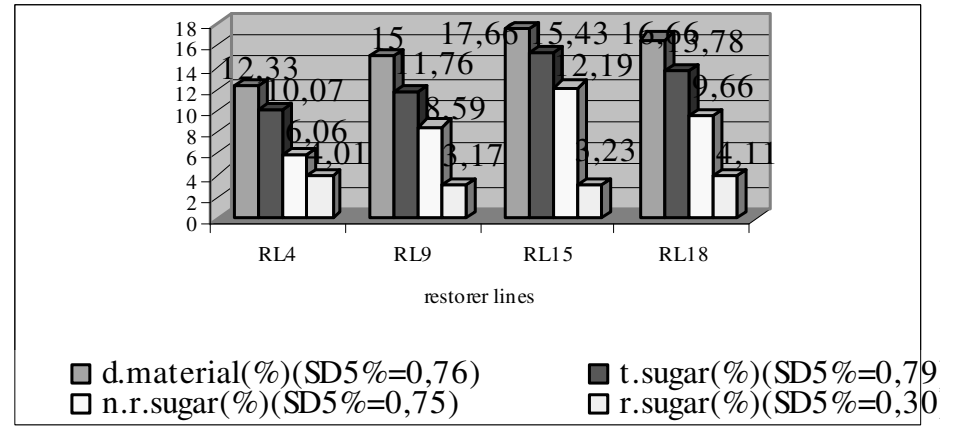

Figure 2. Dry matter, total- and reducing sugar content at sweet sorghum restorer lines in waxy maturation

In case of $R L 9$ mean dry matter content was $15 \%$ in full maturation. During waxy maturation total sugar content was $11,76 \%$, which is decreased $11,08 \%$ at full maturation. In waxy maturation reducing sugar content decreased from $3,17 \%$ to $2,01 \%$. In waxy maturation the mean of total sugar content of dry matter decreased from $15,43 \%$ to $15,36 \%$, while reducing sugar decreased from $3,23 \%$ to $1,71 \%$. Dry matter content of $R L 18$ was $16,66 \%$, in stalk juice of this line average amount of total sugar was decreased from $13,78 \%$ to $13,26 \%$, in addition the reducing sugar was $4,11 \%$ during waxy maturation and $2,23 \%$ in full maturation (Figure 2.3.).

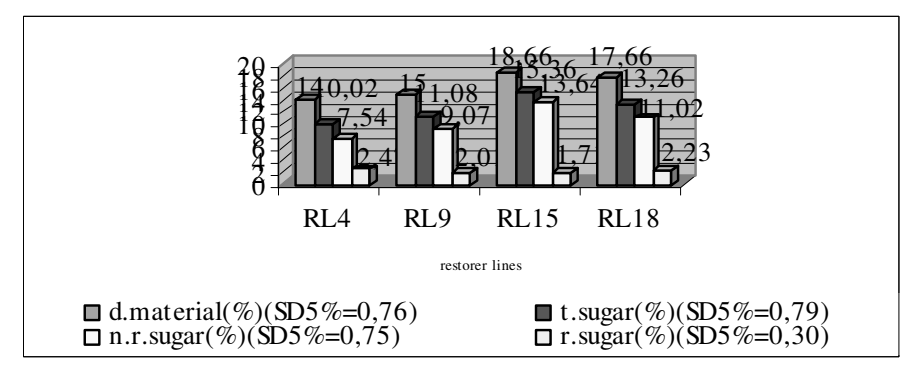

Figure 3. Dry matter, total- and reducing sugar content at sweet sorghum restorer lines in full maturation

Under stress condition we measured the highest reducing sugar content in case of $R L 18$ $(4,11 \%)$ during waxy maturation. In most cases we measured the highest values in case 
of $R L 15$, which were the following: reducing sugar $3,23 \%$ and total sugar content $15,43 \%$. Total sugar varied between $10,07 \%-15,43 \%$ and reducing sugar $3,17-4,11 \%$ in waxy maturation. On the basis of our results we can conclude that there are significant differences between nutritional values (matter-, total sugar-, reducing and non-reducing sugar content) of the examined restorer lines.

\section{Conclusions}

Sorghum is a $\mathrm{C}_{4}$ grass that is well adapted to semiarid tropics. This grain crop is the fifth most important cereal grown worldwide, due in large part to its unusual tolerance to adverse environmental conditions. As far as the biomass materials are concerned, sweet sorghum is a $\mathrm{C}_{4}$ plant characterized by a high photosynthetic efficiency and a high biomass-and sugar-yielding crop. Soluble organic compounds may act as osmoprotectants of proteins under salt and drought stress in addition to their role in osmoregulation. Meanwhile, it contains approximately equal quantities of soluble and insoluble carbohydrates has been considered as an important source for the production of fuel ethanol. The genotypes SSV-7073, SSV-74 and Rio recorded higher brix value. Total sugar and non reducing sugars in juice increased from flowering to physiological maturity. The reducing sugars in juice decreased. This is because reducing sugars are utilized for various metabolic reactions and as energy source. We found significant differences among our lines ( $R L 4, R L 9, R L 15, R L 18)$ investigated on nutritional parameters. We determined the ratio of reducing sugar content to total sugar content. In waxy maturation stage the highest value was $39,82 \%$ in case of $R L 4$, which was reduced to $24,65 \%$ in full maturation. The highest decrease was in the cote of $R L 18$ where ratio of reducing sugar decreased from $29,82 \%$ to 16,81 within the total sugar in waxy maturation. Reducing sugars are indicator of drought tolerance in different sweet sorghum genotypes. The above mentioned Hungarian restorer lines adapted to low input conditions and abiotic and biotic stress factors especially drought.

\section{References}

Antal,K. - Ábrahám É.B. - Blaskó L. - Balogh,I.: 2008. Evaluation of sweet sorghum lines from the point of view of bioethanol and cellulose production, Cereal Research Communications, 36.

Blaskó,L. - Balogh,I. - Ábrahám,É.B.: 2008. Possibilities of sweet sorghum production for ethanol on the Hungarian Plain, Cereal Research Communication, 36. 1251-1254.

Channappagoudar B.B. - Biradar N.R. - Patil J.B. - Hiremath S.M.: 2007. Assesment of Sweet Sorghum Genotypes for Cane Yield, Juice Characters and Sugar Levels,Journal Agricultural Scientist 20(2) 294

Erdei, É. - Pepó, P.: 2008. Sugar contents of stalk juices in sweet sorghum types. Cer. Res. Com. 36:1427

Erdei, É. - Pepó, P.: 2008. Phenometry parameters of sweet sorghum and sugar contents of stalk juice investigation, Acta Agraria Debreceniensis, 32. 41.

Erdei É - Pepó, P. - Boros, N. - Tóth, Sz. - Szabó, B.: 2009. Morphological and biochemical indicators of drought tolerance in sweet sorghum (Sorghum dochna L.) Cereal Research Communication, 37: 157-160.

Erdei É. - Pepó, P. - Boros N. - Tóth Sz. - Szabó B.: 2009. Morphological and biochemical indicators of drought tolerance in sweet sorghum, Cereal Research Communication, 37.157-161.

Farshadfar, E. - Afarinesh,A. - Sutka,J.: 2002. Inheritance of drought tolerance in Maize, Cer. Res. Com., 30. 285-287.

Kohkmetova A. - Sariyeva G. - Kenjebayeva S.: 2003. Yield stability and drought resistance in wheat,Acta Botanica Hungarica 45 1-2. 153-161.

Macesic, D. - Uher, D. - Stafa, Z.: 2008. Biomass production and ethanol potential from sweet sorghum in Croatia, Cereal Research Communication, 36. 527-530.

Stefanis E. - Sgrulletta,P. - Vita,P. - Pucciarmati,S.: 2002. Genetic variabilityto the effects of heat stressduring grainfilling on durum wheat quality, Cereal Researc Communication, 30.1-2.117-120.

Voca, N. - Kricka, T. - Janusic, V. - Matin, A.: 2007. Bioethanol production from corn kernel grown with different cropping intensities, Cereal Research Communication, 35. (2): 1309-131 


\title{
EFFECT OF TWENTY YEARS OF TOBACCO PRODUCTION IN MONOCULTURE AND CROPROTATION UPON THE YIELD AND NO3-N LEACHING ON SEMIGLEY SOIL IN CROATIA
}

\author{
Ivan TURŠIĆ ${ }^{1}$ - Stjepan HUSNJAK ${ }^{2}-$ Suzana $\check{Z} A L A C^{1}$ \\ ${ }^{1}$ Tobacco institute Zagreb \\ ${ }^{2}$ Faculty of Agriculture, University of Zagreb
}

Abstract: Investigations started in 1987 and were carried out on semigley soil (sandy loam) characteristics of the area where flue-cured tobacco is grown in Northern Croatia. Several types of crop rotation were tested: tobacco monoculture (unfertilized tobacco, fertilized tobacco), two-crop (winter wheat, tobacco), three-crop (winter wheat, tobacco, maize), four-crop (winter wheat, tobacco, maize, soybean). Tobacco is the key crop in these investigations while winter wheat was the preceding crops in trials. This investigations will have a longterm character and are carried out on the experimental field of the Tobacco institute Zagreb. Tobacco growing in monoculture reduced the yield from $2.63 \mathrm{t} / \mathrm{ha}$ in the first year (1987) to $1.63 \mathrm{t} / \mathrm{ha}$ in the 20. year (2007). A significantly lower yield and quality were obtained after the fourth year of tobacco monoculture compared to tobacco growing in crop rotation. The highest content in plough and sub-plough layers was recorded at lysimeter where the crop rotation involved maize and wheat, which was succeded by tobacco. The lowest nitrate content $\left(7.8 \mathrm{~kg} \mathrm{NO}_{3}{ }^{-} \mathrm{N} / \mathrm{ha}\right)$ was leached in unfertilized tobacco monoculture which served as check treatment. The highest content of leached nitrogen $\left(53.6 \mathrm{~kg} / \mathrm{ha} \mathrm{NO}_{3}{ }^{-} \mathrm{N}\right)$ was recorded after the harvest of maize, which was fertilized with $180 \mathrm{~kg}$ nitrogen, wheat fertilized with $160 \mathrm{~kg}$ of nitrogen, was shown.

Keywords: Semigley soil, Monoculture, Crop rotation, Tobacco, $\mathrm{NO}_{3}{ }^{-} \mathrm{N}$, leaching

\section{Introduction}

Intensive application of mineral fertilizers, particularly nitrogen fertilizers, in agricultural production may cause certain environmental changes. In contrast to the production of flue-cured tobacco, where small nitrogen rates are applied, much higher nitrogen rates are applied to other agricultural crops (wheat, maize, soybean). Consequently, it is reasonable to expact a higher leaching of nitrates into groundwater. The problem of nitrate load is groundwater, and thus also in drinking water, primarily depends on the nitrate regime in the soil. Some of the nitrates are formed by microbiological processes from the soil organic matter, while others are introduced by fertilization (Addiscott et al., 1992). Soil and water pollution by nitrates is being intensively investigated worldwide. Intensive application of high rates of nitrogen fertilizers, which mostly contain $50 \%$ on nitrate nitrogen, is often cited as the main cause of high nitrogen concentration in water, notably drinking water. In ideal agricultural production, nitrogen fertilization should equal crop requirements for a given yield, i.e. depend on soil fertility and nitrogen outtake with yield. A number of factors stand in the way of such fertilization and higher rates of nitrates are usually added, which remain in the soil after the crops have been harvested at the potential risk of being leached into ground-and surface waters. The main field crops in Nothern Croatia, wheat, maize and soybean, are fertilized with about 50 to $180 \mathrm{~kg}$ N/ha whereas only 20 to $40 \mathrm{~kg} \mathrm{~N} / \mathrm{ha}$ are applied for tobacco. This is the first study of this kind in tobacco growing in monoculture or in crop rotation in Croatia. It has been proven for wheat that its earlier sowing results in smaller amounts of residual nitrogen in the soil than in later sowing, since early sown wheat takes up the gratest part of nitrates (Widdowson et al., 1987). Nitrates are more intensively leached from soils that are left unseen over winter, 
as it is usually the case of soil intended for tobacco, than from soils under a catch crop (Muller et al., 1989). The linear ratio: lower nitrate rate, lower leaching has not been confirmed. Littelmore et al. (1991) investigated tobacco cropping in crop rotation and in monoculture for nine years, but determined only the status of total nitrogen. It is optimalfor tobacco to be grown after wheat in a crop rotation (Butorac et al., 1995; Turšić et al., 1998), so there is no doubt that tobacco takes up part of residual nitrogen in addition to that added, which will be explained in this study. Futher, in the treatment involving tobacco monocropping with standard fertilization, it will be firmly established whether there is a difference in nitrogen leaching and how large it is. Tihe trial treatment of tobacco monocropping without fertilization will demonstrate the balance of soil nitrogen and the from precipitation. The extent of leaching in the case of other crops in the rotation (wheat, maize, soybean) will be determined as well.

\section{Materials and methods}

Investigations started in the summer of 1986 and are carried out on the experimental field of Tobacco institute Zagreb, on semigley soil (sandy loam) characteristic of the tobacco growing region of Croatia. These investigations will have a long term character. There were four crop systems: tobacco monocropping, two-crop (winter wheat, tobacco), three-crop (winter wheat, tobacco, maize) and four-crop (winter wheat, tobacco, maize, soybean) rotation.

Standard agricultural engineering practices where applied to the studied crops in crop rotations. Contents of nitrogen, phosphorus and potassium amounted, respectively, to 30,60 and $160 \mathrm{~kg} / \mathrm{ha}$ for flue-cured tobacco; 160,160 and $140 \mathrm{~kg} / \mathrm{ha}$ for winter wheat; 180,150 and $170 \mathrm{~kg} / \mathrm{ha}$ for maize; 50,90 and $100 \mathrm{~kg} / \mathrm{ha}$ for soybean (before sowing the seed was inoculated). Tobacco was harvested per insertions (3 leaves) in six harvests. After leaf drying, tobacco quality and yield were determined by classifying and weighing. Data obtained from four replications were processed by the analyses of variance. With the aim of finding out the extent of nitrate leaching into groundwater and its pollution, six monolith lysimeters were installed in the trial (Addiscott et al., 1992). Lysimeters were dug into the natural soil profile at a depth of $50 \mathrm{~cm}$, which fully complies with the profile stratigraphy. Lysimeter receptacles were dimensioned $73 \times 73$ $\mathrm{cm}\left(0,533 \mathrm{~m}^{2}\right)$. Lysimeters were installed into the soil profile on unfertilized tobacco, tobacco monoculture, and tobacco in crop rotation with wheat, soybean and maize. Comparision of the results of chemical analysis of water on unfertilized and differently fertilized soils will show the extent to which fertilizer rates applied for the mentioned crops affect the leaching of nitrogen into groundwater from the rhizosphere of tobacco grown in monoculture and in crop rotation, wheat, maize and soybean. Besides the analysis of nitrogen leaching into groundwater, the soil nitrogen content during the growing period was also determined.

\section{Results and discussion}

The climate conditions during tobacco vegetation had influence on the yield of tobacco (Butorac et.al., 1999; Littlemore et al., 1991; Turšić et al., 2005).

A minimum precipitation of $255 \mathrm{~mm}$ was recorded during the vegetation period in 1992, and maximum precipitation of $476 \mathrm{~mm}$ in 1995. The average amount of precipitation during the tobacco vegetation period over twenty years amounted to 353.4 
$\mathrm{mm}$. The results obtained for yields during the twenty years of investigations are presented in table 2 .

Table 1. Precipitation during tobacco growing season (May - September), 1987-2006

\begin{tabular}{|c|c|c|c|c|c|c|c|c|c|c|}
\hline Year & 87 & 88 & 89 & 90 & 91 & 92 & 93 & 94 & 95 & 96 \\
\hline $\mathrm{mm}$ & 285 & 281 & 399 & 261 & 438 & 255 & 310 & 335 & 476 & 398 \\
\hline
\end{tabular}

\begin{tabular}{|c|c|c|c|c|c|c|c|c|c|c|}
\hline Year & 97 & 98 & 99 & 00 & 01 & 02 & 03 & 04 & 05 & 06 \\
\hline $\mathrm{mm}$ & 376 & 394 & 410 & 286 & 397 & 403 & 316 & 328 & 396 & 324 \\
\hline
\end{tabular}

Table 2. Tobacco yield (t/ha) according to crop rotation type

\begin{tabular}{|c||c|c|c|c|c|c|c|c|c|c|}
\hline Year & 87 & 88 & 89 & 90 & 91 & 92 & 93 & 94 & 95 & 96 \\
\hline Mon. & 2.6 & 2.2 & 2.7 & 1.9 & 1.9 & 1.7 & 1.8 & 1.6 & 1.8 & 1.7 \\
\hline 2-year rotat. & 2.7 & 2.4 & 2.8 & 2.5 & 2.5 & 2.3 & 2.1 & 2.0 & 2.3 & 2.1 \\
\hline 3-year rotat. & 2.7 & 2.5 & 2.8 & 2.4 & 2.4 & 2.5 & 2.4 & 2.1 & 2.3 & 2.2 \\
\hline 4-year rotat. & 2.8 & 2.4 & 2.9 & 2.3 & 2.6 & 2.4 & 2.3 & 2.3 & 2.4 & 2.4 \\
\hline LSD 0,05 & NS & NS & NS & 0.3 & 0.3 & 0.3 & 0.3 & 0.2 & 0.4 & 0.2 \\
\hline
\end{tabular}

\begin{tabular}{|c||c|c|c|c|c|c|c|c|c|c|c|}
\hline Year & 97 & 98 & 99 & 00 & 01 & 02 & 03 & 04 & 05 & 06 & Average \\
\hline Mon. & 1.6 & 1.7 & 1.6 & 1.5 & 1.3 & 1.6 & 1.8 & 1.4 & 1.7 & 1.6 & 1.8 \\
\hline 2-year rotat. & 2.3 & 2.4 & 2.4 & 2.4 & 2.6 & 2.8 & 2.7 & 2.6 & 2.9 & 2.4 & 2.5 \\
\hline 3-year rotat. & 2.4 & 2.5 & 2.6 & 2.5 & 2.8 & 2.6 & 2.6 & 2.8 & 2.6 & 2.8 & 2.6 \\
\hline 4-year rotat. & 2.5 & 2.6 & 2.7 & 2.8 & 2.6 & 2.9 & 3.0 & 2.9 & 2.7 & 2.9 & 2.6 \\
\hline LSD 0,05 & 0.3 & 0.3 & 0.4 & 0.3 & 0.5 & 0.4 & 0.3 & 0.5 & 0.4 & 0.3 & \\
\hline
\end{tabular}

The average values of tobacco leaf yields for the 20-year period indicate a trend more or less analogous to that for particular years. Significantly higher yields were recorded in all kinds of crop rotations compared to tobacco monoculture cropping (Butorac et al., 1999; Turšić et al., 2005).

A significantly lower tobacco yield was obtained after three years of tobacco monocropping.

The production of tobacco in monoculture reduced yield from 2.63 tha $^{-1}$ in first year (1987) to 1.64 tha $^{-1}$ in the twenty year (2006).

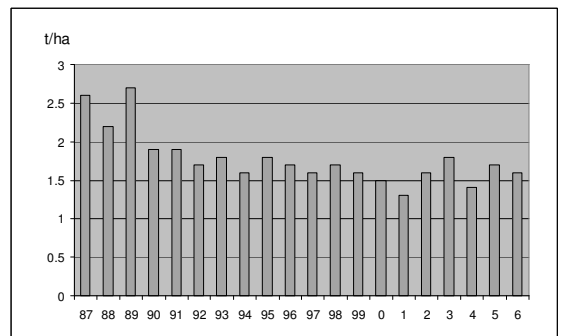

Figure 1. Tobacco yield in monoculture (1987-2006)

A total of $707.7 \mathrm{~mm}$ of precipitation was recoreded during the period of monitoring nitrogen leaching into groundwater, from May 2005 to April 2006 (Figure 1.). Most rain fell in September $(208.3 \mathrm{~mm})$ when the first amounts of water percolated into the 
lysimeters. June, July and August were dry, with high air and soil temperatures, and high evapotranspiration.

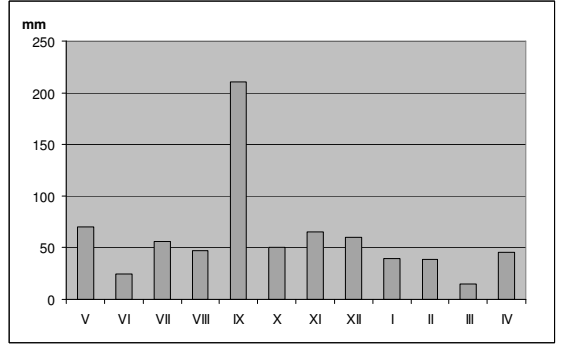

Figure 2. Precipitation during May 2005 until April 2006

The average quantity in lysimeters was 57.51 or $16.3 \%$. The largest quantities of water percolated into lysimeters were recorded in September, when precipitation was the highest as well. Later on, the quantiti of percolated water depends also on the intensity and amount of precipitation.

Table 3. The quantity of $\mathrm{NO}^{-} \mathrm{N}$ leached in lysimeters, $\mathrm{kg} / \mathrm{ha}$

\begin{tabular}{|c|c|c|c|}
\hline Lysimeter & 1996 & 1997 & kg NO3 \\
\hline \hline CHECK & UNFERTILIZED & TOBACCO & 8.7 \\
\hline MONOCULTURE & TOBACCO & TOBACCO & 11.4 \\
\hline 2-CROP ROTATION & TOBACCO & WHEAT & 27.5 \\
\hline 3-CROP ROTATION & MAIZE & WHEAT & 46.3 \\
\hline 4-CROP ROTATION & SOYBEAN & MAIZE & 28.9 \\
\hline
\end{tabular}

\section{Conclusions}

Tobacco grown in monoculture for twenty years gave a significantly lower yield. Tobacco planted in a wider crop rotation gave a significantly higher yield and better quality of leaves. The quantity of leached NO3-N depends on the mineral fertilization applied to the test crops. The quantity of leached nitrogen was smaller then expected due the raised soil compaction, resulting from the high content of silt ald fine sand particles. Higher levels of soil nitrates in the production of crops preceding tobacco should be taken into account when planning tobacco fertilization.

\section{References}

Addiscott, T.M. - Whitmore A.P. - Powlson D.S.: 1992. Farming, Fertilizers and the Nitrate problem. CAB Int. Wallingford, U.K.

Butorac, A. - Turšić, I. - Butorac, J. - Mesić, M. - Bašić, F. - Vuletić, N. - Berdin, M. - Kisić I.: 1999. Results of long-term experiments with growing flue-cured tobacco (Nicotiana tabacum) in monoculture and different types of crop rotations. J. Agronomy and Crop Sci. 183, 271-285.

Littlemore, J. - Tonello, P.E.- Rasmussen, T.S.: 1991. Nine years continous tobacco monocropping compared with alternative cropping frequencies and sequences. Effect on leaf yield and quality. Tob. Sci. 35, 79-84.

Muller, Y.C. - Denys, D. - Morlet, G. - Mariotti, A.: 1989. Influence of catch crops on mineral nitrogen leaching and its subsequent plant use. In J. C. German (ed.) Menagment Systems Impact of Nitrates. Elsevier, London, 85-98.

Turšić , I. - Butorac, A. - Bašić F. - Čavlek, M. - Mesić, M. - Đaković, Z. - Kisić, I. - Tratnik, M. - Svitlica, B.: 2005. Effect of Fifteen Years of Tobacco Production in Monoculture and in Crop Rotation upon the Yield and Quality of Flue-Cured Tobacco in Agricultural Conditions of Croatia. Die Bodenkultur 56(3), 117-120. 


\title{
EFFECT OF VELVETLEAF'S EXTRACTS ON THE GERMINATION AND THE GROWTH OF SOME WEED SPECIES
}

\author{
Viktor NAGY - Attila SZALAI
}

Institute for Plant Protection, Georgikon Faculty, Universtity of Pannonia, H-8360, Keszthely Deák F Str. 57, e-mail: nagyviktor.georgikon@gmail.com

\begin{abstract}
In the last decades the importance of some weed species increased in Hungary. The velvetleaf (Abutilon theophrasti Medic.) also belongs to this group. Allelopathy is a very important ability of weeds in an agro-ecosystem, because it can determine the competitive capacity of a weed species. We studied the allelopatic effect of watery extract made from different plant parts of velvetleaf (air dried leafy stems, seeds, pods without seeds and germinating seeds) on the germination and growth of three weed species. Examinations were started in April of 2009 in Keszthely. Watery extract from germinating seeds of Abutilon theophrasti decreased the germination of amaranth (Amaranthus retroflexus) however increased the growing of its seedlings. In the case of corn cockle (Agrostemma githago) in contrast with amaranth, it increased the germination and decreased the growing of seedlings. Extract of dry abutilon seeds raised the germination percentage of amaranth but inhibited the growing of seedlings. Extracts solved from dry leaves and stems of abutilon decreased the germination of amaranth and thorn-apple (Datura stramonium) significantly, but these extracts had a synergic effect on the growing of seedlings, in case of thorn-apple. It was established, that in the present cases stimulating and inhibitory effects of abutilon extracts led to an opposed change of the growing of seedlings. Extract obtained from dry seedless capsular fruits of abutilon hindered the germination of amaranth with a statistically proved difference (SD5\%) but in this case stimulating effect of the same treatment on the growing of seedling was not observed
\end{abstract}

Keywords: germination, allelopathy, Abutilon theophrasti, Amaranthus retroflexus, Agrostemma githago, Datura stramonium

\section{Introduction}

Allelopathy is a very important ability of weeds in an angro-ecosystems, because it can determine the competitive capacity of a weed species (Rice, 1984; Szabó, 1997; Buzsáki et al., 2008)

The allelopathic trait of the velvetleaf have been examined in several crops e.g. sunflower, corn, alfalfa, soybean, tomato etc.(Dávid and Radócz,2002). The detrimental effect was detected from the leaf and root extract of the velvetleaf and from the dead stem, leaf and root in Keszthely (Kazinczi et al., 1991). Kazinczi et al. (2008) were tested the allelopathic influence of velvetleaf extracts on the development of ragweed (Ambrosia artemisiifolia L.). In this experiment, carried out in pots, aqueous extracts of the velvetleaf stimulated the growth of the ragweed in low concentrations. Moreover, the stimulation was stronger, when the ragweed get it from irrigation. In this way the extracts were utilized as a source of nutrient. The aqueous extracts interfered more the root development, than the germination of the ragweed. From A. theophrasti fresh stems and leaves and separately from the aqueous extract of the root Šćepanović et al. (2007) noticed a very strong restrain on the early development of corn by retarding germination and reducing root and root collar length.

The allelopathic effect of the aqueous extract of velvetleaf plants, growing in different environmental conditions were studied on gardencress pepperweed (Lepidium sativum L.) and sweet corn by Dávid and Borbélyné (2009). The results of the biotests showed 
relationship between the environment, in which the plant grows and the mode and strength of the inter-plant chemical interactions.

The aim of our study was to examine the inhibiting or stimultaing effect of velvetleaf on germination and growth of different weed species, using aqueous extracts made from different parts of the plant.

\section{Materials and methods}

Air dry aboveground parts and aqueous extract of the germinating seed of Abutilon theophrasti Medic. were used for the labor experiment. The effect of the dry stem, the seedless dry capsule, the dry seed and the germinating seed's extract were examined on germination and early growth.

The tested plants was the redroot amaranth (Amaranthus retroflexus L.) the corncockle (Agrostemma githago L.) and the jimsonweed (Datura stramonium L.). This weed can meet the aquous plant residues of the velvetleaf during germination and early growth, due to the wheat/corn succession, which is the most common in Hungary. The extracts made for the trials were prepared with tap water. $4 \mathrm{~g}$ chopped dry plant material were added to $100 \mathrm{ml}$ water. 24 hours later the material was filtered through filter paper. The germinating seed extract contained of the whole germ, including the seed coat, the primer root and the stem. The donor seeds passed a three days pre-germinating.

The experiment were set up in $9^{\text {th }}$ of April, 2009 and repeated with the same conditions in $20^{\text {th }}$ of April. The germination took place in a Binder-type thermostat in dark. 25 seeds were put into one Petri-dish in a filter paper, adding $5 \mathrm{ml}$ to each in four repeats. The timing of germination were checked in every two days and the rate of growth were estimated after a week, by counting the numbers of germinated seeds and measuring the collective length of the radicle and plumula. The germinated plants were eliminated at the end of the experiment. The measured datas were statistically analysed and the effect of extracts on germinating $\%$ and seedling length were evaluated.

\section{Results and discussion}

The extract, made from the seedless dry capsule reduced mostly the germination of $A$. retroflexus in both experiments, resulting 55 and $43 \%$ germinating rate (Table 1).

Both of the germinating seed and the dry stem extract reduced the germinating \%, but in case of these extracts, the difference to the control was significant only in the second experiment.

The dry, mature seed extract was stimulated the germination in both experiments, but there was no significant difference.

A stimulating effect of the dry stem and germinating seed extract were found, when examining the growth of the seedlings. Comparing with the control a lower germinating $\%$ and a higher average growth was observed. The extract of the dry seed was stimulated the germinating rate, while reducing the average germ's length. This can not account for autotoxicity, as in pursuance of the first experiment by higher germinating rate, higher growth was observed in the control, while in case of the second experiment a lower germinating rate was coupling lower seedlings. 
The dry seed extract retarded the early growth, significantly in the first experiment and only as a tendency in the second experiment.

In case of the jimsonweed's germination in both experiments the leafy stem extract of velvetleaf was the strongest retarder.

During the experiment, installed in $9^{\text {th }}$ of April the use of the extract produced only $17 \%$ germinating rate, with $91 \%$ in the control. In the second experiment germination was very weak, so the inhibiting effect was not statistically significant. In case of the extracts that made of the seedless dry capsule, the dry seed and the germinating seed no stimulating or reducing effect was measurable. Between the treatments the dry seed extract resulted the higher germinating rate.

The extract of the dry stem stimulated the jimsonweed germ length in both experiments significantly, while the extract of the dry capsule only in a small compass. The biggest growth was measured by low germinating \%, either in control, or in the treated petri dishes, which can be caused by the autotoxicity of the jimsonweed.

The dry seed extract dramatically reduced the jimsonweed's growth, but it was statistically significant only at the second experiment.

The corncockle germination was the lowest affected by velvetleaf extracts. Each extracts stimulated the corncockle germination in the second experiment, but the difference was not statistically significant.

The same fenomenon was observed in the first experiment, but only in case of the extracts of germinating seed and dry stem.

Table 1. The measured parameters and the belonging datas

\begin{tabular}{|c|c|c|c|c|c|c|c|c|}
\hline $\begin{array}{l}\text { Test } \\
\text { plant }\end{array}$ & $\begin{array}{l}\text { The measured } \\
\text { parameter }\end{array}$ & Experiment & Control & $\begin{array}{l}\text { Germinating } \\
\text { seed's extract }\end{array}$ & $\begin{array}{c}\text { Dry } \\
\text { seed's } \\
\text { extract }\end{array}$ & $\begin{array}{c}\text { Dry } \\
\text { stem } \\
\text { extract }\end{array}$ & $\begin{array}{c}\text { Dry } \\
\text { seedles } \\
\text { capsule } \\
\text { extract }\end{array}$ & SD5\% \\
\hline \multirow{4}{*}{ 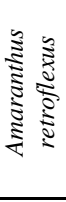 } & \multirow{2}{*}{$\begin{array}{l}\text { Germinating } \\
\text { rate }(\%)\end{array}$} & $1 \mathrm{st}$ & 75.0 & 71.0 & 83.0 & 73.0 & 55.0 & 8.2 \\
\hline & & 2nd & 63.0 & 45.0 & 72.0 & 48.0 & 43.0 & 9.4 \\
\hline & \multirow{2}{*}{$\begin{array}{l}\text { Lenght of } \\
\text { germ }(\mathrm{mm})\end{array}$} & $1 \mathrm{st}$ & 45.5 & 46.4 & 20.0 & 47.3 & 39.6 & 3.91 \\
\hline & & 2nd & 27.3 & 33.6 & 26.7 & 32.7 & 39.3 & 6.99 \\
\hline \multirow{4}{*}{ 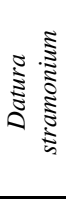 } & \multirow{2}{*}{$\begin{array}{l}\text { Germinating } \\
\text { rate }(\%)\end{array}$} & $1 \mathrm{st}$ & 91.0 & 25.0 & 24.0 & 17.0 & 10.0 & 6.46 \\
\hline & & 2nd & 24.0 & 33.0 & 42.0 & 18.0 & 36.0 & 11.92 \\
\hline & \multirow{2}{*}{$\begin{array}{l}\text { Lenght of } \\
\text { germ }(\mathrm{mm})\end{array}$} & $1 \mathrm{st}$ & 15.7 & 12.4 & 5.2 & 61.5 & 24.0 & 12.45 \\
\hline & & 2nd & 83.4 & 102.8 & 15.2 & 121.7 & 93.1 & 21.75 \\
\hline \multirow{4}{*}{ 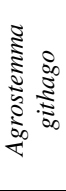 } & \multirow{2}{*}{$\begin{array}{l}\text { Germinating } \\
\text { rate }(\%)\end{array}$} & $1 \mathrm{st}$ & 76.0 & 83.0 & 62.0 & 86.0 & 75.0 & 9.3 \\
\hline & & 2nd & 69.0 & 74.0 & 82.0 & 78.0 & 79.0 & 14.63 \\
\hline & \multirow{2}{*}{$\begin{array}{l}\text { Lenght of } \\
\text { germ }(\mathrm{mm})\end{array}$} & $1 \mathrm{st}$ & 116.4 & 97.3 & 124.7 & 134.2 & 134.4 & 13.32 \\
\hline & & $2 \mathrm{nd}$ & 140.0 & 126.5 & 115.5 & 119.5 & 118.4 & 16.98 \\
\hline
\end{tabular}


From the three experimented plants, the corncockle developed the longest germs. The extract of the germinating velvetleaf seed reduced corncockle germs in both experiments, but significantly only in case of the first. The higher germinating \% observed, the lower growth was measured. The other extracts from velvetleaf didn't affected squarely the corncockle's early growth.

\section{Conclusions}

The allelopathic effect varied according to the part of the plant, the extract made from, and the age of the donor plant material (fresh or died). Moreover the tested plant was also dependent.

Our bioassay surveys on jimsonweed demonstrated the strongest retarder effect from the dry stem extract of velvetleaf.

In some cases the extracts had a stimulating effect on germination and early growth of the test plants. The extract of the germinating seed seemed to be stimulator for the growth of amaranth (A. retroflexus) and the germination of the corncockle (A. githago), which coincide with earlier literature, where amino acids, appears during germination, proved to be stimulating (Colton and Einhellig, 1980).

The extracts that retarded or stimulated the germination of corncockle and jimsonweed had reverse effect on early growth., that the extracts of velvetleaf (leaf, root, died stem, leaf and root) has only retarder effect on germination and growth.

The results of experiments between the two dates were contradictionary in some cases. According to the absolutely same conditions we have found no explanation for this.

\section{Acknowledgement}

"Livable Environment and Healthier People - Bioinnovation and Green Technology Research at the University of Pannonia" (TÁMOP-4.2.2.-08/1/2008-0018)

\section{References}

Buzsáki K. - Kazinczi G. - Béres I. - Lehoczky É.: 2008. The allelopathic effect of yellow nutsedge (Cyperus esculentus L.) on cultivated plants and common ragweed (Ambrosia artemisiifolia L.). Zeitschrift für Pflanzenkrankheiten und Pflanzenschutz, Sonderheft, XXI. 327-332.

Colton C. E. - Einhellig F. A.: 1980 Allelopathic mechanism of velvetleaf (Abutilon theophrasti Medic. Malvaceae) on soybean. Am. J. Bot. (67): 407.

Dávid I. - Borbély M.: 2009. Az allelopátia változékonysága környezeti tényezők függvényében. Magyar gyomkutatás és technológia. 10(1): 70.

Dávid I. - Radócz L.: 2002. Selyemmályva (Abutilon theophrasti Medic.) és olasz szerbtövis (Xanthium italicum Mor.) kivonatok csírázásra gyakorolt hatásának vizsgálata. 7. Tiszántúli Növényvédelmi Fórum. Elöadások. 208-215.

Kazinczi G. - Béres I. - Hunyadi K. - Mikulás J. - Pölös E.: 1991. A selyemmályva (Abutilon theophrasti) allelopatikus hatásának és kompetitív képességének vizsgálata. Növénytermelés 40, 321-331.

Kazinczi G. - Béres I. - Onofri A. - Nádasy E. - Takács A - Horváth J - Torma M.: 2008. Allelopathic effects of plant extracts on common ragweed (Ambrosia artemisiifolia L.). Journal of Plant Diseases and Plant Protection, Special Issue, 21. 335-340.

Rice E. L.: 1984. Allelopathy,. Academic Press, Orlando.

Šćepanović M. - Novak N. - Barić K. - Ostojić Z. - Galzina N. - Goršić M.: 2007. Alelopatski utjecaj korovnih vrsta Abutilon theophrasti Med. i Datura stramonium L. na pocetni razvoj kukuruza. Agronomski Glasnik 69 (6): 459-472.

Szabó L. Gy.: 1997. Allelopathy - Phytochemical Potential - Life Strategy. JPTE, Pécs. 


\title{
ENVIRONMENT REGULATED ECOPHYSIOLOGICAL RESPONSES OF A TALL WHEATGRASS CULTIVAR
}

\author{
Éva SALAMON-ALBERT ${ }^{1}$ - Hajnalka MOLNÁR ${ }^{2}$ \\ ${ }^{1}$ Department of Systematics and Geobotany, Institute of Biology, Faculty of Sciences, University of Pécs \\ H-7624 Pécs Ifjúság útja 6. e-mail: albert@gamma.ttk.pte.hu \\ ${ }^{2}$ Institute of Environmental Sciences, Faculty of Sciences, University of Pécs
}

Abstract: Ecophysiological regulation and threshold limits of significant leaf gas exchange parameters of Hungarian energy grass as a potential biomass plant are discussed. Responses are analysed under non-stressed and water limited field conditions in young plants. Light and relative air humidity turned to be the most effective and limiting enviromental factors in carbon accumulation and water loss. Results could be utilizable from biological and agronomical points of view for planning toward to higher biomass production.

Keywords: energy crop, light response, air humidity, stomatal conductance, $\mathrm{Ci} / \mathrm{Ca}$, water use efficiency, field experiment

\section{Introduction}

Renewable energy sources play increasingly important role in securing both the energy supply and sustainable development. Energy targets in the EU are to increase the proportion of renewable energies up to $20 \%$ of total consumption until 2020. In this process biomass crops will have more and more importance due to various environmental adaptability, leading to action plans on national or international level (Rosillo-Calle, 2007).

Tall wheatgrass is a C3 crop with a cool season characteristic, seasonally different water use efficiency in moderately salt habitats (Johnson, 1991; Bleby et al., 1997). Several cultivars have been developed to be adapted for different environments in the world. The new cultivar „Hungarian energy grass” (Elymus elongatus (Host.) Runemark subsp. ponticus [Podp.] Melderis cv. Szarvasi-1) is originated from Central-European populations of tall wheatgrass. It has recently been introduced to cultivation in Hungary to be an alternative biomass crop. There are some preliminary results on weed composition (Pál and Csete, 2006), but environmental responses regarding the biomass accumulation has not been claryfied yet .

Assimilation is the prominent ecophysiological process in carbon fixation based on biochemical mechanisms. It strongly depends on external abiotic parameters, including e.g. light, air and soil humidity or carbon dioxide (Rawson, 1977; Anda and Lőke, 2003; Csajbók et al., 2008; Hnilicka et al., 2008). Stomatal behavior has an essential role in carbon-dioxide input and water vapour output under environmental regulation additionally. In our study significant ecophysiological responses related to leaf gas exchange of Szarvasi-1 energy grass are discussed. They are essential from biological point of view and may lead to greater biomass production in the practice.

\section{Materials and methods}

In situ field measuring was conducted in South part of Hungary near Bóly (45 $55^{\circ} 09^{\prime} \mathrm{N}$, $\left.18^{\circ} 31^{\prime} 02^{\prime} \mathrm{E}\right)$ on cambisol soil type under natural environmental conditions (Table 1). 
Monocultural stands were planted in $7 \times 7 \mathrm{~m}$ randomized field plots, according to theoretical and experimental measuring protocols (Pearcy et al. 1991). Data had been recorded on the upper fully expanded leaves by a portable IRGA system (LCA-2, ADC UK) by Caemmerer and Farquhar's (1981) calculation. Instantaneous leaf gas exchange parameters and main abiotic environmental variables were measured on three to five replicates, considering 2-5-leaf plants as the phenophases (P2 to P5).

Ecophysiological responses were constructed by first order exponential decay and linear equations. Relationships between abiotic environmental variables (PPFD, RH) and selected leaf gas exchange parameters $\left(\mathrm{A}_{\mathrm{n}}, \mathrm{A}_{\max }, \mathrm{g}_{\mathrm{s}}, \mathrm{C}_{\mathrm{i}} / \mathrm{C}_{\mathrm{a}}, \mathrm{WUE}_{\mathrm{g}}\right)$ were analysed. Goodness of curve fitting were described by coefficient of determination $\left(\mathrm{R}^{2}\right)$.

Abbreviations: PPFD, photosynthetic photon flux density; $\alpha$, apparent quantum yield; $\mathrm{A}_{\mathrm{n}}$, instantaneous net assimilation rate; $\mathrm{A}_{\max }$, assimilation capacity; $\mathrm{g}_{\mathrm{s}}$, stomatal conductance; $\mathrm{RH}$, relative air humidity; $\mathrm{C}_{\mathrm{i}} / \mathrm{C}_{\mathrm{a}}$, ratio of internal to atmospheric carbondioxide; $\mathrm{WUE}_{\mathrm{g}}$, water use efficiency as the ratio of $\mathrm{g}_{\mathrm{s}}$ for $\mathrm{CO}_{2}$ to $\mathrm{g}_{\mathrm{s}}$ for $\mathrm{H}_{2} \mathrm{O}$.

\section{Results and discussion}

Among measured abiotic environmental parameters, photon flux density and relative air humidity turned to be the most significant for leaf gas exchange characteristics. Carbondioxide concentration of the air $\left[\mathrm{CO}_{2}\right]$ and leaf temperature $\left(\mathrm{T}_{1}\right)$ was not straightly correlated with the photosynthesis, but ratio of internal to ambient carbon-dioxide $\left(\mathrm{C}_{\mathrm{i}} / \mathrm{C}_{\mathrm{a}}\right)$ was a relevant calculated gas exchange parameter. Water use efficiency as the ratio of stomatal conductance for $\mathrm{CO}_{2}$ to $\mathrm{H}_{2} \mathrm{O}$ proved to be an indicator. According to OMSZ data originated from regional climatic station in Sátorhely, a seasonal deficiency in precipitation had been registered in late July, affecting soil water content and availability in the experimental plot at P4 phenophase.

Table 1. Values and ranges of environmental parameters in the experimental plot during the measuring period

\begin{tabular}{|l|r|l|r|r|r|r|}
\hline \multicolumn{2}{|c|}{ Soil parameters } & \multicolumn{5}{c|}{ Abiotic environmental parameters } \\
\hline \hline pH by $\mathrm{H}_{2} \mathrm{O}$ & 6.90 & Phenophase & P2 (July) & P3 (Aug) & \multicolumn{1}{c|}{ 44 (Sept) } & \multicolumn{1}{c|}{ P5 (Oct) } \\
\hline $\mathrm{Humus}, \mathrm{m} / \mathrm{m} \%$ & 1.76 & ${\mathrm{PPFD} \mu \mathrm{mol} \mathrm{m}^{-2} \mathrm{~s}^{-1}}$ & $91-1521$ & $99-1480$ & $93-1201$ & $62-1188$ \\
\hline $\mathrm{NO}_{2}+\mathrm{NO}_{3}, \mathrm{mgN} / \mathrm{kg}$ & 40.11 & {$\left[\mathrm{CO}_{2}\right], \mathrm{ppm}$} & $278-415$ & $105-441$ & $321-366$ & $278-428$ \\
\hline $\mathrm{K}$ as $_{2} \mathrm{O}, \mathrm{mg} / \mathrm{kg}$ & 266.19 & $\mathrm{~T}_{1}, \mathrm{C}^{\circ}$ & $21,4-35,0$ & $23,2-35,3$ & $19,6-31,1$ & $16,6-28,4$ \\
\hline $\mathrm{P}_{\text {as }} \mathrm{P}_{2} \mathrm{O}_{5}, \mathrm{mg} / \mathrm{kg}$ & 246.94 & $\mathrm{RH}, \%$ & $18,0-55,5$ & $21,9-52,6$ & $39,8-64,9$ & $13,8-59,6$ \\
\hline
\end{tabular}

Instantaneous data of incident light (PPFD) and net carbon-dioxide exchange rate $\left(\mathrm{A}_{\mathrm{n}}\right)$ were used for constructing light response curves (Fig $1 \mathrm{~A}, \mathrm{R}^{2}=0.559-0.906$ ). Initial slope as the apparent quantum yield $(\alpha)$ and maximal light-saturated net photosynthetic rate $\left(A_{\max }\right)$ as the assimilation capacity showed that highest carbon accumulation had been realized at the beginning of the growing period. According to theoretically estimated parameters for a C3 plant or some other related species (Iqbal et al. 1997, Engloner et al. 2003), Hungarian energy grass was much more effective in carbon fixation during the overall vegetation period as well as under seasonal environmental drought.

Intercellular $\mathrm{CO}_{2}$ concentration is the main limiting factor of assimilation in $\mathrm{C} 3$ plants under non-stressed conditions. In the case of Hungarian energy grass, there had a tight 
linear correlation between $\mathrm{Ci} / \mathrm{Ca}$ as the relative carbon-dioxide concentration and net photosynthetic rate at every growing period (Fig $1 \mathrm{~B}, \mathrm{R}^{2}=0.529-0.942$ ). Slope of the linear regression permanently decreased parallel with decreasing assimilation rates. Maximum and minimum values of $\mathrm{C}_{\mathrm{i}} / \mathrm{C}_{\mathrm{a}}$ differently increased through the growing season, pointing out that instantaneous carbon use efficiency was regulated by external factors and internal processes as well.
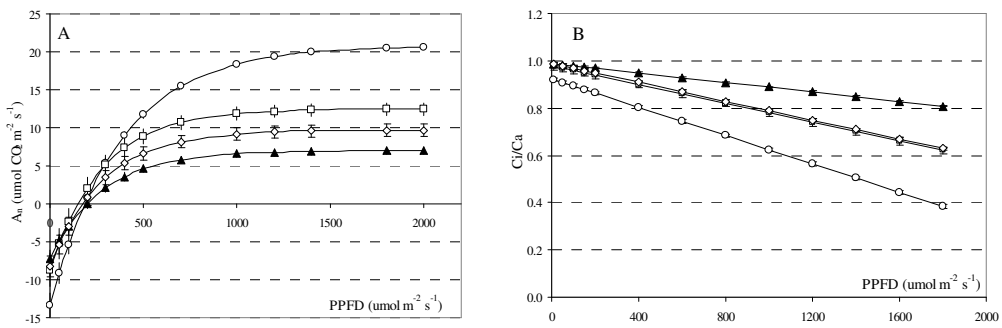

Figure 1. Photosynthetic light response curves (A), and photon flux density to $\mathrm{C}_{\mathrm{i}} / \mathrm{C}_{\mathrm{a}}(\mathrm{B})$. Mean and standard deviation ( \pm SD) are displayed. $\circ=\mathrm{P} 2, \square=\mathrm{P} 3, \boldsymbol{\Delta}=\mathrm{P} 4, \diamond=\mathrm{P} 5$

Stomatal conductance for carbon-dioxide as the reference parameter for assimilation, showed close positive correlation to relative air humidity (Fig $2 \mathrm{~A}, \mathrm{R}^{2}=0.449-0.828$ ), similar to transpiration. Values and efficiency of $\mathrm{g}_{\mathrm{s}}$ were highest at the beginning of the growing period by equal and above $30 \%$ critical humidity value. Threshold value as the intercept permanently increased, slope of the equation permanently decreased through the phenophases. Slope of the equation, threshold and critical values of stomatal conductance has shifted to a much more higher humidity range for getting up sufficient stomatal conductance for $\mathrm{CO}_{2}$ under limited soil water availability.
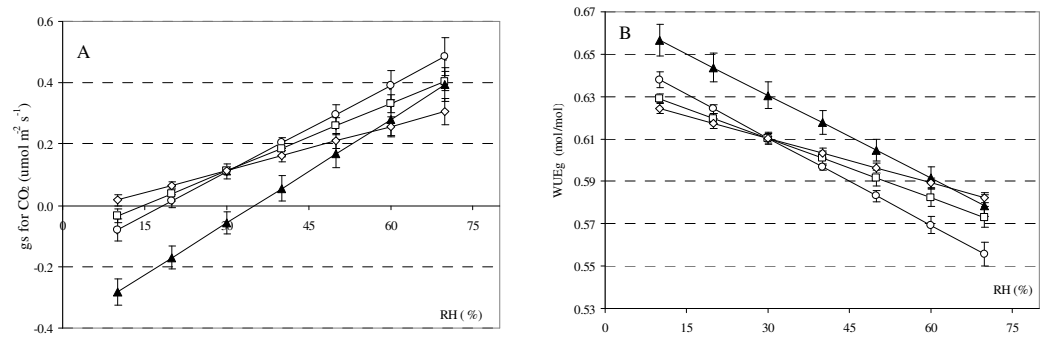

Figure 2. Relative air humidity to $\mathrm{g}_{\mathrm{s}}$ for $\mathrm{CO}_{2}(\mathrm{~A})$, and water use efficiency as the functional ratio of stomatal conductances (B). Mean and standard deviation $( \pm \mathrm{SD})$ are displayed. $\circ=\mathrm{P} 2, \square=\mathrm{P} 3, \boldsymbol{\Delta}=\mathrm{P} 4, \diamond=\mathrm{P} 5$

Instantaneous water use efficiency $\left(\mathrm{WUE}_{\mathrm{g}}\right)$ as the ratio of conductances showed a close negative linear correlation to air humidity owing to intense transpiration that was constantly 1,61-1,89 times higher than assimilation rate in the growing period (Fig 2B, $\mathrm{R}^{2}=0.449-0.922$ ). Equal and above $30 \%$ relative air humidity water use efficiency intensely decreased, especially at the beginning of growing season. In those cases where reduced water availability results in reduced rates of transpiration and assimilation water use efficiency can be dramatically increased. 


\section{Conclusions}

Some abiotic environmental parameters, especially light and air humidity proved to have an essential role in gas exchange regulation of Szarvasi-1 energy grass. Under nonstressed conditions carbon fixation and biomass production were the most favourable at the beginning of growing period. In precipitation deficiency inducing limitation in water availability, reduction in assimilation rate and capacity, stomatal conductance and relative carbon input, but increasing in functional water use efficiency was detected. Determining qualitative and quantitative threshold limits of gas exchange parameters, it is concluded that Szarvasi-1 energy grass could be an appropriate biomass crop among C3 plants for energy purposes in the future.

\section{Acknowledgements}

Research was supported by Hungarian National Office for Research and Technology (NKFP 3A/061/2004). Thanks T. Kalapos (ELTE) for submission data processing software.

\section{References}

Anda A. - Lőke Zs.: 2003. A kukorica párolgását meghatározó tényezők, a sztómaellenállás, a növényhőmérséklet, valamint a fotoszintézis-intenzitás számítása szimulációs modellel. Növénytermelés 52. 34.: 351-363.

Bleby T.M. - Avcote M. - Kennett-Smith A.K. - Walker G.P. - Schachtman R.P.: 1997. Seasonal water use characteristics of tall wheatgrass (Agropyron elongatum (Host) Beauv.) in a saline environment. Plant, Cell and Environment 20: 1361-1371.

Caemmerer S. - Farquhar C.D.: 1981. Some relationships between the biochemistry of photosynthesis and the gas exchange of leaves. Planta 153: 376-387.

Czakó-Vér K. - Biró B.: 2008. Elymus elongatus cv. Szarvasi-1 energiafü talajfüggő biomassza produkciója és néhány rhizobiológiai tulajdonsága. In: Simon L. (ed.): Talajvédelem, különszám: 375-380.

Csajbók J. - Kutasy E. - Borbély-Hunyadi É. - Lesznyák M.: 2008. Effect of soil moisture on the photosynthetic activity and transpiration of plants. Cereal Research Communications 36. 5: 603-606.

Engloner A. I. - Kovács D. - Balogh J - Tuba Z.: 2003. Anatomical and eco-physiological changes in leaves of couch-grass (Elymus repens L.), a temperate loess grassland species, after 7 years old growth under elevated $\mathrm{CO}_{2}$ concentration. Photosynthetica 41 (2): 185-189.

Hnilicka F. - Hnilicková H. - Holá D. - Kocová,M. - Rothová O.: 2008: The effect of soil drought on gases exchange in the leaves of maize (Zea mays L.). Cereal Research Communications 36. 5.: 895-898.

Iqbal R.M. - Rao A.R. - Rasul E. - Wahid A.: 1997. Mathematical models and response functions in photosynthesis: an exponential model. In: Pessarakli, M. (ed): Handbook of photosynthesis. Marcel Dekker Inc., New York, 803-810.

Johnson R.C.: 1991. Salinity resistance, water relations, and salt content of crested and tall wheatgrass accessions. Crop Science 31: 730-734.

Medrano H. - Escalona J.M. - Bota J. - Gulías J. - Flexas J.: 2002. Regulation of photosynthesis of C3 plants in response to progressive drought: stomatal conductance as a reference parameter. Annals of Botany 89: 895-905.

Pál R. - Csete S.: 2008. Comparative analysis of the weed composition of a new energy crop (Elymus elongatus (Host.) Runemark subsp. ponticus [Podp.] Melderis cv. Szarvasi-1) in Hungary. Journal of Plant Diseases and Protection XXI: 215-220.

Pearcy R.W. - Ehleringer J. - Mooney H.A. - Rundel P.W. (eds).: 1991. Plant Physiological Ecology. Field Methods and Instrumentation. Chapman and Hall, London, 209-253.

Rawson H.M. - Begg J.E.: 1977. The effect of atmospheric humidity on photosynthesis, transpiration and water use efficiency of leaves of several plant species. Planta 134: 5-10.

Rosillo-Calle F.: 2007. Overview of biomass energy. In: Rosillo-Calle, K. - de Groot, P. - Hemstock, S.L. Woods, J. (eds): The biomass assessment handbook. Bioenergy for a sustainable environment. EarthScan, London, 1-25. 


\title{
EVALUATION OF RESILIENCE THRESHOLD CONCERNING PRECIPITATION AND THE HAGBERG-FALLING NUMBER
}

\author{
Kornél D. SZALAY ${ }^{1}-$ Judit JASSÓ ${ }^{2}-D e z s o ̈ S Z A L A Y^{3}$ \\ ${ }^{1}$ Hungarian Institute of Agricultural Engineering- Outer Agricultural Technical Department, Szent István \\ University, Gödöllö, szalay@fvmmi.hu \\ ${ }^{2}$ Eötvös Lorand University, Faculty of Science \\ ${ }^{3}$ Secretariat of the Hungarian Academy of Sciences
}

Abstract: Five quality winter wheat varieties were evaluated concerning the connections between their quality parameters and the environmental stresses. Significantly rainy weather prior to harvest usually causes relevant depression in quality parameters. In the experimental year 2008-2009 we studied the affect of rain on the Hagberg-falling number. Agronomic replicated blocks were sown and six different nutrition levels were applied by broadcasting different amounts of nitrogen fertilizer. The experimental plot size was $10 \mathrm{~m}^{2}$. By the preliminary results the measure of the harmful effect depends on the stress-specified resilience referring to a certain variety that is a genetically determinated attribute. Those varieties in which the magnitude of the stress exceeded the threshold limit resulted in higher depression in the parameters examined. Studying the data we can identify what nutrition levels are appropriate to extend the threshold limit and so the level of resilience. Concerning the results it can be stated, that the resilience depends on the variety, the moisture stress and the different levels of nutrition. The levels of threshold are determined by the interaction of these factors. In order to clarify the correlations above, further experiments are needed.

Keywords: winter wheat, resilience, Hagberg-falling number, precipitation

\section{Introduction}

Resilience defines the adaptive capacity that determinates the ecosystem's or a single organism's tolerance according to various stresses. It lays down a threshold limit in witch adverse effects are withstood by a resilient system without quantitative or qualitative depressions. The success of the agricultural production strongly depends on the various environmental stressors such as weather or soil conditions (Erdélyi, 2009a) and nutrient supply (Csiba, 2009). The available water capacity highly influences the crop production all over the world (Erdélyi and Horváth, 2006; Cseuz et al., 2009; Hoffmann et al. 2009). The magnitude of rain increases due to the intemperate weather of Hungary (Gyimes, 2009). Precipitation can be considered as a major stressor in relation with yield quality and quantity performance (Erdélyi, 2009b; Klupács et al., 2009). Producing quality winter wheat the precipitation prior to the harvest has critical effects of the baking parameters. This adverse weather conditions can cause sprouting that can be indicated with the decrease of the Hagberg-falling number. Since the measure of the depression depends on the threshold limit of the wheat variety concerning the rain, the falling number is suitable to mark the stress-specified resilience. The Hagberg-falling number is a crucial value in baking industries that determinates the possibilities of the further processes of flour. This value shows inverse relation with the activity of the alpha-amylase enzyme that is responsible for breaking down the starches providing sugar. While the sprouting process advances the quantity of alpha-amylase increases in the kernel. Both the insufficient and the exaggerated enzyme activity can cause malformations in baking products such as bread. The appropriate enzyme activity, or rather falling number (250-350) results high volume bread with firm and soft texture. Such as the resilience, the Hagberg-value is referred to a certain variety. Generally the 
wheat varieties quantitative and qualitative parameters are genetically determinated attributes which can be suppressed or enhanced by the environmental factors, or the agronomic methods, but cannot be improved (Polhammerné, 1981; Szentpétery et al., 1995). In the following trial five quality winter wheat variety's resilience is evaluated in different nutrition levels concerning the precipitation and the Hagberg-falling number.

\section{Materials and methods}

Experimental plots were sown on chernozem soil (calciustoll) at Hatvan- Nagygombos, (Central Hungary), in the year of 2008. Split-split-plot design with four replications was used. Five wheat varieties were planted with a row spacing $12 \mathrm{~cm}$ at a rate of five million live seeds per hectare. The plot size was $10 \mathrm{~m}^{2}$. Six different nutrition levels were applied by broadcasting nitrogen in form of ammonium-nitrate fertilizer (36-0-0). The data of the treatments were defined by the fenophases of the wheat. The nitrogen doses applied and the fenophases of broadcasts are summarized in Table 1.

Table 1. Applied nitrogen doses and the fenophases of broadcasts

\begin{tabular}{|c|c|c|c|}
\hline \multicolumn{2}{|c|}{ Nitrogen $\left(\mathrm{kg} \mathrm{ha}^{-1}\right)$} & \multirow{2}{*}{$\begin{array}{c}\text { Replication } \\
\text { (plot) }\end{array}$} \\
\hline \hline Tillering & Shooting & Heading & 4 \\
\hline 40 & 0 & 0 & 4 \\
\hline 80 & 0 & 0 & 4 \\
\hline 120 & 0 & 0 & 4 \\
\hline 80 & 80 & 0 & 4 \\
\hline 80 & 40 & 30 & 4 \\
\hline
\end{tabular}

In the experimental arrangement illustrated above 'Alföld 90', 'Csárdás', 'Magdaléna', 'Suba' and 'Toborzó' varieties were studied concerning the falling number, the resilience, the moisture stress and the different levels of nutrition.

\section{Results and discussion}

Precipitation was generally well tolerated by 'Alföld 90' variety. However other nutrition levels achieved the optimal range, the 'Alföld 90' variety's control plots produced falling number figures slightly below the value of 250 . The highest falling number was generated by the $80 \mathrm{~kg} \mathrm{ha}^{-1}$ nitrogen dose. The second maximum (just below the previous one) was resulted by the $80+40+30 \mathrm{~kg} \mathrm{ha}^{-1}$ nutrition level. These two

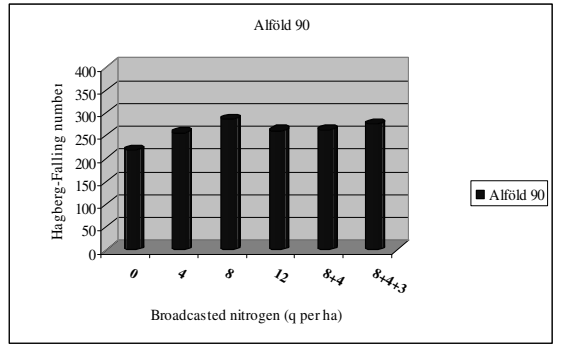

Figure 1. The Hagberg-falling numbers of 'Alföld 90 ' variey

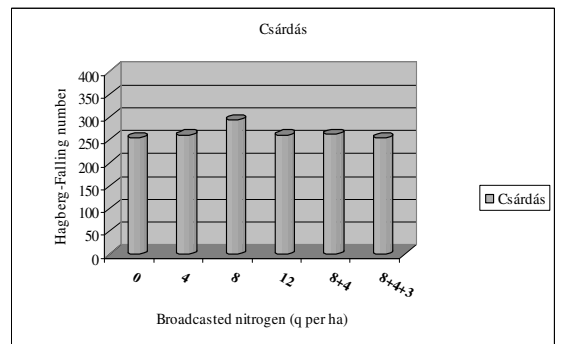

Figure 2. The Hagberg-falling numbers of 'Csárdás' variety 
nitrogen amounts made the most preferential threshold limit resulting resilience to withstand the moisture stress. The data are illustrated in Figure 1. 'Csárdás' variety has resulted in optimal range of falling numbers in all nutrition levels. Data show square distribution. In consequence of the variety's resilience despite of the late precipitation every treatment level resulted in optimal range of falling number. The harmful effect was tolerated the best with $80 \mathrm{~kg} \mathrm{ha}^{-1}$ nitrogen level. These correlations are illustrated in Figure 2. In case of 'Magdaléna' concerning the control treatments without nitrogen, we measured the lowest falling numbers of all studied varieties that were significantly under the level of the optimum value range. The increase of the nitrogen amount shows linear growth of the Hagberg values and all reached the 250-300 range. Nevertheless at a dose of $80+40$ and $80+40+30 \mathrm{~kg} \mathrm{ha}^{-1}$ nitrogen, the values exceeded significantly the optimal range that is unfavorable in the processing technology. With the different levels of nitrogen supply the variety's resilience is outstanding, but the lack of nitrogen resulted in depression in tolerance according to the moisture stress. Data are presented in Figure 3.

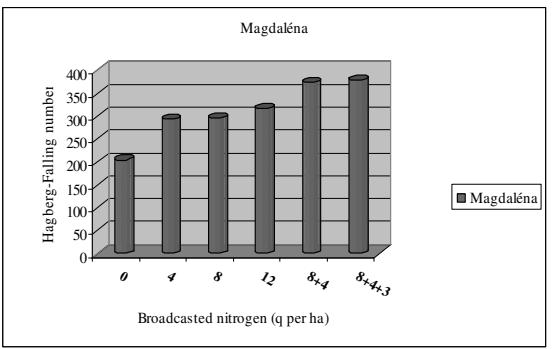

Figure 3.

The Hagberg-falling numbers of 'Magdaléna' variety

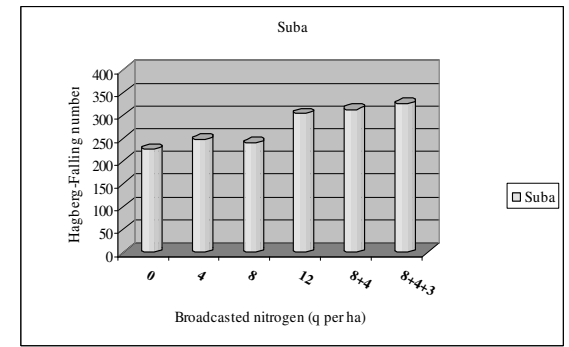

Figure 4.

The Hagberg-falling numbers of 'Suba' variety

Studying 'Suba' variety without fertilizer we found low falling number that does not reach the value of 250 . The 40 and the $80 \mathrm{~kg} \mathrm{ha}^{-1}$ nitrogen doses resulted in suboptimal falling numbers. Increasing the nitrogen doses linear growth of the Hagberg value can be observed. Broadcasting bigger amounts of nitrogen high falling numbers are resulted without exceeding the optimal range of 250-300. By applying big or divided doses of nitrogen the variety's threshold limit was extended, resulting the necessary resilience to withstand the stress of late precipitation. By using lower nutrient supply the tolerance of the variety decreases. The described relations are presented in Figure 4.

'Toborzó' reached the optimal range of falling number only at the $40 \mathrm{~kg} \mathrm{ha}^{-1}$ nitrogen nutrition level. Even high amounts of nitrogen broadcast did not result in any improvement; none of the other treatment level resulted in optimal Hagberg values. The variety showed intense sensitivity to the moisture stress, but by the dose of $40 \mathrm{~kg} \mathrm{ha}^{-1}$ nitrogen amount the level of threshold limit could be extended and the harmful effect could be lessened. The data are illustrated in Figure 5.

The Hagberg-falling numbers determinated by the level of resilience concerning the moisture stress and the nutrition levels are summarized in Figure 6. 


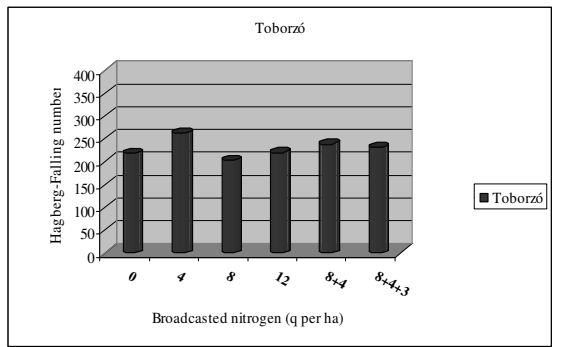

Figure 5.

The Hagberg-falling numbers of 'Toborzó' variety

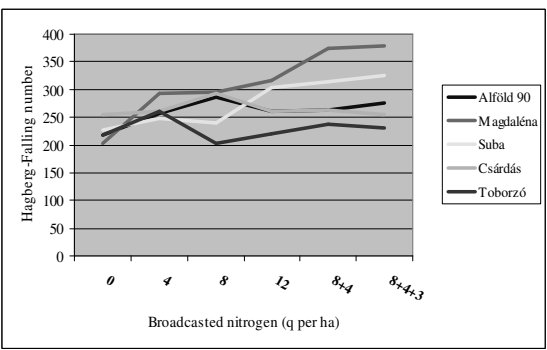

Figure 6.

The Hagberg-falling numbers of the studied varieties

\section{Conclusions}

Those varieties in which the adverse effect of precipitation exceeded the threshold limit that can be tolerated by the certain variety showed lower falling numbers which did not match the optimal value. The threshold limit can be influenced by different levels of nutrient supply. By broadcasting the appropriate amount of nitrogen fertilizer referring to the certain variety, the threshold limit and the level of resilience can be extended. Referring to the results obtained it can be stated, that resilience depends on the variety, the moisture stress and the different levels of nutrition. The levels of threshold are determined by the interaction of these factors. In order to clarify the correlations above, further data and additional experiments are needed.

\section{Acknowledgements}

The authors would express their thanks towards the Hungarian Academy of Sciences and the Szent István University, Gödöllő for the financial support they received.

\section{References}

Cseuz L - Pauk J - Lantos Cs - Kovács I.-né: 2009. Wheat breeding for drought tolernace. (Efforts and results.) Cereal Research Communication 37: 245-248.

Csiba M.: 2009. Comparison between capacitance and NIT sensing technology to nontinuously evaluate grain moisture during harvest. Cereal Research Communication 37: 73-76.

Erdélyi É - Horváth L.: 2006. Climate Change and Precipitation Needs of Winter Wheat, Summer University on Information Technology in Agriculture and Rural Development, Debrecen, 33-40.

Erdélyi É: 2009a. Sensitivity to Climate Change with Respect to Agriculture Production in Hungary In: Precision agriculture '09, Edited by E.J. van Henten, D.Goense, C. Lokhorst, Wageningen Academic Publishers, The Netherlands, 559-566.

Erdélyi É: 2009b. The potential impacts of climate change of main field crops and their yields in Hungary, Case studies, "Klíma-21" Füzetek, English Special Edition, Akaprint Kft, Budapest 55: 55-80.

Gyimes E.: 2009. Wheat kernel size and physical features: A possible consequence of abiotic stress. Cereal Research Communication 37: 257-260.

Hoffmann B - Aranyi N - Hoffmann S - Molnár-Láng M.: 2009. Possibilities to increase stress tolerance of wheat. Cereal Research Communication 37: 93-96.

Klupács H - Nyárai F - Balla I - Jolánkai M.: 2009. Water availability - A stressor influencing quantity and quality of winter wheat Triticum aestivum L. yield. Cereal Research Communication 37: 361-364 pp.

Polhammer E.- né: 1981. A búza és a liszt minősége. In: Ágoston T. (2006): Evaluation of quantity and quality parameters in winter wheat varieties. Cereal Research Communication 34: 2. 369.

Szentpétery Zs - Jolánkai M - Varga J - Fehér Gy.- né: 1995. Az őszi búza hektoliter- tömegének, fehérje és nedves sikér mennyiségének változása az elhúzódó betakarítás hatására. Növénytermelés. 44: 5-6: 475482 . 


\title{
GROWING "ENERGY WILLOW" (SALIX VIMINALIS L.) IN SUSTANABLE AGRICULTURE
}

\author{
Attila KONDOR ${ }^{1}-$ István LENTI $^{2}$ \\ ${ }^{1}$ Agricultural and Rural Develpoment Agency, 4400 Nyíregyháza, Hősök tere 9 . Hungary \\ ${ }^{2}$ Collage of Nyíregyháza, Department of Technology and Agriculture, 4400 Nyíregyháza, Sóstói út 31/B.
}

\begin{abstract}
Growing biomass as potential source of energy has undoubtedly great potential in Hungary. The restructuring of agriculture, the system applied for the $21^{\text {st }}$ century resulted in huge amount of fallow land. In Szabolcs-Szatmár-Bereg County's water rich environment agriculture have been abandoned. The size of this land reaches 100.000 hectares. These lands have to be put back under agricultural management. One possible land use would be utilizing these areas with Energy Willow plantations (Salix viminalis L.). Rehabilitation of arable land can be achieved through the development of the plant's growing technology that is going to be discussed in details here. Considering environmental stress and economics one of the key factors is to establish the details and doses of the fertilization. Based on our research the cropping of energy willow can be achieved in lines with sustainability.
\end{abstract}

Keywords: "energy willow", nutrient replenishment, twig yield, profitability

\section{Introduction}

When talking about biomass plants, there is an old-new one, "energy willow" (Salix viminalis L.), which is outstanding because of its high energy supply capability. The key to its successful production is finding the appropriate production site and the production technology that is best adjustable to the site conditions. The first plantations in Hungary date back to 2002, which means that this plant only has a few years' history. As such, there are rather few data available in relation to the applicable technologies. Our objective is to establish an environment friendly nutrient supplementation system on the basis of the results of our large-plot experiments.

Twig yield, besides several other factors, is considerably influenced by nutrient supply, too. To establish a stock capable of reaching high yield the appropriate nutrient replenishment and supply is essential. "Energy willow" is a nutrient-demanding plant that grows great mass of twigs and green leaves. The annual twig yield is 10-12 t/ha. in the first year, which may as well increase to 25-40 t/ha (Tar et al., 2005). When the issue of twig yield per hectare is being approached we must not forget that this plant, apart from twigs, also has a considerable mass of green leaf surface, the growing of which necessitates a lot of nutrient. The nutrient demand of "energy willow" for the production of 1 ton of dry twig, seen for the different species, is: $\mathrm{N} 5.3-7.5 \mathrm{~kg} ; \mathrm{P}_{2} \mathrm{O}_{5}$ 0.6-0.9 kg; $\mathrm{K}_{2} \mathrm{O}$ 1.8-3.0 kg; Ca 4.2-7.2 kg; Mg 0.4-0.7 kg (Labrecque et al., 2003). Reaping takes place after defoliation, so the nutrient stored in the leaves will be recycled (Kósa and Tóth, 2007).

\section{Materials and methods}

We have been researching nutrient replenishment since 2007. Our relating experiments took place in the exhibition garden of the College of Nyíregyháza. When choosing the site for willow plantation, we took the soil demand into consideration; this is why we decided for a lower, water-saturated land on the exhibition site. 
The production site having been chosen, the plantation itself took place in March 2007. The size of the experiment plots is $200 \mathrm{~m}^{2}$. For planting we applied $1 \mathrm{~m}$ spacing with $1 \mathrm{~m}$ distance between the rows, so 200 plants were placed in one treatment. No nutrient replenishing fertilization took place before the plantation.

Before getting the fertilizer out, we performed a soil test. The soil samples were graded in the Agricultural Laboratory of SGS Ltd. in Nyíregyháza. On the basis of the test results, the experiment table was well supplied with phosphorus and potassium and to a medium extent with nitrogen. The detailed results of the test are included in the following table (Table 1).

Table 1. The soil test results of the experiment table

\begin{tabular}{|l|r|c|l|}
\hline Test parameters & Result & Unit & Test method \\
\hline \hline $\mathrm{pH}(\mathrm{KCL})$ & 7.74 & $\mathrm{pH}$ & MSZ-08 0206/2: 1978. 2.1 \\
\hline Soil water retain & 29 & $\mathrm{~K}_{\mathrm{A}}$ & MSZ 0205: 1978. 5 \\
\hline Total salt solvable in water & $<0.02$ & $\%(\mathrm{~m} / \mathrm{m})$ & MSZ-08 0206/2: 1978. 2.4 \\
\hline Total carbonate content expressed in $\mathrm{CaCO}_{3}$ & 13.49 & $\%(\mathrm{~m} / \mathrm{m})$ & MSZ-08 0206/2: 1978. 2.2 \\
\hline Humus $\%$ & 1.589 & $\%(\mathrm{~m} / \mathrm{m})$ & MSZ 21470: 1983. 2 \\
\hline$\left(\mathrm{NO}_{2}+\mathrm{NO}_{3}\right)-\mathrm{N}$ & 11.31 & $\mathrm{mg} / \mathrm{kg}$ & MSZ 20135: 1999 \\
\hline Phosphorous content expressed in $\mathrm{P}_{2} \mathrm{O}_{5}$ & 271 & $\mathrm{mg} / \mathrm{kg}$ & MSZ 20135: 1999 \\
\hline Magnesium & 396 & $\mathrm{mg} / \mathrm{kg}$ & MSZ 20135: 1999 \\
\hline Potassium content expressed in $\mathrm{K}_{2} \mathrm{O}$ & 238 & $\mathrm{mg} / \mathrm{kg}$ & MSZ 20135: 1999 \\
\hline Sodium & 88.8 & $\mathrm{mg} / \mathrm{kg}$ & MSZ 20135: 1999 \\
\hline Zinc & 1.24 & $\mathrm{mg} / \mathrm{kg}$ & MSZ 20135: 1999 \\
\hline Copper & 1.943 & $\mathrm{mg} / \mathrm{kg}$ & MSZ 20135: 1999 \\
\hline Manganese & 51.9 & $\mathrm{mg} / \mathrm{kg}$ & MSZ 20135: 1999 \\
\hline Sulphate & 14.1 & $\mathrm{mg} / \mathrm{kg}$ & TGV methodology 4.7.12 \\
\hline
\end{tabular}

Getting the fertilizer out took place twice: in autumn (30 October 2007) and in spring (12 March 2008). With respect to the size of the plots and because of the attempt to get the precise amounts out, we did the fertilization manually. In Hungary, 7 "energy willow" species have permission for plantation. The most frequently used is the cv."Tora". This is the one we involved in our experiments in the first year. We performed the test in 4 treatments and 4 repetitions according to the followings (Table 2). We determined the amount of the agent got out in consideration with the nutrient supply level of the soil and with the specific nutrient demand of "energy willow".

To compare the treatments we examined the change of the volumes of the twig produced. Reaping was done manually in November 2008. After measuring the wet twig volumes, on the basis of samples taken randomly from the treatments, we determined the moisture content of the twigs by drying them on $105{ }^{\circ} \mathrm{C}$ through 25 hours. 
Table 2. Treatments in the nutrient replenishment experiment

\begin{tabular}{|c|c|c|c|}
\hline & fertilizer & volume & get-out time \\
\hline \multirow{3}{*}{ treatment 1} & $\mathrm{P}_{2} \mathrm{O}_{5} 10 \%$ & \multirow{3}{*}{$250 \mathrm{~kg} / \mathrm{ha}$} & \multirow{3}{*}{$100 \%$ in autumn } \\
\hline & $\mathrm{K}_{2} \mathrm{O} 24.5 \%$ & & \\
\hline & $\mathrm{Ca} 12 \%$ & & \\
\hline \multirow{4}{*}{ treatment 2} & $\mathrm{P}_{2} \mathrm{O}_{5} 10 \%$ & \multirow{3}{*}{$250 \mathrm{~kg} / \mathrm{ha}$} & \multirow{3}{*}{$100 \%$ in autumn } \\
\hline & $\mathrm{K}_{2} \mathrm{O} 24.5 \%$ & & \\
\hline & $\mathrm{Ca} 12 \%$ & & \\
\hline & ammonium nitrate $(34 \% \mathrm{~N})$ & $200 \mathrm{~kg} / \mathrm{ha}$ & $50-50 \%$ in autumn-spring \\
\hline treatment 3 & ammonium nitrate $(34 \% \mathrm{~N})$ & $400 \mathrm{~kg} / \mathrm{ha}$ & $100 \%$ in spring \\
\hline control & -- & -- & - \\
\hline
\end{tabular}

When statistically evaluating the scaling results we performed single-factor analysis of variance at a significance level of $95 \%$. The sequence of the operations performed on the experiment table is summed up in Table 3.

Table 3. Operations performed on the experiment table

\begin{tabular}{|l|l|}
\hline \multicolumn{1}{|c|}{ operation } & \multicolumn{1}{c|}{ date } \\
\hline \hline soil preparation & 17 March 2007 \\
\hline plantation & 24 March 2007 \\
\hline chemical weed control & April 2007 \\
\hline manual hoeing & June 2007 \\
\hline autumn fertilization & 30 October 2007 \\
\hline spring fertilization & 12 March 2008 \\
\hline chemical weed control & April 2008 \\
\hline Reaping & 12 -14 November 2008 \\
\hline
\end{tabular}

In the course of our experiments we did not only measure how the crop was changing but also examined the changes of the soil characteristics. We intend to back up our researches with duration experiments in the future!

\section{Results and discussion}

To measure twig yield - for each treatment - we reaped the whole plot. Weighing was then done by authenticated bridge-scaling. The results relating to the average yield of the treatments is included in Table 4.

The yields of the treatments compared, we can establish that as an effect of the nutrient replenishment, the twig yield of the roots treated considerably exceeded the yield of those not treated, which was also underlined by the statistic analysis.

403 DOI: 10.1556/Novenyterm.59.2010.Suppl.4 
Table 4. Operations performed on the experiment table

\begin{tabular}{|l|c|c|c|}
\hline & Wet volume (t/ha.) & $\begin{array}{c}\text { Moisture content } \\
(\%)\end{array}$ & Dry weight (t/ha.) \\
\hline \hline treatment 1 & 29.8 & 47.45 & 15.66 \\
\hline treatment 2 & 32.3 & 50.46 & 16.00 \\
\hline treatment 3 & 33.6 & 48.94 & 17.16 \\
\hline Control & 28.1 & 51.58 & 13.61 \\
\hline
\end{tabular}

The biggest, $26 \%$ difference was only detected in case of the nitrogen fertilization (136 $\mathrm{kg} / \mathrm{ha}$. agent). In spite of the good $\mathrm{P}$ and $\mathrm{K}$ supply of the soil, we measured a crop growth higher than $15 \%$ on the plot treated with phosphorous and potassium, too.

When examining the total wet twig yield, we established that the autumn nitrogen fertilization (treatment 2) resulted almost $40 \%$ extra crop compared to the untreated plots.

If we take a look at how the moisture content was changing, we will see that the highest content was measured on the control plot. The extent of the differences is not significant if compared to the 5\% significance level. The laboratory testing of the soil samples taken after reaping is in progress.

\section{Conclusions}

The scale-based fertilization that focuses on the specific nutrient demand of the plant and the nutrient supply of the soil resulted a considerable increase in twig yield, which highly influences the success of production. "Energy willow" belongs to those plants the nutrient reaction of which is easy to measure. Subject to this, our future objective is to work out the nutrient supply technology adapted to the production site. In the course of fertilization, besides increasing twig yield, another important aspect is to preserve the fertility of the soil. When performing nutrient replenishment, we should always keep an eye on this, since out of the available resources of the country the soil conditionally able to renew is the most important one.

With rational nutrient replenishment the extent of environmental load is also easier to decrease, which, seen from the point of view of environmental protection, is a very important factor in case of such an intensive culture.

\section{References}

Kósa F. - Tóth F.: 2007. Amit a füzről tudni kell. Kreátor Kft. Budapest. 1-5.

M. Labrecque - I. Traian: 2003. High biomass production by Salix clones on SRIC following two 3-year coppice rotation on abandoned farmland in southern Quebec. Canada Biomass and Bioenergy Volume 25. Issue 2. August 2003. 135-146.

Tar F. - Kárpáti Z. - Marticsek J.: 2005. Megújuló energiaforrások termelésének és felhasználásának lehetőségei a mezőgazdaságban. FVM., Budapest. 45-46. 


\title{
HEAVY METALS IN THE SOIL - PLANT SYSTEM
}

\author{
László FODOR - László SZEGEDI - Rita TURY
}

Institute of Agrotechnology, Faculty of Natural Resources Management and Rural Development, Károly Róbert College, 36 Mátrai st., H-3200 Gyöngyös, Hungary, e-mail: 1fodor@ karolyrobert.hu

\begin{abstract}
The majority of heavy metals and other contaminants that enter the soil accumulate in the upper 30 $\mathrm{cms}$. The rate of transformation and bonding in the soil is different for each element. Cd remains mobile in the soil-plant system for a long time. Its accumulation can be observed both in vegetative and generative parts of plants without toxic symptoms and yield loss. Other elements ( $\mathrm{As}, \mathrm{Hg}, \mathrm{Cr}$ ) are readily transformed into insoluble, bonding forms. Environmentally dangerous elements (Cd, As, Cr, ) accumulate mostly in the vegetative organs (straw lives, etc.). Heavy metal pollutants affect the humification processes in the soil. The ratio of less stable humus fraction was increased by metal pollution compared to the stable one.
\end{abstract}

Keywords: heavy metal accumulation, soil, humus fractions, crop plants

\section{Introduction}

Environmental pollution is an ever-increasing load on the various resources of the agro environment, including soils. Soils are able to accumulate heavy metals for many years without obvious signs of their acute toxic effect (Simon et al., 1999). However, the buffering capacity of soils is finite. Above a certain level they are no longer to absorb these elements and they become sources of pollution themselves. Toxic elements are released into water, absorbed by cultivated crops. The loading threshold value for soils is a function of the soil properties $(\mathrm{pH}$, humus content, clay content, type of clay minerals, etc.) (Szabó et al., 2008). The ratio of soluble and insoluble humus compounds affects the fate of heavy metal pollutants in the soil. Huminic acids can decrease, while fulvic acids can increase the solubility of heavy metals. It also seems likely that metal pollutants affect the ratio of huminic and fulvic acids (Máthé et al., 2007). Some trace elements, because of their low solubility in the soil, have a negligible uptake and translocation by plants (i.e. $\mathrm{Cr}, \mathrm{Sn}, \mathrm{Ag}, \mathrm{Zr}$ ). Others (i.e. $\mathrm{As}, \mathrm{Pb}, \mathrm{Hg}$ ) are strongly sorbed by plant roots but are not readily translocated to edible plant parts (Kádár, 2006; Kádár-Morvai, 2008). B, Cu, Mn, Ni and Zn elements are partly readily taken up by plants, but are phytotoxic at concentrations. The most detrimental trace elements $(\mathrm{Cd}, \mathrm{Mo}, \mathrm{Se})$ give rise to human and animal health risks at plant tissue contents that generally are not phytotoxic (Kádár, 2003; Kádár-Lehoczky, 2008). The goal of this research - that based on a long term field experiment - is to monitor the transformation of toxic metals and study their uptake and accumulation by crop plants.

\section{Materials and methods}

The field trial was set up in 1994 with 8 elements (Al, $\mathrm{As}, \mathrm{Cd}, \mathrm{Cr}, \mathrm{Cu}, \mathrm{Hg}, \mathrm{Pb}, \mathrm{Zn}$ ), on three application rates each $\left(0 / 30,90,270 \mathrm{~kg}\right.$ element $\left.\mathrm{ha}^{-1}\right)$, i.e. 24 treatments all in triplicate and arranged in split-plot design. The soil type of the experiment field is a slightly acid chernozem brown-forest soil that can be characterized as follows: $\mathrm{pH}_{(\mathrm{H} 2 \mathrm{O})}$ $6.4 ; \mathrm{pH}_{(\mathrm{KCl})} 5.4 ; \mathrm{y}_{1} 9.5 ; \mathrm{CaCo}_{3} 0 \%$; humus $3 \%$; upper limit of plasticity $\left(\mathrm{K}_{\mathrm{A}}\right) 45 ; \mathrm{L} \% 70$; hy 4.8. Treatments were carried out once at initiation using soluble salts of tested elements. Different crop plants were grown each year. Plant samples (shoot, straw, 
grain) were taken yearly and the total element content was determined after microwave digestion using cc. $\mathrm{HNO}_{3}+\mathrm{cc} . \mathrm{H}_{2} \mathrm{O}_{2}$. Soil samples were collected from the upper horizon of the soil (0-30 cms) and then subjected to the Lakanen-Erviö test, using $\mathrm{NH}_{4}$-acetate + EDTA extraction solution to determine the amount of soluble/mobile elements. The total element concentration was also determined using cc. $\mathrm{HNO}_{3}+\mathrm{cc} \cdot \mathrm{H}_{2} \mathrm{O}_{2}$. ICP-AES Plasma Emission Spectrophotometry was used to analyze the element concentration in the soil and plant samples, for 25 elements. Effect of the highest dose of tested metals (270 kg element ha ${ }^{-1}$ ) was studied on humus solubility. Two different extractants were applied: $\mathrm{NaF}$ and $\mathrm{NaOH}$. The $\mathrm{NaOH}$ soluble humus fraction represents the less stable (usually younger) humus, without $\mathrm{Ca}^{++}$ion saturation. The $\mathrm{NaF}$ dissolves the stable and $\mathrm{Ca}^{++}$ion saturated, or condensed humus (Hargitai, 1968). The optical absorbance of the humus solutions is used to characterise the humus concentrations in the soil. The quotient of the optical densities of the $\mathrm{NaF}$ extractable and $\mathrm{NaOH}$ extractable fractions gives the humus stability number $(\mathrm{Q})$. The higher stability number means the higher ratio of insoluble (stable) humus fraction.

Mathematical, statistical analyses of data were carried out using variance analysis of split-plot experiments, and the $\mathrm{LSD}_{5 \%}$ was calculated.

\section{Results and discussion}

Treatments increased significantly the available element content in the soil. For elements $\mathrm{Cu}, \mathrm{Zn}$ and $\mathrm{Pb}$, a rate of $270 \mathrm{~kg} \mathrm{ha}^{-1}$ resulted in a more than 10 -fold increase in concentration of soluble elements in the tilled depth. The increase in concentration was even more pronounced in the case of trace elements $\mathrm{Cd}, \mathrm{Cr}, \mathrm{As}, \mathrm{Hg}$, according to the soil tests conducted in 1995 (Fodor-Szabó, 2006). In physiological respects the available element content is more important than the "total" amount. This varied widely for all tested elements. The results of the soil analysis of 2001 are presented in Table 1. $\mathrm{Hg}$ became insoluble in the soil and unavailable for plants, the $\mathrm{NH}_{4}$-acetate+EDTA extractable fraction was below the $0.1 \mathrm{mg} \mathrm{kg}^{-1}$ detection limit. $\mathrm{Hg}$ could not be detected in all of the plant samples either. Its bonding in the soil was the most pronounced. The rate of available fraction as compared to the "total" amount was less than $1 \%$ in case of $\mathrm{Cr}, 10-20 \%$ in case of $\mathrm{As}$ and $\mathrm{Zn}$ and about $40-60 \%$ for $\mathrm{Cu}$ and $\mathrm{Pb}$. The soil test also provided evidence of the increased mobility/availability of $\mathrm{Cd}$. The $\mathrm{NH}_{4}$-acetate+EDTA extracted $\mathrm{Cd}$ forms represented about $80 \%$ of the "total" amount. For the other $\mathrm{NH}_{4}$ acetate+EDTA well extracted elements $(\mathrm{Pb}, \mathrm{Cu})$, in $7^{\text {th }}$ year of the experiment, the plant analysis did not prove their mobility in the soil-plant system. $\mathrm{Pb}$ concentration was below the detectable limit $\left(0.1 \mathrm{mg} \mathrm{kg}^{-1}\right)$. $\mathrm{Cu}$ and $\mathrm{Zn}$ content remained on the same level in the plant samples. Concentration of other tested elements in the shoot, straw and grain samples are presented in Table 2. As showed only a moderate enrichment in barley with increasing application. The highest concentration was measured in the straw. Results of plant analysis showed, that As mobility decreased considerably in the soil-plant system. In environmental respect $\mathrm{Cd}$ is the most dangerous microelement in this field experiment. Cd content of control plants was negligible, but its concentration increased significantly in each examined plant organ by increasing Cd loads to the soil. The highest $\mathrm{Cd}$ content was measured at harvest in the straw. The increase of $\mathrm{Cd}$ concentration was directly proportional to the $\mathrm{Cd}$ application to the soil. The same 
tendency was also detectable in the grain. Cr content in the barley shoots was almost the same and accumulation was not detectable in the straw either. The grain showed the tendency of $\mathrm{Cr}$ increase but the effect of treatments was not significant.

Table 1. Effect of treatments on the "total" and available element content in the 0-30 cm layer of the soil (Gyöngyös, 2001)

\begin{tabular}{|c|c|c|c|c|c|c|}
\hline \multirow[t]{2}{*}{ Element } & \multirow{2}{*}{$\begin{array}{c}\text { In the } \\
\text { control } \\
\text { soil }\end{array}$} & \multicolumn{3}{|c|}{$\begin{array}{l}\text { Rate of application in } 1994 \\
\mathrm{~kg} \mathrm{ha}^{-1}\end{array}$} & \multirow[t]{2}{*}{$\mathrm{LSD}_{5 \%}$} & \multirow[t]{2}{*}{ Average } \\
\hline & & 30 & 90 & 270 & & \\
\hline \multicolumn{7}{|c|}{$\begin{array}{l}\text { Total element content mg kg-1 } \\
\left(\mathrm{cc} . \mathrm{HNO}_{3}+\mathrm{cc} \cdot \mathrm{H}_{2} \mathrm{O}_{2} \text { digestion) }\right.\end{array}$} \\
\hline As & 4.1 & 10.0 & 15.4 & 33.4 & 3.5 & 19.6 \\
\hline $\mathrm{Cd}$ & 1.2 & 6.2 & 16.5 & 41.9 & 8.5 & 21.5 \\
\hline $\mathrm{Cr}$ & 57.8 & 57.7 & 70.4 & 89.3 & 5.9 & 72.5 \\
\hline $\mathrm{Cu}$ & 26.3 & 35.6 & 39.9 & 55.4 & 6.7 & 43.7 \\
\hline $\mathrm{Hg}$ & 0 & 0 & 4.5 & 10.4 & 1.7 & 6.0 \\
\hline $\mathrm{Pb}$ & 21.5 & 27.0 & 31.9 & 41.8 & 3.7 & 33.6 \\
\hline $\mathrm{Zn}$ & 88.6 & 103.7 & 100.7 & 112.0 & 14.7 & 105.5 \\
\hline \multicolumn{7}{|c|}{$\begin{array}{l}\text { Available element content } \mathrm{mg} \mathrm{kg}^{-1} \\
\left(\mathrm{NH}_{4} \text {-acetate + EDTA extraction }\right)\end{array}$} \\
\hline As & 0.1 & 1.2 & 2.3 & 7.2 & 0.4 & 3.5 \\
\hline $\mathrm{Cd}$ & 0.5 & 4.7 & 13.3 & 35.2 & 7.4 & 17.7 \\
\hline $\mathrm{Cr}$ & 0 & 0.15 & 0.45 & 0.76 & 0.06 & 0.45 \\
\hline $\mathrm{Cu}$ & 6.9 & 16.6 & 12.4 & 24.7 & 4.2 & 17.9 \\
\hline $\mathrm{Hg}$ & 0 & 0 & 0 & 0 & 0 & 0 \\
\hline $\mathrm{Pb}$ & 8.6 & 11.7 & 16.7 & 25.1 & 3.3 & 17.8 \\
\hline $\mathrm{Zn}$ & 8.7 & 10.7 & 10.5 & 15.8 & 6.7 & 12.3 \\
\hline
\end{tabular}

Table 2. Effect of treatments on the element content of winter barley (Gyöngyös, 2001)

\begin{tabular}{|c|c|c|c|c|c|c|}
\hline \multirow{2}{*}{$\begin{array}{c}\text { Plant } \\
\text { samples }\end{array}$} & \multirow{2}{*}{$\begin{array}{c}\text { On the } \\
\text { control } \\
\text { soil }\end{array}$} & \multicolumn{3}{|c|}{$\begin{array}{l}\text { Rate of application in } 1994 \\
\mathrm{~kg} \mathrm{ha}^{-1}\end{array}$} & \multirow{2}{*}{$\mathrm{LSD}_{5} \%$} & \multirow[t]{2}{*}{ Average } \\
\hline & & 30 & 90 & 270 & & \\
\hline \multicolumn{7}{|c|}{ Effect of As load, $\mathrm{mg} \mathrm{kg}^{-1}$} \\
\hline Shoot & 0 & 0.12 & 0.21 & 0.27 & 0.17 & 0.2 \\
\hline Straw & 0 & 0.10 & 0.10 & 0.39 & 0.26 & 0.16 \\
\hline Grain & 0 & 0.10 & 0.35 & 0.31 & 0.46 & 0.24 \\
\hline \multicolumn{7}{|c|}{ Effect of Cd load, $\mathrm{mg} \mathrm{kg}^{-1}$} \\
\hline Shoot & 0 & 0.09 & 0.10 & 1.18 & 0.21 & 0.43 \\
\hline Straw & 0.07 & 0.50 & 1.00 & 1.73 & 0.23 & 1.07 \\
\hline Grain & 0.04 & 0.17 & 0.33 & 0.50 & 0.05 & 0.33 \\
\hline \multicolumn{7}{|c|}{ Effect of Cr load, $\mathrm{mg} \mathrm{kg}^{-1}$} \\
\hline Shoot & 0.70 & 0.80 & 0.71 & 0.81 & 0.62 & 0.77 \\
\hline Straw & 2.5 & 2.4 & 2.5 & 3.7 & 3.8 & 2.8 \\
\hline Grain & 0.29 & 0.28 & 0.37 & 0.75 & 0.63 & 0.46 \\
\hline
\end{tabular}

In the field experiment the stability number of the humus was decreased by each studied heavy metal pollutants. This effect was significant at each treatment (Table 3). This means that the character of the humus was changed by heavy metal pollutants. The decrease of stability index can be resulted by the high increasing of less stable humus 
fraction or decreasing of more stable humus fraction or by combination of both these effects.

Table 3. Effect of heavy metal pollutants on the stability index of humus

\begin{tabular}{|l|c|c|}
\hline $\begin{array}{c}\text { Treatments } \\
\left(270 \mathrm{~kg} \text { element } \mathrm{ha}^{-1}\right)\end{array}$ & Stability index & $\begin{array}{c}\text { Differences between } \\
\text { treated samples and control }\end{array}$ \\
\hline \hline Untreated control & 4.930328 & 0.000 \\
\hline Chromium $(\mathrm{Cr})$ & 2.757952 & -2.17238 \\
\hline Cadmium $(\mathrm{Cd})$ & 2.306683 & -2.62365 \\
\hline Zink $(\mathrm{Zn})$ & 3.00081 & -1.92952 \\
\hline Mercury $(\mathrm{Hg})$ & 2.630766 & -2.29956 \\
\hline Cupper $(\mathrm{Cu})$ & 1.783055 & -3.14727 \\
\hline Lead $(\mathrm{Pb})$ & 1.83357 & -3.09676 \\
\hline Arsenic $(\mathrm{As})$ & 2.512343 & -2.41799 \\
\hline LSD $_{5 \%}$ & 0.4072 & \\
\hline
\end{tabular}

\section{Conclusions}

Evaluating the results of element composition of the test plant it is clear, that the presence of not essential or toxic elements (As, Cd, Cr) in the soil was mostly reflected by their increased concentration in straw. Crops grow well on $\mathrm{Hg}$ and $\mathrm{Pb}$ amended soil. These elements are not mobile in the soil-plant system, their plant uptake and translocation is not considerable. Cd mobility in the soil-plant system was proved both by soil and plant analysis. It remains mobile for a long time and its accumulation can be observed both in vegetative and reproductive parts of plants. It can be found that heavy metal pollutants affect the humification processes in the soil. The ratio of less stable humus fraction was increased by metal pollution so decreasing stability index was resulted compared to the stable one.

\section{References}

Fodor, L. - Szabó, L.: 2006. Chemical detection of heavy metals applied at high rates to soil. Communications in Soil Science and Plant Analysis, 37: (15-20). 2523-2530.

Hargitai, L.: 1968. Characterization and properties of the biochemical threshold range of soils. Agrokémia és Talajtan, 17. 41-46.

Kádár, I.: 2003. Mikroelem terhelés hatása az őszi árpára karbonátos csernozjom talajon. Agrokémia és talajtan. 52:105-120.

Kádár, I.: 2006. Transport of As in the soil-plant system in a long-term field experiment. Agrokémia és Talajtan. 55: 1. 145-154.

Kádár, I. - Lehoczky, É.: 2008. Néhány gyomfaj elemakkumulációja As és Cd szennyezett talajon. Növénytermelés. 57: 2. 113-122.

Kádár, I. - Morvai, B.: 2008. Bőrgyári szennyvíziszap vizsgálata tenyészedényes kísérletben. A Ca-, a Na- és a Cr-elemek forgalma. Agrokémia és Talajtan. 57: 1. 35-48.

Máthé, P. - Máthé-Gáspár, G. - Szili-Kovács, T. - Sipter E. - Anton A.: 2007. Changes in the parts of the rhizosphere phosphorus cycle influencing by heavy metal contamination. Cereal Research Communications, 36: (2) 761-764.

Simon, L. - Vágvölgyi, S. - Győri, Z.: 1999: Kadmium akkumuláció napraforgóban. Agrokémia és Talajtan, 48: 1-2. 99-109. p.

Szabó, Gy. - Elek, Z. - Szabó, Sz.: 2008. Study of heavy metals in the soil-plant system. Cereal Research Communications, 36: 403-406. 


\section{HEMP RESILIENCE WITHIN AGRO-ECOSYSTEM}

\section{Ildikó IVÁNYI}

Agricultural Science Institute, Faculty of Water and Environmental Management, Szent István University 5540 Szarvas, Szabadság út 1-3. Hungary, e-mail:gergely.ildiko@mvk.tsf.hu

Abstract: Industrial hemp cultivation and production would greatly benefit our environment by its resilience, bearing capacity in ecology and economy. By reducing use of toxic chemicals and depletion of natural resources hemp plant growing and development can maintain stabile ecosystem. Industrial hemp cultivation would improve our economy and competitiveness. Create jobs, improve balance of trade, reduce toxic chemicals and other pollution, enhance opportunities for sustainable agricultural systems, and improve national security by conserving natural resources.

To measuring resilience we seek comparative measures of resilience that are responsible for changes in the ecosystem state. Typical among these measures would be indicators of total biomass or productivity, and of the cycling of nutrients. The damaging effects of under- or over-fertilisation (yield losses or environmental problems caused by superfluous mineral fertilisers) can be avoided if more exact knowledge is obtained on how nutrient supplies influence the crop. Soil analyses combined with plant analysis can be efficiently employed in the elaboration of a nutrient supply system for hemp and in evaluating the fertilisation practices applied.

In a long-term field fertilisation experiment was estimated leaf by leaf analysis to eleborate hemp nutrient supply threshold limits for nine elements in hemp at four NPK levels on chernozem meadow soil in Szarvas, Hungary in 1999 (good water supplies) and 2003 (dry).

The low, satisfactory and high threshold values for the concentrations of $\mathrm{N}, \mathrm{P}, \mathrm{K}, \mathrm{Ca}, \mathrm{Mg}, \mathrm{Fe}, \mathrm{Mn}, \mathrm{Zn}$ and $\mathrm{Cu}$ reported in the paper could be used to elaborate a fertiliser recommendation system for hemp.

Keywords: hemp resilience, soil analysis, leaf analysis, threshold limits, plant nutrient contents.

\section{Introduction}

According to the concept of resilience as applied to integrated socioecological systems may be defined as the amount of disturbance a system can absorb and still remain within the same state or domain of attraction, the degree to which the system is capable of self-organization (versus lack of organization or organization forced by external factors), and the degree to which the system can build and increase its capacity for learning and adaptation (Carpenter et al., 2001).

Industrial hemp cultivation and production would greatly benefit our environment by its resilience, bearing capacity in ecology and economy. By reducing use of toxic chemicals and depletion of natural resources hemp plant growing and development can maintain stabile ecosystem. The damaging effects of under- or over-fertilisation (yield losses or environmental problems caused by superfluous mineral fertilisers) can be avoided if more exact knowledge is obtained on how nutrient supplies influence the crop. Soil analyses combined with plant analysis can be efficiently employed in the elaboration of a nutrient supply system for hemp and in evaluating the fertilisation practices applied. Some nutrients can be accumulated in the plant to a great extent without causing any visible or measurable damage, while the optimum range for other elements is very narrow (Smith, 1962; Kádár, 1992; Iványi and Izsáki, 1996; Kádár and Tárkány Szücs, 2003) In the present paper, nutrient supply limit values are reported for hemp leaf samples taken at the optimum date, based on the general rules of leaf analysis, and calculated for nine nutrients from the analytical data of one good water supplies and one dry year. 


\section{Materials and methods}

Since 1990 a long-term, small-plot field experiment on the mineral fertilisation of a full crop rotation system involving four crops (annual legume, fibre hemp, spring cereal, hoed crop) each year has been underway in Szarvas on chernozem meadow soil ( $\mathrm{pH}$ ( $\mathrm{KCl} 5-5,2$, humus 3,0-3,2 \%).

The present paper reports the limit values for nutrient supplies to fibre hemp (Cannabis sativa L.) on the basis of the results achieved in 1999 (good water supplies) and 2003 (dry), which could provide a useful indication of nutrient deficiencies in plants.

All possible combinations of four levels of $\mathrm{N}, \mathrm{P}$ and $\mathrm{K}$ were included, giving a total of 64 fertiliser treatments arranged in a split-split plot design with three replications on 192 plots, where the size of the sub-subplots was $4 \times 5=20 \mathrm{~m}^{2}$. The fertilizer levels applied were $\mathrm{N}_{0}=0, \mathrm{~N}_{1}=80, \mathrm{~N}_{2}=160, \mathrm{~N}_{3}=240 \mathrm{~kg} \mathrm{~N}^{-1}$ year $^{-1}$ for nitrogen; $\mathrm{P}_{0}=0, \mathrm{P}_{1}=100 \mathrm{~kg}$ ha $^{-1}$ year ${ }^{-1}, \mathrm{P}_{2}=500 \mathrm{~kg} \mathrm{ha}^{-1}$ in 1989,1993 and $2001, \mathrm{P}_{3}=1000 \mathrm{~kg} \mathrm{ha}^{-1}$ in 1989,1993 and 2001 for phosphorus $\left(\mathrm{P}_{2} \mathrm{O}_{5}\right)$; and $\mathrm{K}_{0}=0, \mathrm{~K}_{1}=300 \mathrm{~kg} \mathrm{ha}^{-1}$ year $^{-1}$ from 1989-1992, $100 \mathrm{~kg} \mathrm{ha}^{-1}$ year $^{-1}$ from $1993, \mathrm{~K}_{2}=600 \mathrm{~kg} \mathrm{ha}^{-1}$ in 1989 and $2001,1000 \mathrm{~kg} \mathrm{ha}^{-1}$ in 1993 , $\mathrm{K}_{3}=1200 \mathrm{~kg} \mathrm{ha}^{-1}$ in 1989 and 2001, $1500 \mathrm{~kg} \mathrm{ha}^{-1}$ in 1993 for potassium $\left(\mathrm{K}_{2} \mathrm{O}\right)$. The high rates of $\mathrm{P}$ and $\mathrm{K}$ replenishment fertilisers were applied to ensure clearly distinguishable differences in the supply levels in the soil for the investigation of nutrient supply situations.

The hemp varieties sown in the experiment were Kompolti in 1999 and Tiborszállási in 2003. In both years leaf samples for leaf analysis were taken in late May.

From 1998 to 2003, the annual precipitation in three of the six years was less than the average of the previous 75 years. The second part of summer 1999 was wet, with a rainfall surplus of $183 \mathrm{~mm}$. In summer 2003 there was a drought, with a rainfall deficiency of about $217 \mathrm{~mm}$.

\section{Results and discussion}

The effect of $\mathrm{N}$ supplies was clearly illustrated by the $\mathrm{N}$ concentrations recorded in leaf analysis in late May, which approached the $5 \%$ level even at the $\mathrm{N}_{1}$ rate, averaged over the $\mathrm{P}$ and $\mathrm{K}$ treatments, and exceeded this level at the higher $\mathrm{N}_{2}$ and $\mathrm{N}_{3}$ rates. With an improvement in the $\mathrm{N}$ supplies, higher $\mathrm{N}$ contents were associated with higher stem yields, which exceeded $12 \mathrm{tha}^{-1}$ in the wet year (1999), though in the dry year the stem yield was much lower, being only slightly over $6 \mathrm{t} \mathrm{ha}^{-1}$ averaged over the $\mathrm{P}$ and $\mathrm{K}$ treatments (Table 1). Based on the $\mathrm{n}=128$ yield and $\mathrm{N} \%$ data pairs for two years with different rainfall supplies, a leaf $\mathrm{N}$ concentration of 5-6\% was found to be optimum for the achievement of a high yield (in excess of $16 \mathrm{tha}^{-1}$ ), if yield development was not limited by other factors.

The phosphorus concentration in hemp leaves at the date of leaf analysis gave a good indication of the phosphorus supply level. In 1999 the leaf $\mathrm{P}$ concentration at $\mathrm{P}_{1}$ supply levels $\left(\mathrm{P}_{1}=175, \mathrm{P}_{2}=217, \mathrm{P}_{3}=267 \mathrm{mg}\right.$ AL- $\left.\mathrm{P}_{2} \mathrm{O}_{5} \mathrm{~kg}^{-1}\right)$ was higher than the $\mathrm{P}_{0}$ control was over $0.5 \%$ for a stem yield of $12 \mathrm{t} \mathrm{ha}^{-1}$, while in 2003 it only approached this level in the $\mathrm{P}_{3}=339 \mathrm{mg}$ AL- $\mathrm{P}_{2} \mathrm{O}_{5} \mathrm{~kg}^{-1}$ treatment (Table 2). Based on the $\mathrm{n}=128$ yield and leaf concentration data pairs for the two experimental years, if a high stem yield is to be achieved, the optimum $\mathrm{P}$ concentration in the upper 5th-7th leaf pairs of hemp is $0.5-$ $0.6 \%$. 
Table 1. Effect of $\mathrm{N}$ supply on the stem yield and the leaf $\mathrm{N} \%$ of hemp (Szarvas, 1999, 2003)

\begin{tabular}{|l|c|c|c|c|c|c|}
\hline \multirow{2}{*}{$\begin{array}{c}\text { Examined } \\
\text { parameters }\end{array}$} & \multicolumn{7}{c|}{$\mathrm{N}^{2}$ application rate kg ha } & \multirow{2}{*}{ Mean } \\
\cline { 2 - 7 } & $\mathrm{N}_{0}$ & $\mathrm{~N}_{80}$ & $\mathrm{~N}_{160}$ & $\mathrm{~N}_{240}$ & LSD $_{5 \%}$ & \\
\hline \multicolumn{7}{|c|}{1999} \\
\hline \hline Stem yield t ha \\
\hline
\end{tabular}

Table 2. Effect of P supply on the stem yield and the leaf $\mathrm{P} \%$ of hemp (Szarvas, 1999, 2003)

\begin{tabular}{|c|c|c|c|c|c|c|}
\hline \multirow{2}{*}{$\begin{array}{l}\text { Examined } \\
\text { parameters }\end{array}$} & \multicolumn{5}{|c|}{ Al- $\mathrm{P}_{2} \mathrm{O}_{5} \mathrm{mg} \mathrm{kg}^{-1}$ in cultivated soil layer } & \multirow{2}{*}{ Mean } \\
\hline & $\mathrm{P}_{0}$ & $\mathrm{P}_{1}$ & $\mathrm{P}_{2}$ & $\mathrm{P}_{3}$ & $\mathrm{LSD}_{5 \%}$ & \\
\hline \multicolumn{7}{|c|}{1999} \\
\hline P supply & 158 & 175 & 217 & 267 & - & 204 \\
\hline Stem yield $\mathrm{t} \mathrm{ha}^{-1}$ & 8,99 & 11,97 & 12,16 & 11,95 & 1,83 & 11,27 \\
\hline Leaf P \% & 0,49 & 0,51 & 0,52 & 0,57 & - & 0,52 \\
\hline \multicolumn{7}{|c|}{2003} \\
\hline P supply & 128 & 183 & 195 & 339 & 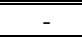 & 211 \\
\hline Stem yield $\mathrm{t} \mathrm{ha}^{-1}$ & 4,98 & 5,66 & 5,97 & 6,54 & 0,42 & 5,79 \\
\hline Leaf P \% & 0,43 & 0,44 & 0,45 & 0,48 & 0,04 & 0,45 \\
\hline
\end{tabular}

Improved potassium supplies caused a significant increase in the $\mathrm{K}$ concentration compared with the control in both years at all the $\mathrm{K}$ rates. In 1999 the leaf $\mathrm{K}$ concentration was as high as $2.7 \%$ even at the $\mathrm{K}_{0}$ level $\left(290 \mathrm{mg} \mathrm{AL}-\mathrm{K}_{2} \mathrm{O} \mathrm{kg}{ }^{-1}\right)$, while in 2003 this concentration was only reached at the highest soil $\mathrm{K}$ rate $\left(\mathrm{K}_{3}=465 \mathrm{mg} \mathrm{AL}-\right.$ $\mathrm{K}_{2} \mathrm{O} \mathrm{kg}^{-1}$ ) (Table 3). Based on the $\mathrm{n}=128$ yield and leaf concentration data pairs for the two experimental years, if a high stem yield is to be achieved, the optimum $\mathrm{K}$ concentration in the upper 5th-7th leaf pairs of hemp is $2.7-3.3 \%$.

In addition to the three major nutrients described above, investigations were also made on the relationship between the stem yield and the leaf contents of $\mathrm{Ca}, \mathrm{Mg}, \mathrm{Mn}, \mathrm{Fe}, \mathrm{Zn}$ and $\mathrm{Cu}$ (Table 4).

Table 3. Effect of K supply on the stem yield and the leaf $\mathrm{K} \%$ of hemp (Szarvas, 1999, 2003)

\begin{tabular}{|c|c|c|c|c|c|c|}
\hline \multirow{2}{*}{$\begin{array}{l}\text { Examined } \\
\text { parameters }\end{array}$} & \multicolumn{5}{|c|}{$\mathrm{Al}-\mathrm{K}_{2} \mathrm{O} \mathrm{mg} \mathrm{kg}{ }^{-1}$ in cultivated soil layer } & \multirow{2}{*}{ Mean } \\
\hline & $\mathrm{K}_{0}$ & $\mathrm{~K}_{1}$ & $\mathrm{~K}_{2}$ & $\mathrm{~K}_{3}$ & $\mathrm{LSD}_{5 \%}$ & \\
\hline \multicolumn{7}{|c|}{1999} \\
\hline "K supply & 290 & 401 & 445 & 490 & - & 406 \\
\hline Stem yield $\mathrm{t} \mathrm{ha}^{-1}$ & 11,46 & 11,65 & 9,45 & 12,51 & - & 11,27 \\
\hline Leaf K \% & 2,72 & 3,02 & 2,80 & 2,92 & 0,17 & 2,87 \\
\hline \multicolumn{7}{|c|}{2003} \\
\hline K supply & 215 & 347 & 394 & 465 & - & 355 \\
\hline Stem yield $\mathrm{t} \mathrm{ha}^{-1}$ & 5,38 & 6,04 & 5,79 & 5,95 & - & 5,79 \\
\hline Leaf $\mathrm{K} \%$ & 2,22 & 2,56 & 2,62 & 2,78 & 0,2 & 2,55 \\
\hline
\end{tabular}


Table 4. Plant nutrient element status for hemp (Szarvas, 1999, 2003)

\begin{tabular}{|l|c|c|c|}
\hline Nutrients & Low & Optimum & High \\
\hline \hline $\mathrm{N} \%$ & $<5$ & $5-6$ & $6<$ \\
\hline $\mathrm{P} \%$ & $<0,5$ & $0,5-0,6$ & $0,6<$ \\
\hline $\mathrm{K} \%$ & $<2,7$ & $2,7-3,3$ & $3,3<$ \\
\hline $\mathrm{Ca} \%$ & $<2,4$ & $2,4-3,0$ & $3,0<$ \\
\hline $\mathrm{Mg} \%$ & $<0,6$ & $0,6-0,8$ & $0,8<$ \\
\hline $\mathrm{Fe} \mathrm{mgkg}$ & -1 & $65-105$ & $105<$ \\
\hline $\mathrm{Mn} \mathrm{mgkg}^{-1}$ & $<65$ & $85-130$ & $130<$ \\
\hline $\mathrm{Zn} \mathrm{mgkg}^{-1}$ & $<85$ & $25-40$ & $40<$ \\
\hline $\mathrm{Cu} \mathrm{mgkg}$ & $2,5-5$ & $5<$ \\
\hline
\end{tabular}

\section{Conclusions}

Nutrient supplies to hemp can be considered satisfactory if plant threshold limits in the youngest fully developed (5th-7th) leaf pairs in late May 5-6\% N, 0.5-0.6\% P and $2.7-3.0 \% \mathrm{~K}, 2.4-3.0 \% \mathrm{Ca}, 0.6-0.8 \% \mathrm{Mg}, 65-105 \mathrm{mg} \mathrm{kg}^{-1} \mathrm{Fe}, 85-130 \mathrm{mg} \mathrm{kg}^{-1} \mathrm{Mn}$, $25-40 \mathrm{mg} \mathrm{kg}^{-1} \mathrm{Zn}$ and $2-540 \mathrm{mg} \mathrm{kg}^{-1}$.

\section{Acknowledgements}

This research project was supported by the Hungarian Scientific Research Fund (OTKA T-034436).

\section{References}

Carpenter, S.R, B. - Walker, J.M. - Anderies - N. Abel: 2001. From metaphor to measurement: Resilience of what to what? Ecosystems 4: 765-781.

Iványi, I. - Izsáki, Z.: 1996. Effect of Nutrient Supplies on the Nutrient Uptake of Fibre Hemp (Cannabis sativa L.) During Vegetation Period. Növénytermelés. 45: 2. 181-193.

Kádár, I.:1992. Principles and Methods in Plant Nutrition. Research Institute for Soil and Agricultural Chemistry, Hungarian Academy of Science: Budapest

Kádár, J. - Tárkány Szűcs, S.: 2003. Effect of Mineral Fertilisation on the Yield of Fibre Hemp (Cannabis sativa L.). Növénytermelés,. 52: 2. 217-228.

Smith, P. F.: 1962. Mineral Analysis of Plant Tissues. Ann. Rev. Plant Physiol. 13: 81-108. 


\title{
IMPACT OF COMMON RAGWEED (AMBROSIA ARTEMISIIFOLIA L.) ON WEED FLORA OF ROW CROPS DURING LAST FOUR DECADES IN CROATIA
}

\author{
Natalija GALZINA - Klara BARIĆ - Maja ŠĆEPANOVIĆ - Matija GORŠIĆ- \\ Zvonimir OSTOJIĆ
}

Department of Herbology, Faculty of Agriculture, University of Zagreb, Svetosimunska 25, 10000 Zagreb, email: ngalzina@agr.hr

\begin{abstract}
In the last twenty years invasive alien plants have been of interest to researchers from different scientific fields as it is known that they are a serious threat to ecosystems and biodiversity. Invasive plants threat also the native weed associations of the agricultural land. The European and Mediterranean Plant Protection Organization (EPPO) lists plant species considered to pose a threat to plant health, the environment and biodiversity in the EPPO region among which is common ragweed, Ambrosia artemisiifolia L. Common ragweed is known as a strong competitor, particularly in row crops (corn, sunflower, sugar beet and soybean) in which it can maintain large populations. We analyzed untreated plots in 167 field trials conducted in row crops (maize, sugarbeet, soybean, sunflower and potato) over last 40 years. Weed species were tabulated in each year and frequency $(\%)$ and species density (plant $\mathrm{m}^{-2}$ ) were calculated and compared. Till 1989. Ambrosia artemisiifolia was less frequent then other weed species while from 1999. its frequency was similar or higher. Polygonum persicaria and Amaranthus retroflexus frequency declined over the time. Ambrosia artemisiifolia came from $10^{\text {th }}$ place in 1979 . on $2^{\text {nd }}$ place in 2009 . If we take into account just annual broadleaf weeds as the most similar weed species regarding life cycle and ecological traits, common ragweed came from $5^{\text {th }}$ to $1^{\text {st }}$ place.
\end{abstract}

Keywords: weed flora, invasive species, common ragweed, frequency

\section{Introduction}

In the last twenty years invasive alien plants have been of interest to researchers from different scientific fields as it is known that they are a serious threat to ecosystems and biodiversity. Invasive plants threat also the native weed associations of the agricultural land (Pál, 2004) causing significant reductions in its productivity (Pimentel et al., 2000). The arable weed vegetation in Hungary has changed greatly in recent decades, mainly through the decrease of diversity of arable field flora (Pál, 2004). EPPO lists plant species considered to pose a threat to plant health, the environment and biodiversity in the EPPO region among them is Ambrosia artemisiifolia L.

Makra et al. (2005) notes that Ambrosia artemisiifolia L. came into Europe with red clover seed and grain seed, and its distribution began probably from European ports: e. g. from Rijeka towards Croatia and the Danube valley, from Trieste and Genoa towards Northern Italy, and from Marseille towards the Rhone valley. In southern parts of the Danube area common ragweed was found in the 1920s (western part of Hungary) and 30 years later it had colonized the whole region.

Croatian herbologist, Josip Kovačević, first found Ambrosia artemisiifolia L. in Croatia in 1940. Examining impurities in red clover seeds originating from Pitomača, he found common ragweed seeds (Kovačević, 1943). In the former Yugoslavia, Maly (1940) noticed the common ragweed in 1935. in the village of Osojci near Derventa (today Bosnia and Herzegovina).

Ambrosia artemisiifolia is known as a strong competitor, particularly in row crops (corn, sunflower, sugar beet and soybean) in which it can maintain large populations. Common ragweed also grows in vegetable crops, on stubble, along roadsides and on other non- 
agricultural areas. Due to lack of competition the common ragweed can become dominant very fast, what is almost the rule in opened and disturbed habitats (Ostojić et al., 1992; Béres, 2003). It can also be present in dense crops, although in those conditions its competitive strength is lower due to strong competitiveness from the crop itself. In these conditions common ragweed will not dominate except in reduced crop stands (empty areas in the field), but after harvest it can cover most of the stubble (Ostojić et al., 1992; Reisinger and Pálmai, 2007).

\section{Materials and methods}

Untreated plots in field trials conducted in row crops over last 40 years were analyzed. Primarily, trials were set up for official herbicide registration purposes. Total number of untreated plots from trials set up on the locations in the continental parts of Croatia was 167. Trials were carried out in following row crops: maize (81), sugar beet (22), soybean (36), sunflower (16) and potato (12). Trials were conducted by researches from Faculty of Agriculture in Zagreb, Department of Herbology and Plant protection institute, Zagreb. Analyzes were performed for each 5 years starting from 1969. to 2009. Experimental design of all trials was a randomized complete block, in four replicates. In all experiments there were natural weed infestations. Botanical analyzes of field trials (determination of weed species and average weed number per $\mathrm{m}^{2}$ ) was performed during June and July, in the stage of intensive growth of weeds. Weed species were tabulated in each year and frequency $(\%)$ and species density (plant $\mathrm{m}^{-2}$ ) were calculated and compared. Number of trials was: 11 ('69.), 8 ('74.), 13 ('79), 7 ('84), 18 ('89.), 15 ('94.), 63 ('99), 23 ('04) and 9 ('09).

\section{Results and discussion}

In all trials 122 plant species were recorded. In table 1 . are presented 10 weed species which were the most frequent during examined period. Those were: 5 annual and 2 perennial broadleaf weed species, 2 annual and 1 perennial grass weed species.

Table 1. Frequency (\%) of the ten top weed species in trials over 40 years (1969.-2009.)

\begin{tabular}{|c|c|c|c|c|c|c|c|c|c|}
\hline Year & 1969 & 1974 & 1979 & 1984 & 1989 & 1994 & 1999 & 2004 & 2009 \\
\hline \hline Wmeed species & & & & & & & & & \\
\hline Chenosia artemisiifolia & - & $\mathbf{1 2 , 5}$ & $\mathbf{1 5 , 4}$ & $\mathbf{5 7 , 1}$ & $\mathbf{1 0 0 , 0}$ & $\mathbf{4 0 , 0}$ & $\mathbf{6 9 , 8}$ & $\mathbf{7 3 , 9}$ & $\mathbf{7 5 , 0}$ \\
\hline Polygonum persicaria & 100,0 & 100,0 & 92,3 & 85,7 & 88,0 & 73,3 & 60,3 & 52,2 & 57,1 \\
\hline Amaranthus retroflexus & 81,8 & 62,5 & 69,2 & 42,9 & 24,0 & 80,0 & 31,7 & 52,2 & 57,1 \\
\hline Chenopodium polyspermum & - & 50,0 & 76,9 & 57,1 & 36,0 & 60,0 & 47,6 & 47,8 & 28,6 \\
\hline \hline Convolvulus arvensis & 90,9 & 62,5 & 53,8 & 42,9 & 12,0 & 53,3 & 30,2 & 34,8 & - \\
\hline Cirsium arvense & 27,3 & 75,0 & 23,1 & 14,3 & 12,0 & 26,7 & 3,2 & 26,1 & - \\
\hline \hline Echinochloa crus -galli & 100,0 & 100,0 & 100,0 & 100,0 & 80,0 & 93,3 & 87,3 & 73,9 & 85,7 \\
\hline Setaria sp. & 81,8 & 75,0 & 84,6 & 85,7 & 33,3 & 33,3 & 39,7 & 47,8 & 50,0 \\
\hline \hline Agropyron repens & 81,8 & 50,0 & 23,1 & 42,9 & 8,0 & 6,7 & 6,3 & - & - \\
\hline
\end{tabular}

Among annual broadleaf weeds Chenopodium album was consistently present in high frequency during the whole period. Till 1989. Ambrosia artemisiifolia was less frequent then other weed species while from 1999. its frequency was similar or higher. In heavily infested trials when both, Chenopodium album and Ambrosia artemisiifolia species were present, we noticed that one of these two species appears to be dominant. In sugarbeet, for example, 
sown earlier than other row crops, Chenopodium album was always more dominant because it germinates earlier than the other thermophilous weeds (data not shown). Polygonum persicaria and Amaranthus retroflexus frequency declined over the time. Echinochloa crusgalli was predominant annual grass weed. Perennial weeds frequency was not high when compared with annual weeds. Usually, weed flora of row crops consist of high number of annual broadleaf weed species and low number of annual grass weed species. But annual grasses can be present also in high numbers per area unit as presented in Table 2. Perennial weeds were less frequent then annual weed species.

Table 2. Averaged plant density (plant $\mathrm{m}^{-2}$ ) of the ten most frequent species

\begin{tabular}{|c|c|c|c|c|c|c|c|c|c|}
\hline Year & 1969 & 1974 & 1979 & 1984 & 1989 & 1994 & 1999 & 2004 & 2009 \\
\hline \hline Weed species & & & & & & & & & \\
\hline Ambrosia artemisiifolia & $\mathbf{0 , 0}$ & $\mathbf{2 6 , 0}$ & $\mathbf{3 6 , 0}$ & $\mathbf{3 , 4}$ & $\mathbf{2 8 , 0}$ & $\mathbf{3 6 , 2}$ & $\mathbf{2 9 , 8}$ & $\mathbf{1 0 , 8}$ & $\mathbf{8 , 3}$ \\
\hline Chenopodium album & 15,2 & 12,8 & 9,0 & 12,7 & 63,2 & 15,0 & 19,2 & 9,1 & 6,7 \\
\hline Polygonum persicaria & 21,2 & 21,8 & 18,8 & 27,8 & 28,7 & 10,8 & 18,1 & 6,3 & 13 \\
\hline Amaranthus retroflexus & 16,4 & 9,4 & 17,7 & 1,0 & 2,0 & 12,4 & 7,2 & 5,2 & 1,5 \\
\hline Chenopodium polyspermum & 0,0 & 6,0 & 5,5 & 7,5 & 14,3 & 12,6 & 15,9 & 2,4 & 4,5 \\
\hline \hline Convolvulus arvensis & 4,2 & 5,0 & 2,6 & 9,7 & 0,3 & 1,0 & 7,0 & 12,3 & 0,0 \\
\hline Cirsium arvense & 5,3 & 1,7 & 2,3 & 9,0 & 2,7 & 2,8 & 7,0 & 3,0 & 0,0 \\
\hline \hline Echinochloa crus-galli & 37,8 & 39,3 & 47,5 & 74,7 & 26,4 & 47,4 & 84,4 & 38,5 & 10,0 \\
\hline Setaria sp. & 21,3 & 60,2 & 20,4 & 61,7 & 58,8 & 2,2 & 77,2 & 24,5 & 5,8 \\
\hline \hline Agropyron repens & 11,4 & 4,3 & 57,7 & 13,0 & 83,0 & 6,0 & 102,2 & 0,0 & 0,0 \\
\hline
\end{tabular}

The number of plants per $\mathrm{m}^{2}$ was high, especially for first 3 broadleaf species and annual grasses. In table 2. we observe that Ambrosia artemisiifolia after 1989. was present in higher numbers of plants per $\mathrm{m}^{2}$ when compared with other annual broadleaf weeds. Before 1989. Ambrosia artemisiifolia was less frequent but present in higher numbers of plants per $\mathrm{m}^{2}$. According to Smetana et al. (2009) presence of dangerous, competitive weed species with more then 16 plants per $\mathrm{m}^{2}$ in sugar beet is considered as heavily infested. Ambrosia artemisifolia outnumbered other broadleaf species over whole period except in 1984 and 1989.

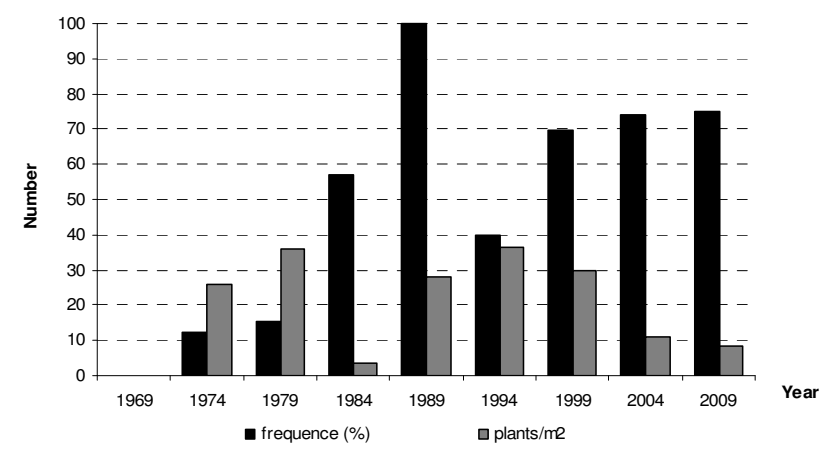

Figure 1. Frequence and density of Ambrosia artemisiifolia $\mathrm{L}$

In the first ten years, common ragweed was found rarely (Fig. 1) and mainly near Croatian-Hungarian border and in the eastern parts of Croatia. Despite the fact that common ragweed was not found in 1969., it's presence was detected in carrot crop 
(Koprivnica) where the botanical analyse wasn't conducted, then 1974. in Velika Gorica (near Zagreb), 1979. in Virovitica and along river Sava in Županja and Slavonski Brod. Afterwards it continued to spread through the whole continental part of Croatia between rivers Sava and Drava and became the most important broadleaf weed (Ostojić et al., 1992). In 1974. and 1979. it is shown that common ragweed was present in small number of trials but with considerable number of plants per $\mathrm{m}^{2}$ (Fig. 1). After 1984. its frequency started to increase while plant density decreased. That trend retained to nowadays. Common ragweed was present in all trials in 1989. while today it is present in more than $70 \%$ of trial area what is consistent with its distribution presented by Galzina et al. (in press).

In this paper according frequency (table 1) Ambrosia artemisiifolia came from $10^{\text {th }}$ place in 1979 . on $2^{\text {nd }}$ place in 2009. If we take into account just annual broadleaf weeds as the most similar weed species regarding life cycle and ecological traits, common ragweed came from $5^{\text {th }}$ to $1^{\text {st }}$ place. Béres (2003) similarly reported that ragweed was $21^{\text {st }}$ on the list of the most common Hungarian weeds in $1950,8^{\text {th }}$ in $1980,4^{\text {th }}$ in 1988 and from the early 1990s it was the most widespread weed in Hungary.

\section{Conclusions}

In all trials were recorded in total 122 plant species. Till 1989. Ambrosia artemisiifolia was less frequent then other weed species while its frequency was similar or higher from 1999. Polygonum persicaria and Amaranthus retroflexus frequency declined over time. Echinochloa crus-galli was predominant annual grass weed. Perennial weeds frequency was not high when compared with annual weeds. Ambrosia artemisiifolia after 1989. was present in higher numbers per $\mathrm{m}^{2}$ when compared with other annual broadleaved weeds. Ambrosia artemisiifolia came from $10^{\text {th }}$ place in 1979. on $2^{\text {nd }}$ place in 2009. If we take into account just annual broadleaved weeds as the most similar weed species regarding life cycle and ecological traits, common ragweed from $5^{\text {th }}$ place came to $1^{\text {st }}$ place.

\section{References}

Béres I.: 2003. The distribution, importance and biology of common ragweed (Ambrosia artemisiifolia L.). Növényvédelem, 39, 293-302

Galzina, N. - Barić, K. - Šćepanović, M. - Goršić, M. - Ostojić ,Z. Distribution of the invasive weed Ambrosia artemisiifolia L. in Croatia. Agriculturae Conspectus Scientificus 0:00-00 (in press)

Kovačević, J.: 1943. Prinos poznavanju sjemenske korovne flore u hrvatskom naturalnom sjemenju crvene djeteline (Ambrosia artemisiifolia L. U sjemenju hrvatske crvene djeteline). Poljodjelska znanstvena smotra, sv. 7, Zagreb.

Makra L. - Juhász M. - Bécszi R. - Borsos E.: 2005. The history and impacts of airborne Ambrosia (Asteraceae) pollen in Hungary. Grana 44: 57-64.

Maly, K.: 1940. Notizen zur Flora von Bosnien-Herzegovina. Glasnik zemaljskog muzeja za Bosnu i Hercegovinu. God. II. Sv. I.-II. Sarajevo.

Ostojić, Z. - Zadro, J. - Radiković, Đ.: 1992. Naši napasni korovi. Limunđik - Ambrosia artemisiifolia L. Glasnik zaštite bilja 9-10: 259-265.

Pál, R.: 2004. Invasive plants threaten segetal weed vegetation of South Hungary. Weed Technology, 18: 1314-1318.

Pimentel, D. et al.: 2000. Environmental and economic costs of nonindigenous species in the United States. BioScience 50: 53-65.

Reisinger P. - Pálmai O.: 2007. Analyses of weed abundance in winter wheat sown at different times. Cereal research communication, 35 (2): 997-1000.

Smatana, J. - Macak, M. - Demjanova, E. - Đalović, I.: 2009. Effect of herbicides on weed control in sugar

beet (Beta vulgaris L.). Herbologia 10 (1). 71-77. 


\title{
INFLUENCE OF FENNEL DEVELOPMENT STAGE ON HERBAGE AND ESSENTIAL OIL YIELD
}

\author{
Ivanka ZUTIC ${ }_{l}^{l}$ - Josip BOROSIC ${ }^{l}$ - Marinko PETROVIC ${ }^{2}-$ Bozidar BENKO $^{l}-$ \\ Sanja FABEK ${ }^{1}$ \\ ${ }^{1}$ Vegetable Crops Department, Faculty of Agriculture, University of Zagreb, 10000 Zagreb, Svetosimunska c. \\ 25, Croatia, e-mail: izutic@ agr.hr \\ ${ }^{2}$ Food Control Center, Faculty of Food Technology and Biotechnology, University of Zagreb, 10000 Zagreb, \\ Jagiceva 31, Croatia
}

\begin{abstract}
European pharmacopoeia distinguishes two varieties of Foeniculum vulgare ssp. capillaceum: vulgare and dulce, differing in the content of main essential oil components. Considering the biological aspect, var. dulce does not over-winter in the continental areas. The aim of the investigation was to determine the effect of fennel development stages on the fresh herbage yield, and essential oil yield and components. Quality parameters of essential oil were analysed by GC-MS method. It was found out that the crop of var. vulgare can be cut three-times a year in the stage $\mathrm{H}$ (herbage before flowering), twice in the stage $\mathrm{F}$ (herbage in the full flowering), and once a year in the stages $\mathrm{G}$ and $\mathrm{W}$ ("green seed" and waxy seed), since var. dulce can be cut twice a year only in the stage $\mathrm{H}$. In all observed stages of plant development var. vulgare gave higher yields of fresh biomass (109, 156, 129 and $140 \%)$ and essential oil $(199,405,304$ and $614 \%)$ compared to var. dulce in the first growing season (crops of equal age). As a two-year old crop, var. vulgare yielded about $150 \%$ of yields achieved in the first year of cultivation. The highest yield of essential oil (38.5 $\left.\mathrm{ml} \cdot \mathrm{m}^{-2}\right)$, besides the lowest herbage yield $\left(2.07 \mathrm{~kg} \cdot \mathrm{m}^{-2}\right)$, was achieved by one-fold harvest in the stage $\mathrm{G}$ of var. vulgare. The essential oil main component in both varieties is anethole, followed by fenchone and $\alpha$-pinene in vulgare, and limonene in dulce. During the vegetation period, a rate of anethole and fenchone increased, while the rate of $\alpha$-pinene and limonene decreased. Plant development was weak in the drought condition (dulce, the second growing season), and the crop was severely damaged by cold winter (valgare, second over-wintering).
\end{abstract}

Keywords: essential oil components, fresh herbage, harvest term, varieties

\section{Introduction}

European pharmacopoeia distinguishes two varieties of Foeniculum vulgare ssp. capillaceum (var. vulgare and var. dulce), differing in the content of main essential oil components. Considering the biological aspect, var. dulce (sweet fennel) is mainly consumed as a specialty vegetable and does not over-winter in the continental areas. On the contrary, var. vulgare (bitter fennel) is commercially produced either for the seed (as spice), and the essential oil extracted from seed. Barros et al. (2010) highlight the nutritional value of species. Essential oil accumulation of $F$. vulgare shows different curves in the vegetative and generative organs (Nemeth, 2005). In the vegetative organs, a small peak can be observed during flowering time, and in the generative organs, the percentage of oil increases from the appearance of buds until the stage of green fruits. The volatile phenylpropenes are the major constituents of the oleoresin of the aerial parts, and their levels vary during plant development (Gross et al., 2009). Water stress imposed by restricting the number of irrigations significantly decreases plant height, branch number, and fruit and oil yield, whereas it increases the percentage of volatile oils (Mohamed and Abdu, 2004). The aim of the investigation was to determine the effect of fennel development stages on the fresh herbage and essential oil yield, in order to find out the stage with maximal essential oil and anethole production. 


\section{Materials and methods}

The field trials were set up during the two seasons in Zagreb County Region (lat. 45 $51^{\prime}$ $\mathrm{N}$, long. $15^{\circ} 45^{\prime} \mathrm{E}$, altitude $\left.186 \mathrm{~m}\right)$, according to randomized complete block with four replications. Two varieties of Foeniculum vulgare Mill. (V - var. vulgare, D - var. dulce) were investigated, along with four harvest terms $(\mathrm{H}$ - herb before flowering, $\mathrm{F}$ herb in full flowering, $\mathrm{G}$ - "green seed" on the $1^{\text {st }}$ range umbel, W - waxy seed, according to Németh et al, 1997). In the first season the experiment was set up with transplants grown in trays with 209 cells. The crop of V over-wintered, and transplants of $\mathrm{D}$ were planted again in the second season. Plant spacing was $0.5 \mathrm{~m} \times 0.25 \mathrm{~m}$, the plot area was $6 \mathrm{~m}^{-2}$. Plants in the stages $\mathrm{H}$ and $\mathrm{F}$ were cut at $20 \mathrm{~cm}$ above the soil, in the stage $\mathrm{G}$ at about $40 \mathrm{~cm}$ from the top of the plant, and in the stage $\mathrm{W}$ only umbels were cut off. Essential oil was distilled from the fresh biomass in the Clevenger apparatus for 2 hours, and quality parameters were analysed by GC-MS method.

Table 1. Harvest of fennel biomass according to different stages of plant development (days after planting, exception for $\mathrm{V}$ in season 2: days from the beginning of the vegetation). ${ }^{\mathrm{z}}$ var. vulgare,${ }^{\mathrm{y}}$ var. dulce

\begin{tabular}{|c|c|c|c|c|c|}
\hline \multirow{2}{*}{ Stage } & \multicolumn{2}{|c|}{ Season 1 } & \multicolumn{3}{c|}{ Season 2 } \\
\cline { 2 - 6 } & I. cut & II. cut & I. cut & II. cut & III. cut \\
\hline \hline Fresh herbage (H) & & & & & \\
V $^{\mathrm{z}}$ & 69 & 152 & 79 & 122 & 184 \\
$\mathrm{D}^{\mathrm{y}}$ & 69 & 152 & 113 & & \\
\hline $\begin{array}{c}\text { Full flowering (F) } \\
\text { V }\end{array}$ & 89 & 167 & 122 & 212 & \\
D & 138 & & 141 & & \\
\hline "Green seed" (G) & & & & & \\
V & 138 & & 156 & & \\
D & 152 & & & & \\
Waxy seed (W) & & & & & \\
V & 167 & & 191 & & \\
D & 169 & & & & \\
\hline
\end{tabular}

\section{Results and discussion}

Shares of particular parts of fennel plant in different harvest terms are shown in the Figure 1. Period from planting (DAP) to stage $\mathrm{H}$ was equal for both varieties (69 days to the first cut and 152 days to repeated cut of the regenerated plants). In the comparison with D, V yielded equal biomass (5,6 vs. $5,2 \mathrm{~kg} \cdot \mathrm{m}^{-2}$, Fig. 2), but double essential oil volume (12,0 vs. $5,9 \mathrm{ml} \mathrm{m}^{-2}$, Fig. 4), because of higher essential oil content in the first cut $(0,17$ vs. $0,09 \%$, Fig. 3$)$. During the vegetation period, D reached the stage F only once (138 DAP), and V did it twice (89 and 187 DAP), along with 1,5-fold higher total herb yield and 2,5-fold higher yield of oil. In the stage $G$ herbage yield was similar, but essential oil yield was $350 \%$ higher at V. Stage W was reached in the similar period at both varieties, but $\mathrm{V}$ yielded multi-fold higher amount of essential oil.

In the second season varieties differed more drastically from the point of reaching particular ontogenetic stages, herbage and essential oil yield, and regeneration of the crop. As a one-year crop, D did not reach the stages $\mathrm{G}$ and $\mathrm{W}$, because of unfavourable meteorological conditions (scarce precipitation until the end of the June, abundant 
rainfall in July and August along with frequent alterations of high and low temperatures).

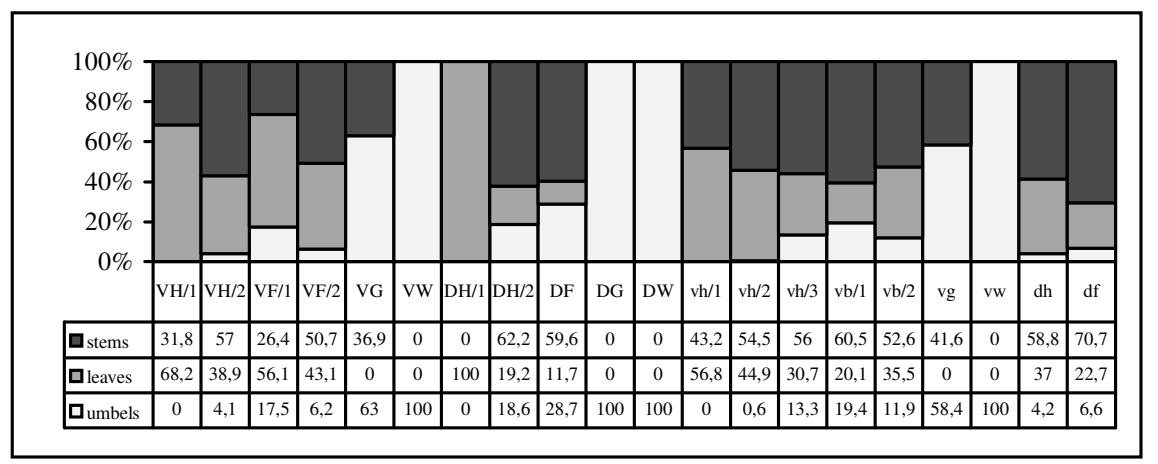

Figure 1. Portions of particular parts of fresh fennel plant in different stages of plant development. Season 1: VH - DW; season 2: vh - db. Legend:V, v - var. vulgare; D, d - var. dulce; $\mathrm{H}$ - herbage before flowering; F - full flowering; G - "green seed", W - waxy seed;

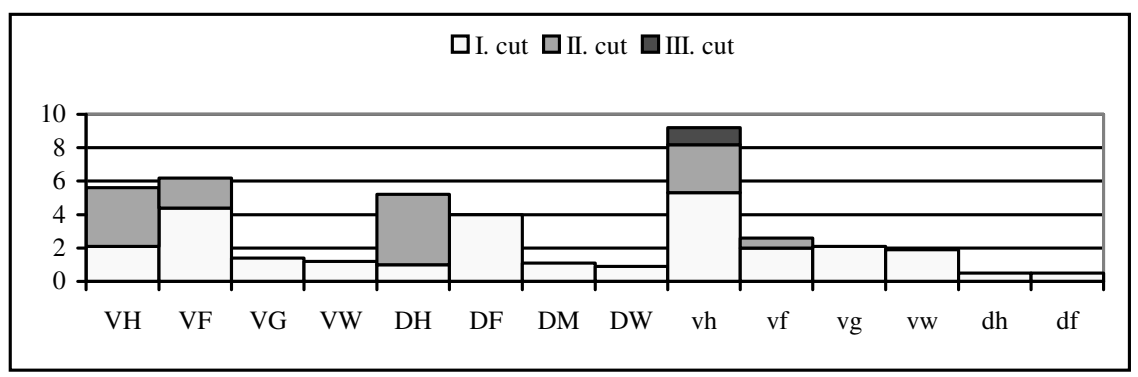

Figure 2. Yield of fresh fennel herbage $\left(\mathrm{kg} \cdot \mathrm{m}^{-2}\right)$ according to different stages of plant development. Season 1: VH - DW; season 2: vh - db. Legend: see Figure 1.

Unfavourable ecological conditions in the second season significantly less influenced $\mathrm{V}$, which over-wintered relatively well and started the vegetation in the middle of March. Consequently, there were three harvests at the stage $\mathrm{H}$ and two harvests at the stage $\mathrm{F}$. Along with relatively low biomass yield in the stage $\mathrm{G}$, high yield of oil was obtained.

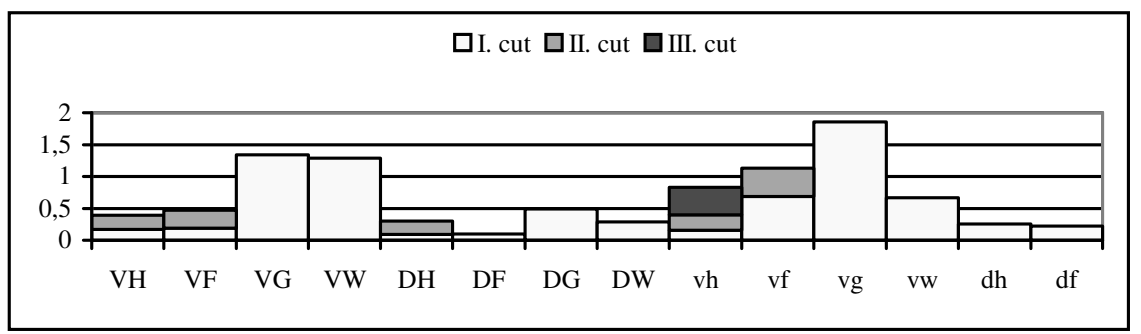

Figure 3. Essential oil content in fresh fennel biomass (\%) according to different stages of plant development. Season 1: VH - DW; season 2: vh - db. Legend: see Figure 1. 
Amounts of anethole, as a main compound of essential oil in all aerial plant parts of $\mathrm{V}$ and D, stay in agreement with reports of Nemeth (2005) and Akgul and Bayrak (1988), but in disagreement with Telci et al. (2009). Anethole is followed by fenchone and $\alpha$-pinene in $\mathrm{V}$, and limonene in D. During the vegetation period, a rate of anethole and fenchone increased, while the rate of $\alpha$-pinene and limonene decreased.

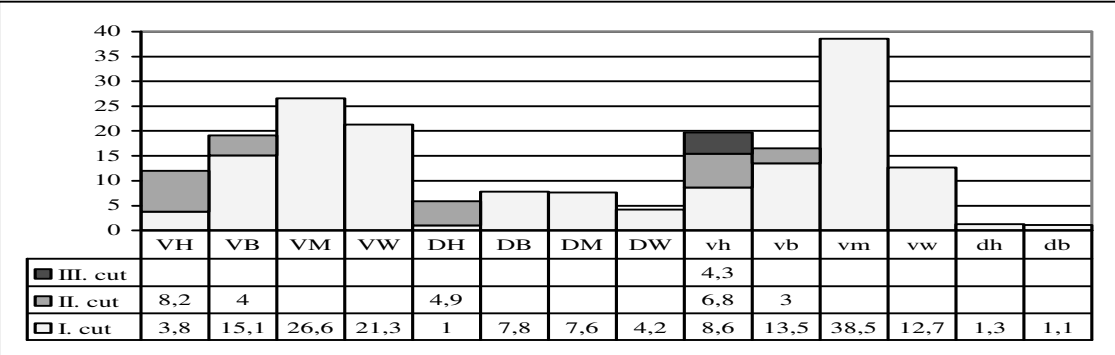

Figure 4. Yield of fennel essential oil $\left(\mathrm{ml} \cdot \mathrm{m}^{-2}\right)$ according to different stages of plant development. Season 1: VH - DW; season 2: vh - db. Legend: see Figure 1.

\section{Conclusions}

Compared to var. dulce, var vulgare gave significantly higher yields of essential oil in all developmental stages, especially as over-wintered crop and in the unfavourable meteorological conditions. Suitable harvesting time should be the stage of "green seed", because of the highest yield of essential oil along with the lowest yield of biomass.

\section{Acknowledgements}

The experiment was funded by Zagreb County and supported by "Ireks aroma", Zagreb.

\section{References}

Akgul A. - Bayrak A.: 1988. Comparative volatile oil composition of various parts from Turkish bitter fennel (Foeniculum vulgare var. vulgare). Food Chemistry, 30: 4. 319-323.

Barros L. - Heleno S.A. - Carvalho A.M. - Ferreira I.C.F.R.: 2009. The nutritional composition of fennel (Foeniculum vulgare): shoots, leaves, stems and inflorescences. LWT - Food Science and Technology. Doi: 10.1016/j.1wt.2010.01.010.

Gross M. - Lewinsohn E. - Tadmor Y. - Bar E. - Dudai N. - Cohen Y. - Friedman J.: 2009. The inheritance of volatile phenylpropenes in bitter fennel (Foeniculum vulgare Mill. var. vulgare, Apiaceae) chemotypes and their distribution within the plant. Biochemical Systematics and Ecology, 37: 308-316.

Mohamed M.A.H. - Abdu M.: 2004. Growth and oil production of fennel (Foeniculum vulgare Mill): Effect of irrigation and organic fertilization. Biological Agriculture and Horticulture, 22. 1:31-39.

Nemeth E. - Bernath J. - Petheo F.: 1997. Study on flowering dynamics and fertilization properties of caraway and fennel. Acta Horticulturae, 502: 77-83.

Nemeth E.: 2005. Changes in essential oil quantity and quality influenced by ontogenetic factors. Acta Horticulturae, 675: $159-165$.

Telci I. - Demirtas I. - Sahin A.: 2009. Variation in plant properties and essential oil composition of sweet fennel (Foeniculum vulgare Mill.) fruits during stages of maturity. Industrial Crops and Products, 30: 126-130. 


\title{
INFLUENCE OF TRICHODERMA HARZIANUM RIFAI ON THE FIBER FLAX GERMINATION AND GROWTH
}

\author{
Snježana TOPOLOVEC-PINTARIĆ
}

Department of Plant Pathology, Faculty of Agriculture, University of Zagreb, Svetošimunska 25, 10000 Zagreb, Croatia, tpintaric@agr.hr

\begin{abstract}
The micorrhizal fungus Trichoderma harzianum is rhizosphere component and take part in the decomposition of soil plant debris. Its agricultural importance is good antagonism against soil born plant pathogenic fungi and promotion of plant growth. Reintroduction of a rhizosphere fungus, such as $T$. harzianum, to the soil as biocontrol agent or biofertilizer is often difficult because such organism must adjust to the environment and survive. Initially it is compete with harmful microbes for the occupation of the rhizosphere. Simultaneously, tries to colonize the available sites along the plant roots and prevent pathogens from making contact with the root tissue. The objectives of this work were to: investigate the possibility of reintroduction and dispersal of indigenous T. harzianum strain to the soil in the form of alginate pellets, and determine its influence on the germination of the "pelleted" flax seed (seed coated alginate matrix enriched with spore inoculum. The indigenous $T$. harzianum strain applied in the form of pellets and through pelleted seeds, positively influenced germination and seedlings emergence.
\end{abstract}

Keywords: Trichoderma harzianum, bio-fertilizer, alginate pellets.

\section{Introduction}

The filamentous fungus Trichoderma harzianum apart from the antagonistic properties is able to stimulate plant growth and therefore is considered to be an opportunistic plant symbiont. Fungus grows and proliferates best when there are abundant healthy roots which are resort of plant pathogenic fungi, the target for T. harzianum as micoparasite. Therefore, it has evolved numerous mechanisms for enhancing solubility of soil nutrient and enhancing nutrient uptake by plant (Altomar et al., 1999). Better plant nourishment result in enhanced root hair development and root growth. Due to that the growth of whole plant is enhanced so T. harzianum may be benefit as bio-fertilizer. But, reintroduction to soil, even the most strongly rhizosphere competent such as $T$. harzianum, can be difficult. Rhizosphere is environment fulfil with spectrum of microbes with whom reintroduced $T$. harzianum must compete, trying to colonize available sites along the plant roots. Therefore, it need to be applied in low-cost but highly densities inocula engineered to maintain fungal propagula viable during the transport, storage and application. To accomplished mentioned goals and effective dispersal of fungal inocula it is necessity to choose the fungal inocula carrier and the type of formulation. The encapsulation of $T$. harzianum in an alginate matrix has been studied and positively evaluated by various authors (Gennari et al., 1990; Leštan and Lamar, 1996; Mafia et al., 2003). The objectives of this work were: to investigate the possibility of reintroduction and dispersal of indigenous $T$. harzianum strain STP to the soil in the form of alginate pellets, and determine its influence on the germination of the "pelleted" flax seed (seed coated alginate matrix enriched with spore inocula). 


\section{Materials and methods}

The alginate pellets of $T$. harzianum strain STP were prepared in order with method by Gennari et al. (1990). The one week old mycelar colony of strain STP with potato dextrose agar medium (PDA) and sterile water was mixed in common blender at low speed for 3-5 minutes in order to make a suspension. After dilution, the concentration to be used contained $4 \times 10^{6}$ spore $\mathrm{ml}^{-1}$. The suspension was mixed with talcum $\left(100 \mathrm{~g} \mathrm{l}^{-1}\right)$ and sodium alginate $\left(10 \mathrm{~g} \mathrm{l}^{-1}\right)$. The formed matrix was placed in a separator funnel modified in order to allow suspension to drip into a $0.1 \mathrm{M}$ suspension of calcium gluconate under stirring at magnetic agitator, thus obtaining gelatinized spherules or pellets. Pellets were dried under a sterile vertical flow for 12 hours. The flax seed was coated with the alginate matrix and dripped in $0.1 \mathrm{M}$ suspension of calcium gluconate under stirring which allowed formation of "pelleted" seeds. "Pelleted" seeds were dried under a sterile vertical flow for 12 hours. The trial was conducted in greenhouse with following variants tested in three repetitions each: 1) "pelleted" untreated seed (natural), 2) "pelleted" treated seed (fungicide Prelude 20 LS), 3) pellets applied near seedlings from untreated seeds, 4) pellets applied near seedlings from treated seeds, 5) untreated seeds as control left without adding the pellets and 6) treated seeds as control left without adding the pellets. The 252 natural flax seeds variety Electra were sown divided in two rows into pots $60 \times 15 \times 16 \mathrm{~cm}$ containing sterilised soil. One pot represented one repetition, so in total there were 18 pots. The germination was checked every day for 21 days, starting from the time the seedlings emerged from the soil. When the young plants were $25 \mathrm{~cm}$ high the $40 \mathrm{~g}$ of pellets were equally distributed between two rows of plants in each pot of variants 1-4, while in the control pots were omitted. After that first application the pellets were added 2 times more at two weeks intervals. After harvesting, the rhizosphere soil layer was collected from each pot. The 18 soil solutions were prepared and purred onto PDA in Petri dishes. After incubation at $25^{\circ} \mathrm{C}$ for 5 days the STP was isolated from every soil sample originated from pots were the fungus was added, either in the form of pellets or pelleted seed.

\section{Results and discussion}

The evaluation of T. harzianum strain STP influence on plant growth was based on measurements data of seedling emergence and seedling growth. The STP applied in the form of pellets and through pelleted seeds, positively influenced germination, seedlings emergence and plants grow. The germination at control pots was lower than in pots with added pellets therefore addition of STP based pellets increased the number of emerged seedlings (fig. 1). The slower germination was observed at the pelleted seeds what is due to the germination blockage posed by the coating film. The reaction of sodium alginate with the $\mathrm{Ca}$-ion from the calcium gluconate is resulting in gel forming which causes slower germination. The similar results obtain Nipoti et al. (1990) in investigation of strain T-581 influence on germination of asparagus seed. Fourteen days after sowing the $50 \%$ of the seeds germinated. There were no visual differences in height of seedlings in comparison to the seedlings from natural, unpelleted seeds. 
Observation of plant growth showed that in the presence of STP plants grow higher and the highest where plants from pelleted seed (fig 1). In first measurement the height of control plants, the plants where pellets were added and plants from pelleted seeds was similar. With time the height of control plants remain lower than height of plants stimulated with STP based pellets and plants from pelleted seeds.
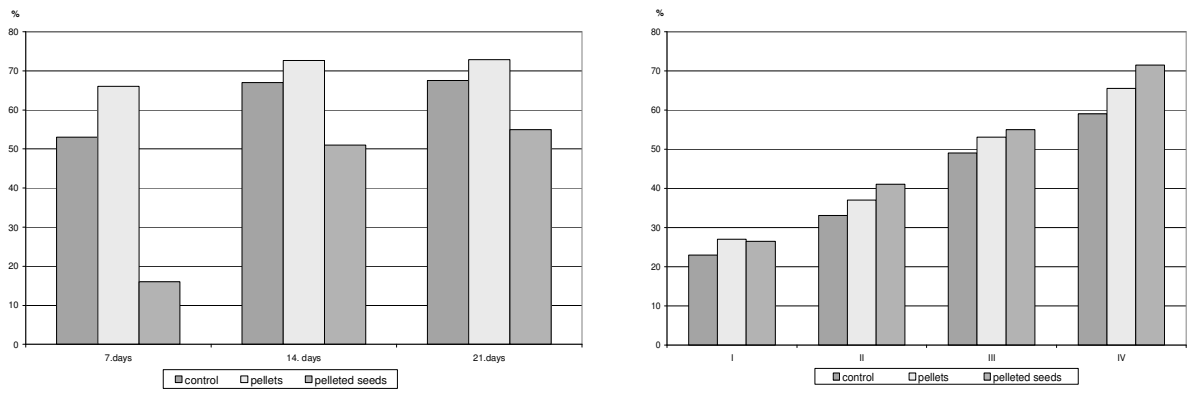

Figure 1. Germination and emergence of seedlings (left), and height of plants (right).

The versatile $T$. harzianum mechanisms are responsible for growth promotion. Numerous authors considered importance of $T$. harzianum production of growthregulating factor which increase the rate of seed germination (Windham et al., 1986; Baker, 1988). Furthermore, there is importance of mycorrhizal effects like increasing the efficiency of nutrient transfer from the soil to roots (Altomar et al., 1999; Harman, 2006). Interesting discussion presented Ousley et al. (1994) that the promoted plant growth can be due to the effect of $T$. harzianum in removing a toxic material from the soil which was inhibitory to plant growth. The revealing of mechanisms was not goal of this investigation. The objective of this study was only investigating indigenously isolated strain STP as plant growth stimulator because there was no report concerning the use of T. harzianum as plant growth stimulator in Croatia.

The strain STP was successfully encapsulated in formulation of alginate pellets. Encapsulation consists of mixing fungal cell with matrix forming material such as gelatinized polysaccharide. Alginate pellets show to be excellent fungal inocula carrier which enables $T$. harzianum transfer to soil. Also, alginate matrix preserves fungal viability as showed the successful colonisation of roots after pellets placement in vicinity of plants. The alginate matrix used for the immobilisation of strain STP and formation of pellets remained in the soil after the harvesting. With the time the reminding pellets slowly decayed, possibly because the soil was sterile, without microbiological activity. In conducted trial only the regular watering enables the decomposition of the pellets. Some of the remaining pellets were took to the laboratory were STP was regenerated from alginate matrix onto PDA substrate after one week incubation (fig. 2). 


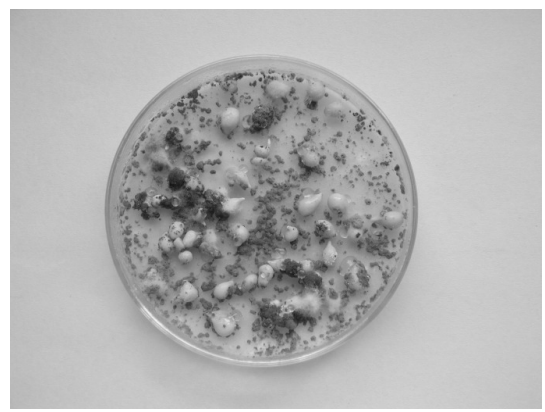

Figure 2. Trichoderma harzianum strain STP regenerated from alginate pellets.

\section{Conclusion}

It could be concluded that the indigenously isolated $T$. harzianum strain STP, applied in the form of pellets and through pelleted seeds, positively influenced germination, seedlings emergence and plants grow. The alginate pellets show to be suitable formulation for $T$. harzianum encapsulation in order to preserve the inocula. Furthermore, alginate pellets are formulation easy for application and therefore for fungal reintroduction to the soil. Obtained results of $T$. harzianum strain STP activity and positive influence to plant growth in earliest phenological phases allowed recommendation for it consideration as good bio-fertilize agent.

\section{References}

Altomare C. - Norvell W.A. - Björkman T. - Harman G.E.: 1999.Solubilization of phosphates and micronutrients by the plant-growth-promoting and biocontol fungus Trichoderma harzianum Rifai 129522. Applied and Environmental Microbiology, 65. 2926-2933.

Baker R.: 1998. Trichoderma spp. as plant-growth stimulans. CRC Crit. Rev. Biotechnol., 7: 2. 97-106.

Gennari S. - Manzali D. - Nipoti P. - D'Ercole N.: 1989. Activity of T. harzianum Rifai on germination of asparagus seed. Proceeding of the $7^{\text {th }}$ Internation Asparagus Symposium. I and II Seed Treatments. Ferara, Italy. 409-414.

Harman G. E.: 2006. Overview of mechanisms and uses of Trichoderma spp.. Phytopathology, 96: 2. 109194.

Leštan D. - Lamar R. T.: 1996. Development of fungal inocula for bioaugmentation of contaminated soils. Applied and Environmental Microbiology, 62. 2045-2052.

Mafia R. G. - Alfenas A. C. - Maffia L.A. - Ventura G. M. - Sanfuentes E. A.: 2003. Encapsulamento de Trichoderma inhamatum para controle biologico de Rhizoctonia solani na propagacaoclonal de Eucalyptus. Fitopatologia Brasileira, 28. 101-105.

Nipoti P. - Manzali D. - Gennari S. - D’Ercole N. - Rivas F.: 1990. Activity of Trichoderma harzianum Rifai on germination of asparagus seeds. Acta Horticulturae, 271. 403-407.

Ousley M.A. - Lynch J.M. - Whipps J.M..: 1994. Potential of Trichoderma spp. As consistent plant growth stimulators. Biol. Fertil. Soils, 17: 1. 85-90.

Windham M. T. - Elad Y. - Baker R.: 1986. A mechanism for increased plant growth induced by Trichoderma spp.. Phytopathology, 76: 5, 518-521. 


\title{
INTERACTION OF SOIL, FERTILIZATION, CROP ROTATION AND CROPYEAR EFFECT IN THE CORN PRODUCTION
}

\author{
Andrea AMBRUS ${ }^{l}$ - Erika FODORNÉ FEHÉR ${ }^{2}$ - Sándor HOLLÓ ${ }^{3}$ \\ ${ }^{1}$ Institute of Agroinformatics and Rural Development, Károly Róbert College, Gyöngyös, e-mail: \\ aambrus@karolyrobert.hu \\ 2 Mátra Secondary Technical School, Mátrafüred \\ ${ }^{3}$ Institute of Agrotechnology, Károly Róbert College, Gyöngyös
}

\begin{abstract}
Besides the nutrient contents of soil economical corn production is also determined by the useful water stock of the soil. These two factors can strongly be affected by the cropyear effect and the preceding crop. Within the framework of the Kompolt experiment the data of 32 years have been processed. In autumn 1961 Károly Pekary launched a three-component long-term fertilization field experiment repeated four times. In 1965 the experiment was transformed into a four-component one. The experiment was launched on a brown forest soil. When selecting variety the ones most adapted to the given plot were selected and sown. The experimental results have been evaluated considering the cropyear effect. Ideal, normal, extraordinarily rainy and extraordinarily dry cropyear have been differentiated. The yield of monocultural and bicultural production of corn has been surveyed by untreated control and four different levels of fertilization. The years surveyed are the so called opening years (the first year of each four-year period), i.e. in case of biculture winter wheat was produced for two years in the given parcel. It has been stated that the yield level of monocultural corn was each year lower than that of same produced in bicultural. In our opinion this fact is undoubtedly due to the effect of preceding crop which independent from cropyear affected the average yield positively. Surveying cropyears we have stated that the greatest differences in average yield showed up in case of extreme cropyears.
\end{abstract}

Keywords: corn, fertilization, crop rotation, cropyear effect

\section{Introduction}

Nowadays more and more attention is paid to economic and environmentally compatible nutrition supply which is to be site specific and adopted to the different utilization goals. (Sipos, 2009) On more than $80 \%$ of the domestic crop land crop production is carried out under natural precipitation circumstances. A soil humidity interval containing enough and easily absorbable water for them can be stipulated for the plants. Besides variety the soil humidity demand of plants can also vary according to phenological phase. In this respect the critical period in case of most plants is round the flowering period. In case of maize the period of July-August is regarded as critical. The water demand of maize in the critical period is $350-500 \mathrm{~mm}$. (Varga-Haszonits et al., 2008) The emergence of nutrition stock is significantly affected by the water resources of the soil. (Várallyay, 2002) In the long term experiments launched by Béla Győrffy in Martonvásár the surveyed crop yields of corn-wheat biculture from 1958 and corn monoculture from 1959 showed that in dry cropyears a lower rate of fertilization resulted in higher yield stability in corn monoculture. By high fertilization rate in dry cropyears manure handling brought about higher stability than NPK fertilizer. In rainy years high rate of NPK fertilization resulted in the best yield. The stability of comparative handling was higher in biculture than in monoculture. (Berzsenyi, 2009) 


\section{Materials and methods}

Kompolt is situated on the northern edge of the Alföld (Plain), south from the MátraBükk mountains. The soil of the experiment is - a transition between field and forest soils with deep humus stratum, free of carbonate - chernozem brown forest soil characteristic of about 220 thousand ha area in the northern part of the country. The total $\mathrm{N}$ content of the soil is in relation to its humus content very low. The nitrogen supplying ability of the soil is low, its AL-soluble $\mathrm{P}$ content is low and the $\mathrm{K}$ content is moderate. The soil of the experiment in the top ploughed stratum is moderately cohesive loam with a clay content of $46 \%$. In the lower soil strata the proportion of clay and the cohesion increases. The physical features of the soil are unfavourable. Through drought it sinters heavily and deep and wide splits appear on the surface. Through water it swells and becomes impermeable. Kompolt is one of the areas of the country poor on water and with capricious precipitation distribution. The nearby annual drought can be expected in any phase of the vegetation and this makes the effectiveness of fertilization uncertain, first of all in case of maize. Within the framework of the Kompolt experiment the data of 32 years have been processed. In autumn 1961 Károly Pekáry launched a three-component long-term fertilization field experiment repeated four times. In 1965 the experiment was transformed into a four-component one. The experiment was launched on a brown forest soil. When selecting variety the ones most adapted to the given plot were selected and sown. The experimental results have been evaluated considering the vintage effect. Ideal, normal, extraordinarily rainy and extraordinarily dry cropyears have been differentiated. The yield of monocultural and bicultural production of corn has been surveyed by untreated control and four different levels of fertilization. (Table 1) The years surveyed are the so called opening years (the first year of each four-year period), i.e. in case of biculture winter wheat was produced for two years in the given parcel. It has been stated that the yield level of monocultural corn was each year lower than that of same produced in diculture.

\section{Results and discussion}

In the present study the effect of cropyear and the different nutrition rates has been surveyed in the initial years of 28. There was no fertilization on the control parcels of the long term field experiment during the experiment. According to their effect on maize crop in the surveyed period we have separated ideal (1986, 1974, 1994), normal (1978, 1966), extraordinarily rainy (humid) $(1970,1990,1982)$ and extraordinarily dry (arid) (1962) cropyears. The effectiveness of fertilization depends besides the preceding crop on the relative moisture content of the soil. In Kompolt this index is on the basis of the average of the years 1950-2000 the highest in February and March with $91.7 \%$ and $90.2 \%$.

The index shows the lowest value in July and August when the moisture content of the soil is $48 \%$ resp. $47.7 \%$. Regarding water the critical period for corn is the period of detasseling which takes place in June-July depending on variety. The quantity of precipitation in the vegetation period does not offer sufficient information for estimating the relative moisture content of the soil. The precipitation after the preceding crop also affects the water stock of the soil significantly (Figure 1). In the course of our surveys the average yields monoculture and biculture growing have been studied by control 
$\left(\mathrm{M}_{0}\right)$ and four different rates of fertilization. We have come to the conclusion that the cumulated average yield of the treated parcels was higher in case of biculture in each surveyed year. The effect of the preceding crop is obvious. In case of extreme dry cropyear (1962) the average yield of monoculture growing by $\mathrm{M}_{0}$ handling with $2.72 \mathrm{t}$ $\mathrm{ha}^{-1}$, by $\mathrm{M}_{2}$ handling with $2.91 \mathrm{t} \mathrm{ha}^{-1}$ was higher than that of the diculture. In case of $\mathrm{M}_{3}$ and $\mathrm{M}_{4}$ handling in monoculture, in case of $\mathrm{M}_{4}$ handling in biculture the bigger quantity of fertilizer resulted in a crop decrease.

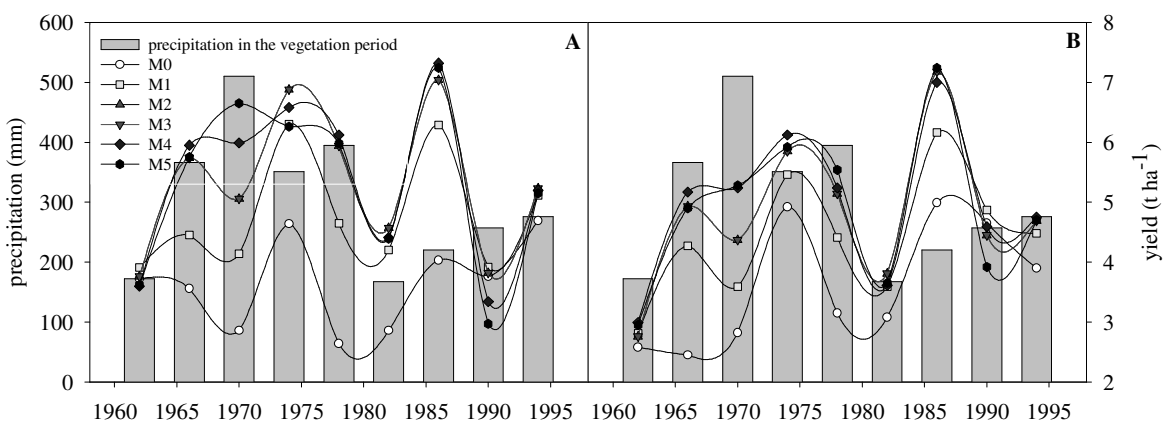

Figure 1. The yield of maize in monoculture (A) and biculture (B) in the Kompolt long term field experiment (1962-1994)

The frequency partition of the yield has been surveyed in case of both mono- and biculture growing by equal level of handling. (Table 1-2)

Table 1. The frequency partition of the average yield of corn in monoculture from 1962 to 1994

\begin{tabular}{|c|c|c|c|c|c|c|c|}
\hline \multirow{3}{*}{ Handling } & \multirow{3}{*}{$\begin{array}{l}\text { Average } \\
\text { yield } \mathrm{t} \\
\mathrm{ha}^{-1}\end{array}$} & \multicolumn{6}{|c|}{ Frequency $(\mathrm{P}) \%$} \\
\hline & & $y<2$ & $\begin{array}{c}y=2- \\
3\end{array}$ & $\begin{array}{c}y=3- \\
4\end{array}$ & $\begin{array}{c}y=4- \\
5\end{array}$ & $\begin{array}{c}y=5- \\
6\end{array}$ & $y>6$ \\
\hline & & \multicolumn{6}{|c|}{$\mathrm{t} \mathrm{ha}^{-1}$} \\
\hline $\mathrm{M}_{0}$ & 2,64 & 33 & 33 & 33 & 0 & 0 & 0 \\
\hline $\mathrm{M}_{1}$ & 3,75 & 0 & 22 & 44 & 11 & 22 & 0 \\
\hline $\mathrm{M}_{2}$ & 4,33 & 0 & 22 & 11 & 44 & 11 & 11 \\
\hline $\mathrm{M}_{3}$ & 4,39 & 0 & 22 & 11 & 33 & 22 & 11 \\
\hline $\mathrm{M}_{4}$ & 4,33 & 11 & 11 & 11 & 33 & 22 & 11 \\
\hline
\end{tabular}

\begin{tabular}{|c|c|c|c|}
\hline \multirow{2}{*}{ Handling } & $\mathrm{3}$ & P2O5 & K2O5 \\
\cline { 2 - 4 } & \multicolumn{3}{|c|}{$\mathrm{kg} / \mathrm{ha} /$ year } \\
\hline \hline $\mathrm{M}_{0}$ & 0 & 0 & 0 \\
\hline $\mathrm{M}_{1}$ & 42,5 & 21 & 50 \\
\hline $\mathrm{M}_{2}$ & 85 & 42,5 & 101 \\
\hline $\mathrm{M}_{3}$ & 127,5 & 64 & 151 \\
\hline $\mathrm{M}_{4}$ & 170 & 85 & 201 \\
\hline
\end{tabular}

On the basis of the frequency partition it can be stated that the average yield of maize grown in monoculture was by M2 level of fertilization in $44 \%$, by M3 and M4 level of fertilization in $33 \% 4-5 \mathrm{t} \mathrm{ha}^{-1}$. Based on the partition of the average yield of corn we can come to the conclusion that the biculture affects the soil more favourably as in $44 \%$ an average yield of 3-4 $\mathrm{tha}^{-1}$ can be achieved even by a lower rate (M1) of fertilization. The average yields of biculture are always higher in the surveyed period than those of the monoculture thank to the favourable preceding crop. 
Table 2. The frequency partition of the average yield of corn in biculture from 1962 to 1994

\begin{tabular}{|c|c|c|c|c|c|c|c|c|}
\hline \multirow{2}{*}{ Handling } & \multirow{2}{*}{$\begin{array}{c}\text { Average } \\
\text { yield t ha }\end{array}$} & \multicolumn{7}{|c|}{ Frequency (P)\% } \\
\cline { 3 - 9 } & & $\mathrm{y}<2$ & $\begin{array}{c}\mathrm{y}=2- \\
3\end{array}$ & $\begin{array}{c}\mathrm{y}=3- \\
4\end{array}$ & $\begin{array}{c}\mathrm{y}=4- \\
5\end{array}$ & $\begin{array}{c}\mathrm{y}=5- \\
6\end{array}$ & $\mathrm{y}>6$ \\
\hline \hline $\mathrm{M}_{0}$ & 3,61 & 33 & 33 & 33 & 0 & 0 & 0 \\
\hline $\mathrm{M}_{1}$ & 4,40 & 11 & 22 & 44 & 11 & 11 & 0 \\
\hline $\mathrm{M}_{2}$ & 4,79 & 11 & 11 & 44 & 22 & 0 & 11 \\
\hline $\mathrm{M}_{3}$ & 4,96 & 11 & 11 & 22 & 33 & 22 & 0 \\
\hline $\mathrm{M}_{4}$ & 4,90 & 11 & 22 & 22 & 33 & 0 & 11 \\
\hline
\end{tabular}

\begin{tabular}{|c|c|c|c|}
\hline \multirow{2}{*}{ Handling } & $\mathrm{N}$ & $\mathrm{P} 2 \mathrm{O} 5$ & $\mathrm{~K} 2 \mathrm{O} 5$ \\
\cline { 2 - 4 } & \multicolumn{3}{|c|}{$\mathrm{kg} / \mathrm{ha} / \mathrm{y}$ ear } \\
\hline \hline $\mathrm{M}_{0}$ & 0 & 0 & 0 \\
\hline $\mathrm{M}_{1}$ & 42,5 & 21 & 50 \\
\hline $\mathrm{M}_{2}$ & 85 & 42,5 & 101 \\
\hline $\mathrm{M}_{3}$ & 127,5 & 64 & 151 \\
\hline $\mathrm{M}_{4}$ & 170 & 85 & 201 \\
\hline
\end{tabular}

\section{Conclusions}

On the basis of the experiment we have stated that the cropyear effect considerably affects the exploitation of the fertilizer. The lowest average yield was achieved in the dry cropyears both in mono- and biculture. In extremely dry years maize does not react to a bigger quantity of fertilizer by higher average yield, moreover, it expressly decreases in case of monoculture. Surveying the total average yield per handling we have stated that the yield of biculture growing was by an average of 0.97-0.46 $\mathrm{tha}^{-1}$ higher. The greatest difference in average yield was to be experienced on the unhandled control parcels. By M1 level of fertilization its average yield was $0.65 \mathrm{t} \mathrm{ha}^{-1}$ higher than that of the diculture. By the further handlings the increased quantity of fertilizer resulted in a yield difference of $0.46-0.57 \mathrm{t} \mathrm{ha}^{-1}$ only between bi- and monoculture. In the cases of high level nutrients delivery the drought sensibility increased as it is obvious from the frequency partition of the average yields. This effect could be more strongly sensed in case of biculture.

\section{Acknowledgements}

The authors are indebted for the support of their reseach for NTTI, SZIU, Gödöllö and Rudolf Fleischmann Research Institute, KRF, Kompolt, Réka Láposi, József Pethes.

\section{References}

Berzsenyi, Z.: 2009. A martonvásári tartamkísérletek jelnetősége. Tartamkísérletek jelentősége a növénytermesztésben, Jubileumi tudományos konferencia, Magyar Tudományos Akadémia Mezőgazdasági Kutatóintézete, Martonvásár, 37-49.

Sípos, M.: 2009. A kukorica (Zea mays L.) termésének, valamint néhány beltarlalmi értékének vizsgálata a hybrid és a tápanyagellátás függvényében öntözési és mütrágyázási tartamkísérletben. Agrokémia és Talajtan. 58: 1. 79-90.

Varga-Haszonits, Z. - Varga, Z. - Lantos, Zs. - Enzsölné Gerencsér, E. - Milics, G.: 2008. A talajok vízellátottsgának hatása a gazdasági növények vízigényének alakulására. Agrokémia és Talajtan. 57: 1. 720.

Várallyay, Gy.: 2002. Soil fertility and environmental aspects of soil water management. Proc. Alps-Adria Scientific Workshop. Cereal Research Communications, 8-14. 


\title{
LEAF NUMBER, LEAF AREA AND GREEN MASS OF SILAGE MAIZE HYBRIDS WITH DIFFERENT MATURITY PERIODS
}

\author{
Zsuzsanna TÓTHNÉ ZSUBORI
}

Agricultural Research Institute of the Hungarian Academy of Sciences, Martonvásár, Hungary, H-2462,

Brunszvik u. 2. e-mail: zsuboriz@mail.mgki.hu

\begin{abstract}
Eighteen silage maize hybrids (including 5 leafy hybrids) with different maturity periods were tested in Martonvásár in 2009. The hybrids were compared according to plant height, leaf number, leaf area, green mass and dry matter yield. Only the leaves above the ear were counted when determining leaf number and leaf area, since they contribute to photosynthesis to a greater extent than the older leaves below the ear. The leaf area was calculated using the formula of Montgomery (1906). The green mass per plant was measured at harvest at the silage maturity stage (35\% dry matter content on average). The above-ear leaf number of leafy hybrids was considerably greater than that of normal hybrids, and in some cases the leaf area above the ear was $0.6 \mathrm{~m}^{2}$ larger. The increased leaf number above the ear results in a greater assimilating leaf area, allowing the plants to harvest the light energy required for photosynthesis more efficiently and thus to produce more nutrients, especially carbohydrates in the leaves. Hybrids with later maturity grew taller and had greater green mass per plant than early maturing hybrids. In general, the dry matter yield per plant of leafy hybrids was above average, though these differences were not statistically significant. The leafy hybrid Mv Massil had the greatest green mass and dry matter yield per plant, significantly. Correlations between these traits were also studied. The green mass and dry matter yield were influenced not by plant height, but by maturity group. Weak positive correlations were found between leaf area and green mass per plant, and between leaf area and dry matter yield, and moderate positive correlations between plant height and leaf number and between plant height and leaf area.Leaf area was influenced more by leaf width than by leaf length.
\end{abstract}

Keywords: maize, leafy, maturity, yield

\section{Introduction}

The value of silage maize hybrids depends not only on the size of the fresh and dry matter yields per hectare, but also on the chemical quality and digestibility of the silage. Digestibility is influenced by the proportion of different plant parts in the dry matter (Bal and Bal, 2009). The ear has the highest energy concentration and digestibility. Leaves are more digestible than the stalk, so a greater proportion of leaves in the whole plant dry matter results in better digestibility. Experiments have been underway all over the world in recent years to improve these parameters through the introduction of new genes such as $B M R$ (brown midrib), $w x$ (waxy), $o_{2}$ (opaque) and floury-2, and the use of hybrids with high oil content, all of which have led to considerable improvements in quality. Their use in practice, however, has been restricted due to poorer yield averages and to the negative effect of these genes on other agronomic traits (Cox and Cherney, 2001). The use of leafy hybrids containing the lfyl gene, on the other hand, has proved to be favourable in the long term.

The main characteristic of leafy hybrids is that they have more leaves than normal hybrids, particularly above the main ear. In addition, the ear attachment height is lower, the internodes are shorter, the stalk below the ear contains more lignin and the plants have greater yield potential. The increased leaf number above the ear results in a greater assimilating leaf area, allowing the plants to harvest the light energy required for photosynthesis more efficiently and thus to produce more nutrients in the leaves (Dwyer et al., 1995). Several authors have noted the positive effects of this on the yield and

429 DOI: $10.1556 /$ Novenyterm.59.2010.Suppl.4 
grain quality (Stewart and Dwyer, 1993; Begna et al., 2001; Modarres et al., 1997; Dijak et al., 1999). The higher ratio of the leaves in the total plant dry matter and the greater carbohydrate content of the leaves above the ear (Andrews et al., 2000) have a favourable influence on the quality and digestibility of the silage.

Experiments carried out in Hungary (Pintér et al., 1988) proved that, above a harvest index of $35 \%$, the energy concentration of the whole plant is determined not by the grain ratio but by the quality traits of the vegetative organs. In other words, a larger leaf area above the ear results in better quality silage. The chemical composition and digestibility of silage maize hybrids was studied in earlier work (Tóthné Zsubori et al., 2009; Hegyi et al., 2009).

\section{Materials and methods}

Eighteen silage maize hybrids (including 5 leafy hybrids) with different maturity periods were tested in Martonvásár in 2009. The hybrids tested in the experiment are presented in Table 1 . The experiment was sown with 21 seeds per row (equivalent to 80,000 plants per hectare) in a randomised complete block design. During the vegetation period measurement were made on plant height, ear attachment height, leaf number, leaf area, green mass and dry matter yield. Only the leaves above the ear were counted when determining the leaf number and leaf area, since they contribute to photosynthesis to a greater extent than the older leaves below the ear (Subedi and Ma, 2005). The leaf area was calculated using the formula of Montgomery (1906). The green mass per plant was measured at harvest at the silage maturity stage $(35 \%$ dry matter content on average). The statistical analysis of the data was performed using the software "Agrobase".

Table 1. Hybrids tested in the experiment

\begin{tabular}{|l|l|l|l|l|}
\hline № & Hybrid name & FAO number & Maturity group & Note \\
\hline \hline 1 & Mv 241 & FAO 260 & very early & \\
\hline 2 & Mv 278 & FAO 270 & very early & \\
\hline 3 & Mv 298 & FAO 290 & very early & \\
\hline 4 & Mv 352 & FAO 330 & early & \\
\hline 5 & Maros & FAO 330 & early & \\
\hline 6 & NK Thermo & FAO 370 & early & standard \\
\hline 7 & Limasil & FAO 380 & early & leafy \\
\hline 8 & MvNK 333 & FAO 390 & early & \\
\hline 9 & Mv Dunasil & FAO 390 & early & leafy \\
\hline 10 & Bogát & FAO 420 & middle & \\
\hline 11 & Geyser & FAO 460 & middle & standard \\
\hline 12 & Mv 437 & FAO 480 & middle & \\
\hline 13 & Kámasil & FAO 510 & late & leafy \\
\hline 14 & Florencia & FAO 530 & late & standard \\
\hline 15 & Maxima & FAO 580 & late & \\
\hline 16 & Mv 504 & FAO 580 & late & leafy \\
\hline 17 & Coralba & FAO 580 & late & standard \\
\hline 18 & Mv Massil & FAO 610 & late & leafy \\
\hline
\end{tabular}




\section{Results and discussion}

There were significant differences between the maturity groups. Hybrids with later maturity grew taller and had a greater green mass per plant than early maturing hybrids with. The latest hybrid, Mv 504, was the tallest with a plant height of $252.64 \mathrm{~cm}$, while the shortest was Mv 278 with $211.13 \mathrm{~cm}$. Earlier maturing hybrids had lower ear attachment height, which was lowest for Mv $298(63.27 \mathrm{~cm})$ and highest for Maxima $(109.00 \mathrm{~cm})$ (Table 2).

The above-ear leaf number and leaf area of leafy hybrids was considerably greater than the mean of normal hybrids. In some cases, their leaf area was $0.6 \mathrm{~m}^{2}$ larger (difference measured between individual plants). Mv 504 had the greatest leaf number and leaf area above the ear $\left(11.73\right.$ leaves, $\left.0.8162 \mathrm{~m}^{2}\right)$. The increased leaf number above the ear results in a greater assimilating leaf area, allowing the plants to harvest the light energy required for photosynthesis more efficiently and thus to produce more nutrients, especially carbohydrates, in the leaves (Dwyer et al., 1995).

The mean dry matter yield per plant for leafy hybrids was superior to that of normal hybrids, though the difference was not statistically significant. The leafy hybrid Mv Massil had the greatest green mass and dry matter yield per plant, significantly. With a dry matter yield of $442.03 \mathrm{~g}$ per plant and a green mass of $1547.50 \mathrm{~g}$ per plant, this hybrid exceeded the mean of all the hybrids to a considerable extent.

Table 2. Summary of results

\begin{tabular}{|l|r|r|r|r|r|r|}
\hline Hybrid name & $\begin{array}{r}\text { Green mass } \\
\text { per plant }(\mathrm{g})\end{array}$ & $\begin{array}{c}\text { Dry matter } \\
\text { yield per } \\
\text { plant }(\mathrm{g})\end{array}$ & $\begin{array}{c}\text { Plant height } \\
(\mathrm{cm})\end{array}$ & $\begin{array}{c}\text { Ear } \\
\text { attachment } \\
\text { height }(\mathrm{cm})\end{array}$ & Leaf number & $\begin{array}{c}\text { Leaf area } \\
\left(\mathrm{m}^{2}\right)\end{array}$ \\
\hline \hline Mv 241 & 745.00 & 272.32 & 221.80 & 68.20 & 6.13 & 0.3549 \\
\hline Mv 278 & 111.11 & 374.55 & 211.13 & 71.40 & 5.50 & 0.3384 \\
\hline Mv 298 & 1045.83 & 365.08 & 218.47 & 63.27 & 6.13 & 0.3685 \\
\hline Mv 352 & 953.33 & 320.03 & 219.90 & 76.00 & 5.42 & 0.3340 \\
\hline Maros & 960.00 & 284.15 & 243.42 & 80.60 & 6.07 & 0.3989 \\
\hline NK Thermo & 986.67 & 324.54 & 230.20 & 83.07 & 6.13 & 0.4065 \\
\hline Limasil & 1009.26 & 330.67 & 231.40 & 72.33 & 8.60 & 0.5488 \\
\hline MvNK 333 & 1150.00 & 292.64 & 203.67 & 72.87 & 5.60 & 0.3417 \\
\hline Mv Dunasil & 1210.90 & 363.05 & 218.80 & 67.43 & 7.17 & 0.4382 \\
\hline Bogát & 990.00 & 286.25 & 239.33 & 96.00 & 5.80 & 0.3756 \\
\hline Geyser & 828.33 & 227.68 & 238.03 & 87.95 & 6.97 & 0.4667 \\
\hline Mv 437 & 1097.04 & 308.49 & 249.07 & 86.47 & 6.27 & 0.4011 \\
\hline Kámasil & 1020.00 & 345.26 & 237.93 & 73.80 & 10.73 & 0.7474 \\
\hline Florencia & 970.00 & 293.30 & 237.53 & 93.47 & 5.67 & 0.4148 \\
\hline Maxima & 1200.00 & 319.64 & 240.87 & 109.00 & 5.80 & 0.4018 \\
\hline Mv 504 & 1218.52 & 372.58 & 252.64 & 90.24 & 11.73 & 0.8163 \\
\hline Coralba & 1320.00 & 378.15 & 238.87 & 94.27 & 6.07 & 0.4168 \\
\hline Mv Massil & 1547.50 & 442.03 & 247.98 & 93.82 & 9.18 & 0.6244 \\
\hline \hline GRAND MEAN & 1075.75 & 327.80 & 232.28 & 82.23 & 6.94 & 0.4553 \\
\hline CV & 18.42 & 17.54 & 4.26 & 6.96 & 5.77 & 10.61 \\
\hline LSD & 328.72 & 95.40 & 16.40 & 9.50 & 0.67 & 0.0802 \\
\hline p & $0.1 \%$ & $0.5 \%$ & $0.1 \%$ & $0.1 \%$ & $0.1 \%$ & $0.1 \%$ \\
\hline
\end{tabular}

431 DOI: 10.1556/Novenyterm.59.2010.Suppl.4 
Correlations between these traits were also studied. There were weak positive correlations between the leaf area and green mass per plant $(\mathrm{r}=0.2559, \mathrm{p}=10 \%)$, and between the leaf area and dry matter yield $(r=0.2800, p=5 \%)$. The green mass and dry matter yield were influenced not by plant height, but by maturity group. Correlations between the plant height and the leaf number and leaf area were positive and moderate $(\mathrm{r}=0.4215$ and 0.5374 , respectively, $\mathrm{p}=1 \%)$. Leaf area was influenced more by leaf width than by leaf length.

\section{Conclusions}

It was concluded that later maturing hybrids grew taller and had greater green mass per plant than hybrids with earlier maturity. In addition, their main ear was attached higher and they had more leaves above the ear. Leafy hybrids had considerably greater leaf number and leaf area above the ear than normal hybrids. The green mass and dry matter yield were influenced more by the maturity group than by the plant height.

\section{Acknowledgements}

This work was supported by the Hungarian-Chinese Cooperation Project OMFB00150/2009.

\section{References}

Andrews C. J. - Dwyer L. M. - Stewart D. W. - Dugas J. A. - Bonn P.: 2000. Distribution of carbohydrate during grainfill in leafy and normal maize hybrids. Can. Journal of Plant Science, 80: 1. 87-95.

Bal M. A. - Bal E. B. B.: 2009. Interrelationship between Nutrient and Microbial Constituents of Ensiled Whole-plant Maize as Affected by Morphological Parts. International Journal of Agriculture and Biology, 11: 5. 631-634.

Begna S. H. - Hamilton R. I. - Dwyer L. M. - Stewart D. W. - Cloutier D. - Assemat L. - Foroutan-pour K. - Smith D. L.: 2001. Morphology and yield response to weed pressure by corn hybrids differing in canopy architecture. European Journal of Agronomy, 14: 293-302.

Cox W. J. - Cherney D. J. R.: 2001. Influence of Brown Midrib, Leafy and Transgenic Hybrids on Corn Forage Production. Agronomy Journal, 93: 4. 790-796.

Dijak M. A. - Modarres M. - Hamilton R. I. - Dwyer L. M. - Stewart D. W. - Mather D.E. - Smith D. L.: 1999. Leafy reduced-stature maize hybrids for short-season environments. Crop Science, 39: 1100-1110.

Dwyer L. M. - Andrews C. J. - Stewart D. W. - Ma B. L. - Dugas J. A.: 1995. Carbohydrate levels in fieldgrown leafy and normal maize genotypes. Crop Science, 35: 1020-1027.

Hegyi Z. - Zsubori Z. - Rácz F. - Halmos G.: 2009. Comparative analysis of silage maize hybrids based on agronomic traits and chemical quality. Maydica, 54: 2-3. 133-137.

Modarres A. M. - Hamilton R. I. - Dwyer L. M. - Stewart D. W. - Dijak M.-Smith D. L.: 1997. Leafy reduced-stature maize for short-season environments: Yield and yield components of inbred lines. Euphytica, 97: 129-138.

Montgomery E. G.: 1906. What is an ear of corn? Popular Science Mon. 68: 55-62.

Pintér L. - Schmidt J. - Kelemen G. - Szabó J. - Henics Z.: 1988. Complex evaluation of different corn genotypes for CCM (corn-cob mix) use. Maydica, 33: 283-294.

Stewart D. W. - Dwyer L. M.: 1993. Mathematical characterisation of leaf shape and area of maize hybrids. Crop Science, 39: 422-427.

Subedi K. D. - Ma B. L.: 2005. Ear position, leaf area, and contribution of individual leaves to grain yield in conventional and leafy maize hybrids. Crop Science, 45: 2246-2257.

Tóthné Zsubori Zs. - Pók I. - Hegyi Zs.: 2009. Az évjárat és a genotípus hatása különböző típusú silókukorica hibridek morfológiai és agronómiai tulajdonságaira. Növénytermelés, 58: 4. 69-80. 


\title{
LOW ADAPTIVE CAPACITY OF SUNFLOWER FOR NECTAR SECRETION UNDER THE CHANGING CLIMATE IN EASTERN CROATIA
}

\author{
Zlatko PUŠKADIJA ${ }^{1}-$ Siniša OZIMEC ${ }^{1}-$ Tihomir FLORIJANČIĆ ${ }^{1}-$ \\ Andelko OPAČAK ${ }^{1}$ - Anto MIJIĆ ${ }^{2}$ \\ ${ }^{1}$ Department of Hunting, Fishery and Beekeeping, Faculty of Agriculture, University of J.J. Strossmayer, Trg \\ Svetog Trojstva 3, HR-31000 Osijek, Croatia, e-mail: pzlatko@pfos.hr \\ ${ }^{2}$ Agricultural Institute, Južno predgrađe 17, HR-31000 Osijek, Croatia
}

\begin{abstract}
Whereas the sunflower is an allogamic plant, its succesful pollination largely depends on the presence of insects, especially honey bee, Apis mellifera carnica. The failure in nectar secretion was observed in recent years, which affected colonies of honey bees, and fertilization of sunflower. In our study, we set up a hypothesis that changes of weather conditions causing failure in nectar secretion during the sunflower's blooming. An experiment was carried out in July 2009, at test field located southeast in the area of city of Osijek. Six hybrids of sunflower were grown in the block system, while the control group of blooming sunflower's heads were covered by nets in order to prevent pollination by insect. Honey bees were transported in Langstroth-Rooth beehives to the site, and placed on three digital scales. A digital wireless weather station was installed at test field. The experiment showed that most favouring weather conditions for nectar secretion in sunflower are: daytime air temperatures of $22-26{ }^{\circ} \mathrm{C}$, absence of rainfalls during the day, relative humidity of $65-75 \%$, and winds from north and east directions. Weight drop of $8 \mathrm{~kg}$ was registered in beehives during the sunflower's blooming. In the same period, lowest daily temperature was $26{ }^{\circ} \mathrm{C}$, and highest $37{ }^{\circ} \mathrm{C}$, the rain in quantity of $22,6 \mathrm{~mm}$ was recorded during eight days (of total 15 days of blooming), and air humidity was $57-82 \%$. It can be concluded that sunflower has low adaptive capacity in relation to climate parameters under the pronounced climate change. Specifically, increased temperature, more frequent rainfalls and wind from south direction negatively affected nectar secretion, and caused losses in honey yield.
\end{abstract}

Keywords: honey bee, pollination, sunflower, climate change, nectar secretion

\section{Introduction}

Sunflower is a plant characterized by entomophylic pollination and it largely depends on number of pollinators present during the phenological phase of blooming as well as on their ability to perform fertilization (Puškadija at al., 2007; 2009). The honey bee is the most numerous and efficient pollinator of sunflower in our region (Miklič, 1996; Hunyadi and Lesznyak, 2006) which collects nectar and pollen from tubular disk flowers. In recent years it was observed that nectaries of sunflower failed in nectar secretion, so the beekeepers are unable to harvest sunflower's honey, despite the usual effective pollination activity of the honey bee. The hypothesis in our experiment was that changed climate conditions under the pronounced climate change (DHMZ, 2009), negatively affected nectar secretion in sunflower.

\section{Materials and methods}

An experiment was carried out in July 2009, at test field located southeast from the city of Osijek (Osijek-Baranja County, eastern Croatia), near the abandoned building of Faculty of Agriculture. Soil type is eutric cambisol with good nutrients supply. Maize was grown on this field a year before. Main cultivation in autumn comprised fertilization with $250 \mathrm{~kg} / \mathrm{ha}$ NPK 7:20:30, and $100 \mathrm{~kg} / \mathrm{ha}$ urea $(46 \% \mathrm{~N})$, and ploughing.

433 DOI: 10.1556/Novenyterm.59.2010.Suppl.4 
Fertilization before sowing was with $150 \mathrm{~kg} / \mathrm{ha}$ NPK15:15:15. Protection against weeds was done by Dual (metaloklor) + Sencor (flurokloridon) and against diseases by Konker (vinklozolin + karbendazin). Date of sowing was 26 April, with final plant density of 55,000 plants/ha. Trial material consisted of six sunflower hybrids (H1-H6), which are the most common in Croatia. Length of trial field was $300 \mathrm{~m}$, and each hybrid was sown in eight rows ( $0,7 \mathrm{~m}$ between rows, and $0,25 \mathrm{~m}$ inside the row). Three days before the start of the sunflower's blooming, the honey bees in the Langstroth-Rooth (LR) beehives were transported on the site, and placed on three digital scales. Weights of the beehives were measured in order to determine uptake of nectar. Strength of transported honey bee colonies was adequate to strength of those prepared for crop plants pollination (McGregor, 1976). Three colonies per hectare were placed at the start of the trial field in order to achieve an equal exposition of sunflower hybrids to honey bees. Monitoring of weather conditions in the field and collection of data for the climate interpretation was done by installed automatic wireless NEXUS weather station. The following climate parameters were measured: air temperature, relative air humidity and rainfall quantity.

\section{Results and discussion}

Many authors researched and proved impact of the climate conditions on nectar secretion in sunflower. Results reported by Miklič (1996) showed that moderate temperature of $20-28{ }^{\circ} \mathrm{C}$ and middle relative air humidity of $40-50 \%$ are optimum values for the activity of honey bees, and for blooming and pollination in sunflower. Škorić (1992) pointed out that dry weather causes desiccation of generative organs and failure in fertilization, while the rainy weather during the phenological phase of blooming disables movements of insects, including honey bee, so the pollination and fertilization failed. Results of our previous research (Puškadija, 2005) are in accordance with aforementioned results. Namely, the best fertilization and highest activity of honey bees occurs at air temperature of $20-25{ }^{\circ} \mathrm{C}$, relative air humidity of $65-75 \%$, in the absence of rainfall and during the daytime. The results obtained in our experiment were compared with data for meteorological station in Osijek, which are available on the web page of the State Meteorological and Hydrological Service (DHMZ).

Air temperature in the field was measured during the whole period of sunflower blooming. According to Figure 1 , minimum daily temperature was $10^{\circ} \mathrm{C}$, and the maximum reached $42{ }^{\circ} \mathrm{C}$. Number of hot days $\left(\mathrm{t}_{\max } \geq 30^{\circ} \mathrm{C}\right)$ at test field was 12 , with 1 day warmer than $40^{\circ} \mathrm{C}$. At meteorological station in Osijek, 11 hot days were recorded in July 2009, while the 30-year average (1961-1990) is 8 hot days. Hence, in our climate monitoring, we measured four hot days more than an average for July, and all of them fall in the period of sunflower blooming. Number of warm days $\left(\mathrm{t}_{\max } \geq 25^{\circ} \mathrm{C}\right)$ in July 2009 was 24, and all 15 days of sunflower blooming belong to this class. 


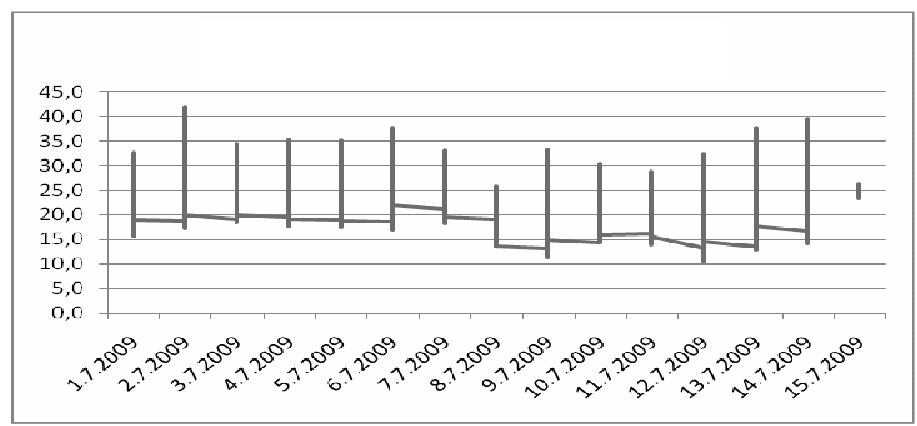

Figure 1. Daily minumum and maximum air temperature $\left({ }^{\circ} \mathrm{C}\right)$ during the sunflower's blooming (July 1-15, 2009)

Rainfalls negatively affects on fertilization of sunflower, mainly because they disabling flying and pollination activity of honey bees. In the period of sunflower blooming, number of eight rainy days was recorded, and in all of these, rain occured during the daytime. Total quantity of $22,4 \mathrm{~mm}$ of rainfalls was recorded. Although it is evidently droughtest part of the year, with only $61.4 \mathrm{~mm}$ of rainfalls in Osijek in July 2009, number of rainy days was 10 , of which eight occured during the sunflower blooming. According to official meteorological data, total quantity of rainfalls in 2009 in Osijek was $699 \mathrm{~mm}$, which is $84 \%$ of the 30-year average (DHMZ,2009).

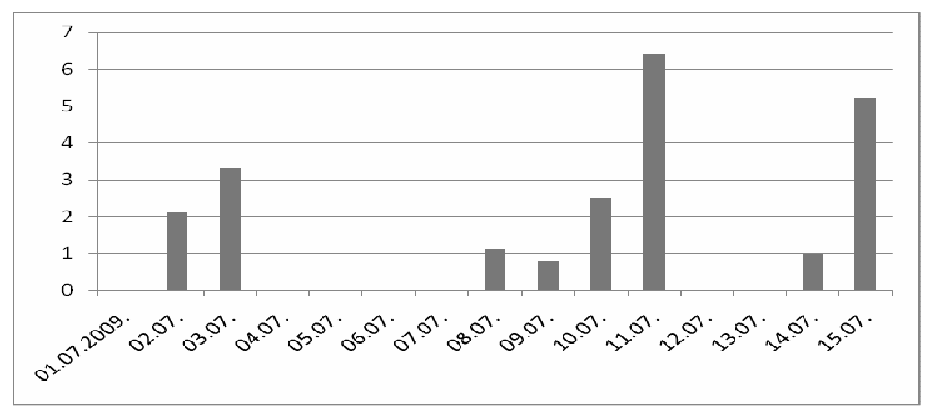

Figure 2. Daily rainfall quantity $(\mathrm{mm})$ during the sunflower's blooming (July 1-15, 2009)

The recorded values of the relative air humidity in the field ranged from minimum $29 \%$ to maximum of $94 \%$. Those values are favourable for the blooming and fertilization of sunflower, and are related to frequent and abundant rainfalls.

Weight of the beehives during the experiment do not show any increase, that means no uptake of nectar. Data from digital scale set up under the beehives indicated constant decreasing tendency, reaching weight drop of $8 \mathrm{~kg}$ on the end of experiment (Figure 3) 


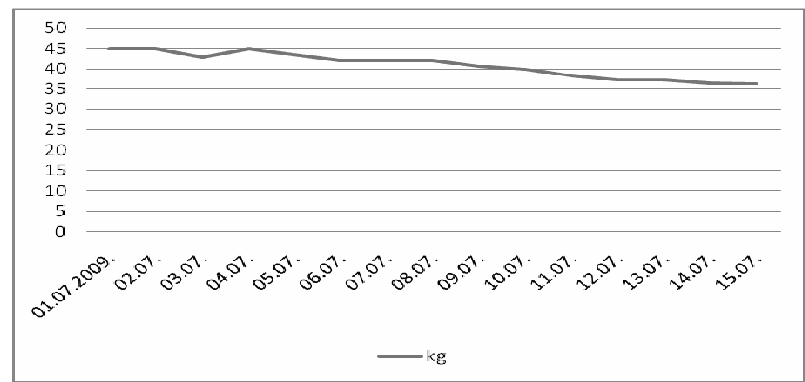

Figure 3. Weight of beehives during the experiment

\section{Conclusions}

As an impact of global climate change, significant changes in climate conditions already happened. Comparison of meteorological data obtained during the measurements in the field with 30-year average values for the meteorological station in Osijek showed large deviation for air temperature and rainfall quantity. Sunflower responds to such climate conditions by low adaptive capacity in relation to monitored climate parameters. The consequence is failure in nectar secretion in sunflower and losses in honey production, which makes the economic problem to the beekeepers.

\section{Acknowledgements}

We would like to express our gratitude to Croatian Beekeepers Association and Beekeepers Association of the Osijek-Baranja County for the support in the project realization, and to Agricultural Institute in Osijek for the expert, scientific and technical support.

\section{References}

Hunyadi Borbély E. - Lesznyák M.: 2006. Investigating yield and phenological stages of sunflower varietes in agro-ecological environment - Cereal Research Communications, 34(1): 417-421.

McGregor S.E.: 1976. USDA Agriculture Handbook No. 496: Insect Pollination of Cultivated Crop Plants. 19-32.

Miklič V.: 1996. Utjecaj različitih genotipova i pojdinih klimatskih činilaca na posjetu pčela i drugih polinatora i oplodnju suncokreta. Magistar thesis. Poljoprivredni fakultet Novi Sad, Serbia.

Puškadija Z.: 2005. Oprašivanje medonosnom pčelom (Apis mellifera carnica L.) različitih genotipova hibrida suncokreta (Helianthus annuus L.). Doctoral Thesis, Faculty of Agriculture, Osijek.

Puškadija Z. - Štefanić E. - Mijić A. - Zdunić Z. - Parađiković N. - Florijančić T. - Opačak A.: 2007. Influence of weather conditions on honey bee visits (Apis mellifera carnica) during sunflower (Helianthus annuus L.) blooming period. Agriculture 13(1): 230-233.

Puškadija Z. - Mijić A. - Florijančić T. - Ozimec S. - Opačak A.: 2009. Influence of biotic and abiotic environmental conditions on sunflower (Hellianthus annuus L.) grain yield. Cereal Research Communications, 37. 105-108.

Škorić D.: 1992. Achievements and future directions of sunflower breeding. Field Crops Research, 30: 231270.

www.DHMZ.hr (on line 11.12.2009). 


\title{
MEASURING THE HETEROGENEITY OF YIELD AND SPAD VALUES OF MAIZE (ZEA MAYS L.) BASED ON PLANT HEIGHT MAP
}

\author{
Attila DOBOS ${ }^{1}$ - Tamás Péter NAGY ${ }^{2}$ - Krisztina MOLNÁR ${ }^{l}$ - Róbert VÍG ${ }^{l}$ \\ ${ }^{1}$ Institute for Land Utilisation, Technology and Regional Development, Center of Agricultural Sciences and \\ Engineering, University of Debrecen, 138 Böszörményi str., Debrecen 4032, Hungary, e-mail: \\ dobosa@agr.unideb.hu \\ ${ }^{2}$ Department of Agricultural Chemistry and Soil Sciences, Center of Agricultural Sciences and Engineering, \\ University of Debrecen
}

Abstract: In Hungary, the income production ability of animal breeding and crop production declined due to the changes in the economic environment, but seed-production may be a perspective for growers henceforward.

In maize sowing seed production, we have to try for develop homogeneous plant populations, because in heterogeneous populations we have to divide tassel-removal into sections, weakly developed population spots react to chemical weed control with yield-depression and harvest-deficit grows.

The aim of our analyses was to determine an examination method for measuring the heterogeneity of the plant populations. The basis of this method is a map representing the height changes of the plant population. We determine the district population spot with different heights and designate sampling points in GIS. We take samples from the yield and measure SPAD values of leaves on each sampling point. Using the suitable statistical method, we determine the differences in SPAD values and yield of plant population parts with different vitality.

Keywords: maize, heterogeneity, SPAD-value, plant height map

\section{Introduction}

We have to prove sustainable development principles in nutrient management, namely we have to harmonize the productional and environmental demands, and apply the principles of environment friendly nutrient supply conforming to site conditions (Láng and Csete, 1992), which often requires precision solutions.

Precision agriculture can be efficiently utilized in case if heterogeneity of yield is significant and factors responsible for heterogeneity are well measurable (Plant, 2001). Thy analyses of soil, plant population (Kravchenko et al., 1999) and yield (Wild és Auernhammer, 1999; Mangalhães and Cerri, 2007) heterogeneity have largely contributed to the investigation of variability, and the exploration and understanding of the causes of variability. Analyses of soil conditions and crop yield estimation, together with the revelation of the connections between them become economically determinative through precision agriculture (Plant, 2001).

The chlorophyll content of leaves is a good indicator of plant health (Gitelson and Merzlyak, 1997), which can be well mapped with SPAD measurement, because chlorophyll content has a close relationship with SPAD-values (Ommen et al., 1999). Analyses of spatial heterogeneity can be carried out by means of remote sensing (Osborne et al., 1999) and also by means of the description of plant population characteristics on sampling points (Kravchenko et al., 1999). 


\section{Materials and methods}

We analyzed the heterogeneity of the seed-maize population in 2007 on meadow chernozem soil, on an inbred maize mother line in no-father sowings, on a 10,4 ha, base fertilized (160 kg ha $\left.{ }^{-1} \mathrm{~N}, 80 \mathrm{~kg} \mathrm{ha}^{-1} \mathrm{P}_{2} \mathrm{O}_{5}, 70 \mathrm{~kg} \mathrm{ha}^{-1} \mathrm{~K}_{2} \mathrm{O}\right)$ sample area.

We randomly measured the height of 100 plants in the population and marked 8 height category based on survey results: $20-40 \mathrm{~cm}, 40-50 \mathrm{~cm}, 50-60 \mathrm{~cm}, 60-70 \mathrm{~cm}, 70-80 \mathrm{~cm}$, $80-90 \mathrm{~cm}, 90-100 \mathrm{~cm}, 100-110 \mathrm{~cm}$. Measuring the height of the plant population with yardstick we determined which height-category the plant population belongs to at the measurement point and we recorded the co-ordinates of the survey site by applying Trimble GPS Pathfinder ProXH and Arc Pad 7.0 software. We measured plant height after tasseling to the intersection of the 2 remained upper leaves on 12633 survey points between 16.07.2007 and 20.07.2007. The average area of survey points was $8,2 \mathrm{~m}^{2}$.

Spatial impoundment of population spots with different height and designation of sampling points took place within an ArcGis 9.1 software environment. Because of their low regional extension we merged $20-40 \mathrm{~cm}$ and $40-50 \mathrm{~cm}$ height population spots, thus we designated 4-8 sample points per plant height-category (together 38) (Figure 1).

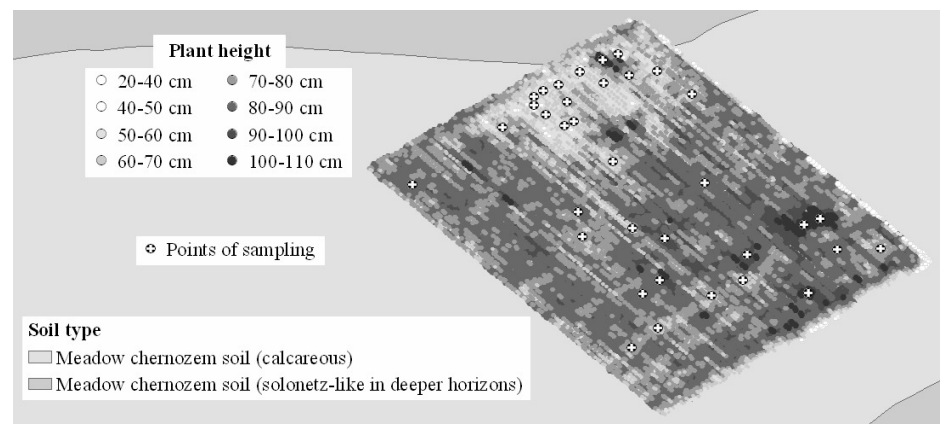

Figure 1. Regional variability of population parts with different height

SPAD-value was measured with Minolta SPAD-502 on 10 plants per sampling point, on the most developed leaf and in 10 points per leaf on 27.07.2007 (after tasseling). We carried out SPAD-measurement proportionally distributed along the leaf-blade, on 5-5 points of the right and left side. We took yield samples from 10 plants per sampling point on 29.08.2007 and 30.08.2007.

Evaluation was carried out by means of the SPSS for Windows 14.0 statistical software package. We used one-factor variance analyses (ANOVA) for the estimation differences of population parts with distinct height, and Duncan's test for simultaneous comparison of mean values of SPAD-values, grain number per stock and yield expressed in gram.

\section{Results and discussion}

On the examined area the most frequent population spots were $70-80(28,6 \%-2,97$ ha) and $80-90$ centimeter high $(37,9 \%-3,94$ ha); while the least frequent ones were the 
population spots under $50 \mathrm{~cm}(1,1 \%$ - 0,11 ha) and over $100 \mathrm{~cm}(1,1 \%-0,12 \mathrm{ha}) .46,7$ percent $(4,85 \mathrm{ha})$ of the plant population is lower than $80 \mathrm{~cm}, 53,3$ percent $(5,55 \mathrm{ha})$ is higher (Table 1).

Table 1. Spatial distribution of population parts with different height

\begin{tabular}{|l|l|l|l|l|l|l|l|}
\hline Plant height (cm) & $<50$ & $50-60$ & $60-70$ & $70-80$ & $80-90$ & $90-100$ & $100-110$ \\
\hline Area (ha) & 0,11 & 0,35 & 1,42 & 2,97 & 3,94 & 1,49 & 0,12 \\
\hline Spatial distribution (\%) & 1,1 & 3,4 & 13,6 & 28,6 & 37,9 & 14,3 & 1,1 \\
\hline
\end{tabular}

Average SPAD-value (27,1-47,7), grain number per plant ( 1 no. stem ${ }^{-1}-286$ no. stem $\left.{ }^{-1}\right)$ and yield $\left(0,2 \mathrm{~g} \mathrm{stem}^{-1}-79,4 \mathrm{~g} \mathrm{stem}^{-1}\right)$ of plant populations with different height represented an increasing tendency in parallel with the increase of plant height. We recorded the smallest averages in population spots with less than $50 \mathrm{~cm}$ of height, and the highest values in the $100-110 \mathrm{~cm}$ height group.

We verified with Duncan's test that SPAD-value and yield of distinct height plant parts differ at a statistically verifiable degree. Grain number per plant (no. stem $\left.{ }^{-1}\right)$ and yield ( $\mathrm{g}$ $\mathrm{stem}^{-1}$ ) in population parts under $60 \mathrm{~cm}$ were significantly lower, but in the height group over 100-110 cm they were significantly higher, than in the rest of the population.

There were no statistic differences between $40-50$ and $50-60 \mathrm{~cm}$ and $80-90 \mathrm{~cm}$ high population parts. Grain number and yield in $70-80 \mathrm{~cm}$ high population spots were significantly higher, than the values measured in the $60-70 \mathrm{~cm}$ population parts, and significantly lower, than in the case of the $80-100 \mathrm{~cm}$ height population parts.

Apart from two exceptions, there were statistic differences in SPAD-values among the examined plant heights. The 50-60 and $60-70 \mathrm{~cm}$ height categories and the $80-90$ and $90-100 \mathrm{~cm}$ height categories were significantly equal according to the results of SPADmeasurement (Table 2).

Table 2. Differences of yield and SPAD-values of population parts with different height

\begin{tabular}{|c|c|c|c|c|c|c|}
\hline Plant height & \multicolumn{2}{|c|}{$\begin{array}{c}\text { Grain number }(\text { no. } \\
\text { stem }\end{array}$} & \multicolumn{2}{c|}{ Yield $\left(\mathrm{g} \mathrm{stem}^{-1}\right)$} & \multicolumn{2}{c|}{ SPAD-values } \\
\hline \hline$<50 \mathrm{~cm}$ & 1 & $\mathrm{E}$ & 0,2 & $\mathrm{E}$ & 27,1 & $\mathrm{E}$ \\
\hline $50-60 \mathrm{~cm}$ & 5 & $\mathrm{E}$ & 1,4 & $\mathrm{E}$ & 34,5 & $\mathrm{D}$ \\
\hline $60-70 \mathrm{~cm}$ & 67 & $\mathrm{D}$ & 15,3 & $\mathrm{D}$ & 36,1 & $\mathrm{D}$ \\
\hline $70-80 \mathrm{~cm}$ & 111 & $\mathrm{C}$ & 31,1 & $\mathrm{C}$ & 39,2 & $\mathrm{C}$ \\
\hline $80-90 \mathrm{~cm}$ & 213 & $\mathrm{~B}$ & 56,8 & $\mathrm{~B}$ & 42,1 & $\mathrm{~B}$ \\
\hline $90-100 \mathrm{~cm}$ & 217 & $\mathrm{~B}$ & 53,8 & $\mathrm{~B}$ & 43,0 & $\mathrm{~B}$ \\
\hline $100-110 \mathrm{~cm}$ & 286 & $\mathrm{~A}$ & 79,4 & $\mathrm{~A}$ & 47,7 & $\mathrm{~A}$ \\
\hline F-value & \multicolumn{7}{|l|}{128,91 *** } & $143,96 * * *$ & $127,13 * * *$ \\
\hline$* * \mathrm{p}<0,001$
\end{tabular}

Average SPAD-value of the examined area was 40,2, from which the values measured in 70-80 $\mathrm{cm}$ height plant parts (-1 SPAD-value) differed at the smallest degree. We observed the highest differences in population spots under $50 \mathrm{~cm}(-13,1$ SPAD-value) and 100-110 cm (+7,5 SPAD-value) of height. 46,7 percent of the sampling area was characterized with SPAD-values between 27,1 and 39,2, the other 53,3 percent were between 42,1 and 47,7 . 
Extreme values of grain number per plant and yield also occurred in population parts under $50 \mathrm{~cm}$ and $100-110 \mathrm{~cm}$ of height. Average grain number of the sampling area was 156 no. stem $^{-1}$, average yield was $41,2 \mathrm{~g} \mathrm{stem}^{-1}$. Average deviation of the examined area was -155 no. stem $^{-1}$ and $-41,0 \mathrm{~g} \mathrm{stem}^{-1}$ in the case of plants with a height less than $50 \mathrm{~cm}$ height was, and in the case of $100-110 \mathrm{~cm}$ height population spots it was +130 no.stem $^{-1}$ and $+38,2 \mathrm{~g} \mathrm{stem}^{-1}$.

\section{Conclusions}

Heterogeneity in seed-maize population significantly corrupts efficiency of production. Underdeveloped plants react more sensitively to herbicides and stress-factors, which causes yield depression. Mechanical tasseling in heterogeneous populations becomes impossible, manual tassel-removal requires division, harvest deficit increases, which results in further expenditure increase.

SPAD-measurement and yield-sampling based on the plant height map makes evaluation of the heterogeneity of inbred maize lines possible. After the chemical analysis of soil and leaf samples taken from population spots with different height, SPAD-value and yield pedological factors eliciting heterogeneity are determinable and sensibility of maize lines to stress factors is analyzable.

\section{References}

Czinege E. - Pásztor L. - Szabó J. Scathó P. - Árendás T.: 2000. Térinformatikai alapokra épülő mütrágyázási szaktanácsadás. Agrokémia és Talajtan. 49: 1-2. 55-63.

Gitelson, A.A. - Merzlyak, M.N.: 1997. Remote estimation of chlorophyll content in higher plant leaves. International Journal of Remote Sensing. 18: 12. 2691-2697.

Kravchenko, A.N. - Boast, C.W. - Bullock, D.G.: 1999. Multifractal Analysis of Soil Spatial Variability. Agronomy Journal. 91: 6. 1033-1041.

Láng I. - Csete L.: 1992. Az alkalmazkodó mezőgazdaság. Agricola Kiadói és Kereskedelmi Kft., Budapest.

Magalhães, P.S.G. - Cerri, D.G.P.: 2007. Yield Monitoring of Sugar Cane. Biosystems Engineering. 96: 1. 16.

Ommen, O.E. - Donnelly, A. - Vanhoutvin, S. - van Oijen, M. - Manderscheid, R.: 1999. Chlorophyll content of spring wheat flag leaves grown under elevated $\mathrm{CO} 2$ concentrations and other environmental stresses within the 'ESPACE-wheat' project. European Journal of Agronomy. 10: 3-4. 197-203.

Osborne, S.L. - Schepers, J.S. - Francis, D.D. - Schlemmer, M.R.: 2002. Detection of Phosphorus and Nitrogen Deficiencies in Corn Using Spectral Radiance Measurements. Agronomy Journal. 94: 6. 12151221.

Pecze Zs. - Neményi M. - Debreczeni Béláné - Csathó P. - Árendás T.: 2001. Helyspecifikus tápanyagvisszapótlás kukoricanövénynél. Növénytermelés. 50: 2-3. 269-284.

Plant, R.E.: 2001. Site-specific management: the application of information technology to crop production. Computers and Electronics in Agriculture. 30: 1-3. 9-29.

Wild, K. - Auernhammer. H.: 1999. A weighing system for local yield monitoring of forage crops in round balers. Computers and Electronics in Agriculture. 23: 2. 119-132. 


\title{
N UTILIZATION OF MAIZE IN LONG-TERM CEREAL CROP ROTATION EXPERIMENT
}

\author{
Zoltán TÓTH - Tamás KISMÁNYOKY
}

Department of Crop Production and Soil Science, Georgikon Faculty, University of Pannonia, 16 Deak Str., 8360 Keszthely, Hungary, tothz@georgikon.hu

\begin{abstract}
Aim of this study was analyzing productivity and nitrogen (N) use efficiency of maize for rotation (maize - winter wheat - winter barley: 2005-2007 period) in the mineral and organic fertilization experiment conducted in 1983 on Keszthely Eutric Cambisol. Mineral $\mathrm{N}$ rates $\left(\mathrm{kg} \mathrm{N} \mathrm{ha}^{-1}\right)$ 0, 70, 140, 210 and 280, for $\mathrm{N}_{0}$, $\mathrm{N}_{1}, \mathrm{~N}_{2}, \mathrm{~N}_{3}$ and $\mathrm{N}_{4}$, respectively (100 kg ha ${ }^{-1}$ of $\mathrm{P}_{2} \mathrm{O}_{5}$ and $\mathrm{K}_{2} \mathrm{O}$ for N0-N4 treatments). Organic fertilizations were as follows: $a)=$ mineral fertilizers only $(\mathrm{MF}), b)=\mathrm{a}+$ farmyard manure $(\mathrm{FYM})$ application $\left(35 \mathrm{tha}^{-1}\right.$ in every third years before maize; $c$ ) b + stalk (St) incorporation (completed with $10 \mathrm{~kg}$ mineral $\mathrm{N}$ for each $\mathrm{t}$ stalk $\mathrm{ha}^{-1}$ ) after barley harvest + green manure (GM) (Raphanus sativus var. Oleiformis) as a 2 nd crop sowing on barley stubble. Mean grain yields $\left(\mathrm{t} \mathrm{ha}^{-1}\right)$ were $6.46,7.46$ and 7.35, and $\mathrm{N}$ uptake (grain + stalk: $\mathrm{kg} \mathrm{ha}^{-}$ $\left.{ }^{1}\right) 101.4,146.8$ and 148.8 , for treatments $a, b$ and $c$, respectively. At the same time, N-balance $\left(\mathrm{kg} \mathrm{ha}^{-1}\right)$ were $+38.6,-6.80$, and -8.80 , respectively. Maize yielded $5.30 \mathrm{t}$ of grain $\mathrm{ha}^{-1}$ on the $\mathrm{N}_{0}$ treatment and by increasing $\mathrm{N}$ yield was increased for $49 \%\left(\mathrm{~N}_{2}=7.92 \mathrm{tha}^{-1}\right)$ and $52 \%\left(\mathrm{~N}_{4}=8.08 \mathrm{t} \mathrm{ha}^{-1}\right)$, respectively.
\end{abstract}

Keywords: mineral and organic fertilization, maize yield, crop residues, nutrient balance, $\mathrm{N}$ utilization

\section{Introduction}

Plant nutrition especially nitrogen application is a basic factor of agronomy influencing either crop quantity or quality (Szentpétery et al., 2005; Berzsenyi and Lap, 2005; Tanács et al., 2005). Maize is a nitrogen demanding crop, but the economically maximal yields need different doses depending on the soil type and particular site (Nagy, 2006) Since nitrogen storage capacity of the soil is limited $\mathrm{N}$ fertilizers should be applied precisely. From the several forms of nitrogen in the soil nitrate and ammonium ions are the uptakeable ones by the roots. $\mathrm{NO}_{3}{ }^{-} \mathrm{N}$ content of soil plays an important role as a mineral nutrient for the plants as well as for microorganisms connected this way to several important processes take place in the soil. On the other hand its surplus value through good solubility has an environmental hazard. Izsáki (2008) reported that the mineral $\mathrm{N}$ content of soil is more adequate for the description of the degree of $\mathrm{N}$ supply in soil and for the determination of the $\mathrm{N}$ fertiliser need of maize than humus content. Nitrogen is also an important nutrient of the weeds. Without efficient weed control nitrogen fertilization can increase weed infestation, consequently reduce nitrogen use as well as water use efficiency (Lehoczky et al., 2006, 2007, 2008, 2009).

\section{Materials and methods}

Mineral and organic nitrogen (N) fertilization experiment was started in 1983 on Keszthely Eutric Cambisol (Ramann-type brown forest soil) with neutral pH. Mineral N rates $\left(\mathrm{kg} \mathrm{N} \mathrm{ha}^{-1}\right) 0,70,140,210$ and 280 , for $\mathrm{N}_{0}, \mathrm{~N}_{1}, \mathrm{~N}_{2}, \mathrm{~N}_{3}$ and $\mathrm{N}_{4}$, respectively (100 $\mathrm{kg} \mathrm{ha}^{-1}$ of $\mathrm{P}_{2} \mathrm{O}_{5}$ and $\mathrm{K}_{2} \mathrm{O}$ for N0-N4 treatments). Organic fertilizations were as follows: $a)=$ mineral fertilizers only $(\mathrm{MF}), b)=\mathrm{a}+$ farmyard manure (FYM) application $(35 \mathrm{t}$ $\mathrm{ha}^{-1}$ in every third years before maize; $c$ ) b + stalk (St) incorporation (completed with 10 $\mathrm{kg}$ mineral $\mathrm{N}$ for each $\mathrm{t}$ stalk ha ${ }^{-1}$ ) after barley harvest + green manure (GM) (Raphanus sativus var. Oleiformis) as a 2 nd crop sowing on barley stubble. The bifactorial

441 DOI: 10.1556/Novenyterm.59.2010.Suppl.4 
experiment has a split plot design with three replications. Aim of this study was analyzing productivity and nitrogen $(\mathrm{N})$ use efficiency of maize for rotation maize winter wheat - winter barley (in 2005-2007 period)

The 100 year average annual precipitation in Keszthely was $683 \mathrm{~mm}$, but the distribution was often unequal. The long-term annual mean temperature was $10.8^{\circ} \mathrm{C}$.

The indices of $\mathrm{N}$ use efficiency were calculated as follows (Huggins and Pan 1993; Crosswell and Godwin 1984):

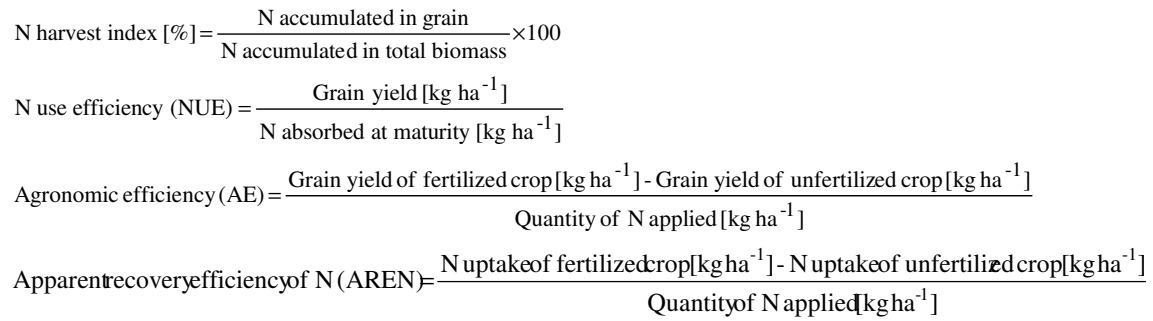

\section{Results and discussion}

The relationship between nitrogen fertilization and yield can be described by quadratic equation (Figure 1.).
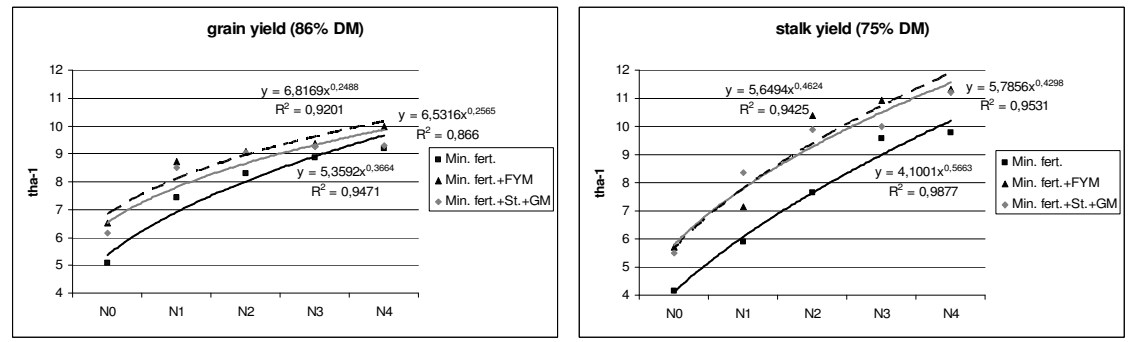

Figure 1. Grain and stalk yield of maize ( $8^{\text {th }}$ rotation)

Without organic manure in the sole mineral NPK fertilizer application (Min. fert.) variant the average yield level was significantly lower compared to the other variants (Min. fert.+FYM and the Min. fert.+St+GM). On the N0 plots the complementary organic manure application resulted in 1-1.5 $\mathrm{t} \mathrm{ha}^{-1}$ extra yield. Between the Min. fert.+FYM and the Min. fert.+St+GM variants no significant different was measured. The yield of the N0 plots was significantly lower than each of the fertilized ones. The yield increasing effect of the higher $\mathrm{N}$ rates was smaller and the differences between the variants of mineral and organic fertilizer application were also smaller at the high $\mathrm{N}$ rates.

In case of stalk yield the tendencies are similar, but the values were registered within a greater interval and the high $\mathrm{N}$ rates resulted in higher stalk yield increase than in case of grain. The extra yields resulted by the complementary organic fertilizer application are proportional to the additional nutrient content of the organic fertilizers. 
Table 1. shows some parameters and results related to the effect of $\mathrm{N}$ fertilization on the grain and straw yield (standardized absolute dry matter [DM]) as well as the $\mathrm{N}$ balance.

Table 1. Grain and stalk yield as well as $\mathrm{N}$ balance of maize production in the $8^{\text {th }}$ rotation cycle $(2005-2007)$

\begin{tabular}{|c|c|c|c|c|c|c|c|c|c|}
\hline \multicolumn{10}{|c|}{ Dry matter (DMY). N concentrations $(\% \mathrm{~N})$ and uptake by maize and $\mathrm{N}$ balance in maize } \\
\hline \multicolumn{2}{|c|}{ DMY t ha ${ }^{-1}$} & \multicolumn{2}{|c|}{$\mathrm{N} \%$} & \multicolumn{3}{|c|}{$\mathrm{N}$ uptake $\left(\mathrm{kg} \mathrm{ha}^{-1}\right)$} & \multirow{2}{*}{$\begin{array}{c}\mathrm{N}- \\
\text { balance }\end{array}$} & \multirow{2}{*}{\multicolumn{2}{|c|}{$\begin{array}{l}\text { Treatment } * \\
\left(\mathrm{~N} \mathrm{~kg} \mathrm{ha}^{-1}: \mathrm{N}_{2}=140, \mathrm{~N}_{4}=280\right)\end{array}$}} \\
\hline Grain & Straw & Grain & Stalk & Grain & Stalk & Total & & & \\
\hline 4.37 & 3.03 & 0.93 & 0.39 & 40.68 & 11.69 & 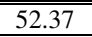 & -52.37 & $\overline{\mathrm{N}} \mathrm{N}_{0}$ & \multirow{3}{*}{$\begin{array}{l}\text { Mineral } \\
\text { Fertilization } \\
(\mathrm{MF})\end{array}$} \\
\hline 7.12 & 5.74 & 1.08 & 0.54 & 76.82 & 31.05 & 107.87 & +32.13 & $\mathrm{~N}_{2}$ & \\
\hline 7.88 & 7.380 & 1.14 & 0.73 & 89.83 & 54.02 & 143.85 & +136.15 & $\mathrm{~N}_{4}$ & \\
\hline 6.46 & 5.38 & 1.05 & 0.55 & 69.11 & 32.25 & 101.36 & 38.64 & \multicolumn{2}{|r|}{ Mean } \\
\hline 5.73 & 4.27 & 1.27 & 0.67 & 72.48 & 28.60 & 101.08 & -101.08 & $\mathrm{~N}_{0}$ & \multirow{3}{*}{$\mathrm{MF}+\mathrm{FYM}$} \\
\hline 8.34 & 6.66 & 1.27 & 0.75 & 105.92 & 49.95 & 155.87 & -15.87 & $\mathrm{~N}_{2}$ & \\
\hline 8.31 & 8.46 & 1.36 & 0.83 & 113.01 & 70.44 & 183.45 & +96.55 & $\mathrm{~N}_{4}$ & \\
\hline 7.46 & 6.46 & 1.30 & 0.75 & 97.14 & 49.66 & 146.80 & -6.800 & \multicolumn{2}{|r|}{ Mean } \\
\hline 5.71 & 4.28 & 1.27 & 0.57 & 72.28 & 24.26 & 96.54 & -96.54 & $\mathrm{~N}_{0}$ & \multirow{3}{*}{$\mathrm{MF}+\mathrm{FYM}+\mathrm{St}+\mathrm{GM}$} \\
\hline 8.29 & 6.98 & 1.29 & 0.74 & 106.60 & 51.30 & 157.90 & -17.90 & $\mathrm{~N}_{2}$ & \\
\hline 8.05 & 8.45 & 1.44 & 0.90 & 115.59 & 76.38 & 191.97 & +88.03 & $\mathrm{~N}_{4}$ & \\
\hline 7.35 & 6.57 & 1.33 & 0.74 & 98.16 & 50.65 & 148.80 & -8.80 & \multicolumn{2}{|r|}{ Mean } \\
\hline 1.01 & 1.04 & 0.19 & 0.24 & \multicolumn{6}{|c|}{ LSD5\% between combinations } \\
\hline & & \multicolumn{8}{|c|}{$\begin{array}{l}* \mathrm{FYM}=\text { application }\left(35 \mathrm{t} \mathrm{ha}^{-1}\right) \text { every third year); } \\
\mathrm{St}=\text { stalk incorporation }\left(\text { completed with } 10 \mathrm{~kg} \text { mineral } \mathrm{N} \text { for each t stalk ha- }{ }^{-1}\right) \\
\mathrm{GM}=\text { green manure application }(\text { Raphanus sativus var. Oleiformis }) \\
\mathrm{N} 2=140 \mathrm{~kg} \mathrm{~N} \mathrm{ha}^{-1}, \mathrm{~N} 4=280 \mathrm{~kg} \mathrm{~N} \mathrm{ha}^{-1}\left(\mathrm{~N} 0-\mathrm{N} 4=100 \mathrm{~kg} \mathrm{P}_{2} \mathrm{O}_{5} \mathrm{ha}^{-1}+100 \mathrm{~kg} \mathrm{~K}_{2} \mathrm{O} \mathrm{ha}^{-1}\right)\end{array}$} \\
\hline
\end{tabular}

The ratio between the grain and stalk yields was closely to 1/1 (in DM values) at the highest fertilizer rates, while at the lower rates the ratio of the grain yield was higher. The average $\mathrm{N}$ content of grain was $1.23 \%$, while in case of stalk it was $0.68 \%$. The specific $\mathrm{N}$ uptake of $1 \mathrm{t}$ grain and its side stalk yield varied between $11.99-23.85 \mathrm{~kg}$. These figures are in accordance with the results published by Kádár and Radics (2008), who measured these values between $14-21 \mathrm{~kg}$ depending on the fertilizer rates applied.

On the N0 (control) plots the soil released an amount of $52.37 \mathrm{~kg} \mathrm{ha}^{-1} \mathrm{~N}$. In case of complementary FYM ( $1^{\text {st }}$ year effect $)$ application the amount of $\mathrm{N}$ uptake was $101.08 \mathrm{~kg}$ $\mathrm{ha}^{-1}$ on the N0 plots and in case of $\mathrm{St}+\mathrm{GM}+\mathrm{N}$ application it was $96.54 \mathrm{~kg} \mathrm{ha}^{-1}$. The nutrient balance was positive in case of each N4 treatments, while it was negative on the N0 plots. N2 treatment resulted in positive balance only in Min. fert. variant, while on the Min. fert.+FYM and Min. fert.+St+GM the balances were slightly negative or at equilibrium.

The $\mathrm{N}$ use indices are shown in Table 2. Harvest index of $\mathrm{N}\left(\mathrm{HI}_{\mathrm{N} \%}\right)$ shows that the maize absorbed $60.21-77.68 \%$ of the $\mathrm{N}$ in the grain and produced $41.93-83.44 \mathrm{~kg}$ grain with the use of $1 \mathrm{~kg}$ of $\mathrm{N}$ (NUE) depending on the fertilizer treatments. The extra yield increasing effect of $1 \mathrm{~kg} \mathrm{~N}$ fertilizer above the yield of control plots (AE) was 8.36$19.64 \mathrm{~kg} \mathrm{ha}^{-1}$ and the utilization of $1 \mathrm{~kg} \mathrm{~N}$ fertilizer for the extra yield above the yield of the control plot was $0.29-0.44 \mathrm{~kg}(\mathrm{AREN})$. 
Table 2. N use indices of maize in the $8^{\text {th }}$ rotation cycle (2005-2007)

\begin{tabular}{|c|c|c|c|c|c|}
\hline \multicolumn{4}{|c|}{$\begin{array}{l}\text { Harvest index of } \mathrm{N}\left(\mathrm{HI}_{\mathrm{N}} \%\right), \mathrm{N} \text { utilization effects (NUE: grain yield per } \mathrm{kg} \\
\mathrm{N} \text { fertilizer) and extra yield above yield of control (AE), utilization of } 1 \mathrm{~kg} \\
\mathrm{~N} \text { fertilizer for extra yield above of the control (AREN) }\end{array}$} & \multicolumn{2}{|c|}{$\begin{array}{l}\text { Treatment } \\
\left(\mathrm{N} \mathrm{kg} \mathrm{ha}{ }^{-1}: \mathrm{N}_{2}=140, \mathrm{~N}_{4}=280\right)\end{array}$} \\
\hline Percent & $\mathrm{kg} \mathrm{ha}^{-1}$ & & & & \\
\hline $\mathrm{HI}_{\mathrm{N}} \%$ & NUE & $\mathrm{AE}$ & AREN & & \\
\hline 77.68 & 83.44 & - & - & $\mathrm{N}_{0}$ & \multirow{3}{*}{$\begin{array}{l}\text { Mineral } \\
\text { Fertilization } \\
\quad(\mathrm{MF})\end{array}$} \\
\hline 71.22 & 66.00 & 19.64 & 0.40 & $\mathrm{~N}_{2}$ & \\
\hline 62.45 & 54.78 & 12.54 & 0.33 & $\mathrm{~N}_{4}$ & \\
\hline 71.71 & 56.68 & - & - & $\mathrm{N}_{0}$ & \multirow{3}{*}{$\mathrm{MF}+\mathrm{FYM}$} \\
\hline 67.95 & 53.51 & 18.65 & 0.39 & $\mathrm{~N}_{2}$ & \\
\hline 61.60 & 45.30 & 9.21 & 0.29 & $\mathrm{~N}_{4}$ & \\
\hline 74.87 & 59.14 & - & - & $\mathrm{N}_{0}$ & \multirow{3}{*}{$\mathrm{MF}+\mathrm{FYM}+\mathrm{St}+\mathrm{GM}$} \\
\hline 67.51 & 52.50 & 18.43 & 0.44 & $\mathrm{~N}_{2}$ & \\
\hline 60.21 & 41.93 & 8.36 & 0.34 & $\mathrm{~N}_{4}$ & \\
\hline
\end{tabular}

\section{Conclusions}

The grain yield increasing effect of organic fertilizers was higher at the lower rates of mineral $\mathrm{N}$ treatments, while in case of stalk it was still high at the high rates of $\mathrm{N}$ too. With the rise of fertilizer rates the efficiency of $\mathrm{N}$ utilization decreased.

\section{Acknowledgements}

This research was supported by the Hungarian Scientific Research Found (OTKA K 60314) as well as the EEA and Norway Grants.

\section{References}

Berzsenyi Z. - Lap D.Q.: 2005. Responses of maize (Zea mays L.) hybrids to sowing date, N fertiliser and plant density in different years. Acta Agronomica Hungarica, 53: 119-131.

Crosswell E.T. - Godwin D.C.: 1984. The efficiency of N fertilizers applied to cereals. In: Tinker, P.B. (ed.), Advances in Plant nutrition. NewYork pp. 1-55.

Huggins D.R. - Pan W.L.: 1993. N efficiency component analysis. Crop Science, 85: 898-965.

Izsáki Z.: 2008. Hatások és kölcsönhatások vizsgálata NPK mütrágyázási tartamkísérletben kukorica (Zea mays L.) jelzőnövénnyel. Növénytermelés, 57: 3. 275-289.

Kádár I. - Radics L.: 2008. Mütrágyázás hatása a kukoricára karbonátos homoktalajon. Növénytermelé, 57: 3. 305-317.

Lehoczky É. - Németh T. - Reisinger P. - Radimszky L. - Kömíves T.: 2006. Effect of weediness on the water content of the soil: a field study. Communications in Soil Science and Plant Analysis, 37: 15-20. 2673-2678.

Lehoczky É. - Kismányoky A. - Németh T.: 2007. Effect of the soil tillage and N-fertilization on the weediness of maize. Cereal Research Communications, 35: 2. 722-725.

Lehoczky É. - Kismányoky A. - Nagy P. - Németh T.: 2008. Nutrient absorption of weeds in maize. Communications in Agricultural and Applied Biological Sciences, 73: 4. 951-957.

Lehoczky É. - Kismányoky A. - Sárkány E. Sz. - Pálmai O. - Németh T.: 2009. Effect of precipitation deficiency on the competition of maize and weeds. Cereal Research Communications, 37: 675-678.

Nagy J.: 2006. Maize production. Akadémiai Kiadó, Budapest.

Szentpétery Zs. - Jolánkai M. - Kleinheincs Cs. - Szöllősi G.: 2005. Effect of Nitrogen Top-Dressing on Winter Wheat. Cereal Research Communications, 33: 619-626.

Tanács L. - Matuz J. - Gerő L. - Petróczi - I. M.: 2005. Effect of NPK Fertilizers and Fungicides on the Quality of Bread Wheat in Different Years. Cereal Research Communications, 33: 627-634. 


\title{
NUTRITIONAL STATUS OF MAIZE (ZEA MAYS L.) IN EARLY DEVELOPMENT STAGE
}

\author{
Zoltán IZSÁKI
}

Institute of Agricultural Science, Faculty of Water and Environmental Management, Szent István University, P.O.Box 3, H-5541 Szarvas, Hungary, e-mal: izsaki.zoltan@vkk.szie.hu

\begin{abstract}
Long-term mineral fertilization field experiment was carried out with maize to elaborate nutrient supply limit values in early development stage. According to the experimental data, satisfactory nutrient supplies are indicated by the following diagnostic plant analysis values in maize leaves in 5-6 leaves stage: $\mathrm{N}$ 3.5-5.0 \%; P 0.30-0.45 \%; K 2.5-4.0\%; Ca 0.25-0.70 \%; Mg 0.15-0.40\%; Fe 130-250 mgkg ${ }^{-1}$ Mn 50-110 $\mathrm{mgkg}^{-1} ; \mathrm{Zn} 15-45 \mathrm{mgkg}^{-1} ; \mathrm{Cu}_{7-11} \mathrm{mgkg}^{-1}$; B 5-25 $\mathrm{mgkg}^{-1}$. The nutritional status of maize can indirectly be as indicator and partly measuring property of soil resilience.
\end{abstract}

Keywords: heavy metal, cadmium accumulation

\section{Introduction}

The concept of soil resilience is an important component of soil quality and a key element of sustainability. Factors that affect soil resilience are soil type, land use, vegetation, climate, agrotechnique and disturbance regime. The nutrient capacity of the soil and indirectly the nutritional status of a crop can be as indicators and partly measuring proporties of the soil resilience. Thus the plant analysis provides information not only for fertilizer recommendation systems but for the soil resilience mechanisms. Many papers (Chapman, 1967; Jones, 1967; Bergmann and Neubert, 1976; Kádár and Elek, 1980; Kádár, 1992; Plénet and Cruz, 1997; Csathó, 1998; Izsáki, 2008, 2009; Kovacevic, 2008) have reported nutrient concentration limit values in various plant organs at various stages of development for the estimation of maize nutrient status. For some nutrients, these published limit values show a high degree of agreement, whereas for others considerable deviations can be observed. An analysis of these research results demonstrates that great importance is still attached to background research linked with the application of plant analysis for diagnostic purposes, as this provides information on the changes in nutrient status, nutrient interactions, and nutritional disturbances that may be caused in maize by the field site, fertilization, and the nutrient supplies of the soil.

The aim of the article is to provide data for nutrient supply limit values of maize which will be useful in the interpretation of diagnostic plant analysis at the given location.

\section{Materials and methods}

Long-term mineral fertilization experiments were set up at the experimental station of the Crop Production Department, in Szarvas, in 1989. The soil of the experimental area had the following parameters: Chernozem meadow soil, calcareous in the deeper layers, 85-100 cm humus layer, $\mathrm{pH}_{(\mathrm{KCl})}$ 5.0-5.2, humus content 3.0-3.2\%, upper limit of plasticity according to Arany $\left(\mathrm{K}_{\mathrm{A}}\right) 50$, and clay content $32 \%$. During the investigated period, the soil contained the following nutrient supplies in the cultivated layer: ALsodium (Na) 60-80 $\mathrm{mgkg}^{-1}$, potassium chloride $(\mathrm{KCl})$-magnesium $(\mathrm{Mg}) 550-650 \mathrm{mg} \mathrm{kg}^{-}$ 
${ }^{1}$, ethylenediaminetetraacetit acid (EDTA)-manganese (Mn) 280-300 $\mathrm{mgkg}^{-1}$, EDTAcopper $(\mathrm{Cu})$ 5-7 $\mathrm{mgkg}^{-1}$, and EDTA-zinc (Zn) 2.0-3.5 $\mathrm{mgkg}^{-1}$.

Fertilization was carried out in all possible combinations of four levels each of $\mathrm{N}$, phosphorus (P), and potassium (K), giving a total of 64 treatments, set up in a split-split plot design with three replications, with $\mathrm{K}$ fertilization as the "A" factor, $\mathrm{P}$ fertilization as the "B" factor, and $\mathrm{N}$ fertilization as the "C" factor. The following fertilizer rates were applied: $\mathrm{N}: \mathrm{N}_{0}=0, \mathrm{~N}_{1}=80, \mathrm{~N}_{2}=160$ and $\mathrm{N}_{3}=240 \mathrm{~kg} \mathrm{~N}$ ha $^{-1}$ year $^{-1} ; \mathrm{P}$ (phosphorus pentoxide; $\mathrm{P}_{2} \mathrm{O}_{5}$ ): $\mathrm{P}_{0}=0, \mathrm{P}_{1}=100 \mathrm{~kg} \mathrm{ha}^{-1}$ year $^{-1}$, and $\mathrm{P}_{2}=500 \mathrm{kgha}^{-1}$ in 1989, 1993 and 2001, $\mathrm{P}_{3}=1000 \mathrm{kgha}^{-1}$ in 1989, 1993, and 2001; $\mathrm{K}$ (potassium oxide; $\left.\mathrm{K}_{2} \mathrm{O}\right): \mathrm{K}_{0}=0, \mathrm{~K}_{1}=300 \mathrm{kgha}^{-1}$ year $^{-1}$ between 1989 and $1992,100 \mathrm{~kg} \mathrm{ha}^{-1}$ year $^{-1}$ from $1993, \mathrm{~K}_{2}=600 \mathrm{kgha}^{-1}$ in 1989 and $2001,1000 \mathrm{kgha}^{-1}$ in 1993, and $\mathrm{K}_{3}=1200 \mathrm{kgha}^{-1}$ in 1989 and 2001 and $1500 \mathrm{kgha}^{-1}$ in 1993. The high rates of $\mathrm{P}$ and $\mathrm{K}$ replenishment fertilization were used to create clearly distinct supply levels in the soil to investigate plant responses to nutrient status. According to the applied $\mathrm{P}$ and $\mathrm{K}$ fertilizer treatments, the $\mathrm{P}$ and $\mathrm{K}$ statuses of the soil cultivated layer in 2007-2008 were as follows: AL$\mathrm{P}_{2} \mathrm{O}_{5}$ 120-275 $\mathrm{mgkg}^{-1}$ and $\mathrm{AL}-\mathrm{K}_{2} \mathrm{O} 210-410 \mathrm{mgkg}^{-1}$.

To determine the nutrient status of maize, the leaf was collected from 15 plants per plot in 5-6 leaves stage. The leaf samples were analysed in two experimental years (20072008 for the following nutrients: N, P, K, Ca, Mg, Fe, Mn, Zn, and $\mathrm{Cu}$.

\section{Results and discussion}

The correlation between the nutrient concentration in the maize leaf and the grain yield investigated in order to establish limit values for nutrient supply levels based on diagnostic plant analysis. The nutrient concentrations in the maize leaves were given in terms of dry matter, as was the maize grain yield. To set limit values, critical concentrations for maize nutrient status, the relative yield (\% of maximum yield) and the nutrient concentrations in the leaf were plotted on a graph, after which a boundary line was fit to the data. The limit values of nutrient concentrations required for a $95 \%$ of maximum grain yield were taken as a satisfactory supply level (Fig. 1). The results of experiment on $\mathrm{N}, \mathrm{P}$ and $\mathrm{K}$ fertilization are most reliable for the determination of limit values for $\mathrm{N}, \mathrm{P}$ and $\mathrm{K}$ supply levels, but they also provide information on the optimum levels of other nutrients required to obtain high yields. According to the experimental data, satisfactory nutrient supplies are indicated by the following diagnostic plant analysis values in maize leaves in 5-6 leaves stage: $\mathrm{N} 3.5-5.0 \%$; $\mathrm{P}$ 0.30-0.45 \%; K 2.5$4.0 \%$; Ca 0.25-0.70\%; Mg 0.15-0.40\%; Fe 130-250 $\mathrm{mgkg}^{-1}$; Mn 50-110 $\mathrm{mgkg}^{-1}$; Zn $15-45 \mathrm{mgkg}^{-1}$; Cu 7-11 $\mathrm{mgkg}^{-1}$; B 5-25 $\mathrm{mgkg}^{-1}$ (Table 1).

\section{Acknowledgements}

This research project was supported by the Hungarian Scientific Research Found (OTKA-T-034436, T-048816). 

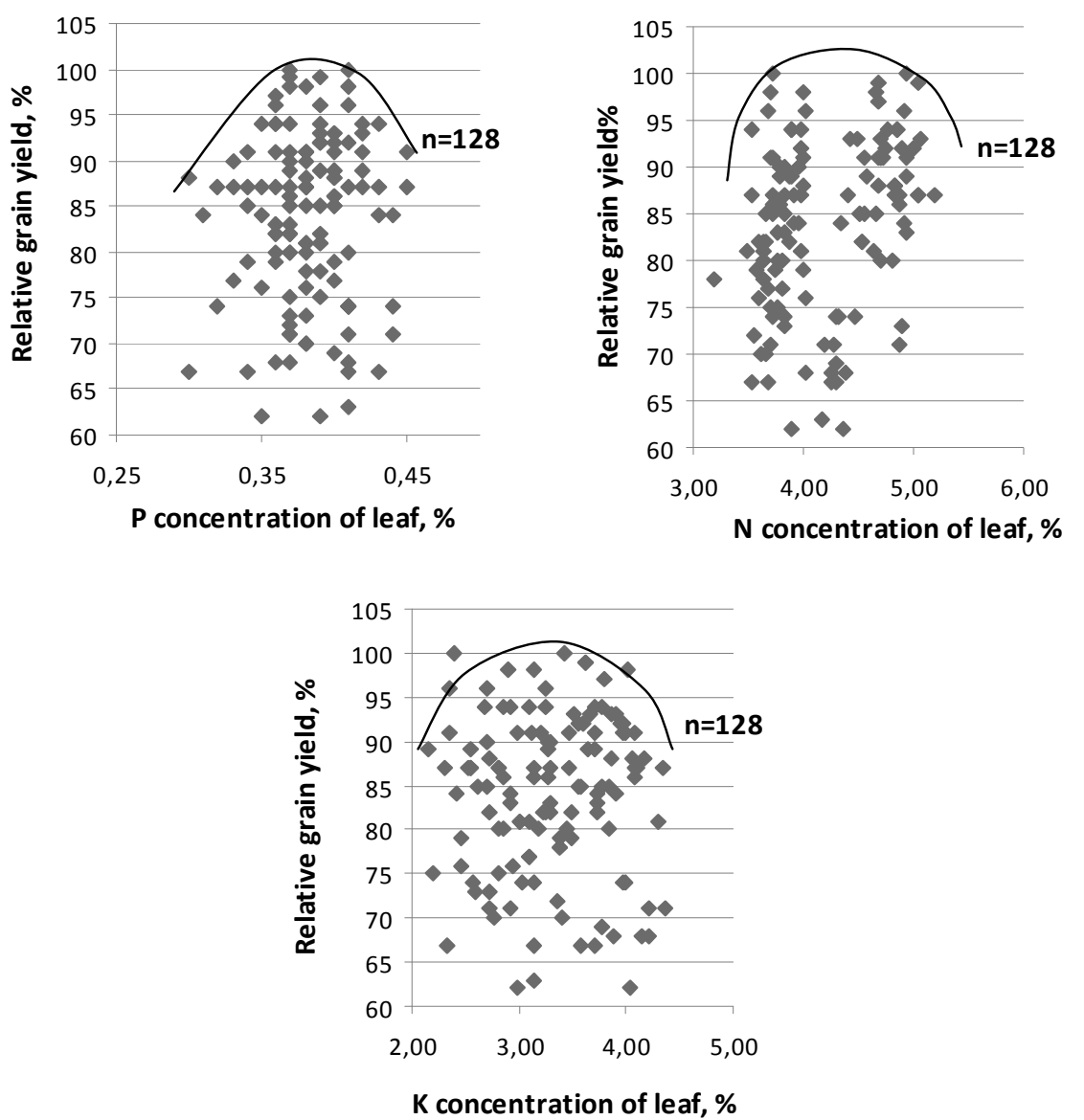

Figure. 1. Relationship between the N, P and K concentrations of the maize leaf and the grain yield in 5-6 leaves stage. (Szarvas, 2007-2008) 
Table 1. Limit values for nutrient supplies to maize based on nutrient content in the leaf at 5-6 leaves stage (Szarvas, 2007-2008)

\begin{tabular}{|c|c|c|c|c|}
\hline & \multirow{2}{*}{ Nutrient } & \multicolumn{3}{|c|}{ Nutrient supply level } \\
\hline & & Low & Satisfactory & High \\
\hline & & \multicolumn{3}{|c|}{ Nutrient concentration } \\
\hline $\mathrm{N}$ & $\%$ & $<3.5$ & $3.5-5.0$ & $5.0<$ \\
\hline $\mathrm{P}$ & $\%$ & $<0.30$ & $0.30-0.45$ & $0.45<$ \\
\hline & $\%$ & $<2.5$ & $2.5-4.0$ & $4.0<$ \\
\hline $\mathrm{Ca}$ & $\%$ & $<0.25$ & $0.25-0.70$ & $0.70<$ \\
\hline $\mathrm{Mg}$ & $\%$ & $<0.15$ & $0.15-0.40$ & $0.40<$ \\
\hline $\mathrm{Fe}$ & $\mathrm{mgkg}^{-1}$ & $<130$ & $130-250$ & $250<$ \\
\hline $\mathrm{Mn}$ & $\mathrm{mgkg}^{-1}$ & $<50$ & $50-110$ & $110<$ \\
\hline $\mathrm{Zn}$ & $\mathrm{mgkg}^{-1}$ & $<15$ & $15-45$ & $45<$ \\
\hline $\mathrm{Cu}$ & $\mathrm{mgkg}^{-1}$ & $<7$ & $7-11$ & $11<$ \\
\hline B & $\mathrm{mgkg}^{-1}$ & $<5$ & $5-25$ & $25<$ \\
\hline
\end{tabular}

\section{References}

Bergmann, W., - P. Neubert: 1976. Pflanzendiagnose und Pflanzenanalyse. Jena, Germany: VEB Gustav Fisher Verlag.

Chapman, H. D.: 1967. Plant analysis values suggestive of nutrient status of selected crops. In Soil testing and plant analysis, part II. Plant analysis, ed. R. C. Dinauer, 77-92. Madison, Wisc.: SSSA.

Csathó, P.: 1998. Correlations between two soil extractans and corn leaf potassium contents from Hungarian field trails. Commun. Soil Sci. Plant Anal. 29: 2149-2160.

Izsáki, Z.: 2008. Effect of soil P supply on P-Zn interactions in a maize (Zea mays L.) long-term field experiment. Cereal Research Communications, 36: 1-4.

Izsáki, Z.: 2009. Effect of N supply on nutritional status of maize. Communications in Soil Science and Plant Analysis, 40: 960-973.

Jones, J. B.: 1967. Integration of plant analysis for several agronomic crops. In Soil testing and plant analysis, part II: Plant analysis, ed. R. C. Dinauer, 49-58. Madison, Wisc.: SSSA.

Kádár, I.: 1992. Principles and methods in plant nutrition. Budapest, Hungary: Magyar Tudományos Akadémia Talajtani és Agrokémiai Kutató Intézete.

Kádár, I., -. É. Elek: 1980. Állókultúrák és szántóföldi növények mintavételi módszere. Budapest, Hungary: MÉM NAK.

Kovacevic, V.- M. Rasztija- B. Simic- L. Andric - D. Kaycic: 2008. Phosphorus and potassium fertilization impacts on yield nutritional status of maize. Cereal Research Communications, 36: 1-4.

Plénet, D., - P. Cruz: 1997. Maize and sorghum. In Diagnosis of the nitrogen status in crops, ed. G. Lemaire, 93-106. Heidelberg, Germany: Springer Verlag. 


\section{PREDICTION OF YIELD AND QUALITY STABILITY OF WHEAT GENOTYPES IN A MULTI-LOCATION TRIAL NETWORK}

Péter FÓNAD - Lajos BÓNA - Lászlóné CSŐSZ - Andrea CSUKÁS - László CSEUZ

Cereal research Non-profit Company, 6726 Szeged, Alsókikötő sor 9., fonadp@ gabonakutato.hu

Abstract: Adaptability depending highly on drought-, winter tolerance and sink-source capacity is a crucial characteristic of wheat. In 2009, multi-location yield tests were set to characterize the adaptability of our advanced winter wheat lines. Field trials were performed at 10 locations under different soil, climatic and agronomical conditions. At each location, 39 wheat genotypes in four replications were tested together nine check varieties. Yield, thousand kernels mass (TKM) and some quality parameters like wet gluten, protein content and hardness index of the seed samples were measured by NIR method. Diverse abiotic and biotic stress factors, like ones affecting susceptibility of the plants to lodging and pathogen pressure, lack of water and nutrient species, soil acidity etc. varied sufficiently at the locations and influenced significantly the important agronomic parameters. The statistical quantity of the locations has been conductive to predict the spatial stability of the yield of each wheat line referring to their tolerance to different stress factors. The main goal of screening some quantitative parameters was the same and promotes to select adaptable wheat lines with stable parameters. Results of the multi location trial network have become the informing principle of our breeding system for variety production. This year, seven new winter wheat candidates have been registered in the Hungarian State variety experiments.

Keywords: adaptability, abiotic stress, wheat

\section{Introduction}

Most of the biotic stresses can be prevented or serious damages can be moderated by chemical plant protection, while the only way in defense is adaptation/resistance against most of the abiotic stresses. After ten years' breeding procedure the advanced wheat lines have reached the peak of their genetic potential from the view point of the capacity of yield and flour quality. By the time we approach the final phase of a breeding program for adaptive ability to environmental stresses the most important step will have been to find a proper selection method by which we can conclude the stability of the yield and quality and we can run an effective selection system. With the help of the multi-location trial network the physiological reaction of the advanced wheat lines have become traceable (Fónad et al., 2007). In addition, the experiences of this system inspire us to maintain or possibly, enlarge the intra-specific diversity of our wheat genetic base (Cseuz et al., 2008).

\section{Materials and methods}

In 2009, ten locations with diversified agronomical, ecological, climatic condition and pathogen pressure belonged to our wheat trial network. 37 winter wheat and two winter durum wheat genotypes were tested together with the early, medium and late ripening check varieties at each location. The plots of the trials were randomized, designed as Latin square block in four repetitions. The size of the plots was $6.5 \mathrm{~m}^{2}$. The yield of each plot and the thousand kernel mass (TKM) of seed samples were measured. Gluten and protein contents, hardness index were determined by Mininfra 2000T (Infracont 
Ltd.) tester. One factor variance analysis, correlation analysis, classification (WinStat) was executed to evaluate of the yield and quality data.

\section{Results and discussion}

The highest level of average yield of the wheat lines was measured at Lippó $\left(7,51 \mathrm{t}^{\cdot} \mathrm{ha}^{-1}\right)$ while the lowest values were registered at Fülöpszállás $\left(3,95 \mathrm{t}^{\cdot} \mathrm{ha}^{-1}\right)$. The correlation between the yield and the TKW found to be significant only at three locations: Kisújszállás, Lippó, Mezőkövesd. This outcome is in accordance to the strong rate of the foliar pathogenes (Lippó) or the post anthesis drought stress (Kisújszállás, Mezökövesd). These stress forms had negative effects on the yield mainly trough decreasing TKW. At all the other locations, there were no significant correspondence between the yield and TKW, a yield loss occurred locally were consisted of other yield components like decreased number of heads caused by virus diseases (Kocs) and/or decreased number of seed per head due to the early drought stress (Fülöpszállás, Enying).

Table 1. The correlation levels among the locations in point of certain agronomical parameter. $\mathrm{G}$ - gluten content, HI- hardness index, Y- yield, T- 1000 kernel weight. ***,**,*- significant correlation at $\mathrm{p}=5,1$ and $0,1 \%$. Negative correlation signed with underlying; ns - no significant, nd - no data.

\begin{tabular}{|c|c|c|c|c|c|c|c|c|c|}
\hline & $\begin{array}{l}\text { Kisújszállás } \\
\text { G HI Y T }\end{array}$ & $\begin{array}{|lll|}\text { Lippó } & \\
\text { G HI Y } & \text { T } \\
\end{array}$ & $\begin{array}{|llll|}\text { Kocs } & & \\
\text { G } & \text { HI } & \text { Y } & \text { T } \\
\end{array}$ & \begin{tabular}{|l} 
Enying \\
G HI Y
\end{tabular} & $\begin{array}{lll}\text { Kiszombor } \\
\text { G HI Y } \\
\end{array}$ & \begin{tabular}{|llll} 
Fülöpszállás \\
G HI Y
\end{tabular} & $\begin{array}{l}\text { Mezökövesd } \\
\text { G HI Y T }\end{array}$ & $\begin{array}{l}\text { Öthalom } \\
\text { G HI Y } \quad \text { T }\end{array}$ & $\begin{array}{llll}\text { Kecskés } & \\
\text { G } & \text { HI } & \text { Y } & \text { T } \\
\end{array}$ \\
\hline Lippó & ******** & & & & & & & & \\
\hline Kocs & $* * * * * *$ ns $* *$ & $* * * * * *$ ns $* * * *$ & & & & & & & \\
\hline Enying & 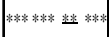 & $* * * * * * * * * * *$ & $* * * * * * * * * *$ & & & & & & \\
\hline Kiszombor & ******** ns & $* * * * * *$ & ns & $* * * * *$ & & & & & \\
\hline Fülöpszállás & ******* ns & $* * * * * * *$ & $* * * * *$ & & **** & & & & \\
\hline Mezőkövesd & & & & & & & & & \\
\hline Öthalom & & 13) & & & & & & & \\
\hline Kecskés & na & $* * *$ nd $n s * * *$ & nd ns & & & nd & nis & *** nd ns $* * *$ & \\
\hline Táplán & *** nd ns nd & **** nd $*$ ns & D tid is ild & 1 .10 1 & & a.... nid nis nad & d $\left.\right|^{* * *}$ nd $n s$ nd & ***** nd ns nd & N*** nd $* *$ nd \\
\hline
\end{tabular}

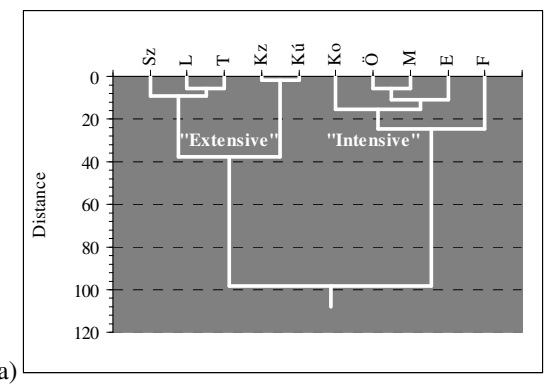

\begin{tabular}{lcc} 
Location & av. yield (t/ha) & variance $(\%)$ \\
\hline Szeged & 7,06 & 2,3 \\
Lippó & 7,51 & 1,7 \\
Táplánszentkereszt & 7,35 & 1,7 \\
Kiszombor & 5,90 & 4,6 \\
Kisújszállás & 4,49 & 38,0 \\
Kocs & 4,54 & 13,6 \\
Öthalom & 4,86 & 5,4 \\
Mezőkövesd & 5,02 & 4,2 \\
Enying & 4,36 & 7,1 \\
Fülöpszállás & 3,95 & 7,9 \\
\hline b) Average & 5,50 & 7,5
\end{tabular}

Figure 1. a) Classification of the locations on the basis of the grain yield data. Agglomeration method was average linkage. Sz-Szeged, L-Lippó, T-Táplánszentkereszt, Kz-kiszombor, Kú-Kisújszállás, Ko-Kocs, Ö-

Öthalom, M-Mezökövesd, E-Enying, -F-Fülöpszállás. b) Average yields at the growing locations and the variance of the yields, 2009. 
The correlation between the yield series of several locations (Table 1.) proved to be significant. Conversely, some pairs of yield series did not show significant correlation, moreover significant negative correlation also occurred (e.g. Kisújszállás-Öthalom, Enying and Mezökövesd). The classification of the yielding ability of the location revealed an intensive and an extensive groups (Figure 1a.). It seems that the yield level of Kisújszállás was not verify its intensiveness but the damage blotted randomly caused by damage of Oulema melanopus L. can account for the lower average yield and the high variance level of the yield there (Figure 1b.). The location mostly diverged from the others is Kocs, with the highest distance, which can be explained with the high level of virus infection as stated above.

The fact of the converse relationship between the average yield and gluten data corresponds to the traditional experiences (Table 2.). The negative correlations between certain parameters and their variance were also expected and confirmed our former experiences (Fónad et al., 2009; Cseuz et al., 2008b).

Table 2. The relationships among the agronomical traits and their variances. G - gluten content; P, Pvar protein content, variance of the protein content; HI, HIvar- hardness index, variance of the hardness index; Y, Yvar- yield, variance of the yield; T, Tvar-TKW, variance of the TKW; ***,**,*- significant correlation at $\mathrm{p}=5,1$ and $0,1 \%$. Negative correlation signed with underlying, ns - no significant.

\begin{tabular}{lcccccc}
\hline & $Y$ & Yvar & $G$ & $P$ & Pvar & $H I$ \\
\hline Yvar & $\frac{* *}{* * *}$ & & & & & \\
G & ns & & & & \\
P & ns & ns & $*$ & & & \\
Pvar & $\mathrm{ns}$ & $\mathrm{ns}$ & $\mathrm{ns}$ & $*$ & & \\
HI & $\mathrm{ns}$ & $\mathrm{ns}$ & $* * *$ & $\mathrm{~ns}$ & $* *$ & \\
HIvar & $\mathrm{ns}$ & $\mathrm{ns}$ & $\mathrm{ns}$ & $\mathrm{ns}$ & $* *$ & $* * *$ \\
Tvar & $\mathrm{ns}$ & $*$ & $\mathrm{~ns}$ & $\mathrm{~ns}$ & $\mathrm{~ns}$ & $\mathrm{~ns}$ \\
\hline
\end{tabular}

However, there is an unexpected finding relative to the correlation between the gluten content and the hardness of the wheat genotypes: the more gluten the seeds contain the more hard they are. Seemingly, the stability of the protein content is was in close connection with the hardness and its stability. Consequently, the positive selection to gluten content, hardness index, at the same time, will be positive to the stability of these parameters. It seems that advanced wheat lines with harder seeds can indicate their higher level of gluten.

Clustering of the hardness index data showed four distinctive groups corresponding to the technically defined hardness forms of the wheat genotypes (Figure 2a,b.). The wheat lines belonging to the soft and intermediate groups showed higher level of standard deviancy than hard and very hard groups. However, the HI stability seems to be, first of all, the cause of the high level of mean HI. There were only a few unique genotypes not belonged to any group. The hard type line 1 showed an enhanced susceptibility to the poor nutrient supply, line 42 is a very stable soft type while line 46 (T. durum L.) was the hardest and most stable genotype of all (Figure 2b.).

Similar classifications were executed relative to all other parameters (not detailed). The evaluation of the clusters simultaneously with other results of the trial network promotes to establish our decision of the final selection steps relative to the advanced wheat lines. Wheat genotypes with wide resistance spectrum and outstanding 
adaptability are applied for registration. In 2009, seven new winter wheat candidates were registered in the State variety experiments.

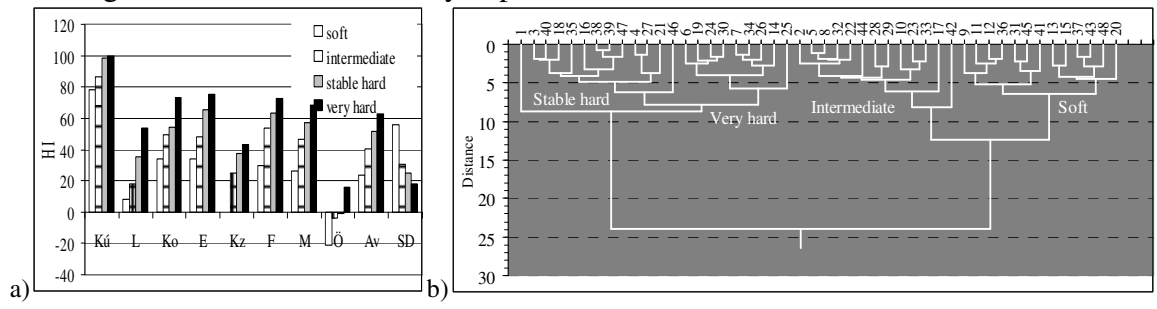

Figure 2. a) Average HIs of the four linkage groups correspond to the seed hardness classes. Sz-Szeged, LLippó, T-Táplánszentkereszt, Kz-kiszombor, Kú-Kisújszállás, Ko-Kocs, Ö-Öthalom, M-Mezökövesd, E-

Enying, -F-Fülöpszállás Av- average, SD - standard deviancy; b) Classification of the wheat lines on the basis of the harvest index NIR data. Agglomeration method was complex linkage. 2009.

\section{Conclusions}

Although, no substituting the many years' routine of breeders, the classification of the relevant agronomic features proved to be very useful for the breeding as a reliable and objective statistical method to distinct and characteristic reaction types of the lines to diverse growing conditions. Such elusive but very important agronomical features like stability of yield, technological quality and their components can objectively described with the help of clustering.

Our results together with the previous ones verified that some agronomical parameters react similarly to the given growing conditions, consequently, these relationships can successfully expendable at the co-selection work of the breeding procedure. The extension of the statistical approach of the experimental trials must become a crucial aspect of the agronomic recommendations attached to the marketed wheat varieties.

\section{Acknowledgements}

This work was funded by the German-Hungarian Research NAP OMFB-00516/2007 Consortium and the Jedlik Ányos project DTR_2007.

\section{References}

Cseuz, L. - Kertesz, Cs. - Fónad, P. - Kovacs, E. - Óvari, J. - Matuz, J. - Kertesz, Z.: 2008a. Progress in Yield Components and Yield Potential in Bread Wheat and Durum Wheat Genotypes. In Option Méditerranéennes, Series A, 81.: 383-386

Cseuz, L. - Matuz, J. - Ács, E. - Fónad, P. - Falusi, J.: 2008b. Changes in bread-making quality of Szeged wheat cultivars due to the differences in location and year effects. VII. Alps-Adria Scientific Workshop, Stara Lesna, Slovakia. Cereal Research Communication 36. 131-134.

Fónad, P. - Cseuz, L. - Mesterhazy, Á. - Csosz, M. - Papp, M. - Bona, L.: 2007. Testing winter wheat genotypes to adaptability in multi-location trials in Hungary - Agricultural Field Trials - Today and Tomorrow - 8-10 october 2007. Hohenheim, Germany.18

Fónad, P. - Csukás, A.: 2009. Selection to adaptability of advanced wheat lines in multi-location trial VIII. Alps-Adria Scientific Workshop, Neum, Bosnia-Hercegovina. Cereal Research Communication 37. 


\title{
RELATION BETWEEN WESTERN CORN ROOTWORM TOLERANCE AND CYCLIC HYDROXAMIC ACID CONTENT OF MAIZE ROOTS
}

\author{
Tamás NÉMETH ${ }^{1}$ - Péter MAKLEIT ${ }^{2}$ - Miklós NÁDASY ${ }^{l}$ \\ ${ }^{1}$ Institute for Plant Protection, Georgikon Faculty, University of Pannonia, H-8360 Hungary, Keszthely, Deák \\ Ferenc u. 57., nemetht83@gmail.com \\ ${ }^{2}$ Department of Agricultural Botany and Crop Physiology, Institute of Plant Sciences, Centre for Agricultural \\ Sciences and Engineering, University of Debrecen, H-4032, Debrecen, Böszörményi út 138., \\ pmakleit@agr.unideb.hu
}

\begin{abstract}
The aim of our research was to investigate the background of tolerance of maize hybrids with different genetic code against Western Corn Rootworm (WCR) (Diabrotica virgifera virgifera LeConte). Tolerance of maize hybrids against larval damage of WCR was studied under field circumstances in 20072009. In order to reveal differences among the hybrids, root damage evaluation according to a modified IOWA scale and surveying of tilted plants was used. In 2009 degree of root damage was measured in pot trials using artificial infestation and evaluated according to Ollefson-Tollefson scale. Based on the results three susceptible and three tolerant hybrids were chosen. Plants of these hybrids were cultivated on nutrient solution in a climate chamber. Whole amount of cyclic hidroxamic acid $(\mathrm{cHx})$ content of roots was measured. Photometric measure of chelated ferric complexes of hydroxamic acids was the basis of the determination assays. Our studies did not show any decided difference between the susceptible and tolerant hybrids in the cyclic hydroxamic acid content of roots. Differences amongst the hybrids were at most the double amount. There were both susceptible and tolerant hybrids with higher and lower hydroxamic acid content. It is suggested making further investigations to reveal the differences in tolerance against WCR among hybrids.
\end{abstract}

Keywords: western corn rootworm (WCR), cyclic hydroxamic acid (cHx), resistance, tolerance

\section{Introduction}

Apart from few pathogens Western Corn Rootworm (Diabrotica virgifera virgifera LeConte) is the most important plant protection challenge in Hungary (Šimić et al., 2007; Szöke et al., 2007). The yield losses caused by the pest may reach as much as 7080\% (Sivcev and Tomasev, 2002; Széll et al., 2005). As cultivation of GMO plants are not yet permitted in Hungary, besides chemical and agrotechnical management methods, there would be practical to exploit natural resistance of maize. Hence introducing rootworm resistant or tolerant hybrids are interest of the growers. Introducing maize hybrids with tolerance based on natural properties into cultivation will probably not affect on the stability of agro-ecosystems, but will provide new protection feasibility to maize growers against WCR. The $\mathrm{cHx}$ content of the roots can be a possible background for susceptibility (Xie et al., 1992).

The cHx-s are secondary metabolites of graminaceous species (Cambier et al., 1999). Among the cHx-s' diverse biological roles it is important that these chemical compounds play role in tolerance and resistance against various pathogens and pests (Niemeyer, 1988). It can be logic, that cHx-s play role in the resistance against WCR too. After all, there are some fact needs to consider in case of examining the role of $\mathrm{cHx}$-s in this field. The one is that different varieties of species contain various amounts of cHx: for example the differences amongst the same organ of maize hybrids in the cHx content can be thirty-fold (Xie et al., 1992). The second one is that the cHx content of plant organs decreases from the age of 2-4 days. What is more, the publications on 
the effect cHx-s on WCR show contradictory results (Xie et al., 1992; Davis et al., 2000).

The purpose of our research was to select WCR susceptible and tolerant maize varieties from domestic ones and to compare the total $\mathrm{cHx}$ content of roots of a few, chosen WCR resistant and susceptible varieties.

\section{Material and methods}

Field experiments were carried out during three years (2007-2009) to determine the tolerance of hybrids against corn rootworm larval damage, using 24 hybrids. Before choosing the locations the corn rootworm egg content and distribution of the singled out plots was measured in late winter with egg washing method (Németh et al., 2007). Soil samples were taken up to ploughing depth, sampling the plots diagonally, equal distance to diagonals, at 10 sampling points/ experimental plot. Such plots were chosen each year, where the numbers of the eggs were high in homogenous distribution. In order to reveal differences among the hybrids, root damage evaluation according to a modified IOWA scale was used. Tolerance of 9 hybrids against corn rootworm damage was also recorded in pot trials in 2009. Artificial infestation was used to guarantee high number and homogenous distribution of eggs. The eggs were collected with our own method. Adults were caught in the previous year with the help of "Csalomon Klpflor +" flower scent containing traps. Collected adults were then put into plastic containers, where sufficient soil, food and air were provided. About 500 adults with 1:1 sexual ratio were introduced into the containers and then placed into climate chambers. The mating and the later egg-laying of adults followed under controlled conditions on $26^{\circ} \mathrm{C}$ temperature and $\mathrm{L} / \mathrm{D}=16 / 8$ photoperiod. Overwintering took place under natural conditions so the containers were dig into the soil to the ground level. Mortality of the eggs is generally 55.63\% (Topfer and Kuhlman, 2005). The eggs, needed for the artificial infestation were separated by egg washing method, using clear tap water, while the eggs could spend maximum 10 minutes under the water. The degree of root damage on different hybrids was evaluated according to the node injury scale (Oleson et al., 2005).

Based on the results of our four investigations, three-three hybrids were chosen which showed lower or higher degree of root damage than the average (Table 1.)

Table 1. The chosen maize hybrids and their susceptibility to WCR root damage

\begin{tabular}{|c|c|c|c|c|c|c|}
\hline Hybrid & PR35F38 & Zamora & DKC5143 & DKC3511 & X000 & PR38A24 \\
\hline Susceptibility & \multicolumn{3}{|c|}{ Susceptible } & \multicolumn{3}{c|}{ Tolerant } \\
\hline
\end{tabular}

The chosen maize varieties were used for evaluation of $\mathrm{cHx}$ content. The $\mathrm{cHx}$ content of roots of 8 days old plants was measured. At this age the plants are developed enough for producing sufficient number of samples for the evaluation.

Plants were cultivated in a climate chamber on nutrient solution according to Treeby et al. (1989) with addition of iron in form of Fe(III)-EDTA in quantity of $10^{-4}$ mole/litre. The surface of the grains was sterilized with fivefold diluted $\mathrm{H}_{2} \mathrm{O}_{2}$ solution. After rinsing with abundant distilled water the grains were kept in $\mathrm{CaSO}_{4}$ solution (concentration: $10^{-2}$ mole/litre) for 4 hours for the better germination. Grains were germinated between watered paper-filters placed in vertical direction. The germinated 
plants were kept in the dark at $24^{\circ} \mathrm{C}$ for elongation of mesocotyl. After, the plants were placed into nutrient solution in a climate chamber, where the environmental factors were controlled: light/dark regime $10 / 14 \mathrm{~h}$ at $24 / 20^{\circ} \mathrm{C}$, relative humidity of $65-70 \%$ and a photosynthetic photon flux of $390 \mathrm{mEm}^{-2} \mathrm{~s}^{-1} .10$ pieces of maize plants were placed into a 3-litre pot. The nutrient solution was changed every three days and was aerated constantly.

The $\mathrm{cHx}$ content of the roots was measured with using the method of Long et al. (1974). Photometric measure of ferric complexes of cHx-s was the basis of the determination. For the evaluation of experimental data the SPSS statistic programme was used. Data of various varieties were compared in couples with t-test and Mann-Whitney test.

\section{Results and discussion}

Results of determination of whole amount of cyclic hidroxamic acid ( $\mathrm{cHx}$ ) content were not harmonize to the results of the degree of root damage, which was measured under field and greenhouse conditions. There were both susceptible and tolerant hybrids with higher and lower hydroxamic acid content (Figure1. and Table 2.).

There was no difference between the hydroxamic acid content of roots of PR35F38, X000 and Zamora hybrids. The cHx content of other hybrids differed from these three hybrids and from each other. Differences between hybrids were based mostly on the genetic background: higher cHx content was measured in roots of DKC hybrids, while PR hybrids had lower cHx content. The probative X000 and Zamora hybrids' $\mathrm{cHx}$ content were low in the experiment (Figure 1. and Table 2.).

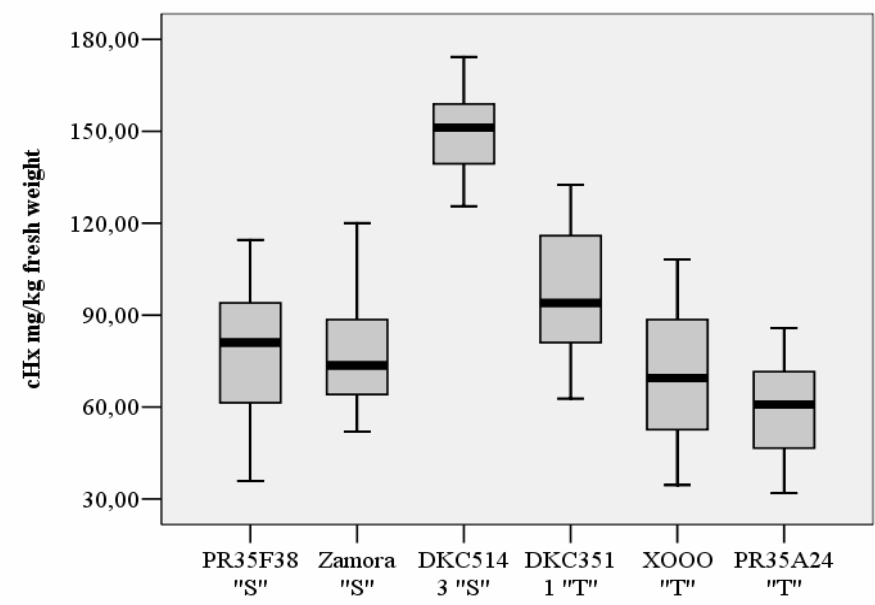

Figure 1. cHx content of susceptible (S) and tolerant $(\mathrm{T})$ varieties $(\mathrm{mg} / \mathrm{kg}$ fresh weight) 
Table 2. chx content and average injury rate of the chosen maize hybrids ( $\mathrm{mg} / \mathrm{kg}$ fresh weight)

\begin{tabular}{|c|c|c|c|c|c|c|}
\hline $\begin{array}{c}\text { Hybrid / } \\
\text { susceptibility }\end{array}$ & \multicolumn{3}{|c|}{ Susceptible } & \multicolumn{3}{c|}{ Tolerant } \\
\cline { 2 - 7 } & PR35F38 & Zamora & DKC5143 & DKC3511 & X000 & PR38A24 \\
\hline \hline cHx content & 77,92 & 77,08 & 149,53 & 97,70 & 70,50 & 60,37 \\
\hline $\begin{array}{c}\text { Average injury } \\
\text { rate }\end{array}$ & $\begin{array}{c}2,6 \\
\text { IOWA }\end{array}$ & $\begin{array}{c}1,96 \\
\text { node in. }\end{array}$ & $\begin{array}{c}2,31 \\
\text { node in. }\end{array}$ & $\begin{array}{c}1,48 \\
\text { node in. }\end{array}$ & $\begin{array}{c}0,12 \\
\text { node in. }\end{array}$ & $\begin{array}{c}2,1 \\
\text { IOWA }\end{array}$ \\
\hline
\end{tabular}

\section{Conclusions}

There are differences in tolerance against WCR among maize hybrids. These observations are worth using in the practice cultivating tolerant hybrids in most infected areas and in cases when monoculture is unavoidable. Thus, examining the tolerance between hybrids is crucial and profitable. There are of course several reasons, causing the difference in tolerance among hybrids. One of the possible reasons can be the variant $\mathrm{cHx}$ content. Our studies did not show any correlation between the susceptibility and the cyclic hydroxamic acid content of roots. Further research is needed with different age of plants and wider sort of varieties to clarify the role of cHx contents in tolerance of maize against corn rootworm.

\section{References}

Cambier, V. - Hance, T. - DeHoffmann, E.: 1999. Non-injured maize contains several 1,4-benzoxazin-3-one related compounds but only as glucoconjugates. Phytochemical Analysis, 10: 119-126.

Davis, C. S. - Ni X. - Quisenberry, S. S. - Foster, J. E.: 2000. Identification and quantification of hydroxamic acids in maize seedling root tissue and impact on western corn rootworm (Coleoptera: Chrysomelidae) larval development. Journal of Economic Entomology, 93: 3. 989-992.

Long, B. J. - Dunn, G. M. - Routley, D. G.: 1974. Rapid procedure for estimating cyclic hydroxamate (DIMBOA) concentration in maize. Crop Science, 14: 601-603.

Németh T. - Takács J. - Simon F. - Nádasy M.: 2007. Forecasting of WCR on the base of GPS technology. Cereal Research Communications, 35: 2. 833-836.

Niemeyer, H. M.: 1988. Hydroxamic acids (4-hydroxy-1,4-benzoxazin-3-ones), defence chemicals in Gramineae. Phytochemistry, 27: 3349-3358.

Oleson, J. D. - Park, Y. L. - Nowatzki, T. M. - Tollefson, J. J.: 2005. Node-injury scale to evaluate root injury by corn rootworms (Coleoptera: Chrysomelidae). Journal of Economic Entomology, 98: 1-8.

Šimić, B. - Ćosić, J. - Rozman, V. - Liska, A.: 2006. Maize inbred lines resistance to fusarium ear rot. Cereal Research Communications, 35: 2. 293-296.

Sivcev, I. -Tomasev, I.: 2002. Distribution of Diabrotica virgifera virgifera LeConte in Serbia in 1998. Acta Phytopathologica et Entomologica Hungarica, 37: 145-153.

Széll E. - Zsellér I. - Ripka G. - Kiss J. - Princzinger G.: 2005. Strategies for controlling Western corn rootworm (Diabrotica virgifera virgifera). Acta Agronomica Hungarica 53: 1. 71-79.

Szőke Cs. - Árendás T. - Rácz F. - Pintér J. - Nagy E. - Marton L. Cs.: 2007. Correlation between maize genotypes and the stalk rot caused by maize Fusarium. Acta Agronomica Hungarica, 55: 4. 447-452.

Topfer, S. - Kuhlmann, U.: 2005. Natural mortality factors acting on western corn rootworm populations: a comparison between United States and Central Europe. In: S.Vidal, U. Kuhlmann, and C.R. Edwards (eds.), Western corn rootworm ecology and management. CABI, Cambridge, MA.

Treeby, M. - Marschner, H. - Römheld, V.: 1989. Mobilisation of iron and other micronutrient cations from a calcareous soil by plant borne, microbial and synthetic chelators. Plant and Soil, 114: 217-226.

Xie, Y. - Arnason, J. T. - Philogéne, B. J. R. - Olechowski, H. T. - Hamilton, R. I.: 1992. Variation of hydroxamic acid content in maize roots in relation to geographic origin of maize germ plasm and resistance to western com rootworm (Coleoptera: Chrysomelidae). Journal of Economic Entomology, 85: 2478-2485. 


\title{
RESILENCE IMPROVEMENT OF WINTER WHEAT RESISTANCE TO DECREASE THE ENVIRONMENTAL PROBLEMS OF ECOSYSTEMS
}

\author{
Pál PEPÓ ${ }^{1}$ - Gabriella TIKÁSZ ${ }^{1}$ - Milán IVANICS ${ }^{2}$ - Gábor TÓTH ${ }^{2}$ - \\ Szilárd TÓTH ${ }^{1}$ - Barnabás JENES ${ }^{2}$ \\ ${ }^{1}$ Debreceni Egyetem Agrár-és Mủszak Tudományok Centruma, Mezőgazdaságtudományi Kar, \\ Kertészettudományi Intézet, 4032 Debrecen Böszörményi út 138. Telefon: 52508 461, e-mail: \\ tikaszg@agr.unideb.hu \\ ${ }^{2}$ Mezőgazdasági Biotechnológiai Központ, Gödöllő, 2101 Pf. 411., e-mail: jenes@abc.hu
}

Abstract: Environmentally friendly plant cultivation is an essential component of sustainable farming. The most important part of it the selection of the suitable genotype. Utilization of pesticides and chemical fertilizers increase the cost of the production, and harmful to the ecological balance. Because of the above mentioned, plant breeders aim to produce varieties with good yield capacity, excellent water and nutrient utilization and good resistance.

In our experiment we used Hajdúság which was state registrated in 2003, this variety has excellent yield capacity, good quality (gluten $34 \%$, flour quality A1) and good resistant to disease, but it is important to improve its resistance to leave rust. Genetic variability of winter wheat has given opportunity for plant breeders to select genotypes with better adaptability that could be grown under different environmental conditions. Application of plant biotechnology gives opportunity to improve the leaf resistance, while the existing agronomic features do not change or only in a small extent. Application of resistant varieties can significantly decrease the utilization of pesticides.

Keywords: ecological resilence, winter wheat (Triticum aestivum L.) leaf rust resistance, in vitro tissue culture, genetic transformation.

\section{Introduction}

The leave rust is one of the most important fungal diseases all over the world. In Hungary the leave rust regularly appeared $(1994,1995,1999)$ and it caused local epidemic diseases in 1996 and in 1997 (Szunics and Szunics, 1995; Békési and Violáné, 1999; Füzi, 2000).

During leaf rust infection 0-40\% yield loss was registered depending on the resistance of wheat varieties (Barabás and Matuz, 1983).

According to sustainable plant production it is a very important question, that what kind of resistance can be developed in different plant races by breeders (Stakman and Harrar, 1957).

The beginning of the determination of wheat rust races was in Kompolt from 1950, in parallel the production of rust resistant wheat varieties was started (Manninger, 2001).

After Hungary's integration into the European Union the technological and environmental quality became more important, so variety- and landscape specific production came to the front (Pepó and Tóth, 1999; Pepó et al., 2003).

Lots of wheat varieties show significant genotype environment interaction $(\mathrm{G} \times \mathrm{E})$ on yield, especially when we compare different years at relatively stable places (Reynolds et al., 2002).

Examination of genotype environment interaction $(\mathrm{G} \times \mathrm{E})$ can lead to the identification of characteristics, which contribute to the better efficiency of varieties (Yan et Hun, 2001). 
Genetic variability of winter wheat has given opportunity for plant breeders to select genotypes with better adaptability that could be grown under different environmental conditions.

According to the criteria of average standard deviation the highest average value must be connected to the lowest standard deviation. Based on this phenomenon we can expect stable yield safety and low yield fluctuation (Hardaker et al., 1997).

Important task is the achievement of agricultural products for human health as well as the apliciation of environment friendly agrotechnics. The Hungarian agriculture can be converted into one of the significant component of sustainable farming in the future if only it is based on the latest technology (Dudits, 2006).

The enviroment friendly agriculture should be based on the use of such cultivars which do not need the application of pesticides. So far there is no breakthrough to prevent the fungus diseases in cereals. The researchers use more offen the tools of biotechnology including genetic transformation.

Our strategy is the introduction of the Cmgl gene (Giczey, 2001) into the wheat genom by the biolistic method (Jenes, 1996) to increase the fungus resistance of Hajdúság registered Hungarian cultivar.

\section{Materials and methods}

We examined yield capacity and yield stability of different winter wheat varieties in comparison with standards in 2006-2008. These wheat varieties were the following: HP 83-00, HP 282-00 which are released and Hajdúság, HP Pusztaszél (HP 306-00) are registered varieties. Weather was average in 2006, while 2007 was dry and 2008 was more humid. In our experiment we used Hajdúság which was state registered in 2003, which had excellent yield capacity, good quality (gluten $34 \%$ or more, flour quality A1, based on Central Agricultural Office data) and good disease resistance, but it is important to improve its tolerance to leave rust. We analysed the yield capacity and yield stability of winter wheat by average-variance criteria. In our project we applied pRubiCmg plasmid to induce leave rust resistance. Data had been worked out by SPSS /Statistical Package for Social Sciences/ and Excel program.

\section{Results and discussion}

According to our results the Hajdúság has the best adaptability values, because it has the greatest average yield (6.86 t/ha) and the least deviation $(0.48)$, so this variety has an excellent yield stability (Figure 1.). 


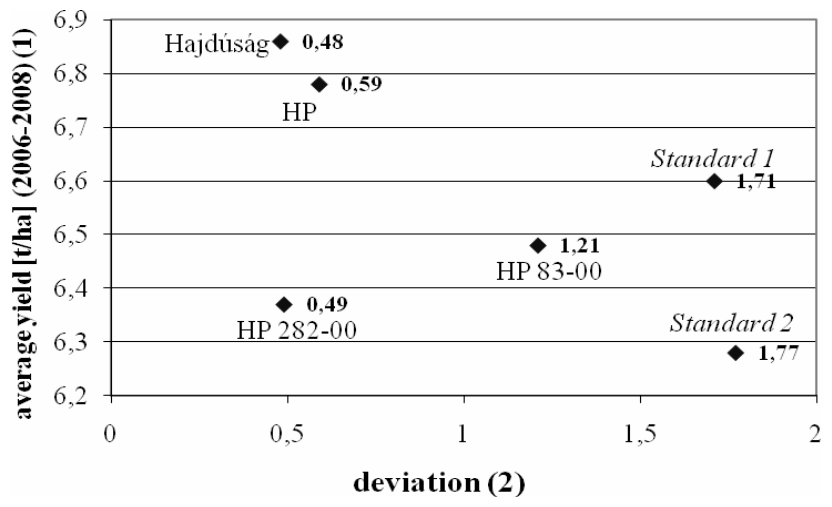

Figure 1. Yield average of different wheat varieties with deviation in comperison with standard varieties (2006-2008). (1): yield average [t/ha]; (2): deviation

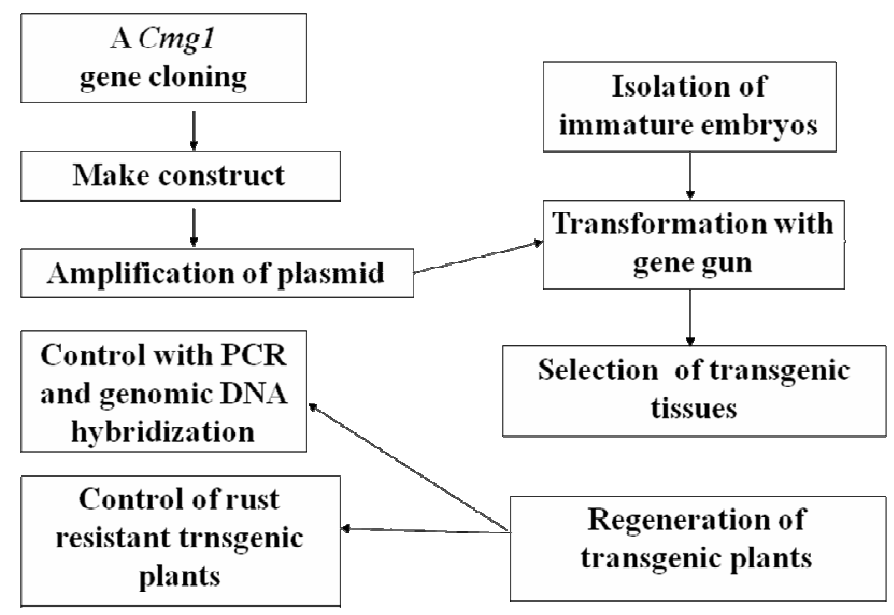

Figure 2. Production of transgenic winter wheat

Cmglgene (Giczey, 2001) expression was controlled by ribulose-1,5-bisphosphate carboxylase/oxygenase (RuBisCo) small-subunit gene promoters in the Hajduság variety. 1,5-bisphosphate carboxylase/oxygenase $(\mathrm{RuBisCo})$ is a green tissue specific regulator sequence of wheat. According to our results we can conclude that the Hajdúság variety did not react to the applied tissue culture method as successfully as other winter wheat varieties, so currently we are working to improve the regeneration conditions. If we put the resistance gene directly into the genome, we can improve the plant resistance without changing any other plant attributes

459 DOI: 10.1556/Novenyterm.59.2010.Suppl.4 
(Figure 2.). In the future we are going to modify the medium component for better callus culture development. We will change hormone ratios and we will add copper and microelements to improve plant shoot induction. Some calluses became infected in Petri dishes. We try to transform the Hajdúság winter wheat variety with resistance gene by biotechnological- and conventional breeding methods. Backcrosses are made with transgenic spring wheat (CY45) under greenhouse conditions. However production of transgenic winter wheat (Hajdúság) takes more time (approximately 3.5 years) with conventional breeding than biotechnological methods, but there are plenty of novel opportunities in the conventional breeding.

\section{Conclusions}

Transgenic plants do not need chemical control, because there are genetically determinated to protect themselves against diseases. This results not only in to decrease of production, but it helps to produce better quality foods, in which there are not chemicals, furthermore will decrease the utilization of pesticides.

\section{Acknowledgements}

We would like to express thanks for Gábor Giczey (PhD) and Andrea Balogh (PhD) proffesional support for making gene construct and accnowledge. András Kis, Henriett Oskolás Kovács and Béla Szabó contribution.

\section{References}

Barabás Z. - Matuz J.: 1983. A levélrozsda és lisztharmat epidémia, illetve különféle rezisztencia típusok befolyása öszi búza genotípusok termésére. Növénytermelés 32, 3:193-198.

Békési P. - Viola J.-né.: 1999. A minősített őszi búzafajták rezisztenciavizsgálatának 199. évi eredményei. Gyakorlati Agrofórum 10, 9: 46-47

Dudits D.: 2006. A búza nemesítésének tudománya a funkcionális genomikától a vetőmagig. MTA Szegedi Biológiai Központ - Winter Fair, 12.

Füzi I.: 2000. A vörösrozsda kártételi jelentősége hazánkban. Gyakorlati Agrofórum 11, 5: 27-29.

Giczey G. - Kerényi Z. - Fülöp L. - Hornok L.: 2001. Expression of cmg1, an Exo- $\beta-1,3-G l u c a n a s e ~ G e n e$ from Coniothyrium minitans, Increases during Sclerotial Parasitism. Appl. Environ. Microbiol. 67:865871.

Hardaker J. B. - Huirne R. B. M. - Anderson J. R.: 1997. Coping with Risk in Agriculture. CAB International, New York. 122-134.

Jenes B. - Bittencourt P. A. L. - Csányi Á. - Pauk J. - Nagy I. - Toldi O. - Balázs E.: 1996. The GENEBOOSTER - a new microprojectile bombardment device - for genetic transformation of plants. Plant Tissue Culture and Biotechnology (2) 42.

Manninger, K.: 2001: Occurance and virulence of wheat leaf rust in Hungary. Beitrage zur Züchtungforschung, 7, 1: 16-20.

Pepó Pá. - Tóth Sz.: 1999. Környezetkímélő gazdálkodás szempontjai a minőségre irányuló őszi búza nemesítési programunkban. V. Növénynem. Tud. Napok. Budapest, 94.

Pepó Pá. - Tóth, Sz. - Petőné, Sipos, L.: 2003. Öszi búza fajták és a minőség. IX. Növénynem. Tud. Napok, Budapest. 126

Reynolds M. P. - R. Trethowan J. - Crossa M. - Vargas - Sayre K. D.: 2002. Physiological factors associated with genotype by environment interaction in wheat. Field Crops Research, 75(2-3):139-160.

Stakman E. C. - Harrar J. G.: 1957. Principless of plant pathology Ronald Press, New York. 1-11.

Szunics L. - Szunics Lu.: 1995. Búzafajták szántóföldi levélrozsda ellenállósága, Növénytermelés 42, 2: 109120.

Yan, W. K. - Hunt L. A.: 2001. Interpretation of genotype x environment interaction for winter wheat yield in Ontario. Crop Science, 41(1):19-25. 


\title{
RESILIENCE IN C3 AND C4 WEED STANDS, IN RESPONSE TO DIFFERENT WATER REGIMES
}

\author{
Zoltán NÉMETH ${ }^{l}$ - Szilárd CZÓBEL ${ }^{l}$ - Csaba NÉMETH ${ }^{2}-$ \\ Klára PÁSZTOR-HUSZÁR ${ }^{2}$ \\ ${ }^{1}$ Institute of Botany and Ecophysiology, Faculty of Agriculture and Environmental Sciences, Szent István \\ University, 2100 Gödöllő Hungary, e-mail: nemeth.zoltan@ mkk.szie.hu \\ ${ }^{2}$ Department of Refrigeration and Livestock Products Technology, Faculty of Food Science, Corvinus \\ University of Budapest
}

Abstract: The weed stands are ineludible components of agro-ecosystems, influencing e.g. the ecophysiology and production of cultivated plants. Their resilience to different, even extreme water regimes could affect the spatial and temporal pattern of the whole agro-ecosystem. The main goal of this research was to investigate the affects of different amount of available water on the adaptation success of two weed species (Chenopodium album, Amaranthus retroflexus) characterizizing different photosynthetic types. In order to achieve this ex situ manipulative experiments were carried out in the Botanical Garden of SZIU. Irrigated and partially precipitation excluded plots were established beside the control stands in both taxa. Manipulation experiments have simulated the predicted climatic extremes on weed species representing different plant functional groups. Shoot number, stand height and above and below ground primer production were measured frequently, while the meteorological parameters were continuously recorded (PAR, $\mathrm{T}_{\text {air }}, \mathrm{T}_{\text {soil }}, \mathrm{SWC}$ ). Considerable or even significant (e.g. at biomass, shoot number) differences were found between control and manipulated stands. Good correlations were found between precipitation and shoot number, mean height of shoot and biomass during the full development of the stands.

Keywords: weed biomass production, drought stress,

\section{Introduction}

The weed stands are ineludible components of agro-ecosystems, influencing e.g. the ecophysiology and production of cultivated plants (Canner et al., 2009). Their resilience to different, even extreme water regimes could affect the spatial and temporal pattern of the whole agro-ecosystem. There are recently very few available studies about the resilience of weed taxa to different water regimes, and to the changing climate. We choose two in Middle Europe wide distributed weed taxa, Chenopodium album and Amaranthus retroflexus (Lososová et al., 2006). These taxa represent different photosynthetic types, witch predestinates different water use efficiency as well (ElSharkawy, 2009; Niu et al., 2005). We have created monodominant stands to examine the taxon specific adaptation differences and characteristics to the manipulation (Borjigidai et al. 2008). Manipulation experiments have simulated the predicted climatic extremes (+/- 50\% precipitation level). Parallel the meteorological measurements we have recorded the shoot number, stand height and above and below ground.

\section{Materials and methods}

Study site: The trial was carried out in the Botanical Garden of Szent István University, Gödöllö, Hungary $\left(19^{\circ} 14^{\prime} \mathrm{E}, 47^{\circ} 25^{\prime} \mathrm{N}, 250 \mathrm{~m}\right.$ altitude). Mean annual rainfall is 500 . Mean temperature is $10,5^{\circ} \mathrm{C}$.

Manipulative experiments: A split plot design with three replications was used. The area of each plot was $1 \mathrm{~m}^{2}(1 \times 1 \mathrm{~m})$. Beside the control stands irrigated and partly water 
excluded plots were established in 3 repetitions. Manipulation experiments have covered the entire vegetation period.

Irrigation: We used rain-like surface irrigation twice a week in $5 \mathrm{~mm}$ dosages. The intensity was adapted to the water absorbtion capacity of the soil.

Partly water exclusion: We put light permeable film every second week over the stands. The film covered the weeds only from above, to minimalise the disturbance of natural air movement and gas exchange.

Meteorological tests: Meteorological tests related to this research can be categorized to continuous and periodic measurements. The continuous measurements were performed by the sensors and automated data recorder of the HOBO (MicroStation, Onset, Massachusetts, USA) micrometeorological station. The instrument was installed next to the tested spots which was functioning 24 hours a day (with sampling frequency of 5minute intervals) thereby providing the meteorological data series for the entire vegetation period of the weed species. The automated station records the actual photosynthetically active radiation (at $40 \mathrm{~cm}$ height), soil temperature and soul moisture in 5-minute intervals both in the control and manipulated spots (both in the depth of 5 $\mathrm{cm})$. The soil moisture measuring sensors were placed in the Amaranthus retroflexus environment. One was installed in the control environment during the entire testing cycle while the other was placed in one of the watered environment of pigweed from 12 March to 1 July 2008 and then in one of the moisture excluding spot of this area.

We planned to measure the soil moisture in all spots and at all measuring times by portable soil moisture measuring device but unfortunately it could not be carried out due to the failure of the measuring instrument. For precise evaluation of $\mathrm{CO}_{2}$-flux data the photosynthetically active radiation (PAR) and air temperature are being measured periodically directly in the tested environment and soil spots by using infrared gas analyzers /CIRAS-2 (PP Systems, Hitchin, UK); LiCor-6400 (Lincoln, Nebrasca, USA)/ and manual Ceptometer (Decagon, Washington, USA)

The moisture was measured by ARG 100 moisture measuring device placed at the ground level and the registered data were stored by a CR21X automated data recorder.

Phenological tests: Phenological sampling was performed every week. In the tested spots we measured the number of plants and new germs. In phonological tests we recorded the actual phenol-phase (presence of flowers, fruits) as well as registered the variations occurring upon the effect of different treatments. In all the tested spots we measured the maximum and mean height of the plants every week. 10 representative stocks were selected from each spot as well as the highest plant from each environment, and its height was measured.

Biomass tests: For the biomass tests the samples were taken from plants outside the tested spots and the individual plants were consistent with the development status (phonological phase) of the environment. During sampling we ensured to collect the full underground biomass (plants, storing and propagating structures) and to remove all possible impurities. From the biomass of tested species located above the ground (shoot + reproductive structures) we took 3 samples for each species and treatment and we collected the entire plants. We measured the fresh mass of the structure below and above the ground separately and we packed them to paper bags. The collected samples were dried until air-dryness (constant mass) by placing into a drying cabinet at $80^{\circ} \mathrm{C}$ for at least 48 hours. 
The above ground biomass (AGB) and the below ground biomass (BGB) were calculated by using the actual number of stocks and plot size and projecting to a square metre surface (this calculation was also compared to the values of the nearly complete biomass cut in September). Statistical evaluation and presentation: On the figures we always show the significant relationships only, indicating the power of correlation. In each case we fit the significant relationship having the greatest power to the data. Regression values were calculated by SigmaPlot 8.0 program. In case of time datasets the significance level of correlation values, the effects of each manipulation experiments and the differences between taxons were checked by T-test. The variation shown in the figures are standard deviation (SD) values. Figures were made by SigmaPlot 8.0 program.

\section{Results and discussion}

For mean shoot height the 3-parametric sigmoid regression had the greatest power $(\mathrm{P}<0,001)$ in case of the treated and control environment of both species. Irrespectively of the treatments both species had similar dynamics (Figure 2). When complete development was achieved the order of mean height of plants reflected the moisture supply. The effect of partial moisture exclusion was shown more in the taxon $\mathrm{C}_{3}$ compared to the weed $\mathrm{C}_{4}$. On the effect of watering greater increase in the mean height was observed in the Amaranthus retroflexus environments compared to the Chenopodium album spots and control. The growth diagram of pigweed - despite the later germination - flattened earlier compared to white goosefoot, i.e. the spots of pigweed achieved the maximum height earlier. When the maximum level of mean height of spot is reached despite the manipulation experiment there was a difference between the spots of the two species which was similar to but more expressed than the number of plants. The mean height of all shoots of Chenopodium album exceeded that of the weed $\mathrm{C}_{4}$ in all measuring time. There were significant differences between the treatments in both species (Figure 1). The biomass changed as it was expected in the function of the available soil moisture. Unlike by grasses (Greco and Cavagnaro 2002) the effect of different moisture quantities showed the same tendency both for AGB and BGB. The biomass reduction in the environment of species $\mathrm{C}_{4}$ with partial moisture exclusion was higher $(53.5 \%)$ than in the taxon $\mathrm{C}_{3}(46.6 \%)$ which is inconsistent with the observations of Ward et al.(1999). The mass of biomass above the ground significantly exceeded that of the biomass under the ground for each species and treatment. For both taxa the environments with partial moisture exclusion had the lowest AGB/BGB ratio (Ama ret: 7.32; Che alb 6.97). From the Amaranthus retroflexus environments the control had the lowest variation. In the Chenopodium album environment SD increased with the increase of biomass. In case of weed species $C_{3}$ the biomass of the control environment was significantly different from that of the environment with partial moisture exclusion $(\mathrm{P}<0.05)$. In the latter species unlike the mean environment height the control and watered spot were more different based on the biomass. 


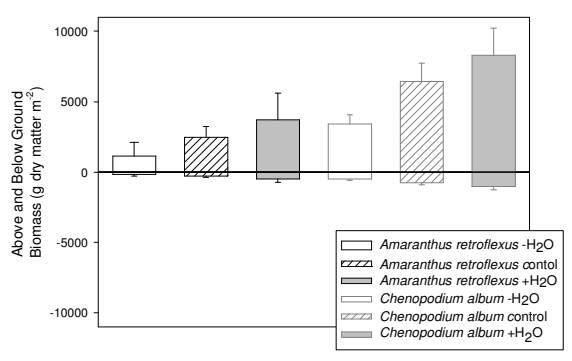

Figure 1. The influence of manipulation on biomass

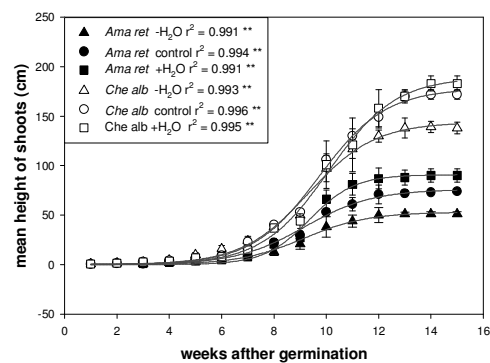

Figure 2. The influence of manipulation on mean shoot number

\section{Conclusions}

Despite the two species belong to different plant function groups both investigated taxa can be characterized with sigmoid growing curve. As a result of the manipulative experiments, we experienced, that the shoot number, mean shoot height and biomass production harmonised with the water regimes in the stands of both weed species. Partial water exclusion reduced biomass with 53,5\% in Amaranthus retroflexus stands, and with $46,6 \%$ in the stand of Chenopodium album. Irrigation raised biomass production with $51 \%$ by white goosefoot, and with only $29,3 \%$ in redroot pigweed stands.

\section{Acknowledgements}

The authors wish to thank Dr. Zoltán Tuba for providing the experimental field and the equipment for our experiments. Thank for the contribution of the co-workers of the Institute of Botany and Ecophysiology and the Botanical Garden of SZIU.

\section{References}

Borjigidai A. - Hikosaka K. - Hirose T.: 2008. Carbon balance in a monospecific stand of an annual herb Chenopodium album at an elevated $\mathrm{CO}_{2}$ concentration. Plant Ecology, 203: 33-44.

Canner S. R. - Wiles L. J. - Erskine R. H. - McMaster G. S. - Ascough II J. C.: 2009. Modeling With Limited Data: The Influence of Crop Rotation and Management on Weed Communities and Crop Yield Loss. Weed Science, 57 (2): 175-186.

Greco S. A. - Cavagnaro J. B.: 2002. Effects of drought in biomass production and allocation in three varieties of Trichloris crinita P. (Poaceae) a forage grass from the arid Monte region of Argentina. Plant Ecology, 64: 125-135.

Lososová Z. - Chytrý M. - Cimalová S. - Otýpková Z. - Pyšek P. - Tichý L.: 2006. Classification of weed vegetation of arable land in the Czech Republic and Slovakia. Folia Geobotanica, 41 (3): 259-273

Sharkawy M. A.: 2009. Pioneering research on C4 leaf anatomical, physiological, and agronomic characteristics of tropical monocot and dicot plant species: Implications for crop water relations and productivity in comparison to C3 cropping systems. Photosynthetica 47 (2): 163-183.

Shuli Niu S. - Yuan Z. - Zhang Y. - Liu W. - Zhang L - Huang J. - Wan S.: 2005. Photosynthetic responses of $\mathrm{C} 3$ and $\mathrm{C} 4$ species to seasonal water variability and competition. Journal of Experimental Botany, 56: 2867-2876.

Ward J. K. - Tissue D. T. - Thomas R. B. - Strain B. D. R.: 1999. Comparative responses of model C3 and C4 plants to drought in low and elevated CO2, Global Change Biology, 5: 857-867. 


\title{
RESILIENCE OF GRASSLAND COENOSYS AFTER CULTIVATION ABANDONMENT
}

\author{
Marietta HARCSA - András SALLAI
}

Szent István University, Crop Production Institute, Páter Károly u. 1., 2103 Gödöllő, Hungary

e-mail: harcsa.marietta@mkk.szie.hu

\begin{abstract}
Succession processes of a phytocoenosis depend on the management practices applied to the agricultural site prior to abandonment. After that, natural or quasi-natural associations provide chance for vegetation resilience in such areas. The aim of our examination was to follow up the changes of a planted grassland phytocoenosis after the quit of intensive management. Processes of succession on an area used for a nutrient supply experiment finished four years ago have been examined. Degree of advancement of the changes have been evaluated by processes of botanical diversity and on the basis of ecological value numbers of the plant association. The results show that the effects of intensive fertilization and management still remain after four years in the vegetation. But secondary succession has been started in the abandonment plots, however this process proved to be slower due to the post effects of the previous intensive management.
\end{abstract}

Keywords: resilience, grassland, secondary succession, cultivation abandonment

\section{Introduction}

Grasslands are important as a feed source for livestock, as a habitat for wildlife, for environmental protection and for the in situ conservation of plant genetic resources. Today conservationists are keen to protect the remaining grasslands because they are home to many uncommon species. Therefore examine the resilience of grasslands is very important for the nature conversation (Suttie et al., 2005).

The intensive management cause lots of changes in grasslands. We can affect the rate of plant species or facies, dosing these substances (Kádár et al., 2007). According to Szemán (2007), the number of grass species increases when nitrogen fertilizers are applied. According to Bánszki (1991), nitrogen fertilizers promote the propagation of Dactylis glomerata L. and Bromus inermis Leyss., as these species prefer nitrogen. The use of large dose fertilizers results in a major decrease in the number of grassland species (Harcsa, 2009). It has also been observed that leguminous species disappear from grasslands after large doses of nitrogen $\left(100 \mathrm{kgha}^{-1}\right)$ are applied (Bánszki 1991, Szemán 2007). Potassium and phosphorous provide favourable conditions for the spreading and survival of leguminous species (Szemán 2007; Barcsák 1978, 2004). Also the lack of fertilizing may cause changes in the plant association. The value of the changes depends on the management type of used and the aim of reserving (Szemán 2007b; Tasi 2007, Harcsa et al. 2008). We can conclude that the level of nutrient supply can modify the proportions of different grassland components in the grassland composition (Tasi, 2007; Kulin et al. 2008). According to Bánszki (1991) in case of major changes in the nutrient level, the type of grasslands can also undergo transformation.

But abandonment of intensive grassland management, grasslands should regenerate.

There are a number of ecological systems for the characterization of the plant associations, e.g. estimator table of Simon (1994), and ecological value of Borhidi (1993, 1995), or Grime (1979). For using these values and systems we should define the naturality of an area after abandonment the intensive management. 
The aim of the examination was to follow up the changes of a planted grassland phytocoenosis after stopping intensive management.

\section{Materials and methods}

The experiments were conducted at the experimental field of the Gabonakutato Nonprofit Közhasznú Kft. in Zsombó, Hungary. We examined the process of succession on an abandoned experiment area used for a nutrient supply experiment (2001-2005). Since end of the nutrient supply experiment the area was reserved with mowing. The seed mixture was the following: Lolium perenne L., Festuca rubra L., Bromus inermis Leyss., Agropyron cristatum (L.) Gaertn., Phalaris arundinacea L., Poa pratensis L. Plots got different fertilizer doses: 1. unattended, 2. $\mathrm{N}_{100}, 3 . \mathrm{N}_{150}, 4 . \mathrm{N}_{100+50}, 5 . \mathrm{P}_{40}, 6$. $\mathrm{P}_{80}, 7 . \mathrm{N}_{100} \mathrm{P}_{40}$, 8. $\mathrm{N}_{100} \mathrm{P}_{80}, 9 . \mathrm{N}_{150} \mathrm{P}_{40}, 10 . \mathrm{N}_{150} \mathrm{P}_{80}, 11 . \mathrm{N}_{100+50} \mathrm{P}_{40}, 12 . \mathrm{N}_{100+50} \mathrm{P}_{80}$ (kg ha $^{-1}$ ). The experiment was finished in 2005, since that time the grassland is mowed once a year. We conducted botanical analysis on $1 \times 1 \mathrm{~m}$ quadrate plots (12 plots x 2 repeats) 4 years after the abandonment. The natural pasture where no fertilizers were applied was used as a control area. The botanical survey was carried out through Braun-Blanquet (1951) method.

\section{Results and discussion}

Table 1 shows cover rates of the plant species identified in the plots. Species planted for the original nutrient experiment have already disappeared from the area in 4 years. The effects of the large-dose fertilizers is also visible for the distribution of the different plots for four years after. The leader components in the recent vegetation are the following: Plantago lanceolata L., Trifolium pretense L., Cynodon dactylon /L./ Pers., Medicago lupulina $\mathrm{L}$..

According to the ecological value (of Borhidi) of these plants (Table 2), it is demonstrable, that the trace of nitrogen fertilizer is even in the soil, but rate of its, decreased. The NB 4 and 5 values of these plants refer to this. Numbers of species are between 14 and 18 (in the average of repeats). Taken the species list with the vegetation of the natural grassland near the experiment (control plot), it is visible, that almost the same species appeared in the seeded grassland. Except Galium verum and Achillea collina, which are in the natural grasslands, but not appear in the experiment plots.

\section{Conclusions}

The conclusion of the botanical survey is that the effects of intensive fertilization and management still remain after four years in the vegetation. But it is visible that secunder succession has been started in the abandonment plots, however this process proved to be slower due to the post effects of the previous intensive management.

According to the appeared weeds, we suggest that grasslands, like this (abandonment after intensive management), demand more weed-clearing and reseeding. Because seeded grass-species, without any treatment, may disappear from the association. Leguminous and weed species took over the function of the leader plants. In case of the 
experiment area will not getting appropriate treatment, it may causes large-scale degradation. However reseeding components of grassland (leader-plant reseeding) is recruits rates of association.

Table 1. Cover rates (in \%) of the species /in average of replications/

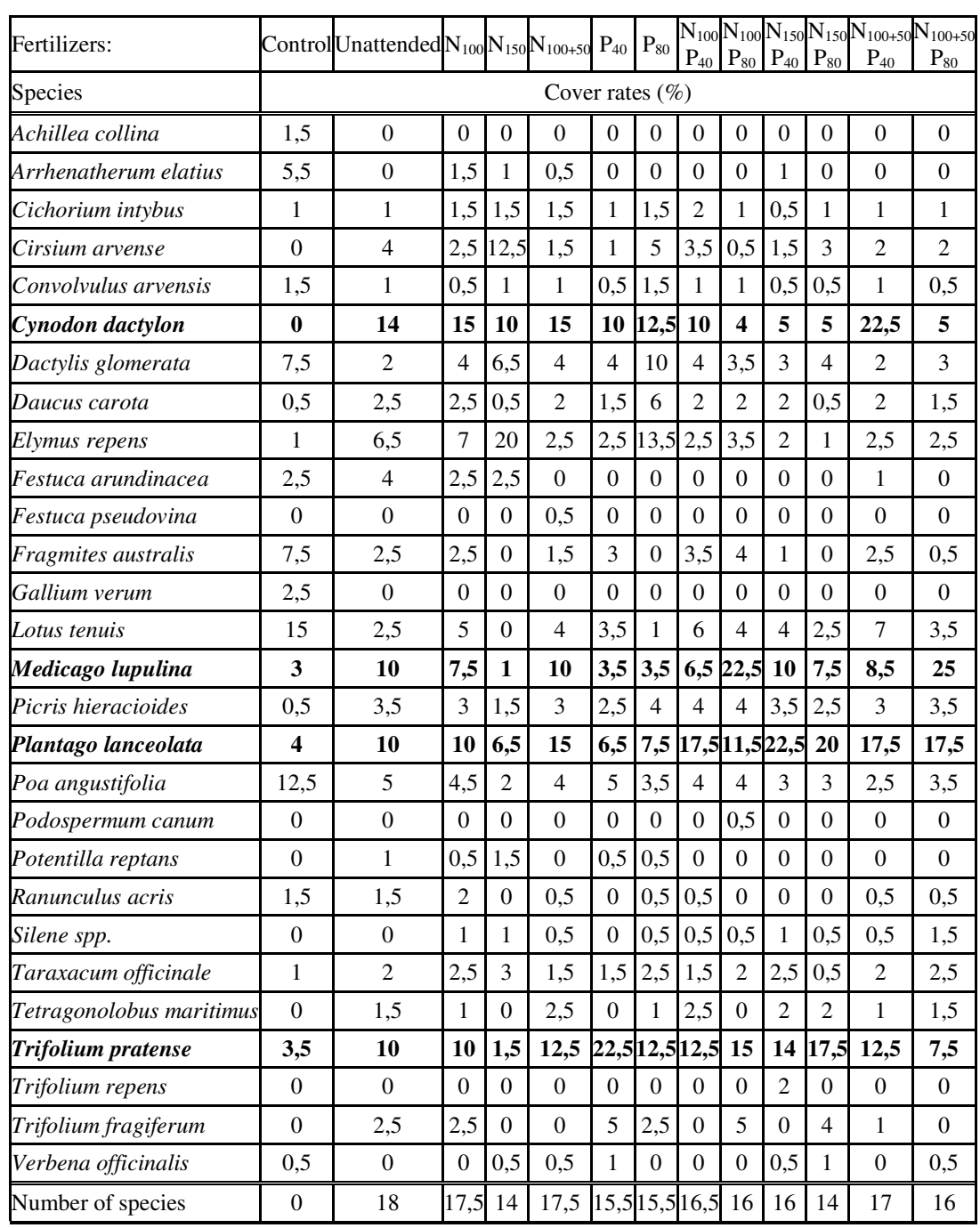


Table 2. Ecological values of the leader plants

\begin{tabular}{|c|c|c|c|c|c|c|c|c|c|c|c|c|}
\hline Genus & Species & Auctor & SBT & Val & TB & WB & RB & NB & LB & KB & SB & Coenolb \\
\hline \hline Plantago & lanceolata & L. & Dt & 2 & 5 & 4 & 6 & 5 & 7 & 3 & 0 & Indiff. \\
\hline Trifolium & pratense & L. & Dt & 2 & 5 & 6 & 6 & 5 & 7 & 3 & 0 & Indiff. \\
\hline Cynodon & dactylon & /L./Pers. & Rc & -2 & 7 & 3 & 7 & 5 & 8 & 3 & 1 & Indiff. \\
\hline Medicago & lupulina & L. & Dt & 2 & 5 & 5 & 8 & 4 & 7 & 4 & 1 & Indiff. \\
\hline
\end{tabular}

Authors will continue work in theme resilience. The aim of our experiment to describe vegetation changes of grasslands after using different management systems and different fertilizers, considering the number and rates of species.

\section{Acknowledgements}

We thank Gabonakutató Nonprofit Közhasznú Kft. for the space and facilities for the experiment.

\section{References}

Barcsák Z.: 2004. Biogyep-gazdálkodás. Biogazda kiskönyvtár. Mezőgazda Kiadó, Budapest

Barcsák Z. - Baksay - Tóth B. - Prieger K.: 1978. Gyeptermesztés és - hasznosítás. Mezőgazdasági Kiadó, Budapest

Borhidi, A.: 1993. A magyar flóra szociálismagatartás-típusai, természetességi és relatív ökológiai értékszámai. KTM Természetvédelmi Hivatala és JPTE, Pécs

Borhidi, A.: 1995. Social behaviour types, the naturalness and relative ecological indicator values of the higher plants in the hungarian flora. - Acta Botanica Hungarica 39: 97-181.

Braun-Blanquet, J.: 1951. Pflanzensoziologie II. Wien.

Grime, J. P.: 1979. Plant Strategies and Vegetation Processes. John Wiley and Sons. Chichester- New YorkBrisbane- Toronto

Harcsa M. - Bajnok M. - Kulin B. - Szemán L. - Prutkay J.: 2008. Effects of ecological soil aptitude on grass stand planning. Cereal Research Communications. 36: 1931-1934.

Kádár I. - Ragályi P. - Szemán L. - Márton L. - Nagy S.: 2007. NPK mütrágyázás és a foltszerü trágyaterhelés hatásának vizsgálata legeltetett ősgyepen. Gyepgazdálkodási Közlemények 2007/5.: 16-25.

Kulin B. - György A. - Prutkay J. - Tóth L. - Zsigó G. (2008): The effect of soil nutrient content on the mowed turf. Cereal Research Communications 36: 879-882.

Simon T.: 1994. A magyarországi edényes flóra határozója. Nemzeti Tankönyvkiadó, Budapest

Suttie, J.M. - Reynolds S.G. - Batello C.: 2005. Grasslands of the world. Food And Agriculture Organization of the United Nations, Rome.

Szemán L.: 2007. Gyepgazdálkodási módszertan. Egyetemi jegyzet, Gödöllő

Szemán L.: 2007b. Environmental consequences of sustainability on grassland. Cereal Research Communications. 35: 2. 1157-1160.

Tasi J.: 2007. Diverse impacts of nature conservation grassland management. Cereal Research Communications. 35: 2. 1205-1208. 


\title{
RESILIENCE OF PEA RHIZOBIA IN TWO SOIL TYPES OF EAST CROATIA
}

\author{
Ranko GANTNER ${ }^{1}$ - Mirko STJEPANOVIĆ ${ }^{1}-$ Bogić MILIČIĆ ${ }^{2}$ - Đorđe \\ KUZMANOVIC ${ }^{2}-$ Tihomir ČUPIC ${ }^{3}$ \\ ${ }^{1}$ Faculty of Agriculture in Osijek, Trg Sv. Trojstva 3, 31000 Osijek, Croatia, e-mail: ranko.gantner@pfos.hr \\ ${ }^{2}$ Institute of Soil Science, Teodora Drajzera 7, 11000 Beograd, Serbia \\ 3 Agricultural Institute Osijek, Južno predgrađe 17, 31000 Osijek, Croatia
}

Abstract: Aim of the research was to asses the pea rhizobia resilience in two soils of east Croatia by means of detecting nodulation induced by indigenous rhizobia and comparing it with nodulation induced by commercial rhizobia strains. Nodules induced by indigenous strains were found as well as ones induced by commercial strains. Inoculation measure has raised nodules initiation in early terms in slightly alkaline soil and nodule counts in both investigated soils in the final term. Indigenous rhizobia have caused the faster nodules growth and coloring. Nodulation was delayed in acid soil but the nodules dryweight was higher in the same soil.

Keywords: pea, soil, rhizobia, nodulation, resilience

\section{Introduction}

Symbiotic nitrogen fixation is important from economic and environmental point of view (Peoples and Craswell, 1992). It depends on the interaction of symbionts (host plants and nodulating rhizobia) with pedoclimatic factors and environmental conditions (Bordelau and Prévost, 1994). Higher soil organic matter and clay content and organic fertilization aid the rhizobia persistence in soil (Zengeni et al., 2006). Extremes of pH affect nodulation by reducing the colonization of soil and the legume rhizosphere by rhizobia (Bordelau and Prévost, 1994). Nitrogen fertilization reduces the nodulation of pea roots (Achakzai, 2007). Some agrochemicals including organochlorine pesticides inhibit or delay recruitment of rhizobia to host plant and decrease the nodulation and nitrogenase activity (Fox et al., 2007). Certain herbicides applied to pea crop have decreased the nodulation of pea roots (Singh and Wright, 2006). Soil organic matter decomposition, soil acidification, excessive pesticides and mineral fertilizers application, and lack of organic fertilization are attributes of conventional and intensive agriculture. Aim of the research is to assess were the indigenous rhizobia resilient to disturbances caused by common agronomy practices in two soils of east Croatia.

\section{Materials and methods}

Resilience of indigenous rhizobia was assessed by detecting pea root nodulation caused by indigenous rhizobia, and by comparing this nodulation with nodulation induced by commercial rhizobia strains. Experiment was conducted in pots (capacity of 15 liters of

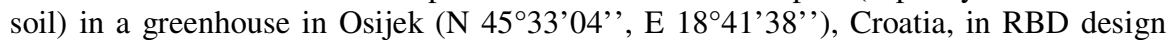
with 3 replicates. Pots were filled with two different and broadly distributed soil types (Table 1): eutric cambisol (of Osijek), slightly alkaline, and stagnic podzoluvisol (of Krndija, N 45 27' 1', E 18 41'38'’), acid soil. Soil samples for investigation were taken from paddocks of arable land with long history of cultivation under conventional tillage and fertilization (common use of mineral fertilizers and very rare organic ones), 
conventional plant protection practices and common crop rotation with prevailing cereals. Rhizobia sp. were never introduced by man to these paddocks. Seeds of field pea (Pisum sativum L. var. arvense, convar. Letin, winter forage type) were seeded into pots on $19^{\text {th }}$ August 2008 . Prior to the seeding, the seeds were treated with 3 commercial strains of rhizobia (Rhizobium leguminosarum bv. Vicie, abbr. R.l.v.), separately with strain 320, 321 and 322, all of the Institute of Soil Science (Belgrade, Serbia), plus control without inoculation. Nodules observation and counting on pea roots were done in 3 terms: $12\left(1^{\text {st }}\right), 20\left(2^{\text {nd }}\right)$ and $47\left(3^{\text {rd }}\right)$ days after pea emergence. Nodules were weighed in the $3^{\text {rd }}$ term only. Analysis of variance was performed using SAS software.

Table 1. Properties of soils used in experiment

\begin{tabular}{|c|c|c|c|c|c|c|}
\hline Soil of locality & $\mathrm{pH}\left(\mathrm{H}_{2} \mathrm{O}\right)$ & $\mathrm{pH}(\mathrm{KCl})$ & Humus \% & $\mathrm{Al}_{2} \mathrm{P}_{2} \mathrm{O}_{5} \%$ & $\mathrm{Al}-\mathrm{K}_{2} \mathrm{O} \%$ & Total N \% \\
\hline \hline Osijek & 7.91 & 7.33 & 2.15 & 23.8 & 20.7 & 0.15 \\
\hline Krndija & 5.29 & 4.45 & 2.21 & 10.4 & 13.4 & 0.14 \\
\hline
\end{tabular}

\section{Results and discussion}

Nodules were observed in the control as well as in all the treatmens (Table 2). This supports the findings of Mutch and Young (2004) that pea rhizobia are ubiquitous in European arable soils and have probably originated on wild hosts of R.l.v., i.e. Vicia and Lathyrus sp. Also, this supports the hypothesis that common agricultural practices did not eliminate pea nodulating rhizobia of investigated soils. Nodule coloration appeared in the $2^{\text {nd }}$ term but in the $3^{\text {rd }}$ term all the nodules were reddish.

Table 2. Averages of the total number of observable nodules per root in all the variants (nodule inceptions in the $1^{\text {st }}$ term, smaller plus bigger developing nodules in the $2^{\text {nd }}$ term, and developed nodules in the $3^{\text {rd }}$ term) and inoculation treatments averaged (Avg.Inoc.)

\begin{tabular}{|c|c|c|c|c|c|c|c|}
\hline Term & Soil & Control & Strain 320 & Strain 321 & Strain 322 & Average & Avg.Inoc. \\
\hline \multirow{3}{*}{$1^{\text {st }}$} & Osijek & 9.33 & 16.76 & 18.44 & 21.30 & 16.46 & 18.83 \\
\hline & Krndija & 4.61 & 3.40 & 3.72 & 0.92 & 3.16 & 2.68 \\
\hline & Average & 6.97 & 10.10 & 11.10 & 11.10 & 9.82 & 10.77 \\
\hline \multirow{3}{*}{$2^{\text {nd }}$} & Osijek & 29.16 & 19.66 & 31.93 & 30.22 & 27.74 & 27.27 \\
\hline & Krndija & 17.47 & 5.54 & 6.62 & 7.18 & 9.20 & 6.45 \\
\hline & Average & 23.31 & 12.60 & 19.28 & 18.70 & 18.47 & 16.86 \\
\hline \multirow{3}{*}{$3^{\text {rd }}$} & Osijek & 45.42 & 56.33 & 66.68 & 56.04 & 56.12 & 59.69 \\
\hline & Krndija & 40.58 & 61.61 & 41.59 & 64.56 & 52.09 & 55.92 \\
\hline & Average & 43.00 & 58.97 & 54.13 & 60.31 & 54.10 & 57.80 \\
\hline \multicolumn{5}{|r|}{ LSD } & $\alpha=0.05$ & $\alpha=0.01$ & \\
\hline \multicolumn{5}{|r|}{ Term } & 2.92 & 3.90 & \\
\hline \multicolumn{5}{|r|}{ Soil } & 2.38 & 3.18 & \\
\hline \multicolumn{5}{|c|}{ Inoculation strain } & 3.37 & 4.50 & \\
\hline \multicolumn{5}{|c|}{ Term $\times$ Soil } & 4.13 & 5.51 & \\
\hline \multicolumn{5}{|c|}{ Term $\times$ Inoculation strain } & 5.84 & 7.79 & \\
\hline \multicolumn{5}{|c|}{ Soil $\times$ Inoculation strain } & 4.77 & 6.36 & \\
\hline \multicolumn{5}{|c|}{ Term $\times$ Soil $\times$ Inoculation strain } & 8.26 & 11.02 & \\
\hline
\end{tabular}


Regarding the nodulae abundance on pea roots, there were significantly less nodules in acid soil of Krndija compared to the slightly alkaline soil of Osijek at the $1^{\text {st }}$ (3.16 vs. 16.46) and $2^{\text {nd }}$ term $(9.20$ vs. 27.74$)$ but this has been altered to insignificant difference between two soil types in the $3^{\text {rd }}$ term $(52.09$ vs. 56.12$)$. Inoculation treatments have significantly raised the average nodule inceptions per root at the $1^{\text {st }}$ term in soil of Osijek (18.83 vs. 9.33), but in acid soil of Krndija inoculation had no significant effect ( 2.68 vs. 4.61$)$. In the $2^{\text {nd }}$ term, there were observed 3 classes of nodules: smaller than $1 \mathrm{~mm}$ in diameter, greater than $1 \mathrm{~mm}$, and reddish colored of greater ones (Table 3 ).

Table 3. Averages of smaller nodules $(<1 \mathrm{~mm}$ in diameter), bigger nodules $(>1 \mathrm{~mm}$ in diameter) and reddish nodules $(>1 \mathrm{~mm}$ in diameter) per pea root

\begin{tabular}{|c|c|c|c|c|c|}
\hline Soil & Control & Strain 320 & Strain 321 & Strain 322 & Average \\
\hline & \multicolumn{5}{|c|}{ Smaller nodules $(<1 \mathrm{~mm})$} \\
\hline Osijek & 13.18 & 11.48 & 25.27 & 25.72 & 18.91 \\
\hline Krndija & 13.69 & 5.15 & 6.22 & 7.18 & 8.20 \\
\hline Average & 13.43 & 8.32 & 15.75 & 16.72 & 13.55 \\
\hline LSD & Soil & Inoculation & Soil $\times$ I & ulation & \\
\hline$\alpha=0.05$ & 2.355 & 3.330 & & & \\
\hline \multirow[t]{2}{*}{$\alpha=0.01$} & 3.279 & 4.638 & & & \\
\hline & \multicolumn{5}{|c|}{ Bigger nodules $(>1 \mathrm{~mm})$} \\
\hline Osijek & 15.98 & 8.18 & 6.67 & 4.50 & 8.83 \\
\hline Krndija & 3.78 & 0.39 & 0.40 & 0.00 & 1.14 \\
\hline Average & 9.88 & 4.28 & 3.53 & 2.25 & 4.99 \\
\hline LSD & Soil & Inoculation & Soil $\times$ I & ulation & \\
\hline$\alpha=0.05$ & 2.195 & 3.105 & & & \\
\hline \multirow[t]{2}{*}{$\alpha=0.01$} & 3.057 & 4.323 & & & \\
\hline & \multicolumn{5}{|c|}{ Reddish nodules $(>1 \mathrm{~mm})$} \\
\hline Osijek & 15.98 & 6.31 & 1.97 & 3.22 & 6.87 \\
\hline Krndija & 1.67 & 0.00 & 0.07 & 0.00 & 0.43 \\
\hline Average & 8.82 & 3.16 & 1.02 & 1.61 & 3.65 \\
\hline LSD & Soil & Inoculation & Soil $\times$ I & ulation & \\
\hline$\alpha=0.05$ & 1.952 & 2.760 & & & \\
\hline$\alpha=0.01$ & 2.718 & 3.844 & & & \\
\hline
\end{tabular}

The grater number of small nodules in inoculated variants (strain 321 and 322 had 25 in average vs. 13 in control) at the $2^{\text {nd }}$ term in slightly alkaline soil hints to the greater nodule initiation when inoculant was applied, similarly as in the $1^{\text {st }}$ term. The grater number of big (15.98 vs. 4.50 to 8.18 ), especially reddish (15.98 vs. 1.97 to 6.31 ) nodules in the control compared to inoculation treatments shows the faster development of nodules induced by indigenous rhizobia. Inoculation treatments did not significantly affect the nodules dryweight per root in the $3^{\text {rd }}$ term (Table 4). Inoculation measure was associated with higher nodule counts both in acid and slightly alkaline soil in the $3^{\text {rd }}$ term compared to control (Table 2) but the nodules dryweight per root was not significantly affected by inoculation (Table 4). Despite the nodules initiation and development were delayed in the acid soil, the nodules dryweight was greater in acid soil (20.92 mg vs. $17.17 \mathrm{mg}$ ) compared to slightly alkaline soil in the $3^{\text {rd }}$ term.

471 DOI: $10.1556 /$ Novenyterm.59.2010.Suppl.4 
Table 4. Averages of nodules dryweight per root (in $\mathrm{mg}$ )

\begin{tabular}{|c|c|c|c|c|c|}
\hline Soil & Control & Strain 320 & Strain 321 & Strain 322 & Average \\
\hline \hline Osijek & 17.00 & 15.67 & 21.00 & 15.00 & 17.17 \\
\hline Krndija & 20.33 & 23.33 & 16.67 & 23.33 & 20.92 \\
\hline Average & 18.67 & 19.50 & 18.83 & 19.17 & 19.04 \\
\hline LSD & Soil & Inoculation & Soil $\times$ Inoculation & \\
\hline$\alpha=0.05$ & 3.275 & 4.632 & \multicolumn{2}{|c|}{6.550} & \\
\hline$\alpha=0.01$ & 4.561 & 6.450 & \multicolumn{3}{|c|}{9.121} \\
\hline
\end{tabular}

\section{Conclusions}

Research has shown that indigenous pea rhizobia were resilient to common agronomy practices in east Croatia in their capacity to nodulate pea roots. Moreover they were capable of inducing faster nodule growth and coloration when compared to commercial strains. Inoculation measure has raised the nodules initiation in earlier terms in the slightly alkaline soil and has caused the higher nodule counts both in acid and slightly alkaline soil in the final counting but it did not significantly affect the average nodules dryweight per root at the final term. Nodules development was delayed in acid soil but in the final term the average nodules dryweight per root was higher there compared to slightly alkaline soil.

\section{Acknowledgements}

Authors wish to thank to the Croatian Ministry of Science, Education and Sports (project: Breeding field pea cultivars of high yield and quality) and to the Norwegian SIU (cooperative project with Norwegian UMB University of Life Sciences: Education, Research and Training for Global Environmental Change and Sustainable Management of Natural Resources in West Balkan) for funding this research.

\section{References}

Achakzai A.K.K.:: 2007. Effect of various levels of nitrogen fertilizer on nodulation of pea cultivars. Pakistan Journal of Botany, 39: 1673-1680.

Bordelau L.M. - Prévost D..: 1994. Nodulation and nitrogen fixation in extreme environments. Plant and Soil, 161: $115-125$.

Fox J.E. - Gulledge J. - Engelhaupt E. - Burrow M.E. - McLachlan J.A.: 2007. Pesticides reduce symbiotic efficiency of nitrogen fixing rhizobia and host plants. Proceedings of the National Academy of Sciences of the United States of America, 104: 10282-10287.

Mutch L.A. - Young P.W.: 2004. Diversity and specificity of Rhizobium leguminosarum biovar. viciae on wild and cultivated legumes. Molecular ecology, 13: 2435-2444.

Peoples M.B. - Craswell E.T.: 1992. Biological nitrogen fixation: Investments, expectations and actual contribution to agriculture. Plant and Soil, 141: 13-39.

Singh G. - Wright D.: 2006. Effect of weed management on weeds, and on the nodulation, nitrogenase activity, growth and yield of pea (Pisum sativum). Acta Agronomica Hungarica, 54: 469-485.

Zengeni R. - Mpepereki S. - Giller K.E.: 2006: Manure and soil properties affect survival and persistence of soyabean nodulating rhizobia in smallholder soils of Zimbabwe. Applied Soil Ecology, 32: 232-242. 


\section{RESILIENCE OF PHENOLOGICAL STAGES OF SUNFLOWER HYBRIDS IN DIFFERENT CROPYEARS}

\section{László ZSOMBIK}

University of Debrecen Centre of Agriculture Sciencies Institute of Plant Sciences

Abstracts: During our research between 2000 and 2008, we examined the changes in the emergence date and the vegetation period and the time of blooming of sunflower hybrids in different cropyears at different (early, optimal, and late) sowing dates on the loess area on the region of Hajdúság. In the case of the earlier sowing time than the optimal, the emergence and the early growth were influenced considerably by the air temperature of middle and the end of April, and the precipitation in the first decade of April. In the case of sowing date at the middle of April, the most important factors affecting the date of emergence were the soil and the air temperatures. At a late sowing date, the meteorological factors had a less definite effect on the date of emergence. The meteorological factors had a considerable effect on the number of days before blooming only when sowing was late, meaning that meteorological factors have a significant effect on vegetative growth at a sowing time later than the optimal.

Keywords: sunflower, sowing date, emergence, blooming period

\section{Introduction}

Beard and Geng (1982) determined with principal component and path analysis that the hybrids with different phenotypes and genotypes react to the different sowing times similarly. In the case of an earlier sowing time than the optimal, the vegetation period of hybrids is shorter by 4-7 days, but in the case of a later sowing time, there is no difference during the vegetation period (Belevtsev et al., 1991). In the examinations of Bilteanu et al. (1986) there was a negative correlation between the number of day until emergence and the temperature of soil and air at sowing. The optimal sowing time was determined as between 15 March and 20 April under Romanian conditions. According to Encseva and Klocskov (1984), the earlier sowing time resulted in a 6-12 days earlier blooming compared to the optimal sowing date, also the ripening of the sunflower seed was faster in the case of an early sowing. Belevtsev et al. (1990) examined sunflower hybrids were sowed in $4-16{ }^{0} \mathrm{C}$ soil and experienced that the vegetation period increased by 3-6 days, but in the case of $10-12{ }^{\circ} \mathrm{C}$ soil the vegetation period was prolonged by 7 12 days.

\section{Material and methods}

The experiment was carried out in calcareous chernozem soil in the loess area of Hajdúság between 2000 and 2008. The field experiment was carried out in four repetitions, in a randomized block design. We have tested the effect of an earlier sowing time (end of March), the optimal (middle of April) and a later sowing time (beginning of May) than the optimal, we applied 55000 plants ha $^{-1}$ plant density, with different sunflower hybrids. We defined the effect of weather parameters per decade on the number of days before blooming and emergence date with Pearson correlation analysis.

\section{Results and Discussion}

In 2000 in early sowing time we measured shorter emergence times (11-13 days), what is favourable temperature one and for precipitation relations due. The hybrid ones produced uniform emergence in the average (middle of April) sowing time. The 
emergence time of the hybrid ones changed between 6-8 days in this sowing time. Bigger scattering appears between the hybrid ones in the concern of the late sowing time, concerning the largest values at this the sowing time we experienced it. The shortest emergence time was at the examined in average sowing time (middle of April). The emergence relations developed peculiarly in the 2001. In early sowing time relatively long (15-18 days) emergence times we measured, caused by the decreased of the temperature. In average sowing time we experienced longer emergence dragging caused the cool air and soil temperature. The temperature defined the emrgence of substances sowed in the early and average sowing time in this cropyear primarily. This it proves that late sowing time the hybrids ones uniform and quick (6-7 days) emergences was produced, a considerable difference did not visible between the hybrids. In 2002 we registered 7-11 days emergence times in the average sowing time. The weather conditions developed similarly on the end of April and the early May to the middle of April, the emergence time was between 8-10 days in the late sowing time. In 2003 the relatively late one springing be coming the temperature of the soil was getting warm in the sowing depth late permanently towards $10{ }^{\circ} \mathrm{C}$. These climatic relations caused the emergence time of the sunflower to have been over the 25 days in the earliest sowing time. The emergence time changed between 10-15 days, which are bigger slightly, in the average sowing time. The sowing done in late sowing time the emergence was uniform and fast. We registered emergence time between 13-18 days in the early sowing time in 2004. The reason of this primarily it to be been looking for, that the soil temperature came short of $10{ }^{\circ} \mathrm{C}$ until long-more lasting time in the period following the sowing. The April wet and relatively cool weather reigned in sowing time in the middle of April, the hybrid ones produced uniform emergence (12 days in average). In 2008 8-18 days we experienced emergence times, which one considerable shortened with the sowing time being shifted on to later one. The longest emergence time arose in the earliest sowing time (14-18 days), this turned into uniform one in the average sowing time (11-12 days), while the late sowing time shortened longer on his case (9-12 days) in the case of the examined hybrid ones. The more year one based on examinations we examined in early sowing time the longest one is the emergence (1125 days). In the average the sowing time is shorter, with 6-18 days interval. The late sowing time the emergence time shortens (averagely 8 days), in 4-13 days interval.

In our examinations the blooming time of the hybrids ones changed between 15-19 days in 2000 in early sowing time. The average sowing time one of the hybrid ones showed the other one two sowing times longer blooming time. The majority of the hybrid ones was with long blooming time in late sowing(18-22 days). The sowing times has a considerable effect on the time of the blooming on the hybrid ones in the 2001 year. The largest one was the average blooming time of the different sowing times in the case of the average sowing time (19 days), compared to this the late sowing time the average time of the blooming shortened with 4 days. The reaction of the blooming time of the hybrid ones paid attention to sowing time tendentiously in the 2002. The longest blooming times in early sowing we experienced it (19-20 days), the blooming time of the hybrid ones rejected in the average time was shorter with 3 days averagely at this, while 1-5 days proved to be shorter at this - without an exception - the blooming time experienced in the late sowing time. The weather reigning in the period of the blooming in the 2003. year was favourable. The examined hybrids ones showed longest blooming 
time in the early sowing time (17 days), the blooming time experienced in the average sowing time was shorter at this (averagely 14 days), while he was shortest (11 days) in the late sowing time. In 2004, longest blooming times - averagely 22 days - the early sowing we experienced it. The values of the hybrids ones and relative one were scattered around 19 days in the average sowing time. This the unifom already uncharacteristic the late sowing, we experienced the shortest blooming time in this sowing time in all cases. The blooming time of the hybrid ones did not show a big difference in 2008 (17-21 days) and in case of average sowing time (17-20 days), the time of the generative phase shortened significantly in case of late sowing time (12-19 days). In average of evamined years the blooming time smaller differences arose between the different sowing times. In early sowing time was the longer blooming period (15-24 days), in average sowing time this value was 12-23 days, while the late sowing time this value was 10-22 days in our experiments.

Among weather parameters, the high temperature of the second and third decades in April and the higher precipitation of the first decade in April had a significant effect on the shorter emergence time at the earliest sowing time, at these factors we obtained a close correlation value (over 0.7 ) at $1 \%$ significance level. We calculated high correlation value (0.600-0.924) between soil temperatures and emergence time in the second half of April and in the beginning of May. Regarding the precipitation, there was a high correlation value between the quantity of precipitation at the end of April and the long of emergence time, however the long of emergence period increased proportionally with the precipitation. In the case of a later sowing time, we did not experience a significant effect for any weather parameters, but there was a positive correlation between the soil temperature in middle May and the emergence time (Table 1).

Table 1. Correlation coefficients between weather parameters during emergence and the date of emergence at sunflower (Debrecen, 2000-2008)

\begin{tabular}{|c|c|c|c|}
\hline & $\begin{array}{c}\text { early sowing } \\
\text { date }\end{array}$ & $\begin{array}{c}\text { optimal sowing } \\
\text { date }\end{array}$ & $\begin{array}{c}\text { late sowing } \\
\text { date }\end{array}$ \\
\hline \hline Soil temperature in the first decade of April & $-0,540^{* *}$ & - & - \\
\hline Soil temperature in the second decade of April & $-0,523^{* *}$ & $-0,924^{* *}$ & - \\
\hline Soil temperature in the third decade of April & $-0,693^{* *}$ & $-0,815^{* *}$ & - \\
\hline Soil temperature in the first decade of May & $-0,298$ & $-0,600^{* *}$ & $0,465^{* *}$ \\
\hline Soil temperature in the second decade of May & $-0,386^{*}$ & $-0,753^{* *}$ & $0,599^{* *}$ \\
\hline Temperature in the second decade of April & $-0,765$ & $-0,869^{* *}$ & - \\
\hline Temperature in the third decade of April & $-0,912^{* *}$ & $-0,534^{* *}$ & - \\
\hline Temperature in the second decade of May & $-0,405^{* *}$ & $-0,531^{* *}$ & $0,460^{* *}$ \\
\hline Precipitation in the first decade of April & $-0,892^{* *}$ & - & - \\
\hline Precipitation in the third decade of April & 0,261 & $0,901^{* *}$ & - \\
\hline Precipitation in the second decade of May & $0,716^{* *}$ & $-0,102$ & $-0,288$ \\
\hline
\end{tabular}

*correlation at $\mathrm{LSD}_{5 \%}$

*** correlation at $\mathrm{LSD}_{1 \%}$

In the case of the earliest sowing time the tested weather parameters did not affect considerably the number of days before blooming. There was a medium positive correlation between the precipitation in the second and third decades of June and the number of days before blooming. The impact of weather factors, which affect the length of the vegetative period, appeared most strongly at the latest (beginning of May) sowing

475 DOI: $10.1556 /$ Novenyterm.59.2010.Suppl.4 
time, which means that the weather factors heavily affect the length of the vegetative period and the yield in the case of a later sowing time. The precipitation at the beginning of June and July caused a longer vegetative period, but the precipitation of July shortened it (Table 2).

Table 2. Correlation coefficients between weather parameters during the vegetation period and the number of days before blooming at sunflower (Debrecen, 2000-2008)

\begin{tabular}{|c|c|c|c|}
\hline & $\begin{array}{c}\text { early sowing } \\
\text { date }\end{array}$ & $\begin{array}{c}\text { optimal sowing } \\
\text { date }\end{array}$ & $\begin{array}{c}\text { late sowing } \\
\text { date }\end{array}$ \\
\hline \hline Temperature in the first decade of April & $0,583^{* *}$ & - & - \\
\hline Temperature in the second decade of June & $-0,648^{* *}$ & $-0,597^{* *}$ & $-0,880^{* *}$ \\
\hline Temperature in the third decade of June & $-0,522^{* *}$ & $-0,409^{*}$ & $-0,765^{* *}$ \\
\hline Precipitation in the third decade of April & $0,687^{* *}$ & $0,356^{*}$ & - \\
\hline Precipitation in the second decade of May & $-0,365^{*}$ & $-0,484^{* *}$ & $-0,812^{* *}$ \\
\hline Precipitation in the third decade of May & $-0,345^{*}$ & $-0,597^{* *}$ & $-0,830^{* *}$ \\
\hline Precipitation in the first decade of June & $0,657^{* *}$ & $0,377^{*}$ & $0,559^{* *}$ \\
\hline Precipitation in the second decade of June & $0,678^{* *}$ & $0,559^{* *}$ & $0,797^{* *}$ \\
\hline Precipitation in the third decade of June & $0,565^{* *}$ & $0,658^{* *}$ & $0,897 * *$ \\
\hline Precipitation in the first decade of July & 0,062 & 0,238 & $0,509^{* *}$ \\
\hline Precipitation in the second decade of July & $-0,382^{*}$ & $-0,344^{*}$ & $-0,567 * *$ \\
\hline
\end{tabular}

*correlation at $\mathrm{LSD}_{5} \%$

$* *$ correlation at $\mathrm{LSD}_{1 \%}$

\section{Conclusions}

The climatic factors determined the time of the early phonological stages on the sunflower hybrids. The temperature of soil in depth of sowing causes big effect in the time of emergence in different cropyears. The sowing time also have an effect on the period of the emergence. In early sowing time the emergence period longer, in late sowing time this period is shorter in proportion to the conventional or average sowing time (middle of April). The time of the generative period depend on the climatic factors (the temperature and the precipitation during the time of blooming of sunflower).

\section{References}

Beard, B. H. - Geng, S.: 1982. Interrelationship of morphological and economic characters of sunflower. Crop Sciences 22. 4. 817-822.

Belevtsev, D. N. - Gorbachenko, V. D. - Timoshenko, N. Y. - Makarova, V. F.: 1991. Reaction of sunflower hybrids in comparison with varieties to agronomic measures of cultivation. Vestnik Selskokhozyaistvennoi Nauki, Moszkva 2. 103-108.

Belevtsev, D. N. - Gorbachenko, V. D. - Timoshenko, N. Y. - Makarova V. F.: 1990. Sowing date and seed covering depth. Tekhnicheskie Kultury 6. 6-8.

Bilteanu, G. - Roman G. V. - Gheorghies, C. - Nica, O.: 1986. Research on sunflower sowing date in the area of red brown soils on the Romanian Plateau. Productia Vegetala Cereale si Plante Tehnice 38. 2. 1323.

Encseva, V. - Klocskov, B.: 1984. The dinamics of sunflower emergence, flowering and ripening in relation to sowing date and seed treatment. Rastenievdni Nauki 21. 8. 68-79. 


\title{
RESILIENCE OF THE NUTRIENT FRESH-SUPPLY IN THE CASE OF SOME DECIDUOUS TREE SPECIES
}

\author{
Marianna MAROZSÁN ${ }^{1}-E_{\text {va }}$ GAJDOS ${ }^{2}$ - László LÉVAI ${ }^{2}$, \\ ${ }^{1}$ NYÍRERDÖ Nyírség Forestry Corporation, Kótaji u. 29. H-4400 Nyíregyháza, Hungary, \\ marozsan@nyirerdo.hu \\ ${ }^{2}$ Division of Agricultural Botany and Crop Physiology, Institute of Plant Science, Faculty of Agriculture, \\ University of Debrecen
}

\begin{abstract}
Wood ash has been identified as an alternative chemical fertilizer to increase soil fertility and crop production in sustainable farming. This experiment has investigated the effects of wood ash on forest production. The higher dose wood ash treatment has increased the dry matter accumulation and nutrient uptake by plants. Generally, significant positive height growth response of trees to wood ash application has been found. The main problem with utilizing wood ash is its heavy metal content. The solubility of heavy metals is very low, and therefore there is no risk in using wood ash in agriculture and silviculture.
\end{abstract}

Keywords: wood ash, chlorophyll contents, height growth, concentration of elements

\section{Introduction}

Acidification is considered to be an unfavourable process in forest soils. Acidification imposes a risk of damage on plant roots and a subsequent risk of decline in ecosystem productivity. Soil acidification has been defined as leading to decrease in the acid neutralization capacity of the soil (Van Breemen et al., 1984). Acid stress can originate from the acidic deposition of air pollutants, biomass, utilization and the natural biological activity of ecosystems (Ulrich, 1983a; Van Breemen et al., 1984)

Wood ash can be used for counteracting the natural and anthropogenic acidification of forest soils and the loss of nutrients as a consequence of tree harvesting (Åbyhammar et al., 1994; Mälkönen, 1996), and thus nutrients can be fed back to forest soils by means of wood ash fertilization.

\section{Materials and methods}

The experiments have been conducted at the Hajdúböszörmény $40 \mathrm{C}$ (Bodaszőlö) forest blocks of NYÍRERDÖ Forestry Corporation with humic sandy soil. The investigated trees species have been black locust (Robinia pseudoacacia L), oak (Quercus robur L) and poplar (Populus x euramericana Guinier). The experimental plots have had 1,000 sq $\mathrm{m}$ unit areas, and 10 trees have been selected on each plot. The element contents of wood ash and leaves have been measured with ICP, and the relative chlorophyll contents have been studies with the use of SPAD 502 (Minolta). The radial and height growth of trees have also been measured. The wood ash (acacia ash) has come from the Nyírbátor Woodworking Factory of NYÍRERDÖ Forestry Corporation. The following two wood ash doses have been applied to each treatment plot of $20 \times 50 \mathrm{sq}$ m: 5 tons ha $^{-1}$ wood ash and 1 tons $\mathrm{ha}^{-1}$ wood ash. 


\section{Results and discussion}

The physical and chemical properties of wood ash vary significantly in view of several factors. Hardwoods usually produce more ash than softwoods, while the bark and leaves generally produce more ash than the inner woody parts of the tree. One of the main valuable properties of wood ash is its ability to increase the $\mathrm{pH}$ of acid soils. This is due to the presence of calcium, potassium, magnesium. The results are shown in Table 1.

Table 1. Contents of different (essential and potentially toxic) elements in wood ash ( $\left.\mathrm{mg} \mathrm{kg}^{-1}\right)$

\begin{tabular}{|c|c|c|c|c|c|}
\hline Essential Elements & Mean & SD. & Potentially Toxic Elements & Mean & SD. \\
\hline \hline $\mathrm{Ca}$ & $34,3070.0$ & $7,725.0$ & $\mathrm{Al}$ & $4,018.0$ & 150.0 \\
\hline $\mathrm{Mg}$ & $19,378.0$ & 527.0 & $\mathrm{Cd}$ & 3.3 & 0.1 \\
\hline $\mathrm{P}$ & $34,042.0$ & $4,750.0$ & $\mathrm{Ni}$ & 40.7 & 1.2 \\
\hline $\mathrm{Fe}$ & $4,235.0$ & 217.0 & $\mathrm{~Pb}$ & 30.3 & 0.9 \\
\hline $\mathrm{Mn}$ & $11,870.0$ & 411.0 & & & \\
\hline $\mathrm{Cu}$ & 97.7 & 2.9 & & & \\
\hline $\mathrm{Zn}$ & 96.6 & 2.8 & & & \\
\hline
\end{tabular}

Calcium is the most abundant element in wood ash. Ash is also a good source of potassium, phosphorus and magnesium. The wood ash is a good source of a lot of micronutrients needed in trace amounts for adequate plant growth. Wood ash contains few elements that pose environmental problems. Cadmium has caused concerns about environmental risks. Heavy metal concentrations are typically low. Field and greenhouse research confirms the safety and applicability of recycled wood ash on agricultural lands (Lévai et al., 2008).

The effects of different wood ash doses on the growth of trees have also been examined. A faster initial growing phase has been identified in case of saplings. This means the potential reduction of wild damage because the saplings become trees sooner than the wild can eat them. The growth of the experimental plants shows that plants treated with wood ash are more luxuriant, and their horizontal growth is increased in comparison with the controll plants. It is another hindering factor for games to damage the peak of the shoot. In the first year after higher wood ash dose application, the increase in height growth was larger than $1 \mathrm{t} \mathrm{ha}^{-1}$ ash application. The results are shown in Table 2.

Table 2. Effects of different wood ash doses on height growth $(\mathrm{cm}),(\mathrm{n}=10 \pm \mathrm{s} . \mathrm{e}$.)

\begin{tabular}{|c|c|c|c|c|c|c|}
\hline & \multicolumn{4}{|c|}{ Hajdúböszörmény 40 C (Bodaszőlő) } \\
\hline & \multicolumn{3}{|c|}{$\begin{array}{c}\text { Controll } \mathrm{t} \mathrm{ha}^{-1} \\
\text { wood ash }\end{array}$} & \multicolumn{2}{c|}{$\begin{array}{c}1 \mathrm{t} \mathrm{ha}^{-1} \\
\text { wood ash }\end{array}$} \\
\hline & Mean & SD. & Mean & SD. & Mean & SD. \\
\hline \hline Oak & 24.8 & 0.93 & 31.9 & 0.3 & 30.1 & 0.6 \\
\hline Poplar & 133.2 & 0.51 & 147.6 & 1.05 & 137.6 & 1.5 \\
\hline Acacia & 145.6 & 0.46 & 155.9 & 0.7 & 151.1 & 0.4 \\
\hline
\end{tabular}


There exists a close correlation between the chlorophyll contents of leaves and their photosynthetic activity. Therefore, it has been reasonable to examine the effects of different treatments on the relative chlorophyll contents of the leaves. More intensive photosynthesis leads to more organic matter. Figure 1 shows changes in the relative chlorophyll contents of leaves as an outcome of various treatments.

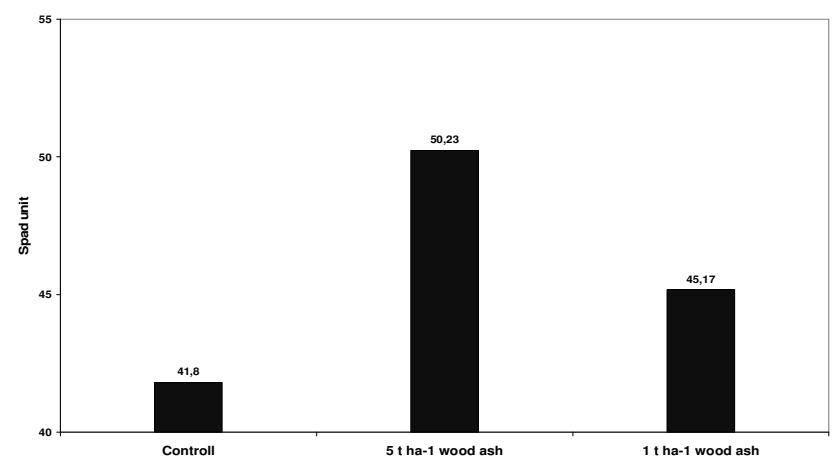

Figure 1. Effects of different dose wood ash on the relative chlorophyll contents of leaves (Spad unit)

There is no correlation between the amount of the utilized wood ash and changes in the elements. At the same time, much more plant mass has grown on areas treated with wood ash. There have been remarkable changes detected at poplars as compared with the controll. In this case, the $\mathrm{Ca}$ and $\mathrm{Cd}$ contents have become tripled, the $\mathrm{Fe}$ and $\mathrm{P}$ contents have increased by $70 \%$, while the $\mathrm{Mg}$ and $\mathrm{Na}$ contents have become $30 \%$ larger, which latter changes explain the higher growing intensity. The amounts of $\mathrm{K}$ and $\mathrm{Al}$ are similar to the controll values, and the potential reason is that the alkaline effect of wood ash results in reduced uptake of $\mathrm{Al}$, yet the question is why the level of $\mathrm{Cd}$ has increased. One probable answer is that the ion uptake mechanism of poplar filters the usable nutrients selectively, which calls for further searches. The results are shown in Table 3.

Table 3. Contents of the examined elements in the fully developed leaves of oak, poplar, acacia plantation, treated with $5 \mathrm{t} \mathrm{ha}^{-1}$ wood ash and $1 \mathrm{t} \mathrm{ha}^{-1}$ wood ash Bodaszölő region $\left(\mathrm{mg} \mathrm{kg}^{-1}\right)$.

The samples were taken on 09.09.2009 $(n=4)$

\begin{tabular}{|c|c|c|c|c|c|c|c|c|c|}
\hline \multicolumn{9}{|c|}{ Hajdúböszörmény 40 C (Bodaszőlö) } \\
\hline & \multicolumn{3}{|c|}{ Controll } & \multicolumn{3}{c|}{$5 \mathrm{t} \mathrm{ha}^{-1}$ wood ash } & \multicolumn{3}{c|}{$1 \mathrm{t} \mathrm{ha}^{-1}$ wood ash } \\
\hline Elements & Oak & Poplar & Acacia & Oak & Poplar & Acacia & Oak & Poplar & Acacia \\
\hline \hline $\mathrm{Al}$ & 165.1 & 185.5 & 87.3 & 168.4 & 221.3 & 76.9 & 165.3 & 216.3 & 74.6 \\
\hline $\mathrm{Ca}$ & $7,484.3$ & $13,337.5$ & $15,315.2$ & $8,774.0$ & $18,179.0$ & $15,996.5$ & $9,802.5$ & $14,575.5$ & $19,025.5$ \\
\hline $\mathrm{Cd}$ & 0.2 & 1.0 & 0.5 & 0.3 & 1.3 & 0.8 & 0.4 & 1.0 & 0.6 \\
\hline $\mathrm{Fe}$ & 169.7 & 238.9 & 105.0 & 142.6 & 212.2 & 104.7 & 171.8 & 189.8 & 108.0 \\
\hline $\mathrm{K}$ & $7,886.8$ & $11,683.0$ & $14,604.5$ & $8,186.0$ & $12,443.0$ & $13,376.0$ & $13,391.0$ & $11,370.0$ & $15,339.0$ \\
\hline $\mathrm{Mg}$ & $1,682.0$ & $2,980.0$ & $2,158.7$ & $1,192.5$ & $3,271.0$ & $2,214.7$ & $1,957.6$ & $3,199.5$ & $2,454.6$ \\
\hline $\mathrm{Na}$ & 596.2 & $1,164.0$ & $1,381.6$ & 643.7 & $1,080.0$ & 928.9 & 839.1 & $1,238.9$ & $1,284.7$ \\
\hline $\mathrm{P}$ & $1,577.0$ & $2,459.5$ & $2,718.8$ & $1,784.0$ & $2,637.5$ & $2,267.5$ & $2,880.4$ & $2,130.0$ & $1,980.5$ \\
\hline
\end{tabular}




\section{Conclusions}

The only way to ensure the long-term progress in the life quality of society is that the social and economic development should go hand in hand with the protection of our natural resources with an appropriate environmental protection strategy. The use of wood ash is line with the requirement for environmental friendly nutrient supply. Wood ash application potentially means increased availability of nutrients for the tree in an environmental friendly way towards the maintenance of forestry soils where the cation cycle is opened. The major reported adverse ecological impacts involve acidophilic ecosystems, particularly the constituent bryophyte, soil bacteria and ectomycorrhizal communities.

\section{Acknowledgements}

I would like to say many thanks to NYÍRERDO Nyírség Forestry Corporation for help and the examined wood ash.

\section{Reference}

Åbyhammar,T. - Fahlin, M. - Nilsson, A. - Henfriendsson ,U.: 1994. Askåterföringssytem. Delprojekt 1:

Tekniker och möjligheter.(Production of wood ash.Techniques and possibilities). NUTEK R 194:3.41.(In Swedish with English summary).

Lévai, L. - Veres, Sz. - Bákonyi, N. - Gajdos, É.: 2008. Can wood ash and bio-fertilizer play a role in organic agriculture? Agronomski Glasnik 3/2008, Croatia, 263-272.

Mälkönen, E.: 1996. Tuhka kangasmetsien lannoitteena (Wood ash as forest fertilizer on mineral soils). In:Finér,L. - Leinonen, A. - Jauhiainen, J. (Eds.), Puun ravinteet tuhkana takaisin metsään? The Finnish Forest Research Institue, Metsäntutkimuslaitoksen tiedonantoja 599:21-26.(In Finnish)

Ulrich, B.: 1983a. A concept of forest ecosystem destabilization and of acid deposition as driving force for destabilization. In: B. Ulrich - J. Pankrath (Editors), Effects of Accumulation of Air Pollutants in Forest Ecosystems. Proc. Workshop. 16-19 May 1982 Göttingen. Riedel, Dordrecht, The Netherlands 1-29.

Van Breemen, N. - Driscoll, C.T. - Mulder, J.: 1984. Acidic deposition and internal proton sources in acidification of soils and waters. Nature (London), 307: 599-604. 


\title{
RESILIENT CHANGES OF COLORATION AND DENSITY OF TURF UNDER MOWING AND INFLUENCE OF DIFFERENT FERTILISER USE
}

\author{
Balázs György KULIN - Balázs PÁZMÁNDI - László SZEMÁN
}

Department of Grassland Management, Crop Science Institute, Szent István University, 2103 Gödöllő Páter

K. u. 1. e-mail: kulin.balazs@mkk.szie.hu

\begin{abstract}
Basically three things can regulate the growing of grass the water the nutrient and temperature. The summer of 2008 was very wet in July: $165 \mathrm{~mm}$ rainwater compare with 2007 which was drier July $19 \mathrm{~mm}$ rainwater were fallen at the experimental site in Hungary. We made the experiment on a park type grass, which took place in the botanical garden of Szent István University. On these plots there is no sited irrigation system, so the rainwater is the most resilient influencing element. Therefore the fertilizer anticipated rate of use changed and shows significant variance on the green mass and the coloration. In July 2008 the total green mass was $33,8 \mathrm{~kg}$ in July 2007 it was $25,5 \mathrm{~kg}$. The less nitrogen uptake affects on the density and allows space for weeds. Accordingly the bristlegrass (Setaria), hairy crabgrass (Digitaria sanguinalis) got enough heat to germinate and appeared on the plots.
\end{abstract}

Keywords: turf, mower, nutrient, coloration of turf

\section{Introduction}

The beautiful green turf is a determinative element in the garden (Hessayon, 2002). Colour is an important constituent of turfgrass cultivar appearance which is often described subjectively with visual scores (Shildrick et al., 1985; Gooding et al.1989). Individual evaluations of plant leaf color, however have been shown to vary wieldy amongst different assessors (Tanno et al., 1982), and the lack of standardisation can make it difficult to compare result from different seasons and experiments. Mowing is a basic cultural technique necessary for turf production. Good mowing practices enhance the aesthetic values of a turfgrass facility and contribute, as much as any single factor, to the well-groomed appearance of turfgrass. Mowing is necessary to develop and to maintain a satisfactory playing surface on those turf sites used for recreational activity. Mowing restricts root development, but proper clipping of adapted grasses stimulates development of tillers and shoots either from the crown or from basal buds of rhizomes and stolons. Thus, proper mowing encourages more rapid coverage of newly established turfgrass and promotes density of established turf. Also, since grasses exhibit basal as opposed to terminal growth, mowing serves to check the growth of weeds.

Plants not grazed could reach generative phase, which supports grassland biodiversity (Szemán et.al., 2008). Evaluation of turfgrass nitrogen $(\mathrm{N})$ status is important for determining proper rates and timing of $\mathrm{N}$ fertilizer applications. Although analytical procedures are available for direct determination of foliar $\mathrm{N}$ concentrations, collection and sample preparation are time consuming and analysis can be expensive if numerous determinations are desired. Because of these limitations, practitioners and researchers frequently use visual assessments of turfgrass colour as an indirect measure of $\mathrm{N}$ status. Several authors have observed associations between foliar $\mathrm{N}$ concentrations and the colour of turfgrasses and some crop plants (Landschoot and Waddington 1987; Schepers et al. 1992; Takebe and Yoneyama 1989; Wood et al. 1992). 
The National Turfgrass Evaluation Program (NTEP) is a leader in evaluation of turfgrass species. The turfgrass industry in the USA and many parts of the world rely heavily on NTEP data. The information collected and summarized by NTEP is currently requested in thirty countries. The quality and scientific merit of NTEP data is extremely important. However, the evaluation of turfgrass species and cultivars is a difficult and complex issue. Furthermore, turfgrass evaluation is generally a subjective process based on visual estimates of factors, like genetic colour, stand density, leaf texture, uniformity and quality. These factors cannot be measured in the same way as other agricultural crops. Turfgrass quality is not a measure of yield or nutritive value. Turfgrass quality is a measure of aesthetics (i.e. density, uniformity, texture, smoothness, growth habit and colour), and functional use. The most common way of assessing turfgrass quality is a visual rating system that is based on the turfgrass evaluator's judgement.

Turfgrass Quality is based on 9 being outstanding or ideal turf and 1 being poorest or dead. A rating of 6 or above is generally considered acceptable. A quality rating value of 9 is reserved for a perfect or ideal grass, but it also can reflect an absolutely outstanding treatment plot. The NTEP requires quality ratings on a monthly basis. Quality ratings take into account the aesthetic and functional aspects of the turf. Quality ratings are not based on colour alone, but on a combination of colour, density, uniformity, texture, and disease or environmental stress (Kevin, 2004).

Lolium.perenne, like all pasture species, is adapted to defoliation, fertilization, and regrowth cycles that quickly alter carbon source and sink capacities. In the Swiss FACE experiment, $L$. perenne was managed as a frequently cut pasture crop at both low- and high-N supply (Hebeisen, Lüscher and Nösberger 1997).

\section{Materials and methods}

Turf grass quality is visually evaluated by human assessors based on a scale of 1 (poorest, the grass is dead) to 9 (ideal, the grass is of outstanding quality) using a common assessment method. A rating of 6 or greater indicates adequate turf quality. Because this evaluation practice is subjective, individual biases are inevitable and lead to some level of inconsistency, even among the most highly trained observers. This variability led to the need for a more objective evaluation technique.

Researchers have developed the Normalized Difference Vegetative Index (NDVI). The Field Scout TCM 500 "NDVI" Turf Color Meter measures reflected light from turf grass in the red $(660 \mathrm{~nm})$ and near infrared $(850 \mathrm{~nm}-\mathrm{NIR})$ spectral bands.

Normalized Difference Vegetative Index (NDVI) is defined as:

NDVI $=($ NIR - Red $):($ NIR + Red $)$ Where:

NDVI $=$ Normalized Difference Vegetation Index

NIR $=$ Reflectance in the band of $850+5 \mathrm{~nm}$

Red $=$ Reflectance in the band of $660+5 \mathrm{~nm}$

The Grass Index has a scale of 1 to 9 and approximates the rating a visual observer would assign to the turf grass. This provides a more objective value for this, generally, very subjective parameter. The Grass Index is calculated as follows:

Grass Index $=($ NDVI X 6.6) +2.26

The experimental site and the plots are located at the Botanical garden of Szent István University. It has sown in fall 2000 from a "park" type mixture $\left(40 \mathrm{~g} / \mathrm{m}^{2}\right)$ which contains: rye-grass (Lolium perenne):20\%, red fescue (Festuca rubra) + (Festuca 
heteophilla Lam.): 70\%, meadow-grass (Poa pratensis) 10\%. The experiment placed on fourteen parcels, seven were cut by rotary mower and seven were cut by push reel mower. The Turf was sustained by regular mowing in the rhythm of growing grass. The height of turf in case of rotary mower was $50 \mathrm{~mm}$, while in case of reel mower it was 32 $\mathrm{mm}$. Mowing is an important tool for the management and restoration of prairie vegetation. Although mowing is largely non-selective, varying the time of mowing can be used to target specific species (Hover and Bragg 1981; Mitchell et al. 1996). Only 30 $\%$ of the vegetation was removed by mowing so at least 2-3 of the leaves were always left on the blades of grass. This is the rule of one third. Every time in each parcel mowing was performed by a grass collecting mower. Yield was measured in every parcel at times and regularity listed in the table while weight of green mass was indicated in the table and illustrated in the diagram. Watering happened occasionally when the stress of droop appeared.

\section{Results and discussion}

Because chlorophyll absorbs the red band $(660 \mathrm{~nm})$ of incoming radiation, the reflectance at that wavelength is relatively low due to the strong absorption of the light by the plant pigments. The high reflectance in the NIR $(850 \mathrm{~nm})$ band is caused by the cellular structure of the plant leaves, particularly the spongy mesophyll leaf structure. As we can see figure 1 the used on each fertilizers were: Ammonium-nitrate $34 \%(150 \mathrm{~g}$ were used), Sierrablen 5-6months N28+P5+K5+Fe (50g were used), Sierrablen 8-9 $\mathrm{N} 27+\mathrm{P} 5+\mathrm{K} 5+\mathrm{Fe}\left(60 \mathrm{~g}\right.$ were used). One plot was $10 \mathrm{~m}^{2}$ The control plots were given the poorest green colour around 7,05 the greenest plots were the Sb56 treated over 7,35.

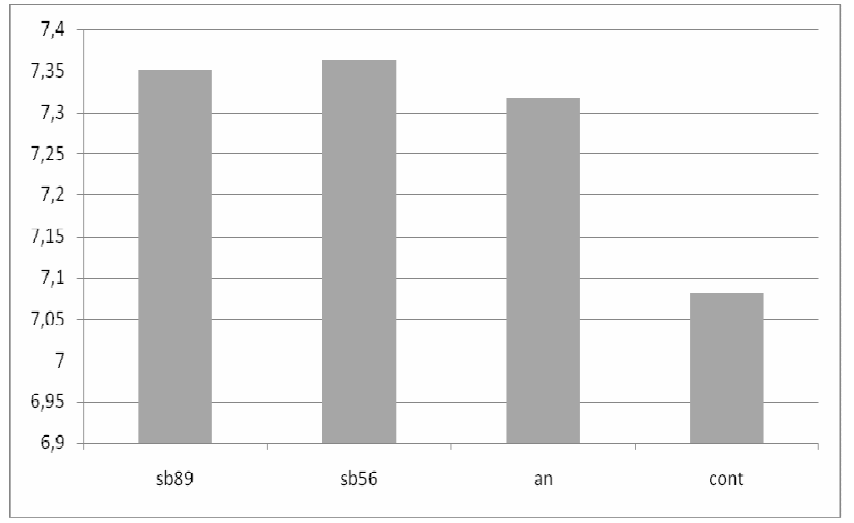

Figure 1. Grass index averages on turf stand

\section{Conclusions}

In 2009 the plots did not show significant differences in grass index because the regular and control released fertilisers were used correctly. Regular fertiliser was spread three times so the grass had the possibility to achieve the nitrogen when it was needed. Control released fertilizers was spread once. These kind of fertilisers have a resin husk where the dissolved nutrients can diffuse in case of the level of humidity is lower in the 
outside than it is inside. The control plots had given fertiliser only in autumn therefore the grasses on these plots could reach minimally sufficient level of nitrogen.

\section{Reflection (\%)}

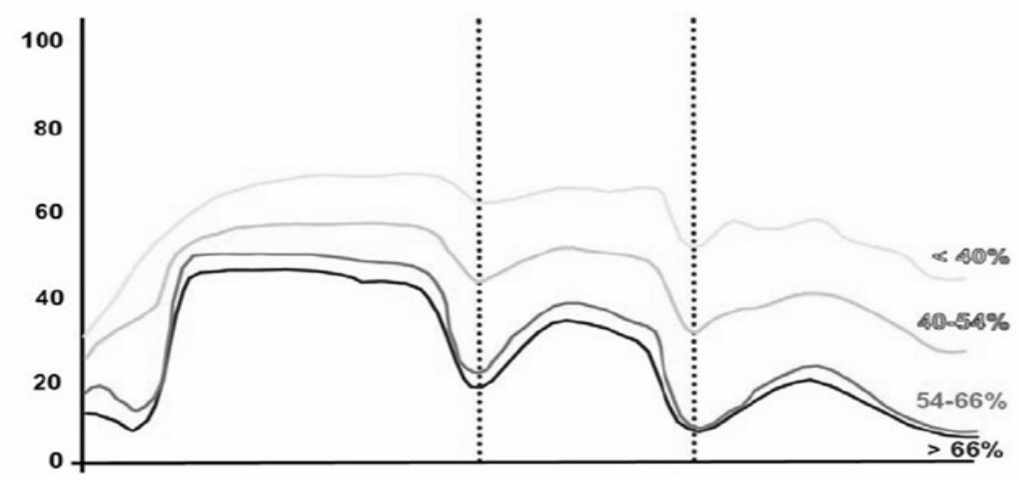

Wavelenght $(\mu \mathrm{m})$

Figure 2. Spectral Reflection on leaf. The numbers shows the water contains in \%, the vertical lines shows the water spectral absorption line.

\section{References}

Gooding, M.J. - Newel, A.J. - Peel, C.H.: 1989. Characteristics of different Poa pratensis and Phleum spp. cultivars under close mowing. J. Sports Turf Res. Inst. 65, 102-108.

Hebeisen T. - Lüscher A. - Nösberger J.: 1997a. Effects of elevated atmospheric CO2 and nitrogen fertilisation on yield of Trifolium repens and Lolium perenne. Acta Oecologica 18, 277-284.

Hessayon, D. G.: 2005. The Lawn Expert, Transworld Publishers, London.

Hover, E.I. - Bragg, T.B.: 1981. Effect of season of burning and mowing on an eastern Nebraska StipaAndropogon prairie. Am. Midl. Nat. 105:13-19.

Kevin N. Morris: National Turfgrass Evaluation Program, Inc.: . National Perennial Ryegrass Test 2008 Data Progress Report NTEP No. 09-11.

Landschoot, PJ. - Waddington, D.V.: 1987. Response of turfgrass to various nitrogen sources. Soil Science Society of America Journal 51, 225-230.

Mitchell, R.B. - Masters, R.A. - Waller, S.S. - Moore, K.J. - Young, L.J.: 1996. Tallgrass prairie vegetation response to spring burning dates, fertilizer, and atrazine. J. Range Manage. 49: 131-136.

Schepers, J.S. - Francis, D.D. - Vigel, M. - Below, F.E.: 1992. Comparison of corn leaf nitrogen concentration and chlorophyll meter readings. Communications in Soil Science and Plant Analysis 23, 2173-2187.

Shildrick, J.P. - Peel, C.H.: 1982. Preliminary trials of meadow-grass (Poa) species, J Sports Turf Res. Inst. 61, 111-131.

Szemán L. - Bajnok M. - Harcsa M. - Prutkay J. - Zsigó G.: 2008. The effect of soil nutrients and animal excrete on grassland biodiversity improvement 36.:1935-1938.

Takebe, M. - Yoneyama, T.: 1989. Measurement of leaf color scores and its implication to nitrogen nutrition of rice plants. Japan Agricultural Research Quarterly 23, 86-93.

Tanno, F. - Takeda, T. - Kai, K.: 1982. Research related to nutritional diagnosis of and predictive technology for wet-land rice. No 4. report: Study of a nutritional diagnosis method that uses leaf colour. Fukushima Agricultural Experimental Research report 21, 61-72

Wood, C.W. - Reeves, D.W. - Duffield, RR. - Edmisten, K.L.: 1992. Field chlorophyll measurements for evaluation of corn nitrogen status. Journal of Plant Nutrition 15: 487-500. 


\title{
ROLE OF AGRONOMIC TRAITS AND DISEASES IN RESILIENCE OF HYBRIDSPECIFIC SUNFLOWER PRODUCTION
}

\author{
András SZABÓ \\ Institute of Crop Sciences, Agronomy Faculty, Centre of Agricultural Science and Engineering, University of \\ Debrecen, H-4032 Debrecen, Böszörményi str. 138. e-mail: szabo@agr.unideb.hu \\ Abstract: There are great differences in the yielding capacity, yield stability, stalk bending parameters and \\ disease resistance of the modern sunflower hybrids in practical growing. Hybrids respond differently to the \\ changes in the environmental parameters and the applied agriculture elements. To determine the optimum \\ yield and yield safety a joint study of the three factors is necessary (study of the genotype $\mathrm{x}$ environment \\ interactions). In a field experiment, we studied the stalk bending parameters, phytopathological factors \\ (infection by Sclerotinia, Diaporthe, and head diseases) and yielding ability of 13 sunflower hybrids at \\ different plant density levels and sowing times on chernozem soil in the vegetation season of 2009. Based on \\ the results, we concluded that by delaying sowing time the diseases infections were reduced, however, the \\ maximum yield was obtained at the average sowing time at mid-April in the average of hybrids $\left(4717 \mathrm{~kg} \mathrm{ha}^{-1)}\right.$. \\ When an early sowing time (end of March) was applied, a greater yield reduction was observed than at a late \\ sowing time at the beginning of May $\left(3712 \mathrm{~kg} \mathrm{ha}^{-1}, 4228 \mathrm{~kg} \mathrm{ha}^{-1}\right)$. The plant density response of the tested \\ hybrids was also significant. An increasement in plant density from 35000 plants ha $^{-1}$ to 65000 plants ha $^{-1}$ \\ resulted higher disease infections and accordingly in a deterioration of stalk bending. For most of the hybrids \\ studied (7 hybrids) the optimum plant density was 55000 plants $\mathrm{ha}^{-1}$. The yield of hybrids at different plant \\ densities ranged from $3350 \mathrm{~kg} \mathrm{ha}^{-1}$ to $6045 \mathrm{~kg} \mathrm{ha}^{-1}$.
}

Keywords: sunflower, plant density, sowing time, infection, yield

\section{Introduction}

Oil plants, including sunflower, have an increasing importance in Hungarian crop production. (Bíró and Pepó, 2008).

After cereals and maize, sunflower has the largest growing area among crops produced in Hungary (Lehoczky and Sárkány, 2007; Göksoy and Turan, 2007).

Sunflower hybrids that can be successfully grown commercially have to fulfil the requirements of yield safety, yield capacity and quality at the same time. Unlike in other crops, yield safety is the most important quality among these three factors (Pepó et al., 2003). Due to its favourable adaptive capacity, sunflower can adapt well to extreme year effects (Bíró and Pepó, 2008).

Sunflower can adapt well to the Hungarian climate conditions, it can be grown well in Hungary. The application of the proper agrotechniques has a decisive impact on the success of growing. The most favourable yields were achieved at around 40 thousand plants/ha ${ }^{-1}$ taking the average of the different genotypes and years on chernozem soil in the Hajdúság region. The increase of plant density (above 50-55 thousand plants/ha ${ }^{-1}$ ) is a cost-increasing and yield-reducing factor (Pepó et al., 2002).

Based on his experiments, Zsombik (2008) found that the testes sunflower hybrids gave the highest yields at an early sowing date $\left(3913 \mathrm{~kg} \mathrm{ha}^{-1}\right)$, yields were lower at the average sowing date $\left(3865 \mathrm{~kg} \mathrm{ha}^{-1}\right)$, while the lowest yields were obtained at the late sowing date in May (3422 kg ha $\left.{ }^{-1}\right)$. According to Pepó and Szabó, (2005), the response of sunflower hybrids to increasing plant density is influenced both by the year and the genotype. Increasing plant density will result in an increasing pathogen pressure. 


\section{Materials and methods}

The experiment was carried out at the Látókép Experimental Station of the University of Debrecen, Centre for Agricultural Sciences and Engineering, Farm and Regional Research Institute in the Hajdúság in 2009. The experimental plots were set up in a randomized block design in four repetitions. In the experiment, we tested 13 modern sunflower hybrids. Four different plant densities were applied (35000-65000 plants ha ${ }^{-1}$ ) increasing in 10000 plants ha $^{-1}$ steps. In the experiment, the sunflower hybrids were sown at early (end of March), average (mid-April) and late (beginning of May) sowing times. The yields were standardized for a moisture content of $8 \%$.

\section{Results and discussion}

The realized yield of modern sunflower hybrids is influenced by several factors. The climate requirements of sunflower are different from those of Hungary's prevailing crops. Due to its strong root system, good drought tolerance and great phytopathological sensitivity, outstanding yields can be expected in dry years. In addition to these, the application of a sowing technology fitted to the hybrid and the growing region - which can be influenced as opposed to the year - can be the most effective tool for maximizing yields. Plant density and sowing time have a significant influence on the harvested yield, the degree of which varies with the hybrid. The weather of 2009 can be described by an alternation of dry and very wet periods. The sunflower hybrids tolerated these effects well.

The stem firmness parameters of the hybrids varied greatly. The degree of stalk bending was lower than the average of hybrids $(6.3 \%)$ for nine hybrids and higher than the average for four hybrids. The greatest stalk bending taking the average of the different plant densities was observed in the hybrids ES Primis (10.6\%) and Ollimi (11.4\%). The lowest average stalk bending values were measured in the hybrids NK Sinfoni $(3.0 \%)$ and NX $63732(3.9 \%)$. The average value of stem breaking under the head was the highest in the hybrids Petunia $(7.4 \%)$ and Ollimi. In most of the hybrids, the ratio of broken heads was low, under $4 \%$. The most favourable values were observed in the hybrids PR64H42 (1.9\%), SF Acton (2.2\%) and NX 63732 (2.3\%). An increase in plant density resulted in the deterioration of stem firmness parameters. An increase in plant density increased also the phytopathological pressure by Diaporthe helianthi, Sclerotinia sclerotiorum and head diseases. Infection by head diseases was the highest in the hybrids Ollimi (22.1\%), PR64H42 (19.9\%), and Petunia (18.1\%). The lowest values were measured for the hybrids NX 63762 (8.1\%) and NK Kondi. Hybrids most sensitive to infection by Sclerotinia sclerotiorum were NK Simfoni (2.9\%) and PR64H62 (2.8\%). The lowest damages were observed in the hybrids Paraisol (1.1\%), NK Kondi (1.4\%), SF Acton (1.5\%) and NK Neoma (1.6\%). The sensitivity of the tested hybrids to Diaporthe helianthi varied with the genotype. The highest infections were observed in the hybrids Ollimi (22\%), ES Artimis (22\%), and ES Petunia (18\%). The most resistant hybrids were SF Acton (10\%), DKF 3333 (12\%), NK Neoma (13\%), ES Primis (13\%) and Paraisol (13\%) (Table 1). 
Table 1. Pathological parameters of sunflower averaging plant density levels in 2009 (Debrecen-Látókép, 2009)

\begin{tabular}{|c|c|c|c|c|c|c|c|c|c|c|c|c|c|}
\hline & 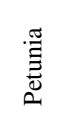 & $\begin{array}{l}: \vec{z} \\
\overline{0} \\
\underline{y} \\
\ddot{Z}\end{array}$ & $\begin{array}{l}\tilde{\Xi} \\
\tilde{D} \\
\ddot{Z} \\
\text { z } \\
z\end{array}$ & 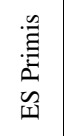 & 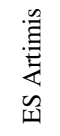 & 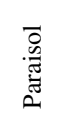 & $\begin{array}{l}\overline{8} \\
8 \\
0 \\
v \\
z\end{array}$ & 槀 & 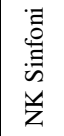 & $\begin{array}{l}\text { N } \\
\hat{\sigma} \\
x \\
z\end{array}$ & $\begin{array}{l}m \\
m \\
m \\
\dot{v} \\
\underline{a}\end{array}$ & 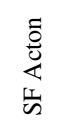 & 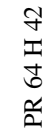 \\
\hline \multicolumn{14}{|c|}{ (\%) average of plant density } \\
\hline Stalk bending (\%) & 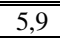 & $5,5,8$ & 4,6 & 10,6 & 6,2 & 8,5 & $\overline{5,6,6}$ & 11,4 & 3,0 & 3,9 & $7,7,3$ & $\overline{44,2}$ & $\overline{44,6}$ \\
\hline Broken Heads (\%) & 7,4 & 3,5 & 4,3 & 3,6 & 2,7 & 4,1 & 2,6 & 6,2 & 3,9 & 2,3 & 2,9 & 2,2 & 1,9 \\
\hline Head diseases (\%) & 18,1 & 9,5 & 13,5 & 15,2 & 13,8 & 11,5 & 12,8 & 22,1 & 12,7 & 8,1 & 11,2 & 11,7 & 19,9 \\
\hline Sclerotinia $(\%)$ & 2,4 & 1,4 & 1,6 & 1,8 & 2,4 & 1,1 & 1,9 & 2,2 & 2,9 & 2,4 & 1,9 & 1,5 & 2,8 \\
\hline Diaporthe (\%) & 18,0 & 14,0 & 13,0 & 13,0 & 22,0 & 13,0 & 14,0 & 22,0 & 15,0 & 17,0 & 12,0 & 10,0 & 14,0 \\
\hline
\end{tabular}

Yield of sunflower hybrids was also greatly influenced by plant density. The hybrids responded differently to the increase of plant density. The highest yields were obtained at plant densities of 45000-65000 plants ha $^{-1}$ varying with the hybrid. The highest yields were obtained at a low plant density of 45000 plants ha $^{-1}$ in the hybrids NK Neoma (4828 kg ha-1), and NX 63732 (4926 kg ha ${ }^{-1}$ ). The yield of the hybrids ES Artimis (4326 $\left.\mathrm{kg} \mathrm{ha}^{-1}\right)$, Paraisol $\left(5270 \mathrm{~kg} \mathrm{ha}^{-1}\right)$ and Ollimi $\left(4926 \mathrm{~kg} \mathrm{ha}^{-1)}\right.$ was the highest at the plant density of 65000 plants ha ${ }^{-1}$. Maximum yields in the other tested hybrids were achieved at the plant density of 55000 plants $\mathrm{ha}^{-1}$. Taking the average of the plant densities, hybrids with the highest yields were NK Kondi $\left(5714 \mathrm{~kg} \mathrm{ha}^{-1}\right)$, SF Acton (4896 kg ha- ${ }^{-1}$ ) and Paraisol (4832 $\mathrm{kg} \mathrm{ha}^{-1}$ ). The lowest yields were realized in the hybrids ES Artimis (3886 kg ha ${ }^{-1}$ ) and PR64H32 (3914 kg ha ${ }^{-1}$. Increasing plant density resulted in a reduction in the productivity of hybrids due to the increasing phytopathological pressure. The lowest yield was obtained at the plant density of 35000 plants $^{-1}$ (Table $^{-1}$ 2).

Table 2. Yields of sunflower hybrids according to different plant density levelss in 2009 (Debrecen-Látókép, 2009)

\begin{tabular}{|c|c|c|c|c|c|c|c|c|c|c|c|c|c|c|}
\hline 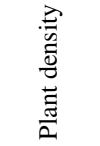 & $\begin{array}{l}. \stackrel{\pi}{\Xi} \\
\stackrel{\Xi}{0} \\
.\end{array}$ & 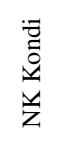 & 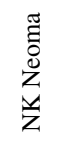 & 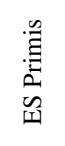 & 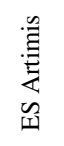 & 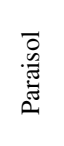 & 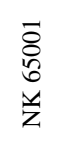 & $\stackrel{\cdot \Xi}{\bar{\Xi}}$ & 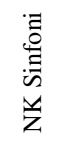 & 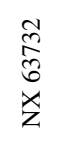 & $\begin{array}{l}\text { mે } \\
\text { ले } \\
\frac{\omega}{\omega}\end{array}$ & 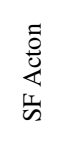 & 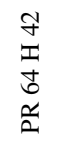 & 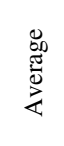 \\
\hline Plant/ha & \multicolumn{14}{|c|}{$\mathrm{kg} \mathrm{ha}^{-1}$} \\
\hline 35000 & 4013 & 5451 & 4430 & 4243 & 3350 & 4055 & 4441 & 3676 & 4227 & 4515 & 4120 & 4663 & 3586 & 4213 \\
\hline 45000 & 4515 & 5802 & 4828 & 4671 & 3889 & 4861 & 4532 & 4230 & 4803 & 4926 & 4441 & 4814 & 4145 & 4651 \\
\hline 55000 & 4680 & 6045 & 4430 & 4852 & 3978 & 5140 & 4990 & 4681 & 4980 & 4810 & 4959 & 5296 & 4050 & 4838 \\
\hline 65000 & 4587 & 5559 & 4408 & 4770 & 4326 & 5270 & 4902 & 4926 & 4836 & 4702 & 4647 & 4811 & 3874 & 4740 \\
\hline LSD5\% & \multicolumn{13}{|c|}{$310 \mathrm{~kg} \mathrm{ha}^{-1}$} & \\
\hline Average & 4449 & 5714 & 4524 & 4634 & 3886 & 4832 & 4716 & 4378 & 4712 & 4738 & 4542 & 4896 & 3914 & 4610 \\
\hline
\end{tabular}

As a result of increasing plant density, yield increased up to 55000 plants ha ${ }^{-1}$ (4838 kg $\left.\mathrm{ha}^{-1}\right)$, however, yield reduction due to the increase of plant density was observed at the plant density of 65000 plants ha ${ }^{-1}\left(4740 \mathrm{~kg} \mathrm{ha}^{-1}\right)$.

The selection of the proper sowing time of the sunflower hybrid also greatly contributes to achieving a maximum yield and to reducing the damage caused by phytopathological factors. At an early sowing, higher occurrence of and damage by pathogens and 
consequently a reduced stem firmness can be expected. In the experiment, the lowest infestation and the best stem firmness were observed at the third (late) sowing date. Maximum yield was obtained at the average sowing date for all the tested hybrids. Hybrids with the highest cropping capacity were NK Kondi $\left(5221 \mathrm{~kg} \mathrm{ha}^{-1}\right)$ and NK Simfoni (4667 kg ha ${ }^{-1}$ ) (Table 3).

Table 3. Yields of sunflower hybrids according to different sowing times in 2009 (Debrecen-Látókép, 2009)

\begin{tabular}{|c|c|c|c|c|c|c|c|c|c|c|c|c|c|c|c|}
\hline$\stackrel{\infty}{\leftrightarrows}$. & 营 & $\begin{array}{l}ت \bar{Z} \\
\tilde{0} \\
v \\
y \\
y\end{array}$ & 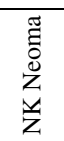 & 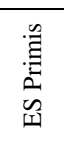 & 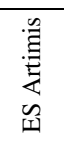 & 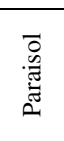 & $\begin{array}{l}\overline{8} \\
8 \\
6 \\
\ddot{z} \\
z\end{array}$ & 泀 & $\begin{array}{l}\tilde{\Xi} \\
\stackrel{0}{\Xi} \\
\tilde{n} \\
\text { z }\end{array}$ & 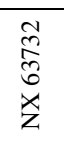 & $\begin{array}{l}m \\
m \\
m \\
m\end{array}$ & $\begin{array}{l}\frac{5}{0} \\
\frac{0}{4} \\
\frac{1}{2}\end{array}$ & 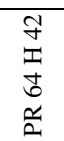 & 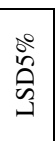 & $\begin{array}{l}8 \\
\frac{8}{5} \\
\frac{\pi}{0} \\
\frac{2}{4}\end{array}$ \\
\hline & & & & & & & & & & & & & & 300 & \\
\hline & & 90 & & & 382 & & & & & & & & & 40 & \\
\hline 5. & 220 & 16 & 584 & 4507 & 3664 & 10 & 44 & 3506 & 45 & 41 & 45 & 72 & 0 & 379 & 4228 \\
\hline Aver & 984 & 221 & 4027 & 4423 & 3464 & 4399 & 4298 & 3714 & 4667 & 4317 & 4482 & 431 & 3534 & 391 & 4219 \\
\hline
\end{tabular}

\section{Conclusions}

Enhancement of yield safety in commercially grown, modern sunflower hybrids necessitates the optimization of agrotechnical factors. Sowing technology can greatly compensate for the unfavourable year effect and can contribute to performing a more successful crop protection and to maximizing yields. Plant density and sowing time are cornerstones of the agrotechniques. Increase in plant density can result in a higher disease pressure, especially in rainy years. In the dry year of 2009, the plant density of 55000 plants $\mathrm{ha}^{-1}$ proved to be optimal $\left(4838 \mathrm{~kg} \mathrm{ha}^{-1}\right)$. Taking the average of hybrids, the maximum yield was obtained at the sowing date of mid-April in $2009\left(4717 \mathrm{~kg} \mathrm{ha}^{-1}\right)$. Earlier or later sowing dates both resulted in yield depression $\left(3712 \mathrm{~kg} \mathrm{ha}^{-1}, 4228 \mathrm{~kg} \mathrm{ha}^{-}\right.$ $\left.{ }^{1}\right)$. Damage caused by the pathogens gradually decreased with delaying sowing time. The response of hybrids to changes in plant density and sowing time varied with the genotype.

\section{References}

Bíró J. - Pepó P.: 2008. Néhány eltérő genotípusú napraforgó (Helianthus Annuus L.) hibrid trágyareakciójának vizsgálata. Növénytermelés. 57: 2. 149-157.

Göksoy A. T. - Turan Z. M.: 2007. Correlations and path analysis of yield components in synthetic varieties of sunflower (Helianthus annuus L.). Acta Agronomica Hungarica, 55: . 3. 339-345.

Lehoczky É. - Sárkány E.SZ.: 2006. Influence of preemergence herbicides on the early growth of sunflower hybrids. Cereal Research Communications, 34: 1. 1033.-1036.

Pepó P. - Szabó A.: 2005. Effect of agrotechnical and meeorological factors on yield formation in sunflower production. Cereal Research Communications. 33: 1. 49-52.

Pepó P. - Borbélyné, H.É. - Zsombik, L.: 2002. A napraforgó-termesztés agrotechnikai fejlesztési lehetőségei. Agrofórum, 13: 1. 19-22.

Pepó P. - Borbélyné, H.É. - Zsombik, L. - Szabó A.: 2003. A napraforgó-termesztés biológiai alapjainak vizsgálata a Hajdúságban. Gyakorlati Agrofórum. 14: 11. 7-15.

Zsombik L.: 2007. Effect of sowing time on yield and oil content of sunflower hybrids in hajdúság. Cereal Research Communications. 35: 2. 1349-1352. 


\title{
SHORT-TERM EFFECT OF DROUGHT ON THE PHOTOSYNTHETIC ACCUMULATION OF ENERGY IN MAIZE
}

\author{
František HNILIČKA ${ }^{l}$ - Helena HNILIČKOVÁ ${ }^{\prime}-$ Dana HOLÁ ${ }^{2}-$ Marie KOČOVÁ $^{2}$ \\ - Olga ROTHOVÁ ${ }^{2}$ \\ ${ }^{1}$ Department of Botany and Plant Physiology, Faculty of Agrobiology, Food and Natural Resources, Czech \\ University of Life Sciences Prague, Kamýcká 129, 16521 Prague 6 - Suchdol, Czech Republic, e-mail: \\ hnilickova@af.czu.cz \\ ${ }^{2}$ De Department of Genetics and Microbiology, Faculty of Science, Charles University in Prague, Albertov 6, \\ 12843 Prague 2, Czech Republic
}

Abstract: The aim of the experiments was to monitor the immediate impact of water deficit on the energy content in selected genotypes of maize. A broader genotype set of maize types was selected as the experimental material ( 5 in-bred parental lines and their cross-breeds). The maize plants were cultivated under controlled conditions in a climate box - the control group and the stressed group. The plants from the control group were irrigated at $70 \%$ of the field water capacity. In the stressed group, irrigation was completely stopped for 18 days. The energy content was identified by the combustion calorimeter IKA C200. It follows from the obtained results that the energy content in the DM of roots was lowest in the stressed plants $704 * 810$ $\left(15.96 \mathrm{~kJ} \mathrm{~g}^{-1}\right)$ and highest in the control plants $2086\left(21.19 \mathrm{~kJ} \mathrm{~g}^{-1}\right)$. The provably lowest energy content in DM of leaves was identified in the stressed genotype $23 * 86-16.97 \mathrm{~kJ} \mathrm{~g}^{-1}$ and the highest in leaves was identified in the control genotype $704 * 13\left(19.82 \mathrm{~kJ} \mathrm{~g}^{-1}\right)$. The genotype $810 * 13$ responds sensitively to stress caused by drought and the genotype CE704 seems to be tolerant to this kind of stress.

Keywords: drought, maize, Zea mays L., net energy

\section{Introduction}

The economic losses resulting from drought are very substantial in the production of maize and this is why it is currently desirable to breed plants with regard to their resistance to drought (Bäzinger and Araus, 2007). Maize responds to water deficit by reducing its yield as well as its energy content, particularly during the blooming period and the grain filling period but water deficit can also have effect during the juvenile phases of the development of the plants. This is why the goal of the plant breeding is to find such crossbreds, which would show resistance to water deficit. The current strategy of increasing the resistance of plants to drought is to study the genome, including QTL identification and cloning, as stated, for example, by Bruce et al. (2002) but these methods still have their pitfalls. An alternative way of breeding plants is to use indirect selective criteria such as physiological characteristics. Mainly the study of gas exchange (Chaves et al., 2009) and calorimetric measurement of the energy content in the plants' biomass can be included among these criteria. It follows from the results of the work of Bláha et al. (2003) that the energy content identified by combustion calorimetry is provably lower in the plants exposed to example drought. The purpose of this work was to identify the changes in the energy content in the parental genotypes of maize and their crossbreds in correlation to the effect of water deficit and to find out whether it is possible to use the said method as an indirect selective method in plant breeding.

\section{Materials and methods}

A broader genotype set of maize was chosen for the experimental material ( 5 in-bred parental lines - 2013, 2023, 2086, CE704, CE810 - and their reciprocal crossbreds of 
F1 generation), organised as dialellic cross. The juvenile maize plants were grown in vessels with a mixture of garden substrate $A$ and sand in the ratio of 2:1, under the controlled conditions of a climate box where the light regimen was 16 hours of light and 8 hours of darkness. The scheme of the experiment included two groups: the control group (the irrigated group) and the stressed group. The control plants were irrigated at the level of $70 \%$ of field water capacity. In the stressed group, the plants were not irrigated for eighteen days. The experiment was started when four right leaves were produced. The irrigation was controlled according to the results obtained by the instrument AT Theta Kit (Delta - T Device, the United Kingdom). The amount of the irrigation water was $250 \mathrm{ml}$ for the stressed plants. In the dry matter of the individual maize organs, the amount of energy was measured at two-day intervals by means of the combustion calorimeter IKA C200. The identification of the gross and net energy was based on the valid ČSN ISO 1928 standards.

The data obtained in the measurements were statistically processed by means of StatSoft, Inc. (2001) -STATISTICA Cz [a software system for data analysis], version 9.0.

\section{Results and discussion}

The obtained levels of combustion heat of the maize roots indicate a statistically provable influence of the altered conditions on this monitored characteristic. The mean value of the combustion heat of the roots of the stressed plants was $10.08 \mathrm{~kJ}^{*} \mathrm{~g}^{-1}$ while in the control plants it was $12.32 \mathrm{~kJ} \mathrm{~g}^{-1}$. Expressed as a percentage, it is an $18.18 \%$ decrease of the combustion heat of the roots of juvenile maize plants. These conclusions are confirmed, for example, by Bláha et al. (2003).

It is apparent from fig. 1 at the energy content of the root system was decreasing with the deepening water deficit, that is, simultaneously with the ontogenetic development of plants. In the control plants, an inverse trend was observed. The $12^{\text {th }}$ and $14^{\text {th }}$ days of the stress were an exception to this trend because on these days, the energy content in the roots provably increased in comparison with the $10^{\text {th }}$ day of the stress. As opposed to that, in the control plants, the content of energy-rich substances in the root biomass was at its lowest on the $0^{\text {th }}$ day of the stress and was at its highest on the $16^{\text {th }}$ day.

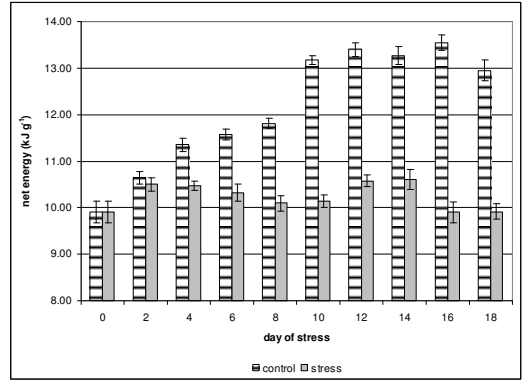

Figure 1. Net energy content $\left(\mathrm{kJ} \cdot \mathrm{g}^{-1}\right)$ in the roots of maize, according to the experimental group.

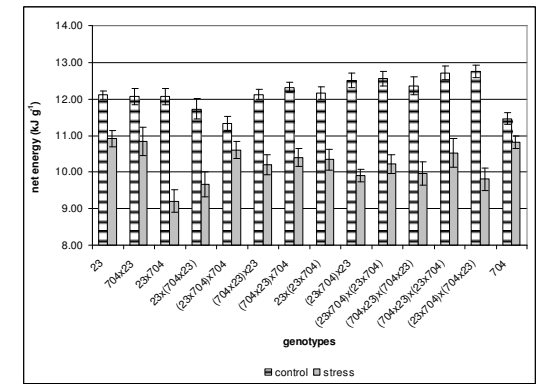

Figure 2. Net energy content $\left(\mathrm{kJ} \cdot \mathrm{g}^{-1}\right)$ in the roots of maize, according to the genotypes. 
The obtained results show that the energy content of the root system of maize plants is fairly even, which is documented in Fig. 2. The smallest differences were identified between the groups with genotypes CE704 $\left(0.64 \mathrm{~kJ} \mathrm{~g}^{-1}\right)$, the control plants had a higher energy content in comparison with the stressed plants. Based on these results, it is possible to state that these genotypes are more tolerant to water deficit. The highest provable differences between the stressed and control plants, as concerns the energy content in their roots, were observed between the genotype $23 \times 704-2.86 \mathrm{~kJ} \mathrm{~g}^{-1}$ in comparison with the stressed plants. The obtained values correspond to the conclusions of Fuksa et al. (2006).

Similarly like with the energy content in roots, the effect of water deficit showed on the levels of combustion heat of the above-ground biomass because the mean value of this characteristic was $13.09 \mathrm{~kJ} \mathrm{~g}^{-1}$ in the stressed plants; see fig. 3. In the control plants, it was higher by $20.63 \%$. In comparison with the energy content in roots, there was a more significant decrease of the combustion heat in the above-ground biomass. This trend probably resulted from the reduced gas exchange in the leaves, which, in turn, resulted in reduced photosynthesis (Lawlor and Tezara, 2009).

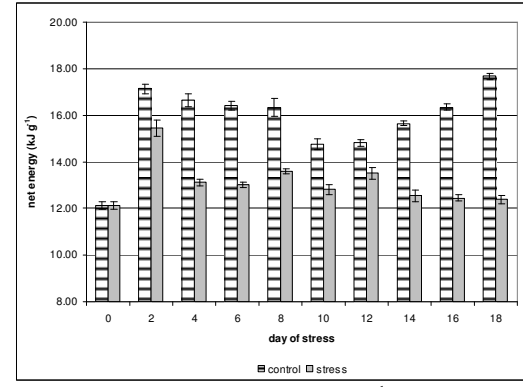

Figure 3. Net energy content $\left(\mathrm{kJ}^{\left.-\mathrm{g}^{-1}\right)}\right.$ in the leves of maize, according to the experimental group

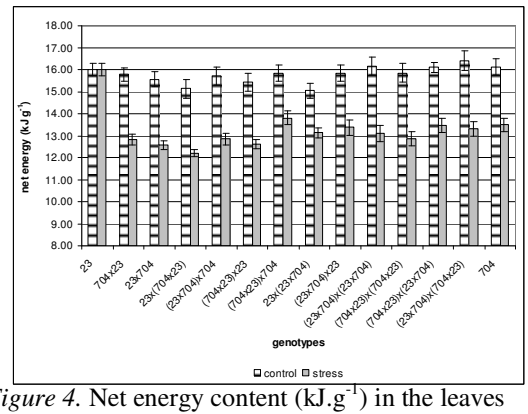

of maize, according to the genotypes.

The amount of substances rich in energy, accumulated in the above-ground biomass, was provably decreasing over the period of water deficit. Similarly, the production of dry matter of the above-ground biomass decreases, as it is declared in the paper by Úžik and Žofajová (2006). On the eighteenth day of the water deficit, the average energy content was $12.39 \mathrm{~kJ} \mathrm{~g}^{-1}$, as it is documented in fig. 3. At the beginning of the monitored period, that is, before inducement of the stress, the average energy content was $12.13 \mathrm{~kJ} \mathrm{~g}^{-1}$. In the stressed group, there was a sharp increase of energy content on the second day after the stress started and a level of $15.45 \mathrm{~kJ} \mathrm{~g}^{-1}$ was reached. Then, there was gradual decline of the combustion heat levels. The energy content in the control plants was between 12.13 $\mathrm{kJ} \mathrm{g}^{-1}$ (the $0^{\text {th }}$ day) and $17.67 \mathrm{~kJ} \mathrm{~g}^{-1}$ (the $18^{\text {th }}$ day). These conclusions are confirmed, for example, by Bláha et al. (2003).

The net energy of the above-ground biomass was also influenced by the sensitivity of the given genotype to drought stress. The said chart also shows that all the monitored genotypes decreased the content of substances rich in energy in their leaves during the water deficit as compared with the control group. From among the monitored genotypes in the experimental groups, this decrease of the content of substances rich in energy was 
lowest in the genotype $23 \times(23 \times 704)$. The difference between the control group and the stressed group was $1.91 \mathrm{~kJ} \mathrm{~g}^{-1}$. This trend was also confirmed in the paper by Christensen and Feldmann (2007).

Based on these results, it is possible to state that these are genotypes, which are more tolerant to water deficit. The highest provable differences between the stressed and control plants in the energy content in the above-ground biomass were observed in the genotypes $(23 \times 704) \times(704 \times 23)-3.11 \mathrm{~kJ} \mathrm{~g}^{-1}$. It follows from the obtained results that these genotypes respond to drought stress more sensitively than the other monitored plants. Similar results are also stated by Nagy (2009) and Berzsenyi (2009) in their papers.

\section{Conclusions}

The obtained results show that the stressed plants provably reduced the energy content in their roots and above-ground biomass in comparison with the control plants. The influence of genotypes on the content of substances rich in energy, accumulated in the individual plant organs, was proved. Therefore, it can be stated that the method of combustion calorimetry can be used as one of the indirect selective methods usable in plant breeding.

\section{Acknowledgements}

These results are financially supported by grant No. 521/07/0470 and Nos. MSM 6046070901 and MSM 0021620858.

\section{References}

Bäzinger M. - Araus J.: 2007. Recent advances in breeding maize for drought and salinity stress tolerance. In: Jenks M.A., Hasegawa P.M., Jain S.M. (eds): Advances in Molecular Breeding Toward Drought and Salt Tolerant Crops, Springer.

Berzsenyi Z..: 2009. A nitrogén mütrágyázás hatásának vizsgálata a kukorica ( Zea mays L.) hibridek növekedésére Richards-függvénnyel. Növénytermelés, 58: 2. 5-21

Bláha L. - Hnilička F. - Hořejš P. - Novák V.: 2003. Influence of abiotic stresses on the yield, seed and root traits at winter wheat (Triticum aestivum L.). Scientia Agriculture Bohemica, 34: 1. 1-7

Bruce W.B. - Edmeades, G.O. - Barker, T.C.: 2002. Molecular and physiological approaches to maize improvement for drought tolerance. Journal of Experimental Botany, 53: 366. 13-25

Chaves M.M. - Flexas J. - Pinheiro C.: 2009. Photosynthesis under drought and salt stress: regulation mechanisms from whole plant to cell. Ann. Bot. 103. 551-560.

Christensen C.A. - Feldmann K.A.: 2007. Biotechnology approaches to engineering drought tolerant crops. In: Jenks M.A., Hasegawa P.M., Jain S.M. (eds): Advances in Molecular Breeding Toward Drought and Salt Tolerant Crops, Springer.

ČSN ISO 1928.: 1999. Solid Fuels - Identifying combustion heat by means of the calorimetric method in a pressure vessel and calculating calorific value. Czech Standardisation Institute, Prague.

Fuksa P. - Kocourková D. - Hakl J. - Kalista J.: 2006. Influence of weed infestation on the calorific value and chemical composition of maize (Zea mays L.). Journal of plant diseases and protection. 20: Special Issue. 823-830

Lawlor D.W. - Tezara W.: 2009. Causes of decreased photosynthetic rate and metabolic capacity in waterdeficient leaf cells: a critical evaluation of mechanisms and integration of processes. Ann. Bot. 103. 561579 .

Nagy J.: 2009. A vetésidő hatása a kukorica- ( Zea mays L.) hibridek terméshozamára és minőségére. Növénytermelés, 58: 2. 85-105

Úžik M. - Žofajová A.: 2006. Translocation and accumulation of dry matter in winter wheat genotypes. Cereal Research Communications. 34: 2 - 3. 1013-1020 


\title{
STUDY OF ENERGY BALANCE IN CORN PRODUCTION
}

\section{Juliana MOLNÁROVÁ}

Department Crop Production, Faculty of Agrobiology and Food Sciences, Slovak University of Agriculture A. Hlinku 2, 94976 Nitra, Slovakia, e-mail: Juliana.Molnarova@uniag.sk

\begin{abstract}
Poly-factor field experiments with corn were founded in years 2003-2005, in a corn production area, situated in a very hot, dry sub-area with the average annual temperature of $9.7^{\circ} \mathrm{C}$ and average annual rainfall of $564 \mathrm{~mm}$. The soil is clayey, medium heavy, medium supplied $\mathrm{P}\left(37.7-56.0 \mathrm{mg} \cdot \mathrm{kg}^{-1}\right.$ of soil) and little or well supplied $\mathrm{K}\left(105-220 \mathrm{mg} \cdot \mathrm{kg}^{-1}\right.$ of soil), humus content $4.53 \%$, neutral soil reaction ( $\left.\mathrm{pH} 6.5-7.2\right)$.

In years 2003-2005 we monitored the effect of the agricultural year and nutrition on the yield of grain of a late hybrid LG 24.81 and on its energy balance. The achieved results showed a significant influence of the year and fertilisation on the amount of yield and on the sum of output energy and energy profit. The increase of yield caused by a favourable year achieved 20.14-52.97\%. The difference between the sum of output energy and the energy profit affected by the year achieved $61.50 \mathrm{GJ}^{-h^{-1}}$ and $48.53 \mathrm{GJ}^{-h^{-1}}$. From the point of view of the achieved yield $\left(10.34 \mathrm{t}^{-h^{-1}}\right.$ ) the optimal level of fertilisation seemed to be the $\mathrm{C}$ level (fertilisation for a theoretical yield of 8 tons of grain and the given biomass), but it was the most energy demanding among the three monitored years $\left(163.48 \mathrm{GJ} \mathrm{ha}^{-1}\right)$. The highest energy profit (130.92 GJ.ha $\left.{ }^{-1}\right)$ was achieved with the B level fertilisation (fertilisation for a theoretical yield of 6 tons of grain and the given biomass). The energy effectiveness $\left(\mathrm{En}_{\mathrm{ef}}\right)$ was decreasing with the increasing doses of nutrition. The highest energy effectiveness (6.40 J.1J output ${ }^{-1}$ ) was achieved on the non-fertilised variant A.
\end{abstract}

Keywords: energy balance, corn production, fertilisation

\section{Introduction}

Energy efficiency is closely related not only to economic but also to ecological aspects of agricultural production. The level of inputs and outputs of crop production energy and individual crops energy is limited by particular units of the site, such as climatic and soil conditions which human can significantly affect, but also by factors that can people affect, such as additional inputs of energy and so on. Energy evaluation is one of the significant objective criteria of expediency of the agricultural production as a whole (Pospíšil and Vilček, 2000). For Slovakian conditions Čislák (1990) analysed the structure of energy inputs. Within the whole agriculture the share of plant production on the consumption of additional energy is $62.2 \%$. One of the biggest energy inputs in plant production are fertilizers. Therefore lately arised the question of the rational use of nutrition by using overground fytomass (dry mass) while the present stability of grain crop and soil fertility are secured. Searching for possibilities of optimizing nutrition and fertilisation for this crop-plant is the subject of research of many authors both internal and foreign (El Hallof and Sárvári, 2006; Ványiné Széles, 2008; Macák et al., 2008 ). Čislák (1990) included grain maize and sugar beet between the most energy demanding crops with energy input from 30.24 GJ to 43.1 GJ.ha $^{-1}$. Differences in the energy balances are caused by agro-climatic differences and possibly also by using different energy equivalents in calculating the inputs and energy outputs (Danko and Repka, 1995). The aim of this work was to find out the crop and energy balance of corn grown for grain in dependency on nutrition and year. 


\section{Materials and methods}

Polyfactorial field experiments with corn were founded in years 2003-2005 in district Komárno Slovakia. The locality is a corn production area with the average annual temperature of $9.7^{\circ} \mathrm{C}$ and average annual rainfall of $564 \mathrm{~mm}$. Phosphorus content of soil was 37.7-56.0 mg. $\mathrm{kg}^{-1}$, potassium $105-220 \mathrm{mg} \cdot \mathrm{kg}^{-1}$, humus $4.53 \%$, pH 6.5-7.2. Soil type is black soil. Experimental parcels were organized by the method of divided blocks in three repetitions. We used a late corn hybrid LG 24.

Table 1 . The really applied $\mathrm{N}, \mathrm{P}, \mathrm{K}$ rates in pure nutrients per hectare

\begin{tabular}{|c|c|c|c|c|c|}
\hline Year & Level of fertilisation & $\begin{array}{l}\text { Nitrogen } \\
\mathrm{kg} \cdot \mathrm{ha}^{-1}\end{array}$ & $\begin{array}{c}\text { Phosphorus } \\
\text { kg.ha }\end{array}$ & $\begin{array}{l}\text { Potassium } \\
\text { kg.ha }^{-1}\end{array}$ & Total applied NPK in kg.ha ${ }^{-1}$ \\
\hline \multirow{3}{*}{2003} & $\mathrm{~A}$ & \multicolumn{3}{|c|}{ control without fertilization } & \\
\hline & $\mathrm{B}$ & 65.0 & 8.0 & 73.0 & 146.0 \\
\hline & $\mathrm{C}$ & 115.0 & 18.0 & 130.0 & 263.0 \\
\hline \multirow{3}{*}{2004} & A & \multicolumn{3}{|c|}{ control without fertilization } & \\
\hline & $\mathrm{B}$ & 39.0 & 0.8 & 46.0 & 85.8 \\
\hline & $\mathrm{C}$ & 89.0 & 11.0 & 103.0 & 203.0 \\
\hline \multirow{3}{*}{2005} & $\mathrm{~A}$ & \multicolumn{3}{|c|}{ control without fertilization } & \\
\hline & $\mathrm{B}$ & 108.0 & 0 & 114.0 & 222.0 \\
\hline & $\mathrm{C}$ & 158.0 & 7.0 & 171.0 & 336.0 \\
\hline
\end{tabular}

Nutrition and fertilisation - we monitored three levels of fertilisation (A, B, C). The dosage of nutritive nutriment was determined according to an agrochemical soil analysis, which was based on the theoretical need of NPK for 1 ton of theoretical crop of grain and given biomass of corn i.e. $25 \mathrm{~kg} \mathrm{~N}, 5 \mathrm{~kg} \mathrm{P}$ and $29 \mathrm{~kg} \mathrm{~K}$ (Fecenko and Ložek, 2000). The nutrition levels were: A-without the application of industry fertilizers; B-the level of fertilization for $6 \mathrm{t}^{-h^{-1}}$ of grain and the given biomass; C-the level of fertilization for $8 \mathrm{t}^{-h^{-1}}$ of grain and the given biomass.

Table 2. Values for the energy inputs calculation

\begin{tabular}{|c|c|c|}
\hline \multirow{4}{*}{ Direct inputs } & $1 \mathrm{MWh}$ electric energy & $12 \mathrm{GJ}$ \\
\cline { 2 - 3 } & $1000 \mathrm{l}$ diesel & $47.8 \mathrm{GJ}$ \\
\cline { 2 - 3 } & $1000 \mathrm{~h}$ human labour & $26.6 \mathrm{GJ}$ \\
\cline { 2 - 3 } Indirect inputs & $1000 \mathrm{~m}^{3}$ gas & $49.5 \mathrm{GJ}$ \\
\hline \multirow{4}{*}{} & 1 ton net nutrients nitrogen $(\mathrm{N})$ & $78.1 \mathrm{GJ}$ \\
\cline { 2 - 3 } & 1 ton net nutrients phosphorus $(\mathrm{P})$ & $39.9 \mathrm{GJ}$ \\
\cline { 2 - 3 } & 1 ton net nutrients potassium $(\mathrm{K})$ & $14.0 \mathrm{GJ}$ \\
\cline { 2 - 3 } & $10.0 \mathrm{GJ}$ \\
\cline { 2 - 3 } & 1 ton pesticides & $100.0 \mathrm{GJ}$ \\
\cline { 2 - 3 } & 1 ton seeds of corn & $15.81 \mathrm{GJ}^{-1}$ \\
\hline
\end{tabular}

Energy inputs were calculated from the really applied fertilizers, seed, fuel, herbicides, and human labor by multiplying the appropriate value according to the authors Demo and Kudrna (1994) and Hernanz and Oritz - Canavate (1999) (Table 2). The data for yield, sum of energy inputs and outputs, energy profit and energy effectiveness $\left(\mathrm{EN}_{\mathrm{ef}}\right)$ were subjected to analyses of variance using program Statistica 8 . The means were compared with the Tukey test at the $P=0.05$ level. 


\section{Results and discussion}

The achieved results showed a significant influence of the year and fertilisation on the amount of yield and on the sum of output energy and energy profit. The increase of yield caused by a favourable year achieved 16.9-52 \%. The difference between the sum of output energy and the energy profit affected by the year achieved 61.50 GJ.ha $^{-1}$ and $48.53 \mathrm{GJ} \cdot \mathrm{ha}^{-1}$. The highest value of energy efficiency $\left(\mathrm{EN}_{\mathrm{ef}} 6.3-8.3\right)$ at the unfertilized control variant (A) noted that with increasing doses of the nutrients this value decreases, which is in full compliance with relevant law of a decreasing effect of the increasing energy input rates in rational energy input rates in rational production

Table 3. Yield of maize, sum of energy input and output, energy profit and effectiveness

\begin{tabular}{|c|c|c|c|c|c|c|}
\hline Year & Fertilization & $\begin{array}{l}\text { Yield of } \\
\text { grain t.ha' }\end{array}$ & $\begin{array}{l}\text { Sum of } \\
\text { Energy } \\
\text { inputs } \\
\text { GJ.ha }^{-1}\end{array}$ & $\begin{array}{l}\text { Sum of } \\
\text { energy } \\
\text { outputs } \\
\text { GJ.ha }^{-1}\end{array}$ & $\begin{array}{c}\text { Energy } \\
\text { profit } \\
\text { GJ.ha }{ }^{-1}\end{array}$ & $\mathrm{EN}_{\mathrm{ef}}$ \\
\hline \multirow{3}{*}{2003} & $A$ & $7.25 \mathrm{~b}$ & $13.73 \mathrm{~d}$ & $114.62 \mathrm{a}$ & $100.89 \mathrm{a}$ & $8.30 \mathrm{~b}$ \\
\hline & $B$ & $7.60 \mathrm{bc}$ & $20.65 \mathrm{a}$ & $120.16 \mathrm{a}$ & $99.51 \mathrm{a}$ & $5.80 \mathrm{a}$ \\
\hline & $C$ & 8.30 bcde & $26.85 \mathrm{~b}$ & $131.22 \mathrm{ab}$ & $104.37 \mathrm{a}$ & $4.90 \mathrm{a}$ \\
\hline \multirow{3}{*}{2004} & $A$ & $8.06 \mathrm{bcd}$ & $20.13 a$ & $127.43 \mathrm{ab}$ & $107.30 \mathrm{a}$ & $6.30 \mathrm{a}$ \\
\hline & $B$ & $10.80 \mathrm{ae}$ & $28.21 \mathrm{~b}$ & $170.75 \mathrm{ab}$ & $142.54 \mathrm{ab}$ & $6.10 \mathrm{a}$ \\
\hline & $C$ & 10.10 acde & $32.22 \mathrm{bc}$ & $159.68 \mathrm{ab}$ & $127.46 \mathrm{ab}$ & $5.00 \mathrm{a}$ \\
\hline \multirow{3}{*}{2005} & $A$ & 10.80 ade & $23.13 \mathrm{a}$ & $160.95 \mathrm{ab}$ & $137.80 \mathrm{ab}$ & $7.00 \mathrm{a}$ \\
\hline & $B$ & $12.02 \mathrm{a}$ & $35.90 \mathrm{~b}$ & $190.04 \mathrm{ab}$ & $154.14 \mathrm{ab}$ & $5.30 \mathrm{a}$ \\
\hline & $C$ & $12.62 \mathrm{a}$ & $41.11 \mathrm{e}$ & $199.52 \mathrm{~b}$ & $158.41 \mathrm{~b}$ & $4.85 \mathrm{a}$ \\
\hline \multirow{3}{*}{$\begin{array}{c}2003- \\
2005\end{array}$} & $A$ & 8.50 & 21.13 & 134.39 & 113.26 & 6.40 \\
\hline & $B$ & 10.14 & 30.39 & 161.31 & 130.92 & 5.31 \\
\hline & $C$ & 10.34 & 35.85 & 163.48 & 127.63 & 4.56 \\
\hline
\end{tabular}

$E n_{\text {ef }}$-coefficient of energy effectiveness

process. This observation has a great importance for the agronomic decision making in determining the intensity of fertilization and discuss about the need for a rational fertilization. The overall input energy reached $21.13-35.85$ GJ.ha $^{-1}$ in dependence on the monitored fertilisation levels. A notable variability of these values achieved by Hruška and Jeníček (1982) (8.9-37.75 GJ.ha ${ }^{-1}$ ) and Hülsberg at. al (2001) (8.9-36.9 GJ.ha $\left.{ }^{-1}\right)$. We found, that the direct energy inputs had 59.4-87.1\% share from the total energy input involved (Table 4). This proportion is much higher than what Pospišil (1995) presented (26.66-29.61\%). Different values may be due to agroclimatic differences, as well as the possible use of different energy equivalents for the calculation of input and output energy. The fertilizers had an important place from the indirect energy inputs with a share of 22.2 to $33.0 \%$ (Table 4), Danko and Repka's (1995) indicated $40.0 \%$. The cost of pesticides, despite their high complexity production presented low share of total inputs (0.6-1.1\%) (Table 4). Čislák indicated (1990) $1.3 \%$. The share of seed energy input reached 7.0-11.8\% share, Dvořáková (1991) indicates $13.6 \%$. On average during the three monitored years it can be conducted, that the $\mathrm{C}$ level of fertilisation was energetically most demanding (35.85 GJ.ha $\left.{ }^{-1}\right)$ with most energy output (163.48 GJ.ha $\left.{ }^{-1}\right)$ 
Table 4. Overall shares energy inputs in years $2003-2005$

\begin{tabular}{|c|c|c|c|}
\hline Fertilization & $\mathrm{A}$ & $\mathrm{B}$ & $\mathrm{C}$ \\
\hline \hline Human labour + Fossil energy & $87.1 \%$ & $68.1 \%$ & $59.4 \%$ \\
\hline Industrial fertilizers & $0 \%$ & $22.2 \%$ & $33.0 \%$ \\
\hline Pesticides & $1.1 \%$ & $0.8 \%$ & $0.6 \%$ \\
\hline Seed & $11.8 \%$ & $8.9 \%$ & $7.0 \%$ \\
\hline Sum of energy input & $100 \%$ & $100 \%$ & $100 \%$ \\
\hline
\end{tabular}

where the greater yield of maize grain was achieved $\left(10.34\right.$ t.ha $\left.^{-1}\right)$ (Table 3). The highest energy profit (130.92 GJ.ha ${ }^{-1}$ ) was achieved with the B level fertilisation (fertilized up to 6 t.ha $^{-1}$ of grain and given biomass). The energy effectiveness was greater at the control variant (A) $6.4 \mathrm{~J}_{1} . \mathrm{J}^{-1}$ of input energy.

\section{Conclusions}

The increase of corn yield caused by a favourable year achieved $20.14 \%-52 \%$. During the three years period the energy inputs grew gradually caused by the human labour and fossil energy input. The results suggest that the energy effectiveness was decreasing with the increasing doses of nutrition. The highest energy profit (130.92 GJ.ha $\left.{ }^{-1}\right)$ achieved by corn at the level of fertilisation up to 6 t.ha $^{-1}$ of grain and given biomass was optimal, even the highest grain yield was achieved at the level of fertilisation up to 8 t.ha $^{-1}$ of grain and given biomass.

\section{Acknowledgements}

This paper was supported by Vega project 1/0152/08.

\section{References}

Čislák, V.: 1990. Energetická efektívnost' pol’nohospodárskych sústav. Veda: Bratislava.

Danko, J. - Repka, J.: 1995. Energi efficiency of maize cultivation system using large - scale production technologies. In Agriculture 41:7. 501-504.

Demo, M. - Kudrna, K.: 1994. Projektovanie pol'nohospodárskych sústav. VŠP, Nitra.

Dvořáková, M. 1991.: Energetická náročnost' rostlinné výroby v podmínkach Jižní Moravy. In Rostlinná výroba 47:11. $955-960$.

Fecenko, J. - Ložek, O.: 2000. Výživa a hnojenie pol'ných plodín. SPU, Nitra.

Hallof El, N. - Sárvári, M.: 2006. Corelarions between the NPK fertilization and the yield of maize hybrids. In Collection of scientific articles from bilateral Slovak-Hungarian project. 134-144.

Hernanz, J. L. - Oritz-Canavate, J.: 1999. Energy saving. In O. Kitari (ED), CIGR Handbook of Agricultural Engineering, St. Joseph. 5. 24-29.

Hruška, L. - Jeníček,J.: 1982. Enrgetická účinnost' některých plodin v kukuřičném výrobním typu. Rotlinná výroba, 28: 1217 - 1224 .

Hülsbergen, K.-J. - Field, B. - Biermann, S. - Rathke, G.-W. - Kalk, W.- D. - Diepenbrock, W. 2001.: A method of energy balancing in crop production and ist application in a long-term fertilizer trial. In Agricurture, Ecosystems and Envinment, 86. 303-321.

Macák, M. - Žák, Š. - Birkás, M. - Djalovic, I. - Slamka, P.: 2008. The influence of an ecological and low input system on yield and yield componets of spring barley. Cereal research communications, 36. 13431346.

Pospišil, R. - Vilček, J.:2000. Energetika sústav hospodárenia na pôde. Bratislava: VÚPOP. 108

Ványiné Széles, A. 2008.: The effect of crop year and fertilization on the interaction between the sped value and yield of maize (Zea mays L.) within non-irrigated conditions. Cereal Research Communications, 36: 2 . 


\title{
SUCCESSION OF FUNGAL POPULATIONS IN COMPOSTING MIXURES CONTAINING BIOGAS SLURRY
}

\author{
Flóra SEBÖK ${ }^{1}$ - Csaba DOBOLYI ${ }^{2}$ - Milán FARKAS ${ }^{2}$ - Balázs KRISZT ${ }^{1}$ \\ ${ }^{1}$ Department of Environmental Protection and Environmental Safety, Institute of Environmental and \\ Landscape Management, Szent István University, H-2103 Gödöllő, Páter K. u. 1. \\ ${ }^{2}$ Regional University Centre of Excellence in Environmental Industry, Szent István University, H-2103 \\ Gödöllő, Páter K. u. 1., Dobolyi.Csaba@mkk.szie.hu
}

Abstract: Wastes of biogas production and those of several other biomass-energy sources were used in our experiments. Qualitative and quantitative changes of fungal populations during the composting process were followed by microbiological culturing methods. We found that the succession of fungal populations in composting processes changed according to regular ecological dynamics. The diversity of thermophilic fungi in the composting mixtures proved to be relatively high. 10 different species were identified from the samples in the thermophilic phase.

Keywords: composting, thermophilic fungi, biogas slurry, sewage sludge

\section{Introduction}

The course of biomass energy production can be sustained only in case of appropriate treatment of its wastes. Moreover, composting of these wastes supplies a valuable humus-containing fertiliser for crop production (Nagy et al., 2008), which is valuable because sustainable agriculture should use composts, beside farmyard manure, for replacement of organic materials to soil (Cserháti et al., 2006). Particularly high quality composts could be used even in horticultural applications. We can benefit from their ability to be the base of different second generation inoculations used in agriculture and bioremediation. Special composts are often applied for improvement of sandy and rocky soils of low organic content (Antal et al., 2009). However, their possibly high heavy metal content is a limiting factor for agricultural use (Anton and Máthé-Gáspár, 2005). Composts not applicable in agriculture are suitable for covering landfills at recultivation (Alexa and Füleky, 2002).

In modern composting technologies, more and more materials of complex composition, harmful to the environment are also processed (Hatvani et al., 2007). The most intensive decomposition takes place in the thermophilic phase.

Biogas as a source of energy may have only limited importance in developed countries at present. Nevertheless, its production increases due to its environmental benefit. The biogas as a product is proceeded from anaerobic decomposition of fluid mass. The most significant waste of that process is a liquid substance, rich in nutrients but it is environmentally objectionable. In the course of bioethanol production another liquid waste, so called vinasse is formed, which could also be composted. Beside the numerous environmental advantages of the biomass incinerators, they have a serious disadvantage. Wood-ashes emitted by them are very aggressive solid wastes, harmful to soil life. Recycling it to the soil by composting could solve that problem. The most significant waste of the modern sewage treatment is sewage sludge; its energy content as biogas is also obtained by digestion.

Composting different wastes of biomass energy production inclusively the presence and role of fungal population was the main goal of our experiments. 


\section{Materials and methods}

\section{Composting materials}

The examined mixtures are consisted of the following materials:

mixture 1: biogas slurry $(60 \% \mathrm{dw})$, wheat straw (15\% dw), "vinasse $60 "(20 \% \mathrm{dw})$ and poultry manure $(5 \% \mathrm{dw})$;

mixture 2: biogas slurry $(60 \% \mathrm{dw})$, wheat straw $(25 \% \mathrm{dw})$, wood ashes $(10 \% \mathrm{dw})$ and poultry manure $(5 \% \mathrm{dw})$;

mixture 3: digested sewage sludge $(60 \% \mathrm{dw})$, garden cutting waste $(35 \% \mathrm{dw})$ and poultry manure $(5 \% \mathrm{dw})$.

Composting procession was carried out at semi-technological scale and lasted for 40 days.

\section{Cultivation and identification}

Qualitative and quantitative changes of fungal populations during the composting process were followed by microbiological culturing methods. Four mycological media (malt extract agar, potato dextrose agar, synthetic medium containing microcrystal cellulose, and that of containing pure lignin) were applied; the cultures were incubated at the actual temperatures of the compost pile. Isolates were obtained from primary cultures and the representative strains were maintained in culture collection and taxonomically identified on the basis of phenotypic characteristics.

\section{Results and discussion}

The diversity of thermophilic fungi in the composting mixtures proved to be relatively high. 10 different species were identified from the samples taken on day 10 and 20, and 2 more types of isolate were not classifiable to any known species on the basis of phenotypic characteristics. We could differentiate 7-7 species from mixture 1 and mixture 2, while 9 form mixture 3. 4 species were common in each mixture. The average frequency of species was 4-12\%, only Myceliophthora thermophila and Thermomyces lanuginosus seemed to be dominant (Table 1.).

Table 1. Incidence of thermophilic fungi in composting mixtures containing different wastes of biomass energy production

\begin{tabular}{|l|c|c|c|}
\hline \multicolumn{1}{|c|}{ Species } & mixture 1 & mixture 2 & mixture 3 \\
\hline \hline Acremonium thermophilum & & & 4.7 \\
\hline Chaetomium thermophilum & 4.7 & 7.9 & \\
\hline Malbranchea cinnamomea & 4.7 & 6.6 & 6.6 \\
\hline Myceliophthora thermophila & 22.5 & 27.1 & 31.5 \\
\hline Paecilomyces sp. & & & 9.3 \\
\hline Rhizomucor pusillus & 11.4 & 6.6 & 8.5 \\
\hline Scytalidium thermophilum & 10.5 & 4.7 & 6.6 \\
\hline Talaromyces thermophilus & & & 8.5 \\
\hline Thermoascus aurantiacus & & & 49.6 \\
\hline Thermomyces lanuginosus & 39.6 & 43.8 & 4.7 \\
\hline Unknown no. 1 & & & 3.3 \\
\hline Unknown no. 2 & 6.6 & & \\
\hline
\end{tabular}

In the initial phase of the composting process mixture 1 contained $10^{6} \mathrm{CFU} \mathrm{g} \mathrm{g}^{-1}$ fungal elements, mesophilic fungi in majority (Fig. 1.). The degrading role of that living fungal 
mass must be taken for granted. In the beginning, the quantity of the mesophiles progressively, later dramatically decreased. It was $1.6 \times 10^{4}$ on day 20 , and only $1.5 \times$ $10^{2} \mathrm{CFU} \mathrm{g}{ }^{-1}$ on day 40 . The thermotolerants, which can grow on $40-45{ }^{\circ} \mathrm{C}$ were represented only in $10^{4}$ magnitude in the initial mixtures, but even on day 10 their number increased only to $2.3 \times 10^{5} \mathrm{CFU} \mathrm{g}^{-1}$. That value seemed to be their optimum.

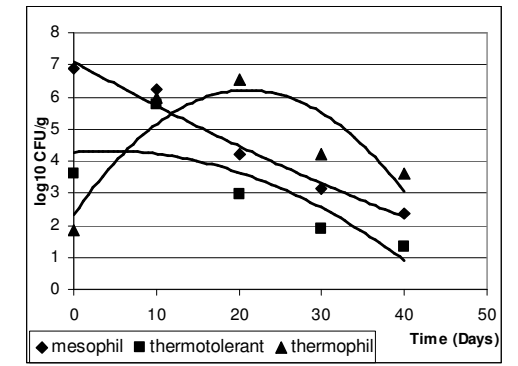

Figure 1. Variation of different fungal populations with composting time in the mixture containing digested sewage sludge

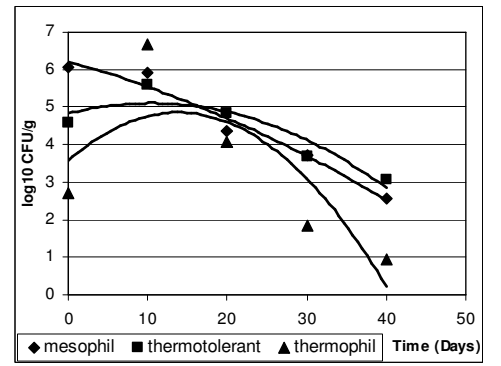

Figure 2. Variation of different fungal populations with composting time in the mixture containing biogas slurry

Their presence was moderated from day 20 (end of thermophil phase), only $8.3 \times 10^{2}$ CFU g ${ }^{-1}$ could be cultured at day 40 (final phase). In spite of the fact that thermophilic fungi may colonise both biogas slurry and poultry manure, they were presented in low quantity in the initial mixture but as the temperature rose their number reached the value of $5.8 \times 10^{6} \mathrm{CFU} \mathrm{g}^{-1}$ by day 10 , though that extremely high value did not last for long. It fell to $2.1 \times 10^{4} \mathrm{CFU} \mathrm{g}{ }^{-1}$ by day 20 and fell on by day 30 and $40\left(4.2 \times 10^{3}\right.$, and $1.3 \times$ $10^{3} \mathrm{CFU} \mathrm{\textrm {g } ^ { - 1 }}$ ). As the metabolism and growth of thermophilic fungi is on minimal level under $40{ }^{\circ} \mathrm{C}$, only persisting forms could be cultured. The initial number of mesophilic fungi was $7.1 \times 10^{6}$, that of the thermotolerants was $8.5 \times 10^{3}$, and that of the termophiles was not higher than $2.4 \times 10^{2} \mathrm{CFU} \mathrm{g}^{-1}$ in mixture 3 (Fig. 2.). Their number was almost equal to the number of fungal community in mixtures containing biogas slurry by day 40 . The quantity of cellulolytic fungi was very high and changed according to ecological rules. Their number $\left(2.1 \times 10^{3} \mathrm{CFU} / \mathrm{g}\right)$ in initial mixtures containing biogas slurry was relatively small (Fig. 3.). It can be discussed with mediumlevel colonization of mesophilic cellulolytic fungi on the component cereal straw. The biogas slurry may contain thermophilic fungal elements in majority CFU g ${ }^{-1} 10^{3}-10^{4}$. Approximately half of the amount of cellulolytic fungi came from the down-bed poultry manure. On day 10 we could get the number $\left(9.8 \times 10^{4} \mathrm{CFU} \mathrm{g}{ }^{-1}\right)$ of thermophilic fungi degrading straw on the high temperature. By that time the easily degradable carbohydrates and lipoids had been metabolised mainly by the activity of mesophilic bacteria and fungi. On day 20 , culturing at $45^{\circ} \mathrm{C}$, we already experienced the decrease of cellulolytic fungi, with the dominance of thermophiles. Comparing the different mixtures, the quantity of thermophilic fungi was found to be higher in mixture containing digested sewage sludge than mixtures containing biogas slurry. 


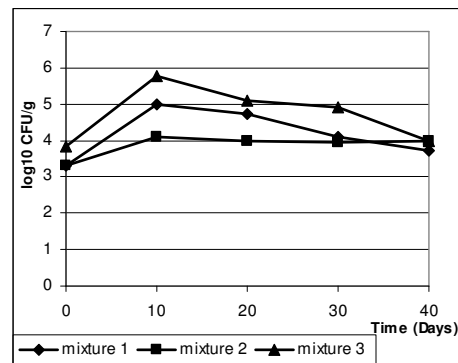

Figure 3. Change of the populations of cellulytic fungi with composting time

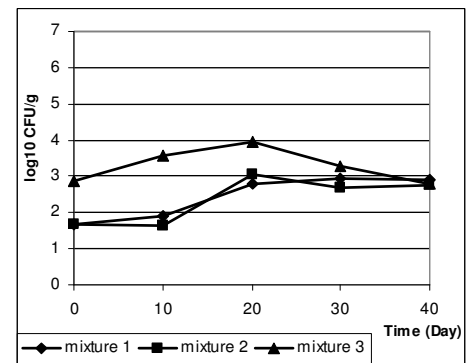

Figure 4. Change of the population of ligninolytic fungi with composting time

The development of the number of ligninolytic fungi indicated that their role was highly significant in composting processes. Their initial quantity was surprisingly low due to the fact that neither the biogas slurry nor the other components were colonised considerably by these organisms (Fig. 4.).

\section{Conclusions}

The quantity of both the cellulolytic and ligninolytic fungi was highly dependent on the initial composition of composting mixtures but the differences within both physiological groups seem to be converged by day 40. Changes both in quantity of fungal elements and taxonomic diversity were found. We could differentiate 7-7 species from mixture 1 and mixture 2, while 9 from mixture 3.4 species were common in each mixture. The average frequency of species was $4-12 \%$, with the dominance of 2 common species, Myceliophthora thermophila and Thermomyces lanuginosus. An ecologically determined real succession of fungal populations can be concluded from their presence and role in composting wastes of biomass energy production.

\section{Acknowledgements}

This study was supported by the NKFP_07-A4(2007)(OM-00120/2007) grant.

\section{References}

Alexa L. - Füleky Gy.: 2002. Measuring the nitrogen supplying capacity of composts with incubation and plot experiments. Növénytermelés, 51: 383-396.

Antal K. - Budai J. - Szabó S.: 2009. How to protect the plants from heavy metal stress in contaminated mine sites with sheep manure compost?. Cereal Research Communications, 37: 549-552.

Anton A. - Máthé-Gáspár G.: 2005. Factors affecting heavy metal uptake in plant selection for phytoremediation. Z. Naturforsch., 60c, 244-246.

Cserháti M. - Kriszt B. - Szoboszlay S. - Atzél B. - Kiss J. - Morvai B.: 2006. The impact of composts produced from animal originated waste on the biological activity of soils. Acta Agronomica Hungarica, 54: 507-516.

Hatvani L. -Antal Z. - Manczinger L. - Szekeres A. - Druzhinina I. S. - Kubicek C. P. - Nagy A. - Nagy E. - Vágvölgyi C. - Kredics L.: 2007. Green mold diseases of Agaricus and Pleurotus spp. are caused by related but phylogenetically different Trichoderma species. Phytopatology, 97: 532-537.

Nagy L. - Mikó P. - Bencsik K.: 2008. Developments and agricultural utilization of yield enhancing substances produced from organic waste. Cereal Research Communications, 36: 283-286. 


\section{SUSTAINABLE AGRICULTURE: IMPORTANCE OF CULTURAL PRACTICES ADAPTATION IN WINTER WHEAT TECHNOLOGY}

Dusan KOVACEVIC ${ }_{2}^{l}$ - Snezana OLJACA ${ }^{1}-$ Zeljko DOLIJANOVIC ${ }^{l}-$ Milena SIMIC ${ }^{2}$

1 Institute for Field and Vegetable Crops, Faculty of Agriculture, University of Belgrade, Nemanjina 6. 11080 Zemun, Republic of Serbia, e-mail dulekov@agrif.bg.ac.rs

2 Maize Research Institute "Zemun Polje", 11185 Zemun Polje, Republic of Serbia

Abstract: The paper deals with adaptations in winter wheat technology from high level inputs to a significant reduction of production costs and a maximum reliance upon natural resources on the weed infestation and grain yield of different cultivars. These adaptations must first and foremost build resilience within agroecosystem, increasing its ability to continue functioning when faced with unexpected events. Winter wheat technology consists from the following tillage systems: conventional, mulch tillage and no-tillage. Plots were fertilized with two nitrogen amount: rational level $\left(60 \mathrm{~kg} \mathrm{ha}^{-1}\right)$ and high level $\left(120 \mathrm{~kg} \mathrm{ha}^{-1}\right)$. Six Serbian cultivars were included in the trial. Four of them were chosen for low-input and two for high-input technology. Different tillage systems, nitrogen level and cultivars applied in four-year crop rotation (maizewinter wheat-spring barley+red clover-red clover. Winter wheat technology based on conventional tillage systems had better effect on weed control than both conservation tillage systems (mulch and no-till.). Lowinput cultivars of winter wheat positively responded to different tillage systems and nitrogen level by their yield than high-input cultivars.

Keywords: sustainable agriculture, low, high-input technology, tillage systems, $\mathrm{N}$ fertilization, weeds, winter wheat.

\section{Introduction}

Sustainable agriculture can be defined as a direction of agricultural development. It needs to secure satisfaction stability of food production and plant production used in other technical purposes, with respect to basic natural resources, energy, ecology, economical efficiency and profitability at the same time. Crop production based upon high mechanical and chemical inputs are becoming less rational because of economic and environmental problems (Barberi et al., 1997). For current conventional systems we have focused on modification and domination of the production environment, using genetic materials that could maximize productivity from these near-ideal conditions. A significant portion of winter wheat production efforts in R. Serbia takes place under conventional high-input conditions with cultivars, which are mostly adapted to these conditions. Conversion from conventional to low-input sustainable systems requires changes in management practices (Kovacevic et al., 1988; Birkas et al., 2006; Jug et al., 2006). Low-input winter wheat technology for more sustainable production generally consist from reduces in tillage systems, lower level of applied chemical fertilizers and pesticides use, more diverse crop rotations. Rational technology with all these elements, would bring better equilibrium and stability of natural conditions inside of agricultural system (soil, water, climate, natural vegetation), and can protect soil from erosion, more effective and significantly decrease production expenses with no decrease of yield quantity and quality. Agricultural producers invested their hopes in the development of sustainable agriculture, a concept that should rely on the breeding of low-input cultivars and cutbacks in production costs. As far as wheat is concerned, we have developed

501 DOI: 10.1556/Novenyterm.59.2010.Suppl.4 
several low-input cultivars. The main goal of this paper is to give readers the new survey of the research aspects in crop production and possible rationalities of intensive land production.

\section{Materials and methods}

The study was carried out during vegetation season from 2006/07-2007/08., at the Experimental fields of the Faculty of Agriculture - Zemun named "Radmilovac". The trial was located on chernozem luvic soil type. The experiment was conducted under 4yr rotations (maize - winter wheat - barley + red clover - red clover) where legumes red clover was nitrogen source. The previous crop every year to winter wheat were maize. The following technology for winter wheat were included three tillage systems in investigations: 1. Conventional tillage system (CT) - traditional, classical tillage mouldboard plow to the depth of $25 \mathrm{~cm}+$ seed bed preparation by disking tools and harowing 2. Mulch tillage (MT) - chisel plow to the depth $25 \mathrm{~cm}+$ seed bed preparation with disking and harowing 3. No-tillage (NT). The whole amounts of chopped residues where lefted on the ground after harvesting of maize on the MT and NT plots. Since more than $30 \%$ of land surface were covered with organic residues those tillage systems could be marked as conservation tillage practice. Six Serbian cultivars were included in the trial. Four of them were chosen for low-input according to previous experience (Pobeda, Francuska, Lasta, NS Rana 5) and two created for intensive technology (Pesma, Rana niska). The main plot $\mathrm{N}$ treatments were arranged in three subplot treatment: 1-Control without $\mathrm{N}$ fertilizer 2. Rational level $\mathrm{N}$ fertilizer, amounth $60 \mathrm{~kg}$ $\mathrm{ha}^{-1} 3$. High level, amounth $120 \mathrm{~kg} \mathrm{ha}^{-1}$. Nitrogen applied (UREA $46 \% \mathrm{~N}$ ) in tillering stage of growth. Investigation plots were herbicide treatment with 1,5 $1 \mathrm{ha}^{-1}$ Monosan $\mathrm{S}$ (2,4-D-DMA+MCPA). Each year, floristic composition, weed number and biomass was assessed at the heading stage of winter wheat. Weed density was assessed by counting the number of plants of each species found in $\mathrm{m}^{-2}$ with four replication. After the harvest plant material was measured and than analysed for morphological characteristics and yield component. Al data were subjected to analysis of variance.

\section{Results and discussion}

Objective of these studies was to determine the effect of different level intensity technology on weed sinuzia as important segment winter wheat technology in

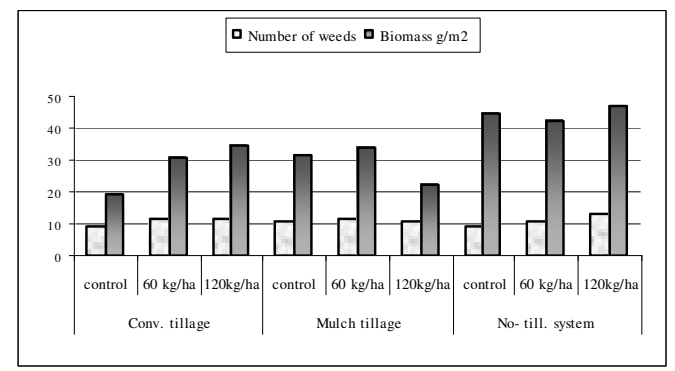

Figure 1. The effect of different winter wheat technology on weed number and biomass 
interaction with environment. Weed communities were product applied technology and crop competition. Dominated species in winter wheat weed sinuzia were Stenactis annua (L.) Ness., from annuals and Agropyrum repens (L.) Beauv., and Convolvulus arvensis L. Technology with conventional tillage had better efficacy decreases number of perennial weeds and biomass compared with both conservation tillage system (MT and NT). Increasing nitrogen amount can increase the ability of cereals to suppress weeds, with the result that number of species and biomass decline (Figure 1). Conservation tillage methods increase number of perennial weeds and biomass compared with conventional and make weed control difficult. Inorganic $\mathrm{N}$ fertilizers increase individuals of weed number and biomass with high amount. However, application with high $\mathrm{N}$ amount decreased total perennial weed species, but increase biomass. Grain yield (Table 1) showed high positive reaction of low-input cultivars to reduction in tillage systems and level inorganic $\mathrm{N}$ fertilizers $\left(3.24 \mathrm{t} \mathrm{ha}^{-1}\right)$ compared with cultivars for high-input condition which gave significantly lower grain yield in that condition $\left(3.04 \mathrm{t} \mathrm{ha}^{-1}\right)$.

Table 1. Effects of different technology on winter wheat grain yield ( $\mathrm{t} \mathrm{ha}^{-1}$ ). Average 2006/07-2007/08.

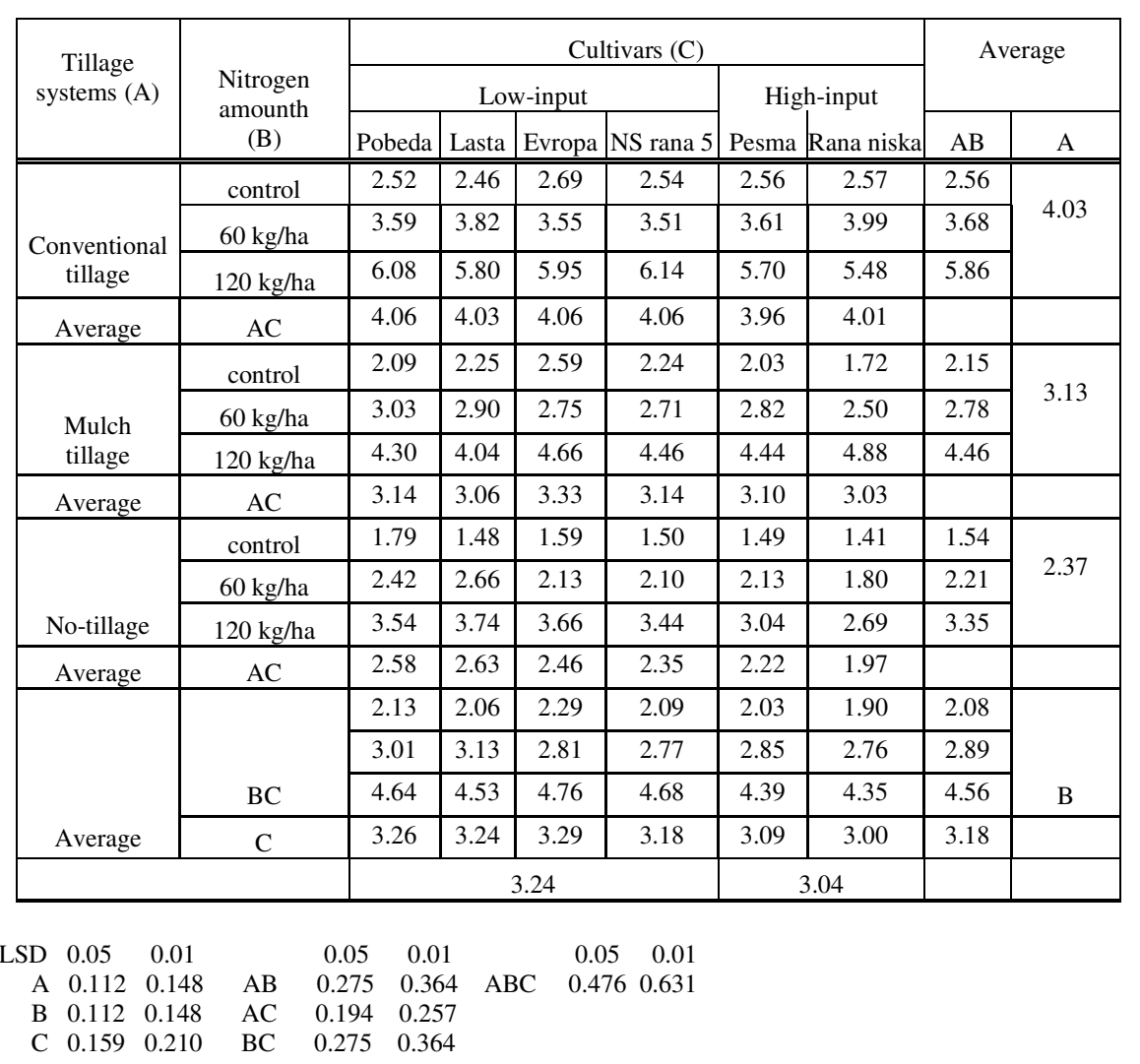


Winter wheat technology with conservation tillage systems (MT and NT) also generally gave statistically lower grain yield $\left(3.13 \mathrm{t} \mathrm{ha}^{-1}-2.37 \mathrm{t} \mathrm{ha}^{-1}\right)$. Conventional tillage system with both amounts inorganic $\mathrm{N}$ gave a higher grain yield $\left(4.03 \mathrm{t} \mathrm{ha}^{-1}\right)$. Results of investigation shows that yield in both conservation tillage were lower than those in conventional practice. The yields in NT system are distinctively lower. These are partly caused by the usually less even germination in the rough and compacted seedbed on the no-tilled soil. Grain yield of winter wheat increased with amount inorganic N, especially in conventional tillage system. Both groups of cultivars have higher yield in interactions with conventional tillage systems. In winter wheat technology with conservation tillage systems decrease significantly grain yield compared with conventional system. Wheat cultivars have different reaction in yield compared three different level intensity of inputs in winter wheat technology. The semi-dwarf cultivars Pobeda, Lasta, Evropa, NS Rana 5 and Pesma show higher differences in yield comparing with tall cultivar Rana niska. Reason for that is probably that in tall cultivars genetic potential for yield is generally low compared to semidwarf genotypes. So that cultivars yielded in low level even under favourable conditions.

\section{Conclusions}

Research has shown that low-input technology which includes conservation tillage, especially no-tillage system increased number of perennial weeds and biomass. Lowinput cultivars positively responded to reduces in tillage systems and different $\mathrm{N}$ amounth. Growing practice with certain reduction of tillage, $\mathrm{N}$ fertilizer and weed control was more favorable for low-input cultivars which positively responded by their yield compared with high-input cultivars. These results demonstrate potential new technologies comprehend higher flexibility of cultural practices (soil tillage, fertilization, integrated weed management, crop rotation,) with proper choose of wheat cultivars adapted on these conditions.

\section{Acknowledgements}

This research was funded by Ministry of Science and Technological Development, Republic of Serbia via Project: TR-20138.

\section{References}

Barberi, P. - Silvestri, N. - Bonari. E.: 1997. Weed communities of winter wheat as influenced by input level and rotation. Weed Research, 37: 301-313.

Birkás, M. - Dexter, A. R. - Kalmár, T. - Bottlik, L.: 2006: Soil quality-soil condition-production stability. Cereal Research Communications, 34: 1. 135-138.

Jug, D. - Stipesevic, B. - Zugec, I. - Horvat, D. - Josipovic, M.: 2006. Reduced tillage systems for crop rotations improving nutritional value of grain crops. Cereal Research Communications, 34: 1. 521-524.

Kovacevic, D. - Momirovic, N. - Dencic, S. - Oljaca, S. - Radosevic, Z. - Ruzicic, L.: 1988. Effects of tillage systems on soil physical properties and yield of winter wheat in low-input technology. Proceedings of International Conference on "Soil Condition and Crop Production". Gödöllö. 58-61. 


\title{
THE ADAPTABILITY OF PHYSIOLOGICAL PROCESSES IN AVENA SATIVA L. DEPENDING ON SIMULATED SOIL CONTAMINATION BY CADMIUM
}

\author{
Jiř́ TƯMA ${ }^{l}$ - Ivana ŠAFRÁNKOVÁ ${ }^{1}$ - Lenka TƯMOVÁ ${ }^{2}$ - Ivo ŠRÁMEK ${ }^{3}$ \\ Marie FLÍDROVÁ ${ }^{1}$ \\ ${ }^{1}$ Department of Biology, Faculty of Education, University of Hradec Kralove, Rokitanskeho 62, 50003 \\ Hradec Kralove, Czech republic, e-mail: jiri.tuma@uhk.cz \\ ${ }^{2}$ Department of Pharmacognosy, Faculty of Pharmacy Hradec Kralove, Charles University Prague, Czech \\ Republic \\ ${ }^{3}$ Health department laboratories, Health Institute of Hradec Kralove, Czech Republic.
}

Abstract: A pot experiment with Avena sativa L. was carried out to examine the effect of two levels of

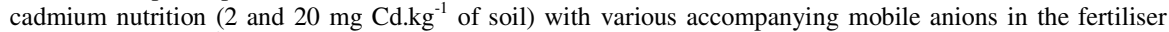
$\left(\mathrm{NO}_{3}^{-}, \mathrm{Cl}^{-}\right.$and $\left.\mathrm{SO}_{4}{ }^{2-}\right)$ on the cadmium content in the dry matter of leaves, the weight of the oat plants, the chlorophyll content in the leaves, the photosynthesis rate, the stomatal conductivity and transpiration rate. The cadmium nutrition had a significant effect in the form of a higher cadmium content in the leaves, especially with the higher intensity of $\mathrm{Cd}$ nutrition. In the variants with the higher intensity of $\mathrm{CdCl}_{2}$ nutrition, a significantly higher cadmium content was identified as compared with the variants for which the nutrition containing $\mathrm{Cd}\left(\mathrm{NO}_{3}\right)_{2}$ and $\mathrm{CdSO}_{4}$ was used. High levels of correlation were found between the measured levels of photosynthesis rate, stomatal conductivity and transpiration rate but no correlation between these levels and the cadmium content in the leaves was proved. In the variants with the Cd nutrition, insignificantly higher levels of photosynthesis rate were observed in the measurements in comparison with the zero variant.

Keywords: oat, cadmium content, photosynthesis rate, transpiration rate, gas conductance

\section{Introduction}

The resilience of ecosystems and the response of plants to stressful conditions created by the risk elements is a comprehensive manifestation. The adaptability of plants to these factors can be considerable (Hasan et al., 2009). Cd is easily received by the root system and its mobility in xylem and phloem is relatively good (Hart et al., 1998). The most frequently mentioned symptoms of the toxic effect of $\mathrm{Cd}$ include the browning of root hair, root tips and necrosis on leaves. Thus, $\mathrm{Cd}$ influences the structure of leaves and brings about many physiological changes. This is related to the negative effect of $\mathrm{Cd}$ on the production of chlorophyll, carotenoids, the activity and reduction of regeneration of enzymes, which participate in the fixation of $\mathrm{CO}_{2}$ (De Filippis and Ziegler, 1993; Pankovič et al., 2000; Gouia et al., 2003; Ekmekçi et al., 2008). Consequently, a decrease of the gas exchange parameters also occurs, the openness of stomata is reduced and the transpiration rates and photosynthesis rates decrease (Sanitá di Toppi and Gabrielli, 1999). With the decreasing life parameters, the synthesis of defensive and reparation proteins increases at the same time. This is true, for example, for glutathione, which is connected with starting the processes of adaptation to $\mathrm{Cd}$ (Hall, 2002).

\section{Materials and methods}

The research was carried out in the form of a pot experiment. The experimental crop was common oat (Avena sativa L.), the Atego variety. Polyethylene buckets with 
perforated bottoms were used as the experimental vessels. $10 \mathrm{~kg}$ of dry soil, including a dose of fertilisers, were weighed and put into each experimental vessels. The agrochemical specifications of the soil used were as follows : $\mathrm{pH} / \mathrm{CaCl}_{2}-6,2$; the content of exchangeable $\mathrm{P} 30, \mathrm{~K} 382, \mathrm{Mg} 166$; all this in $\mathrm{mg} \mathrm{kg}^{-1}$ in a Mehlich III leach; the content levels of chemical elements were as follows: $\mathrm{As}-8.96$; $\mathrm{Cd}-<0.5 ; \mathrm{Cr}-27,0$; $\mathrm{Hg}-0.066 ; \mathrm{Ni}-12.3 ; \mathrm{Pb}-16.9 ; \mathrm{Zn}-49.8$; all this in $\mathrm{mg} \mathrm{kg}^{-1}$ in an aqua regia leach; CEC $142 \mathrm{mmol} . \mathrm{kg}^{-1}$. In the experiment, 7 variants with different versions of fertilisation with triple repetition were created. The diagram of the experiment and the doses of chemicals per pot are stated in Table 1 .

Table 1. Scheme of experiment

\begin{tabular}{|c|c|c|c|c|c|}
\hline \multirow{2}{*}{$\begin{array}{l}\text { Variant } \\
\text { No. }\end{array}$} & \multirow{2}{*}{$\begin{array}{l}\text { Concentration } \mathrm{mg} \mathrm{Cd} \mathrm{kg}{ }^{-1} \\
\text { /Accompanying anion }\end{array}$} & \multicolumn{4}{|c|}{ Chemicals (g per pot) } \\
\hline & & $\begin{array}{l}\mathrm{Cd}\left(\mathrm{NO}_{3}\right)_{2} \\
.4 \mathrm{H}_{2} \mathrm{O}\end{array}$ & $\begin{array}{c}\mathrm{CdCl}_{2} \\
.2 .5 \mathrm{H}_{2} \mathrm{O} \\
\end{array}$ & $\begin{array}{l}\mathrm{CdSO}_{4} \\
.8 \mathrm{H}_{2} \mathrm{O} \\
\end{array}$ & $\mathrm{NH}_{4} \mathrm{NO}_{3}$ \\
\hline I. & control & - & - & - & - \\
\hline II. & $\mathrm{Cd} 2 / \mathrm{NO}_{3}^{-}$ & 0.055 & - & - & 1.130 \\
\hline III. & $\mathrm{Cd} 20 / \mathrm{NO}_{3}{ }^{-}$ & 0.549 & - & - & 1.001 \\
\hline IV. & $\mathrm{Cd} 2 / \mathrm{Cl}^{-}$ & - & 0.041 & - & 1.144 \\
\hline $\mathrm{V}$. & $\mathrm{Cd} 20 / \mathrm{Cl}^{-}$ & - & 0.405 & - & 1.144 \\
\hline VI. & $\mathrm{Cd} 2 / \mathrm{SO}_{4}{ }^{2-}$ & - & - & 0.046 & 1.144 \\
\hline VII. & $\mathrm{Cd} 20 / \mathrm{SO}_{4}{ }^{2-}$ & - & - & 0.456 & 1.144 \\
\hline
\end{tabular}

The experiment took place outdoors with the optimum water regimen. Each experimental pot was sown with 30 cereal grains (14/05/2009). After germination, the number of plants was adjusted to 25 . The measurement of physiological characteristics - photosynthesis rate $\left(\mathrm{P}_{\mathrm{N}}\right)$, transpiration rate $(\mathrm{E})$ and gas conductance $\left(\mathrm{g}_{\mathrm{s}}\right)$ - took place at the stage of $71 \mathrm{DC}$ by means of the infra-red gas analyser LCpro+, manufactured by ADC BioScientific Ltd. UK. Chlorophyll content was measured by the chlorophyllmeter CCM 200, manufactured by OptiScience. The plants were taken on 05/08/2009 in the phase of medium milk ripeness - 75 DC. The upper green, photosynthetically active leaves were separately analysed for $\mathrm{Cd}$ content using of atom absorption. The results were statistically processed in the Statistica software, using analysis of variance, the Wilkinson test with the significance level of 0.95 and a correlation analysis.

\section{Results and discussion}

The Cd content and the photosynthesis rate levels in the oat leaves are shown in Fig. 1. It is apparent from the this figure that the Cd nutrition resulted in a significantly higher Cd content in the leaves, especially in the variants with higher intensity (variants III, V and VII) in comparison with the unfertilised zero variant (variant I, control). In the variant with the higher intensity of nutrition with $\mathrm{CdCl}_{2}$ (variant $\mathrm{V}$ ), a significantly higher $\mathrm{Cd}$ content was identified as compared with the variants with the nutrition containing $\mathrm{Cd}\left(\mathrm{NO}_{3}\right)_{2}$ and $\mathrm{CdSO}_{4}$. McLaughlin et al. (1994) and Backstrom et al. (2004) arrived at similar results. The increased $\mathrm{Cd}$ content can be associated with the direct intake of $\mathrm{CdCl}_{2}$, or possibly with the production of chlorine complexes, which increase the diffusion of $\mathrm{Cd}$ from soil into roots. 


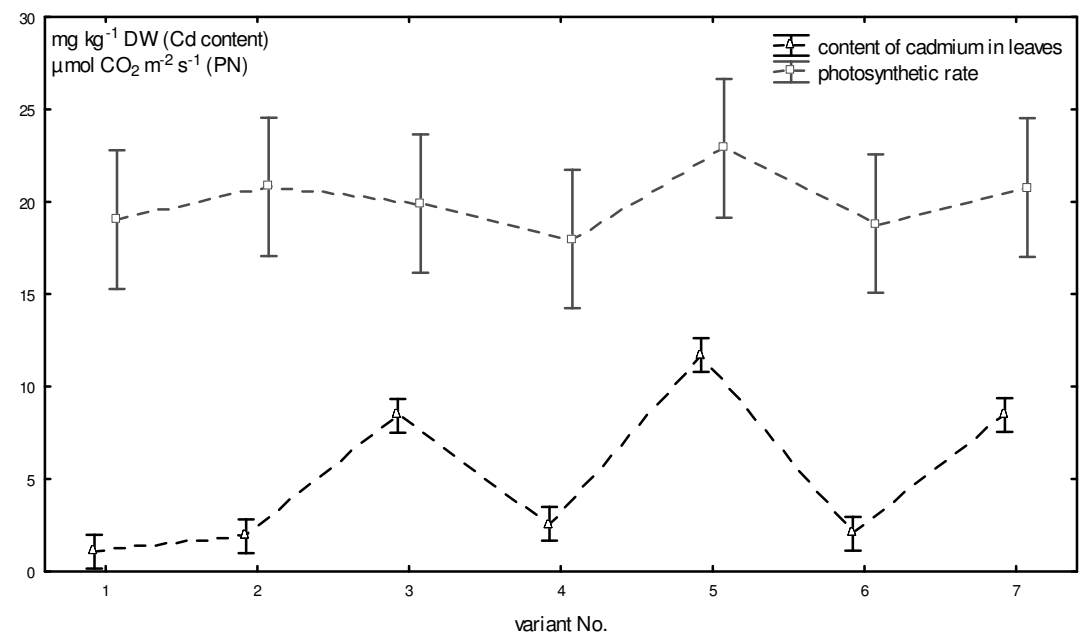

Figure 1. The cadmium content and photosynthesis rate levels in oat leaves

In all the variants with Cd nutrition, only an insignificant decrease of the weight of the above-ground part of the plants was observed in comparison with the zero variant. A more marked decrease of the weight of the plants in the variants with the Cd nutrition might have also been partly eliminated by the dose of nitrogen. No significant decrease of chlorophyll content was observed and no correlation between $\mathrm{Cd}$ content and chlorophyll content in leaves was identified. Even in the experiments carried out by Lagriffoul et al., (1998) and Cheng et al. (2002), a decrease of chlorophyll content was observed only with the highest level of Cd contamination.

High levels of correlation have been identified between the measured levels of photosynthesis rate, stomatal conductivity and transpiration rate (linear correlation coefficients $\mathrm{R}^{2}=0.7194$; or $\mathrm{R}^{2}=0.776, \mathrm{n}=21$ ) but no correlation between these levels and the $\mathrm{Cd}$ content in leaves was proved. In the variants with the $\mathrm{Cd}$ nutrition, insignificantly higher levels of photosynthesis rate were identified in the measurements as compared with the zero variant. The first response of plants to stress can be the increase of the metabolic processes. It follows from the results that oat has a fairly good tolerance and adaptability to a stress induced by a higher content of ions $\mathrm{Cd}^{2+}$. For example, Vassilev et al. (2004) state the following for barley: The maximal shoot $\mathrm{Cd}$ concentration-41 $\pm 8 \mathrm{mg} \mathrm{Cd} \mathrm{kg}^{-1} \mathrm{DW}$-without any visual toxicity symptoms on the shoots was found at $28 \mathrm{mg} \mathrm{Cd} \mathrm{kg}^{-1}$ sand. Reduced leaf gas exchange, photosynthetic pigments content and electron transport activity but not altered lipid peroxidation status of thylakoids was, however, detected at the highest treatment $-42 \mathrm{mg} \mathrm{Cd} \mathrm{kg}^{-1}$ sand. 


\section{Conclusions}

The cadmium nutrition had a significant consequence in the form of a higher cadmium content in leaves, mainly with the higher intensity of $\mathrm{Cd}$ nutrition. In the variants with a higher intensity of nutrition with $\mathrm{CdCl}_{2}$, a significantly higher cadmium content was identified in comparison with the variants where $\mathrm{Cd}\left(\mathrm{NO}_{3}\right)_{2}$ and $\mathrm{CdSO}_{4}$ nutrition was used. In all the variants with $\mathrm{Cd}$ nutrition, only an insignificant decrease of the weight of the above-ground part of the plants was observed. No significant decrease of the chlorophyll content in leaves was observed. Based on the measured levels of photosynthesis rate, stomatal conductivity and transpiration rate, no correlation between these characteristics and the cadmium content in leaves was proved. Oat has developed fairly good tolerance to stress induced by a higher content of $\mathrm{Cd}^{2+}$ ions.

\section{Acknowledgements}

The research was carried out as part of the Specific Research of the University of Hradec Králové no. 2102/2009 and the Research Project MSM 0021620822.

\section{References}

Backstrom M. - Karlsson S. - Backman L. - Folkeson L. - Lind B.: 2004. Mobilisation of heavy metals by deicing salts in a roadside environment. Water Research, 38: 720-732.

Cheng S. - Ren F. - Grosse W. - Wu Z.: 2002. Effects of Cadmium on Chlorophyll Content, Photochemical Efficiency, and Photosynthetic Intensity of Canna indica Linn. International Journal of Phytoremediation, 4: 239-246.

De Filippis L. F. - Ziegler H.: 1993. Effect of sublethal concentrations of zinc, cadmium and mercury on the photosynthetic carbon reduction cycle of Euglena. Journal of Plant Physiology, 142: 167-172.

Ekmekçi Y. - Tanyolaç D. - Ayhan B.: 2008. Effects of cadmium on antioxidant enzyme and photosynthetic activities in leaves of two maize cultivars. Journal of Plant Physiology, 165: 600-611.

Gouia H. - Suzuki A. - Brulfert J. - Ghorbal M.H.: 2003. Effects of cadmium on the co-ordination of nitrogen and carbon metabolism in bean seedlings. Journal of Plant Physiology, 160: 367-376.

Hall J.L.: 2002. 2 Cellular mechanisms for heavy metal detoxification and tolerance. Journal of experimental Botany, 53: 1-11.

Hart, J.J. - Welch R.M. - Norvell W.A. - Sullivan L.A. - Kochian L.V.: 1998. Characterization of Cadmium Binding, Uptake, and Translocation in Intact Seedlings of Bread and Durum Wheat Cultivars. Plant Physiology, 116: 1413-1420.

Hasan S.A. - Fariduddin Q. - Ali B. - Hayat S. - Ahmad A.: 2009. Cadmium: Toxicity and tolerance in plants. Journal of Environmental Biology, 30: 165-174.

Lagriffoul A. - Mocquot B. - Mench M. - Vangronsveld J.: 1998. Cadmium toxicity effects on growth, mineral and chlorophyll contents, and activities of stress related enzymes in young maize plants (Zea mays L.). Plant and soil, 200: 241-250.

McLaughlin M.J. - Palmer L.T. - Tiller K.G. - Beech T.A. - Smart M.K.: 1994. Increased soil-salinity causes elevated cadmium concentrations in field-grown potato-tubers. Journal of Environmental Quality, 23: 1012-1018.

Sanita di Toppy L. - Gabrieli R.: 1999. Response to cadmium in higher plants. Environmental and Experimental Botany, 41: 105-130.

Vassilev A. - Lidon F.C. - Ramalho J.C. - Matos M.D. - Bareiro M.G.: Shoot Cadmium Accumulation and Photosynthetic Performance of Barley Plants Exposed to High Cadmium Treatments. Journal of Plant Nutrition, 27: 775 - 795 . 


\title{
THE CONTRIBUTION OF VARIETY MIXTURE UTILIZATION FOR ENHANCING THE RESILIENCE OF AGRO-ECOSYSTEMS
} Darina MUCHOVÁ ${ }^{1}-$ Danica FAZEKAŠOVÁ ${ }^{2}$

\author{
1 The Plant Production Research Center Piešt'any, Research-breeding station Malý Šariš, 08001 Prešov, \\ Slovakia,muchova@vurv.sk \\ ${ }^{2}$ University of Prešov in Prešov, Faculty of Humanities and Natural Sciences, Department of Ecology, Ul. 17. \\ novembra 1, 08116 Prešov, Slovakia, fazek@unipo.sk
}

\begin{abstract}
Scientists are breeding crop varieties resistant to diseases, pests and other biotic and abiotic constraints. The new varieties lead to improved agricultural productivity, which contributes to human food and ecosystem resilience. But their continuous and extensive cultivation in the form of genetically uniformed monocultures renders the crops and the whole agricultural system vulnerable to pest and disease attacks. Variety mixtures are recognized to offer useful disease control. The objective of this study was to investigate the effect of variety mixtures on fungal disease development in the heterogeneous plant populations of winter wheat in the eastern part of Slovakia. The variety mixture trial implemented seven varieties of wheat. Three of them were very well adapted to local conditions of potato growing region and they were mixed with others, having a high degree of disease resistance, in 3-component variety mixtures. Treatments in this experiment included each variety grown alone and nineteen mixture variants in three different growing seasons. Mixtures in comparison with pure varieties reduced the severity of brown rust, mildew and leaf spot diseases. Severity of yellow rust was not affected by variety mixtures. Disease intensity was strongly dependent on the year and on the variety of components used in the mixtures. This study revealed that variety mixtures may be used as added elements of functional diversity to reduce levels of fungal diseases and they would provide benefits to wheat production and enhancing the resilience in agricultural systems.
\end{abstract}

Keywords: agro-ecosystem, crop diversity, variety mixtures, fungal diseases, winter wheat

\section{Introduction}

Undoubtedly, environmental factors as well as the level of water, fertilizer, pesticide application play a key role in crop yield increasing (Jolánkai et al., 2006; Kováčik, 2009; Kotorová et al., 2009). Together with the genetic factor represents by a great number of varieties is also very important. Scientists and breeders do not stop to develop new improved varieties. However, many of them have narrow genetic base and they are often grown on a large acreage of land in genetically uniform monoculture. The pressures to increase the uniformity and productivity of crops have resulted in major losses in agricultural biodiversity, which can affect the stability and resilience of the agricultural ecosystems. Much of the resilience of the agro-ecosystems is due to complex interactions among species and genotypes at all levels of the system (Finckh, 2008). The lack of genetic diversity can lead to very rapid overcoming of variety resistance and often giving rise to periodic plant disease epidemics.

To manage diversity in a better way, diversification concepts have been developed by pathologists and breeders since the 1950s. Diversification strategies in time and space are being used in many agricultural systems to achieve acceptable levels of important diseases, pests, and weeds together with high product quality and stable yields (Finckh and Wolfe, 2006). There are many possibilities for diversifying cropping system. One of them are variety mixtures, which can help to reduce disease by diluting the inoculum of pathogens, through a barrier effect against spore dispersal provided by resistant plants in the canopy and by induced resistance when nonpathogenic spores trigger biochemical defenses that help protect plants against patogenic strains (Mundt, 2002). 
The objective of the research was to explore the effect of variety mixtures on the fungal disease development in winter wheat under natural field conditions.

\section{Materials and methods}

Experiments were conducted during the 2006-07, 2007-08 and 2008-09 winter wheat seasons at Research-breeding station (RBS) in Malý Šariš, located in the eastern part of Slovakia. This location receives approximately $603 \mathrm{~mm}$ annual rainfall and the longterm average temperature is $7,94^{\circ} \mathrm{C}$. The experimental design was a randomized complete block with four replications. The plots were $10 \mathrm{~m}^{2}$ large.

The set of genotypes selected for research comprised of 7 winter wheat varieties. First group made varieties bred at RBS in M. Šariš Malvína (A), Malyska (B), Torysa (C) with good adaptation for growing in potato growing region. In the second group were varieties Barroko (D), Ilias (E), Hermann (F), Manhattan (G), which were chosen for mixing on the base of their complementarity for disease resistance characteristics. Each of domestic varieties was mixed with two others from the second group in the 1:1:1 three-component mixtures. One mixture (ABC) was composed only from the domestic varieties. Seeding rate was 400 seeds per $\mathrm{m}^{2}$. Treatments in this experiment included each variety grown alone and nineteen mixture variants.

Disease severity of mildew, leaf rust, stripe rust and leaf spot diseases was assessed as $\%$ of leaf area infected. Disease ratings will be taken 3-4 times according to seasons and area under the disease progress curve (AUDPC) was produced. AUDPC measures intensity as well as the rate of the disease increase.

\section{Results and discussion}

Fig. 1 shows the means of AUDPC values of pure line varieties averaged over 3 years. The AUDPC of yellow rust is from 2007, because it occurred only in that year. Wheat varieties used in mixtures as supplement $(\mathrm{D}, \mathrm{E}, \mathrm{F}, \mathrm{G})$ to domestic ones $(\mathrm{A}, \mathrm{B}, \mathrm{C})$ were fully resistant to yellow rust and high resistant to brown rust and powdery mildew. All varieties showed only moderate to low resistance to leaf spot diseases, primarily caused by Mycosphaerella graminicola and Pyrenophora tritici-repentis.

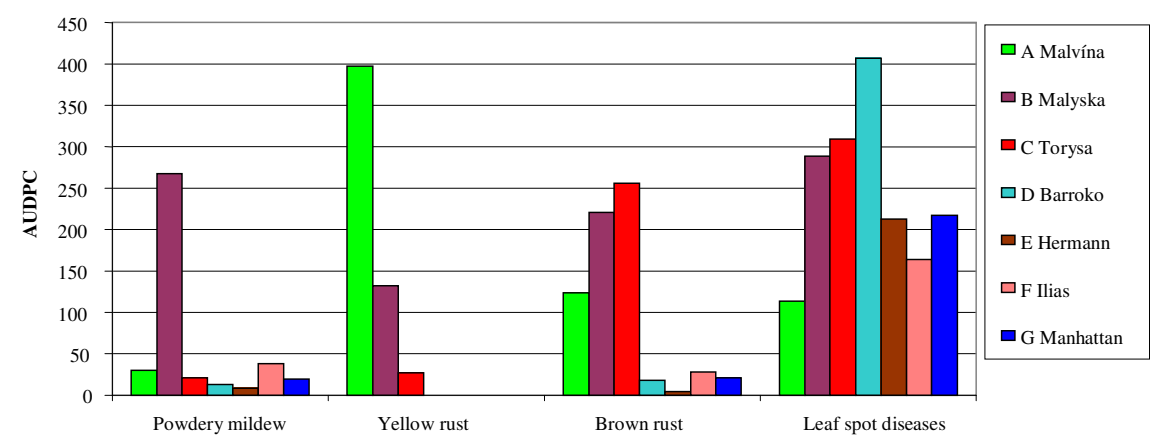

Figure 1. AUDPC values of the individual components used in variety mixtures. 
The paired $t$-test revealed significant differences $(p<0.01)$ for AUDPC between mean of mixtures and mean calculated from the average of the corresponding pure varieties. The observed mean AUDPC of mixtures was lower than expected one for all diseases except yellow rust (Table 1). Variety mixtures exceeded expected AUDPC mean for yellow rust by $67 \%$ (without $\mathrm{ABC}$ ). The ability of mixtures to reduce spreading of yellow rust in this study with $33.3 \%$ proportion of very susceptible variety was insufficient and it is suitable to avoid using those varieties in mixtures in the area where yellow rust is a potential risk. Only in the mixtures with variety Malyska (BDE-BFG) was observed a low reduction in AUDPC. Mixture ABC, consisted only from domestic susceptible varieties, had 2.2 times higher AUDPC than expected. Lannou et al. (1994) suggested that mixture efficacy was limited for a large-lesion parasite as yellow rust because of fast host-plant saturation and they found that substantial lesion expansion of yellow rust decreased host-diversity effect for reduce disease by half compared with brown rust.

Table 1. AUDPC values of the mixtures and differences between mean of the mixtures and mean calculated from the average of variety components

\begin{tabular}{|l|c|c|c|c|c|c|c|c|}
\hline \multirow{2}{*}{ Mixture } & \multicolumn{2}{|c|}{ Powdery mildew } & \multicolumn{2}{c|}{ Yellow rust } & \multicolumn{2}{c|}{ Brown rust } & \multicolumn{2}{c|}{ Leaf spot diseases } \\
\cline { 2 - 9 } & AUDPC & Difference $^{\mathrm{a}}$ & AUDPC & Difference & AUDPC & Difference & AUDPC & Difference \\
\hline \hline ADE & 10.6 & -6.4 & 243.5 & 111.0 & 21.4 & -27.3 & 179.0 & -65.3 \\
\hline ADF & 17.5 & -9.4 & 271.5 & 139.0 & 27.1 & -29.4 & 158.5 & -69.7 \\
\hline ADG & 13.2 & -7.5 & 301.9 & 169.4 & 22.2 & -32.0 & 174.4 & -71.6 \\
\hline AEF & 14.4 & -11.1 & 187.5 & 55.0 & 21.0 & -31.0 & 136.2 & -27.2 \\
\hline AEG & 11.8 & -7.5 & 258.6 & 126.2 & 19.7 & -29.9 & 155.3 & -25.9 \\
\hline AFG & 18.9 & -10.4 & 280.4 & 147.9 & 27.6 & -29.8 & 138.0 & -27.0 \\
\hline BDE & 41.0 & -55.2 & 30.6 & -13.5 & 38.9 & -42.3 & 237.9 & -64.9 \\
\hline BDF & 61.9 & -44.4 & 42.9 & -1.2 & 55.1 & -33.9 & 209.3 & -77.3 \\
\hline BDG & 73.5 & -26.5 & 34.3 & -9.8 & 46.7 & -39.9 & 223.4 & -81.0 \\
\hline BEF & 51.4 & -53.4 & 38.1 & -6.0 & 35.8 & -48.8 & 170.2 & -51.5 \\
\hline BEG & 41.6 & -56.9 & 33.9 & -10.2 & 40.2 & -42.0 & 175.6 & -64.0 \\
\hline BFG & 80.6 & -28.0 & 29.3 & -14.8 & 66.8 & -23.1 & 162.8 & -60.5 \\
\hline CDE & 14.1 & 0.0 & 13.5 & 4.4 & 113.6 & 20.8 & 266.4 & -43.2 \\
\hline CDF & 14.7 & -9.4 & 17.0 & 7.9 & 108.5 & 7.8 & 261.3 & -32.1 \\
\hline CDG & 10.1 & -7.7 & 19.9 & 10.8 & 114.8 & 16.5 & 283.8 & -27.5 \\
\hline CEF & 14.5 & -8.2 & 15.9 & 6.8 & 91.8 & -4.3 & 226.9 & -1.8 \\
\hline CEG & 13.0 & -3.3 & 17.0 & 7.9 & 88.0 & -5.7 & 254.0 & 7.5 \\
\hline CFG & 24.4 & -2.0 & 22.0 & 12.9 & 87.5 & -14.0 & 221.3 & -9.0 \\
\hline ABC & 95.4 & -10.7 & 414.3 & 228.6 & 109.4 & -90.6 & 203.7 & -33.5 \\
\hline Mean & & & & & & & & \\
\hline Observed & $32.8 * *$ & -18.9 & $119.6 * *$ & 51.2 & $59.8 * *$ & -25.2 & $202.0 * *$ & -43.4 \\
\hline Expected & 51.6 & & 68.4 & & 85.0 & & 245.4 & \\
\hline
\end{tabular}

** Difference between the observed mixture mean and the expected one significant at 0.01 probability levels.

${ }^{a}$ Difference between the observed mixture mean and mean calculated from the average of variety components

Garret and Mundt (1999) suggest that the effects of host diversity will tend to be greatest when the pathogen's dispersal gradient is shallow, characteristic lesion size are small, and the number of pathogen generation is large. This is typical for powdery mildew and partially for brown rust with less number of pathogen cycles. Percentage reduction in AUDPC was $57 \%$ for mildew and $14 \%$ for brown rust. In mildew, the lowest AUDPC values showed mixtures with resistant varieties Malvína and Torysa, 
but reduction in disease was usually greater in mixtures with the most susceptible variety Malyska compared to the other ones. Regarding brown rust only 3 mixtures with Torysa (CDE, CDF, CDG) had higher AUDPC values than expected. In these cases besides the susceptibility of Torysa, the presence of other variety Barroko with reduced plant height may play a role in disease progress due to a minor barrier effect. It is noteworthy that significant reductions -90.6 occurred in AUDPC of mixture ABC even though all its components are susceptible varieties to brown rust. Comparison the development of both rusts in this mixture confirms findings concerning different mechanism of rust spreading in the canopy and the influence of lesion expansion of these rusts on host-diversity effects (Lannou et al., 1994).

Mixtures were also effective in reducing AUDPC for leaf spot diseases in 18 of the 19 mixtures, though the amount of reduction varied considerably among mixtures. An average reduction of $21 \%$ was recorded in AUDPC of mixtures compared to the weighted means of the component varieties.

\section{Conclusions}

Variety mixtures in comparison with pure line varieties reduced the severity of brown rust, mildew and leaf spot diseases. Severity of yellow rust was not affected by variety mixtures. This study revealed that mixtures of wheat varieties with different levels of resistance may be used as alternative strategy of managing some fungal diseases to retard their progress and they would provide benefits to wheat production and enhancing the resilience in agricultural systems.

\section{Acknowledgements}

The authors express their thanks to VEGA project 1/0601/08 for the financial support of the research work.

\section{References}

Finckh M. R. - Wolfe M. S.: 2006. Diversification strategies. In: Cooke B. M. et al. (eds.), The Epidemiology of Plant Diseases. Berlin, Springer. 269-307.

Finckh M. R.: 2008. Integration of breeding and technology into diversification strategies for disease control in modern agriculture. European Journal of Plant Pathology, 121: 3. 399-409.

Garrett K. A. - Mundt C. C.: 1999. Epidemiology in mixed host populations. Phytopathology, 89: 11. 984990.

Jolankai M. - Szentpétery Zs. - Hegedüs Z.: 2006. Pesticide residue dischange dynamics in wheat grain. Cereal Research Communications, 34: 1. 505-509.

Kotorová, D. - Šoltysová, B. - Kováč, L. - Mati, R.: 2009. The spatial variability of physico-chemical properties as a stress factor in a non-regularly overflowed area. Cereal Res. Com., 37: 387-390.

Kováčik, P.: 2009. Výživa a systémy hnojení rostlin. Kurent Publisher, České Budějovice, 109. ISBN 978-8087111-16-1

Lannou C. - de Vallavieille-Pope C. - Biass, C - Goyeau, H.: 1994. The efficacy of mixtures of susceptible and resistant hosts to two wheat rusts of different lesion size: Controlled condition experiments and computerized simulations. Journal of Phytopathology, 140: 3. 227-237.

Mundt C. C.: 2002. Use of multiline cultivars and cultivar mixtures for disease management. Annual Review of Phytopatology, 40: 381-410 


\title{
THE EFFECT OF MINERAL NUTRITION ON WEEDINESS AND GRAIN YIELD OF TRITICALE
}

\author{
Desimir KNEZEVIC ${ }^{1}-$ Veselinka ZECEVIC ${ }^{2}-$ Miodrag JELIC ${ }^{1}-$ \\ Aleksandar PAUNOVIC ${ }^{3}-$ Milomirka MADIC ${ }^{3}$ \\ ${ }^{1}$ Faculty of Agriculture, University of Pristina, Zubin Potok 38228, J. Anžujske bb., Kosovo \& Metohija, \\ Serbia, deskoa@ptt.rs \\ ${ }^{2}$ Faculty of Biopharming Backa Topola, University Megatrend Belgrade \\ ${ }^{3}$ Faculty of Agriculture Cara Dusana 34, 32000 Cacak, Serbia acopa@tfc.kg.ac.rs
}

Abstract: Yield variability of triticale cultivar Favorit and weediness in triticale crops affected by different regime of mineral nutrition were studied. The study was conducted at the long term experiment on control variant (without fertilizers), second variant without nitrogen application (two subvariants with different rate of P) $2 \mathrm{P}_{1}\left(80 \mathrm{~kg} \mathrm{P} \mathrm{ha}^{-1}\right)$ and $2 \mathrm{P}_{2}\left(120 \mathrm{~kg} \mathrm{P} \mathrm{ha}^{-1}\right)$, third variant with NP fertilizer with two different rate of $\mathrm{N}$ application: $3 \mathrm{~N}_{1}\left(80-100 \mathrm{~kg} \mathrm{NP} \mathrm{ha}^{-1}\right)$ and $3 \mathrm{~N}_{2}\left(120-100 \mathrm{~kg} \mathrm{NP} \mathrm{ha}^{-1}\right)$ and fourth variant $4 \mathrm{~N}_{1}\left(80-60 \mathrm{~kg} \mathrm{NP}^{-1}\right)$ and $4 \mathrm{~N}_{2}\left(120-60 \mathrm{~kg} \mathrm{NP} \mathrm{ha}{ }^{-1}\right)$. Weediness depends of rate and variant of fertilization. The dominant weed species Consolida regalis, Convolvulus arvensis, Polygonum aviculare, Cirsium arvense, Agropyrum repens, Polygonum convolvulus was on fertilized plots. The analyzed variability of grain yield depends of applied fertilizer variants. The lowest grain yield was found on control variant while the highest grain yield $(4880 \mathrm{~kg}$ $\left.\mathrm{ha}^{-1}\right)$ and low weediness expressed in variant $4 \mathrm{~N}_{2}\left(120-60 \mathrm{~kg} \mathrm{~N} \mathrm{ha}^{-1}\right)$.

Keywords: grain yield, nutrition, rate of fertilizer, weediness, triticale

\section{Intoduction}

Yield and yield components of triticale varied under various factors: scientific farming measures, rate of nitrogen fertilization, usage of pesticides, (Jolánkai et al., 2008) weediness, meteorological conditions (Márton, 2008). In crop production triticale is a better competitor than wheat against the weeds (Kiec, 2003; Avramovic and Knezevic, 2007). Numerous studies reported that yield of wheat, as well other small grains, is in dependence of interaction of genotypes/environment (Pepo, 2007; Oracka and Łapiński, 2006) mineral elements availability (Kovacevic et al., 2005) agro ecological condition (Drezner et al., 2007) precipitation (Balogh et al. 2006) crop weediness (Fodor and Pálmai, 2008; Knezevic et al., 2008). Triticale can achieve high yield and quality under adequately scientific farming measure: soil tillage, optimal time and density of sowing, level of water, fertilizer, pesticide (Oettler et al. 2000; Pawlonka and Skrzyczyńska, 2004; Füleky, 2008). In triticale and other cereals, yield losses at average weediness can reach about $30 \%$ (Mason et al., 2007). One of the most important factors of crops protection is weed control (Jolánkai et al., 2006). Time of sowing and density (Walter et al., 2002) of triticale is important for tillering, enough to suppress weeds in spring season and reduce yield losses caused by late sowing, low temperature during winter and early spring time (Tarnawa et al., 2009). In addition, optimal application of fertilizer will increase vigour and competitiveness of cereal crop (Paunović et al., 2007). Grain yield and protein content are in dependence of NP fertilizer rates (Aguirre et al. 2006; Kassai et al., 2006; Varga et al., 2007). The increasing of $\mathrm{N}$ rate is in connection with increasing of biomass of both cereal and weeds plants (Jolánkai et al., 2006; Knezevic et al., 2007). Within triticale growing technology, herbicides use to suppress damage effect of weeds to grain yield. The aim of this paper is investigation of the 
effect of fertilization to weed communities of winter triticale and variation of grain yield.

\section{Materials and methods}

The weediness and grain yield of Favorit triticale crop, grown under different regime of $\mathrm{N}$ nutrition were studied. Cultivar was grown on long term experimental field of Center for Small Grains in Kragujevac on control variant (unfertilized), second variant without nitrogen (two sub variants with different rate of $\mathrm{P}) 2 \mathrm{P}_{1}\left(80 \mathrm{~kg} \mathrm{P} \mathrm{ha}^{-1}\right)$ and $2 \mathrm{P}_{2}(120 \mathrm{~kg} \mathrm{P}$ $\left.\mathrm{ha}^{-1}\right)$, third variant by NP fertilizer with two different rate of $\mathrm{N}$ : $3 \mathrm{~N}_{1}\left(80-100 \mathrm{~kg} \mathrm{NP} \mathrm{ha}^{-1}\right)$ and $3 \mathrm{~N}_{2}\left(120-100 \mathrm{~kg} \mathrm{NP} \mathrm{ha}^{-1}\right)$ and fourth variant $4 \mathrm{~N}_{1}\left(80-60 \mathrm{~kg} \mathrm{NP} \mathrm{ha}^{-1}\right)$ and $4 \mathrm{~N}_{2}(120-$ $\left.60 \mathrm{~kg} \mathrm{NP} \mathrm{ha}{ }^{-1}\right)$. Analysis of weed community and yield of triticale were conducted on four basic variants of soil fertilization and three replications. Unfertilized plots belonged to type of soil smonitza in the process of degradation with $\mathrm{pH}=6.03-6.10$ in water and 4.76-4.84 in KC1. Floristic structure estimated by method Braun-Blanquet (1964).

\section{Results and discussion}

The weed species in triticale crops cultivated under different regime of fertilization were identified. Different rates of nitrogen and phosphorus were influenced differences of weediness (table 1). The lowest weediness registered on the plots of triticale crops where applied the highest rate of nitrogen. In each variant of applied rate of fertilizer, were registered between 8 and 10 weed species in crop of Favorit cultivar. Mainly in all variants of nitrogen fertilization the weed species Cirsium arvense Consolida regalis, Convolvulus arvensis, Polygonum aviculare was dominant (table 1).

Table 1. Weed species in triticale crops on controls variant (no fertilized plots) $1 \mathrm{~N}_{1}, 1 \mathrm{~N}_{2}$, and on variant with application of different $\mathrm{NP}$ fertilizer rates $2 \mathrm{P}_{1}\left(80 \mathrm{~kg} \mathrm{Pha}^{-1}\right)$ and $2 \mathrm{P}_{2}\left(120 \mathrm{~kg} \mathrm{P} \mathrm{ha}^{-1}\right) 3 \mathrm{~N}_{1}\left(80-100 \mathrm{~kg} \mathrm{NP} \mathrm{ha}^{-1}\right)$ and $3 \mathrm{~N}_{2}\left(120-100 \mathrm{~kg} \mathrm{NP} \mathrm{ha}^{-1}\right) 4 \mathrm{~N}_{1}\left(80-60 \mathrm{~kg} \mathrm{NP} \mathrm{ha}^{-1}\right)$ and $4 \mathrm{~N}_{2}\left(120-60 \mathrm{~kg} \mathrm{NP} \mathrm{ha}^{-1}\right)$

\begin{tabular}{|c|c|c|c|c|c|c|c|c|}
\hline Cultivar & \multicolumn{8}{|c|}{ Triticale- Favorit cultivar } \\
\hline Variant of fertilizer & \multirow[t]{2}{*}{$1 \mathrm{~N}_{1}$} & \multirow[t]{2}{*}{$1 \mathrm{~N}_{2}$} & \multirow{2}{*}{$\begin{array}{l}2 \mathrm{~N}_{1} \\
\left(2 \mathrm{P}_{1}\right)\end{array}$} & \multirow{2}{*}{$\begin{array}{l}2 \mathrm{~N}_{1} \\
\left(2 \mathrm{P}_{2}\right)\end{array}$} & \multirow{2}{*}{$\begin{array}{l}3 \mathrm{~N}_{1} \\
(\mathrm{NP})\end{array}$} & \multirow{2}{*}{$\begin{array}{l}3 \mathrm{~N}_{2} \\
(\mathrm{NP} \\
)\end{array}$} & \multirow{2}{*}{$\begin{array}{l}4 \mathrm{~N}_{1} \\
(\mathrm{NP})\end{array}$} & \multirow{2}{*}{$\begin{array}{l}4 \mathrm{~N}_{2} \\
(\mathrm{NP})\end{array}$} \\
\hline Weed species & & & & & & & & \\
\hline Agropyrum repens & & +.1 & & +.1 & +.1 & +.1 & +.1 & R \\
\hline Consolida regalis & +.1 & +.1 & +.1 & +.1 & $+.1-1.1$ & +.1 & 1.1 & $+.1-1.1$ \\
\hline $\begin{array}{l}\text { Convolvulus } \\
\text { arvensis }\end{array}$ & +.1 & +.1 & +.1 & +.1 & +.1 & +.1 & $1.1-1.1$ & +.1 \\
\hline Linaria vulgaris & +.1 & +.1 & +.1 & $\mathrm{R}$ & +.1 & & +.1 & +.1 \\
\hline Setaria halepense & & & $\mathrm{R}$ & & & $\mathrm{R}$ & +.1 & +.1 \\
\hline $\begin{array}{l}\text { Lamium } \\
\text { amplexicaule }\end{array}$ & & & & & $\mathrm{R}$ & & & \\
\hline Viola arvensis & +.1 & & $\mathrm{R}$ & +.1 & & +.1 & +.1 & +.1 \\
\hline Taraxacum officinale & & & & & +.1 & & & \\
\hline Polygonum aviculare & +.1 & +.1 & +.1 & +.1 & +.1 & +.1 & 1.1 & 1.1 \\
\hline $\begin{array}{l}\text { Polygonum } \\
\text { convolvulus }\end{array}$ & +.1 & +.1 & +.1 & +.1 & +.1 & +.1 & +.1 & $+.1-1.1$ \\
\hline Chenoodium album & & & & $\mathrm{R}$ & & $\mathrm{R}$ & & $\mathrm{R}$ \\
\hline Cirsium arvense & $1.1-2.2$ & 1.1 & $+.1-2.2$ & $1.1-2.2$ & 1.1 & 1.1 & $+.1-1.1$ & $1.1-2.2$ \\
\hline Rubus caesius & +.1 & +.1 & & $\mathrm{R}$ & & $\mathrm{R}$ & & \\
\hline Total no. of species: & 8 & 8 & 8 & 10 & 9 & 10 & 9 & 10 \\
\hline
\end{tabular}


Different rates of nitrogen fertilization are not affected on the weediness level and botanical composition of the community. On control and fertilized plots was expressed similar weediness in triticale crop. By study of floristic structure, determined, that weedy community represents a fragment of association of Consolida regalis-Polygonum aviculare having in its composition 13 species. The weed species Consolida regalis, Convolvulus arvensis, Polygonum aviculare, Cirsium arvens, Polygonum convolvulus were dominant on fertilized plots. These results are in agreement with previous investigation Knezevic et al. (2008). Climatic condition (precipitation, temperature) as well as agronomic scientific farming influence to composition of weed species (Jolànkai et al., 2008; Tarnawa et al., 2009). By investigation other authors were registered the most prevalent weed species Capsella bursa-pastoris and Taraxacum officinale (Harker et al. 2000). Density of weeds is in dependence of weed species and soil properties (Tỳr et al., 2009). Therefore, negative cross-correlation between the density of Viola arvensis Murray and clay content, while, density of Lamium purpureum L. was positively crosscorrelated with the phosphorus content in the soil (Walter et al., 2002). The interaction between variety and $\mathrm{N}$ supply was significant for yield. In this investigation analyzed influence of weed and fertilizer to variation of grain yield in triticale crop. The highest grain yield of triticale Favorit cultivars was found on plots with the highest fertilizer rates. Cultivar Favorit expressed the highest grain yield $\left(5380 \mathrm{~kg} \mathrm{ha}^{-1}\right)$ and low weediness in applied variant of fertilizers $\mathrm{N}_{2}\left(120-60 \mathrm{~kg} \mathrm{NP}^{-1}\right)$ what could be advantage for cultivation (table 2).

Table 2. Average yield of grain of analyzed triticale Favorit $\mathrm{cv}$. under the different variants of fertilization

\begin{tabular}{|c|c|c|c|c|c|c|c|c|}
\hline $\begin{array}{c}\text { Variant } \\
\text { of } \\
\text { nutrition }\end{array}$ & Control 1 & Control 2 & $\begin{array}{c}2 \mathrm{~N}_{1}(60 \\
\left.\mathrm{kg} \mathrm{Pha}^{-1}\right)\end{array}$ & $\begin{array}{c}2 \mathrm{~N}_{2}(100 \\
\left.\mathrm{kg} \mathrm{Pha}^{-1}\right)\end{array}$ & $\begin{array}{c}\mathrm{N}_{1}(80- \\
100 \mathrm{~kg} \\
\mathrm{NP} \mathrm{ha}^{-1}\end{array}$ & $\begin{array}{c}\mathrm{N}_{2}(120- \\
100 \mathrm{~kg} \\
\mathrm{NP} \mathrm{ha}^{-1}\end{array}$ & $\begin{array}{c}\mathrm{N}_{1}(80-60 \\
\mathrm{kg} \mathrm{NP} \mathrm{ha} \\
1\end{array}$ & $\begin{array}{c}\mathrm{N}_{2}(120- \\
60 \mathrm{~kg} \mathrm{NP} \\
\mathrm{ha}^{-1}\end{array}$ \\
\hline \multicolumn{7}{|c|}{ Average yield of grain $\mathrm{kg} \mathrm{ha}^{-1}$} \\
\hline \hline Plot & 1090 & 1110 & 1670 & 1910 & 2210 & 2470 & 2580 & 2690 \\
\hline Hectare & 2180 & 2220 & 3340 & 3820 & 4420 & 4940 & 5160 & 5380 \\
\hline
\end{tabular}

In general, increasing rates of NPK fertilization only caused a significant increasing of yields. Similar results obtained in the crop rotation at lower rates $150-300 \mathrm{~kg} \mathrm{NPK} \mathrm{ha}^{-1}$ Füleky (2008). Some investigation showed that spring triticale strongly reduced the number of weed especially of wild oat plants. In addition, the yield reduction of triticale by studied weed was much lower as compared to other spring small grains, Kiec (2003).

\section{Conclusion}

This study showed that genotype/nitrogen interaction has influence to cultivar traits and weed infestation. The increasing of grain yield of triticale and abundance of weed species in triticale crop are influenced by increased rate of applied fertilizer. In variant by higher rates of $\mathrm{N}$ was efficient competition of triticale plants and weeds that leads to increase of grain yield. The highest yield of triticale $\left(5380 \mathrm{~kg} \mathrm{ha}^{-1}\right)$ was found on variant $\mathrm{N}_{2}$ (120-60kg NP ha ${ }^{-1}$ ). The different weeds with prevalence of weed species Cirsium arvense. Consolida regalis, Convolvulus arvensis, Polygonum aviculare were identified in triticale crop grown under different regime of $\mathrm{N}$ nutrition. For weed management strategy in triticale should be following the same principles as used for wheat.

\section{Acknowledgements}

Authors gratefully acknowledge the financial support by the Ministry of Science and Technology of Republic Serbia, Belgrade, Project Code TR-200097.B. 


\section{References}

Aguirre, A. - Rubiolo, J.O. - Ribotta, D.P - Luján, S.J. - Peŕez,T.G. - Leòn, D.E: 2006.Effects of incident radiation and $\mathrm{N}$ availability on the quality parameters of triticale grains in Argentina.Expl.Agric 42:311

Avramovic S. - Knezevic, D.: 2007. Weed community in wheat and triticale crops. Proceed. of Int. Conf. of Agricultural faculties, Cacak, 2: 129-139.

Balogh A. - Pepo P. - Hornok M.: 2006. Interactions of crop year, fertilization and variety in winter wheat management. Cereal Res. Com. 34: 1. 389-392.

Braun-Blanquet, J. :1964. Pflanzensoziologie.Wien-New York

Drezner G. - Dvojkovic K. - Horvat D. - Novoselovic D. - Lalic A.: 2006. Environmental impacts on wheat agronomic and quality traits. Cereal Research Communications, 35: 2. 357-360.

Fodor, L. - Pálmai, O.: 2008. The influence of nitrogen fertilization and sowing time on the weediness of winter wheat. Cereal Research Communications 36: 1159-1162.

Füleky Gy.: 2008. Results of a 30-year-old fertilisation experiment. Acta Agronomica Hung., 56: 265-273.

Harker K.N. - Baron S. V. - Chanasyk S. D. - Naeth M. A. - Stevenson F. C.: 2000. Grazing intensity effects on weed populations in annual and perennial pasture systems. Weed Science, 231-238.

Jolánkai, M. - Szentpétery Zs. - Hegedűs, Z.: 2006. Pesticide Residue dischange dynamics in wheat grain. Cereal Research Communications, 34: 505-509.

Jolánkai, M. - Nyáral, H.F. - Tarnawa, Á. - Klupács, H. - Farkas, I.: 2008. Plant and soil interrelations. Cereal Res.Comm., 36: 7-10.

Kassai, K. - Nyarai, H.F. - Jolánkai, M. - Szentpétery Zs.: 2006. Investigating nutritional relationship among weediness, yield and quality of winter wheat. Cereal Research Communications, 34: 533-536.

Kiec J.: 2003. Spring triticale competitiveness in wild oat. Zeszyty Problemowe Postepow Nauk Rolniczych, 490:105-111.

Knezevic, D . - Paunovic, A. - Madic M. - Djukic N.: 2007. Genetic analysis of nitrogen accumulation in four wheat cultivars and their hybrids. Cereal Research Communications, 35: 633-336.

Knezevic, D. - Avramovic S. - Brankovic G.: 2008. Weed community in whet crops and influence to grain yield under different regime of nutrition. Act Herbologica, 17: 95-106.

Kovacevic V. - D. Petosic D. - M. Josipovic M.: 2005. Potassium availability in hydromorphic soils of Eastern Croatia. Cereal Research Communications 33: 247-250

Mason, H.E. - Navabi, A. - Frick, B.L. - O'Donovan, J. T. - Spaner, D.M.: 2007. The weed-competitive ability of Canada western red spring wheat cultivars grown under organic management. Crop Sci 47:1167-1176

Márton L.: 2008. Impact of rainfall, liming, nitrogen $(\mathrm{N})$, phosphorus $\left(\mathrm{P}_{2} \mathrm{O}_{5}\right)$, potassium (K2O), calcium $(\mathrm{CaO})$, magnesium $(\mathrm{MgO})$ mineral fertilization on triticale ( $\mathrm{x}$ Triticosecale Wittmack) yield in a monoculture in Hungary. Cer. Res. Com., 36: 333-341

Moinuddin, S. - Afridi, M.M.R.K.: 1997. Grain yield and quality of triticale as affected by progressive application rates of nitrogen and phosphorus fertilizer. Journal of plant nutrition, 20:593-600

Oracka, T. - Łapiński, B.: 2006. Nitrogen and phosphorus uptake and utilization efficiency in $D(R)$ substitution lines of hexaploid triticale. Plant Breeding, 125:221-224

Oettler, G. - Wiethölter S. - Horst W.J.: 2000: Genetic parameters for agronomic traits of triticale and other small-grain cereals grown on aluminium-toxic soil in southern Brazil. Plant breeding, 119: 227-231.

Paunovic, A. - Madic M. - Knezevic, D. - Bokan, N.: 2007. Sowing density and nitrogen fertilization influences on yield components of barley. Cereal Res. Commun., 35: 2. 901-904.

Pawlonka Z. - Skrzyczyńska J.: 2004. The effect of selected agrotechnical factors and weather conditions on the weeding of winter triticale. Annales UMCS, Sec. E, 59: 1037-1047.

Pepo P.: 2007. The role of fertilization and genotype in sustainable winter wheat (Triticum aestivum L.) production. Cereal Res. Comm. 35: 917-920.

Tarnawa, Á. - Kassai, K. - Maté, A. -, Szentpétery, Zs.:2009. Precipitation and temperature stress impacting weed-crop coenology performance. Cereal Res. Comm. 37: 149-152.

Tỳr, S. - Veres, T. - Lacko-Bartosova, M.: 2009. Weed as an important stress factor in ecological farming. Cereal Res. Comm. 37: 181-184

Varga, B. - Svečnjak, Z. - Jurković, Z. - Pospišil, M.: 2007. Quality responses of winter wheat cultivars to nitrogen and fungicide applications in Croatia. Acta Agronomica Hungarica, 55:27-48. 


\title{
THE EFFECT OF TEMPERATURE ON THE GROWTH OF SPRING BARLEY (HORDEUM VULGARE L.) LEAVES
}

\author{
Jana REPKOVÁ ${ }^{l}-$ Marián BRESTIČ ${ }^{1}$ \\ ${ }^{1}$ Department of Plant Physiology, Faculty of Agrobiology and Food Resources, Slovak University of \\ Agriculture, Tr. A. Hlinku 2, 94976 Nitra, Slovakia, e-mail: jana.repkova@uniag.sk
}

\begin{abstract}
Occurrence of climatic changes brings the question how the increased temperature will influence the leaves and crop growth of cereal plants in Slovak region. In experiments with spring barley (Hordeum vulgare L.) growing in conditions of full irradiance and light restriction, the effect of air temperature was collected during two vegetation periods. Mainly at the beginning of growth season leaf appearance and growth was affected by air temperature; rising of average daily temperature was accelerating main stem leaves growth in both light regimes. The rate of leaf expansion was more sensitive to environment influence than duration of expansion. In our experiments leaf expansion rate was in close correlation with air temperature regardless of irradiance amount. The results show that in restricted light conditions leaf area increased because of leaves elongation growth was supported and lower accumulated irradiance sum calculated for the similar elongation growth was required for shaded plants. Quantification of leaf appearance and leaf growth dynamics can be useful for leaf growth models under climatic change conditions to predict the trend of crop development at rising air temperature.
\end{abstract}

Keywords: spring barley, temperature, leaf growth, leaf elongation rate, leaf expansion duration

\section{Introduction}

The 20-year period 1988-2007 represents a start of unusual climate warming also in Slovakia, when the annual temperature increase in $1.6^{\circ} \mathrm{C}$ and annual precipitation decrease in $24 \mathrm{~mm}$ were registered. Regimes of air humidity, potential and actual evapotranspiration, soil moisture and air temperature have been changed predominantly in the southern part of Slovakia (Lapin et al., 2009). Rising of accumulated air temperature sum in $32 \%$ during the main growth period is expected till the period of 2075. Changes of climate conditions cause the shifts in plants phenological development (Nagy, 2008; Arduini et al., 2009) and changes of physiology reactions (Zivcak et al., 2008). Lapin et al. (2009) remarks that the climate change development in Slovakia is at annual temperature rise more rapid than it was supposed by any scenario designed in 1991-2000.

For crops and biomass production, leaf area is the main determining factor affecting light interception. An occurrence of spacious leaf area produced in short time interval is typical trait for spring cereals. Leaf appearance is one of the important aspects of development, which can be used to determine the response of development to temperature (Yin and Kropff, 1996). It is widely accepted that temperature primarily controls the phyllochron and the rate of leaf formation on the stems, with light in secondary role (Porter and Gawith, 1999; McMaster et al. 2003). It was observed that, when air temperature increases, time interval of two successive leaf tips appearance is dropped. The effect of other factors as light environment and soil temperature on leaf growth and tiller appearance in cereals is discussed (Bos and Neuteboom, 1998; Miralles and Richards, 2000; McMaster et al. 2003). The aim of our work was quantify the effect of air temperature to barley leaves appearance and growth situated in different light regimes during the vegetative seasons 2005 and 2006. 


\section{Materials and methods}

Barley plants (Hordeum vulgare L.) were cultivated in plastic pots with soil substrate in the natural environmental conditions with optimalized nutrient and water regimes during the 2005 and 2006 growing seasons. Two variants of light regime were applied; cultivation under natural light environment with full irradiation and under shaded conditions where direct sunlight was restricted to $20 \%$ of the daily solar irradiation.

During whole growing season the microclimate conditions (photosynthetic active radiation, air and soil temperature, relative humidity) were monitored (LiCor 1400, LiCor, Nebraska, USA). Data of air and soil temperature were recorded each minute, photosynthetic photon flux density each second and from them daily maximum, minimum and average values were calculated. Accumulated temperature was calculated for defined time interval as a sum of average daily air temperatures.

Leaves growth was measured by a non-destructive way as leaf area increase. Leaf area was calculated as: $\mathrm{A}=1^{*} \mathrm{~W}^{*} \mathrm{k}$, where $l$ is leaf length, $w$ is leaf width and $k$ is a multiplying factor (0.64) usually used for barley (Šesták et al., 1971). Elongation of main stem leaves was evaluated as the rate of leaf expansion per unit time (LER, mm.d ${ }^{-1}$ ). LER was calculated as maximal individual leaf length divided by the growth period (Singh et al., 2006). Duration of leaf expansion (LED, d) was estimated as the number of days between the appearance and full emergence of an individual leaf (Bahmani et al., 2000). All measured data were evaluated by the statistical packet of Microsoft Excel.

\section{Results and discussion}

In term of climatic characteristic of whole vegetative season, results showed that the accumulated air temperature sum and average daily air temperature were similar during both growing seasons. Substantial differences were found for air temperature, mainly at the beginning of barley growth in April, when average daily temperature in 2006 was $2{ }^{\circ} \mathrm{C}$ higher than year before (Figure 1). This fact had result in reduction of time interval between appearances of successive leaves on the main stem. The first four leaves appeared in 2 - 4 days more quickly than season before. The shift in day of appearance was obtained for both plant variants, sun and shaded plants, independently to light regime in which they were growing (Table 1) (Yin and Kropff, 1996).

It was interesting that in case of sun and shaded plants, accumulated air temperature sum required for each leaf appearance was almost similar for both experimental years (Table 1). This really showed that for leaf initiation and appearance cumulation of temperatures is inevitability as pointed Yin and Kropff (1996) and McMaster et al. (2003). Growth variability between sun and shaded variant emerged from different leaf elongation rate that was intensive, more sensitive to temperature in restricted light conditions (Bos and Neuteboom, 1998; Bahmani et al., 2000). In term of irradiance requirements for leaves growth, only small interval of accumulated irradiance sum (2090 mol. $\mathrm{m}^{-2}$ ) was measured to achieve maximal leaf length for shaded plants in comparison to sun variant, which needs seven times higher irradiance sum for equal leaf elongation rate.

As Table 1 shows, average daily air temperature between sowing date and day of leaf appearance was higher for sun variant in 2006. The rate of leaf initiation and leaf emergence had linear relationships with temperature as also obtained Porter and Gawith (1999) and Hay and Porter (2006). 

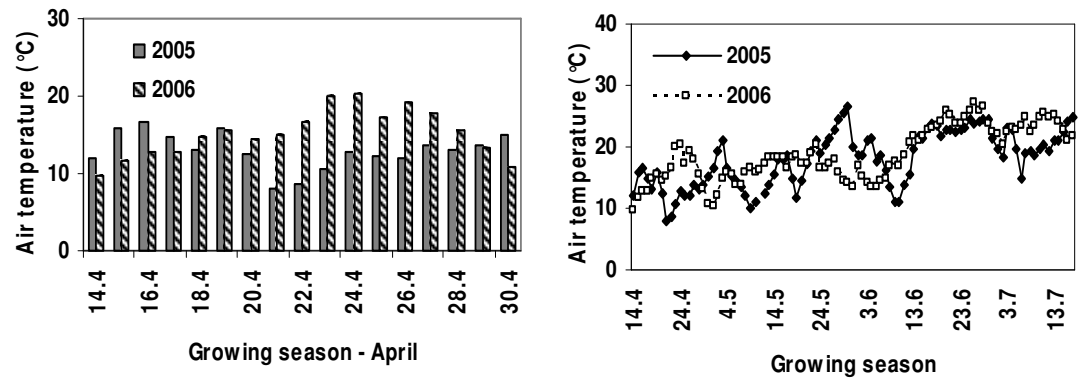

Figure 1. Average air temperature $\left({ }^{\circ} \mathrm{C}\right)$ during April, at the beginning of growing season, when first four leaves of the main stem was appeared (left). Average air temperature $\left({ }^{\circ} \mathrm{C}\right)$ of whole growing season with fluctuation during 2005 and 2006 (right).

Quantification of leaf elongation rate (LER) and duration of leaf expansion (LED) is coessential as the rate of leaf appearance for crop leaf area and its productivity. Hay and Porter (2006) stated that under optimal conditions, duration of leaf expansion from its emergence seems to be constant in thermal time. The results showed that accumulated air temperature sum had a significant effect on LED; leaf expansion duration was a linear function of increased accumulated air temperatures (Repková et al., 2009).

Table 1. Comparison of number of days, accumulated air temperature sum $\left({ }^{\circ} \mathrm{C} \cdot \mathrm{d}^{-1}\right)$ and average air temperature $\left({ }^{\circ} \mathrm{C}\right)$ between sowing day and day of leaf appearance on main stem during 2005 and 2006 measured for sun and shaded barley variant. All leaves were numbered from stem basis in order as they had appeared.

\begin{tabular}{|c|c|c|c|c|c|c|}
\hline \multirow[t]{2}{*}{ Sun variant } & \multicolumn{2}{|c|}{$\begin{array}{c}\text { Days } \\
\text { sowing day - leaf appearance }\end{array}$} & \multicolumn{2}{|c|}{$\begin{array}{l}\text { Air temperature sum }\left({ }^{\circ} \mathrm{C} \cdot \mathrm{d}^{-1}\right) \\
\text { sowing day - leaf appearance }\end{array}$} & \multicolumn{2}{|c|}{$\begin{array}{l}\text { Average air temperature }\left({ }^{\circ} \mathrm{C}\right) \\
\text { sowing day - leaf appearance }\end{array}$} \\
\hline & 2005 & 2006 & 2005 & 2006 & 2005 & 2006 \\
\hline 1st leaf & 6 & 8 & 100,75 & 118,02 & 14,4 & 13,1 \\
\hline 2 nd leaf & 11 & 10 & 153,16 & 154,81 & 12,8 & 14,1 \\
\hline 3rd leaf & 17 & 13 & 237,40 & 211,57 & 13,2 & 15,1 \\
\hline 4th leaf & 18 & 18 & 256,60 & 279,46 & 13,5 & 14,7 \\
\hline 5th leaf & 24 & 22 & 349,48 & 338,02 & 14,0 & 14,7 \\
\hline 6th leaf & 32 & 29 & 448,42 & 447,28 & 14,0 & 14,9 \\
\hline 7th leaf & 39 & 35 & 565,27 & 555,36 & 14,5 & 15,4 \\
\hline 8th leaf & 42 & 40 & 625,91 & 647,93 & 14,9 & 15,8 \\
\hline \multirow[t]{2}{*}{ Shade variant } & \multicolumn{2}{|c|}{$\begin{array}{c}\text { Days } \\
\text { sowing day - leaf appearance }\end{array}$} & \multicolumn{2}{|c|}{$\begin{array}{l}\text { Air temperature sum }\left({ }^{\circ} \mathrm{C} . d^{-1}\right) \\
\text { sowing day - leaf appearance }\end{array}$} & \multicolumn{2}{|c|}{$\begin{array}{l}\text { Average air temperature }\left({ }^{\circ} \mathrm{C}\right) \\
\text { sowing day - leaf appearance }\end{array}$} \\
\hline & 2005 & 2006 & 2005 & 2006 & 2005 & 2006 \\
\hline 1st leaf & 7 & 8 & 108,73 & 118,02 & 13,6 & 13,1 \\
\hline 2nd leaf & 12 & 10 & 165,23 & 154,81 & 12,7 & 14,1 \\
\hline 3rd leaf & 18 & 14 & 256,60 & 229,42 & 13,5 & 15,3 \\
\hline 4th leaf & 22 & 21 & 323,73 & 322,42 & 14,1 & 14,7 \\
\hline 5th leaf & 33 & 26 & 466,91 & 398,27 & 14,1 & 14,8 \\
\hline 6th leaf & 39 & 32 & 565,27 & 502,32 & 14,5 & 15,2 \\
\hline 7 th leaf & 45 & 38 & 698,78 & 608,55 & 15,5 & 15,6 \\
\hline 8th leaf & 47 & 47 & 745,31 & 760,36 & 15,9 & 15,8 \\
\hline
\end{tabular}

519 DOI: 10.1556/Novenyterm.59.2010.Suppl.4 
In contrast to LED, the rate of leaf expansion is more sensitive to fluctuating environment as also previously described Hay and Porter (2006). LER decreased exponentially with raised accumulated air temperature sum without the reference to light regimes in which plants were growing.

\section{Conclusions}

Results showed that increasing of average air temperature at the beginning of growing season could accelerate the leaf appearance of the first four leaves on main stem, sometimes in 2-4 days earlier. Shading environment increased leaf expansion rate and duration of leaf expansion. Accumulated air temperature sum was in linear function with leaf expansion duration and in exponential relationship with leaf elongation.

\section{Acknowledgements}

This work was supported by project of Slovak Research and Development Agency No. APVV- 0770-07 and Scientific Grant Agency (VEGA) of Ministry of Education of the Slovak Republic and the Slovak Academy of Sciences, project No. 1/0803/08.

\section{References}

Arduini I. - Ercoli L. - Mariotti M., Masoni - A.: 2009. Sowing date affect spikelet number and grain yield of durum wheat. Cereal Research Communications, 37: 469-478.

Bahmani I. - Hazard L. - Varlet- Grancher C. - Betin M. - Lemaire G. - Mattew C. - Thom, E. R.: 2000. Differences in tillering of long- and short-leaved perennial ryegrass genetic lines under full light and shade treatments. Crop Science, 40: 1095-1102.

Bos H. J. - Neuteboom J. H.: 1998. Growth of individual leaves of spring wheat (Triticum aestivum L.) as influenced by temperature and light intensity. Annals of Botany, 81:141-149.

Hay R. K. M. - Porter J. R. (eds.): 2006. The physiology of crop yield. Blackwell Publishing, Oxford.

Lapin M. - Gera M. - Hrvol' J. - Melo M. - Tomlain J.: 2009. Possible impacts of climate change on hydrologic cycle in Slovakia and results of observations in 1951-2007. Biologia, 64: 454-459.

Miralles D. J. - Richards R. A.: 2000. Responses of leaf and tiller emergence and primordium initiation in wheat and barley to interchanged photoperiod. Annals of Botany, 85: 655-663.

McMaster G. S. - Wilhelm W. W. - Palic D. B. - Porter J. R. Jamieson P. D.: 2003. Spring wheat leaf appearance and temperature: extending the paradigm. Annals of Botany, 91: 697-705.

Nagy G.: 2008. Spring phenological development of perennial reygrass and its response to annual weather conditions. Cereal Research Communications. Supplement. 36: 787-790.

Porter J. R. - Gawith M.: 1999. Temperatures and the growth and development of wheat: a review. European Journal of Agronomy, 10: 23-36.

Repková J. - Brestič M. - Olšovská K.: 2009. Leaf growth under temperature and light control. Plant, Soil and Environment, 55: 551-557.

Singh,V. - Pallaghy C. K. - Singh D.: 2006. Phosphorus nutrition and tolerance of cotton to water stress II. Water relations, free and bound water and leaf expansion rate. Field Crop Research, 96: 199-206.

Šesták Z. - Čatský J. - Jarvis P. G.: 1971. Plant photosynthetic production. Manual of methods. Dr. W. Junk N.V. Publishers, The Hague.

Yin X. - Kropff M. J.: 1996. The effect of temperature on leaf appearance in rice. Annals of Botany, 77: 215221.

Zivcak M. - Brestic M. - Olsovska K.: 2008. Assesment of physiological parameters useful in screening for tolerance to soil drought in winter wheat (Triticum aestivum L.) genotypes. Cereal Research Communication, 36: 1943-1946. 


\title{
THE IMPACT OF ECOLOGICAL AND AGROTECHNICAL FACTORS ON MAIZE PRODUCTIVITY
}

\author{
Mihály SÁRVÁRI - Beáta BOROS
}

University of Debrecen Faculty of Agriculture, Institute of Crop Sciences, 4032 Debrecen 138 Böszörményi St., e-mail: sarvari@agr.unideb.hu, borosb@agr.unideb.hu

Abstract: Maize is one of the major cereals in Hungary, it is grown on 30-32 \% of the 4.5 million ha arable land. The national average yield ranged between 3.7 and $7.7 \mathrm{t} \mathrm{ha}^{-1}$ in the past decade. Its yield fluctuation reaches $50-60 \%$, which is very unfavourable. Yield fluctuation is caused by climate change and agrotechnical deficiencies. Climate change caused by global warming intensifies weather extremes.

Keywords: crop rotation, sowing time, optimum plant density

\section{Introduction}

Optimum crop rotation is important due to our continental climate which is inclined to drought, but the forecrop also has a great impact on the propagation of weeds, pathogens and pests (Berzsenyi, 1995; Kissné, 2000).

Among others, a great disadvantage of monoculture cropping is that it does not enable a proper rotation of other crops (Menyhért, 1979; Nagy, 1986; Sárvári, 1995).

The optimum sowing time is influenced by climatic and soil features and is determined by the cold tolerance of the hybrid at germination. There is a correlation between sowing time and yield, but there is a significant, tight correlation between sowing time and the grain moisture content at harvest (Sárvári and Futó, 2001; Marton et al., 2005; Szél, 2005).

In the duplication of yields, the applicability of higher plant densities had a significant role (Carlone and Russel, 1987). Increase of plant density is one of the methods for increasing the sunlight adsorption of leaves (Stinson and Moss, 1960). Via increasing plant density, the individual yield (cob size) decreases, while the yield per unit area increases until reaching the optimum plant density. A higher than optimum plant density causes water deficiency, increases the ratio of sterile plants which result in a yield reduction (Bodnár, 1982).

\section{Materials and methods}

The experiments were set up on meadow soil. The soil was characterized by hard tillability, great absorption of phosphorus and potash and a hard release of nitrogen in the spring.

In the last two decades, ten years were dry (Figure 1). In the vegetation period of maize (April-September) the 30-year average of the mean temperature was $16.82{ }^{\circ} \mathrm{C}$ in the region of Debrecen, which increased by $2-3{ }^{\circ} \mathrm{C}$ in recent years. This further increases evaporation, surface evaporation and water deficiency.

Crop rotation Triculture: pea- winter wheat - maize - maize, biculture: winter wheat - maize - maize - winter wheat, monoculture: maize.

Fertilization: crop rotation experiment $\mathrm{N} \mathrm{0-250,} \mathrm{P}_{2} \mathrm{O}_{5}$ 0-200, $\mathrm{K}_{2} \mathrm{O}$ 0-200; sowing time and plant density experiment $\mathrm{N} 120, \mathrm{P}_{2} \mathrm{O}_{5} 80, \mathrm{~K}_{2} \mathrm{O} 110 \mathrm{~kg}^{-1}$ active ingredient. Sowing times in the sowing time experiment: 5-10 April, 22-25 April, 13-15 May. 
In the plant density experiment, plant density varied from 20 to 100 thousand plants $\mathrm{ha}^{-1}$.

The experiments were randomized block experiments in four repetitions.

The experiments were evaluated by analysis of variance, factor analysis and parabolic regression analysis.

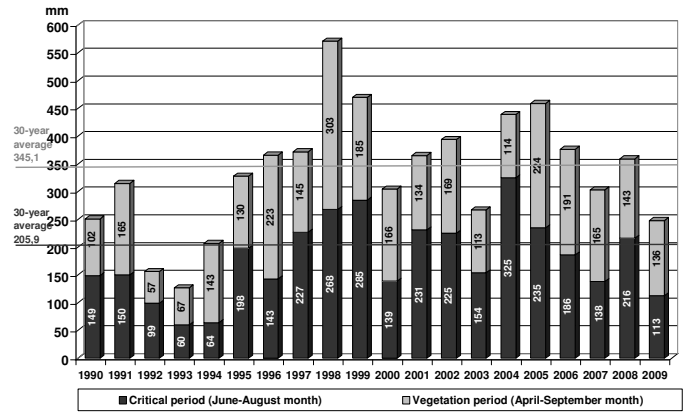

Figure 1. Precipitation data in the critical period and the vegetation period, Görbeháza, 1990-2009

\section{Results and discussion}

Among the ecological factors, climatic factors, precipitation and the changes in temperature greatly determined the yield.

According to the principal component analysis for the 15-year period of 1973-1987, the rank of the yield-determining factors was:

1. The amount of precipitation $(\mathrm{mm})$ in the critical period of maize (June-July-August)

2. The amount of precipitation in the vegetation period (April-September).

3. The annual amount of precipitation (January-December).

4. Temperatures in May, July and August.

5. The amount of precipitation and the changes in temperature in June.

The five factors accounted for $79 \%$ of the changes in the yields.

Average yields obtained in the 15-year period (1976-2000) in the different crop rotations (Figure 2):

- Triculture (pea - winter wheat - maize - maize) $9.70 \mathrm{t} \mathrm{ha}^{-1}$, biculture (winter wheat maize - maize - maize) $9.10 \mathrm{t} \mathrm{ha}^{-1}$, monoculture (maize) $8.71 \mathrm{t} \mathrm{ha}^{-1}$.

The crop rotation influenced the changes in the $\mathrm{pH}$ value of the soil. In monoculture, the $\mathrm{pH}$ value of the soil had been significantly reduced by the 16th year of the experiment (Table 1).

Table 1. Average $\mathrm{pH}(\mathrm{KCl})$ values of the soil in the crop rotation variations $\mathrm{A}, \mathrm{B}$ and $\mathrm{C}$

\begin{tabular}{|c|c|c|c|c|}
\hline & 16th year & 20th year & 24th year & 28th year \\
\hline \hline Crop rotation A & 5.8808 & 6.1333 & 6.3186 & 6.4859 \\
\hline Crop rotation B & 6.0023 & 6.1918 & 6.3744 & 6.3924 \\
\hline Crop rotation C & 5.7395 & 5.8264 & 5.6166 & - \\
\hline $\mathrm{SD}_{5 \%}$ & 0.2358 & 0.2605 & 0.2229 & 0.1216 \\
\hline
\end{tabular}




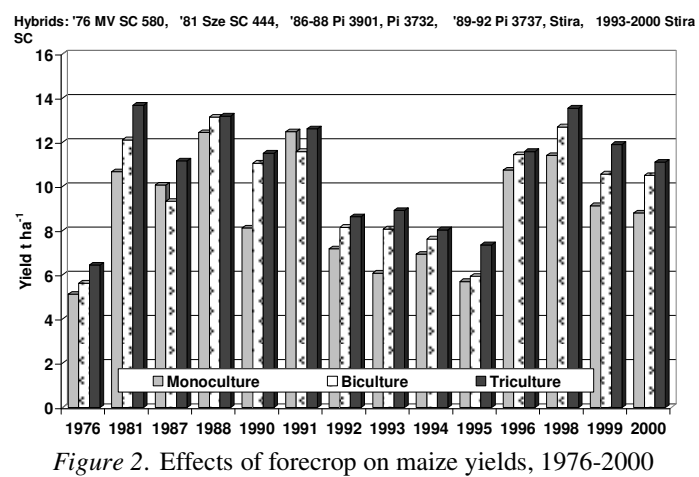

There is a tight correlation between sowing time and yield, and the grain moisture content at harvest. In the past, the optimum sowing time in Hungary was between 15 April and 5 May, due to climate change, sowing can be performed 10-15 days earlier.

Advantages of an earlier sowing time:

- Flowering of male and female flowers and fertilization happen in a more favourable period (end of June), consequently, yield safety is increased.

- Hybrids reach physiological maturity earlier, when the black layer is formed at the end of the grain next to the cob, there is no more nutrient accumulation and the grain starts to release water. In this way, the grain moisture content at harvest can be reduced by even $5-10 \%$. Via reducing the drying costs, the production efficacy of production can be increased.

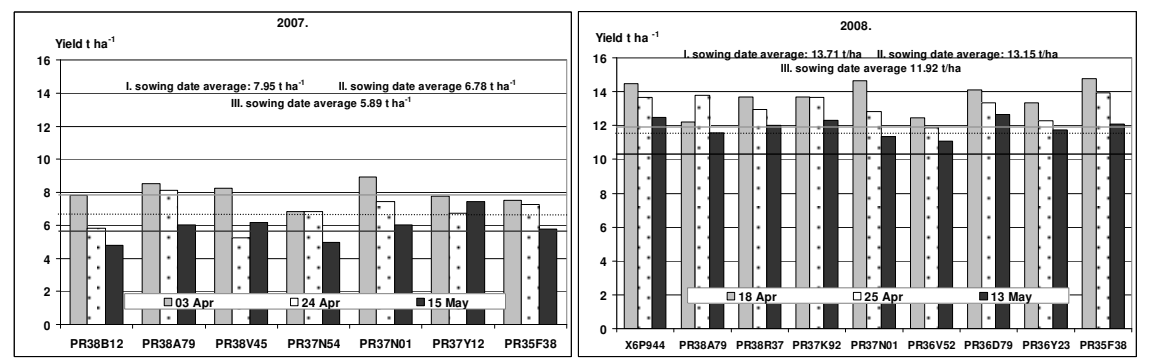

Figure 3. Effect of sowing date on the yield of maize, Görbeháza 2007-2008.

In Figure 3, it can be seen that the yield of the hybrid PR38A79 was the highest at the second sowing date (25 April). However, the yield of other hybrids was higher by 1.79$2.06 \mathrm{t} \mathrm{ha}^{-1}$ at the earliest sowing date.

Optimum plant density is a factor which has a great influence on yield. There is a tight correlation between the vegetation period of the hybrid, the water and nutrient supply and the optimum plant density. However, there are great differences among the hybrids in their response to increasing plant density. There are hybrids, which give the highest yield at 80-90 thousand plants $\mathrm{ha}^{-1}$, while there are hybrids the yield of which is greatly reduced at plant densities higher than 70 thousand plants ha ${ }^{-1}$ (Figure 4). 

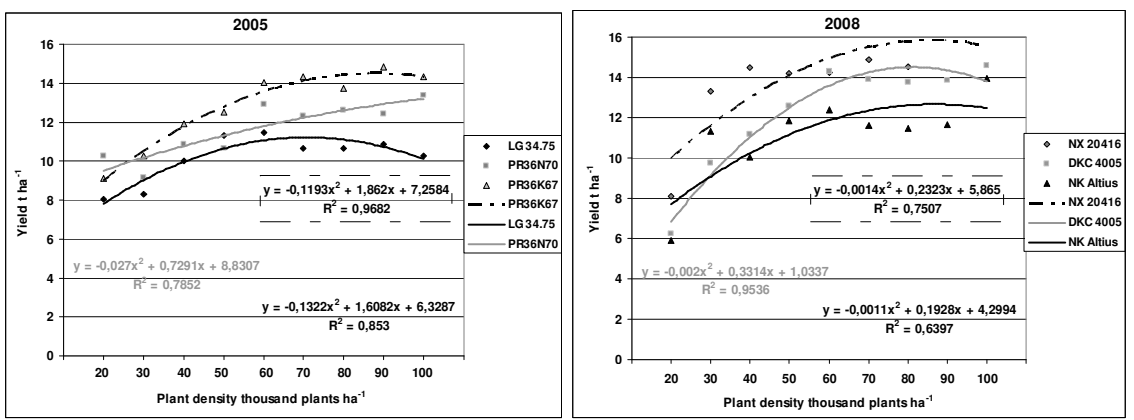

Figure 4. Relationship between plant density and yield of maize hybrids $(2005,2008)$

Hybrids can be classified into the following groups: hybrids with a wide optimum plant density interval; hybrids not requiring high plant density but having a good individual yield (prone to bearing several cobs); hybrids sensitive to increasing plant density having a tight optimum plant density interval. The determination of the plant density should be hybrid-specific, especially for the third group.

\section{Conclusions}

The yield and yield safety of maize could be improved by selecting the hybrid adapting to the ecological conditions, by applying a proper crop rotation and an earlier sowing time within the optimal interval and by ensuring a plant density harmonized with the ecological, biological and agrotechnical factors.

\section{References}

Berzsenyi, Z.: 1995. A kukoricatermesztési technológiák fenntarthatóságának vizsgálata stabilitásanalízissel tartamkísérletben. 37. Georgikon Napok. A fenntartható fejlődés időszerü kérdései a mezőgazdaságban Keszthely. 27-36.

Bodnár, E.: 1982. A kukoricatermelés technológiája. Kukorica és Iparnövény Termelési Együttműködés (KITE kiadványa), Nádudvar.

Carlone, M. R. - Russel, W. A.: 1987. Response to plant densities and N levels for four maize cultivars from different years of breeding. Crop Science. 27. 465-470.

Kiss, I.-né: 2000. A kukorica termesztéstechnológiájának áttekintése. Gyakorlati Agrofórum. 11: 3. 2-9.

Marton, L. Cs. - Szundy, T. - Hadi, G. - Pintér, J. - Berzsenyi, Z. - Árendás, T. - Bónis, P.: 2005. A termelői igényhez igazodó kukoricanemesítés szempontjai. Gyakorlati Agrofórum Extra 9. 11-13.

Menyhért, Z.: 1979. Kukoricáról a termelőknek. Mezőgazdasági Kiadó, Budapest.

Nagy, J.: 1986. Összefüggés a kukoricahibridek öntözése, tápanyagellátása és a terméseredménye között. DATE Tudományos Közleményei, Debrecen. XXVI. 187-201.

Sárvári, M.: 1995. Monokultúrás termesztés hatása a kukorica termésére réti talajon, mủtrágyázási tartamkísérletben. Növénytermelés 44: 4. 359-374.

Sárvári, M. - Futó, Z.: 2001. A vetésidő hatása a különböző genetikai adottságú kukoricahibridek termésére. Növénytermelés, 50: 1. 43-60.

Stinson, H. T. - Moss, D. N.: 1960. Some effects of shade upon corn hybrids tolerant and intolerant of dense planting. Agronomy Journal. 52. 482-484.

Szél, S.: 2005. Kukoricahibridek és a változó kukoricatermesztési körülmények. Gyakorlati Agrofórum Extra 9. 8-10. 


\title{
THE INFLUENCE OF MINERAL FERTILIZING ON THE YIELD COMPONENTS, POLYPHENOLS AND ATIOXIDANT ACTIVITY OF SWEET POTATOES (IPOMOEA BATATAS L.)
}

\author{
Mara BOGOVIC ${ }^{1}$ - Ivana RADOJCIC REDOVNIKOVIC ${ }^{2}-$ Nina TOTH $^{3}-$ Bruno $^{2}$ \\ NOVAK ${ }^{3}$ - Karmela DELONGA ${ }^{2}$ \\ ${ }^{1}$ Croatian Agricultural Extension Institute, Trakošćanska 24, 42000 Varaždin, Croatia, \\ e-mail: Mara.Bogovic@hzpss.hr \\ ${ }^{2}$ Faculty of Food Technology and Biotechnology, University of Zagreb, Pierottijeva 6, 10000 Zagreb, Croatia \\ ${ }^{3}$ Faculty of Agriculture, University of Zagreb, Svetošimunska cesta 25, 10000 Zagreb, Croatia
}

\begin{abstract}
Sweet potato is a perennial tropical plant which has recently been introduced into commercial production in Croatia. The aim of the research was to determine the influence of different mineral fertilization on the yield components, the concentration of polyphenols and the antioxidation activity of sweet potato. The fertilizing test in the field was conducted in 2008 and 2009 in Croatia and included two cultivars Boniato and Bat1, and mineral fertilization with three nitrogen-potassium ratios (1:1, 1:2.5 and 1:5). The yield components were determined on the basis of the root and leaf mass, as well as the share of larger root fraction. The analyses of the total quantity of polyphenols were conducted by means of UV/Vis spectrometric method, and the antioxidation activity by ORAC method. It was found out that the root mass of 'Boniato' and 'Bat1' had increased by $18 \%$ and $12 \%$ at the nitrogen-potassium ratio of $1: 2.5$ and $39 \%$ and $41 \%$ at the $1: 5$ ratio when compared to the control nitrogen-potassium ratio 1:1. More intensive fertilization resulted in a bigger portion of larger root fraction (the mass above $400 \mathrm{~g}$ ) with both cultivars. Regardless of fertilization, 'Boniato' produced significantly larger mass of leaves (43\% to $120 \%$ ) than 'Bat1'. 'Boniato' root contained the total of polyphenols between $5.05-14.38 \mathrm{mg} \mathrm{g}^{-1}$ dry weight and the antioxidant activity ranging from 20.34 to 51.00 $\mu \mathrm{mol}$ Trolox equivalent $\mathrm{g}^{-1} \mathrm{dw}$, whereas the total polyphenols concentration in the root of 'Bat 1 ' ranged from 2.30 to $16.08 \mathrm{mg} \mathrm{g}^{-1} \mathrm{dw}$, and the antioxidant activity from 9.26 to $73.03 \mu \mathrm{mol}$ Trolox equivalent $\mathrm{g}^{-1} \mathrm{dw}$.
\end{abstract}

Key words: cultivar, nitrogen- potassium ratio, leaves, root

\section{Introduction}

Sweet potato is an important new food crop in Croatia because of the high nutritional value of roots and leaves. Cultivation of sweet potato is explored at the Vegetable Crops Department of the Faculty of Agriculture, University of Zagreb (Novak et al., 2001). Sweet potato yields showed annual responses to increased application of $\mathrm{N}, \mathrm{P}$, and $\mathrm{K}$ fertilizer, but they also showed a tendency to decrease, or level off, under the highest application rates. Oya et al. (1977) mentioned that the yield of root tuber may be reduced when to much nitrogen is applied as recognized elsewhere, since excessive nitrogen brings in more vigorous growth of the vine rather than the root tuber of sweet potato. Excessive application of $\mathrm{N}$ fertilizer increased leaf yield but tended to decrease root yield, whereas (Okpara et al., 2009) reported that nitrogen application up to $120 \mathrm{~kg}$ $\mathrm{N}$ ha $^{-1}$ increased light interception, leaf area index and shoot dry matter. Phosphorus applications had no effect on yield, grade, or quality of sweet potato (Nicholaides et al., 1985). Field trials showed that adequate $\mathrm{K}$ inputs greatly increased sweet potato yields. Average tuber weight and starch content, indicators of quality, increased with $\mathrm{K}$ rates up to an optimum of $225 \mathrm{~kg} \mathrm{~K}_{2} \mathrm{O} \mathrm{ha}^{-1}$ (Jian-Wei et al., 2001). Sweet potatoes are rich in dietary fiber, minerals, vitamins, and antioxidants, such as phenolic acid, anthocyanins, tocopherol and $\beta$-carotene (Teow et al., 2007). In recent years, several studies have indicated that the polyphenolic extracts from sweet potato exhibit antioxidant activity, antimutagenicity, potential chemopreventive properties, and antidiabetic effects (Rabah 
et al., 2004; Islam et al., 2009). As previously reported for other vegetables polyphenolic content and antioxidant activity in sweet potato differed between cultivars due to genetic, environmental and cultivation factors (Teow et al., 2007; Padda et al., 2008). Therefore, we found interesting to study the influence of different mineral fertilization on the yield components, total polyphenolic content and antioxidant activity in two different sweet potato cultivars.

\section{Materials and methods}

The experiment in the field was conducted in 2008 and 2009 on a the Experimental Field in Varaždin on an alluvial soil poor in humus, $\mathrm{pH} 7.2$, with a medium quantity of $\mathrm{N}$ and $\mathrm{P}$ and poor in $\mathrm{K}$. The experiment was organized according to the method of random block scheme in four repetations with two cultivars Bat 1 (yellow skin, orange flesh, NK, NG1, NG2) and cultivar Boniato (red skin, white flesh, CK, CG1, CG2). Planting was done on $13^{\text {th }}$ May 2008 and $12^{\text {th }}$ May 2009 with the set of 2 plants $\mathrm{m}^{-2}$ on elevated beds covered with PE film. Fertilization was conducted before planting (N 15, 30 and $\left.50 \mathrm{~kg} \mathrm{ha}^{-1}\right),\left(\mathrm{P} 10,15\right.$ and $\left.30 \mathrm{~kg} \mathrm{ha}^{-1}\right)$, and (K 15, 75 and $\left.250 \mathrm{~kg} \mathrm{ha}^{-1}\right)$. Although the average rainfall during vegetation was less than the needed $500 \mathrm{~mm}$ sweet potato was not irrigated except 0.51 per plant immediately after planting and without applying any pesticide. In the course of the 145 days of vegetation the rainfall in 2008 was 444 $\mathrm{mm}$, whereas in 2009 it was only $260 \mathrm{~mm}$, the average temperature in both years being $18{ }^{\circ} \mathrm{C}$. The development of the leaf mass was surveyed by counting leaves in the first and second month after planting and the total yield and the root mass were measured after the root was taken out manually. Laboratory analyses of polyphenol and the antioxidant activity was conducted at the end of vegetation by picking top leaves and choosing average mercantile roots. Polyphenols were extracted twice from $5 \mathrm{~g}$ fresh sweet potato roots with $70 \%$ aqueous methanol at $70{ }^{\circ} \mathrm{C}$ for $15 \mathrm{~min}$. Prepared extract was used for measurement of total polyphenolic content and antioxidant activity by ORAC assay. Total polyphenolic content was determined by Folin-Cicalteu method (Singleton et al., 1999). The absorbance was measured at $760 \mathrm{~nm}$ and results were expressed as mg of galic acid equivalent $\mathrm{g}^{-1} \mathrm{dw}$ (six points from 0.01 to $0.1 \mathrm{mg} \mathrm{L}^{-1}$ galic acid in $70 \%$ methanol). The Oxygen radical absorbance capacity (ORAC) was determined according to the method of Cao et al. (1993). Fluorescence was read every minute up to a value zero at $485 \mathrm{~nm}$ excitation, $520 \mathrm{~nm}$ emission. ORAC values were reported as $\mu \mathrm{mol}$ Trolox equivalents per $\mathrm{g} \mathrm{dw}$.

\section{Results and discussion}

'Boniato' has formed significantly larger leaf mass as compared with the 'Bat1' (Table 1). The increased fertilization with potassium has had no influence on the increase of leaf mass but had influence on the increase of the yield of both cultivars by $12-41 \%$. The more potassium the fertilizer contained the higher percent of voluminous fraction of the root above $400 \mathrm{~g}$ there was, as compared with the control (Fig. 1 and 2). Influence of different mineral fertilization on total phenolic content and antioxidant activity determined by ORAC assay in two cultivars of sweet potato root grown in 2008 and 2009 are given in Table 2. 
Table 1. Influence of cultivar and fertilizing on the leaf mass

\begin{tabular}{|c|c|c|c|c|c|c|}
\hline \multirow{2}{*}{$\begin{array}{l}\text { Morphological quality } \\
\text { Year of research }\end{array}$} & \multicolumn{2}{|c|}{ Runner length in $\mathrm{cm}$} & \multicolumn{2}{|c|}{ Number of runners } & \multicolumn{2}{|c|}{ Number of leaves } \\
\hline & 2008. & 2009. & 2008. & 2009. & 2008. & 2009. \\
\hline & \multicolumn{6}{|c|}{ Cultivar } \\
\hline Bat $1-\mathrm{N}$ & 62,6 & $76,0 \mathrm{~B}$ & 14,3 & $14,3 \mathrm{~B}$ & $239,8 \mathrm{~B}$ & $247,6 \mathrm{~B}$ \\
\hline Boniato - $\mathrm{C}$ & 59,2 & $76,1 \mathrm{~A}$ & 15,9 & $18,6 \mathrm{~A}$ & $331,5 \mathrm{~A}$ & $328,7 \mathrm{~A}$ \\
\hline LSD & 7,6 n.s. & 1,9 & 1,9 n.s. & 2,3 & 42,1 & 26,0 \\
\hline Factor B & \multicolumn{6}{|c|}{ Fertilizing } \\
\hline Control K (N:K - 1:1) & 59,0 & $69,8 \mathrm{~B}$ & 14,2 & $14,9 \mathrm{~b}$ & 272,2 & $268,1 \mathrm{~B}$ \\
\hline FertilizingG1(N:K- & 61,2 & $71,2 \mathrm{~B}$ & 15,3 & $16,5 \mathrm{ab}$ & 284,5 & $287,9 \mathrm{AB}$ \\
\hline Fertilizing G2 (N:K-1:5) & 62,6 & $73,7 \mathrm{~A}$ & 15,8 & $18,0 \mathrm{a}$ & 300,2 & $308,4 \mathrm{~A}$ \\
\hline LSD & 7,6 n.s. & 2,4 & 2,4 n.s. & 2,1 & 37,3 n.s. & 31,9 \\
\hline Interaction & \multicolumn{6}{|c|}{ Cultivar $\mathrm{x}$ fertilizing } \\
\hline NK & 60,4 & $66,3 \mathrm{c}$ & $12,9 \mathrm{~b}$ & $13,2 \mathrm{C}$ & $226,9 \mathrm{~b}$ & $220,6 \mathrm{D}$ \\
\hline NG1 & 63,8 & $67,1 \mathrm{c}$ & $15,2 \mathrm{ab}$ & $14,9 \mathrm{BC}$ & $253,9 \mathrm{~b}$ & $250,3 \mathrm{CD}$ \\
\hline NG2 & 63,8 & $67,7 \mathrm{c}$ & $14,8 \mathrm{ab}$ & $14,9 \mathrm{BC}$ & $238,6 \mathrm{~b}$ & $271,8 \mathrm{BC}$ \\
\hline CK & 57,5 & $73,3 \mathrm{~b}$ & $15,5 \mathrm{ab}$ & $16,5 \mathrm{BC}$ & $317,5 \mathrm{a}$ & $315,6 \mathrm{AB}$ \\
\hline CG1 & 58,6 & $75,3 \mathrm{~b}$ & $15,4 \mathrm{ab}$ & $18,1 \mathrm{AB}$ & $315,2 \mathrm{a}$ & $325,6 \mathrm{~A}$ \\
\hline CG2 & 61,5 & $79,7 \mathrm{a}$ & $16,8 \mathrm{a}$ & $21,1 \mathrm{~A}$ & $361,7 \mathrm{a}$ & $345,0 \mathrm{~A}$ \\
\hline LSD & 10,8 n.s. & 2,4 & 3,4 & 4,0 & 52,7 & 45,1 \\
\hline
\end{tabular}

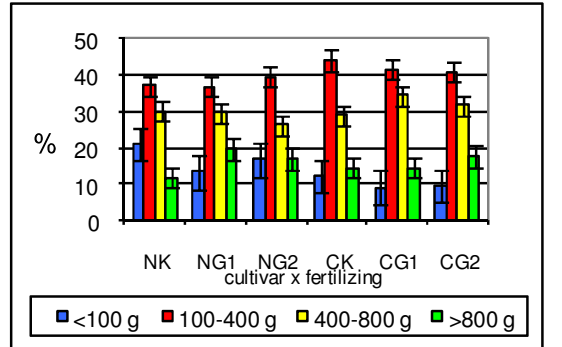

Figure 1. Root fraction 2008.

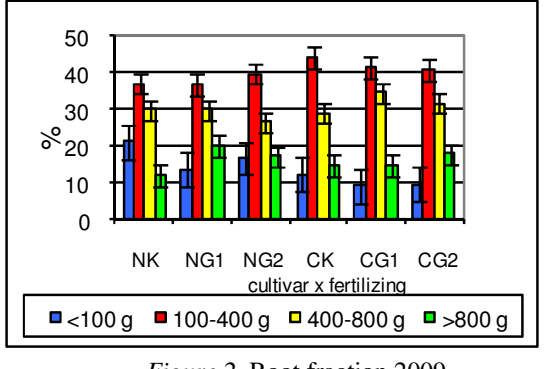

Figure 2. Root fraction 2009.

We found variation of total polyphenols content between two cultivars as well as different influence of growing conditions. In general, total polyphenolic content was higher in both cultivars grown in 2009, probably due to the lower level of rainfall. We found the increase of total polyphenols in 'Bat1' growing in application of mineral fertilization with nitrogen-potassium ratios of 1:2.5 and 1:5 in both years while negative influence was found in 'Boniato'. The greatest antioxidant activity (ORAC $=73.03 \mu \mathrm{mol}$ Trolox $\mathrm{g}^{-1} \mathrm{dw}$ ) was noticed in 'Bat1' cultivars grown in 2009 with application of mineral fertilization with nitrogen-potassium ratios 1:2.5 which had the highest concentration of polyphenols, whilst the lowest antioxidant activity (ORAC $=9.26, \mu \mathrm{mol}$ Trolox g $\mathrm{g}^{-1} \mathrm{dw}$ ) was also found in 'Bat1' grown as control with application of mineral fertilization with nitrogen-potassium ratios 1:1 grown in 2008. Our data were comparable to previous studies although great variations were reported (Padda et al., 2008 and Teow et al., 2007). 
Table 2. Influence of different mineral fertilization on total phenolic content and antioxidant activity determined by ORAC assay in two cultivars of sweet potato root grown in 2008 and 2009 *

\begin{tabular}{|c|c|c|c|c|c|c|c|c|}
\hline \multirow{3}{*}{ Sample } & \multicolumn{4}{|c|}{2008} & \multicolumn{4}{|c|}{2009} \\
\hline & \multicolumn{2}{|c|}{ Total Polyphenols } & \multicolumn{2}{|c|}{ ORAC } & \multicolumn{2}{|c|}{ Total Polyphenols } & \multicolumn{2}{|c|}{ ORAC } \\
\hline & $\begin{array}{c}\mathrm{mg} \mathrm{g}^{-1} \\
\mathrm{dw}\end{array}$ & $\mathrm{SD}^{* * *}$ & $\begin{array}{c}\mu \mathrm{mol} \\
{\text { Trolox } \mathrm{g}^{-1}}^{-1}\end{array}$ & $\mathrm{SD}^{* * *}$ & $\mathrm{mg} \mathrm{g}^{-1} \mathrm{dw}$ & $\mathrm{SD}^{* *}$ & $\begin{array}{c}\mu \mathrm{mol} \\
\text { Trolox } \mathrm{g}^{-1}\end{array}$ & SD \\
\hline$\overline{\mathrm{NK}}$ & $2.30^{\mathrm{d}}$ & 0.19 & $9.26^{\mathrm{e}}$ & 0.79 & 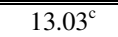 & 1.23 & $446.46^{\mathrm{c}}$ & 6.18 \\
\hline NG1 & $3.75^{\mathrm{c}}$ & 0.14 & $15.10^{\mathrm{d}}$ & 1.89 & $16.08^{\mathrm{a}}$ & 0.40 & $73.03^{\mathrm{a}}$ & 4.58 \\
\hline NG2 & $4.32^{\mathrm{bc}}$ & 0.03 & $17.40^{\mathrm{c}}$ & 0.75 & $15.32^{\mathrm{b}}$ & 0.11 & $63.42^{\mathrm{ab}}$ & 2.48 \\
\hline $\mathrm{CK}$ & $7.62^{\mathrm{a}}$ & 0.03 & $30.69^{\mathrm{a}}$ & 2.21 & $14.38^{\mathrm{bc}}$ & 0.86 & $51.00^{\mathrm{c}}$ & 4.11 \\
\hline CG1 & $5.30^{\mathrm{b}}$ & 0.02 & $21.34^{\mathrm{b}}$ & 1.31 & $13.17^{\mathrm{c}}$ & 0.45 & $50.10^{\mathrm{c}}$ & 5.10 \\
\hline CG2 & $5.05^{\mathrm{b}}$ & 0.08 & $20.34^{\mathrm{b}}$ & 0.91 & $12.95^{\mathrm{c}}$ & 1.33 & $48.08^{\mathrm{c}}$ & 1.59 \\
\hline
\end{tabular}

${ }^{*}$ Results are means \pm S.D. $(n=3)$, values of the same column followed by the same letter $(\mathrm{a}-\mathrm{d})$ are not statistically different $(P<0.05)$ as measured by Duncan's test.

*** Sample: Bat1 cultivar- N; Boniato cultivar -C; K- control mineral fertilization with nitrogen-potassium ratio $1: 1 ; \mathrm{G} 1$ - ratio $1: 2.5$ and $\mathrm{G} 2$ - ratio $1: 5$.

\section{Conclusions}

In Croatia sweet potato can yield 20-30 $\mathrm{t} \mathrm{ha}^{-1}$ of the root and about $15 \mathrm{tha}^{-1}$ of the leaf as valuable good with the balanced fertilization. This study established baseline data on the total polyphenolic content and antioxidant activity in 'Boniato' and 'Bat1' with addition of different mineral fertilization. These results could be useful for sweet potato producers when making decisions which mineral fertilizer to use and might be useful in the future for conventional programs for growing in order to improve the criteria for the desired quality of sweet potatoes.

\section{References}

Cao, G. - Alessio, H. M. - Cutler, R. G.: 1993. Oxygen-radical absorbance capacity assay for antioxidants. Free Radical Biology and Medicine, 14: 3. 303-311.

Islam, I. - Shaikh, A. U. - Shahidul, I. M.: 2009. Antioxidative and antimutagenic potentials of phytochemicals from Ipomoea batatas (L.) Lam. International Journal of Cancer Research , 5: 3. 83-94.

Jian-wei, B. L. - Fang, C. - You-sheng, X. - Yun-fan, W. - Dong-bi, L.: 2001. Sweet potato response to potassium. Better Crops International.15:1.10-12.

Nicholaides, J. J. - Chancy, H. F. - Mascagni, H. J. - Wilson, L. G. - Eaddy, D. W.: 1985. Sweet potato response to $\mathrm{K}$ and $\mathrm{P}$ fertilization. Agronomy Journal. 77: 466-470.

Novak, B. - Zutic, I. - Toth, N.: 2001. Possibilities of growing sweet potato (Ipomoea batatas) in Croatia. Book of abstracts of $37^{\text {th }}$ Symposium of Croatian Agriculturists, Opatija: 218.

Okpara, D. A. - Okon, O. E. - Ekeleme, F.: 2009. Optimizing nitrogen fertilization for production of white and orange-fleshed sweet potato in southeast Nigeria. Journal of plant nutrition. 32: 878-891.

Oya, K. - Tokashiki, Y. - Ishimine, Y.: 1977. Effects of potassium fertilization on the yields of sweet potato autumn crop grown on a calcareous soil of Okinawa. Sci. Bull. Coll. Agr. Univ. Ryukyus.24:191-197.

Padda, M. S. - Picha, D. H.: 2008. Quantification of phenolic acids and antioxidant activity in sweetpotato genotypes. Scientia Horticulturae. 119:1. 17-20.

Rabah, I. O. - Houm, D. E.-X. - Komine, S.-I. - Fujii, M.: 2004. Potential chemopreventive properties of extract from baked sweet potato (Ipomoea batatas Lam. cv. Koganesengan). Journal of Agricultural and Food Chemistry. 52:23. 7152-7157.

Singleton, V. L. - Orthofer, R. - Lamuela-Raventós, R. M.: 1999. Analysis of total phenols and other oxidation substrates and antioxidants means of Folin Ciocalteu reagent. Methods in Enzymology, 299: 152-178.

Teow, C. C. - Truong, V-D. - McFeeters, R. F. - Thompson, R. L. - Pecota, K. V. - Yencho, G. C.: 2007. Antioxidant activities, phenolic and $\beta$-carotene contents of sweet potato genotypes with varying flesh colours. Food Chemistry. 103: 3. 829-838. 


\title{
THE RESILIENCE OF THE COMPOSITION OF VEGETATION IN VARIOUS GRASSLANDS BY DIFFERENT FREQUENCY OF GRASSLAND UTILISATION
}

\author{
Márta BAJNOK - Péter MIKÓ - Julianna TASI
}

Institute of Crop Production, Faculty of Agriculture and Environmental Science, Szent István University, H2103 Gödöllö, Páter K. 1., e-mail: bajnok.marta@mkk.szie.hu

\begin{abstract}
In Hungary more than $11 \%$ of the area (1.02 million ha) is grassland. A significant proportion of this area is occupied by extensively used fields where fodder is grown. Extensive grassland management does not necessarily exclude multiple harvests within one season. In our experiments, we tested the effect of cutting frequency on the species composition of grassland vegetation, the resilience of different grasslands.

Utilisation frequencies (2, 3, 4 cuttings annually) were simulated by the same method at two sites, without fertiliser applications. The utilisation frequency of 2 cuttings/year was represented by a late first cutting (third decade of June) and an autumn cutting. The utilisation frequency of 3 cuttings/year was represented by vegetation surveys performed in the third decade of May, at the end of July and at the beginning of October. The utilisation frequency of 4 cuttings/year meant surveys in May, at the end of June, the end of July and at the beginning of October.

In Mende, on a planted, wet meadow, surveys on vegetation composition mostly yielded less than 10 species. In Bösztör, on a dry, natural pasture, the number of identified species varied between 35-40. From the relative ecological indicators (BORHIDI, 1993), the distributions of relative temperature demand (TB) and social behaviour types (SBT) were analysed.

According to the results of the examined 2 years, we may conclude that from the 3 different utilisation frequencies, the treatment with 3 cuttings/year had the most significant beneficial effect on maintaining or establishing a near-natural vegetation and resilience of grasslands. Further research is needed to confirm long time impacts.
\end{abstract}

Keywords: utilisation frequencies, relative ecological indicators, biodiversity, near-natural vegetation

\section{Introduction}

More than $11 \%$ of the area of Hungary (1.02 million ha) is under grassland management. The area of grassland has decreased significantly in recent decades as pieces of land of better quality have been transformed into arable fields (Barcsák et al., 1986). Yields have been increased primarily by using artificial fertilisers. The amount of nutrient supply necessary to increase the yield of different grassland types has been studied extensively (Nagy, 1991).

Over fertilising, while it increases yields, degrades soil quality (Láng, 1983) and reduces biodiversity (Müller, 1994). According to the results of Szemán (1998), the species diversity and yield of leguminous plants increase on unfertilised grasslands. Nitrogen increases the raw protein content of grass (Bánszki, 1988). Arming (1996) identified 39-68 plant species in an extensively managed plot of poor quality as opposed to the maximum number of 15 species found in intensively managed plots (where $50 \%$ of species were weed species typical in arable fields or ruderal species).

With the drastic decrease in livestock numbers since the 90 's , increasing yields is not as significant an issue as it used to be. As an alternative, new, environmentally friendly methods of pasture management have been introduced, e.g. organic and extensive grassland management (Kiss et al., 2006; Penksza et al., 2003, 2005; Szemán et al., 2008). 
Extensive grassland management does not necessarily exclude multiple cuttings within one season. In our experiments, we tested the effect of cutting frequency on the species composition of grassland vegetation, the related potential changes in composition and the resilience of different grasslands.

\section{Materials and methods}

Experiments were carried out in 2006, 2007 and 2008, at two locations, on flat ground. At one site (Mende), the experimental field, a wet meadow planted previously with Festuca arundinaceatum vegetation, was located in a valley, while at the other site (Bösztör) a dry saline grassland with Festuca pseudovinetum vegetation (in Bösztör) was used. Both sites are managed organically; no artificial fertilisers are applied. In the autumn of 2006, the manure dropped by grazing animals was simulated by broadcasting slurry, as the pastures were only mowed. Grasslands were utilised at 3 levels of intensity, represented by the number of cuttings (Table 1)

Table 1. Details of treatments

\begin{tabular}{|c|c|c|c|}
\hline & 2 cuts/year & 3 cuts/year & 4 cuts/year \\
\hline \hline $1^{\text {st }}$ growth & 19 Jun. & 17 May & 17 May \\
\hline $2^{\text {nd }}$ growth & 10 Oct. & 28 Jul. & 19 Jun. \\
\hline $3^{\text {rd }}$ growth & & 10 Oct. & 28 Jul. \\
\hline $4^{\text {th }}$ growth & & & 10 Oct. \\
\hline
\end{tabular}

Treatments were applied in 3 replicates. Vegetation composition was surveyed using the quadrat method Balázs, where the areas occupied by the different species inside the quadrat are expressed as coverage, or dominance value (DB). The dominance value is proportional to the area utilised by a given plant species. The highest possible value for DB is 32, standing for a surface coverage of $100 \%$.

From the relative ecological indicators (BORHIDI, 1993), the distributions of relative temperature demand (TB), relative nitrogen demand (NB) and social behaviour types (SBT) were analysed.

\section{Results and discussion}

Prior to discussing dominance values, the differences between numbers of plant species at the two examined sites should be mentioned. In Mende, on the planted, wet meadow, surveys on vegetation composition yielded less than 10 species in most of the cases. In Bösztör, on the dry, natural pasture, the number of identified species varied between 35 40. Classifying the examined sites according to the temperature demand shows a clear difference between the grasslands at Mende and Böször. The grassland in Mende (Figure 1) is mostly dominated by TB 5 vegetation (zone of montane deciduous mesophile forests). In 2008, in the plots with cutting frequencies of 2 and 4, the coverage of TB 6 species decreased; these species were replaced by the aforementioned TB 5 vegetation. 


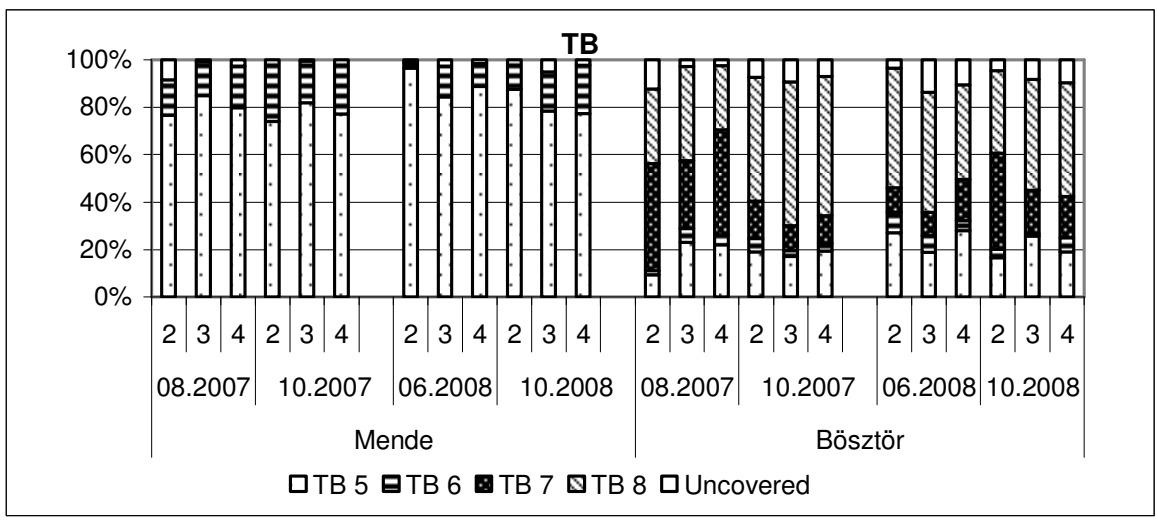

Figure 1. Distribution of plant species according to relative temperature demand (TB); Mende and Bösztör

In Bösztör (Fig. 1), the grassland is mostly dominated by the plant species of thermophile forests and steppic woods (TB7) and the submediterranean sibljak and steppe zone (TB8). As a result of the increased frequency of cutting, the proportion of plant species of higher temperature demand increased. In the treatment with two cuttings, the first cutting is rather late (second half of June), thus the first growth after cutting has a significant shading effect. This may explain the proliferation of species with a lower temperature demand in the case of extensive management.

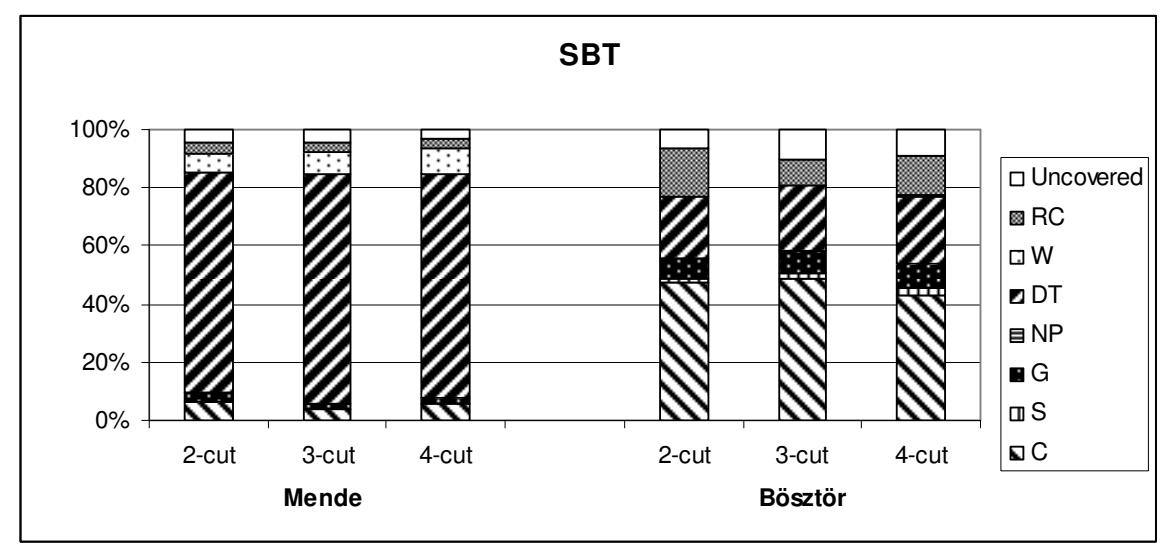

Figure 2. Distribution of plant species according to social behaviour types (SBT) in 2008 October; Mende and Bösztör

The graph of social behaviour types shows a dominance of disturbance tolerant, naturally occurring species (DT) in Mende (Figure 2). Competitor plant species (C) indicating natural conditions have also appeared. In Bösztör, species indicating natural condition (C, S, G, NP) were found in higher numbers than species indicating disturbance (Figure 2). Natural competitors (C) occupied almost $50 \%$ of the area. Endemic weed species were found only in low numbers. Rural competitor species of the 
endemic flora benefited from the cutting frequencies of 2 and $4(16.5 \%$ and $13.7 \%$, respectively) as opposed to 3 cuttings/year (8.5\%).

As SBT values indicate the natural or disturbed nature of the relationship between plant species and their habitats, they may be attributed with indicator values of naturalness. For the wet grassland of good nutrient supply in Mende, indicator values were between 202-216. For the grassland characterised by a high number of species and low nutrient supply, indicator values were between 350-402. As a result of cutting the grass 2 or 4 times a year, indicator values decreased (to 350 and 354, respectively) whereas the treatment with 3 cuttings resulted in significantly higher values (402).

\section{Conclusions}

According to the results of the examined 2 years, we may conclude that from the 3 different utilisation frequencies, the treatment with 3 cuttings/year had the most significant beneficial effect on maintaining or establishing a near-natural vegetation and it shows the most resilience of the composition of vegetation. Further research is needed to confirm long time impacts.

\section{Acknowledgements}

The current publication was created within the frame of the Hungarian Science and Technology Foundation (OMFB-00312/2009) and with the support provided by the Austrian-Hungarian Action Foundation (73öu 4) and by the National Office for Research and Technology (TECH_08-A4/2-2008-0140).

\section{References}

Arming, C.: 1996. Vegetationsökologische und landwirtschaftliche Untersuchungen auf Dauerbeobachtungsfläche eines 30 jährigen Düngeversuches in Scharfling am Mondsee. Diplomarbeit Univ. Salzburg

Bánszky, T.: 1988. Nagy termőképességü füvek és lódiherés gyepkeverék mütrágyázásának eredményei. Növénytermelés, 5. 469-478.

Barcsák, Z. - Kertész, I.: 1986. Gazdaságos gyeptermesztés és hasznosítás. Mg. Kiadó, Budapest

Borhidi, A.: 1993. A magyar flóra szociális magatartásformái. A KTM Term. Hiv. és a JPTE Kiadványa Pécs, 93.

Kiss, T. - Malatinszky, Á. - Penksza, K.: 2006. Comparative coenological axaminations on pastures of the Great Hungarian Plain I. (horse and cattle pasture near Hódmezővásárhely) - Tájökológiai Lapok 4: 339346.

Láng, I.: 1983. Biológiai erőforrások. Kossuth Könyvkiadó, Budapest, 122.

Müller, J.: 1994. Futterwert eines langjährig ungedüngten Grünlandbestandes der Brackmarsch. 38. Jahrestagung vom 25.-27. August 1994 in Cursdorf 198-201.

Nagy, G.: 1991. Az eltérő intenzitású gyepek tápértéke. Legelő az emberiség szolgálatában, Debrecen, 164177.

Penksza, K. - Barczi, A. - Néráth, M. - Pintér, B.: 2003. Hasznosítási változások következtében kialakult regenerációs esélyek a Tihanyi-félsziget gyepeiben az 1994 és 2002 közötti időszakban. Növénytermelés 52: 167-184. (IF: 0,206)

Penksza, K. - Benyovszky, B. M. - Malatinszky, Á.: 2005. Legeltetés okozta fajösszetétel változások a bükki nagymező gyepében. - Növénytermelés 54: 53-64.

Szemán, L. - Bajnok, M. - Harcsa, M. - Prutkay, J. - Zsigó, G.: 2008. The effect of soil nutrients and animal excreta on grassland biodiversity improvement. Cereal Research Communications 36. 1935-1938.

Szemán, L.: 1998. Yield increment on improved grassland. 17.Ecological Aspects of Grassland Management, Konf. Debrecen, 905-908. 


\title{
THE ROLE OF AGRONOMIC FACTORS ON YIELD STABILITY OF WINTER WHEAT
}

\author{
Vladimir SMUTNY
}

Department of Agrosystems and Bioclimatology, Faculty of Agronomy, Mendel University in Brno, 61300 Brno, Czech Republic, e-mail: smutny@mendelu.cz

Abstract: A lack of amount of precipitation or their uneven distribution during vegetation period can be a limiting factor of yield. For this reason it is necessary to adapt the crop management practices of winter wheat to given climatic and soil conditions in such a way that sufficient supply of water to crops would be assured. The impacts of different agronomic factors on yield level of winter wheat were evaluated in a field trial established in dry region of South Moravia. The role of crop rotation, different methods of soil tillage, fungicide treatments and straw management were evaluated in years 2004-2008. The results shown that the fore-crop had the highest impact on grain yield of winter wheat (the difference was $0.87 \mathrm{t} \mathrm{ha}^{-1}$ in yield after safflower than winter wheat). Application of fungicides against fungi diseases increased yield over $0.61 \mathrm{t} \mathrm{ha}^{-1}$ in comparison with untreated variant. Application of nitrogen liquid fertilizers used for increasing of straw decomposition does not have significant impact on yield. Factor of soil tillage (conventional and minimum) was significant in interaction with fore-crop and year. The results obtained illustrate the importance of individual factors which influence winter wheat cropping and the way how do they interact. It is a source of knowledge how to manage these factors and increase or stabilize the yield of crops.

Keywords: winter wheat, yield, soil tillage, fore-crop, straw management, fungicide application

\section{Introduction}

The changes in cropping systems during the last 20 years were characteristic for the Czech agriculture. Mainly the reduction of animal husbandry brought changes in crop structure. Important decrease was observed in area of fodder crops (silage maize, luzerne), pulses, tuber and root crops (potato, sugar beet). Today, wheat (Triticum aestivum L.) is the most important crop in the Czech Republic, it covers more than a half of the production area of cereals. Because wheat production needs to be economically viable and environmentally sustainable, it is necessary to adapt the crop management practices of winter wheat to given climatic and soil conditions. The importance of improving fore-crop as a key factor influencing yield of wheat resulted (Rieger et al., 2008). The impact of suitable soil tillage is discussed in context with possibility of saving soil moisture, because available water is often a limiting factor for crop production in dry areas of the CR. Overall, the sustainability of arable cropping systems is strengthened with conservation tillage (Singh and Malhi, 2006; Cannell and Hawes, 1994). Besides other intensification factors (improving straw decomposition, fertilization, pesticide application) we have to respect, that weather conditions are the most important factors in determining yield of winter wheat (Macák et al., 2009).

\section{Materials and methods}

The impacts of different agronomic factors were evaluated in a field trial established in Žabčice in the years $2004-2008$. This locality ( $179 \mathrm{~m}$ above sea level, $\left.49^{\circ} 01^{\prime} \mathrm{N}, 16^{\circ} 37^{\prime} \mathrm{E}\right)$ is situated $25 \mathrm{~km}$ southwards from Brno (South Moravia region, Czech Republic). It is a warm and dry region with average annual temperature and precipitation of $9.2^{\circ} \mathrm{C}$ and $480 \mathrm{~mm}$.

The soil is classified as gleic fluvisol which has developed on alluvial sediments of the Svratka River, the groundwater level fluctuates between 0.8 and $2.5 \mathrm{~m}$. By textural 
classification, it is a heavy soil. The field trial was established in this locality as a model concept for farming without animal husbandry (all straw is cut and incorporated into the soil). The principle of this experiment was a 5-year crop rotation with a high concentration of cereals (spring barley, safflower, winter wheat, winter wheat, corn). As far as the winter wheat was concerned, the following four experimental factors were assessed: fore-crop (safflower - Carthamus tinctorius or winter wheat), soil tillage (conventional or minimum tillage), straw treatment with different fertilizers and fungicide treatment (treated or untreated). The variant of conventional tillage consisted of stubble breaking after harvest and ploughing down to the depth of 0.20-0.24 m. The variant of minimum tillage included stubble breaking after harvest followed by a shallow loosening to the depth of $0.15 \mathrm{~m}$. Straw and crop residues of all crops were treated with four different liquid fertilizers (variants A-D); the aim of this treatment was to increase microbial activity and straw decomposition by nitrogen addition. The individual variants were as follows:

A - Beta-liq - (a liquid molasses-based organo-mineral fertilizer containing $3 \%$ of $\mathrm{N}$ and $5 \%$ of $\mathrm{K}_{2} \mathrm{O}$ ); the applied dose was $1 \mathrm{t} \mathrm{ha}^{-1}$,

B - DAM 390 - (a nitrogen fertilizer solution composed of urea and ammonium nitrate, containing $30 \% \mathrm{~N}$ ) - the applied dose was $100 \mathrm{~kg} \mathrm{ha}^{-1}$

$\mathrm{C}$ - Unifert - (liquid organo-mineral fertilizer on the base of alimentary waste products, containing $13 \%$ of $\mathrm{N}$ and $3 \%$ of $\mathrm{K}_{2} \mathrm{O}$ ) - the applied dose was $230 \mathrm{~kg} \mathrm{ha}^{-1}$

$\mathrm{D}$ - Control - without fertilizers

In the variant treated against leaf and ear diseases of winter wheat, fungicides were applied twice, at the beginning of stalk shooting (BBCH 32, TANGO SUPER - $84 \mathrm{~g}$ epoxiconazole $+250 \mathrm{~g}$ fenpropimorph) at the dose of $1.01 \mathrm{ha}^{-1}$ and in the growth stage of heading (BBCH 55 , FALCON $460 \mathrm{EC}-250 \mathrm{~g}$ spiroxamine $+167 \mathrm{~g}$ tebuconazole $+43 \mathrm{~g}$ triadimenol) at the dose of $0.61 \mathrm{ha}^{-1}$. The winter wheat variety Sulamit was sown at the rate of 4 million of germinating seeds per hectare. The experimental dose of fertilizers was $120 \mathrm{~kg} \mathrm{~N} \mathrm{ha}^{-1}(30 \mathrm{~kg}$ $\mathrm{N}$ prior to sowing as ammonium sulphate, $50 \mathrm{~kg} \mathrm{~N}$ in the spring for regeneration as calcium ammonium nitrate (CAN, 27.5\%) and $40 \mathrm{~kg} \mathrm{~N}$ till the end of tillering as DAM 390. Data were analysed using software Statistica, version 9 (Statsoft).

\section{Results and discussion}

The five-year results showed that four factors (fore-crop, tillage, fertilization of straw and fungicide treatment) had statistically significant impact on yield level of winter wheat in some years of study (Table 1,2). Grain yield varied significantly among years, in a similar manner to rainfall during the growing season. Only the factor of fore-crop influenced yield significantly in each year. Higher yield was after safflower $\left(0.87 \mathrm{t} \mathrm{ha}^{-1}\right.$ higher than after continuous winter wheat). The grain yield was not affect by soil tillage. Also López-Bellido et al., (1998) concluded that tillage method had no significant effect on grain yield for the three years in Spain. Differences, however, were significant in the wettest and driest years. 


\begin{tabular}{|c|c|c|c|c|c|c|}
\hline \multirow{2}{*}{ Source of variability } & \multirow{2}{*}{$\begin{array}{l}\text { Degrees } \\
\text { of freedom }\end{array}$} & \multicolumn{5}{|c|}{ Year/Mean square } \\
\hline & & 2004 & 2005 & 2006 & 2007 & 2008 \\
\hline (1) Fore-crop & 1 & $10.91^{\text {** }}$ & $22.001^{* *}$ & $68.04^{* *}$ & $31.037^{\text {*** }}$ & $4.161^{* *}$ \\
\hline (2) Tillage & 1 & 0.03 & 0.159 & $19.44^{* * *}$ & $10.943^{* * *}$ & $3.788^{* *}$ \\
\hline (3) Fertilization of straw & 3 & $0.51^{\text {*** }}$ & $0.488^{* * *}$ & 0.523 & $0.572^{* * *}$ & 0.053 \\
\hline (4) Fungicide treatment & 1 & $42.50^{\text {Fint }}$ & $32.86^{* * *}$ & 0.311 & $5.794^{* * *}$ & $2.915^{*}$ \\
\hline $1 * 2$ & 1 & 0.01 & $5.956^{* *}$ & $25.91^{\text {** }}$ & $2.705^{* *}$ & $3.196^{* *}$ \\
\hline $1 * 3$ & 3 & 0.25 & 0.454 & $0.872^{\text {*** }}$ & $2.384^{* * *}$ & $0.339^{* * *}$ \\
\hline $2 * 3$ & 3 & $0.52^{* *}$ & 0.186 & 0.268 & $0.585^{* *}$ & $0.438^{* *}$ \\
\hline $1 * 4$ & 1 & $2.58^{\text {*** }}$ & $4.69^{\text {*** }}$ & 0.053 & $0.856^{* * *}$ & 0.013 \\
\hline $2 * 4$ & 1 & 0.44 & 0.018 & 0.073 & 0.710 & 0.129 \\
\hline $3 * 4$ & 3 & $1.31^{\text {雨 }}$ & 0.417 & 0.249 & 0.114 & $0.617^{*}$ \\
\hline $1 * 2 * 3$ & 3 & $0.96^{\text {** }}$ & 0.112 & 0.242 & $0.825^{* * *}$ & $0.473^{* *}$ \\
\hline $1 * 2 * 4$ & 1 & 0.02 & 0.204 & 0.176 & 0.015 & 0.109 \\
\hline $1 * 3 * 4$ & 3 & 0.12 & 0.364 & 0.038 & $0.671^{\text {**** }}$ & 0.109 \\
\hline $2 * 3 * 4$ & 3 & 0.22 & 0.225 & 0.288 & $0.503^{\text {*** }}$ & $0.253^{* *}$ \\
\hline $1 * 2 * 3 * 4$ & 3 & 0.09 & 0.267 & 0.151 & 0.159 & 0.040 \\
\hline
\end{tabular}

Statistically highly significant effect $(\mathrm{P}=0.99)$

\begin{tabular}{|c|c|c|c|c|c|c|c|c|c|c|}
\hline \multirow{3}{*}{ year } & \multirow{3}{*}{ forecrop } & \multicolumn{8}{|c|}{ variants } & \multirow{3}{*}{ Total } \\
\hline & & \multicolumn{2}{|c|}{ soil tillage } & \multicolumn{4}{|c|}{ fertilization of straw } & \multicolumn{2}{|c|}{ fungicide } & \\
\hline & & $\mathrm{I}$ & II & $\mathrm{A}$ & $\mathrm{B}$ & $\mathrm{C}$ & $\mathrm{D}$ & no & yes & \\
\hline \multirow{2}{*}{2004} & safflower & 9.19 & 9.14 & 9.15 & 9.32 & 9.02 & 9.15 & $8.73^{\mathrm{a}}$ & $9.60^{\mathrm{b}}$ & 9.16 \\
\hline & winter wheat & 8.59 & 8.57 & 8.81 & 8.63 & 8.46 & 8.42 & $7.86^{\mathrm{a}}$ & $9.30^{\mathrm{b}}$ & 8.58 \\
\hline \multirow{2}{*}{2005} & safflower & 7.60 & 7.96 & 7.73 & 7.87 & 7.73 & 7.79 & $7.08^{\mathbf{a}}$ & $8.48^{\mathrm{b}}$ & 7.78 \\
\hline & winter wheat & $7.20^{\mathrm{a}}$ & $6.70^{\mathrm{b}}$ & 6.84 & 6.84 & 6.82 & 7.30 & $6.64^{\mathrm{a}}$ & $7.27^{\mathrm{b}}$ & 6.95 \\
\hline \multirow{2}{*}{2006} & safflower & 7.97 & 8.09 & $7.79^{\mathrm{a}}$ & $8.27^{b}$ & $8.00^{\mathrm{ab}}$ & $8.06^{\mathrm{ab}}$ & 8.00 & 8.06 & 8.03 \\
\hline & winter wheat & $7.41^{\mathrm{b}}$ & $5.73^{\mathrm{a}}$ & 6.80 & 6.62 & 6.28 & 6.60 & 6.50 & 6.64 & 6.57 \\
\hline \multirow{2}{*}{2007} & safflower & $5.93^{\mathrm{a}}$ & $6.81^{\mathrm{b}}$ & $6.46^{\mathrm{b}}$ & $6.03^{\mathrm{a}}$ & $6.21^{\mathrm{a}}$ & $6.80^{c}$ & $6.08^{\mathrm{a}}$ & $6.67^{b}$ & 6.37 \\
\hline & winter wheat & 5.24 & 5.53 & $5.43^{b}$ & $5.75^{\mathrm{c}}$ & $5.17^{\mathrm{a}}$ & $5.19^{\mathrm{a}}$ & $5.26^{\mathrm{a}}$ & $5.52^{b}$ & 5.39 \\
\hline \multirow{2}{*}{2008} & safflower & $8.33^{\mathrm{a}}$ & $9.00^{\mathrm{b}}$ & $8.92^{b}$ & $8.53^{\mathrm{a}}$ & $8.88^{\mathrm{b}}$ & $8.79^{\mathrm{ab}}$ & $8.60^{\mathrm{a}}$ & $8.96^{b}$ & 8.78 \\
\hline & winter wheat & 8.28 & 8.32 & $8.23^{\mathrm{a}}$ & $8.42^{b}$ & $8.29^{\mathrm{ab}}$ & $8.27^{\mathrm{ab}}$ & $8.13^{\mathrm{a}}$ & $8.47^{b}$ & 8.30 \\
\hline
\end{tabular}

Different letters $(a, b, c, d)$ means significant differences $(\mathrm{P}=0.95)$

The yield average was $7.57 \mathrm{t} \mathrm{ha}^{-1}$ in conventional tillage and $7.59 \mathrm{t} \mathrm{ha}^{-1}$ in minimum tillage. This is in relation with other results coming from the Czech Republic and concluded that tillage system had no significant effect on grain yield (Šíp et al., 2009; Javůrek and Tajnsek, 2002; Javůrek et al., 2007). On the other hand, the interaction between fore-crop and soil tillage significantly influenced the yield of winter wheat. When winter wheat was grown after safflower, the higher yield was on minimum tillage ( $0.4 \mathrm{t} \mathrm{ha}^{-1}$ higher). The higher yield (difference $0.37 \mathrm{t} \mathrm{ha}^{-1}$ ) was in continuous growing of winter wheat stand established with conventional tillage system. Explanation of these results could be in different effect of fore-crops on soil properties, especially in extreme years. Wet weather in the second half of vegetative period in 2006 caused yield decrease $\left(1.68 \mathrm{t} \mathrm{ha}^{-1}\right)$ on variant with reduced tillage grown after winter wheat. It could be connected with negative effect of winter wheat on soil structure, stability of soil aggregates, what in combination with reduced tillage means a lack of oxygen which is necessary for roots and also lower level of mineralization. Year 2007 was the opposite of this situation, when drought in April and May caused higher yield in minimum tillage 
after safflower $\left(0.88 \mathrm{t} \mathrm{ha}^{-1}\right)$ because this technology conserved soil moisture. The fungicide application increased the yield after both fore-crops, after winter wheat it was $0.56 \mathrm{t} \mathrm{ha}^{-1}$ and after safflower $0.66 \mathrm{t} \mathrm{ha}^{-1}$. The effect of application of liquid fertilizers to straw was not significant, the differences among variants were almost small, changeable in years.

\section{Conclusions}

The five-year results showed which agronomic factors play important role in yield formation of winter wheat. The cropping system without animal husbandry is resilient in yield, if good fore-crop, which can improve soil fertility, is used and if fungicides against fungal diseases are applied. Tillage system has to be appropriate to chosen forecrop. When winter wheat was grown after safflower, the higher yield was obtained in minimum tillage ( $0.4 \mathrm{t} \mathrm{ha}^{-1}$ higher) applications. The higher yield (difference $0.37 \mathrm{t} \mathrm{ha}^{-1}$ ) was in continuous growing of winter wheat stand established with conventional tillage system. Application of nitrogen liquid fertilizers used for increasing of straw decomposition does not have significant impact on yield. Modification of crop management practices provide possibility how to stabilize a yield level of winter wheat.

\section{Acknowledgements}

This paper was written within the project No. QH 91051 financed by the National Agency for Agricultural Research of the Ministry of Agriculture of the Czech Republic and was supported by the Research plan No. MSM6215648905 financed by the Ministry of Education, Youth and Sports of the Czech Republic.

\section{References}

Cannell R. Q. - Hawes J.: 1994. Trends in tillage practices in relation to sustainable crop production with special reference to temperate climates. Soil Tillage Research. 30: 245- 282.

Javůrek M. - Tajnsek A.: 2002. Impact of conservation tillage on grain yield of field crops comparing to conventional tillage at different sites. Scientia Agriculturae Bohemica 33: 135- 140.

Javůrek M. - Vach M. - Strašil Z.: 2007. Production, economic and energetic aspects of continuous ten-year use of conservation soil tillage. Scientia Agriculturae Bohemica 38: 179- 185.

López-Bellido L. - Fuentes M. - Castillo J. E. - López-Garrido F. J.: 1998. Effects of tillage, crop rotation and nitrogen fertilization on wheat-grain quality grown under rainfed Mediterranean conditions. Field Crops Research, 57: 265- 276.

Macák M. - Žák Š. - Szombathová N. - Candráková E.: 2009. The proportion of weather conditions on agronomic traits variability of winter wheat in environmentally-sound technologies. VIII. Alps-Adria Scientific Workshop Neum, Bosnia-Herzegovina, Cereal Research Communications, 37: 61- 64.

Rieger S. - Richner W. - Streit B. - Frossard E. - Liedgens M.: 2008. Growth, yield, and yield components of winter wheat and the effects of tillage intensity, preceding crops, and $\mathrm{N}$ fertilisation. European Journal of Agronomy. 28: 405- 411.

Singh B. - Malhi S. S.: 2006. Response of soil physical properties to tillage and residue management on two soils in a cool temperate environment. Soil Tillage Research. 85: 143-153.

Šíp V. - Růžek P. - Chrpová J. - Vavera R. - Kusá H.: 2009. The effect of tillage practice, input level and environment on the grain yield of winter wheat in the Czech Republic. Field Crops Research, 113: 131137 . 


\title{
TRITICALE RESPONSE TO DIFFERENT RATE OF NITROGEN NUTRITION
}

\author{
Nevena DJUKIC ${ }^{1}$ - Dejan DODIG ${ }^{2}$ - Kosana KONSTATINOV ${ }^{2}-$ \\ Mirjana MENKOVSKA ${ }^{3}$ \\ ${ }^{1}$ Faculty of Natural Science, Department of Biology Kragujevac, Serbia, nevena@kg.ac.rs \\ ${ }^{2}$ Maize Research Institute ,Zemun Polje“ S. Bajica 1, Zemun, Serbia \\ ${ }^{3}$ PSI Institute of Animal Science, Department of Food Technology and Biotechnology, Skopje, Macedonia
}

Abstract: In our work we investigated the influence of nitrogen on chlorophyll content and its effect on productivity triticale. Chlorophyll content in flag leaf of triticale cultivar Favorit were estimated in two development stage: booting and flowering. Triticale was grown at the long term experiment under three variant of fertilization: first- control variant (without nutrition), second - variant with two subvariants of nitrogen rate: $2 \mathrm{~N}_{1}\left(80 \mathrm{~kg} \mathrm{~N} \mathrm{ha}^{-1}\right)$ and $2 \mathrm{~N}_{2}\left(120 \mathrm{~kg} \mathrm{~N} \mathrm{ha}^{-1}\right)$ and third variant with NPK fertilizer with two different rate of $\mathrm{N}$ application: $3 \mathrm{~N}_{1}\left(80-60-60 \mathrm{~kg} \mathrm{~N}^{-1}\right)$ and $3 \mathrm{~N}_{2}\left(120-60-60 \mathrm{~kg} \mathrm{~N}^{-1}\right)$. The results indicate that chlorophyll content depends from the content of mineral elements in soil. The content of chlorophyll $a$ and chlorophyll $b$ is the lowest in control variants (unfertilized plots). Also content of chlorophyll $a$ was higher than that of chlorophyll $b$. Concentration of chlorophyll $a$ is higher in booting phase than in flowering phase. Concentration of both chlorophyll $a$ and $b$ increasing with increasing of fertilizer rate. The highest concentration of chlorophyll $a(1.892 \mathrm{mg} / \mathrm{g})$ and $b(1.347 \mathrm{mg} / \mathrm{g})$ in booting phase is in variant $3 \mathrm{~N}_{2}(120-60-60$ $\left.\mathrm{kg} \mathrm{N} \mathrm{ha}^{-1}\right)$ while in flowering phase chlorophyll $a(1.772 \mathrm{mg} / \mathrm{g})$ and $b(0.872 \mathrm{mg} / \mathrm{g})$ is in variant $3 \mathrm{~N}_{1}(80-60-$ $\left.60 \mathrm{~kg} \mathrm{~N} \mathrm{ha}^{-1}\right)$. The grain yield of triticale cultivar Favorit depends from rate of fertilizer and was the highest on variant $\mathrm{N}_{2}\left(120-60-60 \mathrm{~kg} \mathrm{~N} \mathrm{ha}^{-1}\right)$

Keywords: triticale, cultivar, nutrition, chlorophyll, yield

\section{Introduction}

Living activity of plants is closely connected to the surrounding environment. By starting with the plants' need for environmental factors which determine the possibility for development of a particular plant species, its productivity and quality of its products, it is possible to determine the degree of conditions favourable for growing a particular plant species. Adaptive value of plants changes to a particular degree in dependence on changes in the environment. In agro-ecosystem, with the aim of achieving larger and higher quality yield by applying agro-technical measures, the technological process of agricultural production must be improved. The additional nutrition by using different variants of manure is one of the aspects of anthropogenic influence. The quantity of used nitrogen depends on type and soil fertility, sort and planned yield. Application of mineral fertilizers have influence to dynamics of leaf surface formation and the photosynthetic potential as well productivity of photosynthesis (Pepó, 2005). The chlorophyll synthesis depends from mineral nutrition.

The chlorophylls, Chl $a$ and $\mathrm{Chl} b$, are the most important of photosynthetic pigments, and are thus virtually essenial for the oxygenic conversion of light energy to the stored chemical energy that powers the biosphere. The amount of solar radiation absorbed by a leaf is largely a function of the concentrations of leaf photosynthetic pigments and, therefore, low concentrations of chlorophyll can directly limit photosynthetic potential and hence primary production (Curran et al., 1990). Much of leaf nitrogen is incorporated in chlorophyll, so quantifying chlorophyll content gives an indirect measure of nutrient status (Moran et al., 2000). Chlorophyll content would provide a 
rapid estimation of wheat $\mathrm{N}$ status (Filella et al., 1995). Assessment of chlorophyll content is a valuable tool for agricultural ecosystem studies, since it provides information on key vegetation properties that are, in turn, linked to net primary production (Serrano, 2008). Leaf chlorophyll content varies from 0.05 to $0.30 \%$ of fresh matter. Differences in chlorophyll contents depends of genetic factors as well environmental factors (Nelson, 1988; Richards, 2000).

The aim of this paper is study of variability of chlorophyll content in flag leaf in triticale, grown under different applied rate of nitrogen in booting and flowering stage of plant development.

\section{Materials and methods}

Triticale cultivar Favorit were grown on long term experimental field of Center for Small Grains in Kragujevac. For analysis flag leaves collected at the two developmental phase: booting phase and flowering phase. For analysis of chlorophyll content, samples were taken from three basic variants of soil fertilization (Table 1). At the each plots was added given the same amounts of potassium ammonium nitrate $(27 \%)$, superphosphate (18 or $\left.45 \% \mathrm{P}_{2} \mathrm{O} 5\right)$ and potassium chloride $(60 \% \mathrm{KCl})$. Unfertilized plots belonged to the smonitza type of soil in the process of degradation with $\mathrm{pH}$ of 6.03 to 6.10 in water and 4.76 to 4.84 in $\mathrm{KC} 1$. For analysis measured $0.5 \mathrm{~g}$ of plant leaves which macerated with the addition of $5-10 \mathrm{ml}$ of $80 \%$ acetone and small amount of $\mathrm{MgCO}_{3}$. This material was homogenized during 3 minutes and filtrated. Since the concentration of pigments was in most cases too great for reading to be performed on a spectrophotometer, the obtained extract was diluted by adding $9 \mathrm{ml}$ of $80 \%$ acetone per $\mathrm{ml}$ of extract. The extract used for reading at the spectrophotometer at 662, 644 and 440 nm. Chlorophyll content was computed according to Holm.

\section{Results and discussion}

The results of measuring chlorophyll content in flag leaf of triticale in booting phase of development presented in Figure 1. The content of chlorophyll $a$ and chlorophyll $b$ is higher at all fertilized variants than in control variants - unfertilized plots $(\mathrm{C} 1$ and $\mathrm{C} 2)$. Also content of chlorophyll $a$ was higher than of chlorophyll $b$ in all variants of soil fertilization. Concentration of both chlorophyll $a$ and $b$ increasing with increasing of fertilizer rate. The highest chlorophyll content (chlorophyll $a$ and $b$ ) $3.239 \mathrm{mg} / \mathrm{g}$ was found in variant $3 \mathrm{~N}_{2}\left(120-60-60 \mathrm{~kg} \mathrm{~N} \mathrm{ha}^{-1}\right)$. The concentration of chlorophyll $a$ at this variant of fertilization $1.892 \mathrm{mg} / \mathrm{g}$, while concentration of chlorophyll b $1.347 \mathrm{mg} / \mathrm{g}$ (Figure 1). Also high concentrations of chlorophyll $a$ and $b(2.853 \mathrm{mg} / \mathrm{g})$ were found in variants $2 \mathrm{~N}_{1}\left(80 \mathrm{~kg} \mathrm{~N} \mathrm{ha}^{-1}\right)$. Concentration of chlorophyll $a$ and $b$ is higher in booting phase than in flowering phase, except for variations $2 \mathrm{~N}_{1}$.

The lowest amounts of chlorophyll in the flowering phase in all fertilization variants were found in the flag leaf (Figure 2). Thus, the content of chlorophyll content and levels of other leaf biochemical constituents can be used as indicators of crop stress under conditions of nutritional or water deficiencies. The highest chlorophyll content (chlorophyll $a$ and $b$ ) in flowering phase was found in variants $2 \mathrm{~N}_{1}\left(80 \mathrm{~kg} \mathrm{~N} \mathrm{ha}^{-1}\right)$. The concentration of chlorophyll a varied from $0.434 \mathrm{mg} / \mathrm{g}$ (unfertilized plots) to 2.882 
$\mathrm{mg} / \mathrm{g}\left(2 \mathrm{~N}_{1} 80 \mathrm{~kg} \mathrm{~N} \mathrm{ha}^{-1}\right)$, while concentration of chlorophyll $b$ varied $0.269 \mathrm{mg} / \mathrm{g}$ (unfertilized plots) to $1.669 \mathrm{mg} / \mathrm{g}\left(2 \mathrm{~N}_{1} 80 \mathrm{~kg} \mathrm{~N} \mathrm{ha}^{-1}\right)$ Figure 2. Also high concentrations of chlorophyll $a$ and $b$ were found in variants $\mathrm{N}_{1}\left(80 \mathrm{~kg} \mathrm{~N} \mathrm{ha}^{-1}\right)$.

Decreasing of chlorophyll content in flowering phase in relation to booting phase of wheat development could be effected by unfavorable environmental factors. (Djukic and Knezevic, 2008)

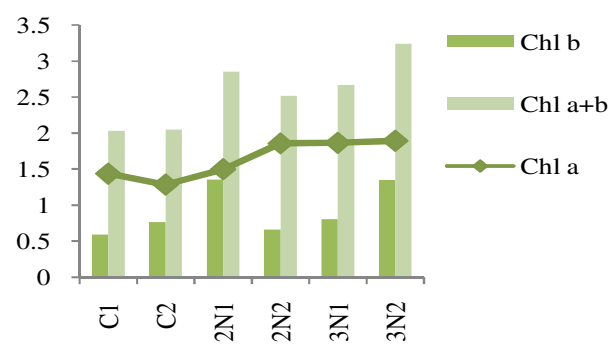

Figure 1. Chlorophyll concentration in triticale flag leaves at booting phase

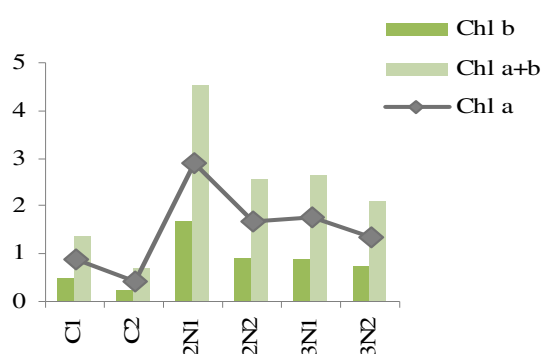

Figure 2. Chlorophyll concentration in triticale flag leaves at flowering phase

The photosynthesis efficiency can enhanced by optimal nutrition. Among mineral elements, the nitrogen play the main role in wheat nutrition because of its importance in protein and nucleic acid synthesis as well plant productivity (Knezevic et al., 2007). On the base of dynamics $\mathrm{N}$ efficiency absorption and its introduction of organic synthesis are increasing speed of these processes and plant productivity. For this reason, wheat responds very positively to application of mineral fertilizers (Nemeth et al. 2000; Pepo, 2005; Balogh et al., 2006).

In this investigation were established differences of grain yield among in variant of applied fertilizer. Grain yield for analyzed triticale was the lowest at control variant. The highest grain yield of triticale cultivar Favorit the fertilized plots were found (5020 $\left.\mathrm{kg} \mathrm{ha}^{-1}\right)$ in variant of NPK fertilizer application by rate $3 \mathrm{~N}_{2}\left(120-60-60 \mathrm{~kg} \mathrm{~N}^{-1}\right)$ Table 1.

539 DOI: 10.1556/Novenyterm.59.2010.Suppl.4 
Table 1. Average yield of grain of analyzed triticale Favorit cv. under the different variants of fertilization

\begin{tabular}{|l|l|l|l|l|l|l|}
\hline $\begin{array}{l}\text { Variant } \\
\text { of } \\
\text { nutrition }\end{array}$ & Control 1 & Control 2 & $\begin{array}{l}2 \mathrm{~N}_{1} \\
\left(80 \mathrm{~kg} \mathrm{~N} \mathrm{ha}^{-1}\right)\end{array}$ & $\begin{array}{l}2 \mathrm{~N}_{2} \\
\left(120 \mathrm{~kg} \mathrm{~N} \mathrm{ha}^{-1}\right)\end{array}$ & $\begin{array}{l}3 \mathrm{~N}_{1} \\
(80-60-60 \\
\left.\mathrm{kg} \mathrm{N} \mathrm{ha}^{-1}\right)\end{array}$ & $\begin{array}{l}3 \mathrm{~N}_{2} \\
(120-60-60 \\
\mathrm{kg} \mathrm{N} \mathrm{ha}^{-1}\end{array}$ \\
\hline & \multicolumn{6}{|c|}{ Average yield of grain kg ha } \\
\hline
\end{tabular}

\section{Conclusions}

Chlorophyll content indicating potential of cultivars photosynthesis and productivity of plants. Photosynthetic activity is very important for increasing grain yield and quality of triticale cultivars. The significant influence to triticale plants development and their leaf surface have nitrogen, which effect could improve by phosphorus and by potassium. Optimization of $\mathrm{N}$ application requires knowledge of the response of crop growth processes to $\mathrm{N}$. Variation in dry matter yield in response to $\mathrm{N}$ may arise from differences in the amount of intercepted photosynthetically active radiation by the canopy, the light use efficiency and harvest index.

\section{References}

Agoston, T. - Pepo, P.: 2005. Effects of genetic and ecological factors on yield formation in winter wheat production. Cereal Research Communications 33: 1. 137-40.

Balogh A. - Pepo P. - Hornok M.: 2006. Interactions of cropyear, fertilization and variety in winter wheat management. Cereal Research Communications 34: 1. 389-392.

Curran, P. J. - Dungan, J. L. - Gholz, H. L.: 1990. Exploring the relationship between reflectance rededge and chloropyll content in slash pine. Tree Physiology.7, 33-48.

Djukic, N. - Knezevic, D.: 2008. Effect of nitrogen nutrition to chlorophyll content in wheat (Triticum aestivum L.) Cereal Res. Commun., 36,II, 1267-1270.

Filella, I. - Serano, L. - Sera, J. - Penuelas. J.: 1995. Evaluating wheat nitrogen status with canopy reflectance indices and discriminant anaiysis. Crop Science. 35, 1400-1405.

Knezevic, D. - Paunovic, A. - Madic, M. - Djukic, N.: 2007. Genetic analysis of nitrogen accumulation in four wheat cultivars and their hybrids. Cereal Res. Commun., 35 2, 633-336.

Moran, J. A. - Mitchell, A. K. - Goodmanson, G. - Stockburger, K. A.: 2000. Differantiation among effects of nitrogen fertilization treatments on conifer seedlings by foliar reflectance: a comparision $\mathrm{f}$ methods. Tree Physiology. 20,1113-1120.

Nelson, J.C.: 1988. Genetic associations between photosynthetic characteristics and yield: review of the evidence. Plant Physiology and Biochemistry 26: 543-554.

Nemeth,T. - Czatho, P. - Arendas, T.: 2000. New environmentally friendly wheat fertilizer advisory system for Hungary. In: Wheat in a Global Environment. (Eds. Z. Bedo \& L. Lang). Kluw. Acad. Publish., 625631

Pepó P.: 2005. Effect of cropyear, genetic and agrotechnical factors on dry matter production and accumulation in winter wheat production. Cereal Res. Comm. 33:1. 29-32.

Richards, R. A.: 2000. Selectable traits to increase crop photosynthesis and yield of grain crops. Journal ofExperimental Botany 51: 447-458.

Serrano, L.: 2008. Effects of leaf structure on reflectance estimates of chlorophyll content. International Journal of Remote Sensing. 29: 17-18, ISSN 0143-1161. 